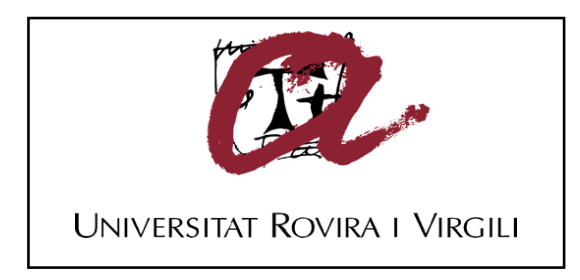

\title{
LA PREPARACIÓN DEL PROCESO CIVIL: LAS DILIGENCIAS PRELIMINARES Rebeca Castrillo Santamaria
}

\begin{abstract}
ADVERTIMENT. L'accés als continguts d'aquesta tesi doctoral i la seva utilització ha de respectar els drets de la persona autora. Pot ser utilitzada per a consulta o estudi personal, així com en activitats o materials d'investigació i docència en els termes establerts a l'art. 32 del Text Refós de la Llei de Propietat Intel·lectual (RDL 1/1996). Per altres utilitzacions es requereix l'autorització prèvia i expressa de la persona autora. En qualsevol cas, en la utilització dels seus continguts caldrà indicar de forma clara el nom i cognoms de la persona autora i el títol de la tesi doctoral. No s'autoritza la seva reproducció o altres formes d'explotació efectuades amb finalitats de lucre ni la seva comunicació pública des d'un lloc aliè al servei TDX. Tampoc s'autoritza la presentació del seu contingut en una finestra o marc aliè a TDX (framing). Aquesta reserva de drets afecta tant als continguts de la tesi com als seus resums i índexs.
\end{abstract}

ADVERTENCIA. El acceso a los contenidos de esta tesis doctoral y su utilización debe respetar los derechos de la persona autora. Puede ser utilizada para consulta o estudio personal, así como en actividades o materiales de investigación y docencia en los términos establecidos en el art. 32 del Texto Refundido de la Ley de Propiedad Intelectual (RDL 1/1996). Para otros usos se requiere la autorización previa y expresa de la persona autora. En cualquier caso, en la utilización de sus contenidos se deberá indicar de forma clara el nombre y apellidos de la persona autora y el título de la tesis doctoral. No se autoriza su reproducción u otras formas de explotación efectuadas con fines lucrativos ni su comunicación pública desde un sitio ajeno al servicio TDR. Tampoco se autoriza la presentación de su contenido en una ventana o marco ajeno a TDR (framing). Esta reserva de derechos afecta tanto al contenido de la tesis como a sus resúmenes e índices.

WARNING. Access to the contents of this doctoral thesis and its use must respect the rights of the author. It can be used for reference or private study, as well as research and learning activities or materials in the terms established by the 32nd article of the Spanish Consolidated Copyright Act (RDL 1/1996). Express and previous authorization of the author is required for any other uses. In any case, when using its content, full name of the author and title of the thesis must be clearly indicated. Reproduction or other forms of for profit use or public communication from outside TDX service is not allowed. Presentation of its content in a window or frame external to TDX (framing) is not authorized either. These rights affect both the content of the thesis and its abstracts and indexes. 


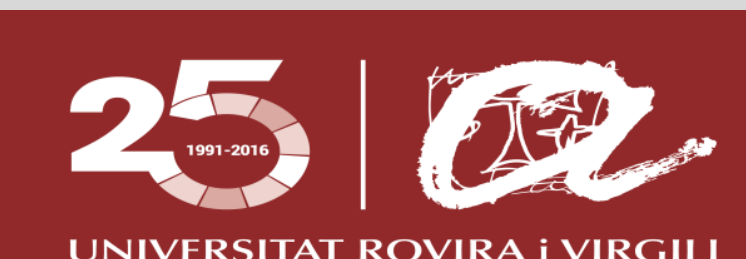

UNIVERSITAT ROVIRA i VIRGILI

\section{LA PREPARACIÓN DEL PROCESO CIVIL: LAS DILIGENCIAS PRELIMINARES}

REBECA CASTRILLO SANTAMARÍA 


\title{
LA PREPARACIÓN DEL PROCESO CIVIL: LAS DILIGENCIAS PRELIMINARES
}

\author{
TESIS DOCTORAL \\ dirigida por la Dra. Elisabet Cerrato Guri \\ Departament de Dret Privat, Processal i Financer

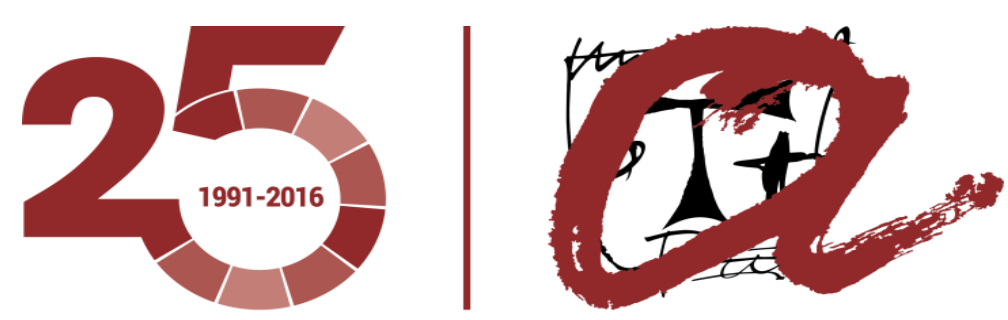 \\ UNIVERSITAT ROVIRA i VIRGILI
}

\section{Tarragona}

2017 


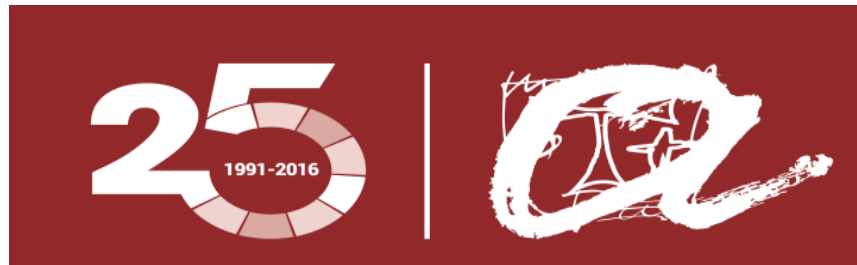

UNIVERSITAT ROVIRA i VIRGILI

Departament de Dret Privat, Processal i Financer

Facultat de Ciències Jurídiques

Av. Catalunya, 35

43007, Tarragona

Tlf. 977558308

FAIG CONSTAR que aquest treball, titulat "La preparación del proceso civil: las diligencias preliminares", que presenta Rebeca Castrillo Santamaría per a l'obtenció del títol de Doctora, ha estat realitzat sota la meva direcció al Departament de Dret Privat, Processal i Financer.

Tarragona, 1 de setembre de 2017

La directora de la tesi doctoral.

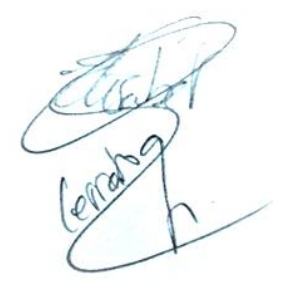

Dra. Elisabet Cerrato Guri 
LA PREPARACIÓN DEL PROCESO CIVIL: LAS DILIGENCIAS PRELIMINARES

Rebeca Castrillo Santamaria

Rebeca Castrilio Santamaria 


\section{AGRADECIMIENTOS}

A la directora de esta tesis, la Dra. Elisabet Cerrato Guri. Por confiar en mí, abriéndome las puertas de la Universitat Rovira i Virgili y darme la oportunidad de iniciar, desarrollar y concluir mis estudios de doctorado. Fueron muchas las puertas académicas que toqué, pero sólo ella consideró que mis circunstancias personales y profesionales y la distancia geográfica que nos separaba no eran un obstáculo para concluir satisfactoriamente esta tesis doctoral.

A todos los profesores del MUDEC (2012-2013), en el que hunde sus raíces esta tesis doctoral. Por su compromiso, sus críticas constructivas y los conocimientos que me aportaron.

A Gloria Macías, bibliotecaria del TSJ de Canarias, a quien en distintas ocasiones tuve que acudir para conseguir varios de los materiales utilizados en esta tesis, por su admirable colaboración y disposición.

Y, a mi familia. A mis padres, Carlos y Celsa, por su ayuda incondicional y preocupación constante porque sus hijas se formaran académicamente. A mi hermana, Rocío, por estar donde yo debía cuando, en tantas ocasiones, mis ocupaciones profesionales y académicas me lo han impedido. A mis abuelos, a quienes tanto echo de menos. A Kymo y Juanjo, mis compañeros de vida, por su paciencia y ayuda pese al tiempo que les he robado y que he empleado en esta y mis mil y una ocupaciones.

A todos, gracias infinitas. 
1. Aplicación de los criterios de interpretación

1.1 Los criterios gramatical y contextual.

1.2 El criterio histórico

1.3 La realidad social

1.4 El espíritu y finalidad de las normas o criterio teleológico

2. Las diligencias preliminares en la jurisprudencia y doctrina judicial

4. Distinción respecto de otras figuras afines.

4.1 Prueba anticipada

4.2 Aseguramiento de la prueba

4.3 Medidas cautelares

4.4 $\mathrm{El}$ discovery

5. Naturaleza jurídica: ¿actos de jurisdicción voluntaria o contenciosa?

6. Numerus clausus o numerus apertus .....

6.1 Postura de la doctrina científica y judicial

6.2 Argumento intermedio: interpretación flexible 
7. Evolución legislativa

7.1 De la ALEC a la LEC

7.2 Las reformas introducidas por la Ley 19/2006.

7.3 Las reformas introducidas por la Ley 21/2014.

8. Características

8.1 Finalidad preparatoria, o de evitación, del proceso ulterior

8.2 Instrumentalidad.

8.3 Autonomía

9. Presupuestos materiales de la solicitud.

9.1 Adecuación a la finalidad perseguida

9.2 Justa causa

9.3 Interés legítimo

10. La caución

10.1 Regulación positiva de la caución.

10.2 La finalidad de la caución

10.2.1 Funciones de la caución.

10.2.2 Ponderación de las funciones de la caución

10.2.3 Propuesta de reforma y delimitación de las funciones de la caución

10.2.4 Especial atención a la caución de las diligencias de comprobación de hechos

10.3 Conceptos resarcibles con cargo a la caución

10.3.1 Gastos.

10.3.2 Daños y perjuicios 
1. Declaración o exhibición documental sobre hechos relativos a la capacidad, representación o legitimación de la persona frente a quien se dirigirá la demanda (art. 256.1.1 LEC)

1.1 Objeto

1.2 Justificación de la diligencia

1.3 Aspectos prácticos de la diligencia

2. Exhibición de cosas (art. 256.1.2 LEC)

2.1 Introducción

2.2 Ámbito de aplicación

2.2.1 Limitación a las cosas muebles

2.2.2 Ampliación a los inmuebles

2.3 La posibilidad de equiparación del documento al concepto de cosa 145

2.4 Cuestiones de legitimación

3.1 Ámbito de aplicación

3.1.1 Objeto de la diligencia

3.1.2 Particularidades

3.2 Legitimación

3.3 Práctica de la diligencia

4. Exhibición de los documentos o cuentas de sociedades o comunidades (art.

4.1 Legitimación

4.2 Presupuestos de admisión

4.3 Ámbito de aplicación 170

4.4 Práctica de la diligencia 
5. Exhibición del contrato de seguro (art. 256.1.5 LEC)

5.1 Ámbito de la diligencia

5.2 Legitimación

5.3 Práctica de la diligencia

6. Exhibición y entrega de la historia clínica (art. 256.1.5 bis LEC

6.1 Justificación de la diligencia

6.2 Las anotaciones subjetivas ¿limitan el objeto de la diligencia?

6.3 Concreción del objeto, legitimación y práctica de la diligencia

7. Concreción de los integrantes del grupo de consumidores y usuarios (art. 256.1.6 LEC)

7.1 Introducción.

7.2 Legitimación

7.3 Admisión de la diligencia

7.4 Práctica de la diligencia

8. Obtención de datos en materia de propiedad industrial o intelectual (art. 256.1.7 LEC)

8.1 Actos que no puedan considerarse realizados por meros consumidores finales de buena fe y sin obtención de beneficios económicos o comerciales

8.2 Objeto de la diligencia

8.3 Presupuestos para la práctica de la diligencia

8.4 Especial atención a la práctica del interrogatorio

8.5 Legitimación

8.6 Confidencialidad de la información

9. Exhibición documental en materia de propiedad industrial o intelectual (art.

9.1 Origen de la diligencia

9.2 Objeto de la diligencia 
9.3 Presupuestos particulares para la práctica de la diligencia

9.4 Legitimación

10. Diligencias y averiguaciones para la protección de determinados derechos previstos en las leyes especiales (art. 256.1.9 LEC)

10.1 Ámbito de aplicación y características 237

10.2 Presupuestos de admisibilidad 239

10.3 Legitimación 243

10.4 Asistencia letrada y práctica de la diligencia

11. Identificación del PSSI (art. 256.1.10 LEC)

11.1 Ámbito de aplicación 249

11.2 Presupuestos de admisión 250

12. Identificación del usuario de SSI (art. 256.1.11 LEC) 254

12.1 Objeto de la diligencia 255

12.2 Legitimación. 256

12.3 Presupuestos para su admisión 257

12.4 Práctica de la diligencia 257

CAPÍTULO III. PROCEDIMIENTO 258

1. Competencia 258

1.1 Competencia objetiva 264

1.2 Competencia territorial 266

1.3 Supuestos especiales de competencia 267

2. Solicitud 273

2.1 Forma 273

2.2 Defensa y representación. 275

2.3 Ofrecimiento de caución 278 
3. Decisión sobre la solicitud

3.1 Inadmisión de la diligencia preliminar

3.2 Admisión de la diligencia preliminar. 286

3.3 Prestación de caución.

4. Oposición a la diligencia preliminar

4.1 Introducción

4.2 Forma

4.3 Defensa y representación

4.4 Motivos de oposición 298

4.5 Decisión sobre la oposición 299

4.6 El pago de las costas 300

5. Práctica de la diligencia preliminar

6. Negativa a la práctica de las diligencias preliminares

6.1 Planteamiento general

6.2 Efectos de la negativa en el ulterior proceso

6.2 Medidas de intervención

6.3 La entrada y registro como consecuencia de la negativa a la práctica de las diligencias preliminares

6.3.1 Planteamiento general de la cuestión

6.3.2 Precedentes de la medida en otros órdenes jurisdiccionales

6.3.3 Cuestionamiento constitucional de la adopción de la medida en el orden jurisdiccional civil

6.3.3.1 Ausencia de atribución expresa en la LOPJ de la competencia para adoptar la medida de entrada y registro a los órganos del orden jurisdiccional civil.

6.3.3.2 Ausencia de reserva de ley orgánica que el art. 81.1 CE exige para el desarrollo de un derecho fundamental como el contenido en el art. 18.2 CE 
6.3.4 Supuestos en que puede acordarse la medida de entrada y registro en lugar determinado del art. 261 LEC.

6.3.4.1 Entrada y registro para la exhibición de títulos y documentos y obtención de estos y otros datos

6.3.4.2 Entrada y registro cuando se haya solicitado la exhibición de una cosa.

6.3.5 Presupuestos para la adopción de la medida de entrada y registro en lugar determinado

6.3.5.1 Concurrencia de indicios suficientes, conocimiento o presunción fundada de que los títulos y documentos o la cosa se encuentra en lugar determinado

6.3.5.2 Que la persona requerida no atienda el requerimiento ni formule oposición

6.3.5.3 Proporcionalidad de la medida. Entre el fin perseguido y el medio empleado

6.3.6 Reflexión final

7. Aplicación de la caución

\section{CAPÍTULO IV. EFICACIA DE LAS DILIGENCIAS PRELIMINARES: ESPECIAL REFERENCIA AL EFECTO INTERRUPTIVO DE LA PRESCRIPCIÓN}

1. El efecto interruptivo de la prescripción de las diligencias preliminares

2. Requisitos que han de concurrir en el procedimiento de diligencias preliminares para que opere la prescripción en el proceso posterior

2.1 Identificación del derecho que se quiere conservar y de la persona frente a la que se trata de hacer valer

2.2 Que la voluntad conservativa del concreto derecho llegue a conocimiento del futuro demandado 
3. Ineficacia de las diligencias preliminares atípicas como instrumento de interrupción de la prescripción

4. Consideraciones finales

CONCLUSIONES 


\section{ABREVIATURAS}

AA

AAP

ADPIC

AEDP

AJMER

AP

ALEC

ALP

Aptdo.

Art.

ATS

$\mathrm{BOE}$

Cap.

CE

$\mathrm{CC}$

CCAA

CCPP

$\mathrm{CCo}$

CGPJ

Cit.

Cfr.

CFR

Directiva 2004/48/CE
Autos

Auto Audiencia Provincial

Acuerdo sobre los Aspectos de los Derechos de Propiedad Intelectual relacionados con el comercio

Agencia Española de Protección de Datos

Auto del Juzgado de lo Mercantil

Audiencia Pronvincial

RD de 3 de febrero de 1881, de promulgación de la Ley de Enjuiciamiento Civil

Ley 11/1986, de 20 de marzo, de Patentes

Apartado

Artículo

Auto Tribunal Supremo

Boletín Oficial del Estado

Capítulo

Constitución Española

Código Civil

Comunidades Autónomas

Comunidades de Propietarios

Código de Comercio

Consejo General del Poder Judicial

Citada

Confróntese

Code Of Federal Regulations

Directiva 2004/48/CE, del Parlamento Europeo y del Consejo, de 29 de abril de 2004, relativa al respeto de los derechos de propiedad intelectual

Edic.

Edición

Edit

Editorial

Etc.

Etcétera

FAA
Federal Arbitration Act 
F.j.

FRCP

JCA

JMER

JPI

Ley 19/2006

Ley $21 / 2014$

Ley 42/2015

LABP

\section{LAJ}

LAJG

LC

LCD

LCDCE

LCS

LEC

LECRIM

LGT

LJCA
Fundamento Jurídico

Federal Rules Of Civil Procedure

Juzgado de lo Contencioso-administrativo

Juzgado de lo Mercantil

Juzgado de Primera Instancia

Ley 19/2006, de 5 de junio, por la que se amplían los medios de tutela de los derechos de propiedad intelectual e industrial y se establecen normas procesales para facilitar la aplicación de diversos reglamentos comunitarios

21/2014, de 4 de noviembre, por la que se modifica el Texto Refundido de la Ley de Propiedad Intelectual, aprobado por el Real Decreto Legislativo 1/1996, de 12 de abril, y la Ley 1/2000, de 7 de enero, de Enjuiciamiento Civil

Ley $42 / 2015$, de 5 de octubre, de reforma de la Ley $1 / 2000$, de 7 de enero, de Enjuiciamiento Civil

Ley 41/2002, de 14 de noviembre, básica reguladora de la autonomía básica del paciente y de derechos y obligaciones en materia de información y documentación clínica

Letrado de la Administración de Justicia

LEY 1/1996, de 10 de enero, de asistencia jurídica gratuita

Ley 22/2003, de 9 de julio, concursal

Ley 3/1991, de 10 de enero, de competencia desleal

Ley 25/2007, de 18 de octubre, de conservación de datos relativos a las comunicaciones electrónicas y a las redes públicas de comunicaciones

Ley 50/1998, de 8 de octubre, de Contrato de Seguro

Ley 1/2000, de 7 de enero, de Enjuiciamiento Civil

Real Decreto de 14 de septiembre de 1882, aprobatorio de la Ley de Enjuiciamiento Criminal

Ley 9/2014, de 9 de mayo, General de Telecomunicaciones

Ley 29/1998, de 13 de julio, reguladora de la Jurisdicción Contencioso-administrativa 
LJV

LM

LN

LO

LO 6/1998

LOPD

LOPJ

LORC

LP

LPDI

LPH

LJRS

LSSI

Núm.

Ob.

$\mathrm{OMC}$

P.

P.p

PSSI

RD

RD Leg.

RMU

RN
Ley 15/2015, de 2 de julio, de la Jurisdicción Voluntaria

Ley 17/2001, de 7 de diciembre, de Marcas

Ley del Notariado, de 28 de mayo de 1862

Ley Orgánica

Ley Orgánica 6/1998, de 13 de julio, de reforma de la Ley

Orgánica del Poder Judicial

Ley Orgánica 15/1999, de 13 de diciembre, de Protección de

Datos del Poder Judicial

Ley Orgánica 6/1985, de 1 de julio, del Poder Judicial

Ley Orgánica 8/2003, de 9 de julio, para la Reforma Concursal

Ley 24/2015, de 24 de julio, de Patentes

Ley 20/2003, de 7 de julio, de Protección Jurídica del Diseño Industrial

Ley 49/1960, de 21 de julio, de Propiedad Horizontal

Ley 36/2011, de 10 de octubre, reguladora de la Jurisdicción Social

Ley 34/2002, de 11 de julio, de Servicios de la Sociedad de la Información y de comercio electrónico

Número

Obra

Organización Mundial del Comercio

Página

Páginas

Prestador de Servicios de la Sociedad de la Información

Real Decreto

Real Decreto Legislativo

Reglamento de la Marca de la Unión.

Decreto de 2 de junio de 1944, por el que se aprueba con carácter definitivo el Reglamento de la organización y régimen del Notariado 
SA

SAP

SRL

Ss.

SS

SSI

SSTC

STC

STMC

STS

T.

TC

TJUE

TMU

TRLGDCU

TRLPI

TRLSC

TS

TSJ

UE

Vid

Vol.
Sociedad Anónima

Sentencia Audiencia Provincial

Sociedad de Responsabilidad Limitada

Siguientes

Sentencias

Servicios de la Sociedad de la Información

Sentencias Tribunal Constitucional

Sentencia Tribunal Constitucional

Sentencia Tribunal Marca Comunitaria

Sentencia Tribunal Supremo

Tomo

Tribunal Constitucional

Tribunal de Justicia de la Unión Europea

Tribunal de Marcas de la Unión

Real Decreto Legislativo 1/2007, de 16 de noviembre, por el que se aprueba el texto refundido de la Ley General para la Defensa de los Consumidores y Usuarios y otras leyes complementarias

Texto Refundido de la Ley de Propiedad Intelectual, aprobado por RD Leg. 1/1996, de 12 de abril

Real Decreto Leg. 1/2000, de 2 de julio, por el que se aprueba el texto refundido de la Ley de Sociedades de Capital

Tribunal Supremo

Tribunal Superior de Justicia

Unión Europea

Véase

Volumen 


\section{INTRODUCCIÓN}

Uno de los temores a que principalmente se enfrenta quien pretende afrontar un proceso judicial, ante el desconocimiento de determinadas circunstancias de orden material y procesal, es el de la inseguridad del correcto planteamiento de la cuestión. En determinadas circunstancias, este desconocimiento conduce al inicio de un procedimiento que podría haberse evitado.

Pero, el ordenamiento jurídico español, consciente de la dificultad que para el administrado puede conllevar el acceso al conocimiento de dichas circunstancias, generalmente, por la ausencia de colaboración de quien las conoce, en el ámbito de la jurisdicción civil, pone a su disposición un mecanismo procesal que bajo el nombre de diligencias preliminares, en la actualidad, se encuentra regulado en los arts. 256 y ss. LEC. Como se verá, la finalidad de tal institución es doble: preparar el futuro proceso y, en su caso, evitar el mismo.

No obstante, y pese a la atractiva utilidad de la institución que acaba de apuntarse, veremos cómo las diligencias preliminares no han tenido la utilidad o éxito en su uso esperado. De hecho, bajo el imperio de la ALEC, cayeron en el práctico desuso y pese a que la LEC pretendió dar un impulso renovado de la institución, en la actualidad las diligencias preliminares siguen siendo vistas como un elemento extraño y de escasa utilidad práctica.

Ante esta realidad, muchos se preguntarán por qué acometer un estudio detallado de una institución que padece tales males y que parece continuar en la senda del fracaso. La respuesta no es otra que la confianza en la misma y en la utilidad que de ella se predica, bajo el convencimiento de que su estudio detallado contribuirá a clarificar su regulación y, por tanto, a allanar el terreno de quienes se planteen hacer uso de las diligencias preliminares.

Partiendo de esta premisa, a través del análisis de la regulación que desarrolla esta institución así como de la doctrina científica y judicial que se ha detenido en su 
estudio, al tiempo que ha despejado algunas lagunas legales, pretendemos ofrecer una visión detallada de la misma, desde el análisis del concepto, la naturaleza jurídica, la tipología y el procedimiento hasta las implicaciones de mayor calado, incluso constitucional, relativas a la importancia de la colaboración del requerido a la práctica de las mismas y la posibilidad de su realización forzosa, entre otras.

En esta tesis no se incorpora un capítulo dedicado al derecho histórico porque se ha querido centrar en la nueva regulación de la LEC, aún cuando si ciertas notas relativas a sus precedentes más inmediatos. Tampoco se ha introducido un apartado de derecho comparado, al encontrarnos ante una institución de tradición española, aunque si referencias puntuales al derecho del common law, concretamente a la figura del discovery que en el derecho anglosajón sirve a la preparación del proceso civil, si bien en unos términos y con unos efectos, como veremos, ciertamente distantes de los que subyacen en las diligencias preliminares.

En concreto, esta tesis se desarrolla en cuatro capítulos diferenciados. En el primero, examinamos las líneas y postulados fundamentales de la institución partiendo de los criterios de interpretación que recoge el art. 3.1 CC para, posteriormente, puntualizar las diferencias que presenta respecto de otras figuras procesales que, en ocasiones, han sido consideradas afines a las diligencias preliminares. Tal labor interpretativa es la que permite introducirnos en la tan cuestionada naturaleza jurídica de las diligencias preliminares para, determinada ésta, posicionarnos sobre el carácter de numerus clausus o apertus que, en tantas ocasiones, ha determinado la admisión o inadmisión de las solicitudes deducidas. Nos encontramos ante un capítulo fundamental en el que, además, se estudian los pilares esenciales de la institución: la adecuación a la finalidad perseguida, la justa causa y el interés legítimo que debe concurrir en toda solicitud de diligencias preliminares para ser admitida. Finalmente, también es objeto de estudio del referido capítulo la cuestión relativa al ofrecimiento y prestación de la caución, como condición sine qua non para la admisión de las diligencias preliminares.

Con la premisa del análisis de los postulados y pilares fundamentales que inspiran las diligencias preliminares, se dedica el capítulo segundo al estudio en 
profundidad del catálogo de diligencias preliminares que se contiene en el art. 256.1 LEC y, por remisión de esta, de las diligencias de comprobación de hechos contenidas en las leyes especiales. Así, partiendo de la más habitual de las diligencias preliminares, la de declaración o exhibición documental sobre hechos relativos a la capacidad, representación o legitimación de la persona frente a quien se dirigirá la demanda (art. 256.1.1 LEC), nos adentramos en el estudio de la diligencia de exhibición de cosas (art. 256.1.2 LEC) donde abordamos cuestiones que han generado un importante y dilatado debate doctrinal, tales como la posibilidad de extensión de la diligencia a las cosas inmuebles o los documentos. Siguiendo el orden establecido en el catálogo de la LEC continuamos con el estudio de las diligencias de exhibición de actos de última voluntad (art. 256.1.3 LEC), con el análisis de la extensión de su objeto a otras realidades actuales, y de documentos o cuentas de sociedades o comunidades (art. 256.1.4 LEC), cuya utilidad práctica nos mostrará la flexibilidad de su aplicación a una diversidad de supuestos. Cerrando el estudio de las diligencias preliminares tradicionales, salvedad hecha de las contenidas en leyes especiales, acometemos el estudio de la diligencia de exhibición del contrato de seguro (art. 256.1.5 LEC) con especial referencia a su relación con la acción directa contemplada en la LCS.

Llegados a este punto, continúa nuestro estudio con el de las diligencias contenidas en el referido catálogo que, no encontrándose en el texto original de la LEC, o sin precedentes en la ALEC, han sido introducidas con ocasión de las sucesivas reformas legales como consecuencia de las necesidades que la práctica cotidiana y evolución del Derecho han puesto de manifiesto. En dicho sentido, la diligencia de exhibición y entrega de la historia clínica (art. 256.1.5 bis LEC) cuyo reconocimiento, pese al criterio de numerus clausus, se produjo en la doctrina judicial previamente a su introducción expresa en el catálogo legal y respecto de la cual efectuamos un amplio examen hasta la fecha no realizado. También la diligencia de concreción de los integrantes del grupo de consumidores y usuarios (art. 256.1.6 LEC), la que constituye el máximo exponente del criterio de interpretación flexible de las diligencias preliminares propugnado en la doctrina. 
Por último, se dedica el capítulo segundo al estudio de las diligencias preliminares especiales en cuanto atañen a las dispuestas por el legislador para la preparación de los procesos por infracción de los derechos de propiedad intelectual e industrial cuyo conocimiento corresponde, en exclusiva, a los JMER. En dicho sentido, las diligencias para la obtención de datos en materia de propiedad industrial o intelectual sobre el posible infractor, el origen y redes de distribución de las obras, mercancías o servicios que infringen los derechos de propiedad intelectual o industrial, para la preparación de procesos por infracciones cometidas mediante actos que no puedan considerarse realizados por meros consumidores finales de buena fe y sin ánimo de obtención de beneficios económicos o comerciales (art. 256.1.7 LEC) y la diligencia de exhibición de documentos bancarios, financieros, comerciales o aduaneros, para la preparación de procesos por infracciones de los mismos derechos cometidas mediante actos desarrollados a escala comercial (art. 256.1.8 LEC). También, las diligencias y averiguaciones para la protección de determinados derechos previstos en las leyes especiales (art. 256.1.9 LEC), en suma, las diligencias de comprobación de hechos cuya referencia la marca la LP. Y, por último, la importante novedad, hasta la fecha no analizada conjuntamente con el resto, de las diligencias destinadas a la preparación de los procesos por infracciones de los derechos especiales cometidas "en línea" para la identificación del PSSI (art. 256.1.10 LEC) y del usuario de SSI (art. 256.1.11 LEC).

El capítulo tercero constituye el bloque esencialmente procesal del trabajo, al dedicarse al procedimiento, cauce a través del cual se podrá dar curso a la solicitud de diligencias preliminares hasta la resolución que ponga fin al mismo, con tratamiento de todas las incidencias que pueden producirse durante su desarrollo. En este capítulo tienen especial relevancia el tratamiento detallado de la competencia del órgano judicial, el trámite de oposición y la negativa a la práctica de las diligencias preliminares, en cuyo epígrafe se hace un detenido estudio de la entrada y registro como consecuencia específica a la negativa a la práctica de determinadas diligencias preliminares. Las implicaciones constitucionales de tal consecuencia, la importante crítica que en la doctrina científica y judicial la misma ha tenido y la ausencia de pronunciamiento al respecto del TC, pese a las oportunidades habidas, hacía necesario tal estudio. 
Por último, hemos dedicado el capítulo cuarto a un aspecto de las diligencias preliminares, en cierta manera desatendido por la doctrina, pese a su relevancia, y que no es otro que el de la eficacia interruptiva de la prescripción extintiva que tienen respecto de las acciones ejercitadas en el ulterior proceso. Veremos en este capítulo las circunstancias que deben concurrir para que la prescripción pueda interrumpirse considerando los distintos supuestos en los que tal eficacia interruptiva no tendrá lugar.

La elaboración de esta tesis ha seguido una metodología dogmática, basada esencialmente en el estudio de la doctrina científica y judicial cuya dimensión práctica nos ha permitido analizar el resultado de la interpretación de la regulación de las diligencias preliminares y verificar el papel integrador de las lagunas legales que aquella ha tenido. Sin embargo, la reciente introducción en el catálogo del art. 256.1 LEC de las diligencias preliminares contenidas en sus ordinales $10^{\circ}$ y $11^{\circ}$, dedicadas a la preparación de los procesos por infracciones "en línea" de los derechos de propiedad industrial e intelectual, ha limitado el estudio efectuado a las escasas aportaciones doctrinales e interpretaciones judiciales habidas hasta la fecha respecto de las mismas. Veremos si el transcurso del tiempo colma esta carencia y si, con la finalidad pretendida con su actuación en el catálogo legal, se termina por dispensar a los titulares de los derechos de propiedad industrial e intelectual de las medidas necesarias para una adecuada preparación de los procesos de dicha naturaleza.

Las fuentes jurídicas empleadas en la presente investigación son de carácter legal, doctrinal y judicial. Respecto a la primera fuente, destacamos el análisis de la actual LEC, y como precedente histórico específico de la institución, de la ALEC, con las citas necesarias del CC en el que se contienen los criterios básicos de interpretación. En cuanto a la segunda, en el presente trabajo se ha pretendido compendiar las opiniones científicas de mayor relevancia en todos y cada uno de los aspectos objeto del mismo, procurando integrarlas en un cuerpo único. Y en cuanto a la doctrina judicial, a falta de jurisprudencia, su compendio ha permitido obtener la pauta de la práctica forense marcada por la interpretación que de la norma han hecho los órganos judiciales. 
Con todo ello, esperamos que el presente estudio contribuya a la actualización de los tan escasos trabajos habidos al respecto de la institución, al menos en tanto que estudios totalizadores de su conocimiento y, por ende, a dar un paso más en la superación del olvido y decadencia que antaño padeció, actualizando las bases sobre las que se asienta, con la esperanza de que en un futuro no muy lejano el uso de las diligencias preliminares deje de verse como excepcional en la práctica ordinaria de los tribunales. A tal efecto, y como es de esperar de un estudio de la naturaleza del que nos ocupa, proponemos o sugerimos una serie de mejoras o reformas legales que entendemos pueden ayudar a clarificar el estado de la cuestión pues, sin desconocer la extraordinaria riqueza de conocimiento que proporciona la interpretación doctrinal, a nuestro juicio, es un hecho innegable que la positivización de esta nos conduce a la siempre ansiada seguridad jurídica. 


\section{CAPÍTULO I. APROXIMACIÓN A LA INSTITUCIÓN PROCESAL}

La solución de un conflicto entre particulares con visos de ser judicializado mediante la interposición de la demanda rectora del procedimiento civil pasa por un proceso de estudio, análisis, valoración y acopio de materiales e información que, en un futuro, permita la preparación del proceso en que aquel pueda derivar o, en su caso, su evitación.

Aquel que pugna por la solución del conflicto no siempre tendrá a su disposición todos los datos y elementos necesarios que, extraprocesalmente, le permitan valorar tanto el alcance y posibilidades de resolución del mismo como, en caso de que esto último no sea posible, la estrategia procesal y sustantiva a proyectar en el ejercicio del derecho a la tutela judicial efectiva, reconocida en el art. $24 \mathrm{CE}$, mediante el acceso al juez, al proceso y al procedimiento. En suma, no siempre tendrá a su disposición todos aquellos elementos de información que le permitan valorar la viabilidad procedimental de una determinada contienda judicial al margen de cualquier exigencia de naturaleza puramente probatoria.

Por ello, y al margen del trabajo de campo y casi de investigación detectivesca que se efectúe por el interesado o su defensa legal en el más estricto ámbito privado ${ }^{1}$, en

\footnotetext{
${ }^{1}$ Así lo pone de manifiesto el AAP de Madrid, (sección 19a) de 13 de septiembre de 2005, ponente Ilmo. Sr. N. Díaz, f.j.1 ${ }^{\circ}$ (LA LEY 175959/2005) cuando señala: “(...) si bien el proceso penal va acompañada de una fase previa, instrucción o fase preliminar, encomendada a un órgano público, dirigida a preparar el juicio oral, en atención a la naturaleza de los intereses en él tutelados, diferentes a los que se tutelan en el proceso civil, preponderantemente, en éste, derechos subjetivos e intereses privados, lo que conlleva que la actividad preparatoria se confíe a las partes, a realizar privadamente sin intervención de ningún órgano público, así con carácter general, constituyendo excepción a esa regla general los supuestos que contempla el citado art. 256 LEC, que tienden bien a preparar el posterior juicio en relación tanto con la sentencia de fondo que se pretenda como en cuanto a evitar que se de sentencia absolutoria en la instancia; excepcionalidad la antes indicada que ya se recoge en la exposición de motivos de la Ley 1/2000 al señalar, aptdo. X, "Por un lado, se amplían las diligencias que cabe solicitar, aunque sin llegar al extremo de que sean indeterminadas", y que impide la aplicación analógica de los supuestos previstos a otros distintos (...)". En la doctrina científica, Bellido Penadés, R., Comentario al artículo 256 LEC, en "Proceso Civil Práctico", T.III, edit. Lex Nova,Valladolid, 2002, p. 5-4 cuando apunta que en proceso civil, en contraposición al proceso penal, "de ordinario la necesaria actividad de preparación del proceso se confía a las partes y a sus abogados, los cuales deberán realizarla privadamente, sin contar con la intervención ni auxilio de un órgano público" siendo excepcional, en el proceso civil, la intervención de
} 
orden a preparar en la forma más adecuada la solución del conflicto y habida cuenta la notoria dificultad y, en ocasiones, imposibilidad del administrado de conseguir, por sus propios medios, tales necesarios elementos, el ordenamiento procesal civil, consciente de la tutela que merece tal situación de desamparo no consecuente con el derecho a la tutela judicial efectiva, articula una herramienta excepcional que, por la doctrina más autorizada, ha sido y es estudiada en el ámbito de los actos previos del proceso $^{2}$ y a la que el administrado puede acudir en determinados supuestos.

Nos estamos refiriendo a las diligencias preliminares, herramienta procesal destinada a una preparación adecuada del proceso que permita dotarlo de mayor eficacia y, en su caso, evitarlo, regulada en los arts. 256 y ss. LEC y que, hasta la entrada en vigor de la LEC, fue uno de los institutos más descuidados e infrautilizados de nuestro ordenamiento procesal civil $^{3}$, pese a ser una institución de honda raigambre en el derecho español.

No obstante, y en respuesta al declive que las diligencias preliminares sufrieron bajo la vigencia de la ALEC, el legislador acometió una importante renovación de las mismas presentando en la LEC, sus modificaciones posteriores y leyes especiales, un conjunto de diligencias dotadas de una mayor efectividad práctica que, en la doctrina científica y judicial, además de en la práctica forense, siguen suscitando numerosos interrogantes.

un órgano jurisdiccional que auxilie "en la obtención de la información precisa para la preparación del proceso que se pretende iniciar".

${ }^{2}$ Díez-Picazo Giménez, I., Las diligencias preliminares, en "Curso de Derecho Procesal Civil II. Parte Especial”, edit. Ramón Areces, Madrid, 2014, pp. 36-42; Moreno Catena, V., Derecho Procesal Civil. Parte General, $6^{a}$ edic., edit. Tirant Lo Blanch, Valencia, 2012, pp. 118-124; Asencio Mellado, J.M., Derecho Procesal Civil, $2^{\mathrm{a}}$ edic., edit. Tirant Lo Blanch, Valencia, 2012, pp. 36-41; Montero Aroca, J., Derecho Jurisdiccional II. Proceso Civil, $20^{a}$ edic., edit. Tirant Lo Blanch, Valencia, 2012, pp. 185-191; Gimeno Sendra, V., Derecho Procesal Civil. I. El proceso de declaración. Parte General, $4^{a}$ edic., edit. Colex, Madrid, 2012, pp. 269-293; Ramos Méndez, F., Enjuiciamiento Civil. Cómo gestionar los litigios civiles, T.II, edit. Atelier, Barcelona, 2008, pp. 1145-1155.

${ }^{3}$ Así lo ponen de manifiesto, por ejemplo, Garnica Martín, J.F., De las diligencias preliminares, en "Comentarios a la Nueva Ley de Enjuiciamiento Civil. Art. 1 al 280", coords. Miguel Ángel Fernández Ballesteros, José María Rifá-Soler, José Francisco Valls Gombau, Iurgium Editores, Barcelona, 2000 (LA LEY 2227/2007), p. 1145 y Garciandía González, P.M., La regulación de las diligencias preliminares en la ley de Enjuiciamiento Civil de 2000, en "Homenaje a Don Eduardo Font Serra", edit. Centro de Estudios Jurídicos, Tomo I, Madrid, 2004, p. 774; en la doctrina judicial, el AAP de Jaén (sección $3^{\text {a }}$ ) de 4 de diciembre de 2003, ponente Ilmo. Sr. J.M ${ }^{\text {a }}$. Passolas, f.j. $1^{\circ}$ (JUR 2004l20056) con cita del aptdo. X de la Exposición de Motivos de la LEC. 
Por ello, a través de la aplicación de los criterios de interpretación que recoge nuestro Código Civil, comenzaremos por indagar en el espíritu y finalidad de la norma, intentando ofrecer un concepto de las diligencias preliminares que se ajuste a su realidad esencial: su finalidad.

\section{Aplicación de los criterios de interpretación}

La aproximación al concepto de diligencias preliminares debe comenzar por la interpretación de la norma que acoge la institución. Esta operación jurídica básica de búsqueda del sentido o significado de las diligencias preliminares, en principio, a través del texto que las exterioriza, nos permitirá decidir y tomar posición sobre la institución procesal objeto de estudio, sirviéndonos para dicha tarea del instrumento de los criterios hermenéuticos contenidos en el art. 3.1 del Código Civil, que señala que "las normas se interpretaran según el sentido propio de sus palabras, en relación con el contexto, los antecedentes históricos y legislativos, y la realidad social del tiempo en que han de ser aplicadas, atendiendo fundamentalmente al espíritu y finalidad de aquellas”.

\subsection{Los criterios gramatical y contextual}

Tomando como punto de partida el anterior precepto legal, y comenzando por la interpretación de la norma según el sentido propio de sus palabras, o criterio de interpretación gramatical ${ }^{4}$, cabe reseñar que es el primero de los artículos que la LEC dedica a las diligencias preliminares, el art. 256.1, el que nos ofrece la nota esencialmente caracterizadora de las mismas cuando dispone: "Todo juicio podrá prepararse...". Así, la norma hace descansar el concepto de diligencias preliminares en el verbo "preparar" que, de forma evidente, "es el que mejor se acerca a definir el sentido de las diligencias preliminares"5. Por tanto, en una primera aproximación

\footnotetext{
${ }^{4}$ Así lo denominan Díez-Picazo, L. y Gullón, A., Sistema de Derecho Civil, Tecnos, $9^{a}$ edic., Vol. I, Madrid, 1998, p. 165.

${ }^{5}$ Carnero Sobrado, J.I., La flexibilización del carácter numerus clausus de las diligencias preliminares en la reciente jurisprudencia, en "Diario La Ley", 2012, núm. 7960, p.1. También Ramos Méndez, F., Enjuiciamiento Civil. Cómo..., ob. cit., p. 1145 cuando apunta que la finalidad confesada de las diligencias preliminares sería preparar el juicio.
} 
gramatical a la norma, podemos señalar que las diligencias preliminares tienen la función de preparar.

Sentado lo anterior, la interpretación derivada del criterio gramatical debe ser completada por el contextual ${ }^{6}$, que permite la relación del verbo "preparar" con el sustantivo "juicio" que le precede. Al tiempo, considerando la ubicación sistemática de la regulación legal de la institución, en el Capítulo II del Título I ("De las disposiciones comunes a los procesos declarativos") del Libro II ("De los procesos declarativos"), arts. 256 a 263 de la LEC, y previa reseña en la Exposición de Motivos, que caracteriza las diligencias preliminares como "medidas eficaces para la preparación del proceso".

La aplicación de los anteriores parámetros a la regulación que la LEC hace de las diligencias preliminares nos permite afirmar, continuando en la labor interpretadora de la norma, que aquello que la institución permite preparar, más que el juicio es el proceso $^{7}$, y más concretamente, el proceso civil.

Es el proceso al que, al hilo de las diligencias preliminares, se refiere la Exposición de Motivos de la LEC atribuyendo a éstas la función de prepararlo. Por tanto, la referencia al "juicio" que contiene el art. 256.1 LEC debe entenderse hecha al proceso $^{8}$ pues en la LEC el término juicio tiene un sentido amplio que lo hace sinónimo de proceso $^{9}$. En caso contrario, se estaría reduciendo absurdamente la función de la institución limitando su virtualidad a un concreto acto procesal al que no

\footnotetext{
${ }^{6}$ Que, como indican Díez-Picazo, L. y Gullón, A., Sistema de Derecho..., ob. cit., p. 66, se dirige "a la fijación del sentido de una proposición entera, a través de la coordinación gramatical que dentro de ella tienen las diferentes palabras y su respectivo valor" así como la consideración de la "tradicional interpretación sistemática de la norma".

${ }^{7}$ En dicho sentido se pronuncia el AAP de Salamanca (sección $1^{\text {a }}$ ) de 29 de febrero de 2012, ponente Ilmo. Sr. J.R. González, f.j.2 $2^{\circ}$ (LA LEY 280744/2012), cuando aludiendo a la finalidad que persigue el solicitante de la diligencia preliminar indica que: "[...] esta no puede ser otra que la expresada por el propio art. 256 LEC: preparar un proceso de declaración (torpe e incorrectamente denominado "juicio")".

${ }^{8}$ En dicho sentido, Álvarez Alarcón, A., Las diligencias preliminares, en "Instituciones del nuevo proceso civil. Comentarios sistemáticos a la Ley 1/2000", Vol. II, coord. Jaume Alonso-Cuevillas Sayrol, edit. Difusión Jurídica, Barcelona, 2000, p. 58 que indicando lo que debe entenderse por "preparar" señala que: "la preparación a que se refiere el art. 256 se deduce del contenido de los números $1^{\circ}$ a $7^{\circ}$ de la misma norma, en cuya virtud consistente en la averiguación de los datos que resultan fundamentales al actor para formular y presentar la demanda correctamente, de modo que se pueda obtener una decisión sobre el fondo y no una absolución en la instancia".

${ }^{9}$ Así lo afirma Montero Aroca, J., Derecho Jurisdiccional II..., ob. cit., p. 228.
} 
necesariamente ha de llegarse en todo proceso y, menos aún, si el resultado de la práctica de las diligencias preliminares aconsejan lo contrario.

Por ello, puede afirmarse que, en el ámbito jurisdiccional civil, las diligencias preliminares son el mecanismo previsto por la ley procesal civil para la preparación de un proceso. Es decir, para la preparación del instrumento único y necesario a través del cual los órganos del Estado con potestad jurisdiccional cumplen la función que se les asigna constitucionalmente de juzgar y hacer ejecutar lo juzgado que contempla el art. 117 de la $\mathrm{CE}^{10}$.

Por tanto, las conclusiones que se derivan de la aplicación de los criterios de interpretación gramatical y contextual nos permiten alcanzar una primera nota definitoria de las diligencias preliminares, como un preludio del propio proceso, en ningún caso imprescindible, sino opcional o potestativo y sujeto al principio dispositivo" ${ }^{11}$, como se desprende del uso por el art. 256.1 LEC del verbo "podrá", cuya finalidad no es otra que la de preparar el juicio, como acción de juzgar y no como acto procesal.

\footnotetext{
${ }^{10}$ Siguiendo la definición de proceso ofrecida por Montero Aroca, J., Derecho Jurisdiccional II..., ob. cit., pp. 226-228.

${ }^{11}$ En dicho sentido, Gimeno Sendra, V., Derecho Procesal Civil. I. El proceso de declaración. Parte General, edit. Ediciones Jurídicas Castillo de Luna, Madrid, 2015, p. 352; Díez-Picazo Giménez, I., Las diligencias preliminares..., ob. cit., p. 36; Díaz Martínez, M., Las diligencias preliminares: supuestos y requisitos de la solicitud, en "Práctica de Tribunales", 2007, núm. 40, p. 1 (LA LEY 2228/2007). También, Garciandía González, P.M., La regulación de..., ob. cit., p.774 cuando señala que las diligencias preliminares tienen carácter facultativo, dependiendo su realización de la voluntad del futuro demandante; Bellido Penadés, R., Comentario al artículo...,ob cit., p. 5-5, que apunta que: "siendo necesaria la previa instancia de persona interesada para que se acuerden diligencias preliminares por un órgano jurisdiccional, no resulta legalmente preceptivo preparar el inicio del proceso civil mediante la práctica de estas diligencias previas" teniendo carácter facultativo; y Lorca Navarrete, A.M., La regulación de las diligencias preliminares en la nueva Ley de Enjuiciamiento Civil. Una regulación inconstitucional, en "Diario La Ley", 2000, núm. 6, p. 2 (LA LEY 21122/2001) cuando afirma que "las diligencias preliminares constituyen una facultad atribuida exclusivamente a quien se proponga demandar...". En la doctrina, judicial, el AAP de Burgos (sección $7^{\mathrm{a}}$ ) de 1 de octubre de 2002, ponente Ilma. Sra. M $^{\text {a }}$.E. Villimar, f.j. $2^{\circ}$ (ROJ AAP BU 386/2002) que las configura como una facultad atribuida exclusivamente a quien se proponga demandar con el objeto de obtener los datos necesarios para facilitar un proceso posterior, condicionar su existencia o, en su caso, asegurar la eficacia de la sentencia que en su día haya de dictarse. También, el AAP de Vizcaya (sección $3^{\text {a }}$ ) de 16 de julio de 2007, ponente Ilma. Sra. A. I. Gutiérrez, f.j.2 (LA LEY 201929/2007) cuando indica: “[...] Es indudable que las diligencias preliminares están sometidas al principio de justicia rogada. Eso significa que nunca pueden ser decretadas de oficio". Sobre el principio dispositivo, vid. Picó i Junoy, J., Los principios del nuevo proceso civil, en "Instituciones del nuevo proceso civil. Comentarios sistemáticos a la Ley 1/2000", Vol. I, coord. J. Alonso-Cuevillas Sayrol, edit. Difusión Jurídica, Barcelona, 2000, pp. 25 a 66.
} 
Aún más. En aplicación de dicho criterio de interpretación contextual, la regulación de las diligencias preliminares en los arts. 256 y ss. LEC debe ponerse en relación con otros preceptos legales contenidos en la misma y que nos llevan a afirmar que aquellas no sólo tienen la finalidad de preparar el futuro juicio sino también, y en su caso, de evitarlo. En otras palabras. Las diligencias preliminares en modo alguno, y necesariamente, tienen que desembocar en un proceso posterior, dado que es perfectamente posible y legítimo que su práctica determine la improcedencia de articular el proceso posterior ${ }^{12}$. La práctica de las diligencias preliminares no puede imponer la necesaria interposición del proceso que se pretende preparar. Ello, en lógica coherencia de su vinculación con las sanciones que prevé la LEC en su art. 247, para las actuaciones que procesalmente no se ajusten a las reglas de la buena fe o se desarrollen con manifiesto abuso de derecho o entrañando fraude de ley o procesal, o en su art. 394.2, para la litigación con temeridad, que a buen seguro tendrían lugar en el caso de excitarse un proceso civil previa solicitud, admisión y conclusión de la correspondiente diligencia preliminar cuyo resultado desaconsejara aquel.

Este contexto nos lleva a considerar, además del carácter preparatorio del proceso que puede atribuirse a las diligencias preliminares, su segunda nota definitoria. La de ser las diligencias preliminares actos tendentes, también, a la evitación del proceso $^{13}$.

En otro orden de cosas. Recordando que el criterio de interpretación contextual exige relacionar la norma en su contexto, no podemos obviar que el más inmediato de sus contextos es el de su ubicación sistemática en la LEC, concretamente, en el Capítulo

\footnotetext{
${ }^{12}$ Así se desprende del AAP de Zamora, (sección $1^{\text {a }}$ ) de 8 de enero de 2003, ponente Ilmo. Sr. A. Encinas, f.j.3 (LA LEY 4170/2003) cuando señala: "[...] es decir que no tienen estas diligencias que desembocar necesariamente en un proceso sino que es perfectamente legítimo el que, tras ese examen de los elementos documentales o documentadores solicitados, se opte por no ejercitar acción alguna".

${ }^{13}$ En dicho sentido, Damián Moreno, J., De las diligencias preliminares, en "Comentarios a la nueva Ley de Enjuiciamiento Civil", $2^{\mathrm{a}}$ edic., edit. Lex Nova, Valladolid, 2000, p. 1682 cuando expone "a veces, la oportunidad de incoar un determinado proceso depende de su resultado", en referencia al resultado de las diligencias preliminares. Así se desprende de lo prevenido por el AAP de Zamora, (sección 1a) de 8 de enero de 2003, ponente Ilmo. Sr. A. Encinas, f.j.3 (LA LEY 4170/2003) cuando señala: “[...] es decir que no tienen estas diligencias que desembocar necesariamente en un proceso sino que es perfectamente legítimo el que, tras ese examen de los elementos documentales o documentadores solicitados, se opte por no ejercitar acción alguna".
} 
II del Título I ("De las disposiciones comunes a los procesos declarativos") del Libro II ("De los procesos declarativos"), lo que nos puede llevar a pensar que las diligencias preliminares están destinadas a preparar, únicamente, los procesos declarativos contenidos en el Libro II de la LEC.

Sin embargo, la aplicación conjunta de los criterios de interpretación contextual y gramatical nos lleva a advertir que el propio tenor literal del art. 256.1 LEC se refiere a la preparación de todo juicio, mejor dicho, de todo proceso sin que en modo alguno se limite dicha actividad a la preparación de todo proceso declarativo. Así las cosas, cabe analizar en este punto lo que la doctrina se ha planteado en numerosas ocasiones. A saber, si las diligencias preliminares permiten, única y exclusivamente, la preparación de todo proceso declarativo o la preparación de todo tipo de proceso, declarativo, especial o incluso de ejecución.

$\mathrm{Al}$ respecto, nos encontramos con autores que afirman que, si bien su ubicación sistemática pudiera llevar a pensar que las diligencias preliminares son propias de los procesos declarativos, al venir incluidas en el Libro II LEC ("De los procesos declarativos"), la referencia legal a "todo juicio" permite afirmar una aplicabilidad general a todo tipo de procesos, incluidos los especiales, entre ellos los de ejecución ${ }^{14}$, máxime si se tiene en cuenta que el legislador no suele condicionar la naturaleza de la institución a su ubicación sistemática ${ }^{15}$.

Otros, sostienen que si bien es claro que las diligencias preliminares se pueden utilizar para la preparación de cualquiera de los procesos contenidos en el Libro II LEC,

\footnotetext{
${ }^{14}$ En dicho sentido, autores como Corbal Hernández, J.E., Diligencias preliminares (arts. 256 a 263), en "Práctica procesal civil, Brocá-Majada-Corbal", T.IV, 23a edic., edit. Bosch, Barcelona, 2014, p. 3496; Pérez Benítez, J.J., Efectos de las diligencias preliminares sobre el proceso ulterior: la negativa del requerido a llevar a cabo la diligencia acordada, en "Diario La Ley", 2006, núm. 6598, p. 8 (LA LEY 3969/2006); y Garnica Martín, J.F., De las diligencias preliminares..., ob. cit., pp. 1147-1148.

${ }^{15}$ En dicho sentido, Banacloche Palao, J., Las diligencias Preliminares, edit. Civitas, Madrid, 2003, p. 47, para quien no resulta significativa la colocación sistemática de las diligencias preliminares en el Libro II LEC ("De los procesos declarativos"), a los efectos de negar su aplicación a los procesos regulados en otros libros de la misma.
} 
no parece que esta consienta su uso en relación a los procesos especiales, además de ser su utilidad nula en los mismos ${ }^{16}$.

Sin embargo lo anterior, a nuestro juicio, no puede afirmarse que la finalidad de las diligencias preliminares sea la preparación, única y exclusivamente, de los procesos declarativos contenidos en el Libro II de la LEC.

Por un lado, coincidimos con la doctrina en que el legislador no suele condicionar la naturaleza de la institución a su ubicación sistemática. De hecho, en la práctica forense no se cuestiona la aplicación a los procesos especiales contenidos en el Libro IV LEC de las disposiciones generales contenidas en dicho Libro II, con la misma ubicación sistemática que las diligencias preliminares, en todo aquello no regulado específicamente en los mismos.

Por otro, el legislador ha sido taxativo cuando afirma, en referencia al proceso, que "todo juicio podrá prepararse", no siendo aconsejable establecer prohibición o limitación alguna donde la ley no lo ha hecho. Y la circunstancia de la escasa utilidad práctica de las diligencias preliminares en relación a los procesos especiales o de ejecución tampoco permite ir en contra de lo que aconseja ese primer criterio de interpretación que es el literal y que lleva a afirmar que todo juicio, en rigor jurídico, todo proceso, podrá prepararse mediante las diligencias preliminares previstas en el art. 256.1 LEC.

De hecho, y aún cuando no sea frecuente en la práctica, a modo de ejemplo podríamos resaltar la enorme utilidad práctica de la diligencia prevista en el art. 256.1 LEC en aquellos procesos de ejecución, bien sea judicial o extrajudicial, en el que el demandado haya fallecido con anterioridad a iniciarse el procedimiento de ejecución. En este supuesto en que el art. 540.1 LEC contempla que pueda despacharse la ejecución frente al que se acredite que es el sucesor de quien en dicho título aparezca como ejecutado y, en cuyo caso, la práctica de la diligencia preliminar podría permitir

\footnotetext{
${ }^{16}$ Álvarez Alarcón, A., Las diligencias preliminares..., ob. cit., p. 35.
} 
determinar la persona del sucesor frente al que pueda despacharse ejecución. Piénsese en aquellos supuestos en que, tras el dictado de la sentencia en un procedimiento declarativo, el demandante, posteriormente ejecutante, quiere dirigir la demanda frente a los sucesores del demandado y supone la condición de tales en determinadas personas. Igualmente en el caso de un procedimiento de ejecución de título no judicial, cuando el ejecutante quiera dirigir el procedimiento de ejecución frente a los sucesores de quien como deudor aparezca en el título.

O, en el ámbito de los procesos especiales, en el caso de la división judicial de la herencia, cuando quien se crea con derecho a la sucesión legítima deba formar inventario (art. 793 LEC) o pretenda la intervención del caudal hereditario (art. 792 LEC) en el que crea deba integrarse un bien que se encuentre en poder de otro heredero o legatario. En estos casos, la diligencia prevista en el art. 256.1.2 LEC permitirá conocer la existencia y localización del bien poseído para su inclusión en el inventario o su afección por las medidas de intervención, facilitando incluso la oposición por quien lo posea para el caso de entender que dicho bien no debe formar parte integrante de aquel.

Menos aplicación práctica, sin embargo, se advierte en el caso de los procedimientos especiales de juicio monitorio o cambiario que, por su propia naturaleza y efectos, presuponen el conocimiento de las circunstancias básicas para la correcta articulación de la pretensión que deben constar en los documentos que sirven de base a dichos procedimientos. A saber, las facturas, albaranes o cualquier otro documento propio del giro comercial así como los títulos cambiarios.

Por todo lo expuesto, y concluyendo en la aplicación del criterio de interpretación contextual de la norma que regula las diligencias preliminares, podemos terminar afirmando que las diligencias preliminares son el mecanismo previsto por la ley procesal civil para la preparación, o evitación, con carácter facultativo, de todo futuro proceso. 


\subsection{El criterio histórico}

Pero la interpretación de la norma debe avanzar con el siguiente de los criterios hermenéuticos que prevé el art. 3.1 del CC. El de sus antecedentes históricos y legislativos, desde los más remotos del Derecho Romano hasta los más próximos de la ALEC, precedente más inmediato de la actual LEC.

En el Derecho Romano, se identifican las actuales y más representativas diligencias preliminares como las de confesión en la interrogatio in iure o las de exhibición de la cosa en la actio ad exhibendum, desarrolladas posteriormente en Las Partidas. La Primera, en la Ley 1, Título 10, Partida III, bajo el título "De las preguntas que pueden fazer al demandador, e al demandado ante se comience el pleyto por demanda, e por respuesta" señalando que son de tal natura que si el demandador non las fiziesse en aquel tiempo e otrosi el demandado non respondiesse a ellas: que no podrían después yr adelante por el pleyto ciertamente ${ }^{17}$. La segunda, en la Ley 16, Título 2, Partida III, bajo el título "Que las cosas muebles que son demandadas, deuen parecer en juyzio" señalando "ca muchas vezesacaesceria que non podria el demandador ciertamente fazer su demanda, ninaduzir pruebas sobre ella, si la cosa que demandasse non fuesse mostrada ${ }^{18}$. Junto a ambos más representativos antecedentes, la Ley 17, Título 2, Partida III, bajo el título "Quales otras cosas deuen ser mostradas en juyzio" refiere actuaciones relativas a los supuestos de exhibición de testamento, evicción, cuentas en común y semejantes ${ }^{19}$.

Esta regulación de Las Partidas continuó vigente hasta llegar a uno de los más próximos precedentes, la Ley de Enjuiciamiento Civil de 1855 que recoge las diligencias preliminares en su art. $222^{20}$, proporcionando un tratamiento único a la

\footnotetext{
${ }^{17}$ Ley 1. Título X, Partida III.

${ }^{18}$ Ley 16, Título 2, Partida III.

${ }^{19}$ Ley 17, Título 2, Partida III.

${ }^{20}$ Según el art. 222 Ley de Enjuiciamiento Civil 1855: "El juicio ordinario podrá prepararse:

$1^{\mathrm{o}}$ Pidiendo declaración jurada el que pretende demandar, a aquel contra quien se propone dirigir la demanda, acerca de algún hecho relativo a su personalidad, sin cuyo conocimiento no pueda entrarse el juicio.
} 
institución, sólo destinada a la preparación de los juicios ordinarios, siempre que la petición se fundara en justa causa y con un claro carácter único y taxativo de las diligencias que podían practicarse. De este modo, fuera de los casos enunciados en dicho precepto legal, ninguna otra podría solicitarse salvo que pudiera "esponerse el actor á perder su derecho por falta de justificación" y en cuyo caso podría decretarse el examen del testigo o testigos que se encontraren en determinadas circunstancias personales de urgencia o riesgo de la vida ${ }^{21}$.

En modo similar, pero sin la limitación al proceso declarativo ordinario, pasaron las diligencias preliminares a su antecedente más inmediato, la ALEC, que expresamente las recogía en el art. $497^{22}$ y ss., bajo las modalidades de declaración jurada, exhibición de la cosa mueble, exhibición del testamento, codicilo o memoria testamentaria, petición de exhibición de títulos u otros documentos, para el caso de

\footnotetext{
$2^{\circ}$ Pidiendo la exhibición de la cosa mueble que en su caso haya de ser objeto de acción real que trate de entablar.

$3^{\circ}$ Pidiendo el que se crea heredero, coheredero o legatario, la exhibición de un testamento o codicilo.

$4^{\circ}$ Pidiendo el comprador, en el caso de evicción, la exhibición de títulos, u otros documentos, que se refieran a la cosa vendida; $5^{\circ}$ Pidiendo un socio o comunero la presentación de los documentos y cuentas de la sociedad o comunidad, al consocio o condueño que los tenga en su poder.

El Juez accederá en estos casos a la pretensión, si estima justa la causa en que se funda. Las demás las rechazará de oficio".

${ }^{21}$ Según el art. 223 Ley de 1885: "Fuera de los casos expresados en el artículo anterior, no podrá pedir el demandante posiciones, informaciones de testigos ni ninguna otra diligencia de prueba; salvo cuando por edad avanzada de algún testigo, peligro inminente de su vida, proximidad de una ausencia al punto con el cual sean difíciles ó tardías las comunicaciones, u otro motivo poderoso, pueda exponerse el actor á perder su derecho por falta de justificación, en cuyo caso podrá pedir, y el Juez decretará, que sea examinado el testigo ó testigos que estén en las circunstancias referidas, verificándose su examen del modo que se previene en los artículos 306 y siguientes de esta Ley."

${ }^{22}$ En atención al art. 497 ALEC: "Todo juicio podrá prepararse:

$1^{\circ}$ Pidiendo declaración jurada el que pretenda demandar a aquel contra quien se propone dirigir la demanda acerca de algún hecho relativo a la personalidad de éste, y sin cuyo conocimiento no pueda entrarse en el juicio.

$2^{\circ}$ Pidiendo la exhibición de la cosa mueble que, en s caso, haya de ser objeto de la acción real o mixta que trate de entablar contra el que tenga la cosa en su poder.

$3^{\circ}$ pidiendo el que se crea heredero, coheredero o legatario la exhibición del testamento, codicilo o memoria testamentaria del causante de la herencia o legado.

$4^{\mathrm{o}}$ Pidiendo el comprador al vendedor, o el vendedor al comprador, en el caso de evicción, la exhibición de títulos u otros documentos que se refieran a la cosa vendida.

$5^{\circ}$ Pidiendo un socio o comunero la presentación de los documentos y cuentas de la Sociedad o comunidad al consocio o condueño que los tenga en su poder, en los casos en que proceda con arreglo a derecho.

El juez accederá en cualquiera de estos casos a la pretensión si estimare justa causa en que se funde. No estando comprendida en ellos, la rechazará de oficio.

La providencia denegando la pretensión será apelable en ambos efectos".
} 
evicción de la cosa vendida, y petición de documentos y cuentas de la sociedad o comunidad por el socio o comunero, concurriendo justa causa y, nuevamente, con un evidente carácter taxativo y cerrado de las diligencias referidas.

Hasta este momento, la legislación precedente había venido recogiendo toda una serie de diligencias preliminares cuya finalidad esencial y evidente era la preparación del proceso posterior, sin distingo alguno entre declarativo, especial o ejecución y con la aislada salvedad de la regulación que de aquellas hizo el art. 222 de la Ley de Enjuiciamiento Civil de 1855 que las limitó no a los juicios declarativos sino única y exclusivamente a los ordinarios.

Ahora bien, es el art. 502 ALEC el que, aún de forma indirecta, introduce una nota distintiva de la finalidad de las diligencias preliminares y en relación a las regulaciones precedentes, al señalar que fuera de los casos expresados en el art. 497, “(...) no podrá el que pretenda demandar pedir posiciones, informaciones de testigos ni ninguna otra diligencia de pruebas...". De esta manera, el precedente histórico del art. 502 ALEC llevó a la doctrina científica y judicial a cuestionar si al carácter preparatorio del juicio que en el primer inciso del art. 497 ALEC se atribuye a las diligencias preliminares se le sumaba una finalidad probatoria de las mismas que, como más adelante se verá, al estudiarse la distinción de las diligencias preliminares de otros figuras, ha sido negada de forma prácticamente unánime.

Por ello, si bien podemos afirmar que los antecedentes históricos confirman el carácter preparatorio de todo juicio posterior que tienen las diligencias preliminares, no permiten concluir de forma unánime sobre la concurrencia de una finalidad probatoria que, además, en la actualidad, y como más adelante veremos, es tajantemente negada.

\subsection{La realidad social}

Otra cuestión que debe ser tenida en cuenta en la interpretación que se desarrolla es la de realidad social del tiempo en que esta norma ha de ser aplicada. En el caso, una realidad marcada por el referente inexistente bajo el imperio de la ALEC que constituye 
la CE, cuyo art. 118 impone a todos el deber de prestar la colaboración requerida por los jueces y tribunales en el curso del proceso y en la ejecución de lo resuelto así como a todos reconoce, en su art. 24, el derecho a la tutela efectiva de los jueces y tribunales en el ejercicio de los derechos e intereses legítimos, sin que, en ningún caso, pueda producirse indefensión.

$\mathrm{Y}$ es que este deber impuesto constitucionalmente, inexistente en las regulaciones previas a la LEC, subyace de forma importante en la regulación actual de las diligencias preliminares, cuyo éxito en buena medida depende de la intervención y colaboración del requerido a su práctica. A nuestro juicio, consciente de esto el legislador, que confiaba decididamente en los beneficios que podían procurar las diligencias preliminares ${ }^{23}$, apostó por dotar a las mismas de una mayor efectividad práctica reforzando el mandato constitucional con la introducción de una serie de consecuencias, de marcado carácter coercitivo, para el supuesto de negativa al cumplimiento de ese deber de colaboración. La experiencia previa de la ALEC había demostrado que la colaboración exigida por la propia dinámica de las diligencias preliminares, desprovista de sanción, había determinado el desuso de las mismas y, por tanto, su inutilidad.

Así, la regulación actual de las diligencias preliminares, bajo el mandato constitucional aludido y con la previsión legal de toda una batería de consecuencias de importante incidencia en la esfera de derechos del requerido a su práctica, pone en evidencia la necesidad de la colaboración de terceros administrados para que las mismas alcancen la finalidad preparatoria del procedimiento posterior.

Por tanto, el criterio hermenéutico de interpretación de la realidad social del tiempo en que han de ser aplicadas las normas, nos permite entender las diligencias

\footnotetext{
${ }^{23}$ Ello es puesto de manifiesto por Aguilera Morales, M., Las diligencias preliminares, en "Tribunales de Justicia: Revista española de derecho procesal”, 2001, núm. 4, pp. 25-26, cuando en relación a la regulación que en la LEC se hace de las diligencias preliminares señala que "la opción del legislador podría perfectamente haber pasado por prescindir de aquel instituto" encontrándose la razón de la regulación de la LEC "en el profundo convencimiento del legislador de que caben medidas eficaces para preparar el proceso", convencimiento que es expresado en la propia Exposición de Motivos de la LEC.
} 
preliminares como el mecanismo previsto por la ley procesal civil para la preparación de todo proceso posterior al que, facultativamente, podrá recurrir el que pretenda preparar dicho proceso posterior, para la obtención de determinados datos y en cuya consecución deberá colaborar aquel que resulte requerido a su práctica.

\subsection{El espíritu y finalidad de las normas o criterio teleológico}

Finalmente, en la interpretación de la norma no podemos olvidarnos, del tan aludido criterio del espíritu y finalidad de la norma que, en el caso, entronca con la consciencia del legislador de la imposibilidad de que el administrador, con los medios a su alcance, pueda en todo supuesto articular procesalmente el futuro proceso, situación esta que, en determinados supuestos, los recogidos en el art. 256.1 LEC, ha estimado digna de amparo introduciendo un mecanismo de auxilio judicial, de forma excepcional y en una fase previa al inicio del proceso. En definitiva, entendemos que la previsión legal de las diligencias preliminares en la LEC se debe a la consideración de la misma como una institución idónea para dar efectividad al derecho a la tutela judicial efectiva constitucionalmente reconocido ${ }^{24}$, lo que se refuerza con el deber de colaboración constitucionalmente impuesto por el art. $118 \mathrm{CE}$ que subyace en las mismas, en aras de no causar indefensión ${ }^{25}$. Como se verá posteriormente, y así se recoge en el art. 258.1 LEC, la concurrencia de justa causa en la petición de diligencias preliminares se traduce, en suma, en la imposibilidad del solicitante de obtener por otros medios la información pretendida con las mismas. Y si dicha información, necesaria para la preparación del futuro proceso, no puede ser obtenida por otros medios, obvio resulta que la intervención del juez, mediante las diligencias preliminares, se erige en una institución no sólo necesaria sino idónea para dar efectividad al derecho a la tutela judicial efectiva constitucionalmente reconocido. Ello, porque pese a no preverse de forma expresa en el art. 3.1 CC, la promulgación de la CE obliga a la interpretación de

\footnotetext{
${ }^{24}$ En dicho sentido, el AAP de Madrid (sección $10^{\text {a }}$ ) de 12 de noviembre de 2007, ponente Ilma. Sra. A.M. Olalla, f.j.3 $3^{\circ}$ (LA LEY 252724/2007) indica que para su adecuada comprensión "[...] ha de partirse del derecho constitucional al acceso al proceso como medio para obtener una tutela adecuada (S 24 mayo 1993, Sección 19 de la AP de Madrid), lo que implica que los órganos jurisdiccionales deben realizar una interpretación flexible, en el sentido más favorable a la efectividad de aquel derecho".

${ }^{25} \mathrm{La}$ influencia del art. $118 \mathrm{CE}$ en la regulación de las diligencias preliminares ha sido observada, entre otros, por Díaz Martínez, M., Las diligencias preliminares..., ob. cit., p. 2.
} 
toda norma de conformidad con la misma al incorporar aquella "el sistema de valores esenciales que ha de constituir el orden de la convivencia pacífica y de informar todo el ordenamiento jurídico" 26 .

\section{Las diligencias preliminares en la jurisprudencia y doctrina judicial}

Llegados a este punto, debe recordarse que la regulación que de las diligencias preliminares hacen los arts. 256 y ss. LEC, como parte del ordenamiento jurídico, debe ser complementada con la doctrina que, de modo reiterado, establezca el TS al interpretar la ley dado que el estudio de la jurisprudencia y doctrina judicial, como fuente del Derecho, constituye un medio de conocimiento del derecho positivo ${ }^{27}$. En este caso, del derecho positivo que tanto en la LEC como en las normas especiales se contiene de las diligencias preliminares.

Si se atiende al concepto estricto de jurisprudencia ${ }^{28}$ que exige la concurrencia, por lo menos, de dos fallos o sentencias de la Sala Civil del Tribunal Supremo que resuelvan recursos de casación, se advertirá pronto que ninguna se ha dado en tales condiciones respecto de las diligencias preliminares. Sólo el ATS de 11 de noviembre de 2002 ha apuntado un concepto de diligencias preliminares en el contexto de una cuestión de competencia planteada entre dos órganos unipersonales al señalar que "[...] pueden considerarse las diligencias preliminares como el conjunto de actuaciones de carácter jurisdiccional por las que se pide al Juzgado de Primera Instancia competente la práctica de concretas actuaciones para resolver los datos indispensables para que el futuro juicio pueda tener eficacia $[\ldots]^{\prime 29}$. Y tal afirmación puede hacerse porque aún

\footnotetext{
${ }^{26}$ STC 9/1981, de 31 de marzo de 1981, ponente Ilmo. Sr. R. Gómez-Ferrer, f.j.3º (LA LEY 6278$\mathrm{JF} / 0000)$.

27 Así lo pone de manifiesto Díez-Picazo, L. y Gullón, A., Sistema de Derecho..., ob. cit., p. 93, al analizar los distintos significados de la expresión "fuentes del Derecho".

${ }^{28}$ Un concepto al respecto se ofrece por Díez-Picazo, L. y Gullón, A., Sistema de Derecho..., ob. cit., pp. 152-153.

${ }^{29}$ ATS de 11 de noviembre de 2002 (sala $1^{\text {a }}$ ), ponente Ilmo. Sr. J.M. Martínez-Pereda, f.j.2 ${ }^{\text {o }}$ (LA LEY 222960/2002). No obstante, debe ponerse de manifiesto que pese a la cita que la resolución hace de la STS de 20 de junio de 1986 (sala 1 a), ponente Ilmo. Sr. J.L. Albácar (LA LEY 11145-JF/0000), señalando que :"[...] Ya la sentencia de esta Sala de 20 de junio de 1986, estimó tales diligencias como el conjunto de actuaciones dirigidas a aclarar las cuestiones que pudieran surgir antes del nacimiento de un proceso principal" tal estimación no se desprende literalmente de la resolución de referencia, si bien es acorde a la
} 
cuando el anterior ATS, y la doctrina judicial de forma reiterada, citan la STS de 20 de junio de $1986^{30}$ como aquella que bajo el imperio de la LEC 1881, definió tales diligencias como "[...] el conjunto de actuaciones dirigidas a aclarar las cuestiones que pudieran surgir antes del nacimiento de un proceso principal [...]" lo cierto es que en dicha resolución el TS no estableció doctrina alguna respecto del concepto de diligencias preliminares. En la STS de 20 de junio de 1986 y, más concretamente, en su fundamento de derecho primero, el TS se limitó a reproducir las conclusiones alcanzadas por la sentencia previamente dictada por la Audiencia Territorial de Granada, recurrida en casación. Tal error de cita ha sido arrastrado en numerosísimas resoluciones judiciales y posiciones doctrinales que señalan el ATS de 20 de junio de 1986 como el referente de definición de las diligencias preliminares en la doctrina judicial española ${ }^{31}$.

Ante dichas circunstancias, podemos sostener que, respecto a las diligencias preliminares, no existe esa doctrina interpretadora de la regulación que la LEC hace de las diligencias preliminares más si una abundante doctrina judicial que iremos examinando a lo largo del presente estudio y que, como se verá, definen las diligencias preliminares atendiendo a la finalidad específica de la institución ${ }^{32}$.

\footnotetext{
caracterización que de las mismas hizo algún insigne autor como Guasp, J., Derecho Procesal Civil, T. II. Parte Especial, $3^{\text {a }}$ edic., Instituto de Estudios Políticos, Madrid, 1968, pp. 659 y ss., que señala que "Las diligencias preliminares son precisamente el conjunto de actuaciones judiciales que se dirigen a aclarar las cuestiones que pueden surgir antes del nacimiento de un proceso principal".

${ }^{30}$ STS de 20 de junio de 1986 (sala 1ª), ponente Ilmo. Sr. J.L. Albácar, f.j.3 (LA LEY 11145-JF10000).

${ }^{31}$ Entre otras muchas, el AAP de Las Palmas (sección $5^{\text {a }}$ ) de 19 de abril de 2004, ponente Ilmo. Sr. J. Manrique de Lara, f.j. $3^{\circ}$ (LA LEY 90223/2004), cuando señala que "[...] cabe señalar que el Tribunal Supremo ha tenido la ocasión de precisar, aún cuando referida a la LEC de 1881, doctrina que, no obstante, permanece aún vigente, que las denominadas diligencias preliminares, que se contemplaban en los artículos 497 y siguientes de la señalada Ley Procesal Civil, actuales artículos 256 y siguientes, se conciben como un conjunto de actuaciones judiciales dirigidas a aclarar las cuestiones que pudieran surgir antes del nacimiento de un proceso principal [...]" y el AAP de Palma de Mallorca (sección $3^{\mathrm{a}}$ ) de 25 de noviembre de 2002, ponente Ilma. Sra. C. Moragues, f.j.1 ${ }^{\circ}$ (LA LEY 197295/2002), cuando define las diligencias preliminares como "[...] un conjunto de actuaciones judiciales que se dirigen a aclarar las cuestiones que pudieran surgir antes del nacimiento de un proceso principal, sin que puedan convertirse en diligencias de anticipación probatoria, lo que conlleva a enjuiciar su admisibilidad desde los principios de adecuación a la finalidad perseguida, justa causa e interés legítimo [...]".

${ }^{32}$ Garciandía González, P.M., La regulación de...., ob. cit., p. 774.
} 


\section{Las diligencias preliminares en la doctrina científica}

Esos criterios de interpretación a que antes nos referíamos son los que, a nuestro juicio, han servido de base a la doctrina científica para definir la institución que ahora nos ocupa como las "actuaciones que se postulan de los órganos judiciales y tienen por objeto lograr información acerca de circunstancias relativas a la personalidad del futuro demandado o a otros extremos que quien pretenda presentar una demanda precise conocer para la iniciación con éxito de un proceso civil, así como obtener documentos u objetos que resulten necesarios para entrar en dicho proceso"33; como "una suerte de actos de investigación sobre aspectos relativos al demandado o al objeto litigioso (en ocasiones también los propios demandantes), necesarios para que el actor pueda ejercitar cumplidamente su derecho constitucional a demandar, cuya petición no engendra obligaciones en el solicitado y cuya negativa a colaborar genera efectos en el proceso posterior, efectos que también provoca el resultado de su realización" ${ }^{34}$; como "actos de postulación de actos instructorios o de aseguramiento de la prueba, efectuados por el futuro demandante y dirigidos al Tribunal para poder preparar, en su caso, el posterior escrito de demanda" ${ }^{35}$; como "un conjunto de trámites a través de los cuales quien pretende preparar un juicio ulterior puede solicitar de la autoridad judicial la adopción y puesta en práctica, incluso de manera coactiva, de una serie de actuaciones tendentes a recabar de terceras personas diversas clases de datos e informaciones, relacionados todos ellos con este futuro proceso, que el solicitante de las diligencias no haya podido obtener por sí mismo, y que necesite conocer para poder fundamentar adecuadamente la pretensión que hará valer en dicho juicio posterior”; como “actuaciones previas a la incoación de un proceso posterior, adoptadas por la autoridad judicial a instancia de parte interesada, y con las que ésta intenta adquirir aquellos datos, informaciones o conocimientos necesarios para preparar debidamente el ejercicio de la pretensión procesal en aquel proceso y los que el futuro demandante no haya podido acceder en condiciones normales" 36 ; o como "aquellas actuaciones que pueden tener

\footnotetext{
${ }^{33}$ Moreno Catena, V., Derecho Procesal Civil..., ob. cit., p. 118.

${ }^{34}$ Asencio Mellado, J.M., Derecho Procesal Civil..., ob. cit., p. 37.

${ }^{35}$ Gimeno Sendra, V., Derecho Procesal Civil..., ob. cit., p. 271.

${ }^{36}$ Garberí Llobregat, J., Las diligencias preliminares en la Ley de Enjuiciamiento Civil, edit. Bosch, Barcelona, 2009, pp. 25-26.
} 
lugar antes de comenzar un proceso con el fin de obtener, a través de la intervención judicial, determinada información de carácter procesal o sustantivo sin la cual aquél no podría iniciarse sin el riesgo de incurrir en errores que conducirían bien a la inutilidad misma del proceso, bien al fracaso de las pretensiones ejercitadas" ${ }^{37}$.

Considerando las anteriores definiciones que fijan su atención en unos u otros aspectos más o menos destacables de las diligencias preliminares así como considerando las conclusiones interpretativas alcanzadas anteriormente, entendemos que las diligencias preliminares pueden definirse, en términos generales, como el mecanismo procesal que, facultativamente y en los supuestos previstos en el art. 256.1 LEC, puede ser utilizado por quien pretenda preparar, o evitar, todo futuro proceso civil.

\section{Distinción respecto de otras figuras afines}

Una constante en el estudio de las diligencias preliminares ha sido su distinción respecto de otras figuras con las que, en ocasiones, han sido confundidas ${ }^{38}$. Hablamos de la anticipación y aseguramiento de la prueba o las medidas cautelares.

La regulación de las diligencias preliminares en la ALEC y la presencia en dicha regulación de determinados elementos más asociados a otras instituciones que a las diligencias preliminares, unido a la propia finalidad preparatoria del proceso posterior, a nuestro juicio, son la fuente de la confusión. De hecho, bajo la vigencia de la ALEC, algún autor apunta que su deficiente regulación arranca en el legislador decimonónico que, no teniendo una idea clara del instituto, mezcló figuras muy diferentes del derecho histórico de origen romano, unas propias de diligencias preparatorias, otras cautelares, como el secuestro y depósito, y otras de la prueba anticipada ${ }^{39}$.

\footnotetext{
${ }^{37}$ Banacloche Palao, J., Las diligencias Preliminares ..., ob. cit., p. 17.

${ }^{38}$ Así lo ponen de manifiesto autores como Garciandía González, La regulación de..., ob. cit., p. 775 cuando señala que las diligencias preliminares han llegado a ser confundidas con otros institutos cercanos, anteriores también al inicio del proceso, como las medidas cautelares o la prueba anticipada.

${ }^{39}$ Alonso Furelos, J.M., La exhibición de cosa mueble en el Derecho Español, en "Revista Jurídica de Catalunya", 1991, núm. 2, pp. 401-402.
} 
Así, la regulación de las diligencias preliminares en la ALEC, cuyo art. 502 preveía la imposibilidad de solicitar diligencia alguna de prueba al margen de las previstas en el art. 497 ALEC, podía llevar a entender que dicho art. 497 ALEC y, en consecuencia, la clasificación precedente del actual art. 256.1 LEC, recogía toda una serie de diligencias tendentes a la obtención de determinadas pruebas que se consideraban imprescindibles para preparar el proceso. Además, cierto sector doctrinal ${ }^{40}$ señalaba que las diligencias preliminares admitían una actividad clara de investigación de datos relevantes para el juicio que, en algunos casos, podían traducirse, además, en pruebas $^{41}$. También la doctrina judicial se pronunció en dicho sentido definiendo las diligencias preliminares como "el conjunto de actuaciones judiciales encaminadas a proporcionar al demandante los medios para que pueda obtener la efectividad de la tutela judicial, respecto del derecho subjetivo que considere perjudicado, siendo un medio adecuado para obtener alguna fuente de prueba" ${ }^{42}$, llegándose a afirmar que "[...] en principio, el art. 497 de la Ley de Enjuiciamiento Civil, de cuya aplicación aquí se trata, establece una serie de medidas, que desarrolla luego, respecto a alguna de ellas (las tres primeras) individualmente, en los arts. que siguen hasta el 501 inclusive, y que se refieren al anticipo de prueba, antes del inicio del juicio oral [...]" ${ }^{43}$.

Por otro lado, la presencia en las diligencias preliminares de elementos tales como la caución, asociado tradicionalmente al procedimiento de medidas cautelares, unido a la finalidad preparatoria de las diligencias preliminares llevaron a advertir en ellas cierta finalidad de aseguramiento del resultado del procedimiento que se quería preparar. También aquí ciertos autores atribuyeron a las diligencias preliminares la

\footnotetext{
${ }^{40}$ Ramos Méndez, F., Enjuiciamiento Civil. Cómo..., ob. cit., p. 1146.

${ }^{41}$ En dicho sentido, Ruíz de Gordejuela López, L., Las diligencias preliminares, en "Cuadernos de Derecho Judicial", Vol. 6, edit. Consejo General Poder Judicial, Madrid, 2000, pp. 176-177, cuando afirma que: "Las diligencias preliminares pueden ser un medio adecuado para obtener alguna fuente de prueba", apuntando que "las diligencias preliminares no tienen como finalidad la de obtener pruebas pero facilitan el fundamental derecho a la prueba, sobre todo de aquellas que deben aportarse con la demanda". ${ }^{42}$ SAP de Zaragoza (sección $2^{\mathrm{a}}$ ) de 27 de febrero de 2001, ponente Ilma. Sra. M.E. Mata, f.j. $2^{\circ}$ (LA LEY 46729/2001).

${ }^{43}$ AAP de Navarra (sección $1^{\text {a }}$ ) de 23 de octubre de 1998, ponente Ilmo. Sr. R. Ruíz, f.j.2º (AC 199812003). Lo que se reitera en el AAP de Navarra (sección 1 1a) de 20 de mayo de 1999, ponente Ilmo. Sr. R. Ruíz de la Cuesta, f.j.2 (AC 19991840), cuando afirma que el art. 497 ALEC enumera las diligencias de prueba que las partes, que pretendan ser litigantes ante dicha jurisdicción, puedan solicitar, para preparar el juicio principal.
} 
finalidad cautelar cuando con ellas se tratara de asegurar lo que fuera objeto del futuro proceso $^{44}$.

No obstante lo anterior, también bajo la vigencia de la ALEC, la doctrina fue mayoritaria al distinguir las diligencias preliminares de otras instituciones procesales que han llegado a considerarse afines, como es el caso de la anticipación y el aseguramiento de la prueba y las medidas cautelares. No faltaron resoluciones judiciales que clarificaron la cuestión rechazando la naturaleza probatoria de las diligencias preliminares. Así, señalando que las mismas se orientan al esclarecimiento de los extremos seleccionados en el art. 497 ALEC, finalidad que “[...] no puede, sin embargo, subvertirse para preconfigurar determinadas probanzas con carácter previo a la iniciación del proceso y sin las garantía que a éste acompañan (singularmente la presencia de la parte contraria), cuando, precisamente, dichas pruebas encuentran perfecto acomodo en el procedimiento que corresponda" 45 .

Por ello, la delimitación del concepto de diligencias preliminares hace necesaria su distinción respecto de otras instituciones con las que, en ocasiones, tienden a confundirse.

\subsection{Prueba anticipada}

Como pone de manifiesto la doctrina científica, "existen determinadas situaciones en las que, ante el peligro de perder la fuente probatoria o deteriorarse los hechos en méritos de los cuales se solicitará, o se está solicitando, una determinada resolución judicial, es necesario anticipar la actividad probatoria antes del juicio o vista e, incluso, a un momento anterior a la presentación de la demanda" ${ }^{46}$.

\footnotetext{
${ }^{44}$ Damián Moreno, J., De las diligencias..., ob. cit., p. 1682.

${ }^{45}$ AAP de Cuenca (sección $1^{\mathrm{a}}$ ) de 21 de octubre de 1998, ponente Ilmo. Sr. L. Puente, f.j.1 ${ }^{\circ}$ (AC 199817927).

${ }^{46}$ Picó i Junoy, J., La prueba anticipada en la nueva Ley de Enjuiciamiento Civil, en "Diario La Ley", 2001, T.VII (LA LEY 1330/2002), p. 2.
} 
En dicho sentido, dispone el art. 293 LEC que: "Previamente a la iniciación de cualquier proceso, el que pretenda incoarlo, o cualquiera de las partes durante el curso del mismo, podrá solicitar del tribunal la práctica anticipada de algún acto de prueba, cuando exista el temor fundado de que, por causa de las personas o por el estado de las cosas, dichos actos no puedan realizarse en el momento procesal generalmente previsto".

De lo anterior, claramente se desprende que el fundamento y finalidad de la prueba anticipada no es otro que la celebración de una diligencia de prueba cuando hay la existencia de un temor fundado de que no pueda realizarse en el momento procesal oportuno $^{47}$. Es decir, en el acto del juicio, lo que nada tiene que ver con la posibilidad, con carácter previo al inicio del posible proceso, aún cuando no seguro, de instar el correspondiente auxilio judicial para recabar ciertos hechos, elementos, datos e informaciones necesarios cuyo conocimiento quepa la posibilidad de entender indispensable para, en su caso, iniciarlo correctamente.

Y esta necesaria distinción ha sido puesta de manifiesto en distintas resoluciones judiciales que señalan que "[...] no cabe confundir estas especiales diligencias con las de anticipación y aseguramiento de la prueba, ahora reguladas en los arts. 293 y ss., cuyos presupuestos, ámbito y finalidad son claramente divergentes" ${ }^{48}$, o que: “[...] no debe confundirse diligencias preliminares con prueba anticipada ya que son dos figuras diferentes, las diligencias preliminares tienen por objeto preparar un juicio y la prueba anticipada persigue constatar un hecho necesario para la prosperabilidad de la pretensión, cuando exista un temor de que no puedan realizarse dentro del proceso, artículo 293 de la LEC, y siendo claro el matiz existente entre ambas figuras procesales,

\footnotetext{
${ }^{47}$ Como señala Álvarez Alarcón, A. Las diligencias preliminares..., ob. cit., p. 29, la prueba anticipada persigue "la realización de una prueba que más tarde, cuando llegue su ocasión en la correspondiente fase probatoria, seguramente no se podrá producir".

${ }^{48}$ AAP de Barcelona (sección $4^{\mathrm{a}}$ ) de 10 de junio de 2008, ponente Ilma. Sra. M.M. Hernández, f.j. $1^{\circ}$ (LA LEY 129981/2008).
} 
es mucho mas la diferencia de estas dos figuras con la carga probatoria del artículo 217 de la LEC, que se desenvuelve dentro del proceso...." ${ }^{49}$.

Sin perjuicio de lo anterior, resulta que más allá del mero carácter de acto previo, existen otros argumentos que permiten ahondar en la diferencia de ambas instituciones. Así, mientras que la prueba anticipada tiene el verdadero carácter de acto procesal, las diligencias preliminares carecen del mismo. A diferencia de lo que sucede con la práctica de una diligencia de prueba, las diligencias preliminares no se producen en el marco de un proceso y no son propias de éste. La prueba es una actuación puramente procesal que está llamada a desplegarse en el seno de un proceso sin cuya existencia éste no tendrá validez alguna, y aún cuando, por las razones antes expuestas, se pueda anticipar su práctica al momento procesal y oportunamente procedente. Por el contrario, la diligencia preliminar, ni tiene el carácter de acto del proceso ni implica la existencia posterior de éste que, eventualmente, y en función tanto del resultado de la diligencia preliminar, como de otras circunstancias, puede tener lugar o no.

Además, la prueba anticipada, que no deja de ser prueba, conforme a lo dispuesto en el art. 289.1 LEC, ha de practicarse contradictoriamente, como así lo constata el art. 295 LEC al disponer que cuando se solicite y se acuerde practicar antes del inicio del proceso, se citará a su práctica a las personas que el solicitante indique se proponga demandar, con posibilidad incluso de su repetición circunstancial si fuera posible y alguna de las partes así lo solicitare (art. 295.4 LEC). Ello choca con la posible práctica de las diligencias preliminares en ausencia del solicitado, conforme permite el art. 261 LEC e, incluso, sin que la persona de éste tenga por qué coincidir con el futuro y eventual demandado o parte del proceso, al ser perfectamente posible que el resultado de la correspondiente diligencia preliminar determine la necesidad de demandar o traer al proceso a quien no fue parte de la misma.

Con lo anterior queda clara la distinción que taxativamente ha sido afirmada por la doctrina ${ }^{50}$ entre la prueba anticipada y respecto de la diligencia preliminar señalando

\footnotetext{
${ }^{49}$ AAP de Valencia (sección 11 ${ }^{\text {a }}$ ) de 22 de octubre de 2007, ponente Ilmo. Sr. A.F. Giménez f.j.2 ${ }^{\circ}$ (LA LEY 288126/2007).
} 
que "ésta tiene por finalidad preparar el proceso, mientras que la prueba anticipada no pretende preparar nada, ni tan sólo la prueba, ya que con ella se procede a su práctica, si bien anticipadamente al momento del juicio o la vista"51 apuntando que entre la diligencia preliminar y la prueba anticipada al inicio del juicio, “existe una fundamental diferencia en cuanto a la fundamentación de una y otra medida, pues mientras aquélla debe servir a la preparación del proceso, obteniendo una información que se precisa para la confección de la demanda, la segunda persigue la realización de una prueba que más tarde, cuando llegue su ocasión en la correspondiente fase procesal, seguramente no se podrá producir ${ }^{52}$ ".

\subsection{Aseguramiento de la prueba}

Se afirma en la doctrina que "la prueba es la actividad procesal clave en la historia de todo pleito, pues de ella depende que el juez logre su convencimiento acerca de los hechos litigiosos y aprecie o desestime las pretensiones formuladas por las partes" ${ }^{\prime 3}$.

Y habida cuenta lo acertado de esta afirmación, en tanto que el derecho a utilizar los medios de prueba pertinentes para la defensa es uno de los reconocidos constitucionalmente (art. $24 \mathrm{CE}$ ), que configura el proceso y por el que el juez o tribunal tiene que velar so pena de causar indefensión, es por lo que a nuestro juicio debe entenderse que el legislador introdujera en la LEC la institución del aseguramiento de la prueba, distinta de las diligencias preliminares y de la prueba anticipada antes examinada, pero estrechamente relacionada con esta última. Así se infiere del art. 297 LEC, que en su aptdo. $1^{\circ}$ dispone que: “Antes de la iniciación de cualquier proceso, el

\footnotetext{
${ }^{50}$ Díez-Picazo Giménez, I., Las diligencias preliminares..., ob. cit., p. 36, afirma que: "Las diligencias preliminares no constituyen prueba anticipada, aunque en algunos casos la frontera entre ambas instituciones sea borrosa. Mientras el fundamento de la prueba anticipada está en el riesgo de que si se espera a la práctica de un medio de prueba en su momento procesal normal, la misma puede ser imposible, el fundamento de las diligencias preliminares está en la imposibilidad de que el futuro demandante obtenga por sí mismo y sin auxilio de la autoridad judicial ciertos datos necesarios para poder presentar una demanda".

${ }_{51}^{5}$ Picó i Junoy, J., La prueba anticipada..., ob. cit., p. 3.

52 Álvarez Alarcón, A., Las diligencias preliminares..., ob. cit., p. 29.

${ }^{53}$ Picó i Junoy, J., La prueba en el Proyecto de Ley de Enjuiciamiento Civil, en "Diario La Ley", 1999, núm. 3 (LA LEY 11116/2001), p.1.
} 
que pretenda incoarlo o cualquiera de los litigantes durante el curso del mismo, podrá pedir del tribunal la adopción, mediante providencia, de medidas de aseguramiento útiles para evitar que, por conductas humanas o acontecimientos naturales, que puedan destruir o alterar objetos materiales o estados de cosas, resulte imposible en su momento practicar una prueba relevante o incluso carezca de sentido proponerla".

Sobre esta cuestión se apunta que el art. 297 LEC provee de un mecanismo útil para garantizar la posibilidad de llevar a cabo, y en un futuro, una diligencia de prueba en un proceso, mediante la adopción de medidas que tienden a la conservación y custodia de las fuentes de prueba y con el propósito de que sea posible practicar, en el momento ordinario, el medio de prueba ${ }^{54}$, habida cuenta que la prueba es susceptible de variación $^{55}$. Por tanto, la finalidad del mecanismo de aseguramiento de prueba es el mantenimiento del estado de las cosas objeto de la prueba ${ }^{56}$ presentando por ello un claro carácter preventivo similar a la medida cautelar pero, en este caso, para asegurar no la efectividad de la tutela judicial que pudiera otorgarse en la sentencia estimatoria que se dictare (art.721.1 LEC) sino de la fuente de prueba ${ }^{57}$.

Ello difiere sustancialmente de la finalidad propia de las diligencias preliminares antes señalada, a saber, la preparación del proceso posterior o, en su caso, la evitación del mismo, al no guardar relación alguna con la actividad probatoria en sí misma considerada, que es precisamente en lo que se fundamenta la institución del

\footnotetext{
${ }^{54}$ Cfr. Rizo Gómez, B., Rizo Gómez, B., La anticipación de la prueba en el proceso civil, edit. Tirant lo Blanch, Valencia, 2010, p. 61. Según Álvarez Alarcón, A., Las diligencias preliminares..., ob. cit., p. 29, las medidas de aseguramiento de la prueba consisten "en la adopción de medidas que aseguren la pervivencia de la fuente de prueba, preservándola de su deterioro, causado por actos humanos o por acontecimientos naturales, de manera que pueda llegar a practicarse en la fase probatoria correspondiente".

${ }^{55}$ En este contexto, Asencio Mellado, J.M., Derecho Procesal Civil..., ob. cit., p. 123 indica que: "las pruebas, cualquiera que sea su naturaleza, material o personal, pueden verse expuestas, por el mero transcurso del tiempo o por la propia decisión de la contraparte o de terceros, a mutaciones o cambios que pueden frustrar su práctica o influir en su fiabilidad".

${ }^{56}$ En este sentido Montero Aroca, J., Derecho Jurisdiccional II..., ob. cit., p. 236 explica que su finalidad es "que se mantenga el estado presente de un objeto o de una situación, esto es, que no se modifique una fuente de prueba".

${ }^{57}$ Así lo sostiene Gimeno Sendra, V., Derecho Procesal Civil..., ob. cit., p. 287, quien indica que: "es una medida preventiva e igualmente excepcional, similar a las medidas cautelares, que persigue proteger $\mathrm{o}$ asegurar la fuente de prueba afectada por la concreta contingencia que puede impedir su práctica en la posterior fase común prevista para el medio de prueba en el que se subsume dicha fuente".
} 
aseguramiento de la prueba mediante la adopción de las medidas que aseguren la pervivencia de su fuente y puedan llegar a practicarse en la fase probatoria correspondiente" 58 .

\subsection{Medidas cautelares}

No puede obviarse que quien pretende preparar correctamente un juicio, y a tal efecto hace uso de las diligencias preliminares, además de la preparación del futuro proceso puede perseguir, aún indirectamente, la obtención de un resultado favorable.

Sin embargo, esta ulterior finalidad no puede ser confundida con la propia de las medidas cautelares" que "persiguen asegurar la efectividad de la futura sentencia estimatoria ante el temor fundado de su incumplimiento por parte del demandado" ${ }^{60}$, tal y como refiere el art. 721.1 LEC cuando señala que las mismas podrán ser solicitadas "para asegurar la efectividad de la tutela judicial que pudiera otorgarse en la sentencia estimatoria que se dictare".

Por tanto, una cosa es la evitación o reducción de situaciones o conductas que pongan en peligro la eficacia y ejecución de la sentencia futura, fin propio de las medidas cautelares, y otra distinta es la necesidad del correcto planteamiento de un proceso $\mathrm{y}$, en su caso, el resultado que favorablemente se pueda obtener como consecuencia, o no, de ello; situación que se puede alcanzar con las diligencias preliminares. Como ha sido puesto de manifiesto por la doctrina científica, que a través de las diligencias preliminares se obtenga el resultado propio de una cautela, el aseguramiento del objeto del proceso, no permite conceptuar las diligencias preliminares como una modalidad de tutela judicial efectiva cautelar ${ }^{61}$.

\footnotetext{
58 Álvarez Alarcón, A., Las diligencias preliminares..., ob. cit., pp. 29-30.

${ }^{59}$ En dicho sentido Garnica Martín, J.F., De las diligencias..., ob. cit., p. 1182 afirma que "no parece que puedan asimilarse a las medidas cautelares".

${ }^{60}$ Gimeno Sendra, V., Derecho Procesal Civil..., ob. cit., p. 291.

${ }^{61}$ Lorca Navarrete, A.M., La regulación de..., ob. cit., p. 2.
} 
Ni que decir tiene que el aseguramiento del hipotético resultado que persiguen las medidas cautelares, que han de ser exclusivamente conducentes a hacer posible la efectividad de la tutela judicial que pudiere otorgarse en una eventual sentencia estimatoria (art. 726.1 LEC), no es una finalidad de las diligencias preliminares que no están orientadas a la efectividad de una eventual resolución posterior sino a la evitación o preparación del futuro litigio.

A mayor abundamiento, en el mecanismo de las diligencias preliminares, a diferencia de lo que sucede con las medidas cautelares, no cabe la posibilidad de determinación de la caución sustitutoria prevista en los arts. 746 y 747 LEC ${ }^{62}$.

Por lo expuesto, no puede sino concluirse que ninguna relación guardan aquellas con las medidas cautelares.

\subsection{El discovery}

Dado que a los tribunales españoles no les resulta extraña la recepción de peticiones internacionales de discovery ${ }^{63}$, disclosure en el Derecho Británico, no resulta ocioso en este estudio realizar unas breves reflexiones sobre esta institución o procedimiento destinado a la averiguación de los indicios materiales y datos necesarios para preparar un pleito ${ }^{64}$. No obstante, debe ponerse de manifiesto que con fundamento en el art. 23 del Convenio de la Haya de 1970, sobre obtención de pruebas en el extranjero en materia civil o comercial, los estados contratantes pueden declarar que no ejecutarán las cartas rogatorias que tengan por objeto el procedimiento conocido en los países del Common Law con el nombre de "pre-trial discovery of documents", lo que ha sido declarado por España ${ }^{65}$.

\footnotetext{
${ }^{62}$ Cfr. Pérez Benítez, J.J., Efectos de las..., ob. cit., p. 5.

${ }^{63}$ En derecho británico disclosure. Sobre el concepto de disclosure, vid. Cerrato Guri, E., Límites a la actividad probatoria en el derecho inglés, en "La prueba civil: aspectos problemáticos", Aranzadi, Barcelona, 2017, pp. 335-337 y 346 -347.

${ }^{64}$ Esteban de la Rosa, G., Prueba judicial y práctica del discovery en la Unión Europea, en "Revista Internacional de Doctrina y Jurisprudencia”, 2014, núm. 5, p. 15.

${ }^{65}$ Sin embargo, como pone de manifiesto Esteban de la Rosa, G., Prueba judicial y..., ob. cit., p. 29, del informe de la Comisión Especial sobre el funcionamiento del Convenio de la Haya de 1970 se desprende
} 
Su finalidad no solo es la de preparar el futuro juicio sino que cada parte sepa con antelación las pruebas que se van a presentar en dicho acto, teniendo siempre presente que las jurisdicciones del Common Law distinguen entre el proceso jurisdiccional y el procedimiento preparatorio o pre-trial procedure, sustanciándose en este último la recopilación de pruebas realizadas por las partes a través del dicovery o disclosure de documentos e información ${ }^{66}$.

En algunos países como los Estados $\operatorname{Unidos}^{67}$, cuya referencia tomaremos a efectos de su examen, el alcance de esta institución es tan extraordinario que los actos preparatorios del juicio a disposición de las partes litigantes, pre-trial, se proyectan sobre cualquier cuestión, relevant to the subject matter involved in the pending action, es decir, sobre todo aquello que pueda ser relevante y relativo a la pretensión procesal ${ }^{68}$, para comprobar la corrección de las respectivas posiciones de las partes y reducir al máximo el factor sorpresa, hasta el punto de poder llegar a un acuerdo que evite el proceso $^{69}$. Los mecanismos más importantes son la aportación de documentos y las llamadas depositions.

Por lo que respecta a la aportación de documentos o fishing expeditions, pese a su amplitud, contempla límites a la información no siendo admisibles requerimientos que carezcan totalmente de relevancia o referidos a materias amparadas por el privilege, tales como comunicaciones con abogados, médico y paciente. La documentación e información debe suministrarse de forma directa por las partes y la negativa a ello puede

que el sentido de la reserva tiene que limitarse a aquellos casos en los que la comisión rogatoria carezca de la suficiente explicación, de tal forma que no permita identificar los documentos que tienen que ser obtenidos o examinados.

${ }^{66}$ Strong, S.I., Fach Gómez, K., y Carballo Piñeiro, L., Derecho comparado para abogados algo- $e$ hispanoparlantes, edit. Edward Elgar, Northampton, 2016, p. 82.

${ }^{67}$ Regulado en las reglas 26 a 37 de las Federal Rules Of Civil Procedure (FRCP), el discovery, tal y como apunta Gual Grau, C., Breves apuntes sobre el discovery, en "Actualidad Jurídica (Uria \& Menéndez)”, 2011, núm. 29, p. 114, “constituye un elemento básico de su cultura jurídica”.

${ }_{68}$ Carballo Piñeiro, L., La actividad preparatoria de un litigio internacional: de las diligencias preliminares a la pre-trial discovery (Los interrogantes que suscita la STCE St. Paul Dairy Insdustries NV c. Unibel Exser BVBA), en “Diario La Ley”, 2005, núm. 6370. p. 2 (LA LEY 5211/2005).

${ }^{69} \mathrm{El}$ discovery se recoge en el Título V de la FRCP bajo la denominación "Disclosures and Discovery" y contiene un total de cinco mecanismos probatorios: a) la exhibición documental; b) las declaraciones testificales; c) los interrogatorios escritos; d) las inspecciones oculares de objetos; e) el examen físico y mental de los declarantes. 
dar lugar a una motion to compel, en la que se solicita al juez que requiera a la parte contraria para aportar la información y cuyo incumplimiento puede dar lugar a sanciones y a la aplicación de la adverse inference, en la que el juez considerará que la información solicitada y no suministrada perjudicaba a la parte requerida. También puede solicitarse una protective order para evitar el hostigamiento con peticiones desproporcionadas y $\operatorname{costosas}^{70}$.

Por su parte, las depositions ${ }^{71}$ son testimonios orales extrajudiciales, amplios interrogatorios de testigos o de partes, bajo juramento y, generalmente, sin la presencia del juez, que quedan registrados y posteriormente son transcritos por el court reporter para su empleo en el juicio, en los que las partes tienen derecho a formular preguntas, y repreguntas en los que tanto el abogado de la parte como del testigo puede formular objeciones que, aún no impeditivas de la respuesta, sirven para indicar al testigo que sea cauteloso y ponen de manifiesto el posible problema con la pregunta al juez que posteriormente examine la deposition.

Así, la principal diferencia entre las diligencias preliminares y el discovery radica en que mientras las primeras se solicitan del juez y se practican ante el mismo, el pre-trial discovery es esencialmente extrajudicial, canalizándose de forma fundamental mediante comunicaciones directas entre las partes.

Por otro lado, se observa que el discovery no participa del carácter facultativo de las diligencias preliminares habida cuenta que las partes deben de reunirse con el fin de considerar la naturaleza y fundamentos de sus pretensiones, buscar la forma de resolver el conflicto, debatir sobre la discoverable information y proponer y desarrollar un discovery plan en que declaren sus propuestas ${ }^{72}$. En dicho discovery plan se debe acordar sobre el plazo y la forma de la solicitud del discovery, los sujetos sobre los que va a recaer, cuando se entenderá que el discovery está completo, la fase o fases en que éste va a ser realizado, si su objeto se va a limitar a determinadas materias, non-

\footnotetext{
${ }^{70}$ Gual Grau, C., Breves apuntes sobre..., ob. cit., p. 118.

${ }^{71}$ Arts. 27 a 32 FRCP.

${ }^{72}$ Art. 26 f) FRCP.
} 
privilege matter, si existe la posibilidad de aportar electronic discovery y si existe alguna normativa aplicable al caso que limite su práctica o aplicación ${ }^{73}$.

Pero es que, además, el discovery también puede ser utilizado para obtener el testimonio de una persona que no va a poder asistir al trial ${ }^{74}$ acercándose así a los postulados de la anticipación de la prueba (art. 293 LEC) de los que ya hemos visto no participan las diligencias preliminares. Tal es el ámbito del discovery que incluso, de conformidad con el art. 26.f FRCP, cada parte tiene el deber de revelar a las demás la identidad de los testigos que pretende citar el día del juicio. Aún más, el discovery puede extenderse a las denominadas non-parties, es decir, a terceros ajenos a la controversia que puedan poseer información relevante de cara al litigio ${ }^{75}$.

En suma, como se afirma en la doctrina científica, el pre-trial discovery, tiene la función de evitar sorpresas en el trial al exigir que todos los indicios materiales de la prueba estén preparados before-trial, encontrándonos ante un auténtico procedimiento de investigación a través del cual se trata de obtener todo tipo de pruebas e información ${ }^{76}$ hasta el punto de decidir qué medios de prueba son relevantes y cómo se van a practicar $^{77}$, finalidad esta de la que en modo alguno participan las diligencias preliminares.

\footnotetext{
${ }^{73}$ Art. 26.f.) 3 FRCP.

${ }_{75}^{74}$ Esteban de la Rosa, G., Prueba judicial y..., ob. cit., p. 16.

${ }^{75}$ Tal es el caso del art. 7 de la Federal Arbitration Act (FAA) conforme al cual los árbitros pueden citar por escrito a cualquier persona, como testigo, para que asista ante ellos para la presentación de documentos o emisión de testimonio que tenga la consideración de prueba. También el art. 1209.31 del Code Of Federal Regulations (CFR) que permite la solicitud de la emisión de una citación de discovery documental a cualquier persona o el art. 45 FRCP conforme al cual el tribunal competente puede ordenar la comparecencia del tercero para que preste declaración o presente algún documento.

${ }^{76}$ Esteban de la Rosa, G., Prueba judicial y..., ob. cit., pp.17-19.

${ }^{77}$ Carballo Piñeiro, L., La actividad preparatoria..., ob. cit., p. 3.
} 


\section{Naturaleza jurídica: ¿actos de jurisdicción voluntaria o contenciosa?}

Una de las cuestiones más debatidas por la doctrina científica en relación a las diligencias preliminares, también reflejada en las resoluciones de los tribunales, es la relativa a su naturaleza jurídica ${ }^{78}$.

Y pese a que hoy dicha cuestión parece resultar indiscutida, no cabe pasar por alto que las posiciones doctrinales mantenidas al respecto, al menos hasta la entrada en vigor de la LEC, oscilaron en torno a la consideración de las mismas como actos de jurisdicción voluntaria o actos propios de la jurisdicción contenciosa ${ }^{79}$.

La discusión doctrinal relativa a si deben considerarse las diligencias preliminares actos de jurisdicción voluntaria o contenciosa ${ }^{80}$ trae causa de la regulación que de las mismas hacía la ALEC en el ámbito de las actuaciones previas a la demanda en los arts. 497 a 501 que, junto con el art. 502, regulador de la prueba anticipada, integraban la Sección $2^{\mathrm{a}}$ del Capítulo I, "Disposiciones comunes a los juicios declarativos", del Título II, del Libro Segundo del referido cuerpo legal ${ }^{81}$.

\footnotetext{
${ }^{78}$ Así lo pone de manifiesto, Álvarez Alarcón, A., Las diligencias preliminares..., ob. cit., p. 3, cuando señala que: "El problema de la naturaleza jurídica de las diligencias preliminares gira en torno a si se trata de un acto de jurisdicción voluntaria o de jurisdicción contenciosa".

${ }^{79}$ En dicho sentido, Díaz Martínez, M., Las diligencias preliminares..., ob. cit., pp. 2-3 y Álvarez Alarcón, A., Las diligencias preliminares..., ob. cit., p. 31.

${ }^{80}$ Considerando que, conforme señaló Calaza López, S., Homenaje al profesor Antonio Fernández de Buján en el veinticinco aniversario de su cátedra. Hacia una Teoría General de la Jurisdicción Voluntaria, en "Revista de Derecho UNED", 2008, núm. 3, pp. 351-352, con la expresión jurisdicción voluntaria, por contraposición a la de jurisdicción contenciosa, se haría referencia a aquellos procedimientos en los que un particular solicita la intervención de un Juez -así como, en su caso, de un Secretario Judicial, de un Notario o de un Registrador-, o aquél interviene de oficio o a instancia del Ministerio Fiscal sin que exista contienda o conflicto de intereses, de especial relevancia, con otra persona configurándose la voluntaria como complementaria de la jurisdicción contenciosa y siendo sus notas distintivas más importantes el numerus clausus del objeto de conocimiento de los procesos voluntarios frente al numerus apertus de los procesos contenciosos, su carácter básicamente preventivo frente al, generalmente, represivo de la contenciosa, el relevante papel asignado al ministerio fiscal y al juez de la jurisdicción voluntaria, en relación con el principio dispositivo y de aportación de parte característico de la jurisdicción contenciosa, y la irrevocabilidad de la cosa juzgada característica del contencioso frente a la revocabilidad de las decisiones judiciales de la jurisdicción voluntaria a las que se suma el "interés público" o "social" de la jurisdicción contenciosa, frente al interés privado de la jurisdicción voluntaria.

${ }^{81}$ Ello, pese a que aún bajo la vigencia de dicha ley se dieron resoluciones tales como la SAP de Barcelona (sección 16a) de 29 de julio de 1994, ponente Ilmo. Sr. E. Mendaña, f.j.3으 (AC 1994l1401) que señalaron que: "[...] siendo las diligencias preliminares del artículo 497 de la Ley de Enjuiciamiento Civil, un precepto perteneciente a la Jurisdicción contenciosa, y de carácter potestativo, como lo será la
} 
En dicho contexto, la mayor parte de la doctrina científica se inclinaba por la inclusión de las diligencias preliminares en los actos de jurisdicción voluntaria ${ }^{82}$, ante la ausencia de demanda y controversia ${ }^{83}$ entre las partes y en tanto no se formulara oposición, en cuyo caso asumía la naturaleza contenciosa ${ }^{84}$. Paralelamente, esta opción fue recogida en el ámbito de la doctrina judicial que les reconocía la naturaleza de jurisdicción voluntaria al considerar que se trataba de procedimientos "[...] en los que no recae resolución judicial, ni se producen declaraciones de derechos" ${ }^{\text {\$5 }}$. También tras la entrada en vigor de la LEC, aún puntualmente, al afirmarse que la institución “[...] no presenta los caracteres propios de un auténtico proceso, puesto que el juez no dicta una resolución que decida una controversia, más bien nos encontramos ante un acto de

posterior demanda que siga a tal diligencia, el Juez no puede limitarse a la actividad del funcionario, como viene a ocurrir con la mayor parte de la actividad jurisdiccional voluntaria; y de no estar regulada tal actividad de jurisdicción voluntaria en el Libro III de la Ley de Enjuiciamiento Civil, el Juez debe abstenerse de llevar a cabo funciones que son propias $\mathrm{y}$, pueden realizarse mediante requerimiento notarial".

${ }^{82}$ Así lo pusieron de manifiesto Díaz Martínez, M., Las diligencias preliminares..., ob. cit., pp. 2-3; Pérez Benítez, J.J., Efectos de las..., ob. cit., 3 y Callejo Carrión, S., Las diligencias preliminares de la LEC 1/2000 y consecuencias derivadas de la negativa a realizarlas, en "Actualidad Civil”, 2006, núm. 1 (LA LEY 5375/2005) pp. 2-3, señalando esta última, como razones por las que las diligencias preliminares eran consideradas actos de jurisdicción voluntaria, que el juez no dictaba resolución resolviendo una controversia y que el resultado de la diligencia no surtía efecto alguno en el proceso posterior dado que el demandado no quedaba vinculado; también Garciandía González, La regulación de..., ob. cit., p. 776; y Álvarez Alarcón, A., Las diligencias preliminares..., ob. cit., pp. 31- 32.

${ }^{83}$ En palabras de Banacloche Palao, J., Las diligencias preliminares..., ob. cit., p. 31-33, "El problema es si esa actuación se realiza para resolver una controversia jurídica entre las partes, en cuyo caso estaríamos ante una actividad jurisdiccional, o si tiene lugar exclusivamente por mor de la autoridad propia que corresponde al Juez competente para ordenar la medida, sin que exista verdadero conflicto, con lo que nos hallaríamos ante una actividad meramente judicial o perteneciente a la denominada jurisdicción voluntaria" siendo que la solicitud de diligencias preliminares "suele ir acompañada de una resistencia lógica, por otra parte- de quien posee los datos pedidos a dárselos a conocer a terceros".

${ }^{84}$ A esta realidad se han referido autores como Asencio Mellado, J.M., Derecho Procesal Civil..., ob. cit., p. 36, que señala que: "la Ley de Enjuiciamiento Civil de 1881 regulaba las diligencias preliminares como meros actos de jurisdicción voluntaria, de modo que, una vez solicitadas, ni engendraban obligaciones procesales en el futuro demandado, ni su resultado producía efectos en el posterior proceso, tampoco cuando no se practicaban por la negativa del solicitado", o Callejo Carrión S., Las diligencias preliminares..., ob. cit., p. 3, cuando apunta que: "bajo la vigencia de la LEC 1881 se afirmaba que las diligencias preliminares no eran procesos porque el juez no actuaba jurisdiccionalmente en ellas, mereciendo la consideración de actos de jurisdicción voluntaria porque en ellas el juez no dictaba resolución resolviendo una controversia y porque el resultado de la diligencia no surtía efecto alguno en el proceso posterior, dado que el demandado no quedaba vinculado con lo que han de considerarse como actuaciones de jurisdicción voluntaria”.

${ }^{85}$ SAP de Jaén (sección $1^{\text {a }}$ ) de 15 de octubre de 1999, ponente Ilma. Sra. M.J. Jurado, f.j.1 ${ }^{\circ}$ (LA LEY 140024/1999). 
jurisdicción voluntaria" 86 y no implica "[...] contienda, sino mera comprobación de un hecho" $"$.

Sin embargo lo anterior, en la doctrina científica, esta postura dejó de sostenerse de forma prácticamente unánime, incluso antes de la entrada en vigor de la LEC, con una batería de argumentos que nos permitirán afirmar, sin ningún género de dudas, que las diligencias preliminares siempre han sido, y actualmente son, actos propios de la jurisdicción contenciosa, que no de la voluntaria ${ }^{88}$. Así, la existencia de controversia o ausencia de voluntariedad, el carácter jurisdiccional de las diligencias preliminares y la regulación sistemática de las mismas al margen de los actos de jurisdicción voluntaria.

Comenzando por el primero de los argumentos, la existencia de controversia, al margen de la propia indefinición que siempre ha gravitado sobre los actos de jurisdicción voluntaria ${ }^{89}$, tanto la $\mathrm{ALEC}^{90}$ como la actual $\mathrm{LJV}^{91}$ han caracterizado los

${ }^{86}$ AAP de Almería (sección 2a) de 9 de septiembre de 2003, ponente Ilmo. Sr. J. Ruíz-Rico, f.j.1 ${ }^{\circ}$ (LA LEY 137189/2003).

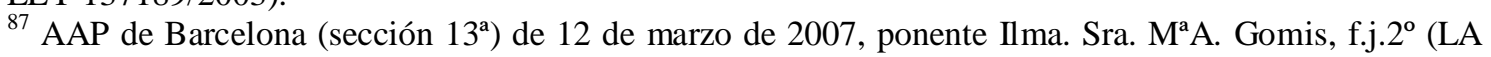
LEY 14888/2007).

${ }^{88}$ Como señala Pérez Benítez, J.J., Efectos de las..., ob. cit., 4, los principales argumentos de la consideración de las diligencias preliminares como actos de jurisdicción voluntaria han sido discutidos en Álvarez Alarcón, A. Las diligencias preliminares de la LEC: conceptos generales, en "Cuadernos de Derecho Judicial", edit. Consejo General del Poder Judicial, Madrid, 1995, núm. 27, pp. 20-24. También, Álvarez Alarcón, A., Las diligencias preliminares..., ob. cit., pp. 32-35, a quien seguiremos en el desarrollo argumental respectivo. De forma no tan explícita autores como Garciandía González. P.M., La regulación de..., ob. cit., p. 777, concluyeron a favor de la consideración de las diligencias preliminares como actos de jurisdicción señalando que: "la exigencia (...) de que el solicitante exprese, y el tribunal tenga en cuenta, a la hora de admitir la diligencia solicitada, la acción que pretende ejercitarse en el ulterior proceso, y el haber reconocido efectos en este proceso al resultado obtenido tras el intento de llevar a la práctica algunas de estas diligencias -los hechos deben ser admitidos (art. 261.1 $1^{\mathrm{a}}$ ) y los documentos contables tenidos por ciertos (art. 261.4 $)$ en el juicio posterior-aleja a la institución de las notas más características de los actos de jurisdicción voluntaria".

${ }^{89}$ Indefinición contemplada, entre otros, por Sánchez Gómez, R., La naturaleza jurídica de la jurisdicción voluntaria según la delimitación prevista en la Ley 15/2015, de 2 de julio, de la Jurisdicción Voluntaria, en "Diario La Ley", 2015, núm. 8623, 5 que, incluso, ha sido destacada en las STC 13\1981, de 22 de abril de 1981, ponente Ilmo. Sr. M. Velasco, f.j.3º (LA LEY 6406-JF/0000) y STC 114/1997, de 16 de junio de 1997, ponente Ilmo. Sr. M. Jiménez de Parga, f.j.3º (LA LEY 7686/1997) al reconocer la dificultad que entraña delimitar la naturaleza jurídica de los actos de jurisdicción voluntaria, puesta igualmente de manifiesto por Álvarez Alarcón, A., Las diligencias preliminares..., ob. cit., p. 32.

${ }^{90}$ Disponía el art. 1.811 ALEC que: "Se consideran actos de jurisdicción voluntaria todos aquéllos en que sea necesaria, o se solicite la intervención del Juez sin estar empeñada, ni promoverse cuestión alguna entre partes conocidas y determinadas"

${ }^{91}$ Cuyo art. 1.2 previene que se consideran expedientes de jurisdicción voluntaria a los efectos de dicha ley, todos aquellos que requieran la intervención de un órgano judicial para la tutela de derechos e 
actos de jurisdicción voluntaria como aquellos en los que no existe contienda entre los interesados ${ }^{92}$. En consonancia con lo anterior, y como ya se ha avanzado, se sostenía la naturaleza de jurisdicción voluntaria de las diligencias preliminares al considerarse que, a través de las mismas, no se resolvía contienda alguna que, por demás, no existía.

Sin embargo, y aún cuando del propio tenor literal del art. 1.2 LJV se desprende que, más que la ausencia de controversia, lo que caracteriza a dichos actos es que la controversia en cuestión no deba dilucidarse en un proceso contencioso ${ }^{93} \mathrm{y}$, por tanto, no que no exista la misma como tal, en modo alguno se podía y se puede sostener la naturaleza voluntaria de las diligencias preliminares cuando, precisamente, nos encontramos ante una herramienta de auxilio judicial del administrado que, por otros medios, no puede conseguir de quien corresponde aquella información que le permita preparar debidamente el procedimiento y, en su caso, evitarlo ${ }^{94}$.

Tanto es así que:

a) El propio art. 256.2 LEC señala que en la solicitud de diligencias preliminares se expresarán sus fundamentos, con referencia al asunto objeto del juicio, o contienda judicial, que se quiera preparar debiendo el juez decidir sobre la existencia de un interés legítimo insatisfecho ${ }^{95}$.

intereses en materia de Derecho civil y mercantil, sin que exista controversia que deba sustanciarse en un proceso contencioso.

92 Así se desprende del texto de ambos preceptos legales y por, consecuencia, es afirmado, entre otros, por Liébana Ortíz, J.R., La nueva jurisdicción voluntaria, en “Actualidad Civil”, 2016, núm. 1, p. 5.

${ }^{93}$ De hecho, como señala Liébana Ortíz, J.R., La nueva jurisdicción voluntaria..., ob. cit., p. 5 “(...) la Ley 15/2015 no resulta coherente con la definición legal de jurisdicción voluntaria puesto que en ella se incluyen expedientes en donde se verifica claramente una controversia entre partes determinadas" tales como "el de la intervención judicial en los casos de desacuerdo en el ejercicio de la patria potestad o de desacuerdo conyugal y en la administración de bienes gananciales (arts. 86 y 90 LJV respectivamente)".

94 En dicho sentido, Banacloche Palao, J., Las diligencias preliminares..., ob. cit., p. 33 y Álvarez Alarcón, A., Las diligencias preliminares..., ob. cit., p. 34.

${ }_{95}$ Como expone Garberí Llobregat, J., Las diligencias preliminares.... ob. cit., p. 29, cuando identifica el interés legítimo insatisfecho con "el del solicitante de obtener los datos o informaciones que precisa para fundamentar debidamente su demanda, y que no ha podido obtener por los cauces normales que el ordenamiento le brinda". Igualmente, Garciandía González, P.M., La regulación de..., ob. cit., p. 777 cuando señala que "la exigencia (...) de que el solicitante exprese, y el tribunal tenga en cuenta, a la hora de admitir la diligencia solicitada, la acción que pretende ejercitarse en el ulterior proceso, y el haber reconocido efectos en este proceso al resultado obtenido tras el intento de llevar a la práctica alguna de 
b) El art. 260 LEC configura la posible oposición del requerido y, por tanto, la posibilidad de contienda incluso respecto de la propia práctica de la diligencia ${ }^{96}$.

c) El art. 261 LEC configura toda una serie de efectos, incluso de marcado carácter coactivo, que el juez puede ejecutar y que están dirigidos a salvaguardar el derecho del peticionario y solventar la injustificada controversia o contienda mantenida por el requerido.

En segundo lugar, y aún cuando tampoco pueda negarse de forma absoluta el carácter jurisdiccional de los actos de jurisdicción voluntaria ${ }^{97}$, de hecho, la voluntaria, como su propio nombre indica, es jurisdicción, el carácter jurisdiccional, por mucho que se haya negado, es absolutamente predicable de una institución como las diligencias preliminares $^{98}$. Con ocasión de las mismas se producen resoluciones judiciales que declaran derechos y deberes ${ }^{99}$, en tanto que el juez decide sobre la admisión o inadmisión de una petición ${ }^{100}$, disponiendo las actuaciones necesarias y conducentes a la ejecución de lo acordado y los términos en que han de llevarse a cabo. Ello es debido a

estas diligencias (...) aleja a la institución de las notas más características de los actos de jurisdicción voluntaria".

96 Oposición que, según Garberí Llobregat, J., Las diligencias preliminares.... ob. cit., p. 29, permite hablar de controversia. También, Garnica Martín, J.F., De las diligencias..., ob. cit., p. 1146 quien señala que: "Si a partir de la regulación de la LEC de 1881 podían encontrarse argumentos para sostener ese carácter de jurisdicción voluntaria, particularmente por la falta de instrumentos para hacer cumplir la resolución u orden dirigida al solicitado, no ocurre así con la nueva regulación, en la que queda muy claro que el solicitado está obligado a cumplir y puede hacer valer sus razones, a través del incidente de oposición".

${ }^{97}$ Pues, como recoge Liébana Ortíz, J.R., La nueva jurisdicción voluntaria..., ob. cit., p. 2, "La doctrina se encuentra profundamente dividida en torno a la esencia de la jurisdicción voluntaria y, en consecuencia, se han expuesto multitud de opiniones que pueden ser agrupadas en tres grandes grupos: 1) las posiciones que estiman que esta es una actividad eminentemente jurisdiccional; 2) las que estiman que la jurisdicción voluntaria es, simplemente, actividad administrativa atribuida a los jueces; y, 3) aquéllas que consideran a la jurisdicción voluntaria como una actividad especial del Estado”.

98 Así tajantemente lo afirma Banacloche Palao, J., Las diligencias Preliminares..., ob. cit.,pp. 31-33, dado que "la información que se pretende obtener con ella no la pueden conseguir los sujetos interesados por sus propios medios, sino que necesitan impetrar el auxilio judicial".

${ }^{99}$ En este sentido lo afirma Álvarez Alarcón, A., Las diligencias preliminares..., ob. cit., p. 34 en contra de lo sostenido previamente por Gómez Orbaneja, E. y Herce Quemada, V., Derecho Procesal Civil. Juicios y procedimientos especiales. Ejecución procesal. Jurisdicción voluntaria, Vol. II, 1976, Madrid, pp. 166 y 167. En contra, en la doctrina judicial, el AAP de Barcelona (sección 15 ${ }^{\mathrm{a}}$ ) de 27 de junio de 2006, ponente Ilmo. Sr. J.L. Forgas, f.j.2 ${ }^{\circ}$ (LA LEY 232044/2006).

${ }^{100}$ Lo que, a diferencia de otros mecanismos procesales o incluso puros procesos, ha sido modificado en las últimas reformas de la LEC que han atribuido la competencia para la admisión del proceso al LAJ reservándose la inadmisión al Juez, en general, en el art. 206.1.2 LEC y, en particular, en cuanto a las diligencias preliminares, en el art. 258.2 LEC. 
que, las diligencias preliminares conllevan una resolución judicial y, por tanto, una actividad jurisdiccional $^{101}$ que, además, encuentra su apoyo en la regulación que de las mismas se hace en la LEC $^{102}$. No obstante, debe precisarse que si bien no cabe duda que la actividad a la que dan lugar tiene naturaleza procesal sus decisiones no producen efecto de cosa juzgada ${ }^{103}$. Cuestión distinta es que la concurrencia de unas previas diligencias preliminares en las que haya sido resuelta la misma petición permita entender que la nuevamente deducida carece del presupuesto de la justa causa necesaria para la admisión y éxito de la petición.

El tercer motivo atiende a la ausencia en las diligencias preliminares de la nota de voluntariedad inserta en la propia definición de los actos de jurisdicción voluntaria y que, en su acepción más básica, pudiera incluso predicarse de aquellas contiendas de cuya naturaleza contenciosa no se duda. Esa voluntariedad propia de los actos de jurisdicción voluntaria cabe incluso que sea predicada de cualquier procedimiento contencioso de juicio ordinario o verbal del que los interesados no demandantes, sin

${ }^{101}$ Como señala Pérez Benítez, J.J., Efectos de las..., ob. cit., p. 4, resulta discutible afirmar que las diligencias preliminares carecen de naturaleza jurisdiccional cuando, en ellas, el juez debe pronunciarse sobre su admisibilidad, determinando sus límites, y cuando sólo desde su consideración de tal se explican los efectos queridos por el legislador frente a la negativa a su práctica. En la doctrina judicial afirman la naturaleza jurisdiccional de las diligencias preliminares, entre otros, el AAP de Asturias (sección $4^{\text {a }}$ ) de 23 de diciembre de 2003, ponente Ilmo. Sr. R. Avelló, f.j.2º (LA LEY 217713/2003) cuando señala que: "[...] las diligencias preliminares constituyen aquel conjunto de actuaciones de carácter jurisdiccional tendentes a conocer los datos precisos para que el futuro juicio pueda tener eficacia", y el AAP de Santa Cruz de Tenerife (sección $4^{\mathrm{a}}$ ) de 18 de abril de 2007, ponente Ilma. Sra. P. Aragón, f.j.3º (LA LEY 50149/2007).

${ }^{102}$ Así lo afirma Banacloche Palao, J., Las diligencias preliminares..., ob. cit., p. 34 al recordar que la Exposición de Motivos de la EC determina que la misma se "configura con exclusión de la materia relativa a la denominada jurisdicción voluntaria".

${ }^{103}$ Vid. los AAP de Vizcaya (sección $3^{\text {a }}$ ) de 28 de junio de 2005 y 16 de julio de 2007, ponente Ilma. Sr. A.I. Gutiérrez, f.j.2º (LA LEY 145270/2005 y LA LEY 201929/2007). En relación a la ausencia de cosa juzgada de las diligencias preliminares, vid. también el AAP de Valencia (sección $6^{\text {a }}$ ) de 2 de julio de 2009, ponente Ilma. Sra. M. Mestre, f.j.2º (LA LEY 191888/2009) cuando señala: “[...] el Tribunal debe fijar que las diligencias preliminares tienen la finalidad de preparar un posterior juicio declarativo, recabando la información necesaria para decidir sobre la procedencia de su interposición y el alcance de las pretensiones a ejercitar; y que dichas diligencias preliminares, como tales no tienen efectos de cosa juzgada pero tampoco tienen efectos mas allá de los sujetos intervinientes.

Es decir, el juicio declarativo posterior que se sustancie en base a dichas Diligencias Preliminares solo podrá ser entre las partes intervinientes y en base, como es el presente caso, en base a los concretos documentos que se tuvieron como ciertos en aquellas diligencias.

Pero cuando como es el caso de autos, el juicio declarativo posterior fundado en diligencias preliminares, es interpuesto por un tercero ajeno a la sustanciación de dichas diligencias preliminares, el rigor de la vinculación de lo actuado anteriormente para prepararlo ya no es el mismo que afectaba a quienes si fueron parte y permite que ambas partes...”. 
perjuicio de los efectos consecuentes, pueden participar o no. Ahora bien, tal voluntariedad no puede predicarse de las diligencias preliminares cuya regulación, en el art. 261 LEC, prevé la adopción de determinadas medidas incluso en contra de la voluntad de aquél a quien, mediante la oportuna solicitud, se ha requerido colaboración.

Por último, y en cuarto lugar, en la actualidad, la regulación de los actos de jurisdicción voluntaria se encuentra fuera de la LEC. Su Disposición Derogatoria Única, en su apartado primero, derogó la ALEC, con la excepción de los Títulos XII y XIII del Libro II y el Libro III, que se mantendrían hasta la entrada en vigor de la LC y de la tan esperada, en cumplimiento de la Disposición Final Decimoctava de la LEC, y reciente LJV. Y qué duda cabe de que si el legislador hubiera querido considerar las diligencias preliminares como actos de jurisdicción voluntaria ni las hubiera regulado de nuevo y más detalladamente en la entonces novedosa LEC $^{104}$ que, además, deroga los preceptos de la ALEC correspondientes a la institución aquí estudiada ni, posteriormente, hubiera dejado de incluirlas en la actual $\mathrm{LJV}^{105}$.

Todo lo anterior nos lleva concluir, junto con la unánime doctrina y posición de los tribunales, que las diligencias preliminares en modo alguno participan de la naturaleza de los actos de jurisdicción voluntaria sino que constituyen verdaderos actos de jurisdicción contenciosa cuyo fundamento se encuentra "en la imposibilidad de que una persona obtenga por sí misma, sin intervención judicial, determinados datos que precisa para poder interponer la demanda" ${ }^{106}$.

\footnotetext{
${ }^{104}$ Así lo afirma Corbal Hernández, J.E., Diligencias preliminares (arts...) ob. cit., p. 3495, cuando señala que la naturaleza contenciosa de las diligencias preliminares "es la que implícitamente sigue el legislador, ya que de considerarla jurisdicción voluntaria habría reservado su regulación a la Ley correspondiente, como hizo con otras materia que tienen tal naturaleza".

${ }^{105}$ Afirmamos lo anterior sin desconocer la postura de autores tales como Díez-Picazo Giménez, I., Las diligencias preliminares..., ob. cit., p. 37, para quien el legislador, al regular las diligencias preliminares en la LEC, ha hecho una excepción, de forma tal que siendo las mismas actos de jurisdicción voluntaria, "la razón de que la LEC regule las diligencias preliminares pese a ser actos de jurisdicción voluntaria debe buscarse en la necesidad que había de introducir cambios en su regulación para darles mayor eficacia, lo que no debía esperar hasta la aprobación de una futura Ley de Jurisdicción Voluntaria" y, también, sin desconocer, que esa futura Ley de Jurisdicción Voluntaria ha sido dada en el año 2015 sin incluir entre sus disposiciones regulación alguna de las diligencias preliminares que anule o derogue la contenida en la LEC.

${ }^{106}$ Garciandía González, P.M., La regulación de...., ob. cit., p. 774.
} 


\section{Numerus clausus o numerus apertus}

\subsection{Postura de la doctrina científica y judicial}

Es el primer precepto que la LEC dedica a las diligencias preliminares, el art. 256, el que correlativamente enumera el catálogo de diligencias que como preliminares pueden ser objeto de solicitud. Y es en relación a dicho catálogo en torno al que se ha suscitado el segundo de los grandes debates relativo a las diligencias preliminares: numerus apertus versus numerus clausus.

Es decir, si la enumeración que de las mismas hace la LEC es la propia de una lista abierta, con la posibilidad de solicitar otras diligencias no expresamente contempladas en el precepto legal, o, por el contrario, nos encontramos ante una lista cerrada que hace que puedan ser objeto de solicitud, única y exclusivamente, aquellas diligencias que el texto enumera de forma exhaustiva ${ }^{107}$.

Nuevamente, en torno a este segundo gran debate que trae causa del art. 497 ALEC que establecía con claridad que se trataba de un numerus clausus, se posicionan los autores con una postura tan unánime como la que actualmente se mantiene en relación a la naturaleza de las diligencias preliminares, aún cuando no exenta de disidentes.

Entre los que entienden que nos encontramos ante un listado cerrado, se afirma que "sólo pueden pedirse y decretarse las diligencias previstas expresamente en alguna Ley" 108 , que "se trata de un número limitado de diligencias, numerus clausus que no cabe extender con la solicitud de actuaciones que pudieran ser útiles para el desarrollo

\footnotetext{
${ }^{107}$ En la doctrina judicial, es el ATS de 11 de noviembre de 2002 (sala $1^{\text {a }}$ ), ponente Ilmo. Sr. J.M. Martínez-Pereda, f.j. $2^{\circ}$ (LA LEY 222960/2002) el que pone de manifiesto tal debate, cuando señala: “[...] planteada en la praxis, si tales diligencias se encuentran o no sujetas a un numerus clausus, o sea si sólo pueden pedirse las consignadas expresamente en la ley o pueden pedirse respecto a otros supuestos de análoga finalidad, la solución fue contradictoria, pues mientras que algunas Audiencias Provinciales en sus sentencias siguieron el criterio taxativo, otras las admitieron en supuestos no previstos en la ley, si bien predominó el criterio restrictivo".

${ }^{108}$ Montero Aroca, J., Derecho Jurisdiccional II..., ob. cit., p. 186.
} 
de un proceso, si no se encauzan por alguno de los supuestos del art. 256.1" ${ }^{109}$, o que las diligencias preliminares "se determinan en la LEC según el criterio de lista cerrada $o$ numerus clausus"110 y que "solamente podrán acordarse aquellas expresamente previstas" 111 . Dicha postura se alcanza en la doctrina judicial como una exigencia derivada del principio de seguridad jurídica y para evitar que puedan usarse para fines distintos de los legalmente establecidos ${ }^{112}$.

En el extremo contrario, contamos con autores que se posicionan sobre la conveniencia de admitir la posibilidad de acordar diligencias preliminares diferentes de las enumeradas por el legislador siempre que a juicio del órgano jurisdiccional se den los presupuestos para que sean ordenadas. A saber, que la medida sea adecuada a la finalidad perseguida por el solicitante y que en su solicitud concurra justa causa e interés legítimo toda vez que, en caso contrario, para dar cabida a situaciones dudosas se haría necesario interpretar de forma flexible, cuando no forzada, los términos empleados por el art. $256 \mathrm{LEC}^{113}$.

En el ámbito de la doctrina judicial, el carácter de numerus apertus de las diligencias preliminares también fue sostenido bajo la vigencia de la ALEC, afirmando que el art. 497 ALEC constituía "una enumeración mínima, y referida a los casos más comunes, pues no cabe duda de que pueden existir otros supuestos en que la parte presunta demandante tenga necesidad de obtener datos para evitar pleitear sin conocimiento de ellos, en cuanto sean imprescindibles; se trata, por lo tanto de integrar analógicamente aquellos supuestos en el precepto [...], función que sin duda corresponde a los Tribunales de Justicia, de acuerdo con los arts. $3^{\circ}$ y $4^{\circ}$ del Código

\footnotetext{
${ }^{109}$ Moreno Catena, V., Derecho Procesal Civil..., ob. cit., p. 119.

${ }_{110}$ Gimeno Sendra, V., Derecho Procesal Civil..., ob. cit., p. 353.

${ }^{111}$ Damián Moreno, J., De las diligencias..., ob. cit., p. 1683.

${ }^{112}$ AAP de Asturias (sección $7^{\mathrm{a}}$ ) de 19 de noviembre de 2002, ponente Ilma. Sra. B. Álvarez, f.j.2º (LA LEY 193224/2002), AAP de Sevilla (sección $5^{\text {a }}$ ) de 16 de septiembre de 2003, ponente Ilmo. Sr. J. Herrera, f.j. $2^{\circ}$ (LA LEY 141979\2003) y de 11 de octubre de 2006, ponente Ilmo. Sr. F. Sanz, f.j.2 ${ }^{\circ}$ (LA LEY 269449/2006), AAP Las Islas Baleares (sección $3^{\mathrm{a}}$ ) de 14 de octubre de 2005, ponente Ilma. Sra. $M^{a}$.R. Rigo, f.j.2 (LA LEY 199921/2005), AAP de Barcelona (sección 13 $3^{\mathrm{a}}$ ) de 12 de marzo de 2007, ponente Ilma. Sra. M ${ }^{a}$.Á. Gomis, f.j.2 $2^{\circ}$ (LA LEY 14888/2007), AAP de Madrid (sección 10ª) de 12 de noviembre de 2007, ponente Ilma. Sra. A.M ${ }^{a}$. Olalla, f.j. $1^{\circ}$ (LA LEY 252724/2007).

${ }^{113}$ Cfr. Vallespín Pérez, D., Diligencias Preliminares ¿Numerus Clausus? (Art. 256 LEC), en "Justicia: Revista de derecho procesal”, 2007, núm. 3-4, pp. 128-129.
} 
Civil, sin que ello suponga invasión alguna de la función legislativa, sino ejercicio congruente de la jurisdiccional, que el propio legislador le encomienda, para adecuar sus preceptos a la realidad social cambiante y en evitación de una casuística agotadora de la norma, que no debe perder su calidad de generalidad" $"$.

No obstante, en la práctica de los tribunales y en el sentido señalado por la Exposición de Motivos de la LEC cuando dice "[....] la presente ley se asienta sobre el convencimiento de que caben medidas eficaces para la preparación del proceso. Por un lado, se amplían las diligencias que cabe solicitar, aunque sin llegar al extremo de que sean indeterminadas", la opción es clara al considerar que la enumeración que realiza el art. 256.1 LEC es exhaustiva y constituye un cuerpo numerus clausus de diligencias preliminares" ${ }^{\prime 15}$.

Esta realidad que acabamos de destacar se encuentra reflejada en el ATS, de 11 de noviembre de 2002, al manifestar que: “[...] planteada en la «praxis», si tales diligencias se encuentran o no sujetas a un «numerus clausus», o sea si sólo pueden pedirse las consignadas expresamente en la ley o pueden pedirse respecto a otros supuestos de análoga finalidad, la solución fue contradictoria, pues mientras que algunas Audiencias Provinciales en sus sentencias siguieron el criterio taxativo, otras las admitieron en supuestos no previstos en la ley, si bien predominó el criterio

\footnotetext{
114 AAP de Navarra (sección $1^{\text {a }}$ ) de 23 de octubre de 1998, ponente Ilmo. Sr. R. Ruíz, f.j.2º (AC 199812003). En el mismo sentido se pronuncia el AAP de Navarra, (sección $1^{\text {a }}$ ) de 20 de mayo de 1999, ponente Ilmo. Sr. R. Ruíz, f.j.2º (AC 19991840).

${ }^{115}$ En dicho sentido, el AAP de Castellón (sección $3^{\text {a }}$ ) de 7 de diciembre de 2007, ponente Ilma. Sra. A. Bardón, f.j.3 $3^{\circ}$ (LA LEY 311060/2007) señala que: "[...] solamente pueden decretarse las que se hallen expresamente previstas en una ley, ya sea la Ley de Enjuiciamiento Civil ya una ley especial, pero en todo caso, las diligencias deben de estar previstas en norma con rango de ley" y el AAP de Cáceres (sección 1 a) de 27 de mayo de 2003, ponente Ilmo. Sr. J.F. Bote, f.j.2 ${ }^{\circ}$ (LA LEY 94997/2003), defiende su desestimación a limine si no se encuadran en alguno de los casos expresamente enumerados en el art. 256 LEC, cuando señala este último que: "[...] como primer requisito básico y esencial debe tratarse de una diligencia contemplada en la Ley que no es el caso". En este contexto, destaca el AAP de Castellón (sección $3^{\mathrm{a}}$ ) de 7 de diciembre de 2007, ponente Ilma. Sra. A. Bardón, f.j.3º (LA LEY 311060/2007) cuando señala que: "[...] solamente pueden decretarse las que se hallen expresamente previstas en una ley, ya sea la Ley de Enjuiciamiento Civil ya una ley especial, pero en todo caso, las diligencias deben de estar previstas en norma con rango de ley". En el mismo sentido, el AAP de Barcelona (sección 16 ${ }^{\mathrm{a}}$ ) de 17 de octubre de 2008, ponente Ilmo. Sr. J.L. Valdivieso, f.j. $1^{\circ}$ (JUR 2009\51421), cuando señala que: “[...] El artículo 256.1 de la Ley de Enjuiciamiento Civil establece los supuestos en que pueden solicitarse diligencias preliminares, de tal manera que no cabe solicitarlas en otros casos distintos, ni para finalidades diferentes de las que establece la citada norma legal".
} 
restrictivo. Tal criterio es el hoy existente en la nueva Ley pues aunque no lo dice expresamente, hay que entenderlo así, porque ha suprimido alguno de la Ley precedente -«ad exemplum»-, la exhibición de títulos en casos de evicción a que se refería el art. 497.4 ${ }^{\circ}$ LEC de 1881, pero ha creado nuevos supuestos, como el núm. 6 del actual art. 256 referido a la defensa de intereses colectivos de consumidores o usuarios.

Finalmente, el núm. 7 admite otros supuestos para la protección de determinados derechos previstos en leyes especiales. Por tanto la conclusión, es que sólo pueden considerarse diligencias preliminares las establecidas en el art. 256 de la vigente Ley de Enjuiciamiento Civil o «las establecidas en las correspondientes leyes especiales», a que se refiere el núm. 7 de dicho artículo. Y si este carácter de «numerus clausus» no impide de suyo la solicitud de cualesquiera diligencias que los peticionarios reputen conducente o conveniente interesar con precedencia al inicio de un proceso jurisdiccional, no permite sin embargo acceder a la práctica de aquéllas que ni se encuentren específicamente previstas, ni resulten «necesarias» de acuerdo con la disciplina legal al existir otros medios por los cuales el peticionario pueda obtener, sin demérito alguno, la información que ambiciona" $" 116$.

Dicho todo cuanto antecede, debe concluirse al respecto que la doctrina judicial mayoritaria aboga por un criterio de numerus clausus de las diligencias preliminares que entiende correlativo a la objetiva necesidad que las justifica, cuando el peticionario no dispone de otro medio legítimo para conocer los datos o informaciones que requiere la correcta activación del proceso ${ }^{117}$. Dicha necesidad objetiva no concurrirá, por ejemplo, cuando la información pueda obtenerse acudiendo a registros públicos ${ }^{118}$.

\footnotetext{
${ }^{116}$ ATS de 11 de noviembre de 2002 (sala $1^{\mathrm{a}}$ ), ponente Ilmo. J.M. Martínez-Pereda, f.j.2 $2^{\circ}$ (LA LEY 222960/2002).

${ }^{117}$ En este sentido, vid. el AAP de Asturias (sección $7^{\mathrm{a}}$ ) de 19 de noviembre de 2002, ponente Ilma. Sra. B. Álvarez, f.j.2 (LA LEY 193224/2002) cuando señala: “[...] deben ser acordadas, exclusivamente, cuando no haya otro medio de preparar el ejercicio de la acción que el solicitante se propone ejercitar" o el AAP de Barcelona (sección 13a) de 12 de marzo de 2007, ponente Ilma. Sra. M.A. Gomis, f.j. $2^{\circ}$ (LA LEY 14888/2007) que las entiende pertinentes cuando "no haya otro medio de obtención de los datos imprescindibles, de manera que no procederá su tramitación cuando legalmente esté prevista otra vía, procesal o administrativa".

${ }^{18}$ A esta cuestión se han referido, entre otros, el AAP de Castellón (sección $3^{\mathrm{a}}$ ) de 10 de septiembre de 2003, ponente Ilma. Sra. A. Bardón, f.j.2 $2^{\circ}$ (LA LEY 138302/2003) con referencia al supuesto de pretenderse mediante diligencia preliminar la obtención de datos obrantes en el Registro de la Propiedad;
} 
Tampoco cuando se trate de datos o informaciones que el solicitante deba razonablemente tener en su poder ${ }^{119}$ o conocer $^{120}$.

\subsection{Argumento intermedio: interpretación flexible}

Ahora bien, de forma paralela a la afirmación del carácter de numerus clausus del art. 256.1 LEC y, de forma especialmente importante, a partir de la entrada en vigor de la LEC, como lógica consecuencia del derecho constitucional de acceso al proceso como medio para obtener una tutela adecuada, la doctrina ha afirmado el principio de interpretación flexible del catálogo de diligencias preliminares contenido en aquél ${ }^{121}$, cuyo máximo exponente se encontraría en la diligencia del art. 256.1.6 LEC relativa a la preparación del proceso para la defensa de los intereses colectivos de consumidores y usuarios y para la concreción de los integrantes del grupo de afectados. Si se repara en el tenor literal de la diligencia preliminar en cuestión se advertirá como, al amparo de dicho precepto legal, el juzgador podrá adoptar "las medidas oportunas para la averiguación de los integrantes del grupo, de acuerdo a las circunstancias del caso y conforme a los datos suministrados por el solicitante, incluyendo el requerimiento al demandado para que colabore en dicha determinación". Es decir, que podrá adoptar cuantas diligencias considere oportunas, que no están tipificadas en el supuesto legal, y

o el AAP de Álava (sección $1^{\text {a }}$ ) de 12 de noviembre de 2007, ponente Ilma. Sra. M ${ }^{\mathrm{a}}$.M. Guerrero f.j. $1^{\mathrm{o}}$ (LA LEY 250988/2007) en el supuesto de datos obrantes en el Registro de Parejas de Hecho; o el AAP de Madrid (sección 14 ${ }^{\mathrm{a}}$ ) de 14 de septiembre de 2004, ponente Ilmo. Sr. J.M. Salcedo, f.j.2 (LA LEY 188968/2004) para el caso de pretenderse datos a disposición de la parte en el Registro Mercantil.

${ }^{119}$ AAP de Baleares (sección $3^{\mathrm{a}}$ ) de 14 de noviembre de 2005, ponente Ilma. Sra. M.R. Rigó, f.j.3º (LA LEY 199921/2005).

${ }^{120}$ AAP de Sevilla (sección $5^{\text {a }}$ ) de 11 de octubre de 2006, ponente Ilmo. Sr. F. Sanz f.j.2 ${ }^{\circ}$ (LA LEY 269449/2006).

${ }^{121}$ En la doctrina científica, Díaz Martínez, M., Las diligencias preliminares..., ob. cit., pp. 4-5, que sostiene la admisión de cualesquiera diligencias que los peticionarios reputen conveniente interesar, aún cuando no de las que ni se encuentren específicamente previstas ni resulten necesarias de acuerdo con la disciplina legal; en la doctrina judicial, destaca el AAP de Madrid (sección 10 a) de 12 de noviembre de 2007, ponente Ilma. Sra. A.M. Olalla, f.j.3 (LA LEY 252724/2007). En el mismo sentido se pronuncia el AAP de Las Palmas (sección $4^{\mathrm{a}}$ ) de 10 de junio de 2010, ponente Ilma. Sra. Ma . E. Corral, f.j.4º (LA LEY 221255/2010) cuando indica que: “[...] Dicha interpretación flexible y extensiva de los términos empleados en los supuestos legales, (...) se ha propugnado y aceptado (...), siempre en relación con exhibición de documentos imprescindibles para formular la demanda, cuando realmente son imprescindibles para ello, es decir, de los que fundarían la pretensión mínima a deducir, que no se hallan en poder y accesibilidad de la parte solicitante, y que si se encuentran en poder de la parte a la que se pretende demandar". 
que permitan la averiguación de los integrantes del grupo. También en las diligencias de comprobación de hechos de los arts. 123 y ss. LP y 36 LCD $^{122}$.

Ahora bien, pese a ser frecuentemente invocado y citado dicho principio de interpretación flexible del catálogo de medidas contemplado en el art. 256.1 LEC, el mismo no ha sido definido en la doctrina con la precisión y seguridad jurídica que la cuestión merece, además de haber dado lugar en la práctica forense a la admisión de solicitudes de diligencias preliminares que, en modo alguno y a nuestro juicio, podrían encontrar acomodo en el art. 256.1 LEC en caso de sostenerse el principio de numerus clausus del catálogo contenido en dicho precepto legal ${ }^{123}$ que continuamente se afirma.

Y, a nuestro juicio, afirmar que el catálogo contenido en el art. 256.1 LEC es una lista cerrada para, por otro lado, sostener que cabe una interpretación flexible del mismo, es un contrasentido. Más aún si, como parece advertirse en la doctrina científica y judicial, en esta interpretación flexible del catálogo de diligencias preliminares del art. 256.1 LEC, subyace la finalidad de procurar que el solicitante de las diligencias preliminares pueda preparar adecuadamente el ulterior proceso. Ello, porque son inimaginables las circunstancias en que cualquier justiciable puede verse privado de la posibilidad de una adecuada preparación del ulterior proceso y, en tales circunstancias, la garantía del derecho a la tutela judicial efectiva que subyace en las diligencias preliminares exigiría, en aplicación de ese principio de interpretación flexible, un análisis del juzgador del caso concreto y la correlativa admisión de la diligencia

\footnotetext{
${ }^{122}$ En dicho sentido se ha pronunciado el AAP de Barcelona (sección $15^{\mathrm{a}}$ ) de 21 de marzo de 2005, ponente Ilmo. Sr. I. Sancho, f.j.2 ${ }^{\circ}$ (LA LEY 65420/2005) en un supuesto de diligencias preliminares para la preparación del proceso de reclamación de los derechos de remuneración compensatoria por copia privada de obras de creación, tras recordar que las diligencias preliminares reguladas en el art. 256.1 LEC constituyen un numerus clausus a diferencia de lo que ocurre con los derechos de propiedad industrial y competencia desleal cuya regulación legal contiene expresamente la posibilidad de ejercitar diligencias de comprobación de hechos.

${ }^{123}$ A modo de ejemplo procede traer a colación el AAP de Cáceres (sección $1^{\text {a }}$ ) de 10 de abril de 2008 , ponente Ilmo. Sr. A.M ${ }^{\mathrm{a}}$. González, f.j. $2^{\circ}$ (LA LEY 294613/2008) en el que, para la preparación de la acción judicial de resarcimiento de los perjuicios causados con ocasión de un accidente de circulación en que se vio implicado un animal cuya titularidad dominical se desconocía, se acordó el libramiento de oficios para que determinados organismos públicos y Fuerzas y Cuerpos de Seguridad del estado, informaran sobre la persona titular del animal y resultado de las diligencias practicadas, al considerar que no cabía otra posibilidad al demandante para conocer la identidad de la persona propietaria del animal contra la que colisionó el vehículo siniestrado.
} 
preliminar, siempre y cuando, la solicitada, prevista o no en el catálogo del art. 256.1 LEC, fuera imprescindible para la preparación del ulterior proceso. Pero esta afirmación obligaría a desterrar el tan afirmado carácter de numerus clausus de las diligencias preliminares y, en consecuencia, a propugnar del catálogo del art. 256.1 LEC una mera labor ejemplificativa. Y no es este el sentir del legislador y la doctrina judicial que aún invocando el principio de interpretación flexible del catálogo continúan afirmando su carácter de numerus clausus.

Por ello, en el contexto actual, en el que se sigue afirmando tal carácter de numerus clausus del catálogo de diligencias preliminares contenido en el art. 256.1 LEC, y al efecto de intentar delimitar lo que se entiende por interpretación flexible del mismo, debemos recurrir a las escasas ocasiones en que la doctrina se ha pronunciado al respeto. En todo caso, dejando al margen aquellos supuestos dados en la práctica forense en los que, como ya antes hemos apuntado, dicho principio de interpretación flexible ha sido utilizado, en realidad, para garantizar el derecho a la tutela judicial efectiva del solicitante de las diligencias preliminares obviando, aún cuando afirmando, su carácter de numerus clausus.

Y a tal efecto no puede sino ponerse de manifiesto que al principio de interpretación flexible del catálogo de diligencias preliminares ha hecho referencia la doctrina judicial afirmando que "solo pueden solicitarse aquellas que se incluyan en la citada norma, debiendo rechazarse toda aquella que no esté contemplada expresamente, aunque ello no impide que se deba realizar una interpretación flexible de los supuestos contemplados en la citada norma" ${ }^{124}$. Así dicha doctrina aclara que el referido principio se identifica con aquella interpretación que permita "cuantas situaciones puedan integrarse en los distintos números del precepto" ${ }^{125}$ o con una identidad de razón con alguno de los supuestos del art. 256.1 LEC que pudiera justificar una aplicación analógica o supuesto parangonable o básico sobre el que poder asentar una

\footnotetext{
${ }^{124}$ AAP de Sevilla (sección $5^{\text {a }}$ ) de 16 de septiembre de 2003, ponente Ilmo. Sr. J. Herrera, f.j. $2^{\circ}$ (LA LEY 141979/2003). En el mismo sentido, el AAP de Barcelona (sección 15a) de 29 de abril de 2009, ponente Ilmo. Sr. L. Garrido, f.j. $2^{\circ}$ (JUR 2009\410747).

${ }^{125}$ AAP de Zamora (sección $1^{\text {a }}$ ) de 8 de enero de 2003, ponente Ilmo. Sr. A.M. Encinas, f.j. $3^{\circ}$ (LA LEY 4170/2003).
} 
interpretación flexible, integrada o extensiva ${ }^{126}$ y no con una interpretación integradora de situaciones no expresamente comprendidas en la enumeración del precepto en cuestión $^{127}$.

No obstante lo anterior, la práctica forense demuestra que el catálogo de diligencias preliminares que han sido admitidas por los tribunales, en algunos casos, dista mucho de poder ser encuadrado, por analogía, en alguno de los supuestos del art. 256.1 LEC. Probablemente porque, a nuestro juicio, el catálogo de diligencias que contempla no comprende, siquiera en una interpretación flexible del mismo, todo el elenco de circunstancias en que cualquier petición de diligencia preliminar puede considerarse admisible si se atiende a los principios que inspiran la institución. A saber, (i) la necesidad de preparar un juicio posterior o, en su caso, evitar el mismo, (ii) la adecuación de la diligencia a la finalidad perseguida, y (iii) la justa causa e interés legítimo.

Por ello, como propuesta de futuro, y retomando en este punto algunos de los argumentos señalados por la doctrina científica ${ }^{128}$, nosotros entendemos que, atendiendo a la realidad de la justicia actual y los beneficios que la institución de las diligencias preliminares puede suponer, sería aconsejable una modificación de la regulación que de las mismas se contiene en la LEC. Una modificación que no impidiera la "congelación legal" de los supuestos en que las diligencias preliminares pueden ser acordadas, o el intento muchas veces forzado de encasillamiento en las mismas, de forma tal que cuando el órgano judicial aprecie la concurrencia de los requisitos generales de adecuación a la finalidad perseguida, justa causa e interés legítimo, pueda acordarse la diligencia preliminar solicitada sin obligar al tribunal, en determinados supuestos y bajo el subterfugio de la interpretación flexible de la tipicidad de la diligencia a que antes hemos aludido, a forzar el tenor literal de la norma para no obstaculizar

\footnotetext{
${ }^{126}$ AAP de Barcelona (sección $15^{\text {a }}$ ) de 29 de abril de 2009, ponente Ilmo. Sr. L. Garrido, f.j. $3^{\circ}$ (JUR 2009\410747).

${ }^{127}$ AAP de Zaragoza (sección $5^{\text {a }}$ ) de 20 de marzo de 2006, ponente Ilmo. Sr. P.A. Pérez, f.j. $1^{\circ}$ (LA LEY 31213/2006).

${ }^{128}$ Bellido Penadés, R., Las diligencias preliminares..., ob. cit., pp. 5-7 y 8.
} 
injustificadamente el derecho del solicitante al acceso al proceso y, en suma, no cercenar su derecho a la tutela judicial efectiva.

\section{Evolución legislativa}

\subsection{De la ALEC a la LEC}

El antecedente legislativo más inmediato de la actual regulación de las diligencias preliminares se encuentra en la ALEC que expresamente las recogía en el art. 497 bajo las modalidades de declaración jurada, exhibición de la cosa mueble, exhibición del testamento, codicilo o memoria testamentaria, petición de exhibición de títulos u otros documentos, para el caso de evicción de la cosa vendida, y petición de documentos y cuentas de la sociedad o comunidad por el socio o comunero, concurriendo justa causa.

Con tales precedentes pasaron las diligencias preliminares a la LEC cuya Exposición de Motivos, sosteniendo su utilidad, anuncia la ampliación del catálogo de diligencias preliminares de la ALEC al tiempo que omite algunas contenidas en ésta.

Así, por un lado, la LEC suprimió la diligencia prevista en el ordinal $4^{\circ}$ del art. 497 ALEC, relativo a la petición del comprador o vendedor o de éste a aquél que exhiba títulos, en el caso de evicción. Por otro, incrementó el número de supuestos respecto de los contemplados en el art 497 ALEC. Como, por ejemplo, la diligencia del aptdo. $5^{\circ}$ del art. 256 LEC, relativa a la petición del que se considere perjudicado por un hecho que pudiera estar cubierto por seguro de responsabilidad civil, de exhibición del contrato por quien lo tenga en su poder. También, el caso de las diligencias previstas en los ordinales $6^{\circ}$, para la concreción de los integrantes de grupo de afectados, y $7^{\circ}$, de diligencias y averiguaciones que, para la protección de determinados derechos, prevean las correspondientes leyes especiales.

En relación a estas últimas, debe ponerse de manifiesto que el catálogo de diligencias preliminares que contemplaba la ALEC no preveía diligencia preliminar 
alguna específica y tendente a la preparación de los procesos de infracción de derechos de propiedad intelectual e industrial. Y aún cuando es cierto que el ordenamiento jurídico español, con carácter previo a la LEC, ya contaba con el antecedente de las diligencias de comprobación de hechos de la $\mathrm{ALP}^{129}$, no fue hasta la publicación de la LEC, y con el antiguo art. 256.1.7 LEC, cuando con cierto rigor sistemático se incluyó en el ordenamiento procesal civil español la posibilidad de preparación de dichos procesos. Y se dice que con cierto rigor sistemático porque la lectura de dicho precepto legal permite también advertir como el mismo tampoco contiene referencia a diligencia específica alguna que permita la preparación de los derechos de propiedad intelectual e industrial, sino una remisión a las diligencias y averiguaciones previstas en las leyes especiales, cuyas previsiones concretas se analizarán en el apartado correspondiente al estudio de la diligencia del art. 256.1.9 LEC $^{130}$.

\subsection{Las reformas introducidas por la Ley 19/2006}

No obstante, el catálogo de diligencias preliminares introducido por la LEC ha sido concretado y depurado con ocasión de las reformas legislativas sufridas hasta la actualidad por dicha norma procesal y las leyes especiales. Así, a los siete supuestos legales de diligencias preliminares contenidas en la redacción inicial de la LEC, entre los que se encontraba el de petición de las diligencias y averiguaciones que, para la protección de determinados derechos, prevean las correspondientes leyes especiales (art. 256.1.7 LEC), se sumaron posteriormente la diligencia del ordinal $5^{\circ}$ bis, relativa a la petición de la historia clínica, y las diligencias entonces contenidas en los ordinales $7^{\circ} \mathrm{y}$ $8^{\circ}$, introducidas por la Ley $19 / 2006^{131}$. Debe tenerse en cuenta que, con anterioridad a la

\footnotetext{
129 Arts. 129 a 132 de la Ley 11/1986, de 20 de marzo, de Patentes, por la que se aprueba la Ley de Patentes de Invención y Modelos de Utilidad (BOE núm. 73 publicado el día 26/03/1986 y con fecha de entrada en vigor general el día 26/06/1986), que, conforme a lo dispuesto en la Disposición Transitoria Tercera de dicha Ley de Patentes, no entraron en vigor hasta el 7 de Octubre de 1992. Debe tenerse en cuenta que dicha norma ha sido derogada por la Ley 24/2015, de 24 de julio, de Patentes, cuya entrada en vigor se ha producido el día 1 de enero de 2015 y que regula las diligencias de comprobación en sus arts. 123 a 126, aún con algunas diferencias entre ambas redacciones.

130 Vid. cap. II, epígrafe 10, dedicado a las diligencias y averiguaciones para la protección de determinados derechos previstos en las leyes especiales.

${ }^{131}$ La Ley 19/2006, de 5 de junio, por la que se amplían los medios de tutela de los derechos de propiedad intelectual e industrial y se establecen normas procesales para facilitar la aplicación de diversos reglamentos comunitarios, publicada en el BOE núm. 134 de 06/06/2006, cuya entrada en vigor se
} 
Ley 19/2006, en sede de propiedad intelectual, el TRLPI, no contenía regulación especial alguna sobre diligencias preliminares por lo que resultaba de aplicación la normativa general del art. 256.1 LEC. Por su parte, la ALP, regulaba las diligencias de comprobación de hechos en sus arts. 129 a 132 que, a su vez, resulta de aplicación en materia de marcas (disposición adicional primera $\mathrm{LM}^{132}$ ) y de diseños (disposición adicional primera $\operatorname{LPDI}^{133}$ ), que se regían por la normativa específica y en lo que no se opusiera a esta por la regulación de la LEC (art. 263 en relación con el art. 256.1.9 LEC). En sede de competencia desleal, el art. $24 \mathrm{LCD}^{134}$, reconocía con gran amplitud la posibilidad de instar diligencias preliminares ${ }^{135}$, con remisión a las diligencias de comprobación de la ALP.

Y dadas las trascendentales modificaciones operadas por la Ley 19/2006 en la LEC, que no afectó a la subsistencia del régimen jurídico anterior, la misma fue el instrumento para la transposición a nuestro ordenamiento interno de la Directiva

produjo el día 07/06/2006. Debe tenerse en cuenta que como consecuencia de la reforma operada por la Ley 19/2006 la diligencia del art. 256.1.7 LEC pasa a ser la diligencia del art. 256.1.9 LEC y que, tras la reforma operada por la Ley 21/2014, de 4 de noviembre, por la que se modifica el texto refundido de la Ley de Propiedad Intelectual, aprobado por Real Decreto Legislativo 1/1996, de 12 de abril, y la Ley 1/2000, de 7 de enero, de Enjuiciamiento Civil, las diligencias de los ordinales $7^{\circ}$ y $8^{\circ}$ introducidas por la Ley 19/2006, mantienen su ordinal si bien modificado en su tenor literal el $7^{\circ}$ en los términos que serán analizados en el presente estudio.

${ }^{132}$ Ley 17/2001, de 7 de diciembre, de Marcas, publicada en el BOE núm. 294 de 8/12/2001 y que, de conformidad con su disposición final tercera entraría en vigor el día 31/07/2002 salvo lo previsto en el Título V, artículo 85, disposiciones adicionales tercera, cuarta, octava, décima, undécima, decimotercera, decimocuarta y decimoquinta, que entrarían en vigor el día siguiente al de su publicación en el BOE.

${ }^{133}$ Ley 20/2003, de 7 de de Protección Jurídica del Diseño industrial, publicada en el BOE núm. 162 de 8/07/2003 cuya entrada en vigor, de conformidad con su disposición final tercera, se produjo el día 9/07/2003 salvo en lo relativo al título IV, el capítulo III del título VII y la disposición adicional quinta, que lo harían al año de su publicación en el BOE siendo que la excepción referida al título IV no afectaría sin embargo al art. 33, en lo que se refiere a los motivos de oposición y legitimación para oponerse, al aptdo. $2^{\circ}$ del art. 35 y al art. 41 sobre revisión de los actos en vía administrativa.

${ }^{134}$ Ley 3/1991, de 10 de enero, de Competencia Desleal, publicada en el BOE núm. 10 de 11/01/1991 cuya entrada en vigor se produjo el día 31/01/1991.

${ }^{135}$ Disponía el aptdo. $1^{\circ}$ de su art. 24 que "quien pretenda ejercitar una acción de competencia desleal podrá solicitar del Juez la práctica de diligencias para la comprobación de aquellos cuyo conocimiento resulte objetivamente indispensable para preparar el juicio", y el aptdo. $2^{\circ}$ del mismo art. establecía que: "tales diligencias se sustanciarían de acuerdo con lo previsto en los artículos 129 a 132 de la Ley 11/1986, de 20 de marzo, de Patentes, y podrán extenderse a todo el ámbito interno de la empresa". Debe tenerse en cuenta que con ocasión de la reforma operada en la LCD por la Ley 29/2009, de 30 de diciembre, por la que se modifica el régimen legal de la competencia desleal y de la publicidad para la mejora de la protección de los consumidores y usuarios, el contenido del art. 24 pasa a corresponderse con el del art. 36. 
2004/48/CE ${ }^{136}$, cuyo punto de partida fue el Acuerdo sobre los Aspectos de los Derechos de Propiedad Intelectual relacionados con el Comercio ${ }^{137}$, en adelante ADPIC, concluido en el ámbito de la OMC tras las negociaciones de la Ronda de Uruguay (1986-1994), y que tenía por objeto, entre otros, lograr que las legislaciones de los estados europeos se armonizaran en el establecimiento de medidas garantizadores del respecto de los derechos de propiedad industrial e intelectual en directa relación con la sociedad de la información.

De este modo, la Ley 19/2006 introdujo las entonces nuevas diligencias $7^{\mathrm{a}}$ y $8^{\mathrm{a}}$ del art. 256.1 LEC orientadas a la obtención de mayor información de las redes de distribución y mercancías y servicios que violan los derechos de propiedad intelectual e industrial, y exhibición de documentos bancarios, financieros o comerciales; las mismas fueron acompañadas de importantes novedades relativas a la competencia judicial y la forma de la resolución que debía de adoptar la decisión del tribunal ante la negativa de llevar a cabo las diligencias en general ${ }^{138}$.

La anterior reforma de la LEC en el régimen de las diligencias preliminares respondió a la principal necesidad de dar cumplimiento al denominado por la Directiva

\footnotetext{
${ }^{136}$ Si bien el título de la Directiva 2004/48/CE no hace referencia a los derechos de propiedad industrial debe tenerse en cuenta que el art. 1 de la misma dispone que: "La presente Directiva se refiere a las medidas, procedimientos y recursos necesarios para garantizar el respeto de los derechos de propiedad intelectual. A los fines de la presente Directiva, el término derechos de propiedad intelectual incluirá los derechos de propiedad industrial".

${ }^{137}$ ADPIC que, como señala Vargas Portillo, J.P., Notas relativas a la relevancia del acuerdo sobre los aspectos de los derechos de propiedad intelectual relacionados con el comercio en Honduras, en "Revista Internacional del Mundo Económico y del Derecho", Vol. V, 2013, p. 17, su objetivo es proteger los derechos de propiedad intelectual, de modo que, por un lado, contribuyan a la promoción de la innovación tecnológica y a la transferencia de la tecnología en beneficio recíproco de productores y de usuarios y, por otro, favorezcan el bienestar social y económico y al equilibrio de derechos y obligaciones, art. 7 del ADPIC. Dicho acuerdo fue ratificado por España en virtud de Instrumento de Ratificación dado en Madrid a 30 de diciembre de 1994.

${ }^{138}$ Así lo pone de manifiesto Villar Fuentes, I.Ma ${ }^{\mathrm{a}}$, Las diligencias preliminares de los procesos de propiedad industrial y competencia desleal, edit. Tirant Lo Blanch, Valencia, 2014, p. 29. Al margen de lo indicado por la autora, resulta importante resaltar que la reforma operada en la LEC por la Ley 19/2006 aprovechó para, al margen de la regulación específica de las nuevas diligencias, zanjar uno de los desencuentros más importantes que, en materia de diligencias preliminares, existía entre la doctrina y el legislador. Concretamente, el de la forma que debía de adoptar la resolución del tribunal ante la negativa de llevar a cabo las diligencias acordadas. Hasta entonces la forma elegida por el legislador había sido la de providencia, que la doctrina consideraba inadecuada para la decisión sobre determinadas consecuencias derivadas de tal negativa tales como la entrada y registro en lugar determinado.
} 
2004/48/CE derecho de información que, recogido en su art. 8, exigía a los estados garantizar que, en el contexto de los procedimientos relativos a una infracción de un derecho de propiedad intelectual -y ya hemos dicho que también industrial- en respuesta a una petición justificada y proporcionada del demandante, los tribunales pudieran ordenar medidas de facilitación de datos sobre el origen y las redes de distribución de mercancías o servicios y que pusieran de manifiesto la posible infracción de los anteriores derechos ${ }^{139}$.

Y partiendo de tal exigencia, el apartado III de la Exposición de Motivos de la Ley 19/2006 se ocupó de precisar que, bajo la denominación de derecho de información, la directiva consideraba necesario poder ofrecer, en el ámbito del proceso civil, cauces para la obtención de información sobre el origen y las redes de distribución de las mercancías o servicios en los que se concretara la infracción de los derechos de propiedad intelectual o industrial, encauzando la norma la posibilidad de instar de un órgano jurisdiccional civil el requerimiento de esta información a través de una nueva diligencia preliminar dentro del art. 256 LEC, en concreto, la del art. 256.1.7 del mismo texto legal.

Pero, junto a la posibilidad anterior y en cumplimiento de las previsiones legislativas comunitarias, también la Ley 19/2006 se ocupó de encauzar la posibilidad del acceso a los documentos bancarios, financieros o comerciales que estuvieran bajo el control del presunto infractor y responsable de los actos realizados con fines comerciales que consumaran dicha infracción, lo que facilitó mediante la diligencia del art. 256.1.8 LEC.

\footnotetext{
${ }^{139}$ Pues debe tenerse presente que pese a estar destinadas las diligencias preliminares a la preparación de los procesos de infracción de derechos de propiedad intelectual ni industrial ni la resolución del tribunal accediendo a la práctica de las mismas permite prejuzgar la infracción de tales derechos ni el resultado de las mismas dar por concurrente tal infracción.
} 


\subsection{Las reformas introducidas por la Ley 21/2014}

No obstante, la evolución legislativa en la protección de los derechos de propiedad intelectual e industrial no se detuvo y, para una mejor protección jurisdiccional de los derechos, el legislador vuelve a incidir en la regulación de la LEC, ahora de forma exclusiva en cuanto a las diligencias preliminares ${ }^{140}$, mediante la reforma operada por la Ley 21/2014, de 4 de noviembre, por la que se modifica el TRLPI y la LEC ${ }^{141}$ y la introducción de las diligencias de los ordinales $10^{\circ}$ y $11^{\circ}$ de esta última.

\footnotetext{
${ }^{140}$ Debe tenerse en cuenta que la Ley 19/2006 no sólo modificó el régimen de diligencias preliminares de la LEC sino que también extendió los mecanismos de protección de los derechos de propiedad intelectual e industrial a otras instituciones el como aseguramiento de pruebas, las medidas cautelares y la obtención de prueba documental. Así, en materia de aseguramiento de prueba, y como consecuencia de las previsiones contenidas en el art. 7 de la Directiva 2004/48/CE, la Ley 19/2006 modificó el régimen procesal del aseguramiento de la prueba contenido en los arts. 297 y 298, en especial, mediante la reforma del aptdo. $2^{\circ}$ del art. 297 LEC, añadiendo una previsión especial para los casos de infracción de los derechos de propiedad industrial y de propiedad intelectual, disponiendo que las medidas de aseguramiento de la prueba podrían consistir, en especial, en la descripción detallada, con o sin toma de muestras, o la incautación efectiva de las mercancías y objetos litigiosos, así como de los materiales e instrumentos utilizados en la producción o la distribución de estas mercancías y de los documentos relacionados con ellas. En materia de exhibición documental, incorporó al art. 328 un aptdo. $3^{\circ}$ que reguló el régimen de exhibición de documentos en los procesos seguidos por infracción de los derechos de propiedad industrial e intelectual. Y, como consecuencia de las previsiones contenidas en el art. 9 de la Directiva, también se produjo la modificación del aptdo. $2^{\circ}$ del art. 733 LEC.

${ }^{141}$ La reforma, que entró en vigor el día 1 de enero de 2015 , vino motivada por la necesaria transposición a nuestro ordenamiento interno de la Directiva 2011/77/UE del Parlamento Europeo y del Consejo, de 27 de septiembre de 2011, por la que se modifica la Directiva 2006/116/CE relativa al plazo de protección del derecho de autor y de determinados derechos afines, y la Directiva 2012/28/UE del Parlamento Europeo y del Consejo, de 25 de octubre de 2012, sobre ciertos usos autorizados de las obras huérfanas y la imposibilidad de demorar la solución de los problemas puestos de manifiesto en la protección de los derechos a la aprobación de de una ley integral de Propiedad Intelectual. Lo anterior se desprende de los apartados I y II de la Exposición de Motivos de la Ley 21/2014. Y no es ocioso recordar que, pese a lo dispuesto en su Disposición Final Cuarta que prevé que: “(...) el Gobierno, en el plazo de un año desde la entrada en vigor de esta ley, realizará los trabajos preliminares necesarios, en colaboración con todos los sectores y agentes interesados, para preparar una reforma integral de la Ley de Propiedad Intelectual ajustada plenamente a las necesidades y oportunidades de la sociedad del conocimiento", hasta la fecha, la reforma integral de la normativa en materia de Propiedad Intelectual no se ha producido. No obstante, la lectura de las directivas citadas nos permite advertir la ausencia de conexión entre la reforma operada en la LEC por la Ley 21/2014 y el contenido de las Directivas citadas, de las que la Exposición de Motivos de aquella dice traer causa. Esta circunstancia es puesta de manifiesto por Díaz Pita, P., Diligencias preliminares y propiedad intelectual tras la reforma operada por la Ley 21/2014, de 4 de noviembre en la Ley de Enjuiciamiento Civil 1/2000, de 7 de enero, en "Cuestiones de actualidad en el ámbito de la propiedad intelectual”, edit. Dykinson, Madrid, 2015, p. 188 que identifica la razones de la reforma operada por la Ley 21/2014 en el escollo insalvable que suponía la regulación anterior de las diligencias, al circunscribir su solicitud a los casos en que se cometieran por actos realizados a escala comercial, y a la dificultad de aplicación flexible del catálogo de diligencias antes de la reforma y que afectaba tanto a la infracción de derechos de propiedad intelectual "en línea" como a las cometidas "fuera de línea".
} 
El origen de ambas diligencias se encuentra en la STJUE de 29 de enero de 2008 (Asunto C-275/06) que tuvo lugar como consecuencia del planteamiento de una cuestión prejudicial civil ${ }^{142}$ en el seno de un procedimiento de diligencias preliminares instado por una sociedad que agrupaba a productores y editores de grabaciones musicales y audiovisuales contra una sociedad prestadora de servicios de Internet. En concreto, la actora solicitó se ordenara a la otra sociedad revelar la identidad y dirección de determinadas personas a las que esta prestaba un servicio de acceso a Internet y de las que se conocía su dirección IP así como la fecha y hora de conexión. Según la solicitante dichas personas utilizaban un programa de intercambio de archivos $P 2 P$ que permitía el acceso a una carpeta compartida de su ordenador personal a fonogramas cuyos derechos patrimoniales de explotación correspondían a los asociados de la solicitante, que entendía que tales usuarios estaban cometiendo actos de competencia desleal y vulneraban los derechos de propiedad intelectual. Pero en fase de oposición la requerida alegó que, conforme al art. 12 de la LSSI, la comunicación de los datos solicitados solo estaba autorizada en el marco de una investigación criminal o para la salvaguarda de la seguridad pública y de la defensa nacional y no en el marco de un procedimiento civil o como medida preparatoria del mismo. La STJUE determinó que tanto la normativa europea vigente en aquél momento como la legislación interna española no obligaba a los Estados miembros a imponer el deber de comunicar datos personales con objeto de garantizar la protección efectiva de los derechos de autor en el

\footnotetext{
${ }^{142}$ Según recoge la STJUE de 29 de enero de 2008 (Asunto C-275/2006), ponente Ilmo. Sr. J. Malenovský (LA LEY 20/2008) caso Promusicae-Telefónica, cuya doctrina fue asumida en posteriores resoluciones como la STJUE de 19 de abril de 2012 (Asunto C-461/10), ponente Ilmo. Sr J. Malenovský (LA LEY 39746/2012), caso Bonnier Audio AB, en dicha cuestión prejudicial, planteada por el AJMER núm. 5 de Madrid, de 13 de junio de 2006, se exponía: “[...] El derecho comunitario y, concretamente, los artículos 15.2 y 18 de la Directiva 2000/31/CE del Parlamento Europeo y del Consejo, de 8 de junio, relativa a determinados aspectos de los servicios de la sociedad de la información,en particular, el comercio electrónico en el mercado interior; los artículos 8.1) y 2) de la Directiva 2001/29/CE del Parlamento Europeo y del Consejo, de 22 de mayo, relativa a la amortización de determinados aspectos de los derechos de autor y derecho afines a los derechos de autor en la sociedad de la información; el artículo 8 de la Directiva 2004/48/CE del Parlamento Europeo y del Consejo de 29 de abril, relativa al respeto de los derechos de propiedad intelectual; y los artículos 17.2 y 47 de la Casta de los Derechos Fundamentales de la Unión Europea, ¿permiten a los Estados miembros restringir el marco de una investigación criminal o para la salvaguardia de la seguridad pública y de la defensa nacional, con exclusión, por tanto, de los procesos civiles, el deber de retención y puesta a disposición de datos de conexión y tráfico generados por las comunicaciones establecidas durante la prestación de un servicio de la sociedad de la información, que recae sobre los operadores de redes y servicios de comunicaciones electrónicas, proveedores de acceso a redes de telecomunicaciones y los prestadores de servicios de alojamiento de datos?"”
} 
marco de un procedimiento dado que, conforme a lo previsto en el entonces vigente art. 12 de la LSSI, los datos que debían de conservar los operadores de redes y servicios de comunicación electrónicas y los proveedores de acceso a redes de telecomunicaciones sólo se conservarían para su utilización en el marco de una investigación criminal o para la salvaguarda de la seguridad pública y la defensa nacional ${ }^{143}$. Y si bien es cierto que, con posterioridad al planteamiento de la cuestión prejudicial civil, dicha previsión legal fue derogada y sustituida por el núm. 1 de la disposición derogatoria única de la $\mathrm{LCDCE}^{144}$, que añadió un nuevo art. 12 bis disponiendo la obligación de los prestadores de servicios de facilitar la información acerca de las posibles responsabilidades en que puedan incurrir sus clientes por el uso de Internet con fines ilícitos y, en particular, para la comisión de ilícitos penales y por la vulneración de la legislación en materia de propiedad intelectual e industrial, no es menos cierto que la misma no vino acompañada de la correspondiente reforma procesal que permitiera al titular de tales derechos, por ejemplo, preparar el futuro proceso por infracción de los mismos mediante una específica y particular diligencia preliminar. La consecuencia de ello fue que cuando los actos de infracción de derechos de propiedad intelectual se cometían en el ámbito de las comunicaciones electrónicas y de las redes públicas de comunicaciones, el titular del derecho infringido sólo podía acudir a alguna de las nuevas diligencias preliminares que había introducido la Ley 19/2006 ${ }^{145}$, ninguna de las cuales hacía mención expresa a actos como los contemplados en la cuestión prejudicial o de infracción cometidos en línea.

\footnotetext{
${ }^{143}$ Se afirma en la doctrina con Castán Pérez-Gómez, A., El nuevo régimen de diligencias preliminares en propiedad intelectual frente a las defraudaciones en el entorno digital, en "Estudios sobre la ley de propiedad intelectual: últimas reformas y materias pendientes", coord. Juan Pablo Aparicio Vaquero, edit. Dykinson, 2016, p. 130, que el art. 12 de la LSSI constituyó un desprecio hacia los derechos de autor al inaugurar una tendencia nefasta en la protección de tales derechos; aún cuando no el único dado que, con ocasión de la regulación de las obligaciones de los operadores de telecomunicaciones en cuanto a la retención de datos generados o tratados con la prestación de sus servicios, la LCDCE, establecía la obligación de los operadores de conservar los datos tratados o generados en el marco de los servicios de comunicaciones electrónicas o redes públicas de comunicación de cederlos a la autoridad judicial de un proceso penal por delitos graves y a la investigación incoada al efecto (arts. 1 y 6). También, el art. 42 de la LGT, que reiteraba lo anterior.

${ }^{144}$ Ley $25 / 2007$, de 18 de octubre, de conservación de datos relativos a las comunicaciones electrónicas y a las redes públicas de comunicaciones, publicada en el BOE núm. 251 de 19 de octubre de 2007 y cuya entrada en vigor se produjo el día 8 de noviembre de 2007.

${ }^{145}$ Díaz Pita, Ma . Paula, Diligencias Preliminares y..., ob. cit., p. 205.
} 
Esta circunstancia, la postura tradicional en la doctrina científica y judicial de inadmisión de aquellas diligencias preliminares que no respondieran al catálogo legalmente tasado, la dificultad de la identificación de los infractores en el entorno digital y, a mayor abundamiento, la STJUE citada ${ }^{146}$, colocaba a los titulares de los derechos de propiedad intelectual e industrial en una situación de verdadera indefensión que la Ley 21/2014 ha pretendido paliar.

La lectura del apartado V de la Exposición de Motivos de la Ley 21/2014 permite advertir que la reforma operada por dicha ley busca la mejora de los mecanismos legales para la protección de los derechos de propiedad intelectual, y también industrial, frente a las vulneraciones que puedan sufrir en el entorno digital, a cuyo efecto entendió necesario el legislador, y así lo pone de manifiesto, adaptar la vía jurisdiccional civil introduciendo mejoras en la redacción de determinadas medidas de información previa necesarias para la protección de los derechos de propiedad intelectual en el entorno digital en línea.

Dicho en otras palabras, mediante la reforma operada por la Ley 21/2014 en el régimen de diligencias preliminares de la LEC se pretende combatir la conocida vulgarmente como piratería informática ${ }^{147}$ y a tal efecto se introdujeron en el catálogo de

\footnotetext{
${ }^{146}$ No obstante, debe ponerse de manifiesto que el TJUE tuvo ocasión de matizar su doctrina en la STJUE de 19 de abril de 2012, asunto Bonnier C-461/10 en el que los editores pretendían obtener de un prestador de servicios de Internet el nombre y la dirección del usuario de la dirección IP desde la que se habían difundido al público 27 obras mediante un servidor FTP, poniendo de manifiesto que la Directiva 2006/24 debía de interpretarse en el sentido de que no se opone a la aplicación de una normativa nacional, basada en el art. 8 de dicha Directiva que, a efectos de identificación de un abonado a Internet o de un usuario de Internet, permite que se requiera judicialmente a un proveedor de acceso a Internet para que comunique al titular de un derecho de autor o su causahabiente la identidad del abonado a quien se ha asignado una determinada dirección IP que supuestamente ha servido para la vulneración de dicho derecho, puesto que tal normativa no es ajena al ámbito de aplicación ratione materiae de la Directiva 2006/24.

${ }^{147}$ Vid. Díaz Pita, P., Diligencias preliminares y..., ob. cit., p. 179. Además, debe tenerse en cuenta que la misma hunde también sus raíces en la Directiva 2004/48/CE denominada en alguna ocasión como "Directiva Antipiratería", tal y como así pone de manifiesto López Sánchez, J., Las nuevas diligencias preliminares en materia de propiedad intelectual y propiedad industrial: el denominado "derecho de información" y la "exhibición de documentos comerciales (1), en "Diario La Ley", 2006, núm. 6429 (LA LEY 320/2006), p. 1. Además, debe tenerse en cuenta que también se aprovechó la Ley 21/2014 para reforzar el procedimiento administrativo de salvaguarda ante la Sección Segunda de la Comisión de Propiedad Intelectual y prácticamente al mismo tiempo la LO 1/2015, de 30 de marzo, de modificación del CP introdujo un nuevo tipo delictivo en derechos de autor directamente relacionado con la puesta a disposición y difusión de obras y contenidos en la red, de forma tal que como pone de manifiesto Obra 1: Castán Pérez-Gómez, El nuevo régimen..., ob. cit., p. 148, "De este modo la reforma, globalmente
} 
diligencias del art. 256.1 LEC las contempladas en los ordinales $10^{\circ}$ y $11^{\circ}$. Su finalidad, tal y como se desprende de su redacción legal, es la de facilitar la preparación de los procesos por infracción de los derechos de propiedad industrial e intelectual cometidos a través de la red mediante la identificación de los prestadores de servicios de la sociedad de la información o de usuarios de los mismos sobre los que concurran indicios razonables de disponer o difundir contenidos, obras o prestaciones objeto de aquellos derechos sin que se cumplan los requisitos legalmente establecidos. En concreto, en el caso del ordinal $10^{\circ}$, para lograr la identificación de un prestador de servicios de la sociedad de la información que indiciariamente esté difundiendo a gran escala contenidos protegidos sin contar con la debida autorización y, en el caso del ordinal $11^{\circ}$, como diligencia exclusiva de las acciones de propiedad intelectual, para la identificación del usuario de un servicio de la sociedad de la información sobre el que, igualmente, concurran indicios de que está difundiendo ilícitamente a gran escala contenidos protegidos.

Como se observa de lo hasta ahora expuesto, con su entrada en vigor, la LEC inicialmente amplió el catálogo de diligencias preliminares contemplado en el precedente art. 497 ALEC, que posteriormente se ha ido extendiendo para, salvedad hecha de la diligencia prevista en el núm.. 5bis del art. 256.1 LEC, como así se anunciaba en el apartado II de la Exposición de Motivos de la Ley 19/2006, de 5 de junio, en el ámbito de los derechos de propiedad intelectual e industrial, ofrecer medios adecuados y suficientes para la tutela jurisdiccional de tales derechos.

considerada, comporta la consagración de tres clases de ilícito -civil, penal y administrativo- perseguibles por tres vías distintas -el orden jurisdiccional civil, el penal y el contencioso administrativo". 


\section{Características}

\subsection{Finalidad preparatoria, o de evitación, del proceso ulterior}

La característica principal de las diligencias preliminares puede extraerse del propio tenor literal del art. 256 LEC, identificándose la misma con la tan recurrentemente afirmada por la doctrina finalidad preparatoria del proceso posterior ${ }^{148}$.

Ahora bien, un estudio adecuado de la cuestión no puede detenerse en una afirmación generalística de dicha finalidad preparatoria que no determine a qué aspectos o ámbitos puede extenderse la misma ${ }^{149} \mathrm{o}$ en relación a qué procesos.

Y dado que la LEC, en la regulación que dedica a las diligencias preliminares, al menos de forma expresa, nada precisa al respecto, nuevamente, la interpretación que de la norma haya hecho la doctrina nos permitirá precisar los aspectos antes apuntados. Ello pese a que, como se verá, la indefinición y ambigüedad que trasciende a dicha interpretación es de gran calado y dificulta la delimitación de dicha finalidad preparatoria de las diligencias preliminares.

Partiendo de lo anterior, el estudio realizado hasta este momento nos permite comenzar señalando que las diligencias preliminares son la herramienta procesal que el ordenamiento jurídico español dispone para la obtención de determinada información que permita al solicitante preparar el juicio posterior que se advierte ante el surgimiento de una contienda entre particulares. Afirmación esta que, además, ha sido matizada por la doctrina al precisar que las diligencias preliminares no buscan, básicamente, facilitar el proceso posterior, sino determinar si tiene o no sentido iniciarlo ${ }^{150}$.

\footnotetext{
${ }^{148}$ Garberí Llobregat, J., Las diligencias preliminares..., ob. cit., pp. 26-27; Garciandía González, P.M., La regulación de...., ob.cit., p. 774, cuando señala que la finalidad de las diligencias preliminares se enmarca en la preparación del proceso.

${ }^{149}$ Pues, en palabras de Alonso Furelos, J.M., La exhibición de..., ob. cit., p. 403, "no es lo mismo que la preparación se refiera al hecho de interponer la demanda, supuesto al que parece referirse la ley, que preparar el juicio a efectos de lograr un medio de prueba en poder de un tercero".

${ }_{150}$ Banacloche Palao, J., Las diligencias preliminares..., ob. cit., p. 30.
} 
Ahora bien, del propio texto legal se desprende que las diligencias preliminares no han sido dispuestas para la obtención de cualquier tipo de información. Es decir, que las diligencias preliminares no pueden ser utilizadas para la obtención indiscriminada de información sino, única y exclusivamente, de aquella información necesaria para preparar el proceso posterior. Pero tampoco para la obtención de aquella información que, para la preparación del proceso posterior, entienda necesaria su solicitante, sino, a nuestro juicio y a priori, para la obtención de aquella información que refiere el catálogo de diligencias contenido en el art. 256.1 LEC. Y se dice que, a priori, porque es mayoritaria la doctrina judicial que entiende procedente la interpretación flexible del catálogo de medidas contenido en dicho precepto legal abogando por la admisión de cuantas diligencias que, sin ser indeterminadas, puedan resultar incluidas en dicho catálogo.

Al margen de lo anterior, puede afirmarse que la búsqueda de notas comunes de esa finalidad preparatoria del proceso posterior que nos permitan delimitar su ámbito, a la vista de la interpretación que la doctrina ha hecho de la misma, no es tarea sencilla.

Así, nos encontramos con resoluciones judiciales que, con una visión amplia y garantista, entienden que la finalidad de las diligencias preliminares es la obtención de [...] la efectividad de la tutela judicial" "151; o que aquella atiende a la "[...] necesidad de todo ciudadano de reunir unos presupuestos y requisitos procesales para poder acceder a la tutela jurisdiccional" 152 permitiendo la iniciación de "[...] un proceso en las adecuadas condiciones para conseguir el fin que con él se pretende, despejando las dudas que podrían comprometer el adecuado planteamiento o su propia utilidad o éxito" ${ }^{153}$, descendiendo en algunos casos a la supresión de “[...] obstáculos procesales que bien pudieran radicarse en excepciones procesales a dilucidar en la Audiencia Previa, o

\footnotetext{
${ }^{151}$ AAP de Vizcaya (sección $3^{\text {a }}$ ) de 17 de octubre de 2007, ponente Ilma. Sra. MC. Marco, f.j.2º (LA LEY 255656/2007).

${ }^{152}$ AAP de Vizcaya (sección $3^{\text {a }}$ ) de 15 de noviembre de 2007, ponente Ilma. Sra. A.I. Gutiérrez, f.j. $2^{\text {o }}$ (LA LEY 239652/2007).

${ }^{153}$ AAP de Las Islas Baleares (sección $3^{\text {a }}$ ) de 18 de noviembre de 2003, ponente Ilma. Sra. C. Moragues, f.j.3ํ (ROJ AAP IB 317/2003).
} 
Juicio Oral, según el Juicio, e incluso pudieran producir el desistimiento en el actor por error a la hora de elegir al demandado" 154 .

Otro grupo de resoluciones identifican su finalidad con la obtención de “[...] los datos indispensables para que el futuro juicio pueda tener eficacia" ${ }^{155} \mathrm{o}$, con la obtención de " [...] datos o cualquier otra circunstancia esencial para la correcta formulación de la demanda, es decir, aquellos hechos o elementos que son necesarios e indispensables conocer o tener para iniciar correctamente un proceso, facilitar su desarrollo o asegurar la eficacia de la Sentencia que en su día se dicte" ${ }^{156}$. También, para la obtención de "[...] información sobre el fundamento mismo de la acción proyectada, con la finalidad de facilitar el desarrollo ulterior del juicio ${ }^{157}$.

Además de lo anterior, existen resoluciones que refieren dicha finalidad al momento inicial del proceso ulterior, es decir, a la obtención de datos necesarios para la iniciación del procedimiento, que no para su desarrollo posterior, al referirse a las diligencias preliminares como "[...] un conjunto de actuaciones judiciales que se dirigen a aclarar las cuestiones que pudieran surgir antes del nacimiento de un proceso principal” ${ }^{158}$ tales como la previa determinación de “[...] la legitimación (...) orientándose al esclarecimiento de aquellos extremos enumerados por el art. 256 LEC y

\footnotetext{
${ }^{154}$ AAP de Jaén (sección $3^{\text {a }}$ ) de 4 de diciembre de 2003, ponente Ilmo. Sr. J.M ${ }^{\text {a }}$. Passolas, f.j. $1^{\circ}$ (JUR 2004l20056).

${ }^{155}$ ATS de 11 de noviembre de 2002 (sala $1^{\text {a }}$ ), ponente Ilmo. Sr. J.M. Martínez-Pereda, f.j.2 ${ }^{\circ}$ (LA LEY 222960/2002). En similares términos, el AAP de Asturias (sección $4^{\mathrm{a}}$ ) de 23 de diciembre de 2003, ponente Ilmo. Sr. R. Avelló, f.j. $2^{\circ}$ (LA LEY 217713/2003) cuando señala que “[...] las diligencias preliminares constituyen aquel conjunto de actuaciones de carácter jurisdiccional tendentes a conocer los datos precisos para que el futuro juicio pueda tener eficacia".

${ }^{156}$ En dicho sentido AAP de Sevilla (sección $5^{\text {a) }}$ de 1 de marzo de 2005, ponente Ilmo. Sr. J. Herrera, f.j. $2^{\circ}$ (LA LEY 48585/2005). En similares términos, el AAP de Madrid (sección 11ª) de 8 de enero de 2007, ponente Ilmo. Sr. J. Zarzuelo, f.j. $2^{\circ}$ (LA LEY 35128/2007) cuando refiere que las diligencias preliminares "[...] tienen por objeto obtener los datos necesarios bien para facilitar un proceso posterior, condicionar su existencia o en su caso asegurar la eficacia dela sentencia que en su día haya de dictarse". En tal sentido, Banacloche Palao, J., Las diligencias preliminares..., ob. cit., p. 29, cuando apunta que "Las diligencias preliminares se instan para obtener información acerca de algún aspecto relevante para un posible proceso posterior, sin cuyo conocimiento dicho proceso podría configurarse de manera errónea o perjudicial para quien solicita tal información".

${ }^{157}$ AAP de Zamora (sección $1^{\text {a }}$ ) de 8 de enero de 2003, ponente Ilmo. Sr. A.M. Encinas, f.j. $3^{\circ}$ (LA LEY 4170/2003).

${ }^{158}$ AAP de Las Islas Baleares (sección $3^{\mathrm{a}}$ ) de 5 de junio de 2003, ponente Ilma. Sra. G. Rosello, f.j.2 ${ }^{\circ}$ (LA LEY 100036/2003).
} 
sin cuyo conocimiento no es posible la iniciación del procedimiento" 159 y otras que extienden dicha finalidad al desarrollo y desenvolvimiento, de un proceso posterior" ${ }^{160}$.

Pero, aun con más detalles, nos encontramos resoluciones que identifican la finalidad de las diligencias preliminares con la de obtención de “[...] información acerca de circunstancias relativas a la personalidad del futuro demandado, o a otros extremos que se precise conocer para la iniciación con éxito de un procedimiento civil ${ }^{161}$ o con “[...] la concurrencia de determinados requisitos en la persona o entidad que pudiera ser demandada. Requisitos o condiciones relativos tanto a capacidad y legitimación, como la preexistencia o posesión de determinados bienes que habrán de ser objeto de la demanda o de la concurrencia de singulares presupuestos de viabilidad apriorística del contencioso que se pretende entablar" ${ }^{162}$. También, con la finalidad de obtener información documentada al señalar que las diligencias preliminares están previstas "[...] con la finalidad de facilitar la posibilidad de conseguir la información documental necesaria para la presentación de la demanda por parte de quién esté legitimado para ello" 163 .

De lo anterior se desprende, como ha sido puesto de manifiesto en la doctrina, que la finalidad esencial de preparación del juicio que contempla el art. 256 LEC comprende un conjunto de actuaciones diversas con el general objetivo de preparación del juicio posterior pero particular de cada uno de los supuestos contemplados en el

\footnotetext{
${ }^{159}$ AAP de Las Palmas (sección $5^{\text {a }}$ ) de 19 de abril de 2004, ponente Ilmo. Sr. J. Manrique de Lara, f.j. $2^{\circ}$ (LA LEY 90223/2004).

${ }_{160}$ AAP de Cádiz (sección 7ª) de 30 de abril de 2003, ponente Ilmo. Sr. M. Gutiérrez, f.j.1 ${ }^{\circ}$ (LA LEY 79289/2003).

${ }^{161}$ AAP de Barcelona (sección 15a) de 27 de junio de 2006, ponente Ilmo. Sr. J.L. Forgas, f.j.2 ${ }^{\circ}$ (LA LEY 232044/2006). En similares términos el AAP de Madrid (sección 11 ${ }^{\text {a }}$ ) de 29 de noviembre de 2003, ponente Ilma. Sra. L. Ruíz de Gordejuela, f.j.1º (LA LEY 198054/2003) cuando refiere que "[...] sirven para averiguar hechos relevantes a los efectos de decidir contra quien debe dirigirse la demanda" y el AAP de Madrid (sección 11 $1^{\mathrm{a}}$ ) de 8 de enero de 2007, ponente Ilmo. Sr. J. Zarzuelo, f.j. $2^{\circ}$ (LA LEY 35128/2007) al referir que "[...] permiten a la parte interesada obtener ciertos datos o documentos relativos al objeto de la controversia o a la personalidad y legitimación de la parte contraria, como también a la legitimación activa (art. 256.6 LEC) o a hechos fundamentales para el éxito de la demanda (art. 256.7 LEC)".

${ }_{162}$ AAP de Huelva (sección $2^{\text {a }}$ ) de 4 de julio de 2006, ponente Ilmo. Sr. F. G. Ruíz, f.j.1º (LA LEY 204861/2006).

${ }^{163}$ AAP de Barcelona (sección 13 $3^{\mathrm{a}}$ ) de 12 de marzo de 2007, ponente Ilma. Sra. Ma A. Gomis, f.j.2 (LA LEY 14888/2007).
} 
catálogo de diligencias que al amparo de aquel se pueden solicitar ${ }^{164}$. En suma, de aquellas que permitan satisfacer el derecho a la tutela judicial efectiva ${ }^{165}$ que el propio art. 256 y ss. LEC pretende asegurar. Es decir, aquellas que den cumplimiento al principio informador de la tutela jurisdiccional consistente en proporcionar a los justiciables una fórmula adecuada para resolver pacífica y justamente sus controversias jurídicas y que, en modo alguno, puede amparar la utilización de las diligencias preliminares como fuente de información de prueba ${ }^{166}$. Podrán referirse a la relación jurídico material o a cuestiones que atañan directamente a la articulación del proceso como herramienta procedimental y en todo caso, deberán referirse a circunstancias o informaciones que no pueda obtener el solicitante por sí mismo ${ }^{167}$.

Y, como cláusula de cierre no prevista legalmente, cabe también afirmar que la finalidad preparatoria del proceso posterior sirve a la evitación del propio proceso para el caso de que la información obtenida demuestre la insostenibilidad del mismo, lo que ha dado lugar a que algún autor haya aludido a la doble finalidad, positiva o de preparación, y negativa o de evitación, de las diligencias preliminares ${ }^{168}$. Esta finalidad negativa de las diligencias preliminares ha sido también reconocida en la doctrina judicial al identificarse las diligencias preliminares como el “[...] conjunto de actuaciones de carácter jurisdiccional, ya previstas en la derogada ley procesal, cuya

\footnotetext{
${ }^{164}$ Garberí Llobregat, J., Las diligencias preliminares..., ob, cit., p. 27.

${ }^{165}$ En dicho sentido, el AAP de Zamora (sección $1^{\text {a }}$ ), de 8 de enero de 2003, ponente Ilmo. Sr. A.M. Encinas, f.j.2 ${ }^{\circ}$ (LA LEY 4170/2003) cuando señala que: "[...] la finalidad esencial del citado precepto es el conceder, a cualquier persona legitimada par ello, la facultad de imprecar la tutela de los órganos judiciales para precisar y aclarar datos, elementos y cuestiones para ser usados en un eventual y posterior proceso judicial, tras la oportuna valoración, estudio y evaluación de las mismas”.

${ }^{166}$ En dicho sentido, el AAP de Zamora (sección $1^{\text {a }}$ ) de 30 de diciembre de 2005, ponente Ilmo. Sr. A.M. Encinas, f.j.2 ${ }^{\circ}$ (LA LEY 250771/2005) cuando señala: “[...] Esta finalidad no puede, en efecto, subvertirse, para preconfigurar determinadas probanzas con carácter previo a la iniciación del proceso y sin las garantías que a éste acompañan (singularmente la presencia de la parte contraria), cuando, precisamente, dichas pruebas encuentran perfecto acomodo en el procedimiento que corresponda. Pero para su adecuada compresión ha de partirse del derecho constitucional al acceso al proceso como medio para obtener una tutela adecuada (S 24 mayo 1993, Sección 19 de la AP de Madrid), lo que implica que los órganos jurisdiccionales deben realizar una interpretación flexible, en el sentido más favorable a la efectividad de aquel derecho".

${ }^{167}$ Con tal parecer, Banacloche Palao, J., Las diligencias preliminares..., ob. cit., p. 29.

${ }^{168}$ En dicho sentido, Garberí Llobregat, J., Las diligencias preliminares..., ob, cit., p. 27, al expresar que las diligencias preliminares "ostentan tanto una clara finalidad positiva, si (la de preparar el futuro proceso para que éste sea eficaz, para facilitar su desenvolvimiento, o para poder iniciarlo con éxito), cuanto una finalidad negativa (la de constatar, con los nuevos datos o informaciones obtenidos, que no procede e interponer ese ulterior, y por tanto eventual proceso).
} 
práctica se solicita al juzgado como necesaria para entablar un futuro pleito, ya sea para determinar su contenido, para concretar quienes deban ser las personas demandadas o incluso para poder determinar la eventual procedencia del proceso" 169 .

Ahora bien, debemos plantearnos si esta finalidad preparatoria de las diligencias preliminares, para la obtención de la información necesaria para la preparación, o evitación, del proceso posterior referida en el catálogo del art. 256.1 LEC cabe sea pretendida respecto de cualquier proceso posterior. Es decir, debemos preguntarnos qué procesos se pueden preparar mediante las diligencias preliminares.

La circunstancia de encontrarse contenida la regulación de las diligencias preliminares en determinados arts. situados en el Libro Segundo LEC, que lleva por título "De los Procesos Declarativos", ha planteado la duda acerca de los procesos que pueden ser preparado o, en su caso, evitado. Más concretamente, ha suscitado la duda de determinar si, a través de dicho catálogo de diligencias preliminares, pueden prepararse o evitarse, única y exclusivamente, aquellos procedimientos de carácter declarativo ${ }^{170}$, como son el juicio ordinario y verbal o, si a mayor abundamiento, pueden prepararse, además de los anteriores, cualesquiera otros procedimientos de naturaleza especial, cautelar o ejecutiva.

En relación a dicha cuestión nos encontramos con autores que afirman que estando claro que las diligencias preliminares se pueden emplear para la preparación de los procesos declarativos regulados en el Libro Segundo LEC, su empleo para la preparación de otros como los especiales contenidos en el Libro IV no parece sea consentido por la LEC siendo en relación a ellos su utilidad nula, al menos si

\footnotetext{
${ }^{169}$ AAP de Santa Cruz de Tenerife (sección $4^{\text {a }}$ ) de 18 de abril de 2007, ponente Ilma. Sr. P. Aragón, f.j. $3^{\circ}$ (LA LEY 50149/2007). Destaca también dicha finalidad negativa de las diligencias preliminares, el AAP de Zamora (sección $1^{\text {a }}$ ) de 30 de diciembre de 2005, ponente Ilmo. Sr. A.M. Encinas, f.j.2 $2^{\circ}$ (LA LEY 250771/2005) cuando señala: "[...] es decir, que no tienen estas diligencias que desembocar necesariamente en un proceso sino que es perfectamente legitimo el que, tras ese examen de los elementos documentales o solicitados, se opte por no ejercitar acción alguna".

${ }^{170}$ Como así se sostiene, entre otros, por el AAP de Álava (sección $1^{\mathrm{a}}$ ), de 12 de noviembre de 2007, ponente Ilma. Sra. Mª.M. Guerrero, f.j. $1^{\circ}$ (LA LEY 250988/2007).
} 
entendemos como diligencias preliminares sólo las enumeradas en el art. 256 se $\operatorname{admiten}^{171}$.

Pero también nos encontramos con autores que ponen de manifiesto cierto sentir de nuestra doctrina judicial conforme a la cual las diligencias preliminares tienen por finalidad la de la preparación de cualquier juicio posterior respecto de la cual las mismas se deduzcan y sea posible, incluso en el caso en que la reclamación futura hubiera de llevarse a cabo a través del procedimiento arbitral ${ }^{172}$. Por ello, como ponen de manifiesto, no se entiende qué excepción no prevista legalmente podría hacerse, por ejemplo, cuando quien pretenda instar un posterior proceso monitorio, de naturaleza especial conforme a la propia designación legal, precise de información sobre la capacidad de su deudor. $\mathrm{O}$, incluso, cuando previamente a la solicitud del despacho de la ejecución sea preciso la obtención de datos que no se encuentran al alcance del solicitante de diligencias preliminares ${ }^{173}$. En este último caso, no podemos olvidar que,

\footnotetext{
${ }_{171}^{171}$ Cfr. Álvarez Alarcón, A., Las diligencias preliminares..., ob. cit., p. 35.

${ }^{172}$ En dicho sentido Garciandía González, P.M., La regulación de..., ob. cit., p. 792, con cita de la SAP de Zaragoza (sección $2^{\mathrm{a}}$ ) de 27 de febrero de 2001, ponente Ilma. Sra. M $^{\mathrm{a}}$.E. Mata, f.j.2 $2^{\mathrm{o}}$ (LA LEY 46729/2001) que, bajo el imperio de la ALEC, rectificando la decisión del tribunal de instancia, admitió la procedencia de una petición de diligencias preliminares dirigida a preparar un posterior procedimiento arbitral al no operar, conforme al texto de la ALEC -al igual que ocurre en la actual LEC- excepción alguna respecto del juicio posterior y que pueda servir para denegar la preparación interesada y necesaria sea cual sea el procedimiento en que se deduzca la posible y futura reclamación.

${ }^{173}$ En la doctrina científica, ello es sostenido por Banacloche Palao, J., Las diligencias preliminares..., ob. cit., p. 47. En la doctrina judicial, así fue admitido en el supuesto del AAP de Cádiz (sección $5^{\text {a }}$ ) de 2 de julio de 2008, ponente Ilma. Sra. R.Mª. Fernández, f.j. único (LA LEY 196482/2008) en el que se contempló un supuesto de diligencia preliminar consistente en la exhibición por parte de su ex esposo de los recibos de salario de un periodo concreto y con la finalidad de ejecutar las obligaciones contraídas por el mismo en un convenio matrimonial consistentes en la entrega a su ex esposa del $30 \%$ de sus haberes en pago de los alimentos debidos a los hijos comunes, confiados a la custodia materna, con un mínimo de 300 euros al mes dado que el ex esposo venía abonando sistemáticamente la cuantía mínima, sin que le constaran a la acreedora sus haberes ni la procedencia o no de superiores cantidades susceptibles de exacción forzosa. Pese a que la diligencia preliminar fue inadmitida en primera instancia, la AP revoca la resolución dada en la instancia admitiendo la diligencia preliminar al considerar que la misma es perfectamente adecuada a la finalidad perseguida. Sin embargo, debe tenerse en cuenta que peticiones similares a las contempladas en la resolución citada niegan tal posibilidad. Así, el AAP de Barcelona (sección 18 ${ }^{\mathrm{a}}$ ) de 31 de marzo de 2009, ponente Ilma. Sra. Ma.D. Viñas, f.j.1º (LA LEY 164675/2009). También, de forma similar, en el AAP de Cáceres (sección $7^{\mathrm{a}}$ ) de 30 de enero de 2004, ponente Ilmo. Sr. J. Pavieso, f.j. $2^{\circ}$ (LA LEY 26999/2004), en el que un progenitor solicitaba la exhibición o presentación en la Secretaría del Juzgado de copia fehaciente del informe de la vida laboral de su hijo, emitida por la Tesorería General de la Seguridad Social, y certificado del INEM sobre los periodos en que hubiera permanecido de alta como demandante de empleo, a fin de determinar el derecho a solicitar la extinción de la pensión alimenticia a favor de su hijo y a cargo del solicitante establecida en la sentencia de separación, en base a las diligencias preliminares en la LEC. El tribunal rechazó las diligencias preliminares interesadas señalando al efecto que: "[...] sin que la pretensión del requerimiento para
} 
en los supuestos de ejecuciones dinerarias, el art. 575 LEC impone la necesidad de despachar ejecución por la cantidad que se reclame en la demanda ejecutiva en concepto de principal e intereses ordinarios y moratorios. Y que, en determinados supuestos, tal cantidad no podrá ser conocida por el ejecutante cuando, por ejemplo, la misma deba venir determinada por datos o informaciones que no estén al alcance de aquel y que no puedan obtenerse, como en algún caso se ha obtenido, a través del procedimiento de los arts. 713 y ss. LEC pues, como este precepto legal dispone, su ámbito de aplicación es el de la determinación de equivalente pecuniario de una prestación no dineraria, el de la fijación de una cantidad debida en concepto de daños y perjuicios o de frutos, rentas, utilidades o productos de cualquier clase o el de la determinación del saldo resultante de la rendición de cuentas de una administración.

Una vez hemos determinado que las diligencias preliminares son, a nuestro juicio, una herramienta útil para la preparación de cualquier proceso posterior cabe preguntarnos si tal proceso posterior que se pretende preparar o, en su caso evitar, debe corresponderse con alguno de aquellos de los que, en todo caso, debe conocer la jurisdicción civil o, también, de los que deban conocer otras jurisdicciones como la contencioso administrativa, cuál sería el caso de la diligencia prevista en el art. 256.1.5 bis LEC en relación a una posterior posible demanda de responsabilidad patrimonial de la Administración Pública, cuyo conocimiento corresponde a la jurisdicción contencioso-administrativa. Pues bien, pese a que la respuesta negativa pudiera parecer evidente, resulta que dicho supuesto tuvo una acogida favorable en la práctica forense en un supuesto de diligencias preliminares consistentes en el requerimiento a un centro sanitario y una Consejería de Sanidad para la exhibición y entrega al peticionario de la copia íntegra de su historia clínica que en su solicitud de diligencias había anunciado una presunta responsabilidad patrimonial de los servicios médicos del hospital y la exigencia de responsabilidades extracontractuales por los daños y perjuicios ocasionados por una mala praxis médica ${ }^{174}$.

exhibición o presentación del informe y certificación solicitados, que por otra no son "cosas" que se encuentren en poder del requerido, tenga claro encaje en alguna de las diligencias legalmente previstas ni tampoco en las específicamente solicitadas pues la acción personal no tendría por objeto una cosa".

${ }^{174}$ AAP de Madrid (sección $8^{\text {a }}$ ) de 30 de junio de 2009, ponente Ilma. Sra. M ${ }^{\text {a }}$.V. Salcedo, f.j.4 ${ }^{\text {o }}$ (ROJ AAP M 8367/2009), cuyo criterio fue avalado por las Conclusiones del Seminario de Jueces 2014. 
Tal solicitud parece chocar con la regulación que de la competencia hace el art. 257 LEC estableciendo que para resolver las peticiones y solicitudes de las diligencias preliminares será competente el juez de primera instancia o de lo mercantil, cuando proceda, del domicilio de la persona que deba exhibir la documentación requerida. Y por ello, el JPI, declaró su incompetencia por considerar que el litigio que, en su caso, interpondría el reclamante, lo sería en reclamación de responsabilidad patrimonial de las Administraciones Públicas y, por tanto, su conocimiento correspondía a la jurisdicción contencioso-administrativa de conformidad con el art. 2e) de la LJCA, y el art. 9.4 LOPJ.

Sin embargo lo anterior, considerando el derecho de todo paciente a acceder a la documentación de su historia clínica ${ }^{175}$, la AP consideró que el solicitante tenía derecho a conocer el contenido que de la misma obraba en los archivos del centro sanitario con el fin de dilucidar si, conforme a su contenido, podía formular algún tipo de reclamación contra el centro hospitalario, los médicos y personal sanitario o contra la entidad aseguradora que, en su caso, cubriera la responsabilidad del centro o de los profesionales que le había prestado asistencia. Ello, con independencia de la estimación que, tras su examen, hiciere la parte sobre la acción judicial que debía ser entablada y la jurisdicción que debía conocer de la misma, determinando el tribunal que no autorizaba el rechazo de las diligencias preliminares la circunstancia de prever la preparación de un proceso de responsabilidad patrimonial de la Administración del que debiera conocer la jurisdicción contencioso-administrativa.

Y es que, si se lee con detenimiento el art. 257 LEC, se observará como, a diferencia de las diligencias previstas en los ordinales $6^{\circ}, 7^{\circ}, 8^{\circ}$ y $9^{\circ}$, la competencia para conocer de la diligencia preliminar del art. 256.1.5 bis LEC no viene ligada a la del tribunal competente que haya de conocer de la demanda ulterior sino, única y exclusivamente, a la del tribunal del domicilio de la persona que, en su caso, hubiera de declarar, exhibir o intervenir de otro modo en las actuaciones que se acordaran para preparar el juicio.

\footnotetext{
${ }^{175}$ Art. 18 LABP.
} 
Sin embargo, y aún la respuesta positiva que ha obtenido el supuesto concreto en la práctica forense, entendemos que no estaba en el espíritu del legislador permitir, a través de las diligencias preliminares, la preparación de procesos ajenos al orden jurisdiccional civil. Máxime cuando, como era el caso, de la solicitud de diligencias preliminares se desprenda que la preparación que se persigue es la de un ulterior proceso que no participa de aquella naturaleza. De hecho, otros órdenes jurisdiccionales como el social, con el mismo sentido preparatorio del ulterior proceso que las contempladas por la LEC, han previsto sus propias diligencias preliminares ${ }^{176}$.Por ello, la circunstancia de haberse admitido el supuesto analizado, a nuestro juicio, si bien pudiera obedecer a la necesidad de dar respuesta a una laguna u omisión de la norma reguladora del proceso contencioso-administrativo ${ }^{177}$ no encuentra acogida en la LEC ni es acorde a la preparación del proceso civil, al que atienden las diligencias preliminares $^{178}$.

\footnotetext{
${ }^{176}$ Dispone el art. 76 LRJS que: “1. Quien pretenda demandar, podrá solicitar del órgano judicial que aquel contra quien se proponga dirigir la demanda preste declaración acerca de algún hecho relativo a la personalidad, capacidad, representación o legitimación de éste, o con igual finalidad aporte algún documento, cuyo conocimiento sea necesario para el juicio.

Igualmente podrá solicitarse, por quien pretenda demandar, la determinación de quiénes son los socios, partícipes, miembros o gestores de una entidad sin personalidad y las diligencias necesarias encaminadas a la determinación del empresario y los integrantes del grupo o unidad empresarial, así como la determinación de las personas concurrentes a la producción de un daño con la persona a la que se pretenda demandar y la cobertura del riesgo en su caso.

2. El juicio podrá también prepararse por petición de quien pretenda iniciar un proceso para la defensa de los intereses colectivos, al objeto de concretar a los integrantes del grupo de afectados cuando, no estando determinados, sean fácilmente determinables. A tal efecto el tribunal adoptará las medidas oportunas para la averiguación de los integrantes del grupo, de acuerdo a las circunstancias del caso y conforme a los datos suministrados por el solicitante, incluyendo el requerimiento al demandado para que colabore en dicha determinación.

3. Podrá formularse también petición de práctica de otras diligencias y averiguaciones necesarias para preparar el juicio de las previstas en el artículo 256 de la Ley de Enjuiciamiento Civil.

4. Cuando la realización de la diligencia solicitada pueda afectar a la intimidad personal $\mathrm{u}$ otro derecho fundamental, el juzgado o tribunal, de no mediar el consentimiento del afectado, podrá autorizar dicha actuación en la forma y con las garantías establecidas en los apartados 4 a 6 del artículo 90.

5. La Inspección de Trabajo y Seguridad Social y, en su caso, la Administración laboral, en el ejercicio de sus funciones, cuando el centro de trabajo sometido a inspección coincidiese con el domicilio de la persona afectada, podrá solicitar la correspondiente autorización judicial, si el titular se opusiere o existiese riesgo de tal oposición, en relación con los procedimientos administrativos de los que conozca o pueda conocer posteriormente la jurisdicción social, o para posibilitar cualquier otra medida de inspección o control que pudiera afectar a derechos fundamentales o libertades públicas.

6. Contra la resolución judicial denegando la práctica de estas diligencias no cabrá recurso alguno, sin perjuicio del que en su día puedan interponerse contra la sentencia”.

${ }_{177}$ Los arts. 43 y 44 de la LJCA regulan las diligencias preliminares con un sentido y finalidad absolutamente distintos a la LEC.

${ }^{178} \mathrm{Y}$, por ello, la diligencia preliminar ha sido rechazada cuando su finalidad era la preparación de procesos correspondientes a otros órganos jurisdiccionales como el penal siendo ejemplo de ello el AAP
} 
Llegados a este punto, entendemos que una reflexión sobre la naturaleza de las cuestiones que pueden dilucidarse a través de la práctica de las diligencias contenidas en el art. 256.1 LEC permite advertir que las mismas ni son una fuente de obtención de pruebas ni tienen por finalidad el aseguramiento del resultado del procedimiento.

Si se lee con detenimiento el contenido de cada una de las diligencias contenidas en el art. 256.1 LEC se advierte que los datos que a través de las mismas pueden obtenerse se entroncan con una serie de elementos que constituyen el presupuesto de todo procedimiento.

En este punto, y sin perjuicio del mayor detalle que se hará al hilo del estudio de cada una de las diligencias contenidas en el art. 256.1 LEC, se advierte que la diligencia contenida en su número $1^{\circ}$ procura el conocimiento de hechos relativos a la capacidad, representación o legitimación, o de los documentos en que tales circunstancias consten. Es decir, que procura el conocimiento de aquello que la doctrina ha estudiado bajo el nombre de presupuestos procesales de las $\operatorname{partes}^{179} \mathrm{y}$ sin cuya concurrencia el órgano judicial en modo alguno entrará a conocer sobre el verdadero fondo del asunto ${ }^{180}$. Y si bien es cierto que no todo defecto de capacidad, representación o legitimación puede considerarse como presupuesto procesal ${ }^{181}$ siendo que, por ejemplo, la legitimación

de Santa Cruz de Tenerife (sección $3^{\mathrm{a}}$ ) de 6 de febrero de 2008, ponente Ilma. Sra. C.M. González, f.j. $1^{\text {o }}$ (LA LEY 45516/2008) que confirma la denegación de la diligencia preliminar interesada en primera instancia, consistente en la obtención de la historia clínica, al no ser preparatoria de un procedimiento civil: “[...] pues del escrito de la actora resulta que dicha parte estima que los actos a que refiere pueden ser constitutivos de un delito de imprudencia profesional, por lo que resulta evidente que su intención no es interponer una demanda civil, evidenciada además por la petición de que sea la policía judicial la que mediante su intervención, obtenga los documentos que requiere", afirmando que deben ser otorgadas cuando se dirijan a la preparación de un proceso civil.

${ }^{179} \mathrm{Al}$ respecto, vid. Gimeno Sendra, V., Derecho Procesal Civil..., ob. cit., pp. 97-153.

${ }^{180}$ En tanto en cuanto, como señala Gimeno Sendra, V., Derecho Procesal Civil..., ob. cit., p. 98, "las partes no pueden, sin más, comparecer en el proceso, sino que han de cumplir también con los presupuestos procesales que les son propios y cuya ausencia impedirá al juez el examen de la relación jurídica debatida".

${ }^{181}$ Como recuerdan, entre otras, las SSTS de 9 de octubre de 1993 (sala 1 ${ }^{\text {a }}$ ), ponente Ilmo. Sr. F. Morales f.j.8 (LA LEY 13445/1993) y de 17 de mayo de 1999, ponente Ilmo. Sr. F. Morales, f.j.3º (LA LEY 80046/1999), debe distinguirse entre legitimación ad procesum, comprensiva de la capacidad para ser parte y la capacidad procesal, cuya ausencia bajo la vigencia de la ALEC podía dar lugar a las desaparecidas sentencias absolutorias en la instancia, y legitimación ad causam, que hace referencia al fondo de la cuestión debatida, en cuanto viene determinada por la titularidad de la relación jurídicomaterial invocada en el proceso concreto de que se trate y cuya solución debe ser abordada en la sentencia que se dicte aún cuando su concurrencia impida entrar en la verdadera cuestión de fondo. 
puede constituirse en una auténtica cuestión de fondo, no es menos cierto que el conocimiento de esa falta de legitimación de aquel frente al que se quiera dirigir el procedimiento también permitirá obtener otra de las finalidades perseguidas por las diligencias preliminares: la evitación del proceso $^{182}$. Y si se evita el proceso difícilmente podrá hablarse de la obtención de una prueba, que sólo puede tener lugar en el marco del mismo ${ }^{183}$.

Similares consideraciones pueden hacerse respecto de la diligencia contenida en el núm. 2 del art. 256.1 LEC, que procura la exhibición de la cosa por la persona a quien se pretende demandar. La diligencia preliminar solicitada al amparo de dicho precepto legal podría partir de una situación posesoria controvertida pretendiendo el aseguramiento de que la persona a la que se tenga intención de demandar, por poseer la cosa, sea la que efectivamente la posea siendo que sólo la recuperación de la posesión de la cosa de ésta se puede pretender. Nuevamente, observamos como la diligencia en cuestión busca el aseguramiento de la legitimación de la persona a quien se vaya a demandar.

Por otro lado, si atendemos al contenido de las diligencias referidas en los números 3 a 5 del art. 256.1 LEC, veremos como a las personas interesadas en una herencia, en una sociedad o comunidad o perjudicados por un hecho que pudiera estar cubierto por un seguro de responsabilidad civil se les procura el conocimiento de presupuestos básicos para el ejercicio de derechos que a su condición de tales se asocian. Procuran así que el que se crea con derecho a una herencia pueda confirmar si tal derecho existe o no o en qué términos; que el socio o comunero pueda ejercitar los derechos derivados de tal condición; o que quien sea perjudicado por un hecho cubierto por un seguro de responsabilidad civil pueda ejercitar la acción directa que el art. 76 LCS, le reconoce, pues si desconoce la identidad de la persona que asegura así como los términos del aseguramiento aquella no podrá ejercitarse. Pero no procuran esas diligencias la obtención de dato alguno que en el procedimiento posterior le permita

\footnotetext{
${ }^{182}$ Por ejemplo, cuando a través de las diligencias preliminares advierta el solicitante que el requerido no ostenta titularidad alguna respecto de la relación jurídico-material que se quiera invocar.

${ }^{183}$ Cfr. Gimeno Sendra, V., Derecho Procesal Civil..., ob. cit., pp. 402-403.
} 
acreditar, por ejemplo, que el siniestro efectivamente se produjo y en qué circunstancias tuvo lugar, sino únicamente que en caso de producirse aquel en unas circunstancias concretas una determinada persona, la que asegure el hecho cubierto, sea la que deba responder. Igualmente, procuran dichas diligencias, que el socio o comunero conozca el estado de las cuentas de la comunidad o sociedad, pudiendo valorar la procedencia de exigir responsabilidad por la ausencia de una administración diligente de las mismas, con independencia de que las circunstancias determinantes de la responsabilidad se prueben o no en juicio.

Pero, continuando con dicho análisis, veremos como la diligencia contenida en el núm. 5 bis del art. 256.1 LEC, la petición de la historia clínica al centro sanitario o profesional que la custodie, en las condiciones y con el contenido que establece la ley, permitirá al paciente o sus causahabientes conocer los profesionales y tratamiento suministrado pudiendo determinar, por ejemplo, quienes pudieran ser los responsables de un posible error médico cuya concurrencia a la postre habrá de probarse debidamente. Ello, teniendo en cuenta que la LABP, configura un verdadero derecho del paciente, o de sus causahabientes, que no requiere la concurrencia de voluntad alguna de demandar en un proceso posterior.

En el caso de la diligencia contenida en el número 6 del art. 256.1 LEC, se procura la averiguación de los integrantes de un grupo de afectados para el inicio de un proceso para la defensa de los intereses colectivos de consumidores y usuarios, sin cuya identificación no podría iniciarse. No se procura con la misma determinar si efectivamente, los integrantes de tal grupo, han sido afectados o no en sus derechos y en qué términos.

Y en el caso de las diligencias contenidas en los números 7 a 11 del art. 256.1 LEC se procura el conocimiento y comprobación de determinados datos que permiten la preparación de los procesos por infracción de los derechos de propiedad industrial e intelectual, que no la constatación de la infracción en cuestión. 
Como conclusión, no cabe sino afirmar que los datos que se procuran conocer a través de las diligencias preliminares contempladas en el art. 256.1 LEC guardan relación directa con una serie de presupuestos previos, de hecho o de derecho, que se ha estimado necesario conocer para iniciar debidamente todo proceso y no para probar los términos en los que han discurrido los hechos objeto de controversia.

\subsection{Instrumentalidad}

Como su nombre pone en evidencia, así como su regulación sistemática en la LEC demuestra, las diligencias preliminares son la herramienta que el ordenamiento jurídico procesal civil pone a disposición de los justiciables en la que pudiera llamarse etapa preliminar de un proceso para, en determinados supuestos, asegurar la debida preparación del proceso posterior y, en caso de resultar procedente, su evitación.

Estas circunstancias permiten afirmar que una de las principales características de las diligencias preliminares es su instrumentalidad respecto del proceso posterior ${ }^{184}$, sin el cual no se entienden. Dicho en otros términos, si no hay proceso posterior que preparar o, en su caso, evitar, en modo alguno podrá admitirse una solicitud de diligencias preliminares que, como ya ha sido afirmado, carecen de finalidad preventiva, probatoria o aseguratoria de fuente de información alguna. De ahí que los autores hayan señalado que el carácter instrumental que estas diligencias tienen es notorio en tanto que las mismas no se pueden acordar si no es en función de un proceso ulterior con el que deben estar relacionadas y en relación al cual se deben verificar sus efectos ${ }^{185}$ hasta el punto de requerir el art. 256.2 LEC que en la solicitud se expresen, además de sus fundamentos, una referencia circunstanciada al asunto objeto del juicio que se quiere $\operatorname{preparar}^{186}$. Tal afirmación se corrobora con el resto de previsiones legales que

\footnotetext{
${ }^{184}$ Ello ha sido afirmado por Garberí Llobregat, J., Las diligencias preliminares..., ob. cit., p. 34 y Garciandía González, P.M., La regulación de...., ob. cit., p. 775. En la doctrina judicial, el AAP de Madrid (sección 11ª) de 8 de enero de 2007, ponente Ilmo. Sr. J. Zarzuelo, f.j.2º (LA LEY 351289/2007). ${ }^{185}$ Cfr. Álvarez Alarcón, A., Las diligencias preliminares..., ob. cit., pp. 35-36.

${ }^{186}$ En la ausencia de vinculación o instrumentalidad en relación al ulterior proceso judicial se han fundamentado distintas resoluciones judiciales denegatorias de las diligencias preliminares interesadas, tales como el AAP de Vizcaya (sección $5^{\text {a }}$ ), de 11 de marzo de 2004, ponente Ilma. Sra. L.A. Cuenca, f.j. $2^{\circ}$ (LA LEY 61879/2004), en el que se denegó la exhibición de un contrato distinto del que sería objeto
} 
conforman su regulación. Así, la pérdida de la caución en favor de quienes hubieran intervenido en las diligencias si, transcurrido un mes desde su terminación dejare de interponerse la demanda, sin justificación suficiente a juicio del tribunal (art. 256.3 LEC); la previsión competencial contenida en el art. 257.1 LEC para el supuesto de las diligencias preliminares de los ordinales $6^{\circ}, 7^{\circ}, 8^{\circ}$ y $9^{\circ}$ del art. 256.1 LEC, a favor del tribunal ante el que haya de presentarse la demanda determinada; y los efectos que el art. 261 LEC dispone para el caso de negativa a llevar a cabo las diligencias preliminares en relación al ulterior proceso. Igualmente, y como al final de este estudio se verá, la eficacia de las diligencias preliminares en orden a la interrupción de la prescripción extintiva de la acción que se pretenda articular en el ulterior proceso.

Ahora bien, este carácter instrumental del proceso posterior en modo alguno implica su ineludible existencia pues, como ya ha sido señalado, el resultado de la información que aquellas arrojen puede determinar la improcedencia o inviabilidad del proceso posterior ${ }^{187}$. Esto nos permite afirmar que dicha instrumentalidad no obliga a que su práctica desemboque, necesariamente, en la celebración del procedimiento posterior $^{188}$. Más aún ante las sanciones que, por mala fe procesal, prevé el ordenamiento procesal civil español.

Por lo expuesto, ese carácter instrumental se puede predicar de las diligencias preliminares en tanto que herramientas preparatorias de un proceso posterior con el que están en directa relación y respecto al cual deben justificarse, ser adecuadas a la finalidad perseguida y concurrir las circunstancias de justa causa e interés legítimo que, como cláusula de salvaguarda del derecho constitucional a la tutela judicial efectiva, concebido como derecho esencial que conviene a ambas partes del futuro proceso,

de la pretensión de anulación contractual a deducir en el ulterior proceso; el AAP de Madrid (sección 20ª de 31 de enero de 2005, ponente Ilmo. Sr. R.F. Rodríguez, f.j.3º (LA LEY 24169/2005), en que se procedió a denegar la exhibición de certificaciones de obras para preparar un ulterior proceso de impugnación de acuerdos sociales; o el AAP de Valencia (sección 11 ${ }^{\text {a }}$ ) de 20 de octubre de 2006, ponente Ilmo. Sr. A. F., Giménez, f.j.2º (LA LEY 244034/2006) en que se procedió a denegar la solicitud de determinados documentos para la preparación de un proceso de repartición del caudal hereditario que no guardaban relación con el objeto litigioso.

${ }^{187}$ Cfr. Corbal Hernández, J.E., Diligencias preliminares (arts...),ob. cit., p. 3496.

${ }^{188}$ Garciandía González, P.M., La regulación de...., ob.cit., p. 774. 
refiere el art. $258 \mathrm{LEC}^{189}$. Y ello con independencia de que, finalmente, tenga lugar o no el proceso ulterior. Así, tal carácter instrumental respecto del proceso posterior impone que el peticionario fije, precise y determine con claridad y concreción cuál es el objeto del juicio al que sirve como instrumento y qué se propone entablar ${ }^{190}$.

\subsection{Autonomía}

Y, precisamente, esa ausencia de obligación en cuanto a la interposición o promoción del futuro proceso posterior, a nuestro juicio, permite afirmar el carácter autónomo de las diligencias preliminares para cuya consecución en modo alguno se hace necesario el procedimiento posterior. Así, las diligencias preliminares sirven al futuro pero eventual procedimiento posterior y no requieren la existencia de este para que puedan tener lugar con absoluta eficacia jurídica. Cuestión distinta son los efectos que las diligencias preliminares puedan tener respecto del ulterior proceso, si este llegara finalmente a tener lugar.

No obstante, en la doctrina se ha negado el carácter autónomo de las diligencias preliminares al considerar las mismas como cuestiones incidentales del proceso de declaración, aún anómalas al producirse antes del proceso de declaración del que dependen, y en el que la tutela que en ellas se pide al tribunal no se agota con la información que se obtenga sino que es instrumental de aquella a la que se aspira en el proceso posterior $^{191}$.

Sin embargo, en nuestra opinión, la autonomía no puede dejar de predicarse de las diligencias preliminares desde el mismo momento en que las mismas, aún cuando tienen por finalidad la preparación del ulterior proceso, no necesitan del mismo para tener lugar. Son previas a cualquier proceso, el que se pretende preparar y el que tendrá

\footnotetext{
${ }^{189}$ Así lo afirma el AAP de Teruel (sección 1ª) de 2 de noviembre de 2010, ponente Ilma. Sra. Mª.D. Cerdá, f.j. $1^{\circ}$ (LA LEY 249155/2010).

${ }^{190}$ Así se infiere del AAP de Sevilla (sección 5a) de 13 de mayo de 2004, ponente Ilmo. Sr. F. Sanz, f.j.3º (LA LEY 113404/2004).

${ }^{191}$ Así lo afirma Banacloche Palao, J., Las diligencias preliminares..., ob. cit., pp. 34-36 quien señala que "al solicitante de una diligencia preliminar no le debe interesar la realización de ésta por lo que ella aporta en sí misma, sino porque le facilita una información que necesita un proceso ulterior".
} 
lugar bien si el resultado de aquellas así lo aconsejan o, no aconsejándolo, así lo quiera el solicitante de las mismas. Aún más, la caracterización de las diligencias preliminares como un incidente del proceso posterior quiebra la regla de atribución competencial contenida en los arts. 61 y 257 LEC que, respectivamente, atribuyen el conocimiento de los incidentes, al tribunal que tenga competencia para conocer del pleito posterior, y de la solicitud de diligencias preliminares al del domicilio de la persona que, en su caso, hubiera de declarar, exhibir o intervenir en las diligencias preliminares, salvedad hecha de los supuestos de los ordinales $6^{\circ}, 7^{\circ}, 8^{\circ}$ y $9^{\circ}$ del art. 256.1 LEC, que corresponderá al tribunal ante el que haya de presentarse la demanda determinada.

Por tanto, concluimos que puede predicarse de las diligencias preliminares la característica de la autonomía.

\section{Presupuestos materiales de la solicitud}

Como ya anticipábamos al inicio de este trabajo, la regulación de las diligencias preliminares en la LEC se encuentra recogida en sus arts. 256 y ss., siendo la simple lectura de la misma la que nos permite advertir las deficiencias de las que adolece, que la doctrina se ha encargado de poner de manifiesto ${ }^{192}$ y que, por lo que en este apartado nos atañe, se concentran en la falta de una adecuada previsión legislativa de los presupuestos materiales que toda solicitud de diligencias preliminares debe cumplir, al margen de los meramente procesales.

Y es que una medida de tales presupuestos materiales sólo la encontramos en el art. 258.1 LEC que, en fase de decisión sobre las diligencias cuya petición haya sido deducida, nos dice que si el tribunal apreciare que la diligencia es adecuada a la finalidad que el solicitante persigue y que en la solicitud concurren justa causa e interés legítimo, accederá a la pretensión. Igualmente, que el tribunal rechazará la petición de

\footnotetext{
${ }^{192}$ En dicho sentido, Díaz Martínez, M., Las diligencias preliminares..., ob. cit., p. 10, cuando pone de manifiesto que el cambio legislativo operado con la LEC no fue aprovechado para regular de forma adecuada y detallada aspectos tales como los requisitos exigibles a la solicitud de diligencias preliminares para que la misma prosperase en forma.
} 
diligencias realizada si no considerase que éstas están justificadas. Por tanto, sólo de tal indeterminada previsión podemos extraer que los presupuestos que toda solicitud de diligencias preliminares debe cumplir son la adecuación a la finalidad que el solicitante persigue y la concurrencia de justa causa e interés legítimo ${ }^{193}$.

\subsection{Adecuación a la finalidad perseguida}

Como ha sido expuesto en el epígrafe anterior, una de las características propias de las diligencias preliminares es la de su instrumentalidad respecto del pleito ulterior, tenga lugar o no el mismo y dado que las diligencias preliminares tienen por finalidad la preparación de ese ulterior proceso y, en su caso, su evitación.

Y es este carácter instrumental el que impone la exigencia legal de la adecuación entre la diligencia preliminar que se interese y el pleito ulterior que con la práctica de las mismas se pretende preparar siendo el art. 258.1 LEC el que habilita al juzgador para admitir la diligencia preliminar que se pretenda, si apreciare que la misma es adecuada a la finalidad que el solicitante persigue. Dicho en otras palabras, si la diligencia preliminar interesada permite preparar el ulterior proceso ${ }^{194}$.

Dado que el tribunal debe realizar un juicio de adecuación de la diligencia preliminar instada a la finalidad que el solicitante persigue, éste deberá proceder a la identificación de la concreta diligencia que se insta y de la pretensión posterior que

\footnotetext{
${ }^{193}$ Así lo pone de manifiesto en la doctrina judicial el AAP de Salamanca (sección $1^{\text {a }}$ ) de 29 de Febrero, de 2012, ponente Ilmo. S. J.R. González, f.j.2 (LA LEY 280744/2012) cuando apunta que: “[...] Y en relación íntima con este particular, el art. 258 impone tres requisitos: uno de carácter subjetivo, el «interés legítimo»-que, aun hallándose expressis verbis puntualizado en relación con «la solicitud», se ha de entender rectamente referido al peticionario-; y dos de índole objetiva: a) la «justa causa», esto es, la justificación para la preparación del eventual futuro proceso; y, b) la «adecuación» o perfecta correspondencia de la diligencia solicitada con «... la finalidad que el solicitante persigue»". También el AAP de Las Palmas (sección de $4^{\mathrm{a}}$ ) 10 de junio de 2010, ponente Ilma. Sra. M $^{\mathrm{a}}$. E. Corral, f.j. $6^{\circ}$ (LA LEY 221255/2010) que examina con detalle cada uno de ellos. Con expresa referencia a dichos requisitos, cabe citar también, entre otros muchos, el AAP de Asturias (sección $7^{\mathrm{a}}$ ) de 28 de junio de 2002, ponente Ilma. Sra. B. Álvarez f.j. $1^{\circ}$ (LA LEY 122404/2002) y el AAP de Barcelona (sección $13^{\text {a }}$ ) de 13 de diciembre de 2005, ponente Ilmo. Sr. J.B. Cremades, f.j.2 $2^{\circ}$ (LA LEY 239881/2005).

${ }^{194} \mathrm{Y}$ aún cuando existen resoluciones como el AAP de Las Palmas (sección 4a) de 10 de junio de 2010, ponente Ilma. Sra. M $^{a}$. E. Corral, f.j.6 $6^{\circ}$ (LA LEY 221255/2010) que, a nuestro juicio, confunden la adecuación con la justa causa equiparando aquella a la inexistencia de modo alguno de que el solicitante pueda preparar la demanda.
} 
persigue $^{195}$. Es decir, y en relación a esta última, del concreto proceso que pretende entablar por lo que, aunque la LEC no lo diga de forma expresa, en la petición deberá hacerse una referencia circunstanciada al futuro proceso que con la diligencia que se pide se quiere preparar habida cuenta que conforme a ello podrá determinarse si lo que se solicita sirve a la preparación de un futuro proceso además de operar como límite en cuanto al uso que se haga de lo obtenido mediante la diligencia preliminar ${ }^{196}$.

En este sentido, no son admisibles expresiones vagas o indeterminadas tales como que se pretenden ejercer acciones legales o depurar responsabilidades, que no concreten cuáles son y en qué términos se ejercitarán tales acciones ${ }^{197}$, fundamentación manifiestamente insuficiente o simplemente retórica o insuficiente. Ello, sin perjuicio de aquellos supuestos en los que la concreción exacta de la acción se encuentra supeditada

${ }^{195}$ En la doctrina científica también se ha identificado la adecuación con la proporcionalidad que debe verificarse en la diligencia preliminar solicitada. En dicho sentido, Garnica Martín, J.F., De las diligencias..., ob. cit., p. 1167, que afirma que ha sido el propio legislador el que ha realizado el correspondiente juicio de proporcionalidad estableciendo para cada caso concreto una particular diligencia preliminar. También Álvarez Alarcón, A., Las diligencias preliminares..., ob. cit., p. 56-61, según el cual la proporcionalidad incluye, como requisitos de la misma: a) La legalidad o taxatividad de la diligencia preliminar, como necesidad de que una norma prevea la diligencia preliminar, y que se traduciría en la admisión, únicamente, de las diligencias preliminares que sirvan para la preparación de los procesos previstos, de las actuaciones definidas en el art. 256 LEC y únicamente en los supuestos de hecho contemplados en la norma correspondiendo a cada situación de hecho un sólo tipo de actuación; b) Finalidad, en cuanto que el fin perseguido por la diligencia preliminar sea constitucionalmente aceptable, señalando como fin último, el de favorecer el derecho a la tutela judicial efectiva o el derecho a la prueba y, a través suyo, el derecho de defensa, y como fin mediato, el de preparar anticipadamente el proceso; c) Utilidad, que exige verificar que la diligencia propuesta es útil a la obtención del fin que se persigue, es decir, si la concreta diligencia solicitada es útil para satisfacer la finalidad perseguida; d) Exigibilidad, es decir, que el medio elegido para alcanzar el fin no pueda ser suplido por otro igualmente eficaz, en el sentido de ser la diligencia exigida la menos gravosa de todas las posibles; y e) Proporcionalidad stricto sensu, o que la gravedad de la lesión y la trascendencia de sus razones justificativas estén en adecuada proporción.

196 Vid. Álvarez Alarcón, A., Las diligencias preliminares..., ob. cit., p. 51.

197 En dicho sentido, los AAP de Cádiz (sección $3^{\mathrm{a}}$ ) de 8 de abril de 2005, ponente Ilma. Sra. A.M . Rubio, f.j. $2^{\circ}$ (LA LEY 77736/2005) y el AAP de Vizcaya (sección $3^{\mathrm{a}}$ ) de 17 de octubre de 2007, ponente Ilma. Sra. M ${ }^{\mathrm{a}}$. C. Marco, f.j.4º (LA LEY 25565312007), con cita del AAP de Sevilla (sección $5^{\text {a }) ~ d e ~} 13$ de mayo de 2004, ponente Ilmo. Sr. F. Sanz, f.j.3 (LA LEY 113404/2004), que determinó que: “[...] Es decir, no basta una vaga y genérica indicación de que se pretenden ejercer acciones legales o de que se trata de depurar responsabilidades, pues estas expresiones son imprecisas y genéricas y nada aclaran para valorar si la petición es adecuada a la finalidad que se persigue, si hay justa causa e interés legítimo, por cuanto que en todo proceso judicial se ejercita una acción y se persigue la depuración o declaración de responsabilidades y obligaciones", el AAP de Vizcaya (sección $3^{\text {a }}$ ) de 17 de octubre de 2007. En la doctrina científica, vid. Garberí Llobregat, J., Las diligencias preliminares..., ob. cit., p. 66. 
a la información que el interesado aspira a obtener, precisamente, como fruto de la

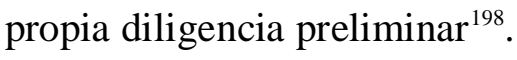

Por tanto, el solicitante de las diligencias preliminares debe fundamentar debidamente su petición, con referencia circunstanciada al asunto objeto del juicio que se quiera preparar ${ }^{199}$, entre otras razones, para que el órgano jurisdiccional pueda analizar si concurre justa causa e interés legítimo, tal y como así exige también el art. 258.1 LEC $^{200}$.

${ }^{198}$ Vid. el AAP de Las Palmas (sección $5^{\text {a }}$ ) de 28 de abril de 2011, ponente Ilma. Sra. M. García, f.j. $2^{\circ}$ (LA LEY 103652/2011) cuando señala. "[...] Y ello aun cuando no resulte exigible una grado extremo de precisión en torno a este particular en aquellos casos en los que la concreción exacta de la acción se encuentra supeditada a la información que el interesado aspira a obtener, precisamente, como fruto de la propia diligencia preliminar solicitada".

${ }^{199}$ En palabras de la SAP Barcelona de 29 de julio de 1994 “"...] es evidente que, para no quedar el Juez reducido a un mero mandatario público del que pide dar diligencia, éste debe expresar la acción que pretende ejercitar; y así se deduce no sólo de la Ley de 1855, sino de las partidas, en cuya partida $3^{\text {a }}$ ya se establecía: "ciertas preguntas son las que puede facer el demandados, sobre la cosa que quiere facer la demanda, ante que el pleyto se comenze..."; y a título de ejemplo cita dicha partida cuatro supuestos en los que siempre se debe justificar la petición con la acción que se pretende ejercitar". En este contexto, señala el AAP de Granada (sección $4^{\mathrm{a}}$ ) de 18 de octubre de 2001, ponente Ilmo. Sr. J. Maldonado, f.j. $4^{\circ}$ (LA LEY 184669/2001) que el destinatario de la práctica de la diligencia tiene el derecho a conocer por qué se pide tal confesióny no exigir tal justificación daría lugar a permitir exhibiciones o declaraciones que no tienen finalidad alguna.

${ }^{200}$ Así lo afirman, el AAP de Sevilla (sección $5^{\text {a }}$ ) de 1 de marzo de 2005, ponente Ilmo. Sr. J. Herrera, f.j. $2^{\circ}$ (LA LEY 48585/2005), cuando dispone: “[...] Como ultimo requisito esencial que se podría señalar, es que el solicitante ha de expresar, al menos sucintamente, el objeto del proceso que se prepara, para que el órgano jurisdiccional puede analizar si concurre justa causa e interés legitimo, como exige el artículo 258-1 ${ }^{\circ}$ de la Ley de Enjuiciamiento Civil"; el AAP de Zaragoza (sección $5^{\mathrm{a}}$ ) de 20 de marzo de 2006, ponente Ilmo. Sr. P.A. Pérez, f.j. $1^{\circ}$ (LA LEY 31213/2006), cuando apunta que: “[...] Pero, conforme a ello, no cualquier persona puede interesar su práctica, pues el juez debe verificar, tal y como impone el artículo 258, que la medida no sólo es adecuada a la finalidad que el solicitante se propone obtener sino que concurra justa causa e interés legítimo, debiendo rechazarse cualquier petición que no se justifique en función de aquella finalidad, por cuyo motivo por un lado el párrafo segundo del primer señalado artículo exige al instante "Una referencia circunstanciada al asunto objeto del juicio que se quiera preparar"; y el AAP de Cádiz (sección 2a) de 15 de marzo de 2007, ponente Ilmo. Sr. A. Marín, f.j. ( $^{\circ}$ (ROJ AAP CA 419/2007) cuando expresa: "[...] A todo ello se une que, además de ser diligencias típicas, necesariamente han de tener una estrecha vinculación con el juicio que se pretende preparar. Y ello tanto en el sentido de ser útiles y eficaces para prepararlo, como desde la perspectiva de la concurrencia de justa causa e interés legitimo en quien las solicite. Conforme al art. 258 de la Ley de Enjuiciamiento Civil, el Tribunal al determinar su admisión o no a trámite debe analizar si la diligencia "es adecuada a la finalidad que el solicitante persigue", y si "concurren justa causa e interés legítimo". Es por ello que si el Tribunal, para apreciar la justificación de la concreta medida solicitada, ha de valorar si ésta es adecuada o no a la finalidad que se persigue, que no es otra que la preparación de un proceso, y que, por tal motivo concurre justa causa en su petición e interés legítimo, resulta absolutamente imprescindible que el solicitante fije, precise y determine con claridad y concreción cual es el objeto del juicio que se propone entablar, para qué pide la diligencia preliminar y contra quién se propone dirigir la futura demanda". También, el AAP de La Rioja (sección única), de 17 de octubre de 2008, ponente Ilmo. Sr. L.M. Rodríguez, f.j.2 (LA LEY 269107/2008). Por su parte, el AAP de Guipúzcoa (sección $2^{\mathrm{a}}$ ) de 22 de diciembre de 2004, ponente Ilma. Sra. $M^{\text {a }}$.T. Fontcuberta, f.j. $2^{\circ}$ (LA LEY 270202/2004), deniega la solicitud de medida cautelar al 
Es necesario, por tanto, que la motivación sea fáctica y jurídica, y no es admisible la mera petición de una de las diligencias tipificadas en el art. 256.1 LEC, sin especificación de las razones que concurren en su solicitud ${ }^{201}$. Si la solicitud carece de la debida fundamentación, con referencia circunstanciada al asunto objeto del juicio que se quiera preparar, o la misma es manifiestamente insuficiente, retórica o protocolaria, se impedirá el examen de la necesaria adecuación de la diligencia preliminar a la preparación del concreto y ulterior juicio. También, el examen de la legitimación activa y pasiva de la solicitud de diligencias preliminares dado que, como hemos visto al hilo del estudio del catálogo de diligencias preliminares del art. 256.1 LEC la legitimación viene ligada a la acción que se pretende preparar.

Pero ni la LEC ni la doctrina indican cuál es la medida de esa adecuación ni cuando puede entenderse que la misma existe, por lo que la verificación de su existencia obliga al examen del caso concreto ${ }^{202} \mathrm{y}$, más concretamente, a verificar la idoneidad de la medida para la preparación del ulterior proceso ${ }^{203}$.

Y no debe concluirse el análisis del presupuesto que nos ocupa sin poner de manifiesto que, a nuestro juicio, tal presupuesto carece de naturaleza procesal y, en consecuencia, la ausencia de su justificación en la solicitud inicial no permitiría la subsanación previo requerimiento del órgano judicial, sin que ello suponga desconocer aquellos pronunciamientos de la doctrina judicial, que en una más que generosa interpretación de la norma han admitido su subsanación ${ }^{204}$.

considerar: "[...] No se menciona en la solicitud si con la obtención de la historia pretende elaborarse un informe pericial con vistas a formular una demanda contra el facultativo, puesto que la solicitante ni siquiera se refiere a un supuesto perjuicio por responsabilidad imputable al mismo". Finalmente, en la doctrina científica, vid. Damián Moreno, J., Las diligencias preliminares..., ob. cit., p. 1686.

${ }^{201}$ En este sentido, Gimeno Sendra, V., Derecho Procesal Civil...., ob. cit., p. 282.

${ }^{202}$ En dicho sentido, el AAP de Madrid (sección $28^{\mathrm{a}}$ ) de 18 de enero de 1013, ponente Ilmo. Sr. A. Galgo, f.j. $2^{\circ}$ (AC 2013l873), cuando señala que: “[...] tal juicio de adecuación ha de descansar en un examen individualizado en relación con cada una de las diligencias integradas en la solicitud".

${ }^{203}$ Sobre la idoneidad de las diligencias preliminares, vid. Banacloche Palao, J., Las diligencias preliminares..., ob. cit., pp. 45-49.

${ }^{204}$ En dicho sentido, el AAP de Barcelona (sección $15^{\text {a }}$ ) de 10 de noviembre de 2011, ponente Ilma. Sra. M. Rallo, f.j.2 (LA LEY 265878/2011). 


\subsection{Justa causa}

Tampoco la LEC nos dice que debemos entender por justa causa. En cambio, la doctrina científica la ha identificado con la necesidad del solicitante de las diligencias preliminares de conseguir con ellas aquellos datos imprescindibles para la preparación del ulterior proceso y que el mismo no puede conseguir por sus propios medios ${ }^{205}$.

Como expusimos al inicio del presente estudio, en el proceso civil, la preparación del ulterior proceso, en la mayoría de las ocasiones, queda relegada a la actividad privada y casi detectivesca de la parte que, con sus propios medios, deberá realizar un importante acopio de datos y documentos que le permitan plantear y estudiar el proceso posterior. Pero también expusimos que en no pocas ocasiones, esa información no está al alcance de los particulares que, como una manifestación más del derecho a la tutela judicial efectiva, pueden instar el auxilio judicial para su obtención $^{206}$.

Por tanto, puede hablarse de justa causa cuando la justificación de la diligencia que se pida para la preparación del eventual ulterior proceso implica la necesidad de la ayuda judicial que conlleva la diligencia preliminar y cuando el conocimiento por el solicitante de los datos o informes que a través de la misma se pretende no ha sido posible por otros medios ${ }^{207}$. Es decir, cuando se justifique que no es o no ha sido posible

\footnotetext{
205 Este requisito también ha sido identificado en la doctrina, vid. Corbal Hernández, J.E., Diligencias preliminares (arts...), ob. cit., p. 3496, con el de subsidiariedad, en cuanto pertinencia de las diligencias preliminares en tanto en cuanto no haya otro medio para preparar el juicio. Por su parte, Garberí Llobregat, J., Las diligencias preliminares..., ob. cit., p. 67 y Banacloche Palao, J., Las diligencias preliminares..., ob. cit., pp, 50-52. También, Garnica Martín, J.F., De las diligencias..., ob. cit., p. 1166 que apunta que la necesidad podrá considerarse que existe "siempre que la diligencia interesada sea imprescindible para la correcta interposición de la demanda" entendida la misma en un sentido abierto en cuanto diligencias "convenientes o útiles para el proceso que se quiere preparar".

${ }^{206} \mathrm{Al}$ respecto, señala Garnica Martín, J.F., De las diligencias..., ob. cit., p. 1167, que no podrá acudirse al auxilio judicial "más que cuando existan razones extraordinarias que así lo impongan”, las que parecen identificarse, siguiendo su argumento, en las comprendidas en el catálogo del art. 256.1 LEC.

${ }^{207}$ Al respecto, el AAP de Madrid (sección $14^{\mathrm{a}}$ ) de 14 de septiembre de 2004, ponente Ilmo. Sr. J.M ${ }^{\mathrm{a}}$. Salcedo, f.j.2 $2^{\circ}$ (LA LEY 188968/2004) que señala: “[...] debiendo añadirse además que para acceder a la solicitud no exista otro medio razonablemente accesible para precisar o determinar la parte que será objeto de posterior demanda"; y el AAP de Guipúzcoa (sección 2a) de 22 de diciembre de 2004, ponente Ilma. Sra. M ${ }^{a}$.T. Fontcuberta, f.j.2º (LA LEY 270202/2004), determinó que: “[...] Y tal necesidad viene determinada por la imposibilidad de obtener la información pretendida antes de acudir a la vía judicial
} 
obtener la información que se precisa a través de otros cauces distintos de la diligencia preliminar, lo que justifica el auxilio judicial. Y no se entenderá que se da esta última circunstancia cuando los datos que pretende obtener el solicitante, por ejemplo, se encuentren en un registro público ${ }^{208}$, sin perjuicio de aquellos supuestos en los que la petición haya sido deducida sin éxito ante dicho órgano y de aquellos en los que quien resulte requerido a la práctica de la diligencia preliminar haya mostrado resistencia a la

(...)". En dicho sentido también, el AAP de Las Palmas (sección 4ª de 10 de junio de 2010, ponente Ilma. Sra. M $M^{a}$.E. Corral, f.j. $6^{\circ}$ (LA LEY 221255/2010) señala que éste implica que "[...] el solicitante necesite algún tipo de ayuda judicial para conocer cuestiones esenciales y que ese auxilio interesado sea proporcional, lo que provoca que se excluya cualquier ayuda abstracta y genérica, (...)". Con mayor profusión se pronuncia al respecto el AAP de Tarragona (sección $3^{\mathrm{a}}$ ) de 24 de septiembre de 2008, ponente Ilmo. Sr. J. Perarnau, f.j. $2^{\circ}$ (LA LEY 225630/2008), conforme al cual la justa causa es: “[...] la justificación de la diligencia que se pide para la preparación del eventual futuro proceso, lo que implica que el solicitante necesite algún tipo de ayuda judicial para conocer cuestiones esenciales y que ese auxilio interesado sea proporcional, lo que provoca que se excluya cualquier ayuda abstracta y genérica, y, además, será necesario que se aprecie cierta resistencia o negativa de quien ha de proporcionar esos datos indispensables para promover el proceso ulterior. Todo ello supone, por su propia naturaleza meramente instrumental, preparatoria y aclaratoria, o incluso para preservar el principio de igualdad entre las partes, que: a) Solo procederán cuando haya imposibilidad de tener acceso a lo que se solicita de otro modo, esto es, que estas diligencias preliminares, como auxilio judicial a la parte que son, deben ser acordadas exclusivamente cuando no haya otro medio de preparar el ejercicio de la acción que el solicitante se propone ejercitar (Auto de la AP Barcelona núm. 73/2007, Sección 13, de 12 marzo); b) Solo procederán cuando sea necesario el conocimiento o la información que se solicita para preparar el futuro procedimiento, conocimiento o información que ha de ser esencial o relevante para tal fin; c) Que no pueden servir de instrumento para preconstituir pruebas para el futuro pleito, pues no debe confundirse diligencias preliminares con prueba anticipada, ya que son dos figuras diferentes: las diligencias preliminares tienen por objeto preparar un juicio y la prueba anticipada persigue constatar un hecho necesario para la prosperabilidad de la pretensión cuando exista un temor de que no puedan realizarse dentro del proceso".En la doctrina científica, vid. Garnica Martín, J.F., De las diligencias..., ob. cit., p. 1167.

${ }^{208}$ En dicho sentido, el AAP de Cádiz (sección $3^{\text {a }}$ ) de 8 de abril de 2005, ponente Ilma. Sra. A.Ma . Rubio, f.j. $2^{\circ}$ (LA LEY 77736/2005), en que se procedió a inadmitir la solicitud de diligencias preliminares para la preparación de una demanda instando la nulidad de acuerdos sociales y el AAP de Tarragona (sección $3^{\mathrm{a}}$ ) de 24 de septiembre de 2008, ponente Ilmo. Sr. J. Perarnau, f.j. $3^{\circ}$ (LA LEY 225630/2008) en que se procedió a confirmar la denegación de la solicitud de diligencias preliminares consistente en la exhibición de un testamento, al determinar el tribunal que el solicitante tenía a su disposición un procedimiento específico para obtener lo que solicitaba, como es el previsto en el art. 231 del Reglamento de la organización y régimen del Notariado y que, por consecuencia, ello eliminaba la justificación de tener que recurrir al auxilio judicial mediante el procedimiento de diligencias preliminares. No obstante, debe tenerse en cuenta que no en todos los supuestos en que no haya sido posible la obtención de los datos pretendidos que obren en un registro público procederá la admisión de la diligencia preliminar, pues pueden darse supuestos como el contemplado en el AAP de Madrid (sección $14^{\mathrm{a}}$ ) de 27 de julio de 2004, ponente Ilmo. Sr. J.M ${ }^{a}$. Salcedo, f.j.2 ${ }^{\circ}$ (LA LEY 177327/2004), en que las mismas se denieguen, como ocurrió en el caso, en que el tribunal estimó que: “[...] el hecho de ser condueño de una finca no conlleva per se interés legítimo para examinar una escritura en la que no ha intervenido y que puede contener estipulaciones que no tiene porqué conocer, puesto que aquellas otras estipulaciones sobre las que podría tener interés legítimo deben estar y están reflejadas en la inscripción registral”. 
facilitación de la preparación del proceso $^{209}$, siempre y cuando tales circunstancias resulten acreditadas.

En consecuencia, sólo procederá que se acuerde la diligencia preliminar y se entenderá, por tanto, que concurre justa causa, ante la imposibilidad de acceso a lo que de otro modo se ha solicitado y resulta necesario y esencial para la preparación del proceso posterior, sin que la diligencia pueda servir como instrumento para preconstituir pruebas para el futuro pleito ${ }^{210}$. Es decir, que por el peticionario ha de justificarse la necesidad de la diligencia preliminar acreditando que se encuentra en una situación de necesidad de obtener la diligencia ante la existencia de un conflicto que evidencia la resistencia de quien debe proporcionar algún dato ${ }^{211}$.

Conforme a lo anterior, el solicitante de las medidas deberá justificar en su solicitud, en tanto que justa causa, que se encuentra incurso en un conflicto que justifica el nacimiento del ulterior proceso que pretende preparar como titular del derecho que se debatirá en el mismo ${ }^{212}$.

Por último, debemos significar que, a nuestro juicio, la justa causa tampoco concurrirá cuando una idéntica petición de diligencias preliminares haya sido ventilada previamente entre las mismas partes. Aún la ausencia del efecto de cosa juzgada en las diligencias preliminares, en este caso, no se dará la circunstancia de no haber podido obtenerse la información necesaria para la preparación del ulterior pleito a través de otros cauces. Más aún, será en esas previas diligencias preliminares donde se haya dilucidado sobre el derecho del peticionario y la concurrencia de los presupuestos necesarios para su admisión y práctica no existiendo causa que justifique la reproducción, en los mismos términos, de una idéntica petición.

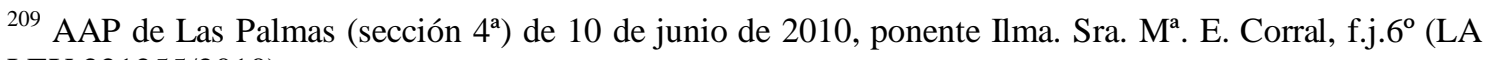
LEY 221255/2010).

${ }^{210}$ Así lo ha sostenido, el AAP de Tarragona (sección $3^{\text {a }}$ ) de 24 de septiembre de 2008, ponente Ilmo. Sr. J. Perarnau, f.j. $2^{\circ}$ (LA LEY 225630/2008).

${ }_{211}$ Álvarez Alarcón, A., Las diligencias preliminares..., ob. cit., p. 55.

${ }^{212}$ Díaz Martínez, M., Las diligencias preliminares..., ob. cit. p. 12. En el mismo sentido, Ruíz de Gordejuela López, L., Las diligencias preliminares..., ob. cit., p. 190.
} 


\subsection{Interés legítimo}

Aún cuando el tenor literal del art. 258.1 LEC hace referencia al interés legítimo que debe concurrir en la solicitud de diligencias preliminares debe precisarse que, en rigor, dicho interés legítimo debe venir referido al que debe concurrir en la persona del solicitante $^{213}$. Por tanto, puede afirmarse que el solicitante de diligencias preliminares no sólo deberá justificar que se encuentra incurso en un conflicto que justifique el nacimiento del ulterior proceso que pretende preparar, es decir, la justa causa, sino también que es titular del concreto derecho que haya de ser objeto de debate de dicho ulterior proceso y que debe encontrarse en conexión con el también objeto de la diligencia preliminar ${ }^{214}$. Así, puede establecerse una correspondencia entre el interés legítimo y la legitimación activa del solicitante de las diligencias preliminares para promover el ulterior juicio que pretende preparar.

\section{La caución}

$\mathrm{Al}$ inicio del este trabajo ya tuvimos ocasión de poner de manifiesto como, bajo el imperio de la ALEC, las diligencias preliminares cayeron en el práctico desuso ante la escasa efectividad de las consecuencias que la norma preveía para el caso de negativa a su práctica por parte del sujeto requerido.

Dicha circunstancia hizo reaccionar al legislador que introdujo en la LEC una serie de mecanismos tendentes a dotar a las diligencias preliminares de una mayor efectividad práctica. Básicamente, las medidas recogidas en el art. 261 LEC para el caso de negativa del sujeto pasivo a colaborar en la práctica de las diligencias preliminares.

\footnotetext{
${ }^{213}$ La concurrencia de este requisito ha sido afirmado en la doctrina científica por Gimeno Sendra, V., Derecho Procesal Civil..., ob. cit., p. 282, si bien no faltan autores que entienden que tal interés legítimo debe entenderse embebido en la justa causa. $\mathrm{Al}$ respecto, vid. Garnica Martín, J.F., De las diligencias..., ob. cit., p. 1167. Entendido como solicitud por parte de la persona legitimada, según el AAP de Barcelona (sección $13^{\mathrm{a}}$ ) de 13 de diciembre de 2005, ponente Ilmo. Sr. J.B. Cremades, f.j.2 $2^{\circ}$ (LA LEY 239881/2005).

${ }^{214}$ Ruíz de Gordejuela López, L., Las diligencias preliminares..., ob. cit., p. 190. En la misma línea, Díaz Martínez, L., Las diligencias preliminares..., p. 12. En dicho sentido, el AAP de Las Palmas (sección 4ª) de 10 de junio de 2010, ponente Ilma. Sra. M ${ }^{a}$. E. Corral, f.j.6 ${ }^{\circ}$ (LA LEY 221255/2010) y el AAP de Tarragona (sección $3^{\mathrm{a}}$ ) de 24 de septiembre de 2008, ponente Ilmo. Sr. J. Perarnau, f.j.2 ${ }^{\circ}$ (LA LEY 225630/2008).
} 
No obstante, como contrapartida, además de requisito indispensable para su práctica, a modo de garantía del resarcimiento del requerido por los gastos, daños y perjuicios que pudiera irrogarle la realización de las diligencias preliminares, la LEC introdujo la obligación de prestar caución ${ }^{215}$.

Pero la introducción de la caución en sede de diligencias preliminares se hizo con una regulación poco sistemática e incompleta que la propia doctrina científica y judicial ha tildado de confusa ${ }^{216}$ y que, a la postre, ha redundado, y lo seguirá haciendo, en una importante inseguridad jurídica. Tal inseguridad se plasma en la disparidad de las soluciones ofrecidas por los tribunales en la resolución de los supuestos sometidos a su consideración, normalmente, al tiempo de dar destino a la caución.

Y siendo como es la caución, un requisito imprescindible para la práctica de las diligencias preliminares y sin cuya prestación en modo alguno podrán practicarse las mismas, hemos creído conveniente dedicarle un apartado específico del presente estudio en el que poder abordar su naturaleza e implicaciones, dado que si bien nos encontramos ante un presupuesto de naturaleza procesal, plantea cuestiones de fondo de suma importancia que no entendemos procedente analizar en el capítulo dedicado al procedimiento, en el que se abordarán, únicamente, las diferencias entre los hitos que constituyen su ofrecimiento, su efectiva prestación y la aplicación o destino de la caución como actos meramente procedimentales.

\footnotetext{
${ }^{215}$ Señala el apartado X de la Exposición de Motivos de la LEC que: "Buscando un equilibrio equitativo, se exige al solicitante de las medidas preliminares una caución para compensar los gastos, daños y perjuicios que se pueda ocasionar a los sujetos pasivos de aquéllas, con la particularidad de que el mismo tribunal competente para las medidas decidirá sumariamente sobre el destino de la caución".

${ }^{216}$ Así lo pone de manifiesto el AAP de Las Islas Baleares (sección $3^{\mathrm{a}}$ ), de 18 de noviembre de 2003, ponente Ilma. Sra. C.M ${ }^{\mathrm{a}}$. Moragues, f.j. $3^{\circ}$ (ROJ AAP IB 317/2003). En la doctrina científica, vid. Garnica Martín, J.F., De las diligencias..., ob. cit., p. 1161 cuando señala: "En cuanto al destino de la caución, los interrogantes que suscita son numerosos", o Álvarez Alarcón, A., Las diligencias preliminares..., ob. cit., pp. 52-53, cuando señala que: "El tercer párrafo del art. 256 contiene diferentes disposiciones amalgamadas de un modo algo forzado (...)", o cuando, en referencia al destino de la caución y la obligación de interponer demanda en el plazo de un mes desde que se practicó la diligencia preliminar apunta que: "Esta obligación está defectuosamente regulada".
} 


\subsection{Regulación positiva de la caución}

La regulación que de la caución hace la LEC en sede de diligencias preliminares la encontramos dispersa en los distintos artículos que la misma dedica a aquellas y al hilo del trámite que al respecto ordena. No le dedica la LEC una regulación en bloque a la caución que deba ofrecerse y prestarse previamente a la práctica de las diligencias preliminares y sobre cuyo destino, en función de su objeto y función o finalidad, debe decidir el tribunal una vez resulte practicada la diligencia preliminar. La LEC configura la caución al hilo del trámite de su ofrecimiento, prestación, o resolución sobre su destino disgregando los efectos del resultado de tales hitos a lo largo de su regulación y, por tanto, como se verá, generando una importante confusión en cuanto a su finalidad o función.

Así, comienza la LEC disponiendo en su art. 256.3 que los gastos que se ocasionen a las personas que hubieran de intervenir en las diligencias serán a cargo del solicitante que, al pedirlas, ofrecerá caución para responder tanto de tales gastos como de los daños y perjuicios que a aquellas se les pudieran irrogar, a favor de quienes se perderá si, transcurrido un mes desde la terminación de las diligencias, dejare de interponerse la demanda, sin justificación, a juicio del tribunal.

Por tanto, comienza regulando la LEC, en el art. 256.3, no sólo la inicial obligación del solicitante de ofrecer caución, al tiempo de la solicitud sino, también, señalando la función de dicha caución, cual es responder de los gastos, daños y perjuicios que la práctica de aquellas pudieran irrogar a las personas que hubieran de intervenir en las diligencias.

Pero, al mismo tiempo, introduce la LEC una consecuencia ciertamente contradictoria al determinar, en el mismo precepto legal, que se producirá la pérdida de la caución en beneficio de quienes hubieran de intervenir en las diligencias -se entiende que como sujeto pasivo de las mismas- para el caso de no interponerse la demanda en el plazo de un mes, sin justificación a juicio del tribunal. Esta afirmación pudiera interpretarse en el sentido de que sólo en el caso de no interponerse, injustificadamente, 
dicha demanda posterior se perderá la caución a favor de quienes hubieran de intervenir en las diligencias, cualquiera que sea la cuantía y justificado que fuera o no el gasto. Igualmente, y en una interpretación a sensu contrario, que la caución no se perderá a favor de quienes intervinieran en las diligencias en el caso de que, justificada o injustificadamente, se interponga la demanda y que, por tanto, en tal caso, dichos intervinientes no serán resarcidos de los gastos, daños y perjuicios que se les hubieran irrogado. Ello, pese a que, como la propia norma señala, la caución se dirige a indemnizar los gastos, daños y perjuicios que se causen a los que deban intervenir en las diligencias preliminares, por lo que cabe preguntarse si, de alguna manera, el resarcimiento de los gastos, daños y perjuicios que se causen viene mediatizado por la interposición de la demanda del ulterior juicio y en el plazo del mes aludido.

Continuando con el examen de la regulación, los aptdos. $1^{\circ}$ y $3^{\circ}$ del art. 258 LEC determinan que, en la resolución en que el tribunal aprecie la adecuación de la diligencia solicitada a la finalidad perseguida por el solicitante así como la concurrencia de justa causa e interés legítimo, fijará la caución que deberá prestarse en el plazo de tres días desde que se dicte el auto en que se conceda la diligencia, bajo apercibimiento de archivo definitivo de las actuaciones. Sin embargo, al tiempo de regular la efectiva prestación de la caución no refiere la LEC la forma en que esta habrá de prestarse, lo que determina, con falta de rigor sistemático, en el último inciso del art. 256.3 y al tiempo de la regulación del ofrecimiento, objeto y finalidad de la prestación de caución.

Por otro lado, dedica la LEC el art. 262 a la regulación de la decisión sobre la aplicación de la caución que deberá tener lugar en el plazo de los cinco días, se entiende que siguientes al de la práctica de las diligencias preliminares o, en su caso, de estimación, por justificada, de la oposición a la misma. Y ello, a la vista de la petición de indemnización y de la justificación de gastos que se le presente al tribunal. No obstante, no determina la LEC en qué momento habrá de deducirse dicha justificación de gastos y petición de indemnización ${ }^{217}$ sobre la que el tribunal habrá de resolver en el

217 De hecho, según refiere Díaz Núñez, J.J., Medidas cautelares y diligencias preliminares, en “Cuadernos Digitales de Formación”, 2014, núm. 28, p. 32, el art. 262 tiene como principal problema interpretativo la determinación del momento en que la justificación de gastos y solicitud de daños y 
plazo de los cinco días siguientes a la práctica de las diligencias preliminares o resolución estimatoria de la justificada oposición.

Tampoco permite la LEC, a priori, resolver sobre el destino de la caución si no media una previa justificación de gastos y petición de daños y perjuicios y se oye a la parte contraria al respecto, siendo una obviedad que el plazo de cinco días para la resolución sobre el destino de la caución, a contar desde la práctica de las diligencias o estimación de la oposición, resulta de todo punto insuficiente para la consecución de tales trámites. Igualmente, debiendo mediar la previa justificación de gastos y petición de indemnización de daños y perjuicios, sin determinar el plazo en que ello haya de promoverse, deja al arbitrio de quien haya intervenido en la práctica de las diligencias como requerido el tiempo en que habrá de resolverse sobre el destino de la caución pues tampoco se establece efecto perjudicial alguno para el caso de no deducirse dicha justificación y petición en un plazo que no determina.

Y, por último, no establece el destino que deberá darse al remanente de la caución, una vez abonados los gastos y satisfechos los daños y perjuicios, y para el caso de transcurso del plazo de un mes prevenido en el art. 256.3 LEC, sin interponerse la demanda ulterior.

Pero es que, además de todas las cuestiones antes objetadas a la regulación de la caución, observamos que la LEC guarda absoluto silencio sobre las reglas que habrán de observarse en la determinación de la cuantía de la caución, lo que deja al absoluto arbitrio del tribunal. No prevé el dictado de resolución alguna por parte del tribunal en relación a la adecuación y forma de la caución prestada en relación con la ordenada así como los efectos de una posible inadecuación a esta última. Omite la regulación del trámite contradictorio al que en todo caso entendemos debe quedar sujeta la resolución de la discrepancia del solicitante con los gastos, daños y perjuicios reclamados de contrario. Y, entre otras tantas circunstancias que iremos examinando, tampoco prevé 
solución alguna para el caso de que la caución prestada resulte insuficiente para satisfacer la totalidad de los gastos, daños y perjuicios que resulten acreditados.

Como veremos, muchas de estas objeciones no sólo redundan y redundarán, como al inicio hemos advertido, en una importante inseguridad jurídica no deseable para el administrado, sino que también han debido de ser resueltas por los tribunales ateniendo al caso concreto y, provocando, en consecuencia, una injustificada disparidad de criterios.

\subsection{La finalidad de la caución}

Un estudio detallado de la caución en sede de diligencias preliminares exige el examen tanto de su regulación procesal como de las razones que la inspiran y la han constituido en condición necesaria para la práctica de las que se soliciten ${ }^{218}$.

Dicho estudio nos obliga a partir tanto del principio sentado en el aptdo. $3^{\circ}$ del art. 256 LEC, según el cual la caución responde de los gastos, daños y perjuicios que se pudieren irrogar a las personas que hubieren de intervenir en las diligencias, como de la Exposición de Motivos de la norma que, en su apartado X, apunta a la búsqueda de un equilibrio equitativo entre el derecho del solicitante de las diligencias preliminares y el de quien haya de intervenir como requerido en las mismas, a ser resarcido de los gastos, daños y perjuicios que se le pudieran irrogar.

\footnotetext{
${ }^{218}$ Como tal condición necesaria la entiende Banacloche Palao, J. Las diligencias preliminares..., ob. cit., pp. 168-169. En otros términos, Garberí Llobregat, J., Las diligencias preliminares..., ob. cit., p. 73, cuando señala que: "La decisión de admitir a trámite la solicitud de diligencias preliminares queda supeditada a la prestación efectiva, en tiempo y forma, de la caución a cargo del solicitante" si bien, a nuestro juicio, del tenor literal del art. 258 LEC se desprende que la admisión de la solicitud de diligencias no queda supeditada a la efectiva prestación de caución. Más precisamente, del tenor literal del art. 258 LEC se desprende que, ofrecida la caución, el tribunal accederá o no a la solicitud y, por tanto, la admitirá, fijando en dicha resolución la caución que deba prestarse. Y, en consecuencia, que lo que efectivamente queda supeditado a la prestación de caución no es la admisión de la diligencia solicitada sino su práctica, al disponer el art. 258.3 LEC que, si la caución no se prestare, se archivarán definitivamente las actuaciones. Es decir, una vez admitida la diligencia pero no habiéndose practicado la misma.
} 


\subsubsection{Funciones de la caución}

Partiendo de las anteriores premisas, preciso resulta recordar que, gramaticalmente, en el contexto jurídico, la caución puede ser definida como la garantía que presta una persona $u$ otra en su lugar para asegurar el cumplimiento de una obligación actual o futura ${ }^{219}$. Y si aplicamos dicha definición a la caución que la LEC regula en sede de diligencias preliminares podría concluirse, previa lectura de su art. 256.3, que ésta es la garantía que el solicitante de diligencias preliminares debe prestar para asegurar el cumplimiento de su obligación futura de resarcimiento de los gastos, daños y perjuicios que se causen a quienes, al margen del solicitante, intervengan en las diligencias $^{220}$. De forma tal que solo si llega a prestarse la caución a practicarse las diligencias tendrá el solicitante obligación de resarcir dichos gastos, daños y perjuicios.

No obstante, aun cuando la LEC nada diga al respecto, tras la caución que la misma regula en sede de diligencias preliminares, no sólo se encuentra la finalidad o necesidad de resarcir, a quien se vea compelido a la práctica de aquellas, los gastos, daños y perjuicios que se le puedan irrogar. Como ha apuntado la doctrina judicial y

\footnotetext{
219 Así lo determina la Real Academia de la Lengua Española (http://www.rae.es/ ?id=7z4jpFL), consultado el 07/08/2017.

${ }^{220}$ En dicho sentido, el AAP de Asturias (sección $7^{\mathrm{a}}$ ) de 23 de septiembre de 2003, ponente Ilmo. Sr. J.L. Casero, f.j. $2^{\circ}$ (JUR 2004147732), cuando señala: “[...] la dicha caución, viene destinada a reintegrar a las personas que hubieren de intervenir en las diligencias de los gastos que tuvieren ( $\mathrm{n}^{\circ} 3$ del Art. 256)"; el AAP de Madrid (sección 9 $9^{\mathrm{a}}$ ) de 13 de abril de 2007, ponente Ilmo. Sr. J.L. Gordillo, f.j.1 ${ }^{\circ}$ (JUR 20071232324) cuando expresa: "[...] la caución tiene la finalidad de cubrir tanto los gastos que se ocasionaron a las personas que hubieron de intervenir en las diligencias como los daños y perjuicios que se pudieron irrogar a las mismas, y lo cierto es que la previsión contenida en el último párrafo del artículo

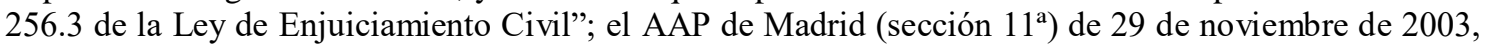
ponente Ilma. Sra. L. Ruiz de Gordejuela, f.j.2 (LA LEY198054/2003) que señala: “[...] se está en el caso de fijar la caución para responder tantos de los gastos que se ocasionen a las personas que han de intervenir en las mismas cuanto de los daños y perjuicios que se les pudieran irrogar, caución que, sin excepción, prevé el artículo 256.3 LEC"; el AAP de Sevilla (sección 5a) de 5 de diciembre de 2003, ponente Ilmo. Sr. F. Sanz, f.j. $2^{\circ}$ (AC 2003\1855) cuando señala: “[...] Es decir, es el Juez el que debe señalar la cuantía de la caución para garantizar los gastos que se ocasionen y los daños y perjuicios que se pudieren irrogar". Y el AAP de Guipúzcoa (sección $3^{a}$ ) de 3 de octubre de 2007, ponente Ilma. Sra. J.Ma, Unanue, f.j. $1^{\circ}$ (ROJ AAP SS 790/2007), cuando señala: "La primera cuestión que deberá de precisarse será que en el art 256-3 de la L.E.Civil se hace mención a dos cuestiones distintas, si bien enlazadas entre sí, los gastos que se originen como consecuencia de lasdiligencias a las personas que puedan intervenir en las mismas y la caución que se establece como presupuesto para la adopción de las diligencias en concordancia con su naturaleza".
} 
científica, aún la discrepancia mantenida al respecto $^{221}$, la caución tiene una doble función. Además de asegurar el resarcimiento de los gastos, daños y perjuicios que pudieran irrogarse a quien intervenga en las diligencias preliminares, cumple también la función de disuadir de peticiones poco fundadas o que tengan por finalidad la de tratar de anticipar o asegurar pruebas relativas al fondo del procedimiento, eludiendo así los requisitos que la LEC exige para la adopción de medidas de anticipación o aseguramiento de la prueba ${ }^{222}$.

${ }^{221}$ Esta discrepancia ha sido puesta de manifiesto con suma claridad expositiva, entre otros, por el AAP de Madrid (sección 20ª) de 31 de marzo de 2009, ponente Ilma. Sra. S. Arroyo, f.j.3 ${ }^{\circ}$ (LA LEY 61310/2009), que expone: "[...] En todo caso, se ha de tener en cuenta, no hay, en la actualidad, una interpretación unánime del artículo 256.3 Ley de Enjuiciamiento Civil, al existir dos tesis en la doctrina de las Audiencias Provinciales, la primera entiende que en el citado precepto la caución no tiene naturaleza sancionadora sino indemnizatoria de los gastos ocasionados al requerido, por lo que éste deberá solicitarla, con lo que sólo cuando se reclamen tales gastos y daños y perjuicios por el tercero directamente afectado (y haya transcurrido un mes desde la terminación de las diligencias preliminares en cuestión sin interponerse injustificadamente la demanda), podrá destinarse el importe -total o parcial- de la caución a subvenir los gastos y perjuicios que efectivamente se haya producido a la vista de los datos y circunstancias que se hubieran aportado (al respecto, podemos citar Auto AP Madrid, Sección 19a de 1 de diciembre 2005, recurso 600/2005 y Audiencia Provincial de Barcelona, Sección 14a, Auto de 28 Mayo 2008, recurso 687/2007).

Por el contrario, otra tesis entiende que la caución, que supone una novedad en relación con la Ley de Enjuiciamiento Civil de 1881, cumple una doble función, de garantía de abono de los gastos que se ocasionan y de los eventuales daños y perjuicios que se pudieran derivar de las diligencias (artículo 262.1 LEC) y una finalidad disuasoria de peticiones poco fundadas. El destino de la caución va en primer lugar ligado a la función de garantía y se contempla en el artículo 262.1, si bien el artículo 256.3 contiene una norma particular para el supuesto concreto de que el solicitante dejare de interponer la demanda dentro del mes siguiente a la terminación de las diligencias, habiendo sostenido la doctrina que se trata de una norma sancionadora que tiende a evitar que pueda acudirse a las diligencias preliminares con fines distintos a la preparación de un proceso. Conforme a esta interpretación, de no interponerse la demanda en el plazo establecido en el artículo 256.3 Ley de Enjuiciamiento Civil, el instante de la diligencia preliminar perderá la caución a favor de la persona que fue requerida, o a la que se refieran las diligencias". En el mismo sentido, el AAP de Córdoba (sección 1 ${ }^{\text {a }}$ ) de 15 de mayo de 2008, ponente Ilmo. Sr. E. Baena, f.j. $3^{\circ}$ (LA LEY 199232/2008).

${ }^{222}$ En la doctrina científica, así lo ponen de manifiesto Díaz Núñez, J.J., Diligencias Preliminares..., ob. cit., p. 28 y Capilla Casco, A., Diligencias preliminares y medidas de anticipación y aseguramiento de prueba, en "Actualidad Jurídica Uría Menéndez", 2005, núm. 12, p. 91. En el mismo sentido se pronuncian el AAP de Alicante (sección $8^{\mathrm{a}}$ ) de 4 de junio de 2015, ponente Ilmo. Sr. L.A. Soler, f.j.3 ${ }^{\circ}$ (JUR 2015 206411); el AAP de Guipúzcoa (sección 3a) de 3 de octubre de 2007, ponente Ilma. Sra. J.M ${ }^{a}$. Unanue, f.j.1 $1^{\circ}$ (ROJ AAP SS 790/2007), cuando señala: “[...] La caución tiene, por otra parte, la finalidad de disuadir de las peticiones de diligencias poco fundadas"; el AAP de Las Palmas (sección $3^{\text {a }}$ ) de 27 de enero de 2006, ponente Ilmo. Sr. R. Moyano, f.j. $2^{\circ}$ (LA LEY 11866/2006) advirtiendo: “[...] "La pérdida de la caución a favor de la contraparte en las diligencias preliminares es una sanción civil automática conforme al art. $256-3^{\circ}$, ya que en realidad en esta norma se distinguen dos supuestos: que la demanda preparada se presente en el plazo de un mes desde la terminación de las diligencias, en cuyo caso nada se señala sobre el destino de la caución, que por tanto dependerá de las vicisitudes del procedimiento principal y de que en efecto se acredite que se causaron daños o gastos a la parte contra la que se dirigió la diligencia preliminar. Por el contrario, el inciso final señala simplemente que si transcurre un mes sin deducir la demanda, la caución se adjudica a dicha parte, sin que se establezca requisito ni acreditación alguna de gastos o de daños, fuera de la necesidad de que la dilación o ausencia de demanda sea 
De ahí, que el aptdo. $3^{\circ}$ del art. 256 LEC disponga que la caución se perderá, en favor de quienes hayan de intervenir en las diligencias preliminares, si transcurrido un mes desde la terminación de las diligencias dejare de interponerse la demanda, sin justificación suficiente a juicio del tribunal. Ello aún cuando disponga el art. 262 LEC, que una vez practicadas las diligencias o denegada su realización tras el correspondiente incidente de oposición, el tribunal decidirá sobre la aplicación de la caución a la vista de la petición de indemnización y de la justificación de gastos que se presente pues una interpretación teleológica de ambas normas lleva a entender la compatibilidad de las dos apuntadas funciones de la caución ${ }^{223}$.

injustificada; por tanto, si bien la finalidad inicial y abstracta de la caución es responder de gastos y de daños y perjuicios, en el caso de que el solicitante de la medida, "de modo injustificado", no presente la demanda dentro de legal término, la adjudicación de la caución se desvincula ya de estas finalidades y de modo automático, como una sanción civil, o presunción "iuris et de iure" de daño, por la demora o la simple falta de ejercicio de la acción preparada. Toda otra interpretación sería absurda, ya que si la pérdida de la caución depende de la justificación del daño, no tendría sentido establecer una distinción entre el caso de que la demanda se presente dentro de plazo o de que no se presente, ya que no existiría un efecto diferente en uno y otro caso"; el AAP de Almería (sección $1^{\text {a }}$ ) de 10 de diciembre de 2003, f.j.2 ${ }^{\circ}$ (LA LEY 206392/2003) distinguiendo entre aplicación de la caución y pérdida de la misma, cuando aclara: "[...] Lo cierto es que no se puede estar de acuerdo con el planteamiento del recurrente pues una cosa es la aplicación de la caución, que es medida con carácter claramente indemnizatorio, y otra es la pérdida de la caución, que es medida que tiene un carácter más bien sancionador. Y cada una de ellas requiere del cumplimiento de una condición diversa: la petición de indemnización y la justificación de gastos son la condición necesaria para que se haga la aplicación de la caución, conforme se establece en el artículo 262.1 LEC; mientras que el dejar transcurrir un mes sin presentar la demanda o sin justificar su no presentación es la condición de la pérdida de la caución a favor de la persona que fue requerida en las diligencias. Por tanto, aunque no se haya hecho petición indemnizatoria ni justificación de gastos, no por ello, automáticamente se tiene derecho a la devolución, sino que se ha de cumplir, para ello, con la condición mentada de presentación de la demanda"; y el AAP de Las Islas Baleares (sección $3^{\mathrm{a}}$ ) de 18 de noviembre de 2003, ponente Ilma. Sra. C.M ${ }^{a}$. Moragues, f.j. $3^{\circ}$ (ROJ AAP IB317/2003) determinando que: "[...] Al respecto debe señalarse que la caución, exigida con carácter general en todos los supuestos en los que se solicitan diligencias preliminares y que supone una novedad en relación a la Ley de Enjuiciamiento Civil de 1881, cumple una doble función, de garantía del abono de los gastos que se ocasionan y de los eventuales daños y perjuicios que se pudieran derivar de las diligencias (artículo 262.1), y una finalidad disuasoria de peticiones poco fundadas. El destino de la caución va en primer lugar ligado a la función de garantía y se contempla en el artículo 262.1, si bien el artículo 256.3contiene una norma particular para el supuesto concreto de que el solicitante dejare de interponer la demanda dentro del mes siguiente a la terminación de las diligencias, tratándose, como se ha puesto de manifiesto por la doctrina, de una norma sancionadora que tiende a evitar que pueda acudirse a las diligencias preliminares con fines distintos a la preparación de un proceso. La aplicación de dicha norma plantea problemas diversos y, entre ellos, el que deba entenderse por "justificación suficiente".

${ }^{223}$ La procedencia de la interpretación literal e imperatividad de la norma es negada por el AAP de Barcelona (sección 14 ${ }^{\mathrm{a}}$ ) de 28 de mayo de 2008, ponente Ilma. Sra. M. Font, f.j. $2^{\circ}$ (LA LEY 105101/2008), señalando que: “[...] Las disposiciones que se establecen en los artículos 256 y 262 son complementarias entre sí, sin que pueda realizarse una interpretación literal del contenido previsto en el párrafo $3^{\circ}$ del art. 256. La interpretación ha de ser restrictiva a favor del instante de las diligencias salvo que se acrediten los daños y perjuicios que se hayan podido ocasionar al demandado, tanto si no se presenta la demanda dentro de los treinta días, como si se han denegado las diligencias al oponerse a la 
Una, asegurar a quien ha sido afectado por la diligencia preliminar la percepción de una cantidad que repare los gastos, molestias o perjuicios que hayan podido surgir como consecuencia de su práctica, a través de las normas que disciplinan la resolución de las peticiones de reintegro o indemnizatorias. Otra, la de evitar que se acuda injustificadamente a las diligencias preliminares con fines desviados o abusivos distintos a los de la obtención de datos necesarios para la incoación de un ulterior proceso $\mathrm{y}$, en concreto, mediante la pérdida de la caución por quien injustificadamente deje de presentar la demanda respecto de la cual aquellas son instrumentales ${ }^{224}$. En este segundo caso, observamos una función de sanción procesal ligada a la falta injustificada, o no razonada, de interposición de la demanda y de la que resultarían beneficiarias las personas que hubieran de intervenir en las diligencias, aunque éstas no hubieran pedido ser reintegradas de gastos o no hubieran cursado pretensiones indemnizatorias $^{225}$ lo que, a nuestro juicio, no siempre debería tener lugar. Así, por ejemplo, cuando el solicitante de la diligencia preliminar deba dirigir la demanda posteriormente contra una persona distinta del destinatario de aquella o cuando el resultado de su práctica haya puesto de manifiesto la improcedencia de comenzar un proceso, la aplicación literal del precepto legal, invitaría a la interposición de demandas carentes de fundamento ${ }^{226}$.

demanda. La literalidad del último párrafo $\left(3^{\circ}\right)$ no permite al Tribunal determinar si existen causas justas para no interponer la demanda, por lo que son las partes quienes han de instar las oportunas acciones".

${ }^{224}$ En dicho sentido, Asencio Mellado, J.M., Derecho Procesal Civil..., ob. cit., p. 41, entiende que "una vez realizados los actos pedidos y como quiera que la regla es que todos los gastos derivados de las diligencias preliminares sean a costas del solicitante de las mismas, la caución se aplicará a sufragar los gastos ocasionados por ellas; de igual modo se actuará si se denegaran las diligencias pero el procedimiento ha producido daños o perjuicios" (...) devolviéndose el sobrante al solicitante una vez transcurrido un mes desde la terminación del procedimiento de diligencias preliminares".

${ }^{225} \mathrm{Al}$ respecto, vid. el AAP de Barcelona (sección $11^{\mathrm{a}}$ ) de 29 de marzo de 2006, ponente Ilmo. Sr. J.A. Ballester, f.j. $1^{\circ}$ (LA LEY 94232/2006). Sin perjuicio de no obviar aquellos pronunciamientos doctrinales que entienden que la pérdida de la caución no es automática y que con este carácter sólo podría perderse cuando el sujeto pasivo que haya intervenido en la práctica de las diligencias haya deducido la petición de resarcimiento de daños y perjuicios. En esta línea, el AAP de Barcelona (sección $14^{\mathrm{a}}$ ) de 28 de mayo de 2008, ponente Ilma. Sra. M. Font, f.j. $2^{\circ}$ (LA LEY 105101/2008) que señala que: “[...] en el art. 256.3 no se establece un principio imperativo de devolución de la caución a favor del demandado por el mero hecho de no presentar la demanda dentro de los treinta días siguientes".

${ }^{226}$ Garciandía González, P.M., La regulación de ..., ob. cit., pp. 792-793. En relación al destino que debe darse a la caución cuando no llega a interponerse la demanda del ulterior proceso, resulta clarificador el AAP de Cádiz (sección $2^{\mathrm{a}}$ ) de 18 de noviembre de 2008, ponente Ilmo. Sr. A. Marín, f.j.2º (LA LEY 237789/2008). 
Por ello puede concluirse que, en primer término, el juez resolverá sobre la aplicación de la caución a los gastos, daños y perjuicios ocasionados, con independencia de que pueda presentarse o no después la demanda en el plazo de un mes desde la terminación de las diligencias y sólo una vez ventilada dicha cuestión podrá el mismo determinar la pérdida de la totalidad de la caución o del remanente a que alude el art. 262 LEC una vez cubiertos los gastos, daños y perjuicios ocasionados por la práctica de las diligencias ${ }^{227}$.

En consecuencia, puede afirmarse que la función primordial de la caución es el resarcimiento de los gastos, daños y perjuicios que se causen a quienes como sujetos pasivos hayan intervenido en la práctica de las diligencias preliminares y, en un segundo término, la de sancionar aquellas solicitudes en que, a la postre, se deje de interponer la demanda del ulterior pleito, sin razón alguna que lo justifique.

\subsubsection{Ponderación de las funciones de la caución}

Llegados a este punto, debemos reflexionar sobre la pertinencia de que quien ha formulado una petición fundada de diligencias preliminares tenga la obligación de resarcir los gastos, daños y perjuicios que se pudieran irrogar al requerido a su práctica cuando dicha práctica no sólo es consecuencia de una resolución fundada en derecho, que en buena medida se sustenta en la obligación de colaborar participando en la práctica de aquellas, sino cuando el solicitante, previamente a formular su solicitud ante los tribunales, de forma extrajudicial, acredita haber intentado obtener la misma información del interesado posteriormente requerido.

Téngase en cuenta que, como ya se expuso, el mecanismo procesal de las diligencias preliminares se inspira tanto en la preparación del futuro proceso como en la imposibilidad del solicitante de obtener, por otros medios, la correspondiente información que le permita preparar tal futuro proceso, lo que en no pocas resoluciones de los tribunales se ha traducido en el rechazo de la diligencia preliminar sin un previo

\footnotetext{
${ }^{227}$ En este sentido, el AAP de Madrid (sección 19a) de 23 de diciembre de 2005, ponente Ilmo. Sr. E. Legido, f.j.3º (LA LEY 247641/2005).
} 
intento privado de obtención de la información ${ }^{228}$. Luego, en el caso de aquellos solicitantes de diligencias preliminares que se ven en la necesidad de acudir al mecanismo de las diligencias preliminares porque previamente, y por causas ajenas a su voluntad, no han podido obtener la información necesaria para la preparación de dicho futuro proceso, esa futura obligación de resarcimiento de gastos, daños y perjuicios resulta más que cuestionable. Piénsese en el supuesto de aquellos que se ven en la obligación de acudir a los tribunales buscando su auxilio para la obtención de su correspondiente historia clínica cuando previamente, sin éxito, se han dirigido a la Administración Pública competente o centro privado de la salud formulando la misma petición. O, simplemente, en aquellos supuestos en que el solicitante acredita haber remitido una petición fehaciente de colaboración a quien luego resulte sujeto requerido en las diligencias preliminares. En dichos supuestos, no parece razonable imponer al solicitante la obligación de resarcir a quien por su negativa extraprocesal e injustificada haya de intervenir en la práctica de la diligencia proporcionando unos datos que debió proporcionar privadamente y, como es el caso de la historia clínica, por disposición legal ${ }^{229}$. En dichos supuestos, el gasto, daño o perjuicio que pudiera sufrir quien como

\footnotetext{
${ }^{228}$ En dicho sentido, el AAP de Madrid (sección 12 $2^{\mathrm{a}}$ ) de 18 de junio de 2015, ponente Ilmo. Sr. J.Mª Torres, f.j. $3^{\circ}$ (ROJ AAP M 456/2015), cuando, aún de forma parcial, funda el rechazo de la diligencia preliminar deducida en el hecho de no haber dirigido la solicitante a la requerida, previamente a la promoción de las diligencias preliminares, requerimiento alguno tendente a obtener la información en cuestión; el AAP de Barcelona (sección 17ª) de 27 de mayo de 2002, ponente Ilma. Sra. M. Sambola, f.j.2 $2^{\circ}$ (JUR 20021208711), que confirma la inadmisión en la instancia de la diligencia preliminar de exhibición de testamento al entender que, en el caso, no se aprecia la concurrencia de justa causa e interés legítimo previsto en el art. 256 al encontrase el testamento cuya exhibición se pretendía en un protocolo notarial y, por tanto, siendo factible su localización, exhibición y obtención de copias auténticas del original a las personas que se encuentran en los supuestos previstos en el art. 226 del Reglamento Notarial, a tenor del cual el Notario otorgante está legitimado para exhibirlo, una vez fallecido el otorgante, [...] a los herederos instituidos o sus representantes, los legatarios, albaceas, contadores y demás personas a quienes se reconozca algún derecho o facultad, los parientes que de no existir el testamento o ser nulo o en que no haya instituido herederos forzosos, serían en todo caso los llamados en todo o en parte a la herencia del causante, y los instituidos en testamento revocado".

${ }^{229}$ Así, en el caso de la diligencia preliminar contemplada en el art. 256.1.5 bis LEC, por petición de la historia clínica al centro sanitario o profesional que la custodie, ante la negativa de entrega de dicha historia clínica, o parte de la misma, cuando por dichos centros se impide o dificulta el ejercicio del derecho de acceso a la historia clínica del paciente, por parte de este o de sus causahabientes, previsto en el art. 18 LABP; o en el caso de la diligencia preliminar contemplada en el art. 256.1.3 LEC, por petición del que se considere heredero, coheredero o legatario, de exhibición, por parte del notario, del acto de última voluntad del causante de la herencia o legado, cuando dicha exhibición se deniegue injustificadamente, a las personas que se encuentran en los supuestos previstos en el art. 226 del Reglamento Notarial; también, en el caso de la diligencia preliminar contemplada en el art. 256.1.4 LEC, por petición de un socio o comunero para que se le exhiban los documentos y cuentas de la sociedad o
} 
requerido intervenga en dicha diligencia preliminar no tendrá más causa que la de su propia negligencia acompañada del incumplimiento de la normativa que regula el derecho de acceso a dicha información. En consecuencia, los gastos, daños y perjuicios en modo alguno le debieran ser indemnizados a quien injustificada y extrajudicialmente ha negado la información y ha obligado a otro a acudir a las diligencias preliminares.

Esto nos lleva a proponer una reforma del texto legal que no imponga al solicitante de las diligencias preliminares la obligación de resarcir, en todo caso, cuantos gastos, daños y perjuicios sufran quienes como requeridos intervengan en la práctica de las diligencias preliminares y aún cuando aquellos resulten probados. Es decir, una reforma del texto legal que no ampare el resarcimiento de gasto, daño o perjuicio alguno a quien, injustificada y extrajudicialmente, se ha negado a colaborar con el interesado en la obtención de la necesaria información para la correcta preparación del futuro proceso. Más aún, en los supuestos en que el auxilio judicial para la obtención de la información en cuestión no resulta necesaria, bastando una mera lectura de las diligencias que enumera el art. 256.1 LEC para advertir que en ninguno de ellos la información o documentos que se puede pretender obtener requiere una previa decisión judicial pues la información que puede obtenerse a través de las diligencias previstas en el art. 256.1 LEC, o bien no afecta a materias especialmente protegidas o reguladas o, cuando lo hace, el acceso a la misma se encuentra debidamente regulado, resultando absolutamente injustificado que quien pretenda dicha información deba dirigirse a un juez para obtener aquello que la ley le concede privadamente y le es negado.

\subsubsection{Propuesta de reforma y delimitación de las funciones de la caución}

Una reforma legal en dicho sentido redundaría en una adecuada utilización del mecanismo procesal, quedando limitado su uso a aquellos supuestos en los que habiéndose pretendido privadamente la obtención de la correspondiente información la negativa a facilitar la misma lo es como consecuencia de la concurrencia de causas justificadas o dudas de hecho o de derecho en quien tiene que proporcionarla. 
Ello, porque a nuestro juicio resulta absurdo, por ejemplo, que quien acredita debidamente ante una concreta aseguradora ser perjudicado por un hecho de la circulación, se vea en la necesidad de acudir a un tribunal para que dicha aseguradora le proporcione los datos necesarios de su asegurado, presunto responsable del daño causado, o los términos del aseguramiento; igualmente, resulta absurdo que quien en forma dirige la correspondiente petición a un centro sanitario, público o privado, se vea en la necesidad de acudir a un tribunal para que dicho centro le proporcione su propia histórica clínica o la de su causahabiente; igualmente, también, porque consideramos absurdo que quien ocupa un inmueble cuya posesión pretende ser recuperada privada o judicialmente, se vea en la necesidad de acudir a un tribunal para la exhibición de un título que bien se pudo exhibir privadamente.

Por todo lo expuesto entendemos que, en modo alguno, de la mera justificación de daños y perjuicios de quien intervenga como requerido en las diligencias preliminares puede concluirse la obligación de indemnización, resultando conveniente realizar la correspondiente reforma legal que, sin obviar la función de garantía que cumple la caución, permita al tribunal valorar si la pretensión de obtención de la concreta información por el solicitante requería un previo pronunciamiento judicial. En consecuencia, debe rechazarse cualquier eventual obligación del solicitante de abonar gasto, daño o perjuicio alguno a quienes injustificada y previamente a la diligencia preliminar, por acción u omisión, se hayan negado a facilitar la necesaria información así como articulando los correspondientes mecanismos de sanción ${ }^{230}$ para aquellos, cuando absurdamente, sin amparo legal alguno, y en ocasiones pretendiendo obstaculizar el ejercicio legítimo ante los tribunales de la correspondientes acciones, obligan a otros a acudir a los tribunales para la obtención de una información que privadamente debieron de obtener. A tal efecto, son varios los mecanismos y momentos que en el articulado de la ley se podrían arbitrar para un correcto funcionamiento de la función de garantía de la caución en los términos propuestos.

\footnotetext{
${ }^{230}$ Por ejemplo, a través de un sistema de imposición de multas pecuniarias similar al previsto en el art. 591 LEC para el supuesto de vulneración del deber de colaboración de las personas físicas y jurídicas en las actuaciones de ejecución.
} 
En un primer momento, y al tiempo de la decisión por el tribunal sobre la pertinencia de la práctica de la diligencia preliminar, en la misma resolución, el tribunal podría valorar si la petición de su práctica viene acompañada de la acreditación por el solicitante de un previo, serio, fehaciente y justificado intento extrajudicial de obtener la información objeto de la diligencia preliminar, examinando a la vez la respuesta del requerido extrajudicialmente, si la hubiera, y ésta se acompañara a la solicitud inicial. Y para el caso de acreditarse dicho previo, serio y fehaciente intento extrajudicial de obtener la información objeto de la diligencia podría eximirse al solicitante, inicialmente, de la prestación de caución.

Y se dice inicialmente porque, en un segundo momento, si el requerido a la práctica de la diligencia preliminar se opusiera, nada impediría que en la vista de oposición se pretendiera por el mismo la prestación de caución, que igualmente podría valorar el tribunal al resolver la oposición y con carácter previo a la práctica de la diligencia preliminar.

Lo anterior, porque entendemos absolutamente injustificado que se obligue a promover el mecanismo de las diligencias preliminares para la obtención de cualquier información que pudiera obtenerse sin la intervención de los tribunales, a no ser por la mera resistencia del requerido. Con dichas conductas no sólo se incrementa injustificadamente la actividad de unos tribunales españoles ya de por si sobrecargados sino que se impone al justiciable la obligación de satisfacer unos gastos, daños y perjuicios que no tienen más origen que la propia conducta obstruccionista de quien debe proporcionar la información, a lo que se deberá de sumar los gastos en que el propio solicitante incurrirá para la promoción de las diligencias preliminares.

Además, en materia de responsabilidad por daños derivados de actuaciones judiciales civiles se ha de partir de la regla conforme a la cual el legítimo ejercicio de un derecho subjetivo, reconocido por el ordenamiento, es causa excluyente de la antijuridicidad, aunque se cause lesión a los intereses de un tercero de forma tal que cuando, sin traspasar los límites de la equidad y buena fe se pone en marcha el instrumento procesal para hacer valer una atribución que el actor estime que le 
corresponde, el derecho a litigar no puede ser fuente generadora de responsabilidad ${ }^{231}$. Esta regla quebrará cuando se estime la inexistencia de iusta causa litigandi, reveladora de un exceso o anormalidad en el ejercicio de un derecho o de un ánimo subjetivo de perjudicar, faltando un fin serio y legítimo, supuestos en que el TS acude a la doctrina del abuso de derecho en el ejercicio del instrumento procesal, determinante del deber de reparación $^{232}$.

\subsubsection{Especial atención a la caución de las diligencias de comprobación de} hechos

Al margen de lo anterior, un detalle especial y separado merece la caución en el ámbito de las diligencias de comprobación de hechos. Respecto de las mismas, el art. 123.4 LP dispone que el juez, al acordar la práctica de las diligencias solicitadas, y de acuerdo con lo previsto en la LEC, fijará la caución que deberá prestar el peticionario para responder de los daños y perjuicios que eventualmente puedan ocasionarse. Además, el art. 126 LP vincula el destino de la fianza al aseguramiento de una responsabilidad de rasgos objetivos, al indicar que con la misma se garantizará la eventual reclamación del sujeto pasivo por los gastos y daños que se le hubieren ocasionado, incluido el lucro cesante, que podrán reclamarse en todo caso. Deja a salvo la norma, a continuación, la responsabilidad general por daños y perjuicios en que pudiera haber incurrido el solicitante de las medidas en los casos en que a ello hubiere lugar.

Así, el art. 126 LP contempla dos categorías o fuentes reparadoras sujetas a distinto régimen jurídico. Una, específica, que procede y se genera en todo caso, cualquiera que fuere el resultado de las diligencias y el interés del peticionario que, como sujeto activo de una responsabilidad objetiva ex lege, queda obligado a resarcir los gastos, daños y lucro cesante derivados de la práctica de las diligencias. De este modo, se trata de proteger al sujeto pasivo contra esa intromisión o injerencia que

\footnotetext{
${ }^{231}$ AAP de Barcelona (sección $15^{\mathrm{a}}$ ) de 26 de julio de 2002, ponente Ilmo. Sr. L. Garrido, f.j.3º (LA LEY 140501/2002).

${ }^{232}$ STS de 5 de diciembre de 1980 (sala $1^{\text {a }}$ ), ponente Ilmo. Sr. J. De Castro, f.j.1º (RJ 1980\4738).
} 
representan las diligencias de comprobación de hechos, con independencia de que las mismas resulten o no infructuosas, de que sea o no demandado con posterioridad el requerido y de cual sea el resultado del pleito principal, de modo que la fianza queda sujeta al resarcimiento de gastos y daños que su mera práctica pueda ocasionar, abstracción hecha de su resultado, sancionando en todo caso la obligación indemnizatoria a cargo del peticionario. Y, otra, en tanto que fuente general de responsabilidad cuando la actividad procesal se ha puesto en marcha traspasando los límites de la equidad y buena fe, al objeto de satisfacer propósitos desviados de su función natural, o cuando no medie la iusta causa litigandi.

En el primer supuesto, la obligación reparadora no puede derivar de la culpa, exceso o anormalidad en el ejercicio del derecho dado que el tratamiento de las consecuencias del ejercicio del mecanismo judicial está regido por una norma que configura una responsabilidad objetiva ex lege, con mayor o menor alcance del deber de resarcimiento, y con efecto práctico de dispensar al sujeto pasivo de la carga de probar el exceso o en definitiva la ilicitud del daño, bastando con que acredite la realidad del mismo causalmente conectado a la activación y desarrollo del instrumento procesal.

En el caso de las diligencias de comprobación la obligación de resarcimiento de los gastos causados se objetiviza en la norma previamente y prescindiendo de tales factores, anudando la obligación reparadora al simple uso del instrumento procesal, a modo de condictio ex lege motivada por la intromisión en la esfera jurídica ajena, por más que exista justa causa para proceder, la autorización judicial ${ }^{233}$.

\footnotetext{
${ }^{233} \mathrm{Al}$ respecto, vid. AAP de Barcelona (sección 15a) de 26 de julio de 2002, ponente Ilmo. Sr. L. Garrido, f.j. $3^{\circ}$ (LA LEY 140501/2002) y AAP de Barcelona (sección $15^{\text {a }}$ ), de 21 de marzo de 2005, ponente Ilmo. Sr. I. Sancho, f.j.2 ${ }^{\circ}$ (LA LEY 65421/2005).
} 


\subsection{Conceptos resarcibles con cargo a la caución}

\subsubsection{Gastos}

Si bien la LEC indica que la caución está destinada a la cobertura de los gastos que se ocasionen a las personas que hubieren de intervenir en las diligencias (art. 256.3 LEC) además de a la indemnización de daños y perjuicios que se causaren, la misma omite toda referencia al concepto de gastos o a lo que por tal debe entenderse. La doctrina científica tampoco se ha detenido en esta cuestión y la judicial, en términos generales, ha ido atendiendo al supuesto concreto para determinar cuáles de los invocados o reclamados tienen las consideración de resarcibles con cargo a la caución y cuáles no.

Aún reconociendo que no puede exigirse al legislador la definición de todos y cada uno de los conceptos que se recojan en cualquier norma, con mayor razón en una como la LEC que no tiene por objeto la definición de instituciones jurídicas sino la ordenación del contexto en que ha de desarrollarse el procedimiento ${ }^{234}$, hubiera resultado deseable que la doctrina judicial, en honor a la función interpretativa del derecho que le atribuye el art. 1.6 CC, hubiera definido un concepto de gasto que ofreciera una referencia dotada de cierta seguridad jurídica. Y, al mismo tiempo, que no amparase la disparidad de criterios de los tribunales en orden a determinar, en el supuesto concreto, qué debe o no considerarse gasto indemnizable en sede de diligencias preliminares. Somos conscientes de que la propia naturaleza de las diligencias preliminares, con escasas posibilidades de ser conocidas por nuestro Alto Tribunal, dificulta la obtención de esa doctrina judicial que, en rigor, no puede identificarse sino con aquella que, de modo reiterado, establezca el Tribunal Supremo al

\footnotetext{
${ }^{234}$ Así interpretamos el apartado I de la Exposición de Motivos de la LEC cuando dispone que una de las finalidades de la LEC es la de dotar de una Justicia civil efectiva, es decir, de un "conjunto de instrumentos encaminados a lograr un acortamiento del tiempo necesario para una definitiva determinación de lo jurídico en los casos concretos" (...) "estructurando procesalmente el trabajo jurisdiccional de modo que cada asunto haya de ser mejor seguido y conocido por el tribunal, tanto en su planteamiento inicial y para la eventual necesidad de depurar óbices y falta de presupuestos procesales nada más ineficaz que un proceso con sentencia absolutoria en la instancia-, como en la determinación de lo verdaderamente controvertido y en la práctica y valoración de la prueba, con oralidad, publicidad e inmediación".
} 
interpretar y aplicar la ley, la costumbre y los principios generales del derecho. Pero, en cualquier caso, son escasísimas las resoluciones recaídas en la práctica forense que han realizado un digno intento por delimitar a qué concepto responden los gastos resarcibles en sede de diligencias preliminares, limitándose la mayor parte de las mismas a analizar, en el caso concreto, si el gasto reclamado es digno de ser indemnizado.

Con carácter general, se afirma que los gastos indemnizables de los que debe responder la caución prestada por el solicitante son los gastos que cumplan con las condiciones que constituyen los presupuestos que debe reunir todo gasto para ser satisfecho ${ }^{235}$. A saber:

1) Que respondan al criterio de necesidad. Es decir, que se trate de gastos producidos con ocasión de las diligencias preliminares, de modo tal que sin efectuarlos no hubiera podido intervenirse en ellas. Por tanto, que se trate de gastos no superfluos ${ }^{236}$.

2) Que respondan al criterio de oportunidad. Es decir, que se trate de gastos justificados.

3) Que respondan al criterio de causalidad. Es decir, que se hayan producido no sólo con ocasión de las diligencias preliminares sino de forma directa e inmediata con ocasión de las mismas.

4) Que respondan al criterio de menos gravosidad. Es decir, que se trate de gastos que no sean susceptibles de sustitución por otros igualmente conducentes a la parte a intervenir en tales diligencias, hábiles por tanto a la necesidad para la que se retribuyen, pero menos gravosos u onerosos.

\footnotetext{
${ }^{235}$ AAP de Alicante (sección $8^{\mathrm{a}}$ ) de 4 de junio de 2015, ponente Ilmo. Sr. L.A. Soler, f.j. $4^{\circ}$ (JUR 2015 206411).

${ }^{236}$ Como apunta el AAP de Granada (sección $3^{\mathrm{a}}$ ) de 5 de mayo de 2005, ponente Ilmo. Sr. A. Mascaró, f.j. $1^{\circ}$ (ROJ AAP GR 399/2005) negándose el carácter de gasto indemnizable con cargo a la caución prestada a aquellos gastos que deriven de actuaciones voluntarias de las partes y no requeridas por el tribunal. En el mismo sentido, el AAP de Barcelona (sección 15a) de 26 de julio de 2002, ponente Ilmo. Sr. L. Garrido, f.j.6º (LA LEY 140501/2002).
} 
A los que nosotros añadiríamos:

5) Que se trate de gastos no evitables. A saber, de gastos producidos como consecuencia de la necesidad de un previo pronunciamiento judicial para la obtención de la información pretendida. Necesidad de previo pronunciamiento judicial que no podrá entenderse concurrente en aquellos supuestos en los que el tribunal considere que al requerido no le asistía razón alguna para negarse a facilitar extrajudicialmente la información pretendida a través de las diligencias preliminares.

Definidas las circunstancias generales que deben concurrir en el gasto para entender que es indemnizable con cargo a la caución, debe ponerse de manifiesto que la doctrina judicial se ha preocupado de recalcar que tales gastos no tratan de satisfacer $\operatorname{costas}_{\text {procesales }}^{237}$, lo que es coherente con la disposición contenida en el art. 241 LEC que distingue los gastos del proceso, que identifica con los desembolsos que tengan su origen directo e inmediato en la existencia de dicho proceso ${ }^{238}$, de las costas, que responden del pago de conceptos tales como los honorarios de la defensa y de la representación técnica cuando sean preceptivas, la inserción de anuncios o edictos que de forma obligada deban publicarse en el curso del proceso, los depósitos necesarios para la presentación de recursos, los derechos de peritos y demás abonos que tengan que realizarse a personas que hayan intervenido en el proceso, las copias, certificaciones,

\footnotetext{
${ }^{237}$ AAP de Guipúzcoa (sección $3^{\text {a }}$ ) de 3 de octubre de 2007, ponente Ilma. Sra. J.M ${ }^{\text {a }}$. Unanue, f.j. $1^{\text {o }}$ (ROJ AAP SS 790/2007), que señala que los gastos "no son propiamente costas procesales, pues el art. 241 de la LEC distingue entre ambos conceptos". En el mismo sentido, el AAP de Granada (sección $3^{\text {a }}$ ) de 5 de mayo de 2005, ponente Ilmo. Sr. A. Mascaró, f.j. $1^{\circ}$ (ROJ AAP GR 399/2005) que determina que como tales no pueden considerarse las minutas de abogado y procurador, al no ser preceptiva su intervención. En similares términos, el AAP de Alicante (sección $8^{\mathrm{a}}$ ) de 4 de junio de 2015, ponente Ilmo. Sr. L.A. Soler, f.j. $4^{\circ}$ (JUR 2015 206411). Sin embargo, en la doctrina científica, no faltan voces que como consecuencia de la estimado el incidente de oposición, las costas a que sea condenado el solicitante de las diligencias preliminares podrán hacerse efectivas con cargo a la caución. En dicho sentido, Álvarez Alarcón, A., Las diligencias preliminares..., ob. cit., p. 70.

${ }^{238}$ En dicho sentido se pronuncia el AAP de Granada (sección $3^{\text {a }}$ ) de 2 de junio de 2004, ponente Ilmo. Sr. J.M ${ }^{\mathrm{a}}$. Jiménez, f.j.3 ${ }^{\circ}$ (LA LEY 130186/2004) cuando aclara: “[...] el concepto de gastos y costas se ha de extraer del art 241 LEC, de modo que los gastos a que alude el art 256 son aquellos que tienen su origen en los actos que haya sido necesario realizar para el cumplimiento por el requerido de lo ordenado por el Juez, previa la admisión de la practica de las diligenciaspreliminares, que en éste caso hubiera consistido en los gastos de desplazamiento y otros íntimamente relacionados con el mismo, efectuado por el requerido desde su lugar de residencia en Albuñol a la localidad de Orgiva. No siendo gastos, sino costas, las expresadas en el $\mathrm{n}^{\mathrm{o}} 1$ de aquel precepto. Y como tales, no incluibles en la previsión legal del articulo 256". También el AAP de Barcelona (sección 15ª) de 21 de marzo de 2005, ponente Ilmo. Sr. I. Sancho, f.j. $2^{\circ}$ (LA LEY 65421/2005).
} 
notas, testimonios y documentos análogos que hayan de solicitarse conforme a la Ley, salvo los que se reclamen por el tribunal a registros y protocolos públicos, que serán gratuitos, los derechos arancelarios que deban abonarse como consecuencia de actuaciones necesarias para el desarrollo del proceso y la tasa por el ejercicio de la potestad jurisdiccional, cuando sea preceptiva.

Por tanto, con carácter general, no revisten el carácter de gasto los honorarios de abogado y procurador, aún cuando existen resoluciones judiciales que, aún tácitamente y afirmando la distinción entre gastos y costas procesales, admiten el resarcimiento del coste de tales profesionales siempre y cuando su participación en las diligencias preliminares no se considere superflua o innecesaria en lo que a la práctica de la diligencia preliminar se refiere ${ }^{239}$. Situación esta que podría producirse, por ejemplo, cuando el procurador interviniera en las diligencias preliminares como mandatario verbal del requerido ${ }^{240}$, a lo que nosotros añadimos que siempre y cuando la actuación con tal carácter fuera admitida por el órgano judicial. Ello, porque la representación del procurador en el procedimiento entendemos que no puede ser más que procesal y, como tal y de conformidad con lo prevenido en el art. 23.3 LEC, su intervención, sin dirección legal, se encuentra limitada a los solos efectos de oír y recibir actos de comunicación y efectuar comparecencias de carácter no personal de los representados con ocasión de las cuales no podrá formular solicitud alguna.

De acuerdo con la doctrina judicial, si revisten el carácter de gasto los derivados del de desplazamiento para la práctica de la diligencia preliminar en los que hubiera

\footnotetext{
${ }^{239}$ AAP de Alicante (sección $8^{\text {a }}$ ) de 4 de junio de 2015, ponente Ilmo. Sr. L.A. Soler, f.j. $4^{\circ}$ (JUR 2015 (206411). En el mismo sentido, el AAP de Barcelona (sección 15 ${ }^{\text {a }}$ ) de 26 de julio de 2002, ponente Ilmo. Sr. L. Garrido, f.j.6 (LA LEY 140501/2002).

${ }^{240}$ Así lo admite el AAP de Granada (sección $3^{\mathrm{a}}$ ) de 2 de junio de 2004, ponente Ilmo. Sr. J.M ${ }^{\mathrm{a}}$. Jiménez, f.j. $3^{\circ}$ (LA LEY 130186/2004) cuando dispone: "[...] en vista de la ausencia de una condena en costas, pero teniendo en cuenta que, en definitiva, la procuradora Sra Molina Sollmann compareció en el Juzgado de Orgiva como mandataria verbal del Sr Rodolfo que, en vista de la distancia, o por cualquier otra circunstancia, no quiso o no pudo comparecer personalmente, resulta evidente que el cumplimiento de ese mandato ocasionó unos gastos necesarios a fin de que el requerido pudiere cumplir con el mandato judicial, representados por la actuación personal de la citada procuradora, los que, como tales gastos, han de ser sufragados por el solicitante de las diligencias, por imperativo del citado articulo 256.3 LEC".
} 
incurrido el sujeto pasivo que deba de intervenir en las diligencias ${ }^{241}$ así como los auxiliares técnicos de los que se acompañen y también efectivamente intervengan ${ }^{242}$. No así, el importe de los servicios que tales auxiliares o peritos puedan suponerle al sujeto pasivo los que, como dispone el art. 259.2 LEC, actuarán siempre a su costa ${ }^{243}$.

\subsubsection{Daños y perjuicios}

Es doctrina reiterada que el resarcimiento de daños y perjuicios requiere la constancia de su existencia y la prueba de los mismos, cuya carga corresponde a quien interesa su resarcimiento, de acuerdo con la norma general del art. 217 LEC, como hecho positivo y constitutivo de su pretensión ${ }^{244}$. Sólo se admite dispensa o relajación de la exigencia y del rigor de la prueba de la existencia de los daños en muy específicos supuestos, como son los casos en los que la existencia de los daños se deduce fatal y necesariamente, en que son consecuencia forzosa, natural, o inevitable, o se trata de daños incontrovertibles, evidentes, o patentes ${ }^{245}$. Por otro lado, se entiende que la mera dispensación de los datos requeridos a través de las diligencias preliminares ocasione daño o perjuicio alguno de quien facilite aquellos por tenerlos en su poder ${ }^{246}$

241 En dicho sentido, el AAP de Cádiz (sección $8^{\text {a }}$ ) de 10 de mayo de 2002, ponente Ilmo. Sr. L.A. De Diego, f.j.2º (LA LEY 90365/2002), el AAP de Barcelona, de 2 de diciembre de 2004, ponente Ilma. Sra. I. Carriedo, f.j.2 $2^{\circ}$ (LA LEY 255515/2004).

242 AAP de Alicante (sección $8^{\text {a }}$ ) de 4 de junio de 2015, ponente Ilmo. Sr. L.A. Soler, f.j.4 $4^{\text {(JUR }}$ 2015 206411).

243 Ello, pese a que existen resoluciones que entienden que dentro del concepto de gasto que debe ser resarcido con cargo a la resolución deben incluirse los de los profesionales que intervengan por cuenta del requerido. En dicho sentido, el AAP de Madrid (sección 13ª) de 9 de julio de 2009, ponente Ilmo. Sr. C. Cezón, f.j.2 $2^{\circ}$ (LA LEY 171400/2009) señala que: “[...] No van a existir perjuicios para la comunidad requerida derivados de la diligencia, pero sí gastos, debiéndose fijar para responder de los mismos una caución que prudencialmente se cifra en 300 euros (gastos de fotocopias, de desplazamiento al Juzgado, de intervención de profesional a cargo de la administración de la comunidad), que se prestarán por la promotora en la forma prevista en el párrafo segundo del apartado dos del artículo 64 de la Ley de Enjuiciamiento Civil, de conformidad con lo dispuesto en el apartado tres del artículo 256 de la ley procedimental civil".

${ }^{244}$ Este criterio se ha seguido desde antiguo, destacando las SSTS de 6 de abril de 1995 (sala $1^{\text {a }}$ ) ponente Ilmo. Sr. L. Martínez-Calcerrada, f.j.2º (RJ 199513416) y de 22 de octubre de 1996 (sala 1ª), ponente P. González, f.j.3(RJ 199617510).

${ }^{245}$ SSTS de 29 de marzo de 2001(sala $1^{\text {a }}$ ), ponente Ilmo. Sr. J. Corbal, f.j.2 ${ }^{\circ}$ (RJ 2001\3189) y 23 de marzo de 2007 (sala 1 ${ }^{\text {a }}$ ), ponente Ilmo. Sr. J. Corbal, f.j.5º (LA LEY 9687/2007).

${ }^{246}$ Así lo afirma el AAP de Cáceres (sección $1^{\text {a }}$ ) de 4 de diciembre de 2012, ponente Ilmo. Sr. L.A. Sanz, f.j.5 (AC 2012\2280). 
Partiendo de lo anterior, en la doctrina judicial se identifica como daño y perjuicio claramente indemnizable como consecuencia de la práctica de las diligencias preliminares el lucro cesante y dentro del mismo el tiempo que de su jornada laboral hubiera de emplear para la práctica de las diligencias preliminares el sujeto pasivo, siempre y cuando este resultase efectivamente justificado ${ }^{247}$, o la merma de rentabilidad de la industria como consecuencia de la dedicación del personal técnico y directivo a la comisión judicial, presente en la práctica de las diligencias de comprobación de hechos, y efectiva disposición de medios técnicos al objeto de satisfacer los requerimientos de aquella en la labor de inspección y verificación ${ }^{248}$. También el tiempo que hubo de invertirse para la recopilación de información de necesaria exhibición a la comisión judicial $^{249}$.

\footnotetext{
${ }^{247}$ AAP de Cádiz (sección $8^{\text {a }}$ ) de 10 de mayo de 2002, ponente Ilmo. Sr. L.A. De Diego, f.j. $2^{\circ}$ (LA LEY 90365/2002) y el AAP de Barcelona (sección 13ª) de 2 de diciembre de 2004, ponente Ilma. Sra. I. Carriedo, f.j. $2^{\circ}$ (LA LEY 255515/2004), en un supuesto del ordinal $1^{\circ}$ del art. 256.1 LEC que requirió la comparecencia personal del sujeto pasivo para la exhibición de los títulos relativos a su capacidad, representación o legitimación.

${ }^{248}$ En dicho sentido, el AAP de Barcelona (sección $15^{\text {a }}$ ) de 26 de julio de 2002, ponente Ilmo. Sr. L. Garrido, f.j. $7^{\circ}$ (LA LEY 140501/2002) conforme al cual la práctica de las diligencias de comprobación en un supuesto como el expuesto gravarían a la empresa con la improductividad temporal de los costes fijos que hace razonable aceptar la existencia de un perjuicio, aún relativizado al no afectar simultáneamente a la totalidad de los medios humanos y materiales o técnicos, sino tan sólo a aquellos decisivos en cada momento para atender la finalidad de la diligencia.

${ }^{249} \mathrm{Al}$ respecto, el AAP de Barcelona (sección 15 ${ }^{\text {a }}$ ) de 21 de marzo de 2005, ponente Ilmo. Sr. I. Sancho, f.j. $2^{\circ}$ (LA LEY 65421/2005) expone que "[...] es un hecho notorio que esto cuesta algo de tiempo, que en la medida que se dedica a esta actividad deja de dedicarse a otra más directamente productiva u ordinaria de la empresa, por lo que resulta lógico que la afectada por las diligencias quiera resarcirse de estos gastos".
} 


\section{CAPÍTULO II. LAS DISTINTAS DILIGENCIAS PRELIMINARES}

Definidos los contornos fundamentales de las diligencias preliminares en general, nos ocuparemos en el presente capítulo de realizar una aproximación a cada una de las diligencias contenidas en el catálogo del art. 256.1 LEC.

\section{Declaración o exhibición documental sobre hechos relativos a la} capacidad, representación o legitimación de la persona frente a quien se dirigirá la demanda (art. 256.1.1 LEC)

"Por petición de que la persona a quien se dirigiría la demanda declare, bajo juramento o promesa de decir verdad, sobre algún hecho relativo a su capacidad, representación o legitimación, cuyo conocimiento sea necesario para el pleito, o exhiba los documentos en los que conste dicha capacidad, representación o legitimación".

\subsection{Objeto}

En el proceso, corresponde a cada una de las partes observar el cumplimiento de los presupuestos procesales necesarios exponiéndose, en caso de que no lo hagan, al dictado de una resolución desfavorable a su pretensión. Entre dichos presupuestos procesales se encuentran aquellos que refiere la diligencia contemplada en el art. 256.1.1 LEC: la capacidad, la representación y la legitimación. En consecuencia, puede determinarse que la diligencia en cuestión viene referida a la capacidad ${ }^{250}$ para ser parte contemplada en el art. 6 LEC y reconocida a las personas físicas, el concebido no nacido para todos los efectos que le sean favorables, las personas jurídicas, las masas patrimoniales o patrimonios separados que carezcan transitoriamente de titular o cuyo titular haya sido privado de sus facultades de disposición y administración, las entidades sin personalidad jurídica a las que la Ley reconozca capacidad para ser parte, el

\footnotetext{
${ }^{250}$ Entendida por Gimeno Sendra, V., Derecho Procesal Civil..., ob. cit.,p. 109, como "la aptitud requerida por la Ley para poder ser demandantes o demandados, ostentar la titularidad de los derechos, obligaciones, posibilidades procesales y cargas procesales y asumir las responsabilidades y efectos que del proceso se deriven".
} 
ministerio fiscal, respecto de los procesos en que, conforme a la ley, haya de intervenir como parte, los grupos de consumidores y usuarios afectados por un hecho dañosos, cuyos individuos estén determinados o sean fácilmente determinables y las entidades habilitadas conforme a la normativa comunitaria europea para el ejercicio de la acción de cesación en defensa de los intereses colectivos y de los intereses difusos de los consumidores y usuarios. También, a la legitimación ${ }^{251}$ a que alude el art. 10 LEC cuando señala que serán considerados partes legítimas quienes comparezcan y actúen en juicio como titulares de la relación jurídica u objeto litigioso, exceptuándose los casos en que por ley se atribuya legitimación a persona distinta del $\operatorname{titular}^{252}$. Y a la representación a que se refiere el art. 7.1 LEC, conforme al cual sólo podrán comparecer en juicio los que estén en el pleno ejercicio de sus derechos civiles, siendo necesario, en caso contrario, la averiguación de la persona que ostenta la representación y a quien habrá de demandarse junto con el representado, tal y como se desprende de los aptdos. $2^{\circ}$ a $8^{\circ}$ de dicho art. 7 LEC.

Con esta diligencia, el peticionario se adelanta a la posibilidad de que el sujeto pasivo pueda oponer en el juicio, en virtud de lo previsto en los arts. 405.3 y 443.2 LEC, su falta de capacidad, representación o legitimación para soportar la acción que pretendiéndose preparar se dirija ulteriormente frente al mismo y que, en otro caso, podría dar lugar a la conclusión del juicio con una resolución desestimatoria de la demanda pero sin pronunciamiento alguno sobre el verdadero fondo del asunto.

\footnotetext{
${ }^{251}$ Entendida no como capacidad procesal o "legitimatio ad proccesum" sino como "legitimatio ad causam" o legitimación en un proceso determinado, en el sentido recogido en la STS de 18 de septiembre de 2006 (sala $1^{a}$ ), ponente Ilmo. Sr. A. Salas, f.j.4 (LA LEY 177099/2009) o el AAP de Barcelona (sección $16^{\mathrm{a}}$ ) de 17 de octubre de 2008, ponente Ilmo. Sr. J.L. Valdivieso, f.j.2 ${ }^{\circ}$ (JUR 2009151421), que señala: En ocasiones se habla de legitimación activa como equivalente al derecho a obtener una prestación y de legitimación pasiva como sinónimo del deber de realizarla. Pero lo de tener derecho a una prestación o deber de prestarla no puede confundirse con la legitimación a efectos del proceso. Lo primero es cuestión de fondo y la legitimación hace referencia a una especial relación con una cosa o con una persona, que confiere a quien tiene esa relación determinados poderes o deberes jurídicos, pero no a la existencia misma del poder o del deber".

${ }^{252}$ Debe tenerse en cuenta, como señala Garberí Llobregat, J., Las diligencias preliminares..., ob. cit., p. 38 , que mediante la diligencia preliminar no podrá obtenerse la certeza plena y absoluta de que el sujeto frente al que se dirige aquella es el legitimado pasivamente habida cuenta que esta es una cuestión material que pertenece al fondo del conflicto y su determinación definitiva no puede sino efectuarse en el curso de proceso posterior.
} 
En la doctrina, se señalan como supuestos típicos de la misma el de quien necesita identificar al dueño de un animal o cosa como causante de daños, el del padre de un menor, el del empleador responsable de los actos realizados por sus trabajadores en el ámbito de la empresa, o el de identificación a los condueños u otras personas que integren un litisconsorcio pasivo necesario ${ }^{253}$.

\subsection{Justificación de la diligencia}

Debe tenerse en cuenta que la carga de la regla procesal recae con mayor peso en el demandante que entabla el procedimiento y puede ver rechazada su pretensión de no observarse, de forma tal que el art. 256.1.1 LEC habilita el instrumento idóneo para que el demandante, y solicitante de la diligencia preliminar, pueda cumplir con la misma facilitando, mediante el recurso a la diligencia preliminar en cuestión, la obtención o conocimiento de hechos relativos a dicha capacidad, representación o legitimación de quien pudiera ser demandado y cuyo conocimiento sea necesario para el pleito ${ }^{254}$. En suma, el ámbito de la diligencia se reduce a aquellos supuestos en los que el futuro demandante, o bien no sabe a quién demandar porque desconoce quién puede ostentar la legitimación pasiva ${ }^{255}$, o bien sabe a quién demandar pero desconoce si dicha persona es

\footnotetext{
${ }^{253}$ Garciandía González, P.M., La regulación de..., ob. cit., p. 779 y Álvarez Alarcón, A., Las diligencias preliminares..., ob. cit., p. 39, sin que podamos compartir la afirmación hecha por este último de ser la de mayor utilidad, dentro de las posibles diligencias al amparo del art. 256.1.1 LEC, la relativa a la identificación de la compañía aseguradora, dado que el art. 256.1.5 LEC regula una específica diligencia preliminar para la exhibición del contrato de seguro por quien lo tenga en su poder y, por tanto también, para la identificación de la compañía aseguradora.

${ }^{254}$ Según Álvarez Alarcón, A., Las diligencias preliminares..., ob. cit., pp. 38-39, “debe interpretarse no en el sentido de que sea necesario para vencer en él, para fundamentar debidamente la pretensión, sino para poder penetrar en el proceso respetando debidamente los presupuestos de capacidad, representación o legitimación, cuyo defecto podría, en último extremo, producir una sentencia absolutoria en la instancia", lo que habremos de considerar en la realidad procesal actual en que dichas sentencias absolutorias en la instancia han desaparecido del ordenamiento jurídico procesal civil articulando este otras fórmulas para solventar los problemas de capacidad, representación y legitimación.

${ }^{255}$ Ejemplo de dicha circunstancia lo constituye el AAP de Barcelona (sección 13a $)$ de 2 de diciembre de 2004, ponente Ilma. Sra. I. Carriedo, f.j. $1^{\circ}$ (ROJ AAP B 5858/2004) que en apelación admite la procedencia de una solicitud de diligencias preliminares de citación de aquellos que ocupaban la finca cuya posesión iba a ser reclamada judicialmente por el peticionario. El JPI consideró que la diligencia solicitada no encajaba en ninguno de los supuestos del art. 256.1 LEC correspondiendo lo pedido a cuestiones de prueba sobre el fondo de lo que se pretendía demandar. Sin embargo, la AP entendió que las diligencias interesadas encajaban en las previsiones del art. 256.1.1 LEC y con el fin de determinar la legitimación con la que se pretendía demandar a los ocupantes de la finca en el futuro proceso así como la causa de dicha legitimación. También, el AAP de Las Islas Baleares (sección $3^{\text {a }}$ ) de 25 de noviembre de 2002, ponente Ilma. Sra. C.M ${ }^{a}$. Moragues, f.j. $2^{\circ}$ (LA LEY 197292/2002), en el que se admitió la
} 
capaz y, de no serlo, quien es su legítimo representante ${ }^{256}$. Sin embargo, no compartimos la reducción del objeto de la misma a la determinación de la legitimación pasiva en el proceso principal ${ }^{257}$ habida cuenta que, como el propio tenor literal de la norma recoge, no sólo la legitimación es objeto de esta diligencia sino también la capacidad o representación, como instituciones jurídicas distintas de la legitimación y aún cuando tales circunstancias vengan referidas al titular pasivo de una relación material. Y debe ponerse de manifiesto la posibilidad advertida por algún autor de que dicha diligencia sea utilizada para obtener una confesión anticipada del futuro demandado señalando que por ello el objeto de la medida debe quedar circunscrita a la averiguación de los hechos condicionantes de la capacidad, representación y legitimación del juicio que se intenta promover por el solicitante quedando fuera de su ámbito cualquier otra indagación ${ }^{258}$.

procedencia de la solicitud formulada por la SGAE, que precisaba conocer la identidad de los titulares de un determinado establecimiento a los efectos de formular demanda contra ellos para que se les condenara a cesar en los actos de comunicación pública llevados a cabo en dicho local sin autorización, y a indemnizar a la sociedad solicitante a tenor de lodispuesto en la Ley de Propiedad Intelectual. No obstante, quedan al margen el art. 256.1.1 LEC supuestos como el contemplado en el AAP de Madrid (sección $18^{\mathrm{a}}$ ) de 12 de febrero de 2013, ponente Ilmo. Sr. L. Pérez, f.j.1º (ROJ AAP M 1853/2013) que entendió improcedente la diligencia preliminar solicitada al amparo del art. 256.1 LEC a través de la cual se pretendía de los requeridos la declaración sobre la intervención que habían tenido en el proceso constructivo otras personas distintas, por lo tanto se excede en mucho del real contenido y alcance del art. 256.1 de la LEC y en consecuencia es correcto el rechazo de la citada solicitud, por otra parte en cuanto a la exhibición de documentos, la misma conforme a lo establecido.

${ }^{256}$ Garberí Llobregat, J., Las diligencias preliminares..., ob. cit., p. 37.

${ }^{257}$ Cfr. Álvarez Alarcón, A., Las diligencias preliminares..., ob. cit., p. 39.

${ }^{258}$ Damián Moreno J., Comentarios a la..., ob. cit., p. 1684. En la doctrina judicial, así lo entiende el AAP de Valladolid (sección $1^{\text {a }}$ ) de 19 de septiembre de 2003, ponente Ilmo. Sr. J.R. Alonso-Mañero, f.j.3 (LA LEY 144165/2003) señalando que: “[...] es el propio juzgador en el trámite de práctica de las referidas diligencias quien deberá cuidar y prevenir que el objeto de dicha diligencia preliminar no se desvía de su específica finalidad evitando en su caso la contestación a preguntas que excediesen de la finalidad propuesta, pero en modo alguno el riesgo indicado puede obstar a la práctica de una diligencia que se reputa inicialmente necesaria". También el AAP de Tarragona (sección $1^{\text {a }}$ ) de 6 de noviembre de 2006, ponente Ilmo. Sr. J.L. Portugal, f.j.3 $3^{\circ}$ (ROJ AAP T 862/2006). En este contexto, el AAP de Madrid (sección $18^{\mathrm{a}}$ ) de 12 de febrero de 2013, ponente Ilmo. Sr. L. Pérez, f.j.1 ${ }^{\circ}$ (ROJ AAP M 1853/2013) deniega la diligencia preliminar dado que lo pretendido por la recurrente no era "[...] simplemente la declaración de los intervinientes en el proceso constructivo, sobre su propia legitimación o capacidad para ser parte en el procedimiento, sino por el contrario lo que se pretende es la declaración bajo juramento o promesa de la intervención que han tenido en el proceso constructivo otras personas distintas de aquellos que van a declarar". Al respecto, debemos llamar la atención sobre el supuesto contemplado en el AAP de Barcelona (sección $17^{\mathrm{a}}$ ) de 1 de junio de 2002, ponente Ilma. Sra. A. Mateo, f.j.1 ${ }^{\circ}$ (LA LEY 104716/2002) en el que se entró a resolver sobre la denegación de una diligencia preliminar solicitada por una CCPP y dirigida a identificar a las personas que, con carácter de habitualidad, residían en unos determinados inmuebles, a realizar por los servicios del SAC asistidos por las fuerzas del orden, si ello fuera necesario. Conforme se desprende del supuesto en cuestión la diligencia preliminar no se dirigía frente a un concreto requerido dado que su finalidad era la de conocer los nombres de los futuros demandados, es decir, de las personas que ocupaban determinados locales del edificio con vistas a una futura demanda. La AP ratificó la denegación de la diligencia preliminar solicitada al amparo del art. 
La legitimación activa para la promoción de dicha diligencia corresponderá a todo aquel que pretenda constituirse en demandante del proceso que a través de las diligencias preliminares se pretenda $\operatorname{preparar}^{259}$.

Y de forma correlativa a la misma, la legitimación pasiva corresponderá, única y exclusivamente, a aquella persona que se pretenda demandar en tanto en cuanto la diligencia se ordena a la obtención de datos que afectan de forma directa a la persona que ostentará la posición de parte demandada en el ulterior juicio ${ }^{260}$.

Ahora bien, esta afirmación no está exenta de debate en la doctrina, que se plantea si cabe instar la declaración o exhibición de los documentos relativos a la capacidad, representación o legitimación por personas distintas del futuro demandado. $\mathrm{Al}$ respecto señala la doctrina científica ${ }^{261}$ que, pese a que durante los últimos años de vigencia de la ALEC se puede advertir en la denominada jurisprudencia menor una línea favorable a esta posibilidad ${ }^{262}$, la tendencia mayoritaria de nuestros tribunales se decanta por la taxatividad de los supuestos legales señalando que la solicitud de declaración por terceros excede de las previsiones legales sobre el contenido y alcance de la diligencia preliminar que autoriza a indagar sobre algún hecho relativo a la personalidad propia del declarante ${ }^{263}$, pero no sobre la de posibles terceros, sobre todo

256.1.1 LEC, por no estar identificados los sujetos pasivos de la misma, afirmando que siquiera la interpretación más laxa que pudiera hacerse de las diligencias preliminares autoriza la labor de investigación policial que se pretendía, decisión esta que ha sido criticada en la doctrina científica por Banacloche Palao, J., Las diligencias preliminares..., ob. cit., p. 136, que la caracteriza como enextremo rigurosa y limitativa, al considerar que la identificación de los requeridos en la solicitud, relacionándoles con un objeto determinado, el inmueble que ocupaban, aún no plena, resultaba suficiente a los efectos del proceso, de forma tal que una vez conocidos los nombres por la actuación judicial procedería la indagación sobre su legitimación pasiva en el proceso posterior.

${ }^{259}$ Así lo afirma Garberí Llobregat, J., Las diligencias preliminares..., ob. cit., p. 36.

${ }^{260}$ Garberí Llobregat, J., Las diligencias preliminares..., ob. cit., p. 36.

${ }^{261}$ Garciandía González, P.M., La regulación de..., ob. cit., p. 780.

${ }^{262}$ Destacan los AAP de Navarra (sección $1^{\text {a }}$ ) de 23 de octubre de 1998, ponente Ilmo. Sr. R. Ruíz de la Cuesta, f.j.2 (AC 1998\2003) y 20 de mayo de 1999, ponente Ilmo. Sr. R. Ruíz de la Cuesta, f.j.2º (AC 19991840) que, en supuestos de responsabilidad extracontractual, permitieron el requerimiento de datos a órganos administrativos, con el fin de determinar la identidad de las personas a las que poder dirigir la demanda de reclamación de daños y perjuicios). También, el AAP de Burgos (sección $3^{\text {a }}$ ) de 1 de octubre de 2002, ponente Ilma. Sra. M $^{\text {a }}$.E. Villimar, f.j.3 ${ }^{\circ}$ (ROJ AAP BU 386/2002) que tácitamente vino a aceptar la posibilidad de requerir al representante de una entidad para la identificación por este de los nombres y circunstancias personales de los socios de aquella.

${ }^{263}$ Aún cuando no en todos los supuestos contemplados en la práctica forense se entendiera con dicha taxatividad dado que, antes de la inclusión en el catálogo del art. 256.1 LEC de la diligencia contenida en 
porque la eventual identificación de la persona o personas obtenida por este medio carecería por si misma de las más elementales garantías procesales para confeccionar válidamente la relación jurídica procesal ${ }^{264}$. La misma conclusión debe alcanzarse cuando la diligencia no consista en la declaración sino en la exhibición de documentos en que conste dicha capacidad, representación o legitimación.

\subsection{Aspectos prácticos de la diligencia}

Llegados a este punto debemos plantearnos los escenarios que pueden plantearse tras la admisión de la diligencia y citación a la práctica de la misma y, más concretamente, por la trascendencia que ello reviste, de la diligencia en su modalidad de declaración. Como se expone en la doctrina, la diligencia preliminar puede concluir de cuatro maneras: con la admisión del sujeto pasivo del hecho relativo a su capacidad, representación o legitimación; con la negación de tales circunstancias; con la incomparecencia del sujeto pasivo; o con la comparecencia sin contestar u ofreciendo respuestas evasivas.

Dejando al margen los efectos de este último supuesto en el proceso posterior, que serán estudiados en el epígrafe dedicado a la negativa a la práctica de las diligencias

el actual art. 5 bis LEC, al amparo del ordinal $1^{\circ}$ fue admitida la diligencia de exhibición de documentación médica que pudiera tener relevancia en orden a fundar la existencia de la capacidad del otorgante del testamento que se pretende impugnar, en tanto que obligación de las personas físicas y jurídicas a exhibir la historia clínica del testador a efectos de conocer su capacidad al dictar testamento, supuesto este en el que el sujeto pasivo resultaba ser una persona ajena al futuro demandado al que, además, también le resultaba ajena la indagación sobre la capacidad objeto de la misma y referida al otorgante de un testamento fallecido. Así, el AAP de Girona (sección $2^{\mathrm{a}}$ ) de 5 de junio de 2003, ponente Ilmo. Sr. J.M. Fernández, f.j. $3^{\circ}$ (LA LEY 100175/2003). Dicha postura parece ser reconducida en el AAP de Valladolid (sección $1^{\text {a }}$ ) de 19 de septiembre de 2003, ponente Ilmo. Sr. J.R. Alonso-Mañero, f.j.3º (LA LEY 144165/2003), que entendió que concurrían los presupuestos básicos precisos para estimar justificada la diligencia promovida al amparo del art. 256.1.1 LEC relativa al juramento o promesa de decir verdad o a la aportación de documentos para la preparación de un procedimiento declarativo relativo a la impugnación de donaciones realizadas por el hermano fallecido de los requeridos, considerando que la misma se encaminaba a determinar o concretar si tales hermanos, con quienes pretendían entenderse estas diligencias preliminares, ostentarían la precisa legitimación para soportar la condición de demandados en el procedimiento declarativo correspondiente.

${ }^{264}$ AAP de Madrid (sección 12a) de 31 de enero de 2000, ponente Ilmo. Sr. J.V. Zapater, f.j. $1^{\text {o }}$ (JUR 20001207446) precisando que: “[...] la ley autoriza a indagar sobre algún hecho relativo a la personalidad propia del declarante, pero no sobre la de posibles terceros, sobre todo porque la eventual identificación de persona o personas obtenida por este medio carecería por sí misma de las más elementales garantías procesales para confeccionar válidamente la relación jurídica procesal que inquieta a la apelante”. 
preliminares, debemos detenernos en el efecto de las declaraciones positivas o negativas que en relación a la legitimación, capacidad o representación el requerido efectúe en el procedimiento de diligencias preliminares dirigido a preparar el ulterior proceso. En relación a ellas se sostiene en la doctrina que para el caso de admitir el sujeto pasivo su legitimación, capacidad o representación para el proceso posterior, no podrá luego el mismo como demandado, negar el hecho admitido; y, para el caso de negación, que no producirá efecto vinculante para el proceso posterior, en el que se resolverá lo pertinente sobre dichos extremos ${ }^{265}$. Por tanto, si bien la diligencia de declaración sobre los hechos relativos a la legitimación, capacidad o representación tiene por finalidad procurar que el solicitante de diligencias preliminares adquiera el conocimiento preciso de circunstancias tan importantes para el correcto planteamiento del asunto como las apuntadas, los efectos de tal declaración en el proceso posterior no pueden ir orientados a dar virtualidad jurídica a tales circunstancias cuando las mismas no existan o lo hagan en circunstancias distintas a las manifestadas por el requerido en la práctica de las diligencias preliminares. Pues, a nuestro juicio, cuando la realidad manifestada resulte divergente a la que se constate en el proceso ulterior, la consecuencia de dicha divergencia no podrá ser otra que la inocuicidad procesal de los perjuicios que para el solicitante, posteriormente demandante pudiera ocasionar. Tratándose, como es el caso, de cuestiones de orden publico apreciables de oficio por el tribunal ${ }^{266}$, el efecto de una manifestada, y distinta a la postre, legitimación, capacidad o representación, no podrá tener más efecto que el de evitar al demandante solicitante de diligencias preliminares una condena en costas por la demanda que resulte desestimada en atención a la realidad de dichas circunstancias e incluso el nacimiento de la obligación a favor del demandante de la indemnización que corresponda por los daños y perjuicios que con la actuación intencionadamente divergente del requerido a la práctica de diligencias preliminares se le hayan podido causar.

\footnotetext{
${ }^{265}$ Callejo Carrión, S., Las diligencias preliminares..., ob. cit., p. 12.

${ }^{266}$ Es doctrina del TS la de que "la existencia o no de legitimación "ad causam" es cuestión que afecta al orden público procesal, examinable de oficio y aún cuando las partes no la hayan planteado. En dicho sentido, SSTS de 3 de julio de $2000\left(\right.$ sala $1^{\text {a }}$ ), ponente Ilmo. Sr. D. P. González, f.j. $2^{\circ}$ (LA LEY 10014/2000), de 12 de diciembre de 2006 (sala 1ª), ponente Ilmo. Sr. P. González, f.j. $4^{\circ}$ (LA LEY 150010/2006) y de 13 de diciembre de 2006 (sala 1 1), ponente Ilmo. Sr. P. González, f.j.5 $5^{\circ}$ (LA LEY 150016/2006), entre otras. En cuanto a la posibilidad de apreciar de oficio la capacidad o conducción procesal, Gimeno Sendra, V., Derecho Procesal Civil..., ob. cit., p. 132.
} 
En cuanto a la cuestión relativa a la forma de realización de la diligencia preliminar, debe ponerse de manifiesto que mientras que la ALEC contenía una remisión expresa a la forma prevenida para la prueba de confesión en juicio (art. 498), la LEC guarda silencio. Tal silencio ha sido interpretado en la doctrina con la voluntad del legislador de aplicación al supuesto de la diligencia preliminar en cuestión de los preceptos relativos al interrogatorio de las partes (arts. 301 y ss. LEC) ${ }^{267}$. Y no faltan autores que han matizado esta interpretación en el sentido de entender que tal remisión lo será únicamente en cuanto a la manera de formular las preguntas y practicar el interrogatorio dado que la falta de previsión expresa de la LEC al respecto también ha permitido entender que las preguntas objeto del mismo deben contenerse en un pliego cuya copia, con la suficiente antelación, debe ser entregada al requerido para que pueda formular oposición ${ }^{268}$.

Nuestra posición al respecto pasa por considerar las posibilidades de oposición que, como ha sido apuntado, no existirán, o al menos no lo harán con rigor jurídico, cuando previamente a la práctica de la diligencia preliminar el sujeto requerido, desconozca el contenido y extensión de las preguntas. Por ello entendemos razonable que en la solicitud de diligencias preliminares se hagan constar los términos de la declaración a practicar con indicación de las preguntas a realizar. Ello, sin perjuicio de que en el momento de la práctica el solicitante, con la venia del juzgador, amplíe su contenido, que el requerido podrá o no responder, al igual que el resto de preguntas inicialmente conocidas $\mathrm{y}$, sin perjuicio también, de las facultades del juzgador, a la vista del resultado de la declaración, de tener o no por realizadas las diligencias preliminares instadas.

En todo caso, entendemos que del acto de la declaración deberá dejarse constancia, bien por escrito, en el acta que al efecto extienda el LAJ, bien en soporte audiovisual que permita la reproducción del acto en un momento posterior.

\footnotetext{
${ }^{267}$ Callejo Carrión, S., Las diligencias preliminares..., ob. cit., p. 11 y Garciandía González, P.M., La regulación de..., ob. cit., p. 779.

${ }^{268}$ Garnica Martín, J.F., De las diligencias..., ob. cit., p. 1150.
} 
Por último, no puede concluirse el examen de la presente diligencia sin recordar que la misma también puede ser instada, incluso conjuntamente con la de declaración, en su modalidad de exhibición de los documentos en los que conste la capacidad, representación o legitimación. En ella tiene encaje la diligencia de exhibición de un contrato de arrendamiento en el que conste la capacidad, representación o legitimación de la persona requerida cuyo conocimiento sea necesario para el pleito cuando el solicitante manifieste que tiene intención de ejercitar las oportunas acciones judiciales de desahucio, bien por precario, bien por expiración del término contractual o por falta de pago de la renta ${ }^{269}$.

Más dudosa a nuestro juicio es la posibilidad de utilizar la diligencia en cuestión para la identificación de los desconocidos ocupantes de una vivienda o la exhibición por estos del título que ampare su ocupación. Civilmente, la vivienda vacía se protege, a través de los procesos sumarios de protección del derecho real inscrito, interdictales (art. 250.1.4 LEC en relación con el 446 CC) o del desahucio por precario, con fuerza de cosa juzgada, y por ello con plenitud de conocimiento y medios probatorios, relativo al ámbito posesorio de cuya recuperación se trata, con fundamento en el derecho a la posesión real del titular, con las consecuentes facultades de exclusión y de recuperación

\footnotetext{
${ }^{269}$ Así lo pone de manifiesto el AAP de Burgos (sección $3^{\text {a }}$ ) de 19 de junio de 2009, ponente Ilmo.Sr. I.J. Barcala, f.j.2 $2^{\circ}$ (LA LEY 105789/2009). En el mismo sentido, el AAP de Cádiz (sección $8^{\mathrm{a}}$ ) de 10 de mayo de 2002, ponente Ilmo.Sr. L.A. De Diego, f.j. $1^{\circ}$ (LA LEY 90365/2002) en un supuesto en el que, antes de presentar la demanda, y al amparo de lo previsto en el art. 256.1.1 LEC se interesó, como diligencia preliminar, la citación del ocupante de la finca respecto de la que la solicitante afirmaba su propiedad. La comparecencia tenía por objeto el interrogatorio del ocupante de la finca y la exhibición por el mismo del título acreditativo de la propiedad del inmueble. Denegada la diligencia preliminar en primera instancia, el tribunal de apelación determinó: "[...] Las diligencias interesadas: interrogatorio de la persona contra la que se dirigiría la demanda y exhibición por ésta del documento en que conste la propiedad de la finca, encajan plenamente en las previsiones del apartado $1 .^{\circ}$ del artículo 256 de la LEC. Bien es verdad que el interrogatorio del Sr. B. V. habrá de ceñirse, en su momento, a hechos relativos a su capacidad, representación o legitimación. Y, precisamente con el fin de determinar cuál sea la legitimación con la que se le ha de llamar como demandado al futuro proceso, pretende la actora que el mencionado Sr. B. V. aclare el título por el que ocupa la finca. Como bien dice la apelante, a efectos de determinar certeramente el o los sujetos pasivos de su futura demanda y la causa que les legitima, no es lo mismo que dicho señor posea a título de dueño por compraventa (con lo que podríamos estar ante un supuesto de doble venta) que la posesión la tenga en precario o en arrendamiento. La misma razón de ser tiene la exhibición por su parte del título acreditativo de propiedad de la finca discutida, en caso de que lo posea, naturalmente."

En consecuencia, entendemos que las diligencias preliminares solicitadas por la apelante se encuentran enmarcadas en el apartado $1 .^{\circ}$ del artículo 256.1 de la LEC, con independencia de que, en el momento del interrogatorio solicitado, la juez de instancia limite las preguntas a los extremos que tengan relación con la legitimación pasiva del interrogado, con el título por el que ocupa la finca".
} 
posesoria, derivados del CC y de la LEC $^{270}$. Por tanto, en estos supuestos, el problema que se plantea no es el de la necesidad del conocimiento de la capacidad, representación o legitimación de las personas frente a las que dirigir la demanda de los procesos señalados sino el del conocimiento de la identidad de los ocupantes, finalidad esta que no subyace en la diligencia preliminar y que, por otro lado, no constituye obstáculo alguno para interponer la demanda del ulterior proceso $^{271}$.

\section{Exhibición de cosas (art. 256.1.2 LEC)}

"Mediante solicitud de que la persona a la que se pretende demandar exhiba la cosa que tenga en su poder y a la que se haya de referir el juicio".

\footnotetext{
${ }^{270}$ SAP de Vizcaya (sección 5 ${ }^{\text {a }}$ ) de 10 de marzo de 2016, ponente Ilma. Sra. L.A. Cuenca, f.j.4 ${ }^{\circ}$ (LA LEY 52499/2016).

${ }^{271}$ En dicho sentido es clarificadora la SAP de Barcelona (sección 13 $3^{\mathrm{a}}$ ) de 2 de noviembre de 2016, ponente Ilma. Sra. I. Carriedo, f.j. $2^{\circ}$ (LA LEY 216704/2016), cuando apunta: “[...] En este sentido, ha venido siendo doctrina constante y reiterada (Sentencias del Tribunal Supremo de 16 de diciembre de 1971, 15 de noviembre de 1974, y 1 de marzo de 1991; RJA 5388/1971, 4237/1974, y 1709/1991) que la identidad del demandado se puede buscar por cualquier circunstancia que permita su determinación, bastando la indicación de cualquier circunstancia que permita su identificación, o la concreción e individualización que permita conocer con exactitud aquél contra quien se entabla la acción.

En concreto, en relación con el precario, ha venido siendo doctrina reiterada (Autos de esta misma Sección Decimotercera de la Audiencia Provincial de Barcelona de 17 de octubre de 2003, 17 de octubre de 2004, y SS de 19 de julio de 2006, 13 de enero de 2009 y 13 de diciembre de 2011) que nada obsta a que se demande a personas desconocidas cuando se destaque su relación con el objeto litigioso y se posibilite su comparecencia y defensa, como sucede en este caso en el que se designa el domicilio en que pueden ser citados.

En consecuencia, para que puedan entenderse cumplidos los requisitos de los artículos 399.1, y 437.1 de la Ley $1 / 2000$, de 7 de enero (LA LEY 58/2000) de Enjuiciamiento Civil, basta que el actor consigne en la demanda los datos y circunstancias de que tenga conocimiento y que puedan permitir la identificación del demandado, bastando en consecuencia en el desahucio por precario la identificación de los ignorados ocupantes demandados por su relación con el inmueble litigioso.

En este caso, en la demanda son llamados al juicio los ignorados ocupantes del inmueble litigioso por desconocerse las personas que ocupaban el mismo, si bien se les identificó por su relación con dicha vivienda, pues de hecho se personó como ocupante Dña. Zulima.

Manifiesta el recurrente no haber tenido conocimiento del proceso dado que ha comenzado a ocupar la vivienda litigiosa desde hace aproximadamente 2 meses. No obstante, reconociendo el recurrente que ocupa la finca, ninguna prueba aporta en el recurso de la ocupación tardía que alega.

Por tanto la relación jurídica procesal al demandar a los ignorados ocupantes, identificándoles por su relación con la vivienda, estuvo bien constituida y la sentencia no infringe precepto procesal alguno al condenar a cualesquiera otros posibles ocupantes del inmueble, por lo que en ningún caso puede alegarse que la sentencia dictada no puede tener efectos sobre la ocupación del apelante pues tampoco se le ha causado ninguna indefensión habida cuenta que por afectarle la sentencia se le ha permitido recurrirla y de hecho el apelante no solicita la nulidad de actuaciones, por lo que no cabe acordarla. Pero es que además tampoco indica título alguno que justifique su ocupación actual ni el pago de renta alguna por lo que el recurso ha de ser desestimado".
} 


\subsection{Introducción}

Mediante solicitud de que la persona a la que se pretende demandar exhiba la cosa que tenga en su poder y a la que se haya de referir el juicio regula la LEC, en su art. 256.1.2, la conocida diligencia preliminar de exhibición de cosa, heredera de la actio ad exhibendum romana.

En relación a la misma, prescindiendo de los antecedentes más remotos y centrándonos en el s. XIX, que es cuando comienza el proceso codificador ${ }^{272}$, cabe comenzar recordando que ya el art. 222 de la Ley de Enjuiciamiento Civil de 1855 dispuso la posibilidad de preparar el juicio ordinario pidiendo la exhibición de la cosa mueble que en su caso hubiera de ser objeto de la acción real que tratara de entablar.

Más tarde, su precedente más inmediato, el art. 497.2 ALEC, sin ceñir el ámbito de las diligencias preliminares a la preparación del juicio ordinario, previno la posibilidad de pedir la exhibición de la cosa mueble que, en su caso, hubiera de ser objeto de la acción real o mixta que se tratara de entablar contra el que la tuviera en su poder.

Y, como se ha anunciado, hoy en día, el art. 256.1.2 LEC prevé la misma posibilidad mediante solicitud de que la persona a la que se pretenda demandar exhiba la cosa que tenga en su poder y a la que se haya de referir el juicio.

La comparativa de las redacciones dadas a la diligencia preliminar que nos ocupa en los textos legales referidos nos permite advertir las diferencias regulatorias de la institución en su evolución, algunas de las cuales, como a la postre se verá, han sido objeto de un importante debate doctrinal que se mantiene abierto en la actualidad.

\footnotetext{
${ }^{272}$ Cfr. Díez-Picazo, L. y Gullón, A., Sistema de Derecho..., ob. cit., p. 48.
} 
En el art. 222 LEC 1885, la diligencia preliminar giraba en torno a dos dimensiones. La exhibición de cosa mueble. Y la acción real a la que debía de servir la exhibición de la cosa para la preparación del ulterior juicio.

La ALEC dio un paso en la evolución de la diligencia preliminar en cuestión ampliando la naturaleza de la acción a la que podía servir la exhibición de la cosa mueble. Así, dicha diligencia estaba llamada a preparar no sólo la acción real sino también la mixta. Y, además, precisaba el art. 497.2 ALEC, la exhibición de la cosa mueble objeto de la acción real o mixta solo podía pretenderse de aquel que tuviera la cosa en su poder y al que se pretendiera demandar, precisión esta última respecto de la que nada decía la LEC 1855.

Por tanto, la ALEC amplió el ámbito de la acción que se podía ejercitar en el juicio que se pretendía preparar y, a diferencia de la LEC 1855, acotó la legitimación pasiva de la diligencia delimitando el ámbito de los posibles sujetos pasivos pues, conforme a su tenor literal, la exhibición sólo podía pretenderse de aquel que tuviera la cosa mueble en su poder y, única y exclusivamente, frente al que se pretendiera entablar la acción real o mixta.

La LEC renueva el régimen anterior. Primero, eliminando el carácter mueble de la cosa que puede ser exhibida que, en todo caso, debe ser aquella a la que se vaya a referir el futuro juicio. Y, segundo, suprimiendo toda referencia a la naturaleza de la acción que se pretende entablar. Además, mantiene la determinación de la legitimación pasiva que introdujo el art. 497.2 ALEC precisando que la solicitud debe ir dirigida a aquel que tenga la cosa en su poder y al que se pretenda demandar.

\section{2 Ámbito de aplicación}

Conforme a lo expuesto, y a priori, en cuanto al objeto de la diligencia, puede afirmarse que mediante la preliminar contemplada en el art. 256.1.2 LEC puede pretenderse la exhibición de la cosa, sin distinción entre mueble o inmueble, a la que se haya de referir el juicio y que esté en poder de aquel al que se pretenda demandar. 
Y se dice que a priori porque si bien la eliminación del carácter real o mixto de la acción que se pretenda entablar y, por tanto, preparar, no ha generado debate alguno dándose por acertada en este extremo la decisión del legislador de no limitar la aplicación práctica de la diligencia, la eliminación del carácter mueble de la cosa objeto de la diligencia es una de las cuestiones que mayor polémica ha generado en la doctrina científica y judicial ${ }^{273}$.

También se dice que a priori porque deberemos valorar si, pese a la limitación legal de la legitimación pasiva que, con origen en el art. 497.2 LEC, se mantiene en el art. 256.1.2 LEC, resulta procedente la admisión de la solicitud frente a aquellos sujetos que, teniendo la cosa en su poder, no ostenten la necesaria legitimación pasiva para ser demandados en el juicio ulterior que se pretenda preparar.

La supresión del carácter real o mixto de la acción que se pretendiera entablar conllevaba una ampliación necesaria del ámbito de aplicación de la diligencia preliminar que fue vista con muy buenos ojos por la doctrina ${ }^{274} \mathrm{y}$, por ello, no generó discusión alguna. Bajo el imperio de la ALEC y conforme al tenor literal de su art. 497.2, no era posible solicitar la diligencia de exhibición de la cosa al amparo de una acción meramente personal. Se vinculaba la procedencia de la diligencia al ejercicio de una acción real o mixta, es decir, de aquella que se ejercitaba en consideración al bien objeto de la misma, la real, o para la tutela de los derechos que participan de la doble condición de real y mixta, la mixta ${ }^{275}$. Sin duda alguna, la ampliación de dicho ámbito de aplicación de la diligencia preliminar en cuestión a la preparación del futuro juicio y cualquiera que fuera la acción que se pretendiera ejercitar se correspondía con ese espíritu renovador de la nueva regulación que ponía de manifiesto la Exposición de Motivos de la LEC.

\footnotetext{
${ }^{273}$ Así lo han puesto de manifiesto Gimeno Sendra, V., Derecho Procesal Civil..., ob. cit., p. 356; Garberí Llobregat, J., Las diligencias preliminares..., ob. cit., p. 41; Banacloche Palao, J., Las diligencias preliminares..., ob. cit., p. 77, según el cual la supresión de la necesidad de que la cosa que se pretende exhibición sea mueble es lo primero que hay que destacar de esta diligencia, al no poder considerarse intrascendente; Bellido Penadés, R., Comentario al artículo..., ob. cit., p. 5-11; y Garnica Martín, J.F., De las diligencias preliminares..., ob. cit., p. 1151.

${ }^{274}$ En dicho sentido, Banacloche Palao, J., Las diligencias preliminares..., ob. cit., p. 79.

${ }^{275}$ Alonso Furelos, J.M., La exhibición de..., ob. cit., pp. 419-421.
} 
Sin embargo, pese a que también la eliminación del carácter mueble de la cosa a la que debe referirse el juicio conlleva una notable ampliación del ámbito de aplicación de la diligencia preliminar y pese a que, también ello es acorde con dicho espíritu de renovación, la orfandad del adjetivo mueble en la nueva regulación ha generado un intenso debate doctrinal que no está zanjado en la actualidad. Dado que la actual LEC no contenía ni contiene referencia expresa alguna al carácter mueble de la cosa objeto de la diligencia contemplada en el art. 256.1.2 LEC surgió la polémica en torno a la necesidad de dicho carácter en orden a la admisión de la diligencia preliminar en cuestión o si, por el contrario, la nueva LEC permitía que dicha cosa fuera mueble o inmueble.

\subsubsection{Limitación a las cosas muebles}

Así, un sector de la doctrina científica ha sostenido que, aún la ausencia de mención legal expresa al carácter mueble de la cosa, la que ha de ser exhibida, en todo caso, debe ser mueble ${ }^{276}$, pues tal posibilidad respecto del inmueble ha sido negada por la doctrinal judicial mayoritaria ${ }^{277}$ al no poderse proceder a su exhibición ${ }^{278}$. Por otro lado, también se ha sostenido que el carácter mueble de la cosa a la que debe de referirse el juicio se alcanza con una interpretación sistemática de los arts. 256.1.2 y 261.3 LEC $^{279}$ pues, en caso de negativa a la exhibición, si se conociese o presumiese fundadamente el lugar en que la cosa se encuentra, sólo la mueble podría presentarse al

\footnotetext{
${ }^{276}$ En esta línea, vid. Asencio Mellado, J.M., Derecho Procesal Civil..., ob. cit., p. 38; Montero Aroca, J., Derecho Jurisdiccional II...., ob. cit., pp. 187-188; Garberí Llobregat, J., Las diligencias preliminares..., ob. cit., p. 41; y Callejo Carrión, S., Las diligencias preliminares..., ob. cit., p. 12.

${ }^{277}$ Así lo pone de manifiesto Garberí Llobregat, J., Las diligencias preliminares..., ob. cit., p. 41, permitiéndonos en este caso corregir la referencia que hace el autor dado que, no existiendo pronunciamientos del TS en relación a la concreta diligencia preliminar, en sentido estricto, no puede hablarse de jurisprudencia. Ejemplo de denegación de exhibición de cosa inmueble es el AAP de Valladolid (sección $3^{\mathrm{a}}$ ) de 24 de mayo de 2004, ponente Ilmo. Sr. F. Salinero, f.j. $1^{\circ}$ (LA LEY 121728/2004) al considerar que: "[...] La cosa a que se refiere el juicio es la dependencia dedicada a estanco de la que la destinataria de la diligencia es arrendataria y el local arrendado no precisa de exhibición. La verdadera naturaleza de lo que solicita la parte recurrente es la de una prueba anticipada que solo procede en los supuestos previstos en el art. 293 de la L.E.Civil, para el caso de que sea imposible realizarla en el momento procesal generalmente previsto".

${ }^{278}$ Asencio Mellado, J.M., Derecho Procesal Civil..., ob. cit., p. 38 y Montero Aroca, J., Derecho Jurisdiccional II..., ob. cit., pp. 188.

${ }^{279}$ Montero Aroca, J., Derecho Jurisdiccional II...., ob. cit., pp. 188. En el mismo sentido, Callejo Carrión, S., Las diligencias preliminares..., ob. cit., p. 12. En la doctrina judicial, el AAP de Granada (sección $4^{a}$ ) de 24 de enero de 2003, ponente Ilmo. Sr. J. Maldonado, f.j.2º (LA LEY 18105/2003).
} 
solicitante y sólo respecto de ella podría pedirse el depósito. Esta postura doctrinal se mantiene en la actualidad, incluso y pese al tenor literal de la LEC, hasta el punto de seguir titulándose la exhibición de la cosa, como mueble, en distintos textos jurídicos que abordan el estudio de la regulación de la institución ${ }^{280}$.

Además, este posicionamiento de la doctrina científica fue reforzado por cierta doctrina judicial que, con variados argumentos, también sostenía el carácter de mueble de la cosa objeto de la diligencia. En unos casos, la afirmación del carácter mueble de la cosa se fundaba en la simple tradición legal que hacía referencia a la cosa mueble como única que, por naturaleza, podía exhibirse y depositarse y ser susceptible de movilidad, habida cuenta que la finalidad de la diligencia, según sostenían, no era otra que la de identificación de la cosa mueble, dada la aprehensibilidad y movilidad que se predica de la misma y no de la inmueble ${ }^{281}$.En otros, de forma única o conjunta con el anterior criterio, se invocaba la necesaria interpretación sistemática de la medida contemplada en el art. 256.1.2 LEC con los efectos que, para el caso de negativa, preveía el art. 261.3 LEC y que, en su tenor legal literal, mal se compadecen con la cosa inmueble, que no admite depósito ${ }^{282}$. En consideración a otras circunstancias, no faltan resoluciones que

\footnotetext{
${ }^{280}$ Díez-Picazo Giménez, I., Las diligencias preliminares..., ob. cit., p. 38; Montero Aroca, J., Derecho Jurisdiccional II..., ob. cit., p. 188; Garciandía González, P.M., La regulación de..., ob. cit., p. 780; y Ruíz de Gordejuela López, L., Las diligencias preliminares..., ob. cit., p. 182.

${ }^{281}$ En esta línea, el AAP de Pontevedra (sección $1^{\mathrm{a}}$ ) de 25 de mayo de 2006, ponente Ilma. Sra. M.B. Rodríguez, f.j. $2^{\circ}$ (LA LEY 326148/2006) cuando señala que: "[...] la razón del precepto, como también lo era el de la LEC de 1881 en su Art. 497 no era sino la exhibición de una "cosa mueble" puesto que el inmueble por naturaleza (otra cosa es el inmueble por disposición y ficción legal) no ha de exhibirse sino que, en principio, se halla visible siempre, de ahí que aunque el precepto no haga mención a si de cosa mueble o inmueble se trata, lo razonable es pensar que el sentido de precepto es que de "mueble" se trate como se refuerza por la expresión que sigue a la frase "que tenga en su poder" puesto que aunque es claro que las cosas inmuebles también se poseen, no es necesario que sea exhibidas"; en el mismo sentido, los AAP de Valencia (sección 11 ${ }^{\text {a }}$ ) de 26 de abril de 2005, ponente Ilmo. Sr. J.A. Arolas, f.j.2 $2^{\circ}$ (LA LEY 93056/2005) y 24 de octubre de 2011, ponente Ilmo. Sr. M.J. López, f.j. $2^{\circ}$ (LA LEY 254572/2011); el AAP de Badajoz (sección $3^{\text {a }}$ ) de 27 de octubre de 2006, ponente Ilmo. Sr. J. Souto, f.j.1 $1^{\circ}$ (LA LEY 169173/2006) y el AAP de Madrid (sección 9a) de 6 de septiembre de 2007, ponente Ilmo. Sr. J.L. Gordillo, f.j. $1^{\circ}$ (LA LEY 163525/2007).

${ }^{282}$ Ello sucede en el AAP de Madrid (sección 9a) de 6 de septiembre de 2007, ponente Ilmo. Sr. J.L. Gordillo, f.j. $1^{\circ}$ (LA LEY 163525/2007) que señala que: “[...] Por eso, si bien en el artículo 256 no se hace mención a cosa mueble, atendiéndose a lo dispuesto en el artículo $261.3^{\circ}$-negativa a la exhibición: presentación y facultad de peticionar el depósito- cabe entender que sólo cabe referir la indicada diligencia a cosas muebles al ser las únicas que pueden exhibirse y depositarse; si bien la Sala es consciente de la diversidad de opiniones doctrinales sobre la cuestión". También, vid. el AAP de Badajoz (sección $3^{\text {a }}$ ) de 27 de octubre de 2006, ponente Ilmo. Sr. J. Souto, f.j.1 ${ }^{\circ}$ (LA LEY 169173/2006) y el AAP
} 
en la exhibición de un inmueble identifican un intento de preconstitución de prueba, rechazándose de plano la misma ${ }^{283}$.

\subsubsection{Ampliación a los inmuebles}

Sin embargo, frente a la anterior postura, también hay autores que defienden la extensión del ámbito de aplicación práctica de la diligencia a la cosa inmueble. El espíritu renovador que se desprende de la Exposición de Motivos de la LEC, que apuesta por un criterio de interpretación flexible del catálogo de diligencias preliminares, la supresión de la mención legal al carácter mueble de la cosa que puede ser objeto de la diligencia y la utilidad que se advierte en la medida en relación a determinados procesos, les lleva a sostener su procedencia no sólo respecto de las cosas muebles sino también de las inmuebles ${ }^{284}$.

Y lo cierto es que, en la doctrina judicial, cada día son más las resoluciones que acceden a la práctica de la diligencia cuando se trata de inmuebles alejándose de disquisiciones doctrinales y amparándose a tal efecto, en principios generales. En dicho sentido, se viene poniendo de manifiesto que lo relevante de la medida en cuestión no es su naturaleza, debiendo indagarse así en su utilidad de cara a la preparación del litigio. Es decir, en la determinación de si la vista de la cosa mueble o la visita del inmueble son útiles a quien ostente un interés legítimo sobre tal cosa, mueble o inmueble, para decidir con fundamento sobre la acción a ejercitar ${ }^{285}$. En suma, y de conformidad con el

de Valencia (sección $11^{\text {a }}$ ) de 26 de abril de 2005, ponente Ilmo. Sr. J.A. Arolas, f.j.2 ${ }^{\text {o }}$ (LA LEY 93056/2005).

${ }^{283}$ En dicho sentido se han pronunciado los AAP de Pontevedra (sección $1^{\text {a }}$ ) de 25 de mayo de 2006, ponente Ilma. Sra. M.B. Rodríguez, f.j.2 $2^{\text {o }}$ (LA LEY 326148/2006), AAP de Badajoz (sección $3^{\text {a }}$ ) de 27 de octubre de 2006, ponente Ilmo. Sr. J. Souto, f.j.1 ${ }^{\circ}$ (LA LEY 169173/2006), AAP de Madrid (sección 9ª) de 6 de septiembre de 2007, ponente Ilmo. Sr. J.L Gordillo, f.j.2 (LA LEY 163525/2007) y AAP de Madrid (sección 18 ${ }^{\mathrm{a}}$ ) de 21 de diciembre de 2011, ponente Ilmo. Sr. L. Pérez, f.j.2 ${ }^{\circ}$ (LA LEY 266342/2011).

${ }^{284}$ Corbal Hernández, J.E., Diligencias Preliminares (arts...), ob. cit., p. 3498; Díaz Martínez, M., Las diligencias preliminares...ob. cit., p. 7; Banacloche Palao, J., Las diligencias preliminares..., ob. cit., p. 77; Bellido Penadés, R., Comentario al artículo..., ob. cit., p. 5-12; Álvarez Alarcón, A., Las diligencias preliminares..., ob. cit., p. 39; Garnica Martín, J.F., De las diligencias preliminares..., ob. cit., p. 1152; y, Lorca Navarrete, A.M., La regulación de las..., ob. cit., p. 3.

${ }^{285}$ AAP de Alicante (sección $5^{\text {a }}$ ) de 9 de septiembre de 2015 , ponente Ilmo. Sr. M ${ }^{\text {a }}$ V. Pérez, f.j. $1^{\text {o }}$ (ROJ AAP A 81/2015). 
art. 258.1 LEC, justificando su procedencia en la adecuación de la diligencia a la finalidad que el solicitante persigue y la concurrencia de justa causa e interés legítimo ${ }^{286}$.

Así, entre los supuestos más frecuentes en que siendo objeto de la diligencia una cosa inmueble se ha accedido a su exhibición conforme al art. 256.1.2 LEC, son comunes aquellos en que, por razón de la acción a ejercitar en el ulterior juicio, se pone de manifiesto la necesidad de proceder al reconocimiento de un inmueble ${ }^{287}$.

Llegados a este punto, puede afirmarse que es un hecho incontestable que la LEC operó un cambio significativo de la diligencia preliminar en cuestión respecto a la regulación anterior del art. 497.2 ALEC, al omitir cualquier referencia al carácter de la cosa que debe ser exhibida. En esta tesitura, y siguiendo el criterio de la tradición legal, se podrá sostener que la referencia a la cosa debe ser entendida, en todo caso, a la

\footnotetext{
${ }^{286}$ Así, el AAP de Cádiz (sección 2a) de 15 de marzo de 2007, ponente Ilmo. Sr. A. Marín, f.j.2º (ROJ AAP CA 419/2007), el AAP de Cáceres (sección 1ª) de 14 de mayo de 2009, ponente Ilmo. Sr. A.M. González, f.j.2 $2^{\circ}$ (LA LEY 77071/2009); el AAP de Barcelona (sección 16aa) de 4 de junio de 2009, ponente Ilmo. Sr. I.C. Zapata, f.j. $2^{\circ}$ (174400/2009); el AAP de Las Islas Baleares (sección $3^{\text {a }}$ ) de 30 de junio de 2009, ponente Ilma. Sra. M $^{\text {a }}$.R. Rigo, f.j.4 (LA LEY 133792/2009); y el AAP de Alicante (sección $5^{\text {a }}$ ) de 12 de enero de 2011, ponente Ilmo. Sr. J.L. Úbeda, f.j. $3^{\circ}$ (AC 2011 279).

${ }^{287}$ En este contexto destaca el AAP de Barcelona (sección 16 $6^{\text {a }}$ de 4 de junio de 2009, ponente Ilmo. Sr. I.C. Zapata, f.j. $2^{\circ}$ (LA LEY 174400/2009) en que a instancia de una comunidad de propietarios se accedió a la diligencia de exhibición de un bien inmueble de varios comuneros a los fines de comprobar determinados extremos de varias construcciones realizadas en un patio interior a través del cual debía de discurrir el ascensor cuya instalación se había acordado en junta de propietarios así como el coste de su retirada y de los eventuales daños que de las mismas se pudieran derivar; el AAP de Salamanca (sección $1^{\text {a) }}$ de 29 de febrero de 2012, ponente J.R. González, f.j.2º (LA LEY 280744/2012), admitiendo la solicitud de diligencias preliminares consistentes en la exhibición del local litigioso y las instalaciones y construcciones existentes en el mismo a fin de identificar, comprobar y valorar el incremento de valor que pudiera haberse tenido con ocasión de la realización de obras de reforma, mejora y acondicionamiento en el inmueble, con carácter previo la emisión del correspondiente informe pericial; el AAP de Alicante (sección $5^{\mathrm{a}}$ ) de 9 de septiembre de 2015, ponente Ilma. Sra. M $^{\mathrm{a}}$.V. Pérez, f.j. $2^{\circ}$ (ROJ AAP A 81/2015), en que era objeto del recurso de apelación la diligencia preliminar consistente en la exhibición de la vivienda del demandado a fin de constatar el origen de las humedades surgidas en la que es propiedad del actor, colindante con aquella, previa indicación de la necesidad de pericia por la técnico correspondiente y ante las discrepancias de las partes sobre el origen de unas humedades; además, muchos otros como los AAP de Barcelona (sección 13 $3^{\mathrm{a}}$ ) de 13 de diciembre de 2005, ponente Ilmo. Sr. J.B. Cremades, f.j.3 ${ }^{\circ}$ (LA LEY 239881/2005); AAP de Cádiz (sección $2^{\mathrm{a}}$ ) de 15 de marzo de 2007, ponente Ilmo. Sr. A. Marín f.j.3ํㅜㅇ (ROJ AAP CA 419/2007); AAP de Madrid (sección 19a) de 24 de octubre de 2008, ponente Ilmo. Sr. E. Legido, f.j.2 $2^{\circ}$ (LA LEY 231309/2008); AAP de La Rioja (sección única) de 9 de diciembre de 2008, ponente Ilmo. Sr. L.M. Rodríguez, f.j.3 $3^{\circ}$ (LA LEY 312622/2008); AAP de Cáceres (sección 1ª) de 14 de mayo de 2009, ponente Ilmo. Sr. A.M ${ }^{a}$ González, f.j.2 ${ }^{\circ}$ (LA LEY 77071/2009); AAP de Las Islas Baleares (sección $3^{\mathrm{a}}$ ) de 30 de junio de 2009, ponente Ilma. Sra. M J. Rigo, f.j.4 (LA LEY 133792/2009); y AAP de Alicante (sección $5^{\mathrm{a}}$ ) de 12 de enero de 2011, ponente Ilmo. Sr. J.L. Úbeda, f.j. $3^{\circ}$ (AC 2011279).
} 
mueble. Pero, entonces deberíamos preguntarnos por qué el legislador, aún desde la más pura comodidad, pudiendo mantener la referencia al carácter mueble de la cosa no lo ha hecho. Y no existiendo en la literatura del debate parlamentario mención alguna al respecto, la conclusión más razonable que cabe alcanzar es que no quiso limitar el ámbito de aplicación de la diligencia a la cosa mueble.

Cierto es que una interpretación hermenéutica de la regulación de la diligencia preliminar en cuestión, por relación del art. 256.1.2 con el 261.3 LEC, nos podría llevar a rechazar el ámbito de aplicación de la diligencia a la cosa inmueble, al no ser ésta susceptible de ser aprehendida materialmente y presentada al solicitante. Pero no es menos cierto que nuestro legislador no es infalible y que resulta probable que cometiera error al omitir, para el caso de negativa del requerido a la exhibición del inmueble, unas consecuencias adecuadas a la naturaleza de la diligencia de exhibición de cosa inmueble. $\mathrm{Y}$ es en este punto donde ha sido decisiva la interpretación de la norma que corresponde a los tribunales que, en la aplicación práctica de la misma y atendiendo a un criterio finalista de la institución y de la medida en cuestión, han corregido tal deficiente regulación. No olvidemos que, conforme a lo dispuesto en los arts. 3 y 4 CC, las normas se interpretarán según el sentido propio de sus palabras, en relación con el contexto, los antecedentes históricos y legislativos, y la realidad social del tiempo en que han de ser aplicadas, atendiendo a su espíritu y finalidad, procediendo su aplicación analógica cuando no contemple un supuesto específico pero regule otro semejante entre el que se aprecie identidad de razón. A lo que debe añadirse que, en cualquier caso, la tipicidad de la norma no limita su ámbito de aplicación a las cosas muebles y que no existe norma que prohíba o impida extender el mismo a las inmuebles.

Pero, también debemos afirmar que no desconocemos que, en ocasiones, el resultado de dicha interpretación correctora de la norma que deben efectuar los tribunales, no sólo permitirá el conocimiento de los datos necesarios para la adecuada articulación de la demanda sino que también dará lugar a la obtención de un resultado con un importante matiz probatorio. Sin embargo, dicho efecto colateral en modo alguno puede introducir un veto que la norma no impone pues, como es de ver en las resoluciones citadas que acceden a la exhibición de la cosa inmueble, la necesidad de la 
medida es correlativa a la del examen del inmueble. Es decir, que en aquellos supuestos en los que se ha accedido a la exhibición del inmueble con fundamento en el art. 256.1.2 LEC no lo ha sido con la finalidad de facilitar al solicitante la obtención de material probatorio alguno sino que única y exclusivamente para permitirle conocer los elementos esenciales para articular su demanda por razón de la acción a ejercitar en el ulterior juicio. Es decir, y descendiendo a los ejemplos de las resoluciones citadas, que permitan al solicitante conocer la titularidad y extensión de la responsabilidad, contractual o extracontractual, que pueda reclamar en dicho ulterior juicio.

Imaginemos el supuesto concreto de quien, con arreglo o no a la normativa vigente, hace en su vivienda una serie de obras que, por ejemplo, acaban provocando fisuras en la estructura de la vivienda colindante. La propiedad de la vivienda colindante, potencial solicitante de la diligencia preliminar, podrá suponer que tales fisuras se han producido como consecuencia de las obras ejecutadas en la vivienda colindante. Pero, en cualquier caso, sin la concurrente voluntad del vecino y sin auxilio judicial, en modo alguno podrá constatar, con carácter previo a la interposición de la demanda, si se han realizado actuaciones susceptibles de causar los daños sufridos en la vivienda de su propiedad. Es decir, que reconociéndole el ordenamiento jurídico el derecho a reclamar el resarcimiento del daño que le ha sido causado, de no admitirse su solicitud de exhibición del inmueble vecino deberá arriesgarse a reclamar la tutela judicial de su derecho en la inseguridad más absoluta. Así, no podrá verificar que las actuaciones constructivas que han provocado las fisuras de su inmueble han sido o no realizadas en el colindante $\mathrm{o}$, por ejemplo, si concurriendo las mismas con una intervención municipal de acondicionamiento vial no se deben a aquellas y sí a ésta. Imaginemos también el supuesto de daños causados por humedades o filtraciones cuyo origen comunitario o privativo necesita conocerse. En estos supuestos, la exhibición e inspección del inmueble, incluso con la intervención de un perito, resultará fundamental para determinar la naturaleza y titularidad de la responsabilidad que deba de reclamarse en juicio. Es decir, será imprescindible para la determinación de algo tan fundamental en el mismo como la legitimación pasiva del demandado, pues solo a través de esta exhibición e inspección del inmueble podrá determinarse, en relación al ejemplo 
referido, si en la vivienda colindante ha tenido lugar algún hecho o suceso susceptible de causar los daños sufridos por el solicitante en la propia.

Por lo expuesto, siendo evidente que ni el legislador ni el ordenamiento jurídico amparan la articulación de procesos inútiles tanto para los particulares como para la propia Administración, debe admitirse que la diligencia del art. 256.1.2 LEC, que no limita la exhibición de la cosa a la mueble, es el cauce apropiado para la debida preparación de un litigio en el que la exhibición o reconocimiento de un inmueble, incluso por un profesional especializado, sea presupuesto necesario para la debida determinación tanto del objeto como de la legitimación pasiva del proceso posterior que se pretende preparar. En definitiva, para determinar si la persona frente a la que se va a interponer la demanda es o no responsable y en qué extensión ${ }^{288}$.

Y es obvio que si el requerido se niega a la exhibición del inmueble, no se podrá acordar la entrada y registro del inmueble para presentarlo al solicitante, pudiendo pedir este el depósito o medida de garantía más adecuada a su conservación. Pero entendemos que esta consecuencia, evidentemente dispuesta para las cosas muebles, y no para los inmuebles, no justifica el rechazo de su aplicación práctica en el caso de los inmuebles al entender que la misma no es más que el reflejo de una deficiente regulación legal que habrá de ser suplida por el juez quien, a través de la correspondiente decisión motivada, establecerá los concretos efectos de dicha negativa. Por ello, partiendo del propio art. 261.3 LEC nada impide que el juez acuerde la entrada en el inmueble, no para su registro, incautación y puesta a disposición del solicitante de dicho bien inmueble, sino para la inspección del mismo. Y será en esa decisión judicial motivada en la que habrá de disponer el juez la extensión y límites de la exhibición e inspección que habrá de practicarse con ocasión de la entrada en el inmueble con la debida presencia del LAJ quien constatará la ejecución de la resolución en los términos dispuestos.

Entendemos que a esta conclusión no se podrá oponer que ya el proceso civil prevé, en su art. 337 LEC, la posibilidad de aportación de dictámenes periciales cuando,

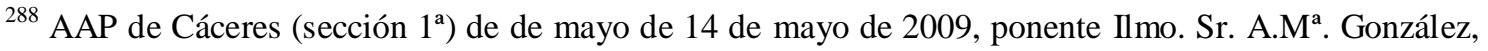
f.j.2 (LA LEY 77071/2009).
} 
como sería el caso, no sea posible su aportación junto con la demanda rectora del procedimiento. Ello porque, como es obvio, previamente a la interposición de la demanda, y para su fundamentación, deberá conocerse si aquel frente al que la misma se va a dirigir es o no, efectivamente, el responsable o legitimado pasivamente. Si así no se hiciera determinado a la postre el informe pericial que aquel frente al que hemos dirigido la demanda no es el legitimado pasivamente para soportar la acción deducida, el demandante se vería obligado a desistir de su proceso, con la consecuente condena en costas o, en el mejor de los casos, con la inútil articulación de un proceso que habrá transcurrido a lo largo de los meses sin sentido alguno.

Insistimos, por tanto, en que este resultado no es el querido por el legislador que, por demás, no ampara conductas contrarias a la buena fe, como sería la de quien voluntariamente se negara a la exhibición del inmueble que acaben imponiendo al administrado la articulación de procesos judiciales inútiles y sin sentido alguno. Igualmente, entendemos que la admisión de una diligencia como la expuesta no permitirá sostener que nos encontramos ante una diligencia probatoria no sólo por cuanto, como ya expusimos, prueba solamente es aquella que se practica en el proceso y en los términos que la ley configura, sino porque cualquier informe pericial que tenga su origen en la diligencia preliminar en cuestión deberá ser objeto de la correspondiente declaración de pertinencia probatoria en el ulterior proceso, donde además podrá ser controvertido con todas las garantías legales.

Por tanto, en este trabajo, sin necesidad de recurrir a ficciones legales, pues la referencia contenida en el art. 256.1.2 LEC en modo alguno impone que la cosa a exhibir, en todo caso, haya de ser mueble, apostamos por una interpretación del término cosa sin las restricciones que la norma no impone y en la que el juzgador, para el caso de negativa del requerido a la práctica de la diligencia preliminar, tendrá la labor fundamental de configurar la concreta consecuencia de dicha negativa que sea más efectiva para dar cumplimiento a la finalidad de la institución. Es decir, para que el solicitante vea colmado su derecho a obtener la información necesaria para poder preparar adecuadamente el ulterior juicio o, en su caso, evitarlo si la obtenida así lo aconseja. 


\subsection{La posibilidad de equiparación del documento al concepto de cosa}

Pero la controversia no ha quedado limitada a la consideración de si en el concepto de cosa que se refiere en el art. 256.1.2 LEC deben entenderse incluidas, únicamente, las cosas muebles, o también las inmuebles. Ello, porque en innumerables ocasiones, y al amparo de dicho precepto legal, se ha solicitado la exhibición de todo tipo de documentos, cuestionándose ambos sectores doctrinales si en el concepto de cosa pueden entenderse incluidos los documentos.

En relación a estos últimos, se indica que el término "cosa" no debe interpretarse de manera tan amplia que permita confundirlo con el de "documento" ${ }^{289}$ pues si se parte del carácter tasado de las diligencias, los “documentos" a solicitar se encuentran expresamente previstos en la práctica totalidad del catálogo del art. 256.1 LEC salvo en el núm. 2, por lo que su interpretación ha de ser restrictiva ${ }^{290}$.

Sin embargo, la doctrina judicial no ha sido tan unánime como la científica encontrándose dividida entre aquellas resoluciones que sostienen que en modo alguno

\footnotetext{
${ }^{289}$ En dicho sentido parece pronunciarse el AAP de Cantabria (sección $2^{\text {a }}$ ) de 6 de noviembre de 2015, ponente Ilmo. Sr. Arias, f.j. $2^{\circ}$ (ROJ S 601/2015) cuando señala: “[...] Tras estas consideraciones iniciales, hay que advertir ahora que, en su conjunto, la exhibición documental intentada no se corresponde con las previsiones del art. 256.1. $2^{\circ}$ o $9^{\circ}$, porque los documentos a exhibir no son "la cosa a la que haya de referirse el juicio", ni tampoco en esos documentos (con la salvedad que se dirá) consta la capacidad, representación o legitimación del Banco Santander S.A.; ni hay previsión en ninguna ley especial que permita una exhibición documental como la solicitada".

${ }^{290}$ Cfr. Gimeno Sendra, V., Derecho Procesal Civil..., ob. cit., p. 276 y Damián Moreno, J., Comentarios a la..., ob. cit., p. 1685, fundando este último su postura en las distintas resoluciones judiciales que determinan que la exhibición de cosa se refiere a la cosa mueble o inmueble que son susceptibles de apropiación, como establece el art. 333 del Código Civil, no pudiéndose extender a exhibición de documentos, pues si se admitiese esta interpretación extensiva, no tendría sentido la referencia a documentos a que alude los números 1, 3, 4 y 5 del citado art. 256, especificándose en el número 1 a la exhibición de documentos en los que se refieren a la capacidad, representación o legitimación, no a los documentos en que se fundamenta su pretensión, entre otras el AAP de Cádiz (sección 2a) de 20 de abril de 2010, ponente Ilmo. Sr. J.C. Ruiz, f.j.2 (LA LEY 77645/2010). No obstante lo anterior, encontramos resoluciones judiciales como el AAP de Las Palmas (sección $4^{\mathrm{a}}$ ) de 10 de junio de 2010, ponente Ilma. Sr. $M^{\text {a }}$.E. Corral, f.j.5 (LA LEY 221255/2010) en la que el juzgado define lo que se ha de entender por "exhibición de la cosa" señalando que "[...] parece razonable entender que "la cosa" a la que se haya de referir el juicio (...) sean los documentos en los que se formaliza los negocios o actos jurídicos en cuestión" citando, entre otros, "[...] el contrato de determinada cuenta corriente, o cualquier otro que incida en su funcionamiento, y documentos anexos a su apertura, y los soportes documentales que han dado lugar a la anotación de determinados y completamente especificados movimientos de cargo, pueden considerarse claramente encuadrados en el núm. 2 del a. 1 del art. 256 LEC. Pero entendemos que es que incluso pueden considerarse encuadrados en el núm. $9^{\circ}$ del mismo apartado del art. 256 LEC".
} 
pueden equipararse los documentos al concepto de cosa que refleja el art. 256.1.2 LEC, no pudiéndose amparar actuaciones tendentes a la obtención de documentos o conocimiento previo de su existencia que pueda considerarse actividad probatoria ${ }^{291}, \mathrm{y}$ aquellas que con fundamento en la interpretación flexible que se predica del catálogo de diligencias recogidas en el art. 256.1 LEC, entienden procedente la exhibición de documentos al amparo del art. 256.1.2 LEC cuando concurran determinadas circunstancias $^{292}$.

Aquí nuevamente deberíamos reflexionar sobre el concepto de cosa a que alude el art. 256.1.2 LEC para concluir no sólo que los documentos también responden a

${ }^{291}$ En dicho sentido, el AAP de León (sección $2^{\text {a }}$ ) de 6 de julio de 2006, ponente Ilmo. Sr. A.F. Álvarez, f.j. $2^{\circ}$ (LA LEY 969173/2006). También el AAP de Madrid (sección 11ª) de 19 de julio de 2004, ponente Ilmo. Sr. F. Almazán, f.j.3 ${ }^{\circ}$ (LA LEY 170886/2004), en un supuesto de denegación de diligencia preliminar solicitada para la exhibición de la documentación relativa al pago del precio de una compraventa en que se anunciaba el ejercicio de acción de nulidad de la misma por la supuesta falta de capacidad de la vendedora, en cuyo casó entendió el órgano judicial: “[...] En el presente caso se pretende, por más que se diga lo contrario, no la exhibición de una cosa mueble que vaya a ser objeto de litigio, sino de la documentación acreditativa del pago del precio de la compraventa que se pretende cuestionar, no debiéndose aceptar, la equiparación que se hace, para englobar en el término "cosa" empleado por el artículo $256.1,2^{\circ}$ de la Ley Procesal, entre el dinero y la documentación acreditativa de su tras vase, pues siendo cierto que el dinero ha de conceptuarse como "cosa", no alcanza tal consideración a los documentos cuya exhibición se pretende"; el AAP de Asturias (sección 7aa) de 30 de enero de 2004, ponente Ilmo. Sr. J. Pavieso, f.j.2 (LA LEY 26999/2004) en un supuesto de solicitud de exhibición de copia fehaciente del informe de vida laboral emitido por la TGSS y certificado del INEM sobre los periodos en que hubiera permanecido de alta como demandante de empleo el hijo del solicitante y a fin de determinar el derecho a solicitar la extinción de la pensión alimenticia a cargo del mismo establecida en la sentencia de separación; y el AAP de Granada (sección $4^{\mathrm{a}}$ ) de 24 de enero de 2003, ponente Ilmo. Sr. J. Maldonado, f.j. $2^{\circ}$ (LA LEY 18105/2003) en el que se pretendía de una entidad bancaria la exhibición y entrega por el requerido de los listados completos de las operaciones de activo y pasivo de las que hubieran sido o fueran entonces titulares los solicitantes de las diligencias, al objeto de entablar un proceso declarativo para dilucidar las relaciones mercantiles entre las partes derivadas de varios préstamos, y en el que se procedió a la denegación de tales diligencias considerando que: "[...] Los documentos a que se refiere la actora en las presentes diligencias no son el objeto del juicio posterior que pretende, sino elementos de prueba de la futura pretensión, por lo que no están comprendidos en el precepto invocado, ni puede pretenderse al amparo de la norma invocada que «se le entreguen», al no estar prevista tal actuación ni en el propio Art. 256.1.2 ${ }^{\circ}$ ni en el Art. $261.3^{\circ}$, que sólo prevé el depósito u otra medida de garantía que tienda a su conservación. A cierto tipo de documentos se refieren los números 3 a 5 del indicado Art. 256.1 NLEC, que, evidentemente, no son los que pretende el interpelante que se exhiban".

${ }^{292}$ En esta línea, el AAP de Las Islas Baleares (sección $3^{\text {a }}$ ) de 15 de marzo de 2005, ponente Ilma. Sra. R. Rigo, f.j. $3^{\circ}$ (LA LEY 60287/2005) señala que "[...] Con respecto al supuesto contemplado en dicho párrafo segundo del artículo 256; que la persona a la que se pretende demandar exhiba la cosa que tenga en su poder y a la que se haya de referir el juicio, el término empleado por el legislador es el de cosa, referido a todo lo que tiene entidad, ser inanimado, en contraposición con los animados y es evidente que una interpretación amplia del concepto cosa podría incluir la petición que realiza la entidad solicitante", de documentos, pese que finalmente deniega la solicitud por consistir en una petición indiscriminada de documentación". 
dicho concepto sino que el tenor literal del art. 256.1 LEC no los excluye. Cierto es, como ha puesto de manifiesto la doctrina, que el legislador se ha ocupado de enumerar o identificar determinados documentos que, en todo caso, pueden ser objeto de las diligencias preliminares, cual es el caso de los números $1,3,4,5$, 5 bis y 8 del art. 256.1 LEC, pero no es menos cierto que, al margen de reminiscencias históricas, no existen datos para afirmar que dicha determinación responda a un criterio restrictivo de los documentos que pueden ser exhibidos con exclusión de otros y no a la preocupación del legislador de dar una relevancia especial a la exhibición de determinados documentos. Así, entendemos, que el hecho de que legislador se haya preocupado de amparar de forma especial la exhibición de determinados documentos no puede llevarnos a afirmar que sólo esos y nada más que esos pueden o deben ser exhibidos. De hecho, son numerosas y cada vez más las resoluciones que, con fundamento en el art. 256.1.2 LEC, han accedido a la práctica de la diligencia de exhibición de documentos no comprendidos en los ordinales del art. 256.1 LEC ajenos al $2^{\circ}$ y con fundamento en este mismo ${ }^{293}$. Incluso, aún cuando la LEC no había introducido de forma expresa la posibilidad de solicitar la historia clínica, como así hizo con el ordinal $5^{\circ}$ bis, ya se dio alguna resolución que accedía a la diligencia con fundamento en el ordinal $2^{\circ}$ de aquel precepto legal ${ }^{294}$.

\footnotetext{
${ }^{293}$ Ejemplo de ello lo constituye el AAP de Barcelona (sección 14 $4^{\text {a }}$ de 17 de marzo de 2004, ponente Ilma. Sra. M ${ }^{\mathrm{a}}$.E. Alegret, f.j. $2^{\circ}$ (LA LEY 67562/2004), en un supuesto de solicitud a una entidad bancaria, en su calidad de depositaria administradora de ciertos valores de su propiedad, de exhibición de la documentación referente a los mismos con la finalidad de examinar la corrección de la gestión realizada en la administración de tales valores, y que al respecto dispuso: “[...] Es cierto como dice el juez de instancia que la petición no esta prevista "nominatum" en el elenco de medidas preliminares descritas en el Art.256 de la LEC 2000, como también lo es que si las medidas constituyen una relación cerrada, los supuestos prevenidos en la norma han de ser de interpretación extensiva o no restrictiva como tenía declarado la jurisprudencia en interpretación del antiguo Art. 497 de la LEC 1881.

De este modo permitiendo la ley Art. 256,4 que el socio o comunero pueda solicitar del consocio o condueño que le exhiba los documentos y cuentas de la sociedad o comunidad, que se presume gestiona en interés de todos los socios y comuneros, y el Art. 256, 2 que se exhiba la cosa que se tenga en su poder y a la que se haya de referir el juicio, tratándose los títulos valores de cosas muebles de cuya gestión y administración, según se afirma en la solicitud inicial se encarga la entidad bancaria instada, valores anotados en cuenta tal como se previene en la ley 24/1988, estimamos ajustada a las previsiones de la ley la petición deducida en tanto que cabe en la letra del $\mathrm{n}^{\circ} 2$ del articulo 256 citado y en el espíritu del $\mathrm{n}^{\mathrm{o}} 4$ con el que guarda identidad de razón habida cuenta que el mandatario o gestor debe rendir también cuentas de sus operaciones ex Art. 1720 del CC. y 263 y ss. del C.Com".

${ }^{294}$ Destacamos el ejemplo del AAP de Madrid (sección 14a ) de 3 de marzo de 2005, ponente Ilmo. Sr. P. Quevedo, f.j.2 (LA LEY 50942/2005).
} 
Por ello, al igual que sucede con la cosa inmueble, entendemos que al margen de los concretos supuestos de exhibición o entrega de documentos previstos en los ordinales $1^{\circ}, 3^{\circ}$ a $5^{\circ}$ bis y $8^{\circ}$ del art. 256.1 LEC, también es posible acceder a la exhibición documental con fundamento en el ordinal $2^{\circ}$ de dicho precepto legal y conveniente admitir la solicitud siempre y cuando, la utilidad de dicha exhibición se ponga de manifiesto con carácter previo a la interposición de la demanda. Y ello, nuevamente, en una interpretación flexible de la norma que no discrimine negativamente aquellas solicitudes de exhibición de documentos cuyo objeto de conocimiento más que la existencia del propio documento sea su contenido ${ }^{295}$ porque, como es obvio, la relevancia del documento no viene dada por su mera existencia sino por su contenido. Aún más se puede decir, sólo el conocimiento del concreto contenido del documento nos permitiría verificar si la exhibición documental obtenida es la solicitada y admitida por el tribunal.

A pesar de ello no sostenemos con dicha afirmación una posibilidad indiscriminada de obtención de documentos por el cauce del supuesto $2^{\circ}$ del art. 256.1 LEC sino, al igual que con los muebles o inmuebles, la obtención de la información que resulte necesaria para un correcto planteamiento del proceso ulterior, lo que deberá verificarse por el tribunal, siempre que concurran los presupuestos del art. 258 LEC, considerando las siguientes circunstancias ${ }^{296}$ :

a) La concurrencia de razones que justifiquen su concesión en relación con el objeto del proceso y la accesibilidad al documento cuyo conocimiento es necesario para la formulación de la demanda.

\footnotetext{
${ }^{295}$ Como así hiciera, entre otros, el AAP de Madrid (sección 19a) de 20 de mayo de 2005, ponente Ilmo. Sr. E. Legido, f.j. $2^{\circ}$ (LA LEY 114140/2005) que rechazó la medida solicitada al considerar "[...] y en nuestro caso concreto el juicio no ha de referirse al concreto documento que se pretende exhibir sino a la responsabilidad que derive del mismo dentro del contrato de seguro de vida entre los demandados, aseguradores, y la beneficiaria del repetido seguro".

${ }^{296}$ Siguiendo en este extremo lo recogido en el AAP de Las Palmas (sección $4^{\mathrm{a}}$ ), de 10 de junio de 2010, ponente Ilma. Sra. M ${ }^{\text {a }}$. E. Corral, f.j. $4^{\mathrm{o}}$ (LA LEY 221255/2010) que recuerda los supuestos en que la doctrina judicial, al examinar la solicitud de exhibición de determinados documentos no nominados expresamente en los distintos apartados del art. 256.1 LEC y solicitados como la exhibición de la cosa, con fundamento en el ordinal $2^{\circ}$ de dicho precepto legal ha admitido la exhibición documental.
} 
b) Cuando los documentos solicitados se consideren imprescindibles para interponer dicha demanda.

c) Cuando los documentos no sean accesibles para la parte solicitante o no se hallaren en poder de esta.

d) Cuando los documentos se encuentren en poder de la parte a la que se pretende demandar y frente a la que se dirige la solicitud de exhibición documental.

La concurrencia de estas circunstancias es la que ha permitido a la doctrina judicial, con fundamento en el art. 256.1.2 LEC, admitir la procedencia de la exhibición de una gran variedad de documentos.

Así, se ha admitido la procedencia de exhibir las grabaciones telefónicas que, de conformidad con las prácticas bursátiles, es necesario que mantengan todas las Sociedades de Valores respecto del registro de órdenes de operaciones ${ }^{297}$, documentos tales como contratos de ejecución de obras $^{298}$, documentos bancarios ${ }^{299}$, contratos de

\footnotetext{
${ }^{297}$ En el AAP de Madrid (sección $8^{\text {a)}}$ ) de 23 de febrero de 2009, ponente Ilmo. Sr. A. García (LA LEY 44613/2009) se planteó la procedencia de admitir la solicitud de exhibición de las grabaciones telefónicas que, de conformidad con las prácticas bursátiles, es necesario que mantengan las Sociedades de Valores respecto del registro de órdenes de operaciones, a solicitud de quien se planteaba demandar a la entidad que había realizado un contrato de compraventa de warrants en su nombre y con dinero perteneciente a éste en ejercicio de la acción de nulidad, sin que él hubiera dado previamente su consentimiento o autorización a dicha operación y a las condiciones en que se realizó. Se pretendía acreditar con dicha diligencia que no existió llamada alguna del solicitante proponiendo o autorizando la operación realizada señalando la Sala que debía tenerse en cuenta que gran parte de los contratos de compraventa en Bolsa se realizan a través de teléfono o correo electrónico u otros medios telemáticos, de forma que no es imaginable poder preparar un juicio, en que se deba justificar el hecho mismo del contrato, sin aportar datos de ese mismo carácter técnico, ya sea para acreditar el contrato, ya para negar su existencia.

${ }^{298}$ Este es el supuesto contemplado en el AAP de Cádiz (sección $2^{\mathrm{a}}$ ) de 19 de enero de 2009, ponente Ilma. Sra. M. Álvarez-Ossorio, f.j.1º (LA LEY 9593/2009) que sin mayores explicaciones accedió a la solicitud formulada por una comunidad de propietarios frente a su anterior Presidente, a quien pretendía reclamar responsabilidad, de exhibición de distintos contratos de obra y otros suscritos con una entidad mercantil, al entender que los documentos solicitados resultaban esenciales para fundar la demanda y justificar su pretensión.

${ }^{299}$ El AAP de Madrid (sección 13a) de 14 de enero de 2009, ponente Ilmo. Sr. J. González, f.j.3º (LA LEY 36758/2009) desestimó la solicitud, dirigida a una entidad bancaria a la que se pretendía demandar, de exhibición de documentos relacionados con la cartera de inversiones del solicitante, pero no por no considerar que el supuesto se encontraba comprendido en el art. 256.1.2 LEC sino porque la solicitante no había acreditado haber solicitado previamente los documentos a la citada entidad y que ésta se los hubiera
} 
arrendamiento y similares ${ }^{300}$, la contabilidad que el agente tiene derecho a exigir del empresario en virtud del art. 15.2 LCA $^{301}$, la exhibición de nóminas ${ }^{302}$, incluso la exhibición de la historia clínica ${ }^{303}$. Con tal admisibilidad de supuestos, en suma, lo que

denegado; por tanto, admitiendo que el objeto de la diligencia que se pretende podría encontrar cobertura en el art. 256.1.2 ${ }^{\circ}$ LEC.

${ }^{300}$ En dicho sentido, el AAP de Vizcaya (sección $5^{\text {a }}$ ) de 4 de diciembre de 2007, ponente Ilma. Sra. LA. Cuenca, f.j. $2^{\circ}$ (LA LEY 320478/2007) que admitió la petición de exhibición de los documentos de contrato de arrendamiento, entrega de señal, abono de la primera renta y puesta a disposición de la vivienda arrendada razonando que "[...] cabe pensar, además en relación con la preclusión respecto de la presentación de los documentos esenciales que para la demanda y contestación establece el art. 264 y ss. LEC, y que como tal se estima aplicable a la solicitud de diligencias preliminares, que a la misma se ha de acompañar algún principio de prueba de la bondad de ese derecho que se pretende irrogar para su práctica, de ese interés legítimo que se aduce, lo cual a juicio de la Sala y discrepando de la resolución recurrida, se estima que concurre en el caso de autos y que por tal motivo procede la práctica de las diligencias preliminares interesadas" lo que tiene por acreditado desde que se justificó que se celebró un acto de conciliación con la agencia inmobiliaria por cuenta de la propietaria de la vivienda en el que dicha inmobiliaria reconoció haber convenido con el actor un contrato de arrendamiento y la exigencia de documentos que lo acreditaban, por lo que "en definitiva y dejando de lado que los contratos de arrendamiento pueden concertarse de manera verbal, no hay duda de que al amparo del art. $256 \mathrm{n}^{\mathrm{o}} 1,1^{\circ} \mathrm{y}$ $2^{\circ}$ LEC, el Sr. Carlos Francisco, tiene interés en conocer: a.- el documento o contrato de arrendamiento y que él mismo firmó y del que no se le ha facilitado copia, respecto del cual niega su firma la Sra. Francisca a quien se atribuía la condición de arrendadora, para determinar la bondad de los hechos sustentadores de la pretensión a ejercitar; b.- el documento por el que la Sra. Francisca autorizaba a la Inmobiliaria Torrecasa para la realización de la gestión del contrato de arrendamiento, y ello como base para determinar si en consideración a tal fue o no conforme a derecho en el caso de autos.

${ }^{301}$ Sobre esta cuestión vid. el AAP de Barcelona (sección 19ª de 11 de febrero de 2009 , ponente Ilmo. Sr. M.J. Collado, f.j. $4^{\circ}$ (LA LEY 33734/2005) y el AAP de Murcia (sección $4^{\mathrm{a}}$ ) de 6 de octubre de 2011, ponente Ilmo. Sr. C. Moreno, f.j. $2^{\circ}$ (LA LEY 215728/2011).

${ }^{302} \mathrm{Al}$ respecto vid. el AAP de Cádiz (sección $5^{\mathrm{a}}$ ) de 2 de julio de 2008, ponente Ilma. Sra. R.Ma . Fernández, f.j.único (LA LEY 196482/2008) que, en un supuesto en que en convenio regulador de separación se había pactado como alimentos un $30 \%$ de los haberes del alimentante con un mínimo de 300 euros al mes, cuando el obligado venía sistemáticamente abonando el canon mínimo, sin que constaran a la acreedora sus haberes ni -por tanto- la procedencia o no de superiores cantidades susceptibles de exacción forzosa consideró la Sala que la diligencia de exhibición de nóminas o recibos solicitada era perfectamente adecuada a la finalidad perseguida, concurriendo en la petición justa causa, y siendo de apreciar en la progenitora solicitante un interés legítimo y tutelable en orden al conocimiento de los meritados datos, todo ello de conformidad con lo dispuesto en el art. 258.1 de la LEC que regula la decisión de las diligencias preliminares, siendo cuestión distinta que "[...] en la instancia se baraja confusamente que la concreta solicitud deducida por la peticionaria no se encontrara exactamente prevista en la relación contenida en el art. 256 LEC que contiene una enumeración exhaustiva debiendo rechazarse a límine otras distintas a las pautadas; lo que no impide, sin embargo, el planteamiento de problemas hermenéuticos relativos a la tipicidad de cada una de las diligencias y la extensión con que esa tipicidad deba interpretarse, exégesis que -entiende la Sala- ha de ser tanto más generosa y flexible cuando no nos hallamos propiamente en los prolegómenos de un juicio, sino ante unas actuaciones preparatorias de la ejecución de un título judicial, cuyo exacto cumplimiento no puede quedar al arbitrio del deudor, al socaire de la formalidad de pago de unas cantidades mínimas, cuya suficiencia sólo es posible conocer a través de los documentos requeridos, en términos que se inscriben sin dificultad en el apartado 2 del artículo 556,1 de la LEC, con el beneficio indiscutible de evitar ejecuciones inútiles si se alcanzara una conclusión positiva, o facilitar la reclamación pertinente en otro caso, máxime en materia tan sensible y tutelada como los alimentos para hijos menores".

${ }^{303}$ AAP de Madrid (sección 14a) de 3 de marzo de 2005, ponente Ilmo. Sr. P. Quecedo, f.j. $2^{\circ}$ (LA LEY 50942/2005), aún cuando dicho supuesto debe entenderse producido antes de la inclusión en el catálogo 
se propugna es, sin rebasar los límites legales, propiciar la tutela judicial efectiva de los derechos facilitando, precisamente, el acceso a la misma a través de la preparación de la demanda y de la misma forma que en otros concretos supuestos del art. 256.1 LEC; como en sus aptdos. $3^{\circ}$ a $5^{\circ}$ bis a través de los que se intenta garantizar que el futuro demandante pueda contar con los documentos que han de servir de base a su demanda porque son los documentos en que consta la realidad de la que dimana, o puede dimanar, su derecho.

\subsection{Cuestiones de legitimación}

Aunque la cuestión relativa a la legitimación activa carece de controversia alguna en este contexto, no debemos concluir el estudio de la diligencia en cuestión sin hacer referencia a la legitimación pasiva, que el art. 256.1.2 LEC fija en la persona que tenga la cosa en su poder y a la que se pretende demandar cerrando, en principio, cualquier posibilidad de dirigir la solicitud de diligencias preliminares a aquellas personas que aún teniendo la cosa en su poder no deban de ser demandados en el ulterior juicio.

En orden a la determinación de la legitimación pasiva de las diligencias preliminares puede suceder que el potencial requerido sea poseedor del bien en cuestión así como legitimado en el proceso principal posterior, lo que no planteará problema alguno en orden a la legitimación; o bien que en dicho potencial requerido, aún detentando la posesión del bien en cuestión, no concurra legitimación pasiva para dicho proceso posterior. En relación a este segundo supuesto es cuando se plantea el problema de la legitimación pasiva del requerido en diligencias preliminares que, conforme al tenor literal del art. 256.1.2 LEC, deberá ser aquel que, a su vez, sea quien se pretenda demandar. De este modo se plantea si, conforme a una interpretación literal de la norma, debe negarse legitimación pasiva de aquel frente al que se inste la diligencia preliminar pero que no resulte ser a quien se pretenda demandar en el pleito principal.

de diligencias del art. 256.1 LEC de la diligencia del ordinal 5 bis, como consecuencia de la reforma operada en la LEC por la Ley 19/2006. 
Así las cosas, sin desconocer la claridad de los términos legales, resulta que negar dicha legitimación pasiva a quien no haya de ser demandado en el proceso principal desvirtuaría la finalidad de la institución, impidiendo injustificadamente la exhibición de la cosa, cuando no concurriera en el requerido la condición de poseedor al tiempo que de legitimado principalmente. Le bastaría así al legitimado pasivamente en el pleito principal, para frustrar el éxito de la solicitud, con disponer la posesión de la cosa a favor de un tercero que de resultar requerido negaría su legitimación principal.

Ante dichas circunstancias y, fundamentalmente, ante la claridad literal de la norma en cuestión, entendemos conveniente una reforma de la norma que no vincule la legitimación pasiva de la diligencia preliminar en cuestión a la legitimación pasiva del proceso ulterior, habida cuenta que la utilidad de la medida reside en la exhibición de la cosa para la obtención de la información necesaria que permita una correcta articulación del proceso posterior resultando de menor relevancia la persona frente a la que dicha diligencia se solicite o se deba de articular el proceso posterior.

\section{Exhibición de actos de última voluntad (art. 256.1.3 LEC)}

"Por petición del que se considere heredero, coheredero o legatario, de exhibición, por quien lo tenga en su poder, del acto de última voluntad del causante de la herencia o legado".

Con el precedente del art. 497.3 ALEC, que permitía la solicitud, por quien se creyera heredero, coheredero, o legatario, de la exhibición del testamento, codicilo o memoria testamentaria, la LEC adecua el objeto de la diligencia preliminar en cuestión dando cabida en la misma no sólo a los antes enunciados actos, sino a todos los actos de última voluntad que se contemplan en el ordenamiento jurídico español, comprensivo también de los derechos civiles forales especiales ${ }^{304}$. Como se pone de manifiesto en la

\footnotetext{
${ }^{304}$ Sobre las distintas formas de actos de última voluntad en Derecho Civil Común, vid. los arts. 676 y ss. del CC. En los derechos civiles forales, y en cuanto normas que prevén especiales actos de última voluntad distintos de los existentes en Derecho Común, vid. los arts. 19 y ss. de la Ley 5/2015, de 5 de junio, de Derecho Civil Vasco; los arts. 421-1 y ss. de la Ley 10//2008, de 10 de julio, del libro cuarto de Código Civil de Cataluña, relativo a las sucesiones; los arts. 183 y ss. de la Ley 2/2006, de 14 de junio, de
} 
doctrina $^{305}$, el CC, de fecha posterior a la ALEC, no regula ni los codicilos ni las memorias testamentarias configurando el testamento como única forma de acto de última voluntad. Por ello, la LEC no podía reducir su objeto a este sino ampliarlo a todos los actos de última voluntad recogidos en las distintas normas forales, lo que efectuó delimitando el objeto de la diligencia preliminar al acto de voluntad, comprensivo no sólo del testamento sino de cuantos actos de última voluntad se encontraran recogidos, tanto entonces como en el futuro, en las distintas normas forales $^{306}$.

\section{1 Ámbito de aplicación}

\subsubsection{Objeto de la diligencia}

En principio, la utilidad práctica de esta diligencia se ve reducida a los supuestos de exhibición de actos de última voluntad que no hayan sido otorgados ante Notario, o de otra forma depositados, ante el mismo, cual sería el supuesto, por ejemplo, del testamento ológrafo ${ }^{307}$. Ello, en la medida que el interesado, para cerciorarse del fallecimiento y obtener, en su caso, copia del certificado de defunción, puede acudir al Registro Civil, y para comprobar si existe testamento notarial; al Registro General de

derecho civil de Galicia; los arts. 316 y ss. del Decreto Legislativo 1/2011, de 22 de marzo, del Gobierno de Aragón, por el que se aprueba, con el título de "Código del Derecho Foral de Aragón"; el Texto Refundido de las Leyes civiles aragonesas; arts. 172 y ss. de la Ley 1/1973 de 1 de marzo, por la que se aprueba la Compilación del Derecho Civil Foral de Navarra.

${ }_{305}$ Banacloche Palao, J., Las diligencias preliminares..., ob. cit., p. 81.

${ }^{306}$ Ello, entendemos que sin desconocer las dificultades de exhibición de aquellos testamentos como el hilburuko, testamento otorgado por el que se halle en peligro inminente de muerte regulado en el art. 23 de la Ley 5/2015, de 5 de junio, de Derecho Civil Vasco cuya redacción por escrito al tiempo del otorgamiento no es necesaria cuando la urgencia del caso no lo permita y sin perjuicio de su redacción lo antes posible una vez hechas las declaraciones por el testador.

${ }^{307} \mathrm{Al}$ respecto afirma Gimeno Sendra, V., Derecho procesal civil..., ob. cit., p. 356 que nos encontramos ante una diligencia de escasa virtualidad práctica que puede ser interesante respecto de los testamentos ológrafos. Ello, pese a que, como pone de manifiesto Garciandía González, P.M., La regulación de..., ob.cit., p. 782 "respecto de este supuesto, se ha llegado a afirmar que con unanimidad la doctrina procesalista lo extiende a todo documento que se encuentre protocolizado o archivado en un despacho u oficina pública o mercantil" con cita del AAP de Asturias (sección 6a) de 22 de noviembre de 1999, ponente Ilmo. Sr. J.M. Barral, f.j.2º (AC 199918143), que afirmó: “[...] Es cierto que el núm. $3^{\circ}$ del referido precepto se refiere exclusivamente al «testamento, codicilo o memoria testamentaria», pero con unanimidad la doctrina procesalista lo extiende a todo documento que se encuentre protocolizado o archivado en un despacho u oficina pública o mercantil . En el presente caso se trata de un banco...” 
Actos de Última Voluntad, que le indicará la notaria donde este se encuentre ${ }^{308}$, y en la que se podrá justificar su interés legítimo así como solicitar la exhibición ${ }^{309}$ del acto de última voluntad ${ }^{310}$. Con fundamento en lo anterior, se ha sostenido en la doctrina que esta diligencia preliminar no podrá prosperar cuando el acto de última voluntad se haya otorgado en escritura pública teniendo en cuenta que la diligencia preliminar que de forma similar contemplaba la ALEC exoneraba explícitamente al obligado si en el acto de ser requerido designaba el archivo o protocolo donde se encontrara el original ${ }^{311}$, considerándose así la exhibición de testamentos hechos ante notario como una exclusión del ámbito objetivo de las diligencias preliminares ${ }^{312}$. Sin embargo lo anterior, debe tenerse en cuenta que la nueva regulación de la diligencia contenida en el ordinal $3^{\circ}$ del art. 256.1 LEC ha eliminado la exención de exhibición del acto de última voluntad que se contenga en un archivo o protocolo, lo que es coherente con la posibilidad de que el titular de los mismos deniegue la exhibición o entrega de copia de última voluntad, situación esta última que entendemos salvaguarda la propia regulación actual de la diligencia preliminar.

Como requisitos propios de la diligencia en cuestión, se sostiene en la doctrina la necesidad de acreditar la defunción de la persona cuyo documento de última voluntad

\footnotetext{
${ }^{308}$ Que, no obstante, podrá negarse a la exhibición con justa causa por aplicación del art. 226 RN, como apunta Montero Aroca, J., Derecho Jurisdiccional II..., ob. cit., p. 188.

${ }^{309}$ Gimeno Sendra, V., Derecho Procesal Civil..., ob. cit., p. 277.

${ }^{310}$ Dispone el art. $224 \mathrm{RN}$ en sus aptdos. $1^{\circ}, 2^{\circ}$ y $3^{\circ}$ que: "1. Además de cada uno de los otorgantes, según el artículo 17 de la Ley, tienen derecho a obtener copia, en cualquier tiempo, todas las personas a cuyo favor resulte de la escritura o póliza incorporada al protocolo algún derecho, ya sea directamente, ya adquirido por acto distinto de ella, y quienes acrediten, a juicio del notario, tener interés legítimo en el documento. 2. Los Notarios darán también copias simples sin efectos de copia autorizada, pero solamente a petición de parte con derecho a ésta. En ningún caso podrá hacerse constar en la copia simple la firma de los otorgantes. Se habilita al Consejo General del Notariado para que establezca las características del papel para copia simple que deberá ser utilizado en su expedición, teniendo carácter de ingreso corporativo las cantidades que dicho Consejo obtenga por su utilización. A tal fin, el Consejo por sí o a través de los Colegios Notariales deberá proveer a los notarios de dicho papel.

El Consejo comunicará a la Dirección General de los Registros y del Notariado las características de dicho papel, así como de sus modificaciones, que se entenderán admitidas si la Dirección no resuelve lo contrario en el plazo de quince días computados desde esa comunicación.

3. Igualmente darán lectura del contenido de documentos de su Protocolo a quienes demuestren, a su juicio, interés legítimo".

311 Damián Moreno, J., Comentarios a la ..., ob. cit., p. 1685.

${ }^{312}$ Vid. el AAP de Tarragona (sección $3^{\mathrm{a}}$ ) de 24 de septiembre de 2008, ponente Ilmo. Sr. J. Perarnau, f.j. $3^{\circ}$ (LA LEY 225630/2008).
} 
de interesa ${ }^{313}$ así como la existencia del documento en cuestión, mediante la aportación de los certificados de defunción y últimas voluntades del causante ${ }^{314}$.

Tiene así por objeto la diligencia la exhibición del documento en que conste la última voluntad del causante, lo que permitirá tomar conocimiento del contenido de éste $\mathrm{y}$, por tanto, de la certeza o no de la condición del solicitante de la diligencia de heredero, coheredero o legatario. Para el caso de obtener dicha certeza, la diligencia, además, permitirá al solicitante conocer el alcance exacto de su herencia o legado, siendo idónea en aquellos casos en que se pretenda promover un proceso posterior de reclamación de la herencia o legado ${ }^{315}$, pudiendo servir la misma tanto para determinar la legitimación activa, es decir, si el que solicita la diligencia preliminar reúne la condición de heredero, coheredero o legatario, como pasiva del ulterior proceso e incluso la averiguación de los datos necesarios para fundamentar la demanda rectora del mismo $^{316}$. No obstante, y aún cuando ello, a nuestro juicio, resulta contrario al objeto y legitimación activa que con absoluta claridad delimita la diligencia preliminar en cuestión, encontramos supuestos en la doctrina en los que, al amparo del art. 256.1.3 LEC, se ha admitido la diligencia preliminar consistente en la obtención de la copia testimoniada del testamento otorgado ante fedatario público para, con conocimiento de su contenido, poder determinar la identidad de los herederos del causante frente a los que debía de despacharse ejecución judicial, al entender que este era el único medio de iniciar y llevar a término la previa sentencia dictada en un procedimiento declarativo frente a la herencia yacente ${ }^{317}$.

\footnotetext{
${ }^{313}$ Cfr. Díez-Picazo Giménez, I., Las diligencias preliminares..., ob. cit., p. 38, que apunta al señalado como el único requisito que ha sido considerado necesario para poder solicitar la diligencia del art. 256.1.3 LEC.

${ }_{314}$ Cfr. Banacloche Palao, J., Las diligencias preliminares..., ob. cit., p. 82.

${ }^{315}$ Cfr. Garberí Llobregat, J., Las diligencias preliminares..., ob. cit., p. 44. A la finalidad de esta diligencia se refiere Banacloche Palao, J., Las diligencias preliminares..., ob. cit., p. 81 al afirmar que "la información que se quiere obtener aquí es la relativa a si una persona es beneficiaria o no de dicho documento, o en qué grado lo es, pues sólo podrá reclamar con fundamento sus derechos sucesorios en un proceso posterior si previamente conoce los términos del documento hereditario, que es lo que busca obtener con la diligencia preliminar".

${ }^{316}$ Así lo refiere Díaz Núñez, J.J., Medidas cautelares y..., ob. cit., p. 15. En el mismo sentido Díaz Martínez, M., Las diligencias preliminares...., ob. cit., p. 13 y García Vila, M., Diligencias preliminares $y_{117}$, ob. cit., p. 13.

317 Vid. el AAP de Soria (sección $1^{\text {a }}$ ) de 7 de septiembre de 2004, ponente Ilmo. Sr. J.M. García, f.j.2º (JUR 2004l315253).
} 
Por otro lado, la posibilidad de solicitar la diligencia preliminar para la exhibición del acto de última voluntad que conste en un testamento ológrafo pone de manifiesto otra de las finalidades de la diligencia en cuestión. Debe tenerse en cuenta que, de conformidad con lo dispuesto en el art. $689 \mathrm{CC}$, el testamento ológrafo debe ser protocolizado presentándolo con dicho objeto al Juez de Primera Instancia del último domicilio del testador o al del lugar en que éste hubiese fallecido, dentro de los cinco años, contados desde el día del fallecimiento, pues en otro caso no será válido. También que, de conformidad con lo dispuesto en el art. $690 \mathrm{CC}$, la persona en cuyo poder se halle deberá presentarlo ante el citado juez desde que tenga noticias de la muerte del testador y, no verificándolo dentro de los diez días siguientes, será responsable de los daños y perjuicios que se causen por la dilación. Por tanto, en el caso que nos ocupa, no sólo servirá la diligencia en cuestión para la constatación de la condición de heredero del solicitante sino también para la verificación de la persona que lo posee, con el objeto de instar u obligar a la misma a la oportuna protocolización o, en su caso, reclamar la correspondiente indemnización de daños y perjuicios por la falta de presentación del testamento ológrafo ante el Juez de Primera Instancia y para su protocolización.

\subsubsection{Particularidades}

Por otro lado, debe ponerse de manifiesto que la diligencia preliminar en cuestión no ampara la obtención de documentos ajenos a los actos de última voluntad, a los que expresamente se ciñe la misma, de forma tal que quedarán fuera de su objeto, por ejemplo, las operaciones de partición de la herencia ${ }^{318}$. También, aquellos supuestos en los que por el solicitante, sin reunir la condición de heredero, coheredero o legatario, se pretenda la obtención de copia o exhibición del acto de última voluntad de un causante con el objeto de verificar si su deudor es el legítimo heredero de aquel para poder exigirle procesalmente la aceptación de la herencia con la que cobrarse la deuda $^{319}$. Por otro lado, discrepamos de la posibilidad de extender el objeto material de

\footnotetext{
${ }^{318}$ Así se afirma, en la doctrina científica, por Garciandía González, P.M., La regulación de..., ob. cit., p. 782. En la doctrina judicial, SAP de Madrid (sección $8^{\text {a }}$ ), de 4 de julio de 1996, ponente Ilmo. Sr. M. Camino, f.j. $1^{\circ}$ (AC 1996\1400).

${ }^{319}$ Vid. el AAP de Lleida (sección $2^{\text {a }}$ ) de 30 de mayo de 2003, ponente Ilma. Sra. A.V. Sainz, f.j.2º (LA LEY 97510/2003). En dicho supuesto considero la AP que la finalidad de la diligencia preliminar
} 
la diligencia a la exhibición de un testamento ya protocolizado y para la comprobación de la autenticidad de la firma del causante ${ }^{320}$ toda vez que, precisamente, constituye el objeto propio del acto de protocolización la verificación de la autenticidad de la firma del testador (art. $691 \mathrm{CC}$ ) de forma tal que la protocolización tendrá lugar cuando el juez estime justificada su identidad (art. 693 CC).

Pero, llegados a este punto, en la época en que nos encontramos, se hace preciso plantearnos si la diligencia preliminar contemplada en el art. 256.1.3 LEC ampararía la solicitud, por ejemplo, de la exhibición y entrega de copia de las conocidas como instrucciones previas a que se refiere el art. 11 LBAP, como supuesto que por analogía podría entenderse encuadrable en la diligencia preliminar que nos ocupa.

Conforme a lo indicado en dicho precepto legal, mediante dichas instrucciones previas, la persona mayor de edad, capaz y libre, puede manifestar anticipadamente su voluntad, con el objeto de que ésta se cumpla en el momento en que llegue a situaciones en cuyas circunstancias no sea capaz de expresarlos personalmente, sobre los cuidados y el tratamiento de su salud o, una vez llegado el fallecimiento, sobre el destino de su cuerpo o de los órganos de la misma. Dichas instrucciones deben constar por escrito en la historia clínica del paciente además de en el Registro Nacional de Instrucciones Previas al que pueden acceder, al margen de las personas que las otorguen y conforme a lo dispuesto en el art. 4 del RD 124/2007, de 2 de febrero, por el que se regula el Registro Nacional de instrucciones previas y el correspondiente fichero automatizado de datos de carácter personal, los representantes legales de aquellas o los que a tal efecto hubieran sido designados de manera fehaciente por estas, los responsables acreditados

solicitada no era otra que la de averiguar si existían o no bienes susceptibles de embargo en el proceso de ejecución ya entablado siendo que, a tal efecto, ya se establecen en la LEC los mecanismos oportunos para dotar de eficacia a la obligación del ejecutado de formular manifestación de cuales son sus bienes, con el correspondiente apercibimiento de sanción en caso de que excluya bienes propios susceptibles de embargo (art. 589.2 LEC) y con posibilidad de que el tribunal recabe de los organismos y registros públicos la información oportuna sobre el patrimonio del ejecutado (art. 590 LEC).

${ }^{320}$ AAP de Valladolid (sección $1^{\text {a }}$ ) de 18 de noviembre de 2004, ponente Ilmo. Sr. J.A. San Millán, f.j. $2^{\mathbf{o}}$ (LA LEY 10985/2005) en que, en apelación, se estimó procedente la diligencia preliminar consistente en la exhibición de un testamento ológrafo al objeto de comprobar si la firma que obraba en el mismo fue realizada por la causante. 
de los registros autonómicos y las personas designadas por la autoridad sanitaria de la CCAA correspondiente o por el Ministerio de Sanidad y Consumo.

A tal efecto, debe tenerse en cuenta que, como se previene legalmente, la persona otorgante de instrucciones previas o, en su caso, sus representantes legales o los designados en el documento registrado ejercerán su derecho de acceso mediante la presentación de la oportuna solicitud escrita al encargado del registro quien, previa comprobación de la identidad del peticionario, procederá a expedir la oportuna certificación acreditativa. En este caso, imaginemos que por cualesquiera circunstancias, el acceso a dicho registro hubiera de verificarse por el legítimo heredero del otorgante, que no hubiera sido designado por este representante, y que entendiera procedente conocer el contenido de las instrucciones previas otorgadas por ser su voluntad, por ejemplo, ejercitar la oportuna acción judicial para el resarcimiento de los daños y perjuicios causados como consecuencia del incumplimiento de las instrucciones previas dadas por el otorgante de las mismas. A nuestro juicio, un supuesto como el expuesto sería subsumible en la diligencia contemplada en el ordinal $3^{\circ}$ del art. 256.1 LEC en aplicación del tan aludido principio de interpretación flexible de las diligencias preliminares que se predica en la doctrina científica y judicial.

\subsection{Legitimación}

En cuanto a la legitimación activa necesaria para solicitar la diligencia en cuestión, la atribuye la LEC a quien se considere heredero, coheredero o legatario. No obstante, la redacción del precepto legal no debe llevarnos a pensar que la mera invocación o creencia del solicitante de su condición de heredero, coheredero, o legatario será suficiente para la admisión de la diligencia preliminar pues el solicitante deberá acreditar en su petición que tiene interés y justa causa para que se le exhiba el acto de última voluntad ${ }^{321}$, lo que algún autor ha identificado con el necesario

\footnotetext{
${ }^{321}$ Así lo afirma Garnica Martín, J.F., De las diligencias..., ob. cit., p. 1152, que resalta la improcedencia de una exigencia exhaustiva y la necesidad de un examen de la solicitud que permita la admisión de la diligencia cuando la exposición de razones justifiquen su necesidad.
} 
acompañamiento de un principio de prueba que justifique la condición que se invoque $^{322}$.

Sin embargo, a nuestro juicio, deberá siempre tenerse presente que la propia finalidad de la diligencia, en general, la constatación de una condición de heredero o legatario que no pueda ser verificada por otros medios, así como las circunstancias que caractericen esa condición, no permite la aplicación de un criterio estricto en el trámite de admisión, pues será lo lógico que quien se encuentre en la posición de tener que solicitar la diligencia apenas disponga de información o documentación que le permita justificar fehacientemente su relación con el causante y, en consecuencia, su interés en el conocimiento del contenido del acto de última voluntad ${ }^{323}$. No obstante, sí que deberá acreditar el solicitante su imposibilidad de obtener, por otros medios, la información que precisa con la exhibición del acto de última voluntad ${ }^{324}$, debiendo inadmitirse la diligencia preliminar cuando existan otros medios para la obtención del acto de última voluntad y el solicitante no justifique que los ha activado sin éxito alguno ${ }^{325}$.

322 Vid. Díaz Núñez, J.J., Medidas cautelares y..., ob. cit., p. 15; García Vila, M., Diligencias preliminares y..., ob. cit., p. 13. También Damián Moreno, J., Comentarios a la..., ob. cit., p. 1685, aún cuando no precisa lo que, en el caso, constituiría tal principio de prueba.

323 Como apunta Díez-Picazo Giménez, Las diligencias preliminares..., ob. cit., p. 38, resultaría "contradictorio con el contenido de la diligencia exigir al solicitante que acreditase su condición de heredero o legatario".

${ }^{324}$ En dicho sentido, el AAP de Cáceres (sección $1^{\text {a }}$ ) de 13 de junio de 2001, ponente Ilmo. Sr. A.M ${ }^{\mathrm{a}}$. González, f.j.2 $2^{\circ}$ (JUR 2001 228492). En este supuesto objeto de dicha resolución, el solicitante, desheredado por el causanteinteresaba del notario autorizante la obtención de copias de los actos de última voluntad anteriores al último en que había resultado desheredado y cuya ineficacia pretendía demandar judicialmente, al considerar que los anteriores recobrarían eficacia. La diligencia preliminar había resultado inadmitida en primera instancia, al considerar que "[...] si los documentos que pretendan aportarse al proceso se encuentran en archivo, protocolo, expediente o registro del que se puedan pedir y obtener copias fehacientes, se entenderá que el actor dispone de ellos y deberá acompañarlos con la Demanda, estimando innecesario que el Juzgado sustituya a la actividad de la parte en un Procedimiento". El solicitante recurrió en apelación al considerar que no ostentaba la condición de heredero testamentario del causante por haber sido desheredado, careciendo de legitimación para el acceso a los Protocolos de los respectivos Notarios, quienes -según afirmaba- podían denegarle lícitamente su entrega. La AP confirmó la resolución dictada en primera instancia al considerar que el solicitante, en todo caso, ostentaba la condición de heredero forzoso del causante lo que, como interesado, y de conformidad con el art. 226 del $\mathrm{RN}$, le habilitaba ante el Notario para pedir y obtener las copias de las disposiciones testamentarias interesadas.

${ }^{325}$ Tal es el supuesto contemplado en el AAP de Tarragona (sección $3^{\text {a }}$ ) de 24 de septiembre de 2008, ponente Ilmo. Sr. J. Perarnau, f.j. $3^{\circ}$ (LA LEY 225630/2008), en el que se procedió a denegar la diligencia preliminar consistente en la comparecencia del notario que autorizó un determinado acto de última voluntad, para la exhibición de este último, al existir un procedimiento específico regulado en los arts. 231 y ss. RN para obtener lo solicitado. 
En cuanto a la legitimación pasiva, la LEC la atribuye a cualquier persona física o jurídica, pública o privada ${ }^{326}$, por referirse el art. 256.1.3 LEC a la persona que tenga en su poder el acto de última voluntad del causante, por lo que será lo normal que aquella coincida con el notario que autorizó el acto de última voluntad, para el supuesto de actos de última voluntad autorizados o depositados ante el mismo, o con aquellas otras personas que por cualesquiera razones tengan en su poder el acto de última voluntad, como podría ocurrir en el caso del testamento ológrafo o los testamentos otorgados en peligro inminente de muerte o en caso de epidemia.

\subsection{Práctica de la diligencia}

En cuanto a los términos en que deberá llevarse a cabo la práctica de la diligencia preliminar, debe tenerse en cuenta que, tras su admisión, el órgano judicial deberá dirigirse al requerido para la exhibición y presentación del acto de última voluntad o instrucciones previas.

En dicho sentido, dispone el art. 259.1 LEC que deberá citarse y requerirse a los interesados para que, en la sede de la Oficina Judicial, o en el lugar y del modo que se consideren oportunos lleven a cabo la diligencia que haya sido solicitada y acordada. Pero también señala el art. 259.2 LEC que los documentos y títulos podrán ser presentados ante el juzgado para su exhibición por medios telemáticos o electrónicos, en cuyo caso su examen se realizará en la sede de la oficina judicial.

Sin perjuicio del estudio más detallado que en relación a las diligencias consistentes en la presentación de documentos y títulos se hará en el aptdo. correspondiente a la práctica de las diligencias preliminares ${ }^{327}$, entendemos que en el caso de la práctica de la diligencia de exhibición de actos de última voluntad deben distinguirse los supuestos en los que el acto de última voluntad se encuentre en un protocolo notarial, en un registro como el nacional de instrucciones previas, o en posesión de un particular. El propio art. 259.1 LEC a ello nos autoriza al señalar que

\footnotetext{
${ }^{326}$ García Vila, M., Diligencias preliminares y..., ob. cit., p. 13.

${ }^{327}$ Vid. cap. III, epígrafe 5, dedicado a la práctica de la diligencia preliminar.
} 
deberá citarse y requerirse a los interesados para que, del modo que se considere oportuno, lleven a cabo la diligencia que haya sido solicitada y acordada.

Partiendo de lo anterior, en el primero de los supuestos, cuando el acto de última voluntad se encuentre en un protocolo notarial, entendemos que deberá estarse a lo dispuesto en el art. $149.5^{\circ}$ LEC debiendo el órgano judicial dirigirse al notario mediante mandamiento en el que se interese la exhibición y/o exhibición por medios telemáticos de la copia autorizada del acto de última voluntad ${ }^{328}$ dado que el art. $32 \mathrm{LN}$ recoge la prohibición de que los documentos custodiados por los notarios salgan del edificio en que se hallen, sin perjuicio de su posterior exhibición, aún por copia autorizada.

En el caso de las instrucciones previas, de conformidad con lo dispuesto en el art. 149.6 LEC, se dirigirá oficio al Registro Nacional de instrucciones previas, solicitando la remisión por medios telemáticos de copia certificada de las mismas.

Y cuando obre en poder de un tercero, mediante citación para que el mismo comparezca en la sede de la Oficina Judicial y, sin perjuicio de la previa presentación, telemática o no, del acto de última voluntad, proceda a su exhibición. No obstante, también se admite en la doctrina que el requerido proceda a la designación del archivo protocolo donde se encuentra el documento ${ }^{329}$, entendemos, para el caso de no disponer del mismo pero conocer su localización.

\footnotetext{
${ }^{328}$ Conforme al art. $221 \mathrm{RN}$, una reproducción total de la matriz del acto de última voluntad.

${ }^{329}$ García Vila, M., Diligencias preliminares y..., ob. cit., p. 14 quien considera que la supresión de lo prevenido en el art. 500 ALEC, en cuanto a la posible liberación del particular de la exhibición del acto de última voluntad mediante la designación del archivo o protocolo donde se encuentre aquel, "no supone que el mismo no pueda seguir aplicándose". Nosotros matizamos tal afirmación en tanto en cuanto si bien la derogación de los preceptos de la ALEC no permite aplicar preceptos en ella contenidos, nada impediría la consideración de lo en él expuesto en cuanto forma de práctica de la concreta diligencia preliminar, al disponer el art. 259.1 LEC que la diligencia se lleve a cabo en el modo que se considere oportuno, entendemos, a juicio del órgano judicial. Ello permitiría, en el sentido indicado por la autora citada, que el día señalado para la práctica de la diligencia preliminar el requerido compareciera en la sede de la Oficina Judicial para designar el archivo o protocolo donde se encuentre el acto de última voluntad.
} 


\section{Exhibición de los documentos o cuentas de sociedades o comunidades} (art. 256.1.4 LEC)

"Por petición de un socio o comunero para que se le exhiban los documentos y cuentas de la sociedad o comunidad, dirigida a éstas o al consocio o condueño que los tenga en su poder".

La realidad de las relaciones de aquellos que participan de algo en común, cual es el caso de las sociedades o comunidades ${ }^{330}$, en ocasiones pone de manifiesto la necesidad de una diligencia preliminar como la enunciada, en aras a obtener una mayor protección de los derechos que el ordenamiento jurídico reconoce a los miembros de aquellas y un más ágil funcionamiento de tales entes. Ahora bien, esto debe precisarse. Una cosa es el derecho del socio o comunero a preparar el proceso y, por tanto, a solicitar de la sociedad o comunidad y de otros socios y comuneros, la exhibición de los documentos a que hace referencia el art. 256.1.4 LEC, como una manifestación más del

\footnotetext{
${ }^{330}$ Estos conceptos deben entenderse en el sentido más amplio posible y, por tanto, deben asimismo extenderse a la sociedad de gananciales, conforme al AAP de Jaén (sección $2^{\text {a }}$ ) de 27 de noviembre de 2007, ponente Ilma. Sra. M.E. Arias-Salgado, f.j. $2^{\circ}$ (LA LEY 269250/2007) y AAP de Valladolid (sección $1^{\mathrm{a}}$ ) de 10 de marzo de 2011, ponente Ilmo. Sr. F. Salinero, f.j. $1^{\circ}$ (LA LEY 44350/2011), incluso para la formación de inventario en el proceso de liquidación de la sociedad, conforme a los AAP de Madrid (sección 22a) de 4 de marzo de 2011, ponente Ilma. Sra. C. Neira, f.j. $2^{\circ}$ (LA LEY 26897/2011) y AAP de Pontevedra (sección $1^{\mathrm{a}}$ ) de 11 de noviembre de 2008, ponente Ilmo. Sr. F.J. Valdés, f.j. $3^{\circ}$ (LA LEY 327495/2008), a los clubes de fútbol, según el AAP de Madrid (sección 10ª) de 28 de mayo de 2008, ponente Ilmo. Sr. A.V. Illescas, f.j.3 $3^{\circ}$ (LA LEY 84016/2008), a las asociaciones culturales o de recreo, según el AAP de Sevilla (sección $8^{\text {a }}$ ) de 10 de julio de 2002, ponente Ilmo. Sr. J.P. Maroto, f.j. $4^{\circ}$ (LA LEY 130076/2002); a las federaciones deportivas, según el AAP de Vizcaya (sección $5^{\text {a }}$ ) de 3 de febrero de 1999, ponente Ilmo. Sr. Mª.E. Huerta, f.j.2º (AC 19991286). Así lo pone de manifiesto el AAP de Las Islas Baleares (sección $3^{\mathrm{a}}$ ) de 13 de septiembre de 2002, ponente Ilmo. Sr. C. Gómez, f.j. $3^{\circ}$ (LA LEY 149008/2002) cuando en términos generales señala que: "[...] Además, el artículo 256.1.4 debe ser interpretado en forma extensiva de manera que resulte aplicable a otros supuestos, distintos de los de la comunidad y sociedad expresamente previstos en el texto, en los que es necesaria la exhibición de documentos y cuentas para preparar correctamente un proceso, siempre que se cumplan los requisitos de justa causa e interés legítimo. Así, el auto de la Audiencia Provincial de Barcelona de 5 Jul. 1989, hizo aplicación del artículo $497.5^{\circ}$ de la Ley de Enjuiciamiento Civil, de contenido equivalente al artículo $256.1 .4^{\circ}$ de la vigente ley, a un supuesto de prestación de servicios en que se pretendía reclamar una cantidad procedente de aquellos". En cuanto a las CCPP, el AAP de Granada (sección $4^{\mathrm{a}}$ ) de 18 de octubre de 2001, ponente Ilmo. Sr. J. Maldonado, f.j. $2^{\circ}$ (LA LEY 184669/2001), dispone respecto de las mismas que: "[...] La primera consecuencia que ha de extraerse de los preceptos legales que regulan las diligencias preliminares es que, como la Ley no distingue al referirse a sociedades o comunidades, han de entenderse comprendidas dentro del mismo las Comunidades de Propietarios reguladas en la Ley de Propiedad Horizontal, por lo que, en principio, una pretensión de exhibición de cuentas por parte de un copropietario dirigida al Presidente de la Comunidad estaría incluida dentro del número 4 del art. 256 LEC antes referido".
} 
derecho fundamental a la tutela judicial efectiva reconocido en el art. $24 \mathrm{CE}$ y cuya realización tiene un cauce expresamente previsto en la LEC. Y otra muy distinta es el derecho de información que el ordenamiento jurídico les reconoce a los socios o comuneros como miembros de esas masas comunes a las que pertenecen y que, en ocasiones, podrá verse colmado a través de la diligencia preliminar que nos ocupa, pero no como modo ordinario de ejercicio del derecho de información sino como remedio subsidiario ante la necesidad de preparar el futuro proceso.

\subsection{Legitimación}

En el estudio de esta concreta diligencia cobra especial importancia la cuestión de la legitimación activa cuya regla general se desprende del propio precepto legal atribuyéndola a quien ostente la condición de socio o comunero y respecto de su sociedad o comunidad ${ }^{331}$.

Y decimos que cobra especial importancia porque, pese al tenor literal del precepto legal, la utilidad práctica de la diligencia y la diversidad de situaciones en que puede adquirirse o perderse la condición de socio o comunero, permite extender la legitimación activa al solicitante que no reúna dicha condición y en el que concurra el necesario interés legítimo exigible para la procedencia de la misma, así como negarla a aquellos en quienes concurra la referida condición.

Sobre esta cuestión, la doctrina judicial ha puesto de manifiesto tres excepciones a la regla general ${ }^{332}$. A saber:

a) Los casos en los que quien solicita la diligencia reconoce no ser socio o comunero, cuando afirme que lo que pretende reivindicar en el proceso civil posteriores

\footnotetext{
${ }^{331}$ Garciandía González, P.M., La regulación de..., ob. cit., p. 783 sostiene que "solo quien tiene esa condición puede promover esas diligencias referidas a datos y circunstancias que sólo a la sociedad y a los socios afecta y que carece de sentido que salga del ámbito societario" si bien admite los supuestos de futuros demandantes que han formado parte de la sociedad demandada y las consecuencias de su salida de la misma son las que se hallan en el origen de sus eventuales discrepancias", con cita de la SAP de Burgos (sección 2a) de 21 de febrero de 2001, ponente Ilmo. Sr. A. Picón, f.j. $4^{\circ}$ (LA LEY 41445/2001).

${ }^{332}$ Cfr. Garberí Llobregat, J., Las diligencias preliminares ..., ob. cit., pp. 45-46.
} 
el reconocimiento judicial de dicha condición que le es negada por la sociedad o comunidad, contra la que dirigirá su pretensión ${ }^{333}$.

b) Cuando quien inste la diligencia, aun cuando reconozca no ser en ese momento socio o comunero, afirme haberlo sido con anterioridad y siempre que la acción que pretende ejercitar sea, precisamente, la de nulidad del acto societario en virtud de aquel que perdió esa condición ${ }^{334}$.

${ }^{333}$ El AAP de Baleares (sección $4^{\text {a }}$ ) de 30 de septiembre de 2002, ponente Ilmo. Sr. M.A. Artola, f.j. $2^{\circ}$ (LA LEY 159501/2002) entendió que siendo el objeto de debate en la cuestión que subyacía y sería objeto del correspondiente procedimiento declarativo, la determinación de si la actuación del administrador social único había sido o no irregular en orden a privar a los solicitantes de la condición de socios que ostentaban, en sede de diligencias preliminares no cabía hacer uso del hecho formal de no ser en tal momento socios los solicitantes para denegarles el acceso a las diligencias preliminares al ser, precisamente, la eventual irregular privación de la condición de socios la que se discutiría en el proceso posterior. Por ello, considerando la resolución que, como quiera que el objeto de las diligencias preliminares, por definición, es facilitar a la parte instante una información de que carece y que precisa para ejercitar una eventual acción declarativa, información a la que, pese a tener derecho a conocer, no puede acceder sin auxilio de los tribunales, la interpretación que debe hacerse no es otra que la de facilitar el acceso a la información. Ello, para concluir que el art. 256.1.4 LEC debe interpretarse: "[...] en el sentido de que si la legitimación activa corresponde al «un socio o comunero» deberá entenderse comprendida en la misma la de quien en el momento en que se produjo la pretendida irregularidad, cuya información se pretende obtener a través de las diligencias preliminares, ostentaba tal condición de socio o comunero, aunque merced a la pretendida irregularidad hubiera sido privado de tal condición".

${ }^{334}$ Esta situación se plantea en el AAP de Vizcaya (sección $4^{\mathrm{a}}$ ) de 16 de julio de 2004, ponente Ilmo. Sr. $M^{a}$.R. Castresana, f.j. $2^{\circ}$ (LA LEY 1691059/2004) que dispuso: “[...] No puede el Tribunal acoger el contenido del auto dictado por el Juzgado de Primera Instancia, que desestima la exhibición del libro de accionistas (...) por falta de legitimación activa de la solicitante, basada en que ya su padre dejó de ser accionistas antes de su fallecimiento, pues siendo precisamente ésta el objeto de debate en la cuestión hereditaria que subyace, no cabe, en sede de diligencias preliminares, hacerse uso del hecho formal de que ya no era socio, para denegarle el acceso al libro de accionistas de la sociedad familiar en su día constituida por su padre, hermano y cuñada, pues precisamente es la transmisión o no de las accionista y si ésta fue anterior o posterior al fallecimiento de su padre, lo que se discute. Como quiera que el objeto de las diligencias preliminares, por definición, es facilitar a la parte instante una información de que carece y que precisa para ejercitar una eventual acción declarativa, información a la que, pese a tener derecho a conocer, no puede acceder sin el auxilio de los Tribunales, la interpretación judicial que ha de hacerse a tales preceptos legales no puede ser otra que la de facilitar el acceso a dicha información a aquella persona que tiene, aunque solo sea en principio, una apariencia bastante de buen derecho para acceder a tal información, pues será en el juicio declarativo donde definitivamente se juzgará su derecho". Por tanto, el art. 256.4 de la Ley de Enjuiciamiento Civil, deberá interpretarse en el sentido de que si la legitimación activa corresponde al "un socio o comunero" deberá entenderse comprendida en la misma la de quien en el momento en que se produjo la pretendida transmisión de las acciones nominativas, cuya información se pretende obtener a través de las diligencias preliminares, ostentaba tal condición de socio o comunero". En el mismo sentido, y en interpretación del art. 497.5 ALEC, la SAP de Burgos (sección $2^{\mathrm{a}}$ ) de 21 de febrero de 2001, ponente Ilmo. Sr. A. Picón, f.j.4 (LA LEY 41445/2001) Que al efecto determinó" “....] Ciertamente, el artículo 497.5 de la Ley de Enjuiciamiento Civil de 1881, concede exclusivamente a los socios la posibilidad de instar diligencias en relación con la entidad de la que forman parte y que, por ello, parece admisible que solo quien tiene esa condición pueda promover esas diligencias, referidas a datos y circunstancias que solo a la sociedad y los socios afecta y que carece de sentido que salga del ámbito societario. Sin embargo, el hecho de que los hoy recurrentes hayan formado 
c) En sentido contrario, cuando el peticionario tenga la condición de socio o comunero no podrá serle admitida a trámite la diligencia cuando a la luz de los estatutos o por la normativa por la que se rijan la sociedad o comunidad afectada, la pretensión procesal que pretende preparar no pueda ser ejercitada individualmente por el mismo sino por un colectivo de socios o comuneros ${ }^{335}$.

La doctrina judicial opta por una interpretación amplia de la legitimación activa que permita al socio o comunero obtener, en los términos que más adelante veremos, la información necesaria para la protección jurisdiccional de sus derechos en correspondencia a la relación que mantenga o haya mantenido con la sociedad o comunidad y a los términos en que esta haya discurrido o pueda discurrir. Ejemplo de ello es la negación de la legitimación activa para promover la diligencia para la preparación de un ulterior proceso en el que el solicitante no ostente legitimación individual sino colectiva.

Por lo expuesto, la afirmación realizada en la doctrina en cuanto a la necesaria acreditación de la condición de socio o comunero ${ }^{336}$ debe ser matizada en los términos anteriormente expuestos.

parte recientemente de la sociedad cooperativa demandada y de que sean las consecuencias de su salida de la misma lo que se halla en el origen de sus eventuales discrepancias con la misma, no deja de guardar una identidad de razón que hace admisible, de acuerdo con la doctrina constitucional antes dicha, la posibilidad de instar esas diligencias, pues en otro caso se limitaría sin razón de ser la posibilidad de defender los derechos de los ex-socios respecto a su actuación como tales; es decir, se estaría aplicando un mero dato formal, cual es la extinción reciente de la condición de socios, para evitar proporcionar la información que era debida a los socios cuando quienes han dejado de serlo desean poder resolver, en su caso, las diferencias que esa misma extinción de la relación societaria haya podido crear".

${ }^{335}$ El AAP de Barcelona (sección 15 ${ }^{\text {a }}$ ) de 10 de abril de 2006, ponente Ilmo. Sr. I. Sancho, f.j. $2^{\circ}$ (LA LEY 130622/2006) resuelve un supuesto en que se negó la legitimación activa al socio de un conocido club de fútbol que alegaba su voluntad de impugnar los acuerdos adoptados por las juntas directivas de la entidad deportiva regida por la normativa general de las asociaciones y por la específica de las asociaciones deportivas. Determinó la resolución que disponiendo el apartado $2^{\circ}$ del art. 20 de la Ley catalana de asociaciones, que regula el régimen de impugnación de los acuerdos adoptados por los órganos de gobierno colegiado de una asociación, que la legitimación para la impugnación correspondía, de un lado, a cualquier miembro de la Junta Directiva y, de otro, al 10\% de las personas asociadas, como quiera que el solicitante de las diligencias preliminares no acreditó representar al menos al 10\% de las personas asociadas, no era posible reconocerle legitimación para realizar la impugnación anunciada de los acuerdos adoptados por la Junta Directiva de la entidad demandada y, por ende, para prepararla interesando las diligencias preliminares solicitadas".

${ }^{336}$ Cfr. Damián Moreno, J., Comentarios a la ..., ob. cit., p. 1685. 
En cuanto a la legitimación pasiva, el propio precepto legal indica que corresponderá a la sociedad o comunidad así como al consocio o condueño, si bien exige el precepto legal la posesión por los anteriores de los documentos objeto de las diligencias preliminares. En dicha exigencia la doctrina ha encontrado la necesidad de una cierta demostración por el solicitante de la efectiva posesión de los documentos por parte de los sujetos a que se dirige la petición de diligencias preliminares ${ }^{337}$, circunstancia esta que, a nuestro juicio, puede entenderse notoria en el caso de que la solicitud de diligencias preliminares se dirija frente a la comunidad o sociedad pero no cuando la misma se dirija frente al consocio o al comunero de una edificación en régimen de propiedad horizontal, o condueño de otra forma, respeto de los que ningún deber de llevanza, custodia o posesión de los documentos objeto de la diligencia impone el ordenamiento jurídico. De hecho, la diferencia de redacción que la diligencia presenta respecto de la ALEC (art. 497.5) reside, precisamente, en que en esta última la diligencia debía de dirigirse al consocio o condueño que los tuviera en su poder y en los casos en que procediera con arreglo a derecho, mientras que en la actualidad debe dirigirse a la sociedad o comunidad o al consocio o condueño que, simplemente, los tenga en su poder. Con esto no desconoce la LEC la inexistencia de deber alguno de llevanza, custodia o posesión de los documentos de la sociedad o comunidad por aquellos en los que simplemente concurra la condición de miembros pero tampoco descarta la posibilidad de exhibición por parte de los mismos, cuando, y aquí es donde entendemos entra en juego la necesidad de una cierta demostración, los documentos pudieran estar bajo el poder de disposición de uno de los miembros de la comunidad o sociedad y no de estas.

Por otro lado, entendemos que no podrá extenderse la legitimación pasiva a los administradores de las sociedades o presidentes y secretarios de otro tipo de sociedades o comunidades cuya cualidad sea la de representantes legales de las mismas y que, por su condición de tales, podrán intervenir en el procedimientos de diligencias preliminares

\footnotetext{
${ }^{337}$ Según señala Banacloche Palao, J., Las diligencias preliminares..., ob. cit., p. 139-141, de forma especial cuando la diligencia se dirija frente a una persona física, el consocio o condueño, bastará con la aportación de los datos necesarios que puedan llevar a pensar que el requerido tiene los datos o documentos exigidos. En la doctrina judicial, corrobora lo anterior el AAP de Zamora (sección única) de 8 de enero de 2003, ponente desconocido, f.j.3 (LA LEY 4170/2003).
} 
como representantes de aquellas y no a título personal, pero si es predicable frente a cualquier tipo de agrupación de ciudadanos en que exista una puesta en común de derechos e intereses, lo que a su vez justifica el acceso a todos los documentos y cuentas comunes donde se refleje la marcha del negocio común.

\subsection{Presupuestos de admisión}

En cuanto a los presupuestos de admisión de la diligencia preliminar, como se afirma con carácter general respecto del resto de diligencias contenidas en el catálogo del art. 256.1 LEC, la misma será admisible cuando la información pretendida no pueda ser obtenida por los medios ${ }^{338}$ e incluso en los supuestos en que, según las normas civiles o mercantiles, se tenga derecho a la información y no se haya consentido al solicitante el acceso a ella evitando así que el socio o comunero se vea en la obligación de iniciar un procedimiento declarativo con la única finalidad de obtener la condena a la entrega de los libros y documentos en que consten los datos requeridos y así poder preparar el ulterior pleito, por ejemplo, en ejercicio de la acción civil de responsabilidad o de reclamación de beneficios no repartidos ${ }^{339}$.

Así, la redacción actual de la diligencia nos sitúa en el caso de las sociedades de capital, en relación a las cuales el TRLSC recoge distintos supuestos de reconocimiento del derecho de información del socio y las vías para su efectividad ${ }^{340}$. O en el caso de las

\footnotetext{
${ }^{338}$ AAP de Toledo (sección $2^{a}$ ) de 17 de diciembre de 2003. ponente Ilmo. Sr. J.M. de la Cruz, f.j. único (JUR 2004\100380).

${ }^{339}$ Así lo afirma Banacloche Palao, J., Las diligencias preliminares..., ob. cit., p. 85, lo que debe conjugarse con otros autores, como Álvarez Alarcón, A., Las diligencias preliminares..., ob. cit., p. 43 que niegan con rotundidad que la diligencia contenida en el ordinal $4^{\circ}$ del art. 256.1 LEC sea un medio para el ejercicio del derecho de información de los socios o comuneros, afirmación esta última con la que efectivamente coincidimos aún matizando que aquella será la única vía no tanto para el ejercicio de dicho derecho como para la preparación de cualquier acción civil que se vea obstaculizada mediante la cercenación del derecho de información del socio o comunero. En la doctrina judicial, el AAP de Asturias (sección $4^{\mathrm{a}}$ ) de 14 de mayo de 2003, ponente Ilmo. Sr. F. Tuero, f.j. $1^{\circ}$ (JUR 2003l232663) rechazó el recurso de apelación formulado frente al auto por el que se desestimaba la oposición a la diligencia preliminar fundada en la inexistencia de constancia de que las diligencias solicitadas sirvieran para preparar un proceso concreto "sino que más bien parece deducirse un derecho de información del socio".

${ }_{340}$ Así, el art. 93 d) TRLS que reconoce el derecho de información del socio; los arts. 196 y 197 lo concretan estableciendo los cauces para su efectividad en las SRL y SA, respectivamente; el art. 272.2 y 3 en relación a la aprobación de las cuentas anuales, y el art. 281.2 en relación a la publicidad de los documentos depositados en el Registro Mercantil.
} 
comunidades de propietarios, en que si bien la $\mathrm{LPH}^{341}$ no concreta el alcance del derecho del comunero a la información puede darse el caso de negativa del secretario a poner a disposición del comunero la documentación que tiene bajo su custodia (art. 20.e LPH), en cuyo caso este puede utilizar, por ejemplo, la facultad de pedir la convocatoria de una Junta o que se incluya en el orden del día de esta que sea tratado cualquier tema de interés para la comunidad (art. 16 LPH) $)^{342}$. Y, en cualquier caso, nos sitúa ante cualquier supuesto de necesidad de información para la preparación del ulterior proceso y con independencia de las previsiones normativas societarias existentes al respecto, dado que, a diferencia de la ALEC, la LEC ha eliminado toda referencia a los casos en que proceda con arreglo a derecho ${ }^{343}$, lo que permite afirmar que el órgano judicial deberá resolver la petición atendiendo a las circunstancias del caso concreto ${ }^{344}$.

Ahora bien, a nuestro juicio, aún cuando coincidimos con la doctrina en que la diligencia preliminar no ampara un acceso ilimitado a la documentación social o comunitaria ni un chequeo exhaustivo de la documentación social, menos aun si esta puede ser obtenida por sus propios medios por el solicitante, cual sería el caso del socio que pretende la exhibición de documentos o información obrante en el Registro

\footnotetext{
${ }^{341}$ En relación a las Comunidades de Propietarios, el AAP de Granada (sección $4^{\text {a }}$ ) de 18 de octubre de 2001, ponente Ilmo. Sr. J. Maldonado, f.j.2 $2^{\circ}$ (LA LEY 184669/2001) señala que: "La primera consecuencia que ha de extraerse de los preceptos legales que regulan las diligencias preliminares es que, como la Ley no distingue al referirse a sociedades o comunidades, han de entenderse comprendidas dentro del mismo las Comunidades de Propietarios reguladas en la Ley de Propiedad Horizontal, por lo que, en principio, una pretensión de exhibición de cuentas por parte de un copropietario dirigida al Presidente de la Comunidad estaría incluida dentro del número 4 del art. 256 LECiv antes referido". Y el AAP de Cantabria (sección $2^{\mathrm{a}}$ ) de 3 de junio de 2015, ponente Ilmo. Sr. D. M.C. Fernández, f.j. ( $^{\circ}$ (ROJ AAP S 107/2015), que señala que: "Debe comenzarse señalando que el art. 256. 4 LEC, dispone que el socio o comunero puede pedir que se le exhiban los documentos y cuentas de la sociedad o comunidad, sin hacer distinción alguna en cuanto a la clase o naturaleza de la comunidad en cuestión, por lo que no ha de hacerse tal distingo y debe entenderse que tal norma comprende también a la comunidad de propietarios, como vienen entendiendo en términos generales las audiencias provinciales (...)”.

$342 \mathrm{Al}$ respecto, vid. el AAP de Castellón (sección $1^{\mathrm{a}}$ ) de 15 de diciembre de 2009, ponente Ilmo. P.L. Garrido, f.j. $2^{\circ}$ (LA LEY 309054/2009).

${ }^{343}$ Y que en la doctrina judicial se equiparó con el derecho de examen de la contabilidad que preveía el art. 86 de la Ley de Sociedades de Responsabilidad Limitada de 23 marzo 1995 aún cuando no concebido en sentido amplio temporal sino concretado a la convocatoria de la Junta General, momento este único en el que podrá interesarse. Vid. el AAP de Córdoba (sección $3^{\text {a }}$ ) de 6 de noviembre de 1998, ponente Ilmo. Sr. E. Baena, f.j.2 (AC 199812155).

${ }^{344}$ Banacloche Palao, J., Las diligencias preliminares..., ob. cit., p. 86.
} 
Mercantil $1^{345}$, entendemos que la exhibición de los documentos o cuentas de la sociedad o comunidad no puede verse mediatizada por el carácter instrumental que se le atribuye al derecho de información del socio o comunero en relación con el de voto en la junta social o de propietarios, como formas comunes de órganos de decisión en los que se dilucida la voluntad social ${ }^{346}$. Es decir, que entendemos que el ámbito de la exhibición de documentos que contempla el art. 256.1.4 LEC no puede quedar ceñido al de la documentación necesaria para la preparación del pleito ulterior en el que, por ejemplo, se pretenda la declaración de nulidad de determinados acuerdos adoptados con ocasión de una junta y sin que el socio o comunero haya visto realizado, con ocasión de los mismos, su derecho de información. En este caso, lo que se dilucidará en el ulterior pleito es si se dio o no cumplimiento al derecho de información del socio o comunero y a tal efecto, probablemente, no será necesaria la exhibición de documentación de la sociedad o comunidad. A nuestro juicio, el ámbito objetivo de la diligencia preliminar que nos ocupa resulta independiente del derecho de voto en junta y, por tanto también, del carácter instrumental del de información respecto de este y se extiende a toda aquella documentación societaria o comunitaria que deba conocer el socio o comunero, en tanto que miembro de los entes societarios o comunitarios y para la preparación de cuantos ulteriores pleitos estime oportuno interponer contra la sociedad o comunidad o cualquiera de sus representantes o socios y por razón de esa masa de intereses que tienen en común. Pues no podemos olvidar que el socio o comunero no ostentan la condición de meros terceros sino de miembros de tales entidades.

\footnotetext{
${ }^{345}$ Ver Álvarez Alarcón, A., Las diligencias preliminares..., ob. cit., p. 42. En la doctrina judicial, vid. el AAP de Toledo (sección $2^{\mathrm{a}}$ ) de 17 de diciembre de 2003. ponente Ilmo. Sr. J.M. de la Cruz, f.j. único (JUR 2004\100380).

${ }^{346}$ Sobre el derecho de información del socio, vid. las STS de 16 de abril de 1993 (sala 1 ${ }^{\text {a }}$ ), ponente Ilmo. Sr. L. Martínez, f.j. $1^{\circ}$ (LA LEY 13128/1993), STS de 30 de noviembre de 2011 (sala $1^{\text {a }}$ ), ponente Ilmo. Sr. R. Gimeno-Bayón, f.j.2 $2^{\circ}$ (LA LEY 241444/2001) y STS de 24 de Noviembre del 2011 (sala 1a), ponente Ilmo. Sr. R. Gimeno Bayón, f.j. $3^{\circ}$ (LA LEY 240595/2011). En cuanto al derecho de información de los comuneros pertenecientes al una comunidad de propietarios, puede desprenderse del art. 20 e) LPH que impone al administrador de la comunidad la obligación de custodiar a disposición de los titulares la documentación de la comunidad.
} 


\section{3 Ámbito de aplicación}

Adentrándonos así en el objeto de las diligencias preliminares, cabe recordar que el art. 256.1.4 LEC apunta de forma expresa a los documentos y cuentas de la sociedad o comunidad, lo que nos obliga a plantearnos la extensión del objeto de la diligencia en un contexto en que, por ejemplo, las cuentas de una sociedad son objeto de publicación oficial en el Registro Mercantil al que cualquier interesado, incluido el socio, puede acudir. Entendemos que en los supuestos en que lo que se pretenda sea la exhibición de documentos que obren publicados en un registro público la mera negativa de la sociedad o comunidad a su exhibición no podrá servir de excusa para pretenderlos de la sociedad o comunidad a través de las diligencias preliminares, al ser un mecanismo tendente a remediar la imposibilidad de obtención de la información necesaria para la preparación del ulterior pleito que no esté ni pueda estar al alcance de los solicitantes. Cuestión distinta es que entendamos, como así lo hacemos, que su objeto es más extensivo que el de las propias cuentas de la sociedad o comunidad, como supuesto este último en que los documentos no estén publicitadas en ningún registro público, y en cuyo caso es el órgano judicial el que tendrá que dilucidar si la información cuya exhibición se solicita está o no a disposición del solicitante y si, no estándolo, es necesaria su obtención para la preparación del posterior pleito. Y en el ámbito societario con especial consideración de lo previsto en el aptdo. $3^{\circ}$ del art. 32 CCo conforme al cual fuera de los supuestos previstos en su aptdo. $2^{\circ}$ (sucesión universal, suspensión de pagos, quiebras, liquidaciones de sociedades o entidades mercantiles, expedientes de regulación de empleo, y cuando los socios o los representantes legales de los trabajadores tengan derecho a su examen directo) la exhibición de los libros y documentos de los empresarios que pueda decretarse debe limitarse a los puntos que tengan relación con la cuestión de que se trate. Por lo que se refiere a las comunidades y, dentro de estas y como más representativas, a las comunidades de propietarios, entendemos, al igual que lo hemos hecho con las sociedades, que la diligencia preliminar consistente en la exhibición de los documentos y libros de la comunidad debe ceñirse a aquellos que, en función de las circunstancias o interés específico, sean necesarios para la preparación del ulterior pleito. 


\subsection{Práctica de la diligencia}

En cuanto al modo de llevarse a cabo la diligencia preliminar, debe tenerse en cuenta que el art. 259 LEC ordena la presentación, física o telemática, de la documentación para su posterior exhibición en la Oficina Judicial, sin perjuicio de que el auto que accede a su práctica estime pertinente proceder a la exhibición de otro modo.

Así, pese a la confusa regulación que del modo de realización de la diligencia se contiene en dicho precepto legal citado, puede precisarse que, de conformidad con lo dispuesto en el art. 273 LEC, lo ordinario será que los documentos objeto de la diligencia se presenten físicamente en la Oficina Judicial si el requerido, persona física, comparece sin asistencia letrada y representación procesal, siendo con ocasión de la cita para la realización de la diligencia cuando proceda a la exhibición, lo que podrá coincidir con la propia presentación y, como habitualmente sucede en la práctica forense, aportación de copia en soporte papel o electrónico para la parte solicitante. Ello, porque no pesa sobre tal requerido persona física obligación alguna de comunicarse electrónicamente con la Administración de Justicia. Caso distinto sería el del requerido persona jurídica o el de la persona física que comparece en el procedimiento con asistencia letrada y representación procesal, en cuyo caso entendemos deberán proceder a la presentación en forma telemática de la documentación, sin perjuicio de comparecer el día señalado para la práctica de la exhibición ${ }^{347}$.

Ahora bien, no debe perderse de vista que en el ámbito societario, de conformidad con lo dispuesto el art. $33 \mathrm{CCo}$, el reconocimiento de los libros y documentos de la sociedad, ya sea general o particular, debe hacerse en el establecimiento del empresario, en su presencia o en la de la persona que comisione, debiendo adoptarse las medidas oportunas para la debida conservación y custodia de los libros y documentos. Luego, debemos preguntarnos como puede conjugarse esta previsión legal con las de los aptdos. $1^{\circ}$ y $2^{\circ}$ del art. 259 LEC. Al respecto no puede más

\footnotetext{
${ }^{347}$ En relación a la presentación de documentos y títulos, vid. el cap. III, epígrafe 5, dedicado a la práctica de la diligencia preliminar.
} 
que señalarse que es el propio tenor literal del aptdo. $1^{\circ}$ del art. 259 LEC el que permite que la exhibición de los libros y documentos sea realizada en un lugar distinto del de la Oficina Judicial, al disponer que en el auto por el que se acceda a la diligencia se citará y requerirá a los interesados para que, en la sede de la Oficina Judicial o en el lugar y del modo que se consideren oportunos, lleven a cabo la diligencia que ha sido solicitada y acordada debiendo entenderse que la exhibición en la Oficina Judicial a que se refiere su aptdo. $2^{\circ}$, en principio, debe quedar ceñida a los supuestos en que, facultativamente o por disposición del órgano judicial, procédala presentación física de la documentación ante el órgano judicial.

Por tanto, entendemos que en los supuestos de exhibición de documentos y libros de la sociedad deberá estarse a lo dispuesto en el art. 33 CCo procediendo a la exhibición en la sede social de la sociedad.

Y en cuanto a la exhibición de libros y documentos de la comunidad, especialmente de las CCPP, siendo reiterada la doctrina judicial que entiende que estas son entidades sin personalidad jurídica a las que la ley reconoce capacidad para ser parte (art. 6.1.5 LEC) ${ }^{348}$, deberá estarse a lo dispuesto en el art. 259 LEC. Lo anterior, teniendo siempre presente que, en la actualidad, el término documentos, a falta de previsión en contrario al respecto, debe entenderse comprensivo de todo documento que bien se halle en soporte papel bien en otro tipo de soportes instrumentales tales como los electrónicos.

\footnotetext{
${ }^{348}$ Entre las más recientes resoluciones, vid. la SAP de Valencia (sección $7^{\mathrm{a}}$ ) de 30 de junio de 2016, ponente Ilmo. Sr. M.P.E. Cerdán, f.j.2 $2^{\circ}$ (LA LEY 231584/2016); la SAP de Madrid (sección $25^{\text {a }}$ ) de 22 de enero de 2016, ponente Ilmo. Sr. C. López-Muñiz, f.j. $2^{\circ}$ (LA LEY 5843/2016); la SAP de Burgos (sección $2^{\mathrm{a}}$ ) de 19 de febrero de 2015, ponente Ilmo. Sr. J.M. Carreras, f.j.2 (LA LEY 26271/2015); la SAP de Madrid (sección 14 $4^{\mathrm{a}}$ ) de 19 de septiembre de 2012, ponente Ilma. Sra. A. Camazón, f.j.3º (LA LEY 151352/2012); la SAP de Jaén (sección 3a) de 21 de enero de 2011, ponente Ilmo. Sr. S. Regidor, f.j. $2^{\circ}$ (LA LEY 62353/2011); la SAP de Barcelona (sección 16a) de 12 de abril de 2006, ponente Ilmo. Sr. A. Ferrer, f.j. $1^{\circ}$ (LA LEY 104338/2006); y el AAP de Las Islas Baleares (sección $5^{\text {a }}$ ) de 16 de enero de 2004, ponente Ilmo. Sr. M.J. Cabrer, f.j.1º (LA LEY 9974/2004).
} 


\section{Exhibición del contrato de seguro (art. 256.1.5 LEC)}

"Por petición del que se considere perjudicado por un hecho que pudiera estar cubierto por seguro de responsabilidad civil, de que se exhiba el contrato de seguro por quien lo tenga en su poder".

Introducida la diligencia en virtud de la Enmienda número 295 del Grupo Socialista del Congreso $^{349}$ al proyecto que fue de la LEC, el art. 256.1.5 LEC refiere la petición, del que se considere perjudicado por un hecho que pudiera estar cubierto por seguro de responsabilidad civil, de exhibición del contrato por quien lo tenga en su poder.

Nos encontramos ante una diligencia preliminar que se contempla, por vez primera, en el catálogo recogido en el art. 256.1 LEC y que presenta una evidente finalidad: facilitar al perjudicado el ejercicio, por un hecho que pudiera estar cubierto por un seguro de responsabilidad civil, de la acción directa frente al asegurador (art. 76 LCS) y evitar que quede al margen de los procesos en que se dilucida la responsabilidad por los hechos dañosos cubiertos por la misma. Además, esta diligencia se justifica tanto por lo expuesto como por la inseguridad propia del perjudicado que no tiene modo alguno a su alcance de conocer la identidad del asegurador y los términos de la cobertura prestada por este ${ }^{350}$.

\section{1 Ámbito de la diligencia}

Así, el perjudicado solicitante de las diligencias podrá conocer quien ostenta la legitimación pasiva para responder en el ulterior proceso de reclamación de los daños y

\footnotetext{
${ }^{349} \mathrm{http} / / /$ www.congreso.es/portal/page/portal/Congreso/PopUpCGI?CMD=VERLST\&BASE=puw6\&DO CS=1-1\&DOCORDER=LIFO\&QUERY=\%28CDA19990326014709.CODI.\%29\# (Página183), consultado el 07/08/2017.

${ }^{350}$ En dicho sentido, Garnica Martín, J.F., De las diligencias..., ob. cit., p. 1155, puso de manifiesto que: "La falta de este instrumento procesal ha impedido que en muchos casos se haya podido ejercitar por el perjudicado la acción directa, con lo que el asegurador no ha podido ser llevado al proceso como parte en multitud de supuestos". En la doctrina judicial, el AAP de Cádiz (sección 7 $7^{\text {a }}$ de 30 de abril de 2003, ponente Ilmo. Sr. M. Gutiérrez, f.j.3 ${ }^{\circ}$ (LA LEY 79289/2003) cuando apunta que las diligencias preliminares son: “[...] el único de poder conocer la existencia de seguro que se trata de conocer".
} 
perjuicios ocasionados con ocasión y por razón del siniestro y, en suma, todas las circunstancias necesarias para fundamentar, en el ulterior juicio, su pretensión resarcitoria ${ }^{351}$. Es decir, la diligencia en cuestión persigue tener acceso, mediante la exhibición, a la información relativa al contrato de seguro que cubre la concreta responsabilidad y del que no es parte el perjudicado ${ }^{352}$ y, más concretamente, si el contrato existe, quien es su tomador, el asegurado, el asegurador y los términos y cláusulas del contrato ${ }^{353}$.

De la transcrita redacción del precepto legal se desprende, como premisa de la petición de la diligencia en cuestión, la necesidad de haber acaecido un hecho que pudiera estar cubierto por un seguro de responsabilidad civil ${ }^{354}$, sin cuya concurrencia no podrá entenderse procedente tal petición y que, a los fines de la admisión de la diligencia preliminar, deberá ser debidamente acreditado.

Determinado lo anterior, y tomando como premisa la concreta referencia a la exhibición del contrato de seguro de responsabilidad civil y no de otro distinto, descendiendo al caso concreto, debe ponerse de manifiesto que el tercero perjudicado por un evento cubierto por un seguro de responsabilidad civil será probable que desconozca su existencia y, en su caso, contenido, de forma tal que a los efectos de la acción directa prevista en el art. 76 LCS $^{355}$, el asegurado está obligado a manifestar al

\footnotetext{
${ }^{351}$ Cfr. Garberí Llobregat, J., Las diligencias preliminares..., ob. cit., pp. 47-48. En la doctrina judicial, vid. el AAP de Guipúzcoa (sección $2^{\mathrm{a}}$ ) de 14 de junio de 2007, ponente Ilmo. Sr. f.j.3º (LA LEY 172255/2007).

${ }^{352}$ Bellido Penadés, R., Comentario al artículo..., ob. cit., p. 5-19 y Álvarez Alarcón, A., Las diligencias preliminares..., ob. cit., p. 44.

${ }^{353}$ Banacloche Palao, J., Las diligencias preliminares..., ob. cit., p. 86.

${ }^{354}$ Entre los que se deben entender incluidos los más variados y distintos supuestos de cobertura de responsabilidad civil tales como los derivados de la circulación de vehículos a motor, responsabilidad civil médica, centros docentes, responsabilidad civil profesional, por animales, daños en bienes. Así lo confirman, el AAP de Valencia (sección $7^{\mathrm{a}}$ ) de 24 de octubre de 2008, ponente Ilma. Sra. C. Domenech, f.j. $2^{\circ}$ (JUR 2009164560), que contempló un supuesto de daños en bienes muebles depositados; el AAP de Madrid (sección 21 ${ }^{\mathrm{a}}$ ) de 3 de noviembre de 2009, ponente Ilma. Sra. R.M ${ }^{\mathrm{a}}$. Carrasco, f.j. $2^{\circ}$ (JUR 2010138530) que contempló un supuesto de responsabilidad civil de un arquitecto por las obras llevadas a cabo en una CCPP; el AAP de Valencia (sección 6a) de 12 de enero de 2012, ponente Ilma. Sra. M ${ }^{\mathrm{a}}$. Mestre, f.j. $3^{\circ}$ (JUR 2012\171755), que contempló un supuesto de responsabilidad civil profesional de una asesoría, y el AAP de Lleida (sección $2^{\mathrm{a}}$ ) de 21 de febrero de 2008, ponente Ilmo. Sr. A. Guilanya î, f.j. $3^{\circ}$ (LA LEY 23190/2008), en un supuesto de daños causados por un animal.

${ }^{355}$ Según el art. 76 LCS: "El perjudicado o sus herederos tendrán acción directa contra el asegurador para exigirle el cumplimiento de la obligación de indemnizar, sin perjuicio del derecho del asegurador a repetir
} 
tercero perjudicado o a sus herederos la existencia del contrato de seguro y su contenido.

Y, a nuestro juicio, no así otros documentos derivados de la ocurrencia del evento perjudicial y a los que, en ocasiones, la práctica de la diligencia se ha extendido, como es el caso de los informes periciales efectuados por razón del hecho cubierto por el seguro de responsabilidad civil ${ }^{356}$; o los recibos de pago de la prima correspondiente, dado que tales extremos son absolutamente ajenos al objeto de exhibición que configura el art. 256.1.5 LEC y a la propia finalidad de la diligencia. La literalidad de artículo en cuestión no puede ser más determinante de lo que constituye el objeto de la diligencia, el contrato de seguro, y, por tanto, ninguna interpretación flexible de la misma, a nuestro juicio, ampararía la exhibición de documentos que en modo alguno son necesarios para el ejercicio de la acción directa frente al asegurador prevista en el art. 76 LCS o, como a continuación exponemos, para el ejercicio de cualquier acción derivada del contrato de seguro y cuyo contenido sea de necesario conocimiento al efecto.

contra el asegurado, en el caso de que sea debido a conducta dolosa de éste, el daño o perjuicio causado a tercero. La acción directa es inmune a las excepciones que puedan corresponder al asegurador contra el asegurado. El asegurador puede, no obstante, oponer la culpa exclusiva del perjudicado y las excepciones personales que tenga contra éste. A los efectos del ejercicio de la acción directa, el asegurado estará obligado a manifestar al tercero perjudicado o a sus herederos la existencia del contrato de seguro y su contenido".

${ }^{356}$ Ello se admitió por el AAP de Barcelona (sección 19a) de 23 de enero de 2008, ponente Ilmo. Sr. M.J. Collado, f.j. $4^{\circ}$ (LA LEY 7780/2008) en el que se accedió a la práctica de la diligencia preliminar consistente en la exhibición por parte de la entidad aseguradora del informe pericial y expediente confeccionados con ocasión del siniestro cubierto por el seguro, disponiendo que: “[...] Atendidos los antecedentes expresados observamos como el solicitante, en su escrito inicial se refiere a la negativa de la compañía aseguradora a facilitarle la pericial en la que se sustentó el rechazo del siniestro así como las circunstancias temporales que impidieron la practica de otra pericial por su parte. Un ajustado examen de la solicitud del recurrente y la pretensión manifestada sobre la causa futura permiten acceder a su solicitud en cuanto si el apartado $5^{\circ}$ del Art. 256,1 LEC contempla que un perjudicado por un hecho que pudiera estar cubierto por seguro de responsabilidad civil pueda solicitar exhibición del contrato de seguro por quien lo tenga en su poder mucho mas le corresponderá esta opción a quien ha sido parte del mismo; en el mismo sentido y en cuanto a la documentación referida a la pericial practicada así como la que sustenta la negativa de la compañía aseguradora considerada la naturaleza del contrato suscrito entre las partes y la necesaria justificación de la decisión de la aseguradora, parece oportuna su admisión a los mismos efectos". En contra, vid, el AAP de Alicante (sección 5a) de 12 de mayo de 2004, ponente Ilma. Sra. M ${ }^{a}$.V. Pérez, f.j. $1^{\circ}$ (LA LEY 112104/2004), en el que se procedió a denegar la diligencia preliminar consistente en la exhibición de un informe pericial elaborado por una entidad aseguradora para la CCPP de la que formaba parte el solicitante de diligencias preliminares y en relación a un siniestro padecido por el mismo en un local de su propiedad determinando la resolución que la diligencia del art. 256.1.5 LEC: “[...] sólo permite la exhibición de contrato de seguro y no de los informes que se hayan podido realizar con ocasión del mismo". 
No obstante, debe ponerse de manifiesto el planteamiento que hace la doctrina científica y judicial en relación a la posibilidad de extender el objeto de la diligencia preliminar a la exhibición de otros contratos de seguro, que no a otros documentos, distintos del de responsabilidad civil $^{357}$, lo que a nuestro juicio sería perfectamente admisible en virtud del principio de interpretación flexible de las diligencias preliminares que ha sido invocado en la doctrina judicial y científica ${ }^{358}$ y dado que, en este caso, se respetaría la esencia de la diligencia, la exhibición del contrato. Aún más,

357 Posibilidad que es admitida en la doctrina científica por Garberí Llobregat, J., Las diligencias preliminares..., ob. cit., p. 47 y Banacloche Palao, J., Las diligencias preliminares..., ob., cit., pp. 86-87. En la doctrina judicial, por el AAP de Madrid (sección 19a) de 20 de mayo de 2005, ponente Ilmo. Sr. E. Legido, f.j.3 (LA LEY 114140/2005), en relación a la exhibición de un seguro de vida, explicando profusamente que: “[...] adoptar una diligencia preliminar hace necesario no sólo la concurrencia de los requisitos generales sino estar en presencia de los supuestos que contempla la ley. En nuestro caso concreto la parte recurrente, que en su día solicitó la diligencia preliminar, acudió y acude al $n^{\circ} 5^{\circ}$ del apartado $1^{\circ}$ del artículo 256, lo que hace razonadamente por entender que no se puede acudir a una interpretación restrictiva o exclusivamente literal a la hora de acercarse al repetido apartado $5^{\circ}$ cuando hace mención a la exhibición del contrato de seguro por quien lo tenga en su poder conectándolo, exclusivamente, con el seguro de responsabilidad civil. Idéntica razón a la recogida en el apartado $5^{\circ}$ se da también cuando estemos en presencia del seguro de vida, e incluso en este segundo caso se agudizará más la necesidad de dar entrada a la diligencia preliminar pues normalmente el seguro de vida se celebra por persona distinta al beneficiario, que puede no tener en su poder la total documentación del repetido seguro, sin la cual difícil será ejercitar, en el marco de la tutela efectiva, y con garantía de éxito, la pretensión que derive del contrato de seguro y de las obligaciones asumidas por la aseguradora en aquél contrato aleatorio. Por tanto el "númerus cláusus" comporta la necesidad de interpretar extensivamente los supuestos que contempla la LEC conectando el artículo 256, esencialmente, con el artículo 261 del propio cuerpo legal, de manera que si el desarrollo de la propia medida cautelar permite dar entrada a hechos novedosos, que tengan encaje en el artículo 256, preciso será, cuando se den los requisitos generales y la necesaria conexión entre el supuesto contemplado en la norma y el que se pretende introducir en la misma, extender la medida cautelar a aquellas peticiones que puedan desde la razonabilidad y la utilización de los criterios interpretativos del artículo 3.1 del Código Civil, especialmente los criterios sistemáticos y finalista, acoger peticiones que ciertamente se ajustan a derecho, como ocurre con póliza y hacer viable, sin perjuicio de lo que se resuelva en sentencia definitiva, la articulación de la pretensión". También el AAP de Barcelona (sección 14 a) de 15 de junio de 2006, ponente Ilmo. Sr. F.J. Pereda, f.j.1 ${ }^{\circ}$ (LA LEY 150667/2006), en un supuesto de exhibición de la póliza del seguro de accidentes, determinó: “[...] Es cierto que el art. 256.1,5 LEC solo regula el deber de exhibición de contrato de seguro para el caso de que se trate de seguro de responsabilidad civil, de conformidad con las previsiones de los arts. 73 a 76 LCS y no para los seguros de personas (vida, accidentes, enfermedad y asistencia sanitaria). La Ley configura este contrato de tal forma que el tercero perjudicado puede desconocer su existencia, y por ello, a los efectos de la acción directa, el asegurado está obligado a manifestar al tercero perjudicado o a sus herederos la existencia del contrato de seguro y su contenido.

Sin embargo, en relación con cualquier contrato de seguro el art. 1258 C.c. obliga a la compañía aseguradora a responder, conforme a la buena fe, de los términos del contrato y a dar la información precisa a la otra parte contratante para su efectividad. Es cierto que el asegurado no es, propiamente, ni tomador ni asegurador pero sí es una persona a cuyo favor se estipula un derecho, que puede exigir su cumplimiento (art. $1257,2^{\circ}$ C.c.)".

${ }^{358} \mathrm{Y}$ así lo corrobora en la doctrina científica Garberí Llobregat, J., Las diligencias preliminares..., ob cit., p. 48 y, en la doctrina judicial, el AAP de Madrid (sección 19ª ) de 20 de mayo de 2005, ponente Ilmo. Sr. E. Legido, f.j.3º (LA LEY 114140/2005). 
no apreciamos en la labor legislativa circunstancia alguna que permita afirmar la voluntad del legislador contraria a una aplicación de la diligencia a supuestos de exhibición documental que no lo sean del concreto contrato de seguro de responsabilidad civil, y si de otros, y que guarden con este una identidad de razón.

\subsection{Legitimación}

En cuanto a la legitimación activa, la misma corresponde a quien pretenda iniciar, como perjudicado, un proceso para exigir la responsabilidad en que otro hubiera incurrido $^{359}$, razón por la cual en el escrito de petición de la diligencia preliminar se deberán hacer constar las circunstancias del hecho dañoso causante del perjuicio ${ }^{360} \mathrm{y}$, añadimos nosotros, acompañándose de la acreditación de la realidad del anterior.

En cuanto a la legitimación pasiva, no limitándola el art. 256.1.5 LEC a persona alguna concreta, coincidimos con la doctrina científica en que no es necesario que la diligencia se dirija ni contra la compañía de seguros, cuya identificación además será parte del resultado de la exhibición del contrato, ni contra el propio causante de los daños, permitiendo el precepto legal que sea dirigida contra cualquier persona respecto de la que, fundadamente, se intuya o presuma, la tenencia del contrato, cual sería, por ejemplo, el caso de los agentes o corredores de $\operatorname{seguros}^{361}$.

\subsection{Práctica de la diligencia}

En cuanto a la práctica de la concreta diligencia preliminar, son válidos en este apartado los comentarios realizados al hilo del estudio de las anteriores diligencias preliminares en cuanto a que, de conformidad con lo dispuesto en el art. 273 LEC, lo

\footnotetext{
359 Álvarez Alarcón, A., Las diligencias preliminares..., ob. cit., p. 44 y Banacloche Palao, J., Las diligencias preliminares..., ob. cit., p. 131.

${ }_{360}$ Garberí Llobregat, J., Las diligencias preliminares..., ob. cit., p. 47.

${ }^{361}$ Banacloche Palao, J., Las diligencias preliminares..., ob. cit., p. 140. En similares términos, Álvarez Alarcón, A., Las diligencias preliminares..., ob. cit., p. 44. En la doctrina judicial, el AAP de Guipúzcoa (sección $2^{\mathrm{a}}$ ) de 14 de junio de 2007, ponente Ilma. Sra. Y. Domeño, f.j.2º (LA LEY 172255/2007), en cuyo supuesto contemplado se ordenó la exhibición del contrato de seguro por el representante de la entidad mercantil frente a la que se pretendía accionar en reclamación de los daños y perjuicios sufridos como consecuencia del fallecimiento de una paciente asistida médicamente por la mercantil".
} 
ordinario será que el contrato de seguro objeto de la diligencia se presente físicamente en la Oficina Judicial si el requerido, persona física, comparece sin asistencia letrada y representación procesal siendo con ocasión de la cita para la realización de la diligencia cuando proceda a la exhibición, lo que podrá coincidir con la propia presentación y, como habitualmente sucede en la práctica forense, aportación de copia en soporte papel o electrónico para la parte solicitante. Ello, porque no pesa sobre tal requerido persona física obligación alguna de comunicarse electrónicamente con la Administración de Justicia. Caso distinto sería el del requerido persona jurídica o el de la persona física que comparece en el procedimiento con asistencia letrada y representación procesal, en cuyo caso entendemos deberán proceder a la presentación en forma telemática de la documentación, sin perjuicio de comparecer el día señalado para la práctica de la exhibición.

$\mathrm{Y}$, en contra de lo sostenido por algún autor ${ }^{362}$, entendemos que la exhibición objeto de la diligencia no puede ser sustituida con la mera facilitación a quien la reclame de la información precisa para poder interponer la demanda correspondiente, pues el art. 256.1.5 LEC es claro al prevenir la exhibición del documento.

\section{Exhibición y entrega de la historia clínica (art. 256.1.5 bis LEC)}

"Por petición del que se considere perjudicado por un hecho que pudiera estar cubierto por seguro de responsabilidad civil, de que se exhiba el contrato de seguro por quien lo tenga en su poder"

La diligencia contemplada en el art. 256.1.5 bis fue introducida en la LEC por la Disposición Final Tercera de la Ley 19/2006 363.

El propio título y contenido de la norma que introduce la diligencia preliminar, que ninguna relación guardan con la misma, así como el examen del trámite

\footnotetext{
${ }^{362}$ Damián Moreno, J. Comentarios a la..., ob. cit., p. 1686.

${ }^{363}$ Publicada en el BOE núm. 134, de 6 de junio de 2006, cuya entrada en vigor se produjo el día 07/06/2006 (Disposición Final 5a).
} 
parlamentario hasta la publicación, sin referencia alguna que justifique su introducción en el proyecto de ley, evidencia el criterio de oportunidad seguido por el legislador para introducir una diligencia preliminar que, sin apoyo normativo alguno, ya había sido admitida por cierto sector de la doctrina judicial ${ }^{364}$.

En efecto, con anterioridad a la reforma operada en la LEC por la Ley 19/2006, cierta doctrina judicial había venido admitiendo la diligencia de petición de la historia clínica.

Una veces con fundamento en una interpretación flexible y, a nuestro juicio, muy forzada, del supuesto contemplado en el art. 256.1.1 LEC, que alude a la petición de declaración de la persona a quien se dirigiría la demanda, entre otras circunstancias, sobre algún hecho relativo a la capacidad, por entender el tribunal que no resultaba ajeno a dicho supuesto el que pudiera interesarse la exhibición de documentación médica relevante en orden a fundar un criterio sobre la existencia o no de capacidad de la otorgante de un testamento que se quería impugnar ${ }^{365}$. Y decimos que, a nuestro juicio, en una muy forzada interpretación, porque resulta obvio que la capacidad sobre la que debe declararse a tenor del art. 256.1.1 LEC es la del requerido a la práctica de la diligencia preliminar y no a la del difunto cuya historia clínica se solicita y que, pudiendo carecer de capacidad, otorgó testamento. De hecho, otras resoluciones admitieron la diligencia en cuestión, con idénticos fines, sin justificación de encuadre alguno en el catálogo de la LEC y con ordenación de un trámite totalmente ajeno a la regulación contenida en la misma ${ }^{366}$.

\footnotetext{
${ }^{364}$ De hecho, a juicio de Garberí Llobregat, J., Las diligencias preliminares..., ob. cit., p. 48, su inclusión expresa en el catálogo de diligencias preliminares vino motivada por la reticencia de nuestros tribunales a incluir la entrega de un documento tan sensible como la historia clínica de un paciente en alguno de los supuestos del art. 256.1 LEC.

${ }_{365}$ El AAP de Girona (sección $2^{\text {a }}$ ) de 5 de Junio de 2003, ponente Ilmo. Sr. J.M. Fernández, f.j. $3^{\circ}$ (LA LEY 100175/2003) vino a aceptar la procedencia de la diligencia preliminar solicitada a los efectos de poder conocer la capacidad que tenía una testadora cuando otorgó testamento al ser la voluntad del solicitante de las diligencias preliminares la de impugnar dicho acto de última voluntad.

${ }^{366} \mathrm{Tal}$ es el caso del AAP de Barcelona (sección $11^{\mathrm{a}}$ ) de 18 de abril de 2006, ponente Ilmo. Sr. F. Herrando, f.j. $2^{\circ}$ (LA LEY 116299/2006), que ordenó la realización de la diligencia preliminar por los trámites de los arts. 300 y ss. LEC relativos a la exhibición de documentos por terceros.
} 
Otras veces, al considerar el tribunal que la solicitud de la historia clínica de un familiar fallecido, al resultar necesaria para efectuar un análisis de las circunstancias concurrentes durante el ingreso de aquel en un centro médico, con la finalidad de documentar y, en su caso, poder dirigir las acciones judiciales contra quienes se entendiera concurriera responsabilidad, es una expresión del derecho a la tutela judicial efectiva $^{367}$.

También, al entender que los derechos especiales reconocidos en los arts. 16 y 18 LABP, y arts. 8 y 15 LOPD, podían ser ejercidos por el interesado a través de las diligencias previstas en los aptdos. $2^{\circ}$, referido a la exhibición de la cosa, y $7^{\circ}$, cuya redacción originaria venía referida a la petición de las diligencias y averiguaciones que, para la protección de determinados derechos, prevean las correspondientes leyes especiales $^{368}$, del art. 256.1 LEC.

Incluso bajo el régimen de la ALEC, que tampoco contemplaba la diligencia en cuestión, en el caso de historiales de los propios solicitantes ${ }^{369}$, como expresión de un derecho reconocido en la legislación sanitaria, y pese a que en relación al catálogo de diligencias preliminares que aquella contemplaba operó en su máxima y más estricta aplicación el criterio del numerus clausus. De hecho, ya vigente la LEC pero aún no introducida la diligencia del actual art. 256.1.5 bis LEC, la doctrina judicial también negó la procedencia de la diligencia con amparo en dicho criterio ${ }^{370}$.

\footnotetext{
${ }^{367}$ AAP de Vizcaya (sección $3^{\text {a }}$ ) de 18 de enero de 2005, ponente Ilma. Sra. M ${ }^{\text {a }}$ C. Marco, f.j.3 $3^{\circ}$ (LA LEY 9171/2005).

${ }^{368}$ AAP de Madrid (sección 14 ${ }^{\text {a) }}$ de 3 de marzo de 2005, ponente Ilmo. Sr. P. Quecedo, f.j.2 ${ }^{\circ}$ (LA LEY 50942/2005).

${ }^{369}$ El AAP de Las Islas Baleares (sección $3^{\text {a }}$ ) de 5 de Octubre de 2000, ponente Ilma. Sra. C.M. Moragues, f.j. $2^{\circ}$ (LA LEY 178637/2000) señala: “[...] Aplicando la doctrina anteriormente expuesta al caso hoy sometido a la decisión de este Tribunal, en el que, además no existe real oposición del INSALUD a la exhibición solicitada respecto de la historia clínica de D. Antonio F. G., como no podía ser de otra forma al ser un derecho del paciente expresamente reconocido en la legislación sanitaria procederá, con estimación del recurso interpuesto revocar en parte la sentencia apelada, en el sentido de estimar en parte la solicitud de diligencias preliminares formulada por D. Antonio F. G. en el extremo referido a la exhibición de su historial médico urológico".

${ }^{370}$ Así, el AAP de Las Palmas (sección 4a ) de 23 de septiembre de 2005, ponente Ilma. Sra. E. Galcerán, f.j.único (LA LEY 183769/2005) señala que: "[...] no puede ser estimada ya que no puede incardinarse en ninguno de los apartados que contempla el art. 256 LEC, regulador de las diligencias preliminares precepto legal que tiene la naturaleza de "numerus clausus"; o el AAP de Barcelona (sección 19a) de 27 de abril de 2006, ponente Ilmo. Sr. M.J. Collado, f.j. $2^{\circ}$ (LA LEY 123501/2006); o el AAP de Guipúzcoa
} 
Pero lo cierto es que el legislador entendió pertinente el reconocimiento legal expreso de la diligencia preliminar en el catálogo del art. 256.1 LEC permitiendo al justiciable la petición de la historia clínica al centro sanitario o profesional que la custodiase, "en las condiciones y con el contenido que establece la ley" y, como el resto de diligencias preliminares, a los únicos fines de preparar el juicio posterior ${ }^{371}$.

Ello cuando, a diferencia del resto de supuestos de diligencias preliminares, el derecho que subyace en la misma, el de acceso a la historia clínica, ya tenía reconocimiento legal, nada más y nada menos que desde la LGS que en sus arts. 10.5 y 6 plasmó por vez primera el derecho de acceso del paciente a su historia clínica, siendo reconocido el mismo como una prestación del Sistema Nacional de Salud. Por ello hemos de reflexionar sobre las razones que, desde nuestro punto de vista, justificarían la introducción de la diligencia preliminar en cuestión en el referido catálogo.

A tal efecto no podemos desconocer que siempre han sido frecuentes las dificultades que los pacientes, o las personas a él vinculadas, han encontrado para acceder a sus propias historias clínicas ${ }^{372}$. Ello, pese a que el incumplimiento de la obligación de hacer efectivo el derecho de acceso a los pacientes constituye una lesión grave del derecho fundamental a la intimidad, a la protección de datos y justificaría tanto la acción de tutela ante las AEPD como la apertura de un procedimiento contencioso administrativo o un procedimiento civil preferente y sumario de tutela de los derechos fundamentales ${ }^{373}$.

(sección $2^{\mathrm{a}}$ ) de 14 de junio de 2007, ponente Ilma. Sra. Y. Domeño, f.j.2 ${ }^{\circ}$ (LA LEY 172255/2007), si bien es cierto que en este último caso la solicitud de la diligencia preliminar se fundó en el núm. $4^{\circ}$ del art. 256.1 LEC que siquiera una mínima relación puede unirle a la exhibición de la historia clínica.

${ }^{371}$ Pues como se indica el AAP de A Coruña (sección $4^{\mathrm{a}}$ ) de 28 de abril de 2011, ponente Ilmo. Sr. C.Fuentes, f.j. $3^{\circ}$ (AC 2011\11317), no se puede "[...] acudir directamente al procedimiento judicial de las diligencias preliminares por comodidad o una desconfianza injustificada".

372 Así lo pone de manifiesto Lamarca Iturbe, I., Los problemas que la ciudadanía ha planteado al Ararteko con relación a la historia clínica, en "Papeles Médicos", Vol. 23, nº 1, 2014, pp. 20-24, donde se vienen a analizar los problemas que la ciudadanía ha planteado ante el Ararteko (conforme a lo dispuesto en el art. 15 de la Ley del Ararteko 3/1985, de 27 de febrero, Alto Comisionado del Parlamento Vasco para la defensa de los derechos de las personas en relación con las actuaciones y políticas públicas de las administraciones públicas de la CCAA del País Vasco).

${ }^{373}$ Así lo afirma Troncoso Reigada, A., La protección de datos personales en búsqueda del equilibrio, edit. Tirant Lo Blanch, Valencia, 2010, p. 1185. 
Y aún cuando es cierto que esta mera problemática, por si sola, no justificaría la introducción en el ordenamiento jurídico de una diligencia preliminar como la que nos ocupa, pues puede ser solventada por los cauces antes expuestos, no lo es menos que la misma se manifiesta en toda su extensión cuando tal derecho de acceso se ejercita con una finalidad distinta del mero acceso. Es decir, cuando se ejercita con la finalidad instrumental de contar con mejores elementos de juicio que los, por ejemplo, transmitidos por la entidad sanitaria, con el fin de analizar lo sucedido y decidir si se inicia o no un procedimiento judicial. Más aún, si tenemos en cuenta que será el propio centro sanitario que custodie la documentación el que, a la postre y de hecho, decida los términos en que da cumplimiento a tal derecho fundamental, cuando el mismo, por los términos en que es ejercido, pudiera llegar a comprometer otro como el de la tutela judicial efectiva. Por tanto, no podremos perder de vista que el acceso a la historia clínica con fines judiciales está vinculado con el derecho a la tutela judicial efectiva que tiene el mismo nivel de derecho fundamental que el derecho a la intimidad.

\subsection{Justificación de la diligencia}

La primera y principal justificación de la introducción en el catálogo del art. 256.1 LEC de la diligencia preliminar que nos ocupa es la de garantizar el derecho a la tutela judicial efectiva cuando la preparación de cualquier procedimiento judicial ponga de manifiesto la necesidad de la obtención de una historia clínica, con independencia de que la solicitud la formule el propio paciente, los familiares a él vinculados o un tercero. Incluso, cuando el fallecido hubiera prohibido expresamente tal acceso, los datos contenidos en la historia clínica pueden resultar determinantes para el resarcimiento de los daños causados a los herederos.

Y es que no podemos olvidar que, ejercido el derecho de acceso, el centro sanitario que custodie la historia clínica, para dar cumplimiento a tal derecho, deberá ajustarse a los términos que a tal efecto marcan la LABP y LOPD, que no le otorgan margen alguno para permitir el acceso a la historia clínica, por ejemplo, de las personas vinculadas al paciente fallecido en caso de que tal acceso haya sido prohibido por el 
propio paciente, o de terceros ajenos a los anteriores y cuyo pretendido acceso no venga motivado por un riesgo para su salud.

Llegados a este punto parece razonable entender que se hace necesaria la intervención del juez cuando se pretende hacer un uso legítimo de esa finalidad instrumental $^{374}$ del derecho de acceso a la historia clínica y tal derecho no ha sido satisfecho por el centro sanitario público o privado que la custodie pues, en otro caso, entendemos que el derecho fundamental a la tutela judicial efectiva (art. $24 \mathrm{CE}$ ) podría verse cercenado.

De hecho, el reconocimiento legal del derecho de acceso a la historia clínica que se hace en el art. $18 \mathrm{LABP}^{375}$ a favor del propio paciente, a favor de las personas vinculadas a el por razones familiares o de hecho ${ }^{376}$, en caso de fallecimiento de este y salvo que el mismo haya dispuesto lo contrario no es pleno. Y, además, es inexistente para terceros ajenos a dicha historia clínica pues como sujetos activos del derecho no incluye la LABP a aquellos terceros que, ostentando un interés legitimo en el

${ }^{374}$ La misma ha sido reconocida por autores como Flores Prada, I., Algunas consideraciones sobre el régimen jurídico-procesal de los informes clínicos, en "Revista Electrónica de Ciencia Penal y Criminología", 15-17, 2013, p. 3.

${ }^{375}$ Dispone el art. 18 LABP que: "1. El paciente tiene el derecho de acceso, con las reservas señaladas en el apartado 3 de este artículo, a la documentación de la historia clínica y a obtener copia de los datos que figuran en ella. Los centros sanitarios regularán el procedimiento que garantice la observancia de estos derechos.

El derecho de acceso del paciente a la historia clínica puede ejercerse también por representación debidamente acreditada.

El derecho al acceso del paciente a la documentación de la historia clínica no puede ejercitarse en perjuicio del derecho de terceras personas a la confidencialidad de los datos que constan en ella recogidos en interés terapéutico del paciente, ni en perjuicio del derecho de los profesionales participantes en su elaboración, los cuales pueden oponer al derecho de acceso la reserva de sus anotaciones subjetivas.

Los centros sanitarios y los facultativos de ejercicio individual sólo facilitarán el acceso a la historia clínica de los pacientes fallecidos a las personas vinculadas a él, por razones familiares o de hecho, salvo que el fallecido lo hubiese prohibido expresamente y así se acredite. En cualquier caso, el acceso de un tercero a la historia clínica motivado por un riesgo para su salud se limitará a los datos pertinentes. No se facilitará información que afecte a la intimidad del fallecido ni a las anotaciones subjetivas de los profesionales, ni que perjudique a terceros".

${ }^{376}$ El informe 171/2008 de la AEPD ha interpretado la expresión "personas vinculadas a él por razones familiares o de hecho", a la luz de lo dispuesto en la Ley Orgánica 1/1982, de 5 de mayo. La interpretación conjunta de ambas normas permitiría el ejercicio del derecho de acceso a la historia clínica del fallecido al cónyuge o persona vinculada con aquél por una relación de hecho similar, ascendientes y descendientes, así como a las personas que hubieran sido designadas por el fallecido para ejercer las acciones a las que se refiere la propia Ley Orgánica y, en última instancia, a los herederos que además se encontrasen vinculados a aquél por relaciones familiares o de hecho. 
conocimiento del contenido de una concreta historia clínica, ni tengan con el paciente fallecido vínculos familiares o de hecho, ni cuya salud no corra riesgo alguno ${ }^{377}$.

Por tanto, la intervención judicial no sólo se haría necesaria en determinados supuestos de dificultad en que el paciente o, en caso de fallecimiento del mismo y sin que concurra prohibición, las personas a él vinculadas pretendieran preparar un juicio posterior que ponga de manifiesto la necesidad de conocimiento del contenido de la historia clínica. También se haría necesaria en aquellos supuestos en los que el paciente fallecido hubiera prohibido el ejercicio del derecho a las personas a él vinculadas, pues por imperativo legal el centro sanitario no podría entregársela, y en aquellos supuestos de terceros que por las mismas razones, y en ausencia de riesgo para su salud, necesitaran el conocimiento de su contenido. Estas personas quedan al margen de la configuración legal del derecho de acceso a la historia clínica de la LABP y, por ello, necesitarían del auxilio judicial propio de las diligencias preliminares.

\subsection{Las anotaciones subjetivas ¿limitan el objeto de la diligencia?}

Pero resulta que también desde el punto de vista de la extensión material del derecho legalmente reconocido se aprecian limitaciones que, entendemos, en caso de ejercitarse el derecho con la aludida finalidad instrumental, deben ser corregidas.

Centrándonos por tanto en la situación del ejercicio del derecho de acceso a la historia clínica por el paciente o, en caso de su fallecimiento, por las personas a él vinculadas, y también por terceros ajenos a los anteriores que ostenten un interés legítimo tutelable jurisdiccionalmente, cabe comenzar por señalar que, en el caso del paciente, dispone el aptdo. $1^{\circ}$ del art. 18 LABP que el mismo tiene el derecho de acceso a la documentación de la historia clínica y a obtener copia de los datos que figuran en ella, con las reservas señaladas en el aptdo. $3^{\circ}$ del mismo precepto legal.

\footnotetext{
${ }^{377}$ En tal supuesto encajaría el de aquellos cuyo derecho se pusiera de manifiesto como consecuencia de su decisión de proceder a la legítima impugnación de un testamento otorgado por un fallecido de cuya capacidad psíquica, al tiempo del dicho otorgamiento, se pudiera dudar.
} 
De conformidad con el tenor literal del precepto legal, el derecho de acceso no puede ejercitarse por el paciente en perjuicio del derecho de terceras personas a la confidencialidad de los datos que constan en ella recogidos en interés terapéutico del paciente, ni en perjuicio del derecho de los profesionales participantes en su elaboración, los cuales pueden oponer al derecho de acceso la reserva de sus anotaciones subjetivas. Y, aún cuando la norma no lo precise, entendemos que dichas limitaciones son igualmente oponibles a las personas vinculadas al paciente a las que alude la norma, en tanto que causahabientes de su derecho.

Así las cosas, sin que objeción alguna pueda merecer el derecho de terceras personas a la confidencialidad de sus datos que puedan obrar en la historia clínica de un paciente, lo que más llama la atención, y más controvertido ha sido, es la exclusión que se hace del derecho de acceso del paciente y, por extensión, de sus familiares, a las llamadas anotaciones subjetivas ${ }^{378}$, respecto de las que se ha puesto de manifiesto un supuesto derecho a la intimidad de los profesionales sanitarios ${ }^{379}$ que pudiera entrar en colisión con el derecho de acceso a la historia clínica que la LABP reconoce. De ahí la posibilidad de dichos profesionales de oponer la reserva de sus anotaciones subjetivas que reconoce el aptdo. $3^{\circ} \mathrm{del}$ art. $18 \mathrm{LABP}$.

Centrados por tanto en las anotaciones subjetivas de los profesionales la primera cuestión que nos planteamos es si esta reserva, en cuanto limitación del derecho de acceso a la historia clínica, es oponible en el procedimiento de diligencias preliminares dado que, como ya expusimos, la petición que permite el art. 256.1.5 bis LEC debe admitirse en las condiciones y con el contenido que establece la ley.

Y resulta que el primer problema que plantea la limitación del derecho en cuanto a las anotaciones subjetivas gira en torno a lo que debe entenderse con tal expresión,

\footnotetext{
${ }^{378}$ Tal circunstancia es advertida por Gallego Riestra, S., Historia Clínica Electrónica y derecho a la autonomía del paciente: un conflicto de intereses, en "Papeles Médicos", Vol. 23, núm. 1, 2014, p. 10 y Sáiz Ramos, M. y Larios Risco, D., El derecho de acceso a la historia clínica por el paciente: Propuesta para la reserva de anotaciones subjetivas, en "DS: Derecho y Salud, Vol. 18, núm. 1, 2009, p. 26.

${ }_{379}$ Así se pone de manifiesto en el art. 18.3 LABP y lo resaltan determinados autores como Hernando, P., Seoane, J.A., y De Asís, J.F., La reserva de las anotaciones subjetivas: ¿derecho o privilegio?, en "Revista Calidad Asistencial", Vol. 21, núm. 1, 2006, p. 36.
} 
sorprendiendo que, pese a constituir una evidente limitación de un derecho como el que nos ocupa, la LABP nada diga al respecto. Sí lo hace la diversa normativa autonómica, aún contradictoriamente.

Así, en las diversas normas que han hecho referencia a ellas, se definen las anotaciones subjetivas como "las impresiones de los profesionales sanitarios, basadas en la exclusiva percepción de aquéllos, y que, en todo caso, carecen de trascendencia para el conocimiento veraz y actualizado del estado de salud del paciente, sin que puedan tener la consideración de un diagnóstico" 380; "las valoraciones personales, sustentadas o no en los datos clínicos de que se disponga en ese momento, que no formando parte de la historia clínica actual del/de la paciente o usuario/a, puedan influir en el diagnóstico y futuro tratamiento médico una vez constatadas" ${ }^{381}$; "las impresiones de los profesionales sanitarios no sustentadas directamente en datos objetivos o pruebas complementarias y que, en todo caso, resulten de interés para la atención sanitaria al paciente y que expresamente sean calificadas como tales por el profesional que las realiza" "382; o, "las impresiones o valoraciones personales de las y los profesionales sanitarios no sustentadas directamente en datos objetivos o pruebas complementarias y que, en su criterio, resulten de interés para la atención sanitaria de la persona paciente" ${ }^{383}$. También aquellas que puedan encuadrarse en los conceptos de "valoraciones sobre hipótesis diagnósticas no demostradas, sospechas acerca de incumplimientos terapéuticos, sospechas de tratamientos no declarados, sospechas de hábitos no reconocidos, sospechas de haber sido víctima de malos tratos, comportamientos insólitos" ${ }^{384}$.

Y en el ámbito de la doctrina científica se definen como "los comentarios o impresiones personales que puede hacer el médico en un momento determinado,

\footnotetext{
${ }^{380}$ Art. 32.4 d) de la Ley 3/2005, de 8 de julio, de información sanitaria y autonomía del paciente, de Extremadura.

${ }^{381}$ Art. 21 del Decreto 29/2009, de 5 de febrero, por el que se regula el uso y acceso a la historia clínica electrónica en Galicia.

${ }^{382}$ Art. 21 del Decreto 24/2011, de 12 de abril, de la documentación sanitaria en Castilla y La Mancha.

${ }^{383}$ Art. 7.4 Decreto 38/2012, de 13 de maro, sobre historia clínica y derechos y obligaciones de pacientes y profesionales de la salud en materia de documentación clínica, en el País Vasco.

${ }^{384}$ Circular 1/2009 del SECAM en base a los trabajos desarrollados en el seno del Proyecto de Historia Clínica Digital del Sistema Nacional de Salud.
} 
siempre que tengan trascendencia clínica (en otro caso no deberían incluirse en el historial)" 385 .

A la vista de las definiciones expuestas y teniendo en cuenta que uno de los principios generales que informan la regulación jurídica e interpretación de la historia clínica es el principio de vinculación asistencial con el paciente ${ }^{386}$, lo primero que cabe cuestionarse es qué observaciones subjetivas de un profesional sanitario que, evidentemente deben guardar relación con la asistencia sanitaria del paciente, pueden o deben contenerse en su historia clínica y que el mismo, o las personas con él vinculadas, o incluso terceros con un interés legítimo en el conocimiento de aquella, no puedan o no deban conocer $^{387}$.

Al efecto de documentar tal posibilidad podríamos traer a colación el supuesto del paciente de avanzada edad aquejado por distintas patologías cuyo médico que ha llevado el caso, tras observar ciertas actitudes y algunos comentarios de los familiares, cree que estos no tienen interés en que el paciente se recupere y que están pendientes de su fallecimiento para repartirse la herencia. El profesional escribe tal suposición en la historia clínica porque piensa que en el domicilio podrían darse actitudes de abandono del paciente y para conocimiento de los profesionales y el caso de que vuelva a ingresar. Dado el aceptable estado general del enfermo, pese a su afectación, es dado de alta hospitalaria con indicación de tratamiento e imprescindible control evolutivo por su médico de cabecera y con la conveniencia de completar su estudio por un especialista. Su médico de cabecera considera al paciente terminal, el enfermo refiere estar cansado de los controles del especialista y, por dichos motivos, y para no agobiar al paciente, no se completó el estudio. A la semana reingresa y fallece. Al cabo de unos días algunos

\footnotetext{
${ }^{385}$ Sánchez Caro, J. y Abellán-García, F., Derechos y deberes de los pacientes (Ley 41/2002, de 14 de noviembre: consentimiento informado, historia clínica, intimidad e instrucciones previas), edit. Comares, 2003 , p. 75.

${ }^{386} \mathrm{Al}$ respecto, vid. Gallego Riestra, S., Historia Clínica Electrónica..., ob. cit., p. 8.

${ }^{387}$ Como ponen de manifiesto Sáiz Ramos, M. y Larios Risco, D., El derecho de..., ob. cit., pp. 36-37, discrepando las definiciones normativas y doctrinales en un punto fundamental como es la trascendencia clínica o no de las anotaciones subjetivas y debiendo descartarse las definiciones que excluyen la relevancia clínica de las anotaciones subjetivas -por su inadecuación a lo dispuesto en el art. 15 LABP-si partimos de la irrelevancia clínica de las anotaciones subjetivas, la pregunta es obligada: ¿que sentido tiene incorporarlas a la historia clínica?
} 
familiares solicitan al médico del hospital un informe de la estancia del paciente, que les es entregado. Una semana más tarde solicitan la historia clínica completa alegando una posible mala praxis ${ }^{388}$.

Sin dejar de conocer las distintas resoluciones de la AEPD que avalan la reserva $^{389}$, nos preguntamos la razón por la cual las impresiones de los profesionales sanitarios que carecen de trascendencia para el conocimiento veraz y actualizado del estado de salud del paciente deben constar en la historia clínica. Conforme a las definiciones ofrecidas podríamos considerar que las anotaciones subjetivas son datos improcedentes en la historia clínica que en modo alguno en ella debieran constar. Y si se incluyen se debería afirmar que tales anotaciones son relevantes y, por tanto, no deben excluirse de la copia o información que se facilite al interesado, pues no se alcanza a comprender como las mismas, por el documento en que se insertan, pueden comprender aspecto alguno relevante de la intimidad de los profesionales que elaboran la historia clínica pues, en rigor entendemos, los datos que afecten a la intimidad de tales profesionales en modo alguno debieran hacerse constar en ella.

Lo anterior se entendería mejor frente al impensable símil de incluir en un expediente administrativo, o incluso judicial, apreciaciones personales del funcionario de turno que, obviamente, no deben incluirse en el mismo, o cualquier otro dato que debiendo incluirse en el expediente su conocimiento se pretenda hurtar a los interesados en el mismo. Este derecho de reserva de datos que, en suma, obran en un expediente administrativo, llamado historia clínica, resulta impensable en otros ámbitos de la administración ${ }^{390}$. Resultaría impensable que un magistrado, o un LAJ, hurtara del conocimiento del interesado parte de un determinado expediente judicial invocando su

\footnotetext{
${ }^{388}$ Ejemplo tomado de Beltran, J.M., et. al., Intimidad, confidencialidad y secreto, en "Guías de ética en la práctica médica”, Fundación de Ciencias de la Salud, 2005, Madrid, pp. 33-36.

${ }^{389}$ En dicho sentido, la AEPD en su resolución $n^{\circ} \mathrm{R} / 02690 / 2012$, afirma: "Esto es, que a la hora de reproducir las historias clínicas solicitadas por los pacientes o allegados se reservará la información aportada por un tercero recogida en interés terapéutico del pacientes y las anotaciones subjetivas de los facultativos que se opongan a su entrega. Impidiendo que a la hora de reproducir el documento que las contiene éstas aparezcan en la copia, debiendo facilitar toda la documentación que se establece en el artículo 15 de la LAP, entre la que se encuentra, la hojas evolución, las horas de órdenes médicas, la evolución y planificación de cuidados de enfermería...".

${ }^{390}$ Consideraciones que, por razón del derecho en cuestión, deben entenderse extensivas a aquellos supuestos en que la historia clínica sea custodiada por centros sanitarios privados.
} 
derecho a la intimidad. Menos aún frente al propio interesado y salvo que, como ocurre en el ámbito de la Administración de Justicia, la imposibilidad venga determinada por una previa y motivada decisión judicial con fundamento en razones que ninguna relación guardarán con la intimidad del juzgador o funcionario en cuestión.

Esto debe ponerse en relación con las condiciones en que la petición de diligencia preliminar puede concederse conforme a lo dispuesto en el art. 256.1.5 bis LEC. Es decir, en las condiciones y con el contenido que establece la ley. La pregunta que nos hacemos a la vista de lo establecido por dicho precepto legal es la respuesta que obtendría una solicitud de petición de diligencia preliminar articulada para obtener, a través de la misma, una historia clínica que extrajudicialmente hubiera sido entregada pero con reserva de las anotaciones subjetivas. Incluso, la respuesta que obtendría la negativa del centro sanitario a cumplimentar la diligencia preliminar sin la reserva de las anotaciones subjetivas de los profesionales.

Así las cosas, y aún lo dispuesto en el art. 18.3 LABP, podríamos afirmar que no existe un derecho de reserva de los profesionales sanitarios, diferente de los mecanismos de tutela de la confidencialidad y de los derechos disponibles para cualquier ciudadano, que pueda actuar a modo de privilegio ${ }^{391}$. Máxime cuando la LBAP no aclara qué son las anotaciones subjetivas, pese a que se permite su reserva, ni tampoco qué debe entenderse cuando precisa que la disponibilidad de la historia clínica no puede ir en perjuicio de los profesionales, como si estos no estuvieran sujetos a responsabilidad o la investigación de esta, por ejemplo, por una mala praxis, fuera la única finalidad de la obtención de la historia clínica.

Por ello entendemos que, solicitada la diligencia preliminar, si el tribunal considera necesaria la aportación de los datos contenidos en una historia clínica los mismos deben ser proporcionados, dado que la decisión del centro de no facilitar la información solicitada, o facilitarla parcialmente, resultaría contraria al art. 118 CE. Y, en cualquier supuesto, para el caso de entender el centro sanitario que esta no debe

${ }^{391}$ Hernando, P., Seoane, J.A. y De Asís, J.F., La reserva de...., ob. cit., p. 37. 
remitirse completa, incluso por la reserva del profesional en cuestión, cumplimentar la diligencia en los términos que se considere con la oportuna formulación de oposición en cuanto a aquellos datos que bien en virtud de reserva de anotaciones subjetivas, bien en virtud de cualquier otra razón, el centro considere que no se deben aportar. Ello, porque pese al tenor literal del art. 18.3 LABP, entendemos que deberá ser el tribunal el que, ponderando las circunstancias del caso concreto determine si resulta procedente que la diligencia preliminar en cuestión sea cumplimentada, o no, con la reserva de las anotaciones subjetivas de los profesionales dado que es la intervención de aquel la única que puede garantizar y, por tanto asegurar, la relevancia de cualquier dato que obre en una concreta historia clínica para la preparación de un litigio posterior. Entendemos que la relevancia de tales datos no puede quedar a criterio de aquellos cuyas anotaciones subjetivas, por ejemplo, puedan incidir en la posible responsabilidad que legalmente pueda serles reclamada. Igualmente, siquiera el denominado estado de necesidad terapéutica recogido en el art. 7 LABP podrá oponerse al conocimiento del contenido de tales anotaciones subjetivas, dado que también dicha limitación podrá ser invocada por el requerido de diligencias preliminares en la fase de oposición, como deber legal y no como derecho, siendo el tribunal quien determine si excepcionalmente está justificada la reserva de información por una finalidad legítima, específica y determinada: la finalidad asistencial.

Al margen de supuestos que entendemos no comprendidos en el ámbito de la diligencia preliminar del art. 256.1.5 bis LEC como, por ejemplo, el de un paciente que requiriera su historia clínica, para la búsqueda y contraste de una segunda opinión y no para la preparación de un ulterior proceso, resulta que la diligencia del art. 256.1.5 bis LEC sería la única vía por la cual tanto el paciente, como fallecido este, sus familiares $\mathrm{y}$, en su caso, los terceros ajenos no unidos a aquel por vínculo alguno de parentesco y sin riesgo para su vida, podrían acceder a la historia clínica de forma íntegra. Ello sí, siempre que en la correspondiente solicitud de diligencias preliminares se precise que la misma se solicita, por ejemplo, con inclusión en ella de las anotaciones subjetivas de los profesionales que hayan participado en la elaboración de la historia clínica y sin posibilidad de que por estos se oponga reserva alguna, lo que tampoco podrá evitar, habida cuenta el reconocimiento legal de la oposición de la reserva, que por el requerido 
se discuta los términos del requerimiento, lo que entendemos habrá de discutirse en la correspondiente oposición. De no hacerse tal precisión, nada impedirá que la historia clínica se facilite sin inclusión de dichas anotaciones subjetivas de los profesionales cuya ausencia de la que se facilite entendemos, en tal caso, siquiera debe ser referida.

Limitaciones como la apuntada pueden dar lugar a supuestos no deseados por la Ley. A saber, que el paciente y, fallecido este, las personas a él vinculadas, obtengan la historia clínica de los centros sanitarios públicos o privados en la forma que ellos entiendan más oportuna y pertinente y no de forma tal que permita al solicitante preparar el proceso ulterior en aquellos términos a que tiene derecho, con absoluto conocimiento de todas y cada una de las circunstancias contempladas en la misma.

\subsection{Concreción del objeto, legitimación y práctica de la diligencia}

Como del precepto legal se desprende, el objeto de la diligencia no es otro que la exhibición de la historia clínica, definida en el art. 3 LABP, como el conjunto de documentos que contienen los datos, valoraciones e informaciones de cualquier índole sobre la situación y la evolución clínica de un paciente a lo largo del proceso asistencial y cuyo fin principal es, como señala el art. 15.2 LABP, facilitar la asistencia sanitaria, dejando constancia de todos aquellos datos que, bajo criterio médico, permitan el conocimiento veraz y actualizado del estado de salud.

Y a nadie se le escapará que es el destacado carácter confidencial de estos datos, por demás expresado en el art. 7.1 LABP, el que aconsejaba la introducción de la diligencia en la LEC, compatibilizando así la imposibilidad de que "cualquiera" pueda tomar conocimiento de dichos datos y la finalidad fundamental de ayudar en la resolución de los casos más evidentes de conflicto, producidos como consecuencia de algún tipo de negligencia médica tras la cual se pretenda perseguir las eventuales responsabilidades que de la misma puedan derivar.

Ello, porque dichos datos y la documentación en la que se contienen constituyen no sólo un objeto de especial protección, desde el punto de vista ético, deontológico y 
legal, sino también un medio de prueba de extraordinaria importancia ante reclamaciones judiciales de responsabilidad frente a los profesionales de la sanidad o sus empleadores en las que convergen intereses diversos, fundamentalmente del paciente, el médico o sanitarios y el centro ${ }^{392}$. Y no parece razonable que la revisión y consideración de las anotaciones subjetivas se deje a criterio de los propios facultativos que las crean.

En último lugar, y como nota a destacar, cabe señalar que la legitimación activa para formular dicha petición la ostentará “cualquier potencial litigante inmerso en alguna clase de conflicto relacionado con el contenido de una historia clínica" ${ }^{393}$ habida cuenta que, conforme a lo dispuesto en el art. 18 LABP, toda persona puede acceder a su propia historia clínica y, si ha fallecido, podrán hacerlo las personas vinculadas por razones familiares o de hecho, salvo que el fallecido lo hubiese prohibido expresamente y así se acredite.

En cuando a la forma de practicarse la diligencia, son predicables al presente supuesto todas las consideraciones hechas al hilo del estudio de las diligencias anteriores, en cuanto a la presentación y exhibición de los documentos.

\section{Concreción de los integrantes del grupo de consumidores y usuarios (art.}

\subsubsection{LEC)}

"Por petición de quien pretenda iniciar un proceso para la defensa de los intereses colectivos de consumidores y usuarios al objeto de concretar a los integrantes del grupo de afectados cuando, no estando determinados, sean fácilmente determinables. A tal efecto el tribunal adoptará las medidas oportunas para la

\footnotetext{
${ }^{392}$ Como indica Rives Seva, J.M., Consideraciones generales acerca de la responsabilidad civil médica y sanitaria. Cuestiones de Derecho sustantivo y procesal en la materia, en "Diario La Ley", 2004, núm. 6011 (LA LEY 846/2004) p. 8: "Desde el punto de vista jurídico interesa la documentación clínica por constituir el elemento probatorio más importante de la actuación de los profesionales sanitarios en un determinado proceso. Dado el detalle y exactitud con que se elaboran las historias clínicas, tanto respecto a las actividades realizadas, las medidas adoptadas y los momentos de su ejecución, es por lo que en la mayoría de las acciones este soporte documental constituye el único elemento disponible para la reconstrucción de los hechos acaecidos".

${ }^{393}$ Cfr. Garberí Llobregat, J., Las diligencias preliminares..., ob. cit., p. 50.
} 
averiguación de los integrantes del grupo, de acuerdo a las circunstancias del caso y conforme a los datos suministrados por el solicitante, incluyendo el requerimiento al demandado para que colabore en dicha determinación".

\subsection{Introducción}

Como bien sabemos todos, la protección de los consumidores y usuarios al contratar bienes y servicios con un empresario ha adquirido un importante protagonismo en los últimos años. Quizá, porque hoy en día se encuentran al alcance de las personas todo tipo de productos y bienes para el consumo, proliferando las relaciones de intercambio propias del consumo masivo de bienes y servicios.

Pero, en la misma medida en que dichas relaciones proliferan, los conflictos entre los prestadores de los servicios y los consumidores son absolutamente frecuentes. $\mathrm{Y}$ en dicho contexto, cobra especial importancia el mandato contenido en el art. 51 CE conforme al cual corresponde a los poderes públicos garantizar la defensa, entre otros, de los legítimos intereses económicos de los consumidores y usuarios protegiéndolos mediante procedimientos eficaces.

No obstante tal mandato constitucional, esa relación de conflicto entre consumidores y empresarios suele estar presidida por una patente desigualdad de las posiciones de las partes que, habitualmente, opera como elemento disuasorio del consumidor en la defensa judicial de sus derechos, pues son numerosas las dificultades a las que se puede enfrentar un consumidor en el acceso a la justicia. Los importantes costes de cualquier litigio frente a la escasa cuantía económica de la gran mayoría de los procedimientos en materia de consumo, la falta de recursos económicos de muchos consumidores, la duración del proceso, la complejidad jurídica de determinadas relaciones de consumo, las habituales trabas que los prestadores de servicios oponen a los consumidores ante reclamaciones de información que permitan al consumidor preparar el futuro litigio, la ventaja de los prestadores de servicios debido a su familiaridad con el proceso y su fácil acceso al asesoramiento profesional, entre otras muchas, son circunstancias que, por regla general, llevan al consumidor individual a 
desechar la posibilidad de emprender un litigio en reclamación de sus derechos como consumidor $^{394}$.

Antes de la publicación de la LEC, eran varias las normas que desde tiempo atrás venían reconociendo de forma progresiva un mayor y mejor haz de derechos a favor del consumidor ${ }^{395}$. No obstante, se trataba de normas que operaban en la dimensión material o sustantiva, y no procesal, de la defensa de los derechos de los consumidores de forma tal que el mero reconocimiento de tales derechos sin dotación de medios o procedimientos procesales eficaces para hacer valer aquellos, resultaba de todo punto insuficiente para garantizar la auténtica defensa del consumidor. Y aún cuando el art. 7.3 LOPJ determinaba que los Juzgados y Tribunales protegerían los derechos e intereses legítimos, tanto individuales como colectivos, sin que en ningún caso pudiera producirse indefensión reconociendo, para la defensa de estos últimos, la legitimación de las corporaciones, asociaciones y grupos que resulten afectados o que estén legalmente habilitados para su defensa y protección, la ALEC nada preveía al respecto. Tampoco las reformas posteriores a su publicación atajaron la cuestión y tan sólo de forma puntual determinadas normas establecían reglas procesales de aplicación a la materia ${ }^{396}$.

Por ello, el legislador nacional y comunitario fue centrando sus esfuerzos en adoptar las medidas necesarias que permitieran la implantación de métodos

\footnotetext{
${ }^{394}$ Vid. Bachmaier Winter, L., La tutela de los derechos e intereses colectivos de consumidores y usuarios en el proceso civil español, en "Las acciones para la tutela de los intereses colectivos y de grupo", UNAM, México,https://archivos.juridicas.unam.mx/www/bjv/libros/7/3046/3.pdf, (consultado el 10 de agosto de 2017), p. 2.

${ }^{395}$ Comenzando por la norma fundamental que en la materia vino integrada por la Ley 26/1984, General para la Defensa de los Consumidores y Usuarios (LGDCU) que fue el primer texto legal que, además, reconoció la accionabilidad de pretensiones colectivas y, simultáneamente, la legitimación para que las ejercitaran las asociaciones de consumidores. Y, con posterioridad, y especialmente, otras como la Ley 34/1988, de 11 de noviembre, General de Publicidad; la Ley 26/1991, de 21 de noviembre, sobre contratos celebrados fuera de establecimientos mercantiles, la Ley 7/1995, de 23 de marzo, de Crédito al Consumo; la Ley 7/1996, de 15 de enero, de Ordenación del Comercio Minorista; la Ley 7/1998, de 13 de abril, de Condiciones Generales de la Contratación; la LSSI; la Ley 23/2003, de Garantías en la Venta de Bienes de Consumo y el TRLGCU.

${ }^{396}$ En materia de prueba, los arts. 26 y 28 LGDCU y art. 24 LSSI; sobre publicidad de las sentencias, el art. 21 LCGC o art. 31 LGP; y sobre acumulación de acciones colectivas en el art. 16 de esta última.
} 
extrajudiciales o procesos judiciales útiles y ventajosos para el consumidor ${ }^{397}$. Así, en el ámbito del consumo en masa, fue el reconocimiento de la existencia de una pluralidad de intereses de tipología diversa, pero con la nota común de su carácter supraindividual, el que determinó la evolución del derecho procesal en relación a las acciones dirigidas a obtener una tutela de los intereses generales o supraindividuales de los consumidores y usuarios $^{398}$. Dicho en otros términos, en relación a la defensa colectiva de los derechos de consumidores y usuarios como instrumento adecuado de tutela y satisfacción de intereses que afectan a una pluralidad de individuos de difícil determinación.

Y en España fue con ocasión de la entrada en vigor de la LEC cuando la protección del consumidor adquirió un verdadero y unitario tratamiento procesal que facilitaría su tutela ${ }^{399}$. La LEC no sólo hizo un reconocimiento expreso de la legitimación de las asociaciones de consumidores y usuarios para defender en juicio los derechos e intereses de sus asociados y sus intereses generales, además de los de la asociación (art. 11.1 LEC), sino que también reconoció la legitimación necesaria para litigar a los propios consumidores y usuarios, perjudicados por un hecho dañoso, constituidos en un grupo de afectados, cuyos componentes estén determinados o sean fácilmente determinables (art. 11.2 LEC) siempre que dicho grupo esté constituido por la mayoría de afectados (art. 6.1.7 LEC), condición esta necesaria para, junto con las anteriores, entender que el grupo ostenta la necesaria capacidad para ser parte en el proceso civil.

Ahora bien, con la nueva regulación y ante la dificultad de la determinación de los miembros integrantes del grupo $^{400}$, resultaba indispensable establecer los

\footnotetext{
${ }^{397}$ Vid. Marcos Francisco, D., Nuevas medidas de defensa de los consumidores en materia de acciones colectivas, asistencia jurídica gratuita, costas y tasas judiciales, en "InDret", 2015, núm. 4, p. 5.

${ }^{398}$ Gascón Inchausti, F., La protección de los consumidores en el proceso civil español, en http://eprints.ucm.es/23856/1/2005_La_protecci\%C3\%B3n_de_los_consumidores_en_el_proceso_civil_e spa\%C3\%B1ol.pdf (consultado el 10 de agosto de 2017), pp. 9 y 10.

${ }^{399}$ Cfr. Larrosa Amante, M.A., Mecanismos procesales para el acceso de los consumidores a la justicia, en "Revista Jueces para la Democracia. Información y Debate," 2003, núm. 47, p. 13.

${ }^{400} \mathrm{Al}$ respecto vid. Alvariño Viega, C., La tutela judicial efectiva de las asociaciones de consumidores y usuarios tras la Ley de Enjuiciamiento Civil, en "Boletín del Ministerio de Justicia", 2003, núm. 1953, p. 3669.
} 
instrumentos adecuados para la efectividad de esa nueva forma de tutela ${ }^{401}$. Un avance de la LEC como el que acabamos de exponer hubiera quedado vacío de contenido si, al expreso reconocimiento de la legitimación y capacidad para ser parte de los grupos de afectados, no le hubiera acompañado la necesaria herramienta que permitiera a cualquier consumidor o usuario la determinación de sus componentes para, a la postre, poder constituirlo en su mayoría.

Será lo normal que quien pretenda el ejercicio de una acción colectiva carezca de los datos necesarios para identificar a los concretos consumidores afectados por el hecho dañoso, tratándose además esta de una información que estará en posesión del profesional a quien se pretende demandar y que no estará muy dispuesto a facilitar a quien se dispone a demandarlo. $\mathrm{Y}$ en dicha tesitura es donde, a juicio de la doctrina científica $^{402}$, encuentra su justificación la diligencia preliminar del ordinal $6^{\circ}$ del art. 256.1 LEC cuya finalidad última, como de su tenor literal se desprende, es el conocimiento de los sujetos que deben formar parte del grupo de afectados que pretende $\operatorname{accionar}^{403}$ y que, de conformidad con el art 15.2 LEC, deberán comunicar su propósito de demandar, previamente a su presentación, a todos los afectados ${ }^{404}$.

Justificada la previsión legal de la diligencia preliminar en cuestión, su concreto análisis pasa por un estudio del sujeto activo, los posibles sujetos pasivos, su objeto y los medios o concretas actuaciones a través de las cuales poder materializar las formas de determinación del grupo de afectados que, debidamente constituido, y conforme al art. 11.2 LEC, pueda litigar en juicio.

\footnotetext{
401 En dicho sentido, Garnica Martín, J.F. De las diligencias..., ob. cit., p. 1155, al afirmar que "consecuentemente con la nueva regulación que se introduce con la protección de los derechos de grupos, resultaba indispensable establecer los instrumentos adecuados para la efectividad de esa nueva forma de tutela".

${ }^{402}$ Gimeno Sendra, V., Derecho Procesal Civil, ob. cit., p. 279.

${ }^{403}$ Cfr. Garberí Llobregat, J., Las diligencias preliminares..., ob. cit., p. 52 y Larrosa Amante, M.A., Mecanismos procesales para..., ob. cit., p. 17. En la doctrina judicial ello es identificado con la justa causa e interés legítimo, sirviendo de ejemplo el AAP de Madrid (sección $20^{\mathrm{a}}$ ) de 8 de julio de 2010, ponente Ilmo. Sr. R.F. Rodríguez, f.j.4 (LA LEY 138539/2010), que identificó la justa causa e interés legítimo con la necesaria colaboración de una entidad bancaria en la determinación de aquellos clientes que contrataron un determinado producto.

${ }^{404}$ Salvedad hecha, de conformidad con el art. 15.4 LEC, de la preparación de los procesos en ejercicio de una acción de cesación para la defensa de los intereses colectivos y de los intereses difusos de los consumidores y usuarios, en cuyo caso no será necesaria la comunicación prevista en el art. 15.2 LEC.
} 


\subsection{Legitimación}

Comenzando por el estudio de la legitimación activa para promover la diligencia preliminar, debe recordarse que el art. 256.1.6 LEC reconoce la misma a favor de quien pretenda iniciar un proceso para la defensa de los intereses colectivos de consumidores y usuarios, lo que exige determinar quiénes pueden iniciar tal proceso. A priori, tal y como se concluye en la doctrina científica, de conformidad con el art. 11.2 LEC están legitimadas, tanto las asociaciones de consumidores y usuarios como las entidades legalmente constituidas que tengan por objeto la defensa o protección de éstos y los propios grupos de afectados ${ }^{405}$, sujetos estos últimos a quienes el art. 6.1.7 LEC les reconoce capacidad para ser parte en juicio civil. En todo caso, cuando resulten afectados por un hecho dañoso y los individuos que lo compongan estén determinados o sean fácilmente determinables, siendo necesario, para demandar en juicio, que el grupo se constituya con la mayoría de los afectados.

Conforme a lo anterior podrá afirmarse, por tanto, que no sólo las asociaciones de consumidores y usuarios y las entidades que tengan por objeto la defensa o protección de éstos tendrán legitimación activa para promover la diligencia del ordinal $6^{\circ}$ del art. 256.1 LEC sino también los propios afectados por un hecho dañoso que, a título individual, pretendan constituir el grupo de afectados, para conocer el número e identidad del resto, lo que no impide que estando determinado un número importante de los afectados todos ellos, de consuno, promuevan la diligencia preliminar para la identificación del resto. En cualquier caso, acreditando su condición de afectados por el hecho dañoso.

Lo anterior determinará que quien solicite la diligencia preliminar no sea quien, finalmente, actúe como demandante en el proceso posterior con el grupo de afectados ya conformado, pues la legitimación activa del proceso principal se reconoce a este último.

${ }^{405}$ Garberí Llobregat, J., Las diligencias preliminares..., ob. cit., p. 52. 
En cuanto a la legitimación pasiva nada dice el art. 256.1.6 LEC, que con una mínima referencia apunta a la clara posibilidad de no coincidir esta con la persona del futuro demandado al determinar que el tribunal adoptará las medidas oportunas para la averiguación de los integrantes del grupo, incluyendo el requerimiento al demandado para que colabore en dicha determinación. Es decir, la LEC admite la posibilidad de que la persona del sujeto pasivo de la diligencia preliminar coincida o no con el futuro demandado hasta el punto de admitir la colaboración, como sujeto pasivo de la diligencia, de cualquier otra persona distinta del requerido (art. 261.5 LEC) ${ }^{406}$. Lo que ocurrirá cuando, por ejemplo, un consumidor solicite la diligencia para determinar a los integrantes de un grupo de afectados y lo haga frente a quien intervino en la venta directa y no frente al fabricante, que es a quien pretende demandar en el proceso posterior.

\subsection{Admisión de la diligencia}

En cuanto a la solicitud de la diligencia, entendemos que la admisión de la misma exige la verificación por el tribunal de las siguientes circunstancias:

a) La existencia de un hecho dañoso susceptible de afectar a una pluralidad de afectados fácilmente determinables ${ }^{407}$ (arts. 256.1.6 y 6.1.7 LEC), dado que el proceso

\footnotetext{
${ }^{406}$ Así lo contempla Garnica Martín, J.F., De las diligencias..., ob. cit., p. 1158 que señala que "también puede ser frecuente que esa petición de auxilio judicial para la formación del grupo vaya dirigida tanto frente a los eventuales demandados, como incluso a eventuales actores, o miembros del grupo, e incluso a terceros que puedan solicitar información necesaria para la conformación del grupo" resaltando que "es equivocada la idea de que la legitimación activa y pasiva de este procedimiento deba coincidir con la del proceso principal".

${ }^{407}$ En dicho sentido, el AAP de Barcelona (sección 16aa) de 31 de mayo de 2011, ponente Ilma. Sra. I. Zapata, f.j. $5^{\circ}$ (AC 2011\1347) al señalar que: "[...] no es suficiente que exista efectiva posibilidad de identificar a los consumidores del producto o servicio que ostenten aquella condición sino que es preciso que tal identificación pueda lograrse fácilmente". En el mismo sentido, el AAP de Girona (sección $1^{\text {a }}$ ) de 31 de enero de 2011, ponente Ilmo. Sr. F. Ferrero, f.j. $2^{\circ}$ (LA LEY 24220/2011). Debe tenerse presente que el art. 15 de la LEC distingue, a los efectos de comunicar a los consumidores y usuarios la acción ejercitada por una asociación de consumidores, que el grupo de afectados sea o no determinable. Si tal grupo de afectados no está determinado o es de muy difícil determinación, la acción ejercitada deberá simplemente comunicarse a los consumidores o perjudicados mediante medios de comunicación con difusión en el ámbito territorial en el que se haya manifestado la lesión. Mientras que si los afectados están determinados o son de fácil determinación, la demandante deberá comunicar previamente la presentación de la demanda a todos los interesados, a cuyo efecto la diligencia preliminar del art. 256.1.6 LEC permite su identificación.
} 
que a través de la diligencia preliminar puede preparar es el relativo a la defensa de los intereses colectivos ${ }^{408}$ y por un grupo de afectados, por un hecho dañoso, que sea fácilmente determinable, cuestión esta última que queda al arbitrio del tribunal ${ }^{409}$.

b) La necesidad de la diligencia o por la imposibilidad del solicitante de determinar, por si mismo, a los integrantes del grupo de afectados por el hecho dañoso, circunstancia esta que entendemos, en la generalidad de los casos y habida cuenta la naturaleza de la diligencia, podrá ser objeto de presunción. En nuestra opinión, es fácilmente advertible la circunstancia de desconocer cualquier consumidor o usuario por las personas que, en sus mismas circunstancias, se han podido ver afectadas por un hecho dañoso cuyo origen puede encontrarse en muy distintos y variados agentes productores o transmisores del daño ${ }^{410}$. No obstante, no descartamos la posibilidad de exigir el tribunal al solicitante de la diligencia una mínima actividad previa o intento de identificación, sin éxito, del resto de afectados por el hecho dañoso, lo que podría entenderse cumplido mediante la comunicación directa del solicitante de la diligencia con aquella persona física o jurídica que pudiera estar en disposición de ofrecer los datos que permitan la identificación del resto de usuarios, y por medio que permita acreditar su la fehaciencia de tal comunicación.

c) La idoneidad de la diligencia con el fin pretendido, lo que exige la exposición, con precisión, de la acción o juicio que se pretende preparar y que habrá de ser puesta en relación con la legitimación que la LEC reconoce en su art. 11.2. Por ello, entendemos que no concurrirá dicha idoneidad cuando:

(i) el solicitante de la diligencia no tenga legitimación para promover el juicio que se pretende preparar;

\footnotetext{
${ }^{408}$ Los que, según Bachmaier Winter, L., La tutela de..., ob. cit.,p. 7, existirán "cuando un grupo se encuentra en una misma situación jurídica o cuando una pluralidad de sujetos se ven afectados por un mismo hecho, y los integrantes del grupo o los afectados están determinados o pueden ser determinados sin dificultad".

${ }^{409}$ Alvariño Viega, C., La tutela judicial..., ob. cit., p. 3668.

${ }^{410}$ Sobre esta cuestión, el AAP de Madrid (sección 19 ${ }^{\text {a }}$ ) de 23 de abril de 2004, ponente Ilmo. Sr. R. Ruíz, f.j.1 ${ }^{\circ}$ (LA LEY 95517/2004) determina: “[...] Es evidente la imposibilidad o dificultan grave cuando menos para el demandante potencial de obtener los datos que solicita, debiendo estimarse el recurso (...)".
} 
(ii) cuando la acción que en ulterior juicio se pretenda promover no tenga por objeto la defensa de los intereses colectivos de consumidores y usuarios ${ }^{411}$;

(iii) cuando se persiga una finalidad que nada tiene que ver con la conformación del grupo de afectados para la defensa de intereses colectivos ${ }^{412}$;

(iv) cuando no se ofrezca al tribunal una relación circunstanciada de los hechos y fundamentos en que se funda la solicitud y la acción futura que se pretenda interponer ${ }^{413}$.

\footnotetext{
${ }^{411}$ Vid. el AAP de Madrid (sección $28^{\text {a }}$ ) de 4 de febrero de 2011, ponente Ilmo. Sr. A. Arribas, f.j. $2^{\circ}$ (AC 20111378), que al respecto señaló:“[...] sin que estén contempladas en el art. 12 de la Ley de Condiciones Generales de la Contratación. Se trata, en consecuencia, de acciones individuales que se acumularán a la acción colectiva de cesación y que se ejercitarán, según se deduce del recurso de apelación, no por la asociación en defensa de los derechos de sus asociados sino por los propios asociados bajo la misma defensa y representación que aquélla, previo otorgamiento del correspondiente poder a procurador y el pago de determinadas cantidades a la asociación". Sobre las acciones colectivas en materia de consumo según la legislación española y las pretensiones ejercitables para la tutela colectiva de los intereses, resulta muy ilustrativa la exposición hecha por Gascón Inchausti, F., La protección de..., ob. cit., pp. 1017.

${ }^{412}$ El AAP de Madrid (sección 20 $0^{\mathrm{a}}$ ) de 8 de julio de 2010, ponente Ilmo. Sr. R.F. Rodríguez, f.j. $4^{\circ}$ (LA LEY 138539/2010), denegó la diligencia preliminar que, con fundamento en el art. 256.1.6 LEC, interesó una asociación de servicios bancarios para la determinación de aquellas personas que habían contratado un concreto producto con una determinada entidad bancaria, para que esta, y a su propia costa, transmitiera a sus clientes un texto previamente preparado por la solicitante en el que se procedía a informar a los consumidores de su intención de promover una demanda en relación a aquel producto, invitándoles a personarse e intervenir en el proceso a través de la asociación. Es decir, como determina la resolución, pretendiendo utilizar a la entidad bancaria requerida como transmisora de propaganda de la propia asociación y medio de publicidad de sus servicios.

${ }^{413}$ El AAP de Madrid (sección $28^{\mathrm{a}}$ ) de 21 de mayo de 2010, ponente Ilmo. Sr. P.M ${ }^{\text {a }}$ Gómez, f.j. $1^{\circ}$ (LA LEY 101083/2010), inadmitió la solicitud de diligencias preliminares formulada al amparo del art. 256.1.6 LEC por una asociación de usuarios que omitió proporcionar al tribunal una referencia circunstanciada del asunto objeto del juicio que se quería preparar. También, el AAP de Madrid (sección $11^{a}$ ) de 1 de junio de 2010, ponente Ilmo. Sr. C.F. Duro, f.j. $4^{\circ}$ (LA LEY 107207/2010), que traía causa de una solicitud formulada por una asociación de usuarios frente a una entidad financiera y para la obtención de los listados de clientes que, en una determinada fecha, tenían en vigor determinados productos financieros comercializados por aquella y que concluyó: "[...] Precisamente en este caso ha sido la insuficiencia en la determinación de la demanda que se pretende interponer lo que ha llevado al juzgador a estimar justificada la oposición deducida”, en tanto que la definición de la demanda que se anunciaba era la de (...) interponer demanda colectiva en ejercicio de la acción de cesación, de declaración de nulidad de determinadas cláusulas por abusivas, de nulidad contractual y de reclamación de daños y perjuicios a tramitar por el cauce del juicio ordinario", considerando que resultaba insuficiente (...) la inconcreta referencia a acciones de cesación, nulidad por abusivas, nulidad contractual y reclamación de daños y perjuicios, pues es sin duda exigible una mayor concreción sobre la pretensión y el objeto del proceso". En los mismos términos, el AAP de Madrid (sección $28^{\mathrm{a}}$ ) de 4 de febrero de 2011, ponente Ilmo. Sr. A. Arribas, f.j. $2^{\circ}$ (AC 20111378).
} 


\subsection{Práctica de la diligencia}

En cuanto a la forma de llevar a la práctica las diligencias, cabe resaltar que es el propio art. 256.1.6 LEC el que nos permite afirmar que no existe un catálogo de medidas a las que el tribunal deba ceñirse para la obtención de los datos necesarios para la identificación de los miembros del grupo de afectados sino que tales medidas, las oportunas según la LEC, se corresponderán con aquellas que se soliciten por la parte y el tribunal, en el caso concreto, estime pertinentes ${ }^{414}$, lo que no excluye la posibilidad de que este module las solicitadas o acuerde otras que de forma más efectiva, e incluso menos lesiva para el requerido, conduzcan al mismo fin.

Ahora bien, dada la naturaleza de la medida y la información que a través de la misma se pretende, será lo más común que el órgano judicial se dirija al sujeto pasivo de la diligencia preliminar solicitando cuantos datos obren en su poder y que permitan la identificación de los afectados que han de constituir el grupo, lo que nos coloca ante la dimensión constitucionalmente considerada de la posible vulneración del derecho fundamental a la intimidad (art. 18.1 CE) y a la protección de datos de carácter personal $\left(\text { art. 18. } 4 \mathrm{CE}^{415}\right)^{416}$.

\footnotetext{
${ }^{414}$ Vid. Larrosa Amante, M.A., Mecanismos procesales para..., ob. cit., p. 17; Álvarez Alarcón, A., Las diligencias preliminares..., ob. cit., p. 46; Garnica Martín, J.F., De las diligencias..., ob. cit., p. 1155, que justifica la posibilidad en la dificultad que entrañaría su preestablecimiento. También Bellido Penadés, R., Las diligencias preliminares..., ob. cit., p. 5-24, que afirma que si bien el solicitante debe proceder a la identificación de la diligencia en la solicitud inicial, constituye una excepción a dicha exigencia el supuesto del ordinal $6^{\circ}$ del art. 256.1 LEC en cuyo caso entiende que la determinación de la diligencia preliminar no es una carga atribuida al solicitante.

${ }_{415}$ Considerando que el derecho a la protección de los datos de carácter personal que deriva del art. 18.4 CE consagra en sí mismo un derecho o libertad fundamental (SSTC 254/1993, de 20 de julio de 1993, ponente Ilmo. Sr. F. García-Mon, f.j.6 (LA LEY 2282-TC/1993) y 254/2000, de 30 de octubre de 2000, ponente Ilmo. Sr. R. de Mendizabal, f.j.5 (LA LEY 11996/2000), que excede el ámbito propio del derecho fundamental a la intimidad (art. 18.1 CE) y que se traduce en un derecho de control sobre los datos relativos a la propia persona.

${ }^{416}$ Esta es la situación planteada por la STC 96/2012, de 7 de mayo de 2012, ponente Ilmo. Sr. M. Aragón, f.j.11 (LA LEY 66248/2012) en la que se concluyó que: “[...] las resoluciones judiciales impugnadas han vulnerado el art. 18.4 CE. Y ello, porque una diligencia preliminar consistente en requerir a una entidad bancaria la entrega de datos personales de sus clientes, sin el previo consentimiento de éstos, para su posterior entrega a una asociación de consumidores que pretende iniciar un proceso para la defensa de los intereses colectivos de consumidores y usuarios, implica un claro límite en el derecho fundamental a la protección de datos de carácter personal (art. 18.4 CE) y, en consecuencia, no es suficiente la existencia de una genérica habilitación legal (ex art. 256.1.6 LECiv), sino que dicha medida ha de adoptarse mediante resolución especialmente motivada, exteriorizando los elementos de juicio en los que se basa la resolución, de forma que las razones fácticas y jurídicas queden perfectamente
} 
Lo habitual será que los datos que se soliciten al sujeto pasivo se encuentren protegidos por el art 18.4 CE, dado que el objeto de tutela del derecho fundamental a la protección de datos que de él deriva se extiende a cualquier tipo de dato personal, sea o no íntimo, cuyo conocimiento o empleo por terceros pueda afectar a sus derechos, sean o no fundamentales, porque su objeto no es sólo la intimidad individual, sino también los datos de carácter personal que alcanza a aquellos datos personales públicos, que por el hecho de serlo, de ser accesibles al conocimiento de cualquiera, no escapan al poder de disposición del afectado porque así lo garantiza su derecho a la protección de datos $^{417}$.

Así las cosas, al tiempo de acordarse la diligencia preliminar del art. 256.1.6 LEC deberá verificarse por el órgano judicial si la misma limita el derecho fundamental a la protección de datos de carácter personal y, en caso afirmativo, si tal injerencia es constitucionalmente legítima, teniendo presente que tal derecho fundamental posee una peculiaridad que lo distingue de otros y que radica en su contenido, al conferir a la persona el poder jurídico de imponer a terceros el deber de abstenerse de toda intromisión en la esfera íntima de la persona y la prohibición de hacer uso de lo así conocido $^{418}$. Confiere tal derecho a su titular la facultad de consentir la recogida, la

expuestas y, además, debe someterse a un estricto juicio de proporcionalidad, como principio inherente del Estado de Derecho, cuya condición de canon de constitucionalidad tiene especial aplicación cuando se trata de proteger derechos fundamentales frente a limitaciones o constricciones que procedan de normas o resoluciones singulares (STC 85/1992, de 8 de junio, F.4). Sin embargo, nada de esto se ha hecho en las resoluciones jurídicas impugnadas.

Tal vulneración material del art. 18.4 CE implica, correlativamente, la lesión del derecho a la tutela judicial efectiva (art. 24.1 CE) de la entidad bancaria demandante de amparo que, cuando se opone al requerimiento de entrega de los ficheros informáticos con los datos personales de aquellos de sus clientes que hubieran suscrito determinados productos financieros, datos sobre los que tiene una obligación jurídica de custodia, no obtiene del órgano judicial una respuesta fundada en una aplicación del ordenamiento jurídico conforme a la Constitución, de acuerdo con las exigencias demotivación y proporcionalidad anteriormente referidas".

417 STC 292/2000, de 30 de noviembre de 2000, ponente Ilmo. Sr. J.D. González, f.j.6º (LA LEY $11336 / 2000)$.

${ }^{418}$ SSTC 73/1982, de 2 de diciembre de 1982, ponente Ilmo. Sr. L. Díez-Picazo, f.j.5º (LA LEY 7397JF/0000), 110/1984, de 26 de noviembre de 1984, ponente Ilmo. Sr. A. Latorre, f.j.3º (LA LEY 353TC/1985); 89/1987, de 3 de junio de 1987, ponente Ilmo. Sr. F. Rubio, f.j.3º (LA LEY 810-TC/1987); 231/1988, de 2 de diciembre de 1988, ponente Ilmo. Sr. L. López, f.j.3º (LA LEY 1166-TC/1989); 197/1991, de 17 de octubre de 1991, ponente Ilmo. Sr. J. Leguina, f.j.3º (LA LEY 7518/1991); 196/2004, de 15 de noviembre de 2004, ponente Ilmo. Sr. F.J. Delgado, f.j.2 (LA LEY 2437/2004); 206/2007, de 24 de septiembre de 2007, ponente Ilmo. Sr. M. Aragón, f.j.5º (LA LEY 139143/2007); 70/2009, de 23 de marzo de 2009, ponente Ilma. Sra. M ${ }^{a}$.E. Casas, f.j.2 (LA LEY 14334/2009) y 12/2012, de 30 de enero de 2012, ponente Ilma. Sra. A. Asua, f.j.5º (LA LEY 2303/2012). 
obtención y el acceso a los datos personales, su posterior almacenamiento y tratamiento, así como sus posibles usos por un tercero, derecho que requiere como complementos indispensables la facultad de saber en todo momento quién dispone de esos datos personales y a qué uso los está sometiendo, y, por otro lado, el poder oponerse a esa posesión y usos ${ }^{419}$.

De lo anterior se desprende que, cuando el juez de las diligencias preliminares acuerde, como medida de averiguación, la entrega de datos personales con la finalidad de hacérselos llegar, por ejemplo, a una asociación que pretenda iniciar un proceso para la defensa de los intereses colectivos de consumidores y usuarios, al objeto de concretar a los integrantes del grupo de afectados, está limitando el contenido del derecho fundamental a la protección de datos protegido por el art. 18.4 CE y, en consecuencia, deberán darse los presupuestos habilitantes necesarios para que dicha injerencia en el derecho fundamental pueda calificarse de constitucionalmente legítima ${ }^{420}$. Es decir, que la medida limitativa del derecho fundamental esté prevista por la Ley, que se adopte mediante resolución judicial especialmente motivada y que sea idónea, necesaria y proporcionada en relación con un fin constitucionalmente legítimo ${ }^{421}$.

En el caso que nos ocupa, existiría habilitación legal a favor del juez para la obtención de datos de carácter personal sin el previo consentimiento del interesado, la del art. 11.2 d) LOPD, al actuar aquel en el ejercicio de las funciones que tiene atribuidas conforme al art. 256.1.6 LEC. La resolución, en tanto que limitativa de un derecho fundamental, debe ser una motivación reforzada que no reside en la genérica obligación de motivación de todas las resoluciones judiciales que resulta del derecho a la tutela judicial efectiva (art. 24.1 en relación con el 120.3 CE) sino de la protección del derecho sustantivo y que, en el caso que nos ocupa, determinaría que no se puedan obtener bajo la cobertura del art. 256.1.6 LEC y, sin el previo consentimiento de los

\footnotetext{
419 STC 292/2000, de 30 de noviembre de 2000, ponente Ilmo. Sr. J.D. González, f.j.7 (LA LEY $11336 / 2000)$.

${ }^{420}$ STC 96/2012, de 7 de mayo de 2012, ponente Ilmo. Sr. M. Aragón, f.j.7º (LA LEY 66248/2012).

421 SSTC 207/1996, de 16 de diciembre de 1996, ponente Ilmo. Sr. V. Gimeno, f.j.4 (LA LEY 1527/1997) y 25/2005, de 14 de febrero de 2005, ponente Ilmo. Sr. R. García-Calvo, f.j.6º (LA LEY 462/2005). En relación con la concreta facultad de disposición y control de datos personales, cfr. la STC 292/2000, de 30 de noviembre de 2000, ponente Ilmo. Sr. J.D. González, f.j.13º (LA LEY 11336/2000).
} 
afectados, datos de carácter personal que no sean imprescindibles para el ejercicio de la acción colectiva que se pretenda iniciar ${ }^{422}$. Por último, que la medida resulte proporcionada a la injerencia en el derecho a la protección de los datos de carácter personal. Es decir, que la medida sea susceptible de conseguir el objetivo propuesto (juicio de idoneidad), que sea necesaria, en el sentido de no existir otra medida más moderada para la consecución del propósito con igual eficacia (juicio de necesidad) y si la misma es ponderada o equilibrada, por derivarse de ella más beneficios o ventajas para el interés general que perjuicios sobre otros bienes o valores en conflicto (juicio de proporcionalidad en sentido estricto $)^{423}$.

Esto supone, al no concretar el art. 256.1.6 LEC el modo en que se pueden hacer efectivas las medidas de averiguación de los eventuales integrantes del grupo de afectados, que la resolución debe exteriorizar las razones por las que la medida es idónea para conseguir el fin propuesto, la inexistencia de otra medida menos lesiva para identificar a los integrantes del grupo (juicio de necesidad) y la valoración y exteriorización de si la solicitud de los datos personales es una medida ponderada o equilibrada, por derivarse de ella más beneficios o ventajas para el interés general que perjuicios sobre otros bienes o valores en conflicto ${ }^{424}$.

Por último, debemos plantearnos en qué momento podrá darse por concluida la práctica de la diligencia preliminar lo que, conforme con determinada doctrina, entendemos tendrá lugar una vez que, atendiendo a un criterio exclusivamente cuantitativo, se entienda que el grupo está determinado en una mayoría suficientemente representativa de los intereses de los afectados ${ }^{425}$. Discrepamos así de aquellos autores que han entendido que el procedimiento no se agotará hasta que se conozca tanto a quienes integran el grupo propiamente dicho como también a quienes de ellos están

\footnotetext{
${ }^{422}$ STS 96/2012, de 7 de mayo de 2012, ponente Ilmo. Sr. M. Aragón, f.j.9º (LA LEY 66248/2012).

423 SSTC 207/1996, de 16 de diciembre de 1996, ponente Ilmo. Sr.V. Gimeno, f.j.4 ${ }^{\circ}$ (LA LEY 1527/1997); 49/1999, de 5 de abril de 1999, ponente Ilmo. Sr. T. Vives, f.j.7 (LA LEY 4215/1999); 159/2009, de 29 de junio de 2009, ponente Ilmo. Sr. V. Conde f.j.3º (LA LEY 119316/2009); 86/2006, de 27 de marzo de 2006, ponente Ilmo. Sr. P. Pérez, f.j.3 (LA LEY 36241/2006); 206/2007, de 24 de septiembre de 2007, ponente Ilmo. Sr. M. Aragón, f.j.6º (LA LEY 139143/2007) y 173/2011, de 7 de noviembre de 2011, ponente Ilmo. Sr. E. Gay,f.j.2(LA LEY 211654/2011).

${ }^{424}$ STS 96/2012, de 7 de mayo de 2012, ponente Ilmo. Sr. M. Aragón, f.j.10º (LA LEY 66248/2012).

${ }^{425}$ Bachmaier Winter, L., La tutela de..., ob. cit., p. 19.
} 
dispuestos a constituirlo ${ }^{426}$, dado que como también se apunta en la doctrina científica, este no es el fin específico de la diligencia preliminar ${ }^{427}$.

\section{Obtención de datos en materia de propiedad industrial o intelectual (art.}

\subsubsection{LEC)}

"Mediante la solicitud, formulada por quien pretenda ejercitar una acción por infracción de un derecho de propiedad industrial o de un derecho de propiedad intelectual cometida mediante actos que no puedan considerarse realizados por meros consumidores finales de buena fe y sin ánimo de obtención de beneficios económicos o comerciales, de diligencias de obtención de datos sobre el posible infractor, el origen y redes de distribución de las obras, mercancías o servicios que infringen un derecho de propiedad intelectual o de propiedad industrial y, en particular, los siguientes:

a) Los nombres y direcciones de los productores, fabricantes, distribuidores, suministradores y prestadores de las mercancías y servicios, así como de quienes, con fines comerciales, hubieran estado en posesión de las mercancías;

b) Los nombres y direcciones de los mayoristas y minoristas a quienes se hubieren distribuido las mercancías o servicios.

c) Las cantidades producidas, fabricadas, entregadas, recibidas o encargadas, y las cantidades satisfechas como precio por las mercancías o servicios de que se trate y los modelos y características técnicas de las mercancías".

En el estudio de la diligencia que nos ocupa cabe comenzar recordando que el proceso civil se rige por los principios dispositivo y de aportación de parte que implican que el actor tenga la carga de aportar y acreditar los hechos constitutivos de su pretensión y, por tanto y a priori, de obtener cuantos datos sean necesarios para fundamentar su demanda. En dicha tarea, las diligencias preliminares en materia de propiedad intelectual e industrial juegan un papel fundamental dado que en estos ámbitos la confidencialidad y el secreto de la contabilidad dificultan la obtención de

\footnotetext{
${ }^{426}$ Garnica Martín, J.F., De las diligencias..., ob. cit., p. 1156.

${ }^{427}$ Bachmaier Winter, L., La tutela de..., ob. cit., p. 35.
} 
datos que le permitan al titular de los derechos preparar como debe el futuro proceso ${ }^{428}$. Pero debe tenerse en cuenta que si se impide al titular de tales derechos, con indicios de que otros están desarrollando conductas infractoras de los mismos, que haga efectiva la posibilidad de interesar la práctica de diligencias para constatar la posible vulneración de sus derechos, se estaría amparando la impunidad del posible infractor, al carecer el titular de la información precisa para poder evaluar la situación y, en su caso, reaccionar en defensa de sus derechos además de generarse una litigiosidad injustificada como consecuencia de la promoción preventiva de litigios por parte del titular de los $\operatorname{mismos}{ }^{429}$.

En orden a salvar estas dificultades, la diligencia preliminar que nos ocupa fue introducida en el ordinal $7^{\circ}$ del catálogo del art. 256.1 LEC con ocasión de la reforma operada en esta última por la Ley 19/2006. Con tal reforma se consagraba en el ordenamiento jurídico español el derecho de información ${ }^{430}$, a nuestro juicio de petición de información, contemplado en el art. 8 de la Directiva 2004/48/CE ${ }^{431}$, disponiendo el

\footnotetext{
${ }^{428}$ Corbal Hernández, J.E., Diligencias Preliminares (arts...), ob. cit., p. 3508.

${ }^{429}$ En dicho sentido, el AAP de Madrid (sección $28^{\mathrm{a}}$ ) de 13 de diciembre de 2007, ponente Ilmo. Sr. E. García, f.j.3º (LA LEY 300153/2007) que contempló un supuesto de diligencias de comprobación de hechos relativo a la fabricación de medicamentos con posible infracción de una patente.

${ }^{430}$ Tal derecho ha sido considerado por Larena Beldarraín, J., Las diligencias preliminares en materia de propiedad industrial e intelectual, en "Revista Vasca de Administración Pública", 2010, nº 87-88, p. 694, como el "instrumento al servicio de la persona que pretenda iniciar un proceso para la tutela" de los derechos de propiedad intelectual e industrial y dirigido a obtener información del futuro demandado o de terceros que pudieran facilitarla. Vid. también Castán Pérez-Gómez, A., El nuevo régimen de las diligencias preliminares en propiedad industrial, en "Estudios de Derecho Judicial", 2007, núm. 145, p. 26.

${ }^{431}$ El art. 8 de la Directiva 2004/48/ CE dispone que: "1. Los Estados miembros garantizarán que, en el contexto de los procedimientos relativos a una infracción de un derecho de propiedad intelectual y en respuesta a una petición justificada y proporcionada del demandante, las autoridades judiciales competentes puedan ordenar que faciliten datos sobre el origen y las redes de distribución de las mercancías o servicios que infringen un derecho de propiedad intelectual el infractor o cualquier persona que: a) haya sido hallada en posesión de las mercancías litigiosas a escala comercial; b) haya sido hallada utilizando servicios litigiosos a escala comercial; c) haya sido hallada prestando a escala comercial servicios utilizados en las actividades infractoras; o d) haya sido designada por la persona a que se refieren las letras a), b) o c) como implicada en la producción, fabricación o distribución de dichas mercancías o en la prestación de dichos servicios. 2. Los datos a los que se refiere el apartado 1 incluirán, según proceda: a) los nombres y direcciones de los productores, fabricantes, distribuidores, suministradores y otros poseedores anteriores de las mercancías o servicios, así como de los mayoristas y minoristas destinatarios; b) información sobre las cantidades producidas, fabricadas, entregadas, recibidas o encargadas, así como sobre el precio obtenido por las mercancías o servicios de que se trate.3. Los apartados 1 y 2 se aplicarán sin perjuicio de otras disposiciones legales que: a) concedan al titular derechos de información más amplios; b) regulen la utilización de los datos que se comuniquen con arreglo al presente artículo en procedimientos civiles o penales; c) regulen la responsabilidad por abuso
} 
legislador de un cauce para la obtención de información sobre el origen y las redes de distribución de las mercancías o servicios ${ }^{432}$ en los que se concretara la infracción de los derechos de propiedad intelectual o industrial mediante actos desarrollados a escala $\operatorname{comercial}^{433}$. Y, fruto de la reforma operada por la Ley 21/2014, la diligencia también podrá extenderse a la obtención de cuantos datos sean considerados necesarios sobre el posible infractor y sobre el origen y redes de las obras, que no únicamente al origen y distribución de las mercancías o servicios. Los problemas de identificación y localización del presunto infractor para la práctica del interrogatorio que de forma expresa preveía la redacción anterior del art. 256.1 LEC LE $^{434}$ y el obstáculo que constituía la tradicional concepción restrictiva de las diligencias preliminares frente a infracciones no materializadas en soportes tangibles ${ }^{435}$, hacían aconsejables dichas expresas referencias.

\subsection{Actos que no puedan considerarse realizados por meros consumidores}

\section{finales de buena fe y sin obtención de beneficios económicos o comerciales}

Y llegados a este punto debemos detenernos en una circunstancia fundamental que diferencia la regulación actual de la diligencia con la que tuvo cuando la misma fue introducida en el art. 256.1.7 por la Ley 19/2006 dado que, como hemos apuntado al inicio del presente capítulo, la Ley 21/2014 reformó su tenor literal y, por tanto, su

del derecho de información; d) ofrezcan la posibilidad de negarse a facilitar datos que obliguen a la persona a la que se refiere el apartado 1 a admitir su propia participación o la de sus parientes cercanos en una infracción de un derecho de propiedad intelectual; o e) rijan la protección de la confidencialidad delas fuentes de información o el tratamiento de los datos personales".

${ }^{432}$ No obstante, cabe recordar que hoy en día, y como consecuencia de la modificación operada por la Ley 21/2014, de 4 de noviembre, la información podrá extenderse al origen y redes de distribución de las obras, y no sólo de las mercancías o servicios, en los que se concrete la infracción, y la infracción ya no será necesario que venga referida a actos desarrollados a escala comercial sino a actos que no puedan considerarse realizados por meros consumidores finales de buena fe y sin ánimo de obtención de beneficios económicos o comerciales, expresión que analizaremos más adelante.

${ }^{433} \mathrm{Y}$ en unos términos literales muy similares a los contenidos en el art. 47 de los ADPIC que prevenía que: "Los Miembros podrán disponer que, salvo que resulte desproporcionado con la gravedad de la infracción, las autoridades judiciales puedan ordenar al infractor que informe al titular del derecho sobre la identidad de los terceros que hayan participado en la producción y distribución de los bienes o servicios infractores, y sobre sus circuitos de distribución".

${ }^{434}$ Cfr. Armengot Vilaplana, A., Las nuevas diligencias preliminares y las especialidades en materia probatoria introducidas por la Ley 19/2006 en la LEC, en "Revista General de Derecho Procesal", 2007, núm. 13, p. 18 y Díaz Pita, P., Diligencias preliminares y..., ob. cit., p. 199.

${ }^{435}$ Cfr. Obra 1: Castán Pérez-Gomez, A., El nuevo régimen..., ob. cit., pp. 139-141. 
configuración inicial. A saber la eliminación en la nueva redacción de la referencia a los actos desarrollados a escala comercial, como forma de comisión de la infracción de los procesos que se pretendan preparar, y su sustitución por la de actos que no puedan considerarse realizados por meros consumidores finales de buena fe y sin ánimo de obtención de beneficios económicos o comerciales.

Con el fin de analizar tal cambio legislativo debemos comenzar por señalar que el Considerando 14 de la Directiva 2004/48/CE preveía que las medidas establecidas en sus arts. 6.2, 8.1 y 9.2 tenían que aplicarse sólo con respecto a actos llevados a cabo a escala comercial que, según precisó, son los realizados para obtener beneficios económicos o comerciales directos o indirectos, excluyendo los actos realizados por los consumidores finales de buena $\mathrm{fe}^{436}$. Y pese a que el propio Considerando 14 de la Directiva también disponía que ello no afecta a la posibilidad de que los Estados miembros aplicaran las medidas a otros actos, el legislador español, lejos de utilizar una fórmula más abierta que permitiera la preparación de los procesos por infracción de los derechos de propiedad intelectual e industrial en general, ciñó la posibilidad de la actividad preparatoria de dichos procesos a los supuestos de infracción desarrollados a escala comercial.

Tal limitación dio lugar a innumerables resoluciones de los tribunales inadmitiendo la petición de la diligencia cuando no quedaba debidamente justificado que la infracción hubiera sido desarrollada mediante tales $\operatorname{actos}^{437}$ e imposibilitaba su aplicación a aquellas infracciones imputables a usuarios de redes de intercambio peerto-peer $^{438}$, en el entendimiento de que tales sujetos no llevaban a cabo actos a escala

\footnotetext{
${ }^{436}$ Como puso de manifiesto Armengot Vilaplana, Las nuevas diligencias..., ob. cit., p. 20, ello parecía excluir la admisibilidad de esta diligencia cuando se hubiera producido una singularizada usurpación de los derechos que no hubiera generado para el infractor un beneficio económico.

${ }^{437}$ Según García Sanz, F.J. y Vendrell Cervantes, C., Doctrina judicial en..., ob cit., p. 2, "la limitación del ámbito objetivo de las infracciones cometidas mediante actos desarrollados a escala comercial excluye las conductas que no se realizan para obtener beneficios económicos o comerciales directos o indirectos, esto es, los supuestos en que falte el ánimo de lucro en la actividad infractora". En la doctrina judicial, vid. los AAP de Barcelona (sección 5a) de 10 y 15 de diciembre de 2009, ponente Ilmo. Sr. I. Sancho, f.j. $2^{\circ}$ (LA LEY 308466/2009 y 308468/2009), STJUE de 29 de enero de 2008, Asunto C-275/06 y STJUE de 19 de abril de 2012, Asunto C-461/10.

${ }^{438}$ Las mismas son definidas en la doctrina judicial, entre otras, por la AAP de Madrid (sección $28^{\text {a }}$ ) de 31 de marzo de 2014, ponente Ilmo. Sr. E. García, f.j.1º (LA LEY 36709/2014), como: [...] una herramienta
} 
comercial sino actos con alcance particular, por los que no se cobraba una contraprestación $^{439}$. Aun cuando cabe precisar que esta circunstancia no fue la única que llevó a los tribunales a rechazar la diligencia para la preparación de los procesos por infracciones imputables a usuarios de redes de intercambio peer-to-peer. Las

tecnológica que permite la conexión entre ordenadores y con ello el que diversos sujetos puedan compartir contenidos que alojan en una carpeta común de sus respectivos ordenadores personales. La instalación de dichos programas permite a los usuarios de los mismos establecer una comunicación directa en red entre ellos, sin necesidad de una intervención de apoyo por parte del que les suministró el software, que posibilita de forma muy eficiente que se intercambien entre sí archivos digitales. En concreto, las aplicaciones MP2P, que constituyen un modelo evolucionado de protocolos $\mathrm{P} 2 \mathrm{P}$ de tipo descentralizado, están diseñadas para permitir el intercambio de archivos de audio (ogg, mp3 y wma aunque luego ha sido ampliado a otras posibilidades) mediante la interconexión vía Internet entre los ordenadores que tienen instalada alguna de ellas. Tanto para realizar búsquedas de archivos de audio como para intercambiarlos no hace falta pasar por las webs de los demandados, sino que, una vez que se han descargado la aplicación comercializada por éstos, todo el proceso de intercambio se desarrolla de modo directo entre los ordenadores de los usuarios". Previamente a dicha resolución, en la doctrina científica, Xalabarder Plantada, R., Jornada Usos y abusos del peer-to-peer, en "Revista de Internet, Derecho y Política", 2010, núm. 10, p. 2, se ponían de manifiesto las posturas de los titulares de páginas web que permitían el intercambio de ficheros con sistemas P2P que señalaban que los enlaces y las remisiones a localizaciones desde donde se pueden descargar ficheros que contienen obras y grabaciones protegidas por el régimen de propiedad intelectual son actos puramente técnicos, necesarios para el propio funcionamiento de Internet y que no suponen un acto de explotación sujeto a la propiedad intelectual mientras que, desde el ámbito más estrictamente jurídico, se sostenía que aún cuando los enlaces no afectaran al régimen de propiedad intelectual, los actos de descarga de archivos y su posterior puesta a disposición del resto de miembros que tuvieran instalado el programa P2P si que son actos de explotación de la propiedad intelectual que necesitan ser autorizados por los respectivos titulares para evitar ser considerados una infracción dado que el actual límite de la copia privada era insuficiente para dar cobertura legal a los actos de reproducción y comunicación no autorizados que implican las redes P2P y, en consecuencia, eran constitutivos de infracción de acuerdo con el TRLPI.

${ }^{439}$ Así lo puso de manifiesto el Informe del Pleno del CGPJ de 23 de julio al Anteproyecto de Ley de modificación del Texto Refundido de la Ley de Propiedad Intelectual, aprobado por Real Decreto Legislativo 1/1996, de 12 de abril y de la Ley 1/2000, de 7 de enero, de Enjuiciamiento Civil, http://prontuario.net/cgpj/es/Poder-Judicial/Consejo-General-del-Poder-Judicial/Actividad-del-

CGPJ/Informes/Informe-al-Anteproyecto-de-Ley-de-modificacion-del-Texto-Refundido-de-la-Ley-dePropiedad-Intelectual--aprobado-por-Real-decreto-Legislativo-1-1996--de-12-de-abril--y-de-la-ley-12000--de-7-de-enero--de-Enjuiciamiento-Civil, consultado el 10 de agosto de 2017. En la doctrina judicial, ejemplos de la situación puesta de manifiesto por el CGPJ lo constituyen los AAP de Barcelona (sección $15^{\text {a }}$ ) de 10 y 15 de diciembre de 2009, ponente Ilmo. Sr. I. Sancho, f.j. $2^{\circ}$, (LA LEY 308466/2009 y JUR 2010 117178). No obstante, más recientemente la SAP de Madrid (sección $28^{\mathrm{a}}$ ) de 31 de marzo de 2014, ponente Ilmo. Sr. E. Garcia, f.j.4 (LA LEY 36709/2014), consideró que: “[...] el intercambio entre usuarios de Internet de archivos que estén amparados por derechos de propiedad intelectual, si no se cuenta con la autorización del titular de los mismos, entraña una infracción de aquéllos. La misma se comete por inmiscuirse en la órbita de los derechos exclusivos de explotación que incumben al titular de los mismos (artículo 17 del TRLPI), en concreto, el de comunicación pública, en su modalidad de puesta a disposición del público de forma interactiva de las obras (artículo 20, párrafo 2, apartado i del TRLPI y artículo 116 del mismo cuerpo legal en lo que respecta a los productores de fonogramas), de modo que se confiere la posibilidad de acceder a ellas vía Internet a voluntad del que esté interesado, y el de reproducción (artículo 18 del TRLPI, con carácter general, y artículo 115 en lo que atañe a los productores de fonogramas), por la realización inconsentida de copias digitales de las obras protegidas, sin que ello lo ampare el límite de copia privada (artículo 31.2 del TRLPI), pues su vocación es la de la utilización colectiva de esas copias, que además, en muchos casos, se realizan precisamente a partir de un ejemplar ilegítimo". 
previsiones de los arts. 1 y 6 LCDCE, también constituyeron el fundamento de la denegación de las solicitudes de diligencias para la preparación de procesos por tales infracciones al desprenderse de aquellos que los datos retenidos de conexión y tráfico generados por las comunicaciones establecidas durante la prestación de un servicio de la sociedad de la información sólo podían utilizarse para la detección, investigación y enjuiciamiento de delitos graves contemplados en el Código Penal o en las leyes penales especiales, quedando excluida la cesión para promover un procedimiento civil por infracción de los derechos de propiedad intelectual ${ }^{440}$.

Atendiendo a dicha situación, la reforma acometida por la Ley 21/2014 suprimió el requisito de haberse cometido la infracción mediante actos desarrollados a escala comercial exigiendo que las infracciones fueran llevadas a cabo por actos que no puedan considerarse realizados por meros consumidores finales de buena fe y sin ánimo de obtención de beneficios económicos o comerciales, lo que parece solventar el inconveniente con el que se habían topado los titulares de propiedad intelectual a la hora de solicitar esta medida y que se mantuvo en la diligencia del art. 256.1.8 LEC $^{441}$.

Pero resulta que la LEC no nos dice, siquiera a modo ejemplificativo, qué debemos entender por la expresión "actos que no puedan considerarse realizados por meros consumidores finales de buena fe y sin obtención de beneficios económicos o comerciales". Al respecto, pocas son las opiniones sobre las que podremos teorizar. Por un lado, el Informe del Pleno del CGPJ de 2013 al Anteproyecto de Ley 21/2014 determinó que ambas expresiones no son equivalentes afirmando, únicamente, que la supresión del requisito de la infracción mediante actos desarrollados a escala comercial solventaría el inconveniente con el que se habían encontrado los titulares de los derechos al solicitar la diligencia. Pero nada más dice al respecto y nada más podía decir

\footnotetext{
${ }^{440}$ Vid. los AAP de Madrid (sección 28 $8^{\text {a }}$ ) de 19 de febrero, de 12 de abril de 2010 y 12 de noviembre de 2010, ponentes Ilmos. Srs. A. Arribas, J. Zarzuelo y E. García, f.j.3, $2^{\circ}$ y $3^{\circ}$ (LA LEY 25238/2010, AC 2010\1001 y AC 2010\2305).

${ }^{441}$ En el que, además, se comete una errata cuando, in fine, al determinar lo que debe entenderse por actos desarrollados a escala comercial a los efectos de los ordinales $7^{\circ}$ y $8^{\circ}$ del art. 256.1 LEC, cuando tal magnitud como presupuesto de admisión de la diligencia preliminar, la de cometerse la infracción por actos desarrollados a escala comercial, no es exigida en el ordinal $7^{\circ}$ del art. 256.1.7 LEC que determina que los actos infractores no deben de poder considerarse realizados por meros consumidores finales de buena fe y sin ánimo de obtención de beneficios económicos o comerciales.
} 
dicho Informe, al no ser competencia del indicado órgano la definición de la norma. Por otro lado, en la doctrina científica se ha apuntado a la equivalencia de las expresiones al considerar que lo hecho por el legislador con ocasión de la reforma no ha sido sino sustituir la expresión "actos desarrollados a escala comercial" por la definición que, a contrario sensu, se extraería de la dada de aquellos por la Directiva 2004/48/CE ${ }^{442}$.

Sin embargo lo anterior, entendemos que el cambio del presupuesto de la diligencia, suprimiendo la referencia a la comisión de la infracción mediante "actos desarrollados a escala comercial" por la de "actos que no puedan considerarse realizados por meros consumidores finales de buena fe y sin ánimo de obtención de beneficios económicos o comerciales", no sólo conlleva una diferencia de conceptos sino que atiende al espíritu del legislador de no limitar el derecho de información en el caso de infracciones de los derechos no realizadas, única y exclusivamente, por el sujeto que responda al concepto de consumidor final. Es decir, al espíritu de no limitar el derecho de información en la preparación de los procesos por infracción de los derechos de propiedad intelectual e industrial frente a sujetos que hayan cometido aquella para un uso o servicio que exceda del mero consumo. Tal postura es la que parece apuntarse también en la doctrina cuando se indica que el cambio del presupuesto de la adopción de la medida obedece a la intención de eximir de responsabilidad, únicamente, a los consumidores finales que obren de buena fe y sin ánimo de obtener lucro alguno ${ }^{443}$. Y en este amplio espectro no sólo entendemos quedarían incluidos los actos desarrollados a escala comercial sino también todos aquellos que pudieran encontrarse en el indefinido ámbito que existe entre estos y los actos desarrollados por meros consumidores finales de buena fe y sin ánimo de obtención de beneficios económicos o comerciales.

Y tal espíritu flexible del legislación igualmente se manifiesta en la eliminación, en la redacción actual del art. 256.1.7 LEC, de toda referencia a la forma en que pueden obtenerse los datos que permitan preparar el proceso posterior. La supresión del

\footnotetext{
${ }^{442}$ Díaz Pita, P., Diligencias preliminares y..., ob. cit., p. 191, indica, pese a su postura, que la previsión de la nueva redacción permite extender la infracción a los actos realizados por sujetos que, aún cuando aparenten ser y actuar como consumidores finales de buena fe, actúen de mala fe con el ánimo de obtener beneficios económicos o comerciales infringiendo un derecho de propiedad intelectual.

${ }^{443}$ Obra 1: Castán Pérez-Gómez, A., El nuevo régimen..., ob. cit., p. 140.
} 
interrogatorio $^{444}$, que en la doctrina había hecho a la diligencia merecedora de la calificación de diligencia de identificación ${ }^{445}$, y la exhibición de documentos, en modo alguno puede llevarnos entender que los datos a que se refiere la diligencia del art. 256.1.7 LEC no podrán ser obtenidos por las vías que antes de la modificación preveía el precepto legal, pues la razón de la misma reside en el interés advertido en la doctrina científica de no limitar las posibles fórmulas de obtención de la información ${ }^{446}$. La supresión, como tal intencionada, a nuestro juicio, permitirá practicar cuantas diligencias sean interesadas por el solicitante y el juzgador considere oportunas para la averiguación de los datos relativos a la infracción de los derechos de propiedad intelectual e industrial ${ }^{447}$. Esta afirmación viene corroborada por el propio art. 259.3 LEC que, con expresa cita del art. 256.1.7 LEC, dispone que el tribunal podrá ordenar que la práctica del interrogatorio se celebre a puerta cerrada. Cierto es que esta afirmación no es fruto de la reforma operada por la Ley 21/2014 y que podría sostenerse la concurrencia de una errata similar a la contenida en la redacción de la diligencia del art. 256.1.8 LEC que mantiene la referencia, en la definición de los actos desarrollados a escala comercial, al art. 256.1.7 LEC. Pero no es menos cierto que, aún los errores de redacción y concordancia a que nos tiene acostumbrados el legislador, la referencia al interrogatorio contenida en el art. 259.3 LEC es coherente con el espíritu que entendemos ha inspirado la reforma del ordinal $7^{\circ}$ al suprimir una referencia expresa al interrogatorio y exhibición de documentos que, en cualquier caso, servía para limitar las fórmulas de obtención de datos a través de dichas diligencias y no otras. Y en una materia como la que nos ocupa no parece oportuno limitar los medios de obtención de cuantos datos puedan resultar necesarios para la preparación del proceso posterior imaginándonos la posibilidad de obtener tantos como fueran necesarios a tal efecto y

\footnotetext{
${ }^{444}$ Debe recordarse que la redacción inicial del art. 256.1.7 LEC preveía la posibilidad del interrogatorio de quien el solicitante de la diligencia preliminar considerara autor de la violación así como de quien a escala comercial, hubiera prestado o utilizado servicios o hubiera estado en posesión de mercancías que pudieran haber lesionado los derechos de propiedad industrial o intelectual y de aquel a quien los anteriores hubieren atribuido intervención en los procesos de producción, fabricación, distribución o prestación de aquellas mercancías y servicios así como la exhibición de documentos por los mismos.

${ }_{445}^{45}$ Vid. Díaz Pita, P., Diligencias preliminares y..., ob. cit., p.199.

${ }^{446}$ Díaz Pita, P., Diligencias preliminares y..., ob. cit., p. 196.

${ }^{447} \mathrm{Al}$ respecto el AAP de Madrid (sección $28^{\mathrm{a}}$ ) de 19 de octubre de 2015, ponente Ilmo. Sr. G. Plaza, f.j. $4^{\circ}$ (LA LEY 246907/2015) apunta que: "[...] Tras la reforma operada por la ley 21/2014, de 4 de noviembre, la diligencia prevista en el ordinal $7^{\circ}$ del apartado primero del artículo 256 LEC se plantea en términos amplios, sin referencia expresa a los cauces del interrogatorio o exhibición de documentos".
} 
mediante diligencias tan variadas como se quiera y resulten precisas que permitan, por ejemplo, la obtención de información de entidades públicas y privadas sobre las actividades de producción, fabricación, transporte o prestación de servicios relacionadas con la posible infracción.

Con todo, podemos afirmar que el legislador, aún implícitamente, mantiene la posibilidad del interrogatorio como fórmula de obtención de los datos a que se refiere el art. 256.1.7 LEC permitiendo, como ya hiciera con la redacción anterior, que el sujeto requerido acuda asesorado por un experto en la materia que siempre actuará a costa del solicitante (art. 259.2 LEC) y que dicho interrogatorio se celebre a puerta cerrada, conforme indica el art. 259.3 $\mathrm{LEC}^{448}$, fiel a la necesidad de preservar la confidencialidad que subyace en la materia.

\subsection{Objeto de la diligencia}

En cuanto a la finalidad de la diligencia en cuestión se afirma en la doctrina que, en términos generales, no es otra que facilitar al titular del derecho de propiedad industrial o intelectual la adecuada preparación del procedimiento ${ }^{449}$. Y, particularmente, averiguar la identidad de los sujetos infractores, el número de productos o servicios infractores y el precio obtenido mediante su comercialización ${ }^{450}$. En otros términos, la

\footnotetext{
${ }^{448}$ Siempre que la decisión se adopte en los términos del art. 138.3 LEC, es decir, mediante auto, previa audiencia de las partes presentes en el acto y a solicitud de cualquiera que acredite interés legítimo.

${ }^{449}$ Cfr. Soler Pascual, L.A., Las diligencias preliminares. Notas sobre la reforma acaecida por la Ley 19/2006, de 5 de junio, con relación a los derechos de autor e inventor, en "Práctica de los Tribunales", 2007, núm. 40 (LA LEY 2227/2007) p. 3. En similares términos, Armengot Vilaplana, A., Las nuevas diligencias..., ob. cit., p. 3, cuando señala que se trata de una diligencia específica para la preparación de los procesos civiles en los que se pretenda la tutela de los derechos de propiedad intelectual e industrial y "dirigida a obtener inflamación sobre os sujetos que han intervenido en la infracción y sobre el alcance de esta última". Corbal Hernández, J.E., Diligencias Preliminares (arts...), ob. cit., p. 3542, señalaba que: "La finalidad de la diligencia es la de preparación del proceso mediante la obtención de una información que no se puede conseguir por los propios medios y que es necesaria para formular la demanda" además de "meramente informativa".

${ }^{450}$ Recogiendo lo indicado por el Anteproyecto así lo ponen de manifiesto García Sanz, F.J. y Vendrell Cervantes, C., Doctrina judicial en torno a las diligencias preliminares en materia de propiedad intelectual, en "Diario La Ley", 2013, núm. 8128 (LA LEY 4398/2013) p. 2. En dicho sentido, el AAP de Granada (sección $3^{\mathrm{a}}$ ), de 27 de abril de 2007, ponente Ilmo. Sr. J.M ${ }^{\mathrm{a}}$. Jiménez, f.j.2 ${ }^{\circ}$ (LA LEY 60757/2007) cuando señala que "[...] la finalidad de las diligencias contempladas en el apartado $7^{\circ}$ reside en la averiguación de quienes hayan intervenido en una conducta infractora de los derechos sobre propiedad intelectual e industrial y en la determinación del alcance de la conducta infractora...”. En esta
} 
averiguación de la identidad del infractor, la entidad de la infracción y sus circunstancias $^{451}$.

Así, a través de la misma podrán prepararse aquellos procesos en los que se dispute la titularidad de un derecho de propiedad intelectual o industrial, que versen sobre la vulneración de tales derechos respecto de los cuales el solicitante afirme su exclusiva titularidad ${ }^{452}$ o para la verificación de la legitimación pasiva de la acción que por infracción de los mismos se pretenda ejercitar ${ }^{453}$, teniendo en cuenta que lo esencial en este tipo de procedimientos es conocer el tipo de infracción y la identidad del que la ha cometido ${ }^{454}$. Así, en sede de propiedad intelectual, las acciones de cesación de actos consistentes en reproducir y distribuir ilícitamente obras protegidas y de indemnización de los daños y perjuicios; y en sede propiedad industrial, las acciones de cesación de actos consistentes en fabricar y distribuir productos infringiendo tales derechos ${ }^{455}$, sin perjuicio de que los procesos por infracciones de este derecho de propiedad industrial también puedan ser preparados a través de las conocidas diligencias de comprobación de hechos reguladas en los arts. 123 y ss. de la LP.

línea, vid. el AAP de Madrid (sección 28 $8^{\mathrm{a}}$ ) de 19 de octubre de 2015, ponente Ilmo. Sr. G. Plaza, f.j. $4^{\circ}$, el 246907(2015).

${ }^{451}$ Cfr. López Sánchez, J., Las nuevas diligencias..., ob. cit., p. 2.

${ }^{452}$ Así, en el atípico supuesto contemplado por el AAP de Madrid (sección 28a) de 19 de junio de 2008, ponente Ilmo. Sr. P. Gómez, f.j. $3^{\circ}$ (LA LEY 110440/2008) en el que se accedió a practicar la diligencia consistente en recabar de un colegio profesional de arquitectos la documentación relativa a proyectos visados por la institución y elaborados por el solicitante de la diligencia por encargo de una empresa y con la finalidad tanto de poder constatar la efectiva infracción de sus derechos de propiedad intelectual sobre los planos y proyectos que en su día elaboró para dicha empresa como de cuantificar, en caso afirmativo, la envergadura y extensión de dicha infracción.

${ }^{453}$ López Sánchez, J., Las nuevas diligencias..., ob. cit., p. 5.

${ }^{454}$ AAP de Sevilla (sección $5^{\mathrm{a}}$ ) de 30 de abril de 2010, ponente Ilmo. Sr. F. Sanz, f.j.4º (LA LEY 180840/2010).

${ }^{455}$ Corbal Hernández, J.E., Diligencias Preliminares (arts...), ob. cit., p. 3544. También López Sánchez, J., Las nuevas diligencias..., ob. cit., p. 5. Quedarían excluidos supuestos como el contemplado por el AAP de Madrid (sección 28 $8^{\text {a }}$ de 5 de diciembre de 2008, ponente Ilmo. Sr. P.Ma Gómez, f.j. $2^{\circ}$ (LA LEY 263211/2008), en el que se pretendía la obtención de información sobre el tratamiento de prendas, proceso de corte, confección y lavado de las mismas que era utilizado por las requeridas, en el que el tribunal entendió que se trataba de una información relativa al proceso industrial de elaboración de los productos que no aparece contemplados en el art. 256.1.7 LEC ni puede considerarse abarcado por la finalidad genérica de obtención de datos relativos al origen y redes de distribución de los productos, a cuyo efecto la LP regula el trámite especial de las diligencias de comprobación de hechos. 
Y a tal efecto, el art. 256.1.7 LEC, en concordancia con lo prevenido en el art. 47 del ADPIC ${ }^{456}$, articula el derecho de información como el derecho de obtener la identidad de los terceros que hayan participado en la producción y distribución de los bienes o servicios infractores y sobre sus circuitos de distribución. Y además, fruto también de la reforma operada por la Ley 21/2014, el derecho de obtener la identidad del posible infractor y al origen y distribución de las obras ${ }^{457}$ que no únicamente de las mercancías o servicios ${ }^{458}$.

A tal efecto, el art. 256.1.7 LEC ofrece al sujeto legitimado para instar la diligencia preliminar distintos cauces de información sobre los aspectos que pueden resultarle relevantes ${ }^{459}$, tales como:

a) Los nombres y direcciones de los productores, fabricantes, distribuidores, suministradores y prestadores de las mercancías y servicios y de quienes, con fines comerciales, hubieran estado en posesión de las mercancías.

b) Los nombres y direcciones de los mayoristas y minoristas a quienes se hubieren distribuido las mercancías o servicios, en consonancia con la previsión contenida en el art. 41 LM, que autoriza al titular del derecho de marca infringido a dirigirse no sólo contra el autor directo de la infracción sino también frente a los intermediarios a cuyos servicios haya recurrido el infractor, aunque los actos de dichos intermediarios no constituyan en sí mismos infracción.

\footnotetext{
${ }^{456}$ Así lo afirma el AAP de Madrid (sección 28ª) de 19 de octubre de 2015, ponente Ilmo. Sr. G. Plaza, f.j. $4^{\circ}$ (LA LEY 246907/2015).

${ }^{457}$ Como pone de manifiesto Obra 1: Castán Pérez-Gomez, A., El nuevo régimen..., ob. cit., p. 139, si bien ello podía entenderse implícito en el texto anterior la ausencia de referencia expresa, ante una concepción restrictiva de las diligencias, podría constituirse en un obstáculo de la concesión de la diligencia, al que se sumaban, como indican Díaz Pita, P., Diligencias preliminares y..., ob. cit., p. 199 y Armengot Vilaplana, A., Las nuevas diligencias..., ob. cit., p. 18, los problemas de identificación y localización del mismo para la práctica del interrogatorio que la redacción actual expresamente prevé.

${ }^{458}$ Según Obra 1: Castán Pérez-Gómez, A., El nuevo régimen de..., ob. cit., pp. 140-141, también en cuanto a la extensión del objeto de las diligencias al origen y redes de distribución de las obras y no exclusivamente de las mercancías o servicios, en cuanto abría paso a otras interpretaciones más amplias en las que la infracción no se materializa en un soporte tangible.

${ }^{459}$ El AAP de Sevilla (sección $5^{\text {a }}$ ) de 30 de abril de 2010, ponente Ilmo. Sr. F. Sanz, f.j.4 (LA LEY 180840/2010), señala cuales son esos cauces con reproducción de los recogidos en los aptdos. a), b) y c) del art. 256.1.7 LEC.
} 
c) Las cantidades producidas, fabricadas, entregadas, recibidas o encargadas, y las cantidades satisfechas como precio por las mercancías o servicios de que se trate, y los modelos y características técnicas de las mercancías, en consonancia con lo previsto en el art. 43 LM que, a los efectos de poder fijar la indemnización de daños y perjuicios, establece que se tendrán en cuenta los beneficios que haya obtenido el infractor como consecuencia de la violación, sirviendo la diligencia para definir adecuadamente la acción indemnizatoria a ejercitar, justificar la opción indemnizatoria que se ejercite y cuantificar la indemnización mínima a que se tiene derecho.

Así, nos encontramos ante una diligencia preliminar en que se investiga la infracción desde el punto de vista de la organización misma ${ }^{460}$, pero debe aclararse que la práctica de la diligencia no podrá dirigirse a la determinación del carácter, lícito o ilícito, de la actividad dado que la diligencia en cuestión, al igual que el resto de diligencias preliminares contempladas en el catálogo del art. 256.1 LEC, ni tiene ni puede tener una finalidad probatoria de dicho aspecto ${ }^{461}$. Ello pese a que, como se afirma en la doctrina científica, la misma permita realizar una suerte de investigación judicial que, en todo caso, deberá estar limitada a la finalidad de obtener la información necesaria para la preparación de los procesos en materia de propiedad intelectual e industrial en los que es necesario conocer previamente el alcance de la infracción a efectos indemnizatorios y de concreción de los posibles responsables y a cuyo fin resulta indispensable la colaboración del órgano judicial ${ }^{462}$, pues la razón fundamental de la concesión de la diligencia en cuestión estribaría en la imposibilidad, por otros medios, de averiguar una serie de datos que resultan imprescindibles para emprender con garantías el proceso judicial posterior ${ }^{463}$.

Y es esa necesaria colaboración del órgano judicial la que nos permite afirmar que el derecho de información que decíamos consagra en el ordenamiento jurídico español la Ley 19/2006 es, en realidad, un derecho de petición de información que no

\footnotetext{
${ }^{460}$ Villar Fuentes, I.M ${ }^{\mathrm{a}}$, Las diligencias preliminares..., ob. cit., p. 45.

${ }^{461}$ Vid. Corbal Hernández, J.E., Diligencias Preliminares (arts...), ob. cit., p. 3542.

462 Así lo pone de manifiesto López Sánchez, J., Las nuevas diligencias..., ob. cit., p. 5, lo que reitera Armengot Vilaplana, A., La nuevas diligencias preliminares..., ob. cit., p. 3.

${ }^{463}$ Vid. Larena Beldarrain, J., Las diligencias preliminares...., ob. cit., p. 698.
} 
un derecho de información, dado que el art. 256.1.7 LEC no ampara la obtención de información, en cualquier caso sino, única y exclusivamente, en los términos previstos en dicho precepto legal y siempre sometida al control judicial, dándose en los parámetros que el tribunal disponga de acuerdo a la legalidad vigente y en cuanto sea necesaria para la preparación de los procesos por infracción de los derechos de propiedad intelectual e industrial. Por tanto, no podrá hacerse efectivo el derecho de información a través de aquellas solicitudes de diligencias preliminares que el tribunal entienda que no encuentran acomodo en las previsiones del art. 256.1.7 LEC, incluso cuando a través de las mismas se pretenda preparar procesos en materia de propiedad intelectual o industrial, aún cuando no por infracción de tales derechos, teniendo en cuenta además que nada impide acudir a aquellas otras diligencias que al efecto pudieran resultar adecuadas ${ }^{464}$.

\subsection{Presupuestos para la práctica de la diligencia}

Son presupuestos necesarios y particulares que se exigen para la admisión de la diligencia en cuestión, además de los ya considerados para el régimen general de las diligencias preliminares:

1) El propósito de preparar el futuro juicio por infracción de los derechos de propiedad intelectual e industrial, lo que exige que la solicitud concrete el detalle de la acción que se pretende ejercitar con indicación de los hechos en que la misma se sustenta con justificación de la posición jurídica que ampara al solicitante para la articulación de dicho juicio ${ }^{465}$. A tal efecto, la solicitud deberá sustentarse en la

\footnotetext{
${ }^{464}$ En este contexto, vid. García Sanz, F.J. y Vendrell Cervantes, C., Doctrina judicial en..., ob. cit., p. 2, cuando señala que: "Las acciones fundamentadas en la normativa de propiedad intelectual no solo pueden prepararse con las concretas diligencias reseñadas en los apartados $7^{\circ}$ y $8^{\circ}$ del art. 256.1 LEC, sino también, en la medida en que resulten útiles, con las previstas con carácter general para todo tipo de procesos en el resto de apartados del mismo precepto". Así lo puso de manifiesto también Armengot Vilaplana, A., Las nuevas diligencias preliminares..., ob. cit., p. 3, con cita del antiguo art. 129 de la Ley 11/1986, de 20 de marzo, de Patentes que, al igual que el actual art. 123.1 de la LP ampara la solicitud de las diligencias de comprobación de hechos que pudieran constituir una violación del derecho exclusivo otorgado por la patente, sin perjuicio de las que puedan solicitarse al amparo del art. 256.1 LEC.

${ }^{465}$ En dicho sentido, lo señala el AAP de Madrid (sección $28^{\mathrm{a}}$ ) de 15 de abril de 2008, ponente Ilmo. Sr. R. Sarazá, f.j.2 $2^{\circ}$ (LA LEY 37506/2008), al destacar que: “[...] parece evidente, en primer lugar, que la determinación de los datos relativos al interés legítimo de la solicitante, entre los que ha de estar entablar
} 
infracción de los derechos de propiedad intelectual e industrial ${ }^{466}$, para lo que deberá estarse a lo dispuesto en el TRLPI y a las LP, LM y LPDI.

Igualmente habrá de examinarse si la solicitud responde a la finalidad propia de las diligencias, la preparación de una demanda en la que se ejercite una acción por infracción de un derecho de propiedad industrial sobre una base verosímil, y no a otros fines indagatorios, como establecer si hay motivo o no para un proceso debiendo tenerse en cuenta que no nos encontramos ante diligencias de comprobación (arts. 123 y ss. LP) que si que tienen por objeto la comprobación de hechos que pudieran constituir violación del derecho exclusivo otorgado por la patente y cuya finalidad y objeto es distinto de la diligencia que nos ocupa ${ }^{467}$.

2) La acreditación de indicios de la comisión de la infracción de los derechos de propiedad intelectual o industrial ${ }^{468}$ mediante actos que no puedan considerarse realizados por meros consumidores finales de buena fe y sin ánimo de obtención de beneficios económicos o comerciales, tales como la reproducción y distribución de

un futuro proceso a la vista de los datos que se obtengan en las diligencias preliminares, ha de encontrarse en la solicitud de diligencias preliminares...", y f.j. $4^{\circ}$ cuando indica: "[...] aunque no es exigible una total precisión en la expresión de la finalidad para la que se piden las diligencias preliminares, puesto que los pormenores de la demanda a entablar dependerán del resultado de las mismas, sin embargo no son admisibles solicitudes de diligencias preliminares en las que la finalidad que se dice perseguir no concuerde con el sentido y alcance de las concretas diligencias solicitadas".

${ }^{466}$ Así lo consideró el AAP de Madrid (sección $28^{\mathrm{a}}$ ) de 19 de octubre de 2015, ponente Ilmo. Sr. G. Plaza, f.j. $6^{\circ}$ (LA LEC 246907/2015) que desestimó el recurso de apelación interpuesto frente a la denegación de la diligencia preliminar por considerar, entre otras razones, que no se manifestaba un hecho que pudiera sustentar la interposición de una demanda en la que se ejercitaría una acción por infracción de un derecho de propiedad industrial que sirviera de sustento a la solicitud de diligencias preliminares en la que únicamente se acreditaba que la requerida había procedido a la fabricación de un producto aún no cuando para su comercialización sino para la iniciación del procedimiento de autorización previa al que no se extienden los derechos contenidos por la patente (art. 52 LP 11/1986, de 20 de marzo hoy, en términos similares, art. $61 \mathrm{LP})$.

${ }^{467}$ AAP de Madrid (sección 28 $8^{\mathrm{a}}$ ) de 19 de octubre de 2015, ponente Ilmo. Sr. G. Plaza, f.j. $4^{\circ}$ (LA LEY 246907/2015).

${ }^{468}$ Señala Corbal Hernández, J.E., Diligencias Preliminares (arts...), ob. cit., p. 3543, que es presupuesto de la diligencia la existencia de la infracción del derecho aún cuando con la diligencia preliminar no se pretende averiguar la realidad de la infracción cuya información al respecto pueda encaminarse a su concreción o determinación de su alcance. No obstante, se excluye la admisión de diligencias para la obtención de indicios de la comisión de la infracción, como así determinó el AAP de Sevilla (sección 5a) de 30 de abril de 2010, ponente Ilmo. Sr. F. Sanz, f.j.4º (LA LEY 180840/2010). 
fonogramas y videogramas ilícitos y la fabricación y distribución de determinados bienes como bolsos, relojes, productos de cosmética, perfumes, etc. ${ }^{469}$.

A tal efecto, el juez deberá verificar si existe una cierta verosimilitud que integre el requisito de la presunción de violación o de la justa causa y no de alcanzar grado alguno de convicción sobre la vulneración de los derechos ${ }^{470}$.

\subsection{Especial atención a la práctica del interrogatorio}

Por lo que se refiere a la concreta práctica de la diligencia del interrogatorio, también posible con la nueva redacción del art. 256.1.7 LEC, nada dice la ley sobre la posibilidad de acudir el requerido con asistencia letrada, la que ha sido ciertamente negada en la doctrina al entender que el derecho de defensa del requerido queda garantizado con la posibilidad de oposición a la práctica de la diligencia considerando, además, que ello supondría un desequilibrio entre las partes interesadas en su práctica, que no en un proceso civil ${ }^{471}$. También, al considerar que el interrogatorio no es sino la ejecución de una decisión sobre la procedencia de la diligencia solicitada en cuyo interrogatorio ninguna intervención debieran tener las asistencias letradas del solicitante y requerido ${ }^{472}$.

Sin embargo discrepamos de dichas posiciones doctrinales al considerar que el derecho de defensa del requerido no tiene por qué articularse, en todo caso, a través de la oposición a la práctica de la diligencia y que la dirección del interrogatorio que, como acto judicial, corresponde al tribunal, no le permitiría a este determinar a través de qué preguntas debe desarrollarse el mismo ${ }^{473}$.

\footnotetext{
${ }^{469}$ Vid. Armengot Vilaplana, A., Las nuevas diligencias..., ob. cit., p. 19.

${ }^{470}$ Vid. el AAP de Madrid (sección 28 ${ }^{\text {a }}$ ) de 19 de octubre de 2015, ponente Ilmo. Sr. G. Plaza, f.j. $4^{\text {o }}$ (LA LEY 246907/2015).

${ }^{471}$ Armengot Vilaplana, A., Las nuevas diligencias..., ob. cit., p. 23.

472 López Sánchez, J., Las nuevas diligencias..., ob. cit., p. 4.

${ }^{473}$ Sin perjuicio, como ponen de manifiesto García Sanz, F.J. y Vendrell Cervantes, C., Doctrina judicial en..., ob cit., p. 5, del especial celo con que el juez debe verificar los términos en que discurra el interrogatorio y que resulte imprescindible para la adecuada configuración de la pretensión.
} 
Así, habrá supuestos en que el requerido pueda mostrarse conforme con la práctica de la diligencia pero no con los concretos términos en que pueda desarrollarse el posterior interrogatorio y en los que la intervención letrada puede resultar fundamental, por ejemplo, en orden a protestar ante un interrogatorio más dirigido a la prueba de la infracción que a la obtención de los datos a que hace referencia el art. 256.1.7 LEC y que permitan al solicitante concretar la formulación de la pretensión principal que pretende deducir ${ }^{474}$. También, habrá supuestos en que las propias preguntas que se efectúen en el interrogatorio pongan de manifiesto la necesidad, en el mismo acto, de realizar otras que la parte o su defensa, considere oportuno y que no podrán quedar a criterio del tribunal, siempre sujeto al principio de imparcialidad.

No debe olvidarse que esta diligencia preliminar, como las restantes, tiene por finalidad la preparación de un proceso posterior en el que aquellas respuestas que pueda ofrecer el requerido tendrán su oportuna incidencia. Si no la tuvieran, ningún sentido tendría la diligencia. Así, entendemos que la necesidad de la defensa del requerido a la práctica de la diligencia preliminar, en el caso, se adelanta a la fase preparatoria del proceso con el que se encontrará ineludiblemente unido de forma tal que ello impide considerar que el requerido sea un mero destinatario de un simple acto de comunicación como es el requerimiento del art. 149.4 ${ }^{\circ}$ LEC y que, por ello, su defensa letrada en el acto de la diligencia es improcedente. Tal consideración de la diligencia como mero acto de comunicación podría compartirse cuando la actuación requerida se limitara a la mera presentación o exhibición de unos concretos documentos que previamente hayan sido señalados por el tribunal, a cuyo efecto ninguna asistencia letrada entendemos sería

\footnotetext{
${ }^{474} \mathrm{Al}$ respecto, vid. Larena Beldarraín, J., Las diligencias preliminares..., ob. cit., p. 699, considerando que las preguntas que se formulen deberán tener por objeto los datos relativos a la procedencia y canales de distribución de las mercancías o servicios infractores, a lo que añadimos nosotros de las obras distribuidas, la determinación de las identidades y domicilios de todos los intervinientes en la producción y distribución de aquellos y los datos alusivos a las cantidades producidas así como los beneficios obtenidos con tales actuaciones infractoras. En similares términos, vid. García García, E., Las diligencias preliminares en los litigios sobre infracción de patentes en España, en "XXIV Jornadas de estudio sobre propiedad industrial e intelectual", 2009, núm. 42. p. 27. Por otro lado, debemos recordar que la diligencia se dirige a la obtención de datos relativos a la infracción tales como las cantidades producidas, fabricadas, entregadas, recibidas o encargadas, el precio satisfecho, etc. o incluso sobre su autor de modo tal que el solicitante pueda cerciorarse sobre su identidad y que, como señala López Sánchez, J., Las nuevas diligencias..., ob. cit., p. 4, las diligencias no tienen eficacia probatoria alguna y su objeto "queda limitado por la propia ley sin que sea admisible abordar en él cuestiones ajenas señaladas por la nueva norma procesal".
} 
necesaria. Pero cuando la obtención de datos se pretenda a través de un interrogatorio cuya forma de practicarse se halla absolutamente indefinido en la norma ${ }^{475}$ y cuyo contenido incidirá en el debate del proceso que se prepara ${ }^{476}$, la asistencia letrada, a nuestro juicio, se hace indispensable. Más aún si no está negada en la LEC ${ }^{477}$. Ello aún cuando pueda afirmarse que las consecuencias que la LEC liga a la negativa a responder a las preguntas que se realicen en el interrogatorio no son aplicables al supuesto de interrogatorio que se pueda practicar en el seno del art. 256.1.7 $\mathrm{LEC}^{478}$, al no prever este efecto para la misma el art. 261 LEC, pues resulta evidente que la asistencia letrada, ante la negativa a responder, será innecesaria. Cuestión distinta es que el requerido a la práctica de la diligencia decida prescindir de dicha asistencia o que, para el caso de querer servirse de la misma, deba o no comunicarlo previamente al órgano judicial o a la parte solicitante, supuestos que entendemos ninguna incidencia tienen en la práctica del interrogatorio pues cuando la LEC ha entendido que la referida asistencia es imprescindible o no siéndolo debe ser comunicada previamente, así lo ha determinado.

\footnotetext{
${ }^{475}$ En la doctrina científica, vid. Obra 2: Castán Pérez Gómez, El nuevo régimen de..., ob. cit., p. 28, que ha manifestado la posibilidad de realizar tal interrogatorio en la forma prevista en el art. 381 LEC para las respuestas escritas a cargo de personas jurídicas y entidades públicas. También, algún autor como López Sánchez, J., Las nuevas diligencias..., ob. cit., p. 4, ha puesto de manifiesto la posibilidad de que en el requerimiento que se dirija al sujeto cuyo interrogatorio se pretende el tribunal indique cuáles son los extremos y actos sobre los que versará el interrogatorio pero lo cierto es que la LEC nada prevé en dicho sentido, siquiera cuando se trata del interrogatorio practicado en el seno del cualquier proceso civil. Ello, previa exigencia, como señala Larena Beldarrain, J., Las diligencias preliminares..., ob. cit., p. 697, de que el peticionario señale en su solicitud las preguntas sobre las que versará el interrogatorio a efectuar.

${ }^{476}$ Hasta el punto de señalarse en la doctrina científica, vid. López Sánchez, J., Las nuevas diligencias..., ob. cit., p. 4 que: "Pudiera suceder que, en el posterior interrogatorio practicado en el proceso, la parte, o en su caso el testigo, incurriese en contradicciones con lo afirmado preliminarmente en la nueva diligencia informativa o negase hechos que hubiera afirmado conocer. Esta circunstancia podrá ser tenida en cuenta por el tribunal al proceder a valorar la prueba de interrogatorio de parte o de testigos conforme a las reglas de la sana crítica".

477 Vid. García García, E., Las diligencias preliminares..., ob. cit., p. 27, cuando señala que: "En la práctica de las diligencias preliminares, no se excluye, a diferencia de lo anteriormente analizado para las diligencias de comprobación, la permanente intervención del solicitante, su procurador y abogado, sin que conste exclusión alguna al respecto".

${ }^{478}$ Larena Beldarraín, J., Las diligencias preliminares..., ob. cit., p. 699 y Corbal Hernández, J.E., Diligencias Preliminares (arts...), ob. cit., p. 3545. En la doctrina judicial, el AAP de A Coruña (sección $4^{\mathrm{a}}$ ) de 21 de febrero de 2008, ponente Ilmo. Sr. J.M. Busto, f.j.4 (LA LEY 28300/2008) ya dispuso que el efecto consistente en la atribución de eficacia en ulterior proceso a los hechos afirmados y los datos presentados está prevista para los casos en que el destinatario de la diligencia se niegue a declarar sobre su capacidad, representación o legitimación cuyas preguntas, por demás, no podrían venir referidas a cuestiones sobre el fondo del asunto.
} 
Con los mismos parámetros legales señalados al inicio del análisis del interrogatorio, podemos afirmar la posibilidad de la práctica de la diligencia mediante la exhibición de documentos que, tras la reforma operada por la Ley 21/2014, podrán ser presentados ante el juzgado para su exhibición por medios telemáticos o electrónicos en la sede de la Oficina Judicial, pudiendo obtener la parte solicitante, con los medios que aporte, copia electrónica de la misma (art. 259.2 LEC).

\subsection{Legitimación}

En cuanto a la legitimación activa, el tenor literal del precepto legal permite advertir que corresponderá a quien pretenda ejercitar una acción por infracción de un derecho de propiedad industrial o intelectual ${ }^{479}$, pudiendo instarla tanto los titulares originarios de los derechos citados como los titulares derivativos, en materia de propiedad intelectual, o licenciatarios de los mismos, en materia de propiedad industrial $^{480}$.

En cuanto a la legitimación pasiva, puede afirmarse que corresponderá a aquellos sujetos que refiere el art. 256.1.7 ${ }^{\circ} \mathrm{LEC}^{481}$. Es decir:

a) A aquél a quien el solicitante considere autor de la violación y que, por ello, debe ser concretado en la solicitud ${ }^{482}$.

\footnotetext{
${ }^{479}$ En dicho sentido, García Sanz, F.J. y Vendrell Cervantes, C., Doctrina judicial en..., ob. cit., p. 3, que advierte que deberá atenderse a las reglas y presupuestos de legitimación de la acción principal y, en particular, en el caso de la entidades de gestión de derechos, al art. 150 de la LPI. También, Armengot Vilaplana, A., Las nuevas diligencias..., ob. cit., p. 16, que señala que en el ámbito de la propiedad intelectual, si la actividad infractora ha consistido en la reproducción y distribución de fonogramas o videogramas en los que se han explotado ilícitamente un gran número de obras musicales y audiovisuales, estarán legitimados los productores fonográficos y audiovisuales y titulares derivados de otros derechos de propiedad intelectual sobre las obras reproducidas y, en el ámbito de la propiedad industrial, el titular del derecho de patente o de marca sobre el producto explotado ilícitamente y al licenciatario de esos derechos.

${ }^{480}$ Larena Beldarraín, J., Las diligencias preliminares..., ob. cit., p. 696; Armengot Vilaplana, A., Las nuevas diligencias..., ob. cit., p. 16; Corbal Hernández, J.E., Diligencias Preliminares (arts...), ob. cit., p. 3544.

${ }^{481}$ Cfr. Armengot Vilaplana, A., Las nuevas diligencias..., ob. cit., pp. 16-17 y Larena Beldarraín, J., Las diligencias preliminares..., ob. cit., pp. 696-697.
} 
b) A quien, a escala comercial, haya prestado o utilizado servicios ${ }^{483} \mathrm{o}$ haya estado en posesión de mercancías que pudieran haber lesionado los derechos de propiedad industrial o intelectual ${ }^{484}$.

c) A aquél a quien los anteriores hubieren atribuido intervención en los procesos de producción, fabricación, distribución o prestación de aquellas mercancías y servicios $^{485}$.

\subsection{Confidencialidad de la información}

Y como cláusula de cierre no podemos sino recordar que la Exposición de Motivos de la Ley 19/2006, ante la posibilidad de un irregular uso de las diligencias preliminares para la preparación de los procesos por infracción de los derechos de propiedad intelectual e industrial, ya dispuso que la regulación de la práctica de estas diligencias preliminares estaba presidida por la doble cautela de garantizar la confidencialidad de la información requerida y de evitar que los datos obtenidos pudieran utilizarse para fines distintos a la preparación del juicio, tales como el acceso a

\footnotetext{
${ }^{482}$ Como señala Armengot Vilaplana, A., Las nuevas diligencias..., ob. cit., p. 17, sin perjuicio de que como consecuencia de la práctica de la diligencia preliminar solicitada se determine que el señalado no es el autor de la infracción o de que se concreten otros posibles autores.

${ }^{483}$ Que Armengot Vilaplana, A., Las nuevas diligencias..., ob. cit., p. 17, identifica con quienes realizan las labores de producción o fabricación de mercancías ilícitas, emplean maquinaria o procedimientos que infrinjan un derecho de patente, los prestadores de servicios a quienes acuden los proveedores de contenidos para que puedan explotarse ciertas obras en redes de comunicación si bien respecto a estos últimos cabe añadir que tanto la doctrina científica como la judicial consideraron, antes de la reforma operada por la Ley 21/2014, que quedaban excluidas del ámbito de la diligencia del art. 256.1.7 LEC las infracciones cometidas en línea. En dicho sentido, Díaz Pita, P., Diligencias preliminares y..., ob. cit., p. 188, cuando afirma que no se extrae conexión entre la reforma operada con el texto de la Ley 21/2014 y el contenido de las Directivas de las que la misma, en su Exposición de Motivos, dice traer causa, atribuyendo la modificación que la misma introduce al escollo insalvable que suponía la regulación anterior de las diligencias al circunscribir su solicitud a los casos en que se cometieran por actos realizados a escala comercial y a la dificultad de aplicación flexible del catálogo de diligencias antes de la reforma y que afectaba tanto a la infracción de derechos de propiedad intelectual "en línea" como a las cometidas "fuera de línea".

${ }^{484}$ Vid. Obra 2: Castán Pérez-Gómez, A., El nuevo régimen..., ob. cit., p. 26; también Armengot Vilaplana, A., Las nuevas diligencias..., ob. cit., p. 17, que identifica a los poseedores con quienes realizan las labores de transporte o distribución de las mercancías ilícitas, o quienes desarrollan la labor de almacenamiento de las mismas.

${ }^{485}$ Que, según Armengot Vilaplana, A., Las nuevas diligencias..., ob. cit., p. 17, albergaría el mismo contenido normativo que el aptdo. c).
} 
ámbitos reservados o secretos de la empresa como medio de coacción o la actividad indagatoria en búsqueda de ilícitos no definidos (fishing expedition) $)^{486}$. En dicho sentido, el art. 259.3 LEC prevé, para garantizar la confidencialidad de la información requerida, que el tribunal pueda ordenar que la práctica del interrogatorio se celebre a puerta cerrada imponiendo, por otro lado, una limitación respecto al uso de la información, dado que el art. 259.4 LEC exige que el solicitante destine la información obtenida exclusivamente para la tutela jurisdiccional de los derechos de propiedad industrial o intelectual del solicitante de las medidas, con prohibición de divulgarla o comunicarla a terceros, es decir, para el exclusivo fin para el cual fue obtenida.

Tales previsiones no se justificarían si no fuera porque, como se pone de manifiesto en la doctrina científica ${ }^{487}$, en el ámbito de esta diligencia preliminar pudieran ponerse de manifiesto informaciones estratégicas de un competidor, secretos industriales o comerciales ${ }^{488}$ así como la contabilidad de la empresa ${ }^{489}$, lo que explica la excepción al principio de publicidad del proceso contemplada en los arts. 24.2 y 120.1 CE y 138 LEC y que en el ámbito de esta diligencia preliminar quedará en mano de los interesados, a diferencia de lo que ocurre en el ámbito de las diligencias de comprobación en que se impone la actuación de oficio del tribunal.

\footnotetext{
${ }^{486}$ AAP de Madrid (sección 28 $8^{\mathrm{a}}$ ) de 19 de octubre de 2015, ponente Ilmo. Sr. G. Plaza, f.j. $4^{\circ}$ (LA LEY 246907/2015).

${ }^{487}$ García Sanz, F.J. y Vendrell Cervantes, C., Doctrina judicial en..., ob cit., p. 5 señalan como tales la identidad de productores o clientes, cantidades facturadas y características de las mercancías producidas. También García García, E., Las diligencias preliminares..., ob. cit.,p. 29.

${ }^{488} \mathrm{~A}$ tal efecto debe ponerse de manifiesto el problema frecuente en las diligencias en materia de patentes farmacéuticas en que la negativa a facilitar la información requerida se sustenta en el deber de guardar secreto. Como pone de manifiesto Obra 2: Castán Pérez-Gómez, A., El nuevo régimen..., ob. cit., pp. 3536, se trata del caso frecuente en que la Agencia Española del Medicamento rechaza la petición de información formulada por un juzgado sobre un expediente de autorización de medicamentos genéricos al entender que los mismos gozan de confidencialidad conforme a la normativa administrativa, ejemplo del cual lo constituye la STCJ de 5 de marzo de 2007, ponente Ilmo. Sr. E. Calvo, f.j. $3^{\circ}$ (LA LEY11590/2007) y en que este determinó que son los jueces y no la Administración los que deben ponderar en el curso de las diligencias preliminares la incidencia de la garantía de confidencialidad recogida en la legislación sanitaria. Aún cuando no faltan resoluciones en sentido contrario y en las que se han desestimado solicitudes de diligencias de comprobación de hechos dirigidas a la Agencia Española del Medicamento. Vid. también el AAP de Madrid (sección $28^{\mathrm{a}}$ ) de 16 denoviembre de 2006, ponente Ilmo. Sr. G. Plaza, f.j.4º (JUR 2007\75909).

${ }^{489}$ Cuyo carácter sensible o reservado no podrá ser invocado para oponerse a la práctica de la diligencia preliminar habida cuenta lo dispuesto en el art. 32 CCo que determina el secreto de la contabilidad sin perjuicio de lo dispuesto en las Leyes. En dicho sentido, vid. el AAP de Granada (sección $3^{\mathrm{a}}$ ) de 11 de octubre de 2012, ponente Ilmo. Sr. E.P. Pinazo, f.j.3º (ROJ AAP GR 553/2012).
} 


\section{Exhibición documental en materia de propiedad industrial 0 intelectual} (art. 256.1.8 LEC)

"Por petición de quien pretenda ejercitar una acción por infracción de un derecho de propiedad industrial o de un derecho de propiedad intelectual cometida mediante actos desarrollados a escala comercial, de la exhibición de los documentos bancarios, financieros, comerciales o aduaneros, producidos en un determinado tiempo y que se presuman en poder de quien sería demandado como responsable. La solicitud deberá acompañarse de un principio de prueba de la realidad de la infracción que podrá consistir en la presentación de una muestra de los ejemplares, mercancías o productos en los que materialice aquella infracción. El solicitante podrá pedir que el Secretario extienda testimonio de los documentos exhibidos si el requerido no estuviera dispuesto a desprenderse del documento para su incorporación a la diligencia practicada. Igual solicitud podrá formular en relación con lo establecido en el último párrafo del número anterior.

A los efectos de los números $7^{\circ}$ y $8^{\circ}$ de este apartado, se entiende por actos desarrollados a escala comercial aquellos que son realizados para obtener beneficios económicos o comerciales directos o indirectos".

Partiendo de lo anterior, quien pretenda iniciar un proceso civil por infracción de los derechos de propiedad intelectual o industrial cometida mediante actos desarrollados a escala comercial podrá instar el auxilio del órgano judicial para la exhibición de los documentos bancarios, financieros, comerciales o aduaneros producidos en un determinado tiempo y que se presuman en poder del posible responsable.

Dicha diligencia ha sido justificada en la doctrina en la necesidad de quien pretenda iniciar un proceso para reparar el daño producido por infracción de los derechos de propiedad industrial o intelectual, de conocer con exactitud la cuantía de los beneficios fraudulentamente obtenidos, ya que solo así el solicitante podrá fijar en su demanda posterior lo que pida, con claridad y precisión (art. 399.1 LEC). Debe tenerse en cuenta que en los supuestos de infracción a escala comercial, de derechos de 
propiedad intelectual e industrial, no sólo la indemnización que el actor pueda solicitar vendrá delimitada por los beneficios que el infractor haya obtenido como consecuencia de su actividad ilícita sino que es presumible que el responsable obtenga unos ingresos notables cuya cuantía exacta, de no tenerse acceso a los documentos que acreditan las transacciones comerciales efectuadas o los ingresos realizados en cuentas bancarias, es muy difícil de determinar ${ }^{490}$. Por ello, se afirma en la doctrina judicial que su finalidad es la de facilitar la fijación del importe económico de la pretensión indemnizatoria derivada de la infracción de derechos ${ }^{491}$. Y esta, normalmente, vendrá determinada por los beneficios obtenidos por el infractor como consecuencia de la utilización ilícita y en los términos previstos en los arts. 140 TRLPI $^{492}$, en cuanto a los derechos de propiedad intelectual, $74 \mathrm{LP}^{493}$, en los supuestos de patentes, $43 \mathrm{LM}^{494}$, en los casos de actos de

${ }^{490}$ López Sánchez, J., Las nuevas diligencias..., ob. cit., p. 7.
${ }^{491}$ AAP de Madrid (sección $28^{\text {a }}$ ) de 19 de octubre de 2015 , ponente Ilmo. Sr. G. Plaza, f.j.4 (LA LEY
$246907 / 2015$ ).
${ }^{492}$ Dispone el art. 140 TRLPI que: "1. La indemnización por daños y perjuicios debida al titular del derecho infringido comprenderá no sólo el valor de la pérdida que haya sufrido, sino también el de la ganancia que haya dejado de obtener a causa de la violación de su derecho. La cuantía indemnizatoria podrá incluir, en su caso, los gastos de investigación en los que se haya incurrido para obtener pruebas razonables de la comisión de la infracción objeto del procedimiento judicial. 2. La indemnización por daños y perjuicios se fijará, a elección del perjudicado, conforme a alguno de los criterios siguientes: a) Las consecuencias económicas negativas, entre ellas la pérdida de beneficios que haya sufrido la parte perjudicada y los beneficios que el infractor haya obtenido por la utilización ilícita. En el caso de daño moral procederá su indemnización, aun no probada la existencia de perjuicio económico. Para su valoración se atenderá a las circunstancias de la infracción, gravedad de la lesión y grado de difusión ilícita de la obra. b) La cantidad que como remuneración hubiera percibido el perjudicado, si el infractor hubiera pedido autorización para utilizar el derecho de propiedad intelectual en cuestión. 3. La acción para reclamar los daños y perjuicios a que se refiere este artículo prescribirá a los cinco años desde que el legitimado pudo ejercitarla". En dicho sentido, vid. la SAP de Girona (sección 1ª) de 17 de febrero de 2010, ponente Ilmo. Sr. F. Ferrero, f.j.3º (LA LEY 37550/2010).

${ }^{493}$ Señala el art. 74 LP que: "1. La indemnización de daños y perjuicios debida al titular de la patente comprenderá no sólo el valor de la pérdida que haya sufrido, sino también el de la ganancia que haya dejado de obtener el titular a causa de la violación de su derecho. La cuantía indemnizatoria podrá incluir, en su caso, los gastos de investigación en los que se haya incurrido para obtener pruebas razonables de la comisión de la infracción objeto del procedimiento judicial. 2. Para fijar la indemnización por daños y perjuicios se tendrán en cuenta, a elección del perjudicado: a) Las consecuencias económicas negativas, entre ellas los beneficios que el titular habría obtenido previsiblemente de la explotación de la invención patentada si no hubiera existido la competencia del infractor o alternativamente, los beneficios que este último haya obtenido de la explotación del invento patentado. En el caso de daño moral procederá su indemnización, aun no probada la existencia de perjuicio económico. b) Una cantidad a tanto alzado que al menos comprenda la cantidad que el infractor hubiera debido pagar al titular de la patente por la concesión de una licencia que le hubiera permitido llevar a cabo su explotación conforme a derecho. Para su fijación se tendrá en cuenta especialmente, entre otros factores, la importancia económica del invento patentado, el tiempo de vigencia que le reste a la patente en el momento en que comenzó la infracción y el número y clase de licencias concedidas en ese momento. 3. Cuando el órgano jurisdiccional estime que el titular no cumple con la obligación de explotar la patente establecida en el artículo 90 la ganancia dejada de obtener se fijará de acuerdo con lo establecido en el párrafo b) del apartado anterior. 4. Cuando se 
violación de la marca, y 55 LPDI $^{495}$, respecto de los actos de explotación no autorizada del diseño registrado.

condene a la cesación de los actos que infrinjan una patente el Tribunal fijará una indemnización coercitiva a favor del demandante adecuada a las circunstancias por día transcurrido hasta que se produzca la cesación efectiva de la infracción. El importe definitivo de esta indemnización, que se acumulará a la que le corresponda percibir con carácter general en aplicación del apartado 2, así como el día a partir del cual surgirá la obligación de indemnizar, se fijarán en ejecución de sentencia, de acuerdo con lo previsto en la Ley 1/2000, de 7 de enero, de Enjuiciamiento Civil. 5. Las diligencias relativas al cálculo o cuantificación y liquidación de daños de acuerdo con los criterios establecidos en este artículo se llevarán a cabo a partir de las bases fijadas en la sentencia conforme al procedimiento previsto en el Capítulo IV del Título V del Libro III de la Ley de Enjuiciamiento Civil". En dicho sentido, vid. la STS de 3 de mayo de 2017 (sala 1ª), ponente Ilmo. Sr. I. Sancho, f.j.6º (LA LEY 35031/2017).

${ }^{494}$ Señala el art. 43 LM que: "1. La indemnización de daños y perjuicios comprenderá no sólo las pérdidas sufridas, sino también las ganancias dejadas de obtener por el titular del registro de la marca causa de la violación de su derecho. El titular del registro de marca también podrá exigir la indemnización del perjuicio causado al prestigio de la marca por el infractor, especialmente por una realización defectuosa de los productos ilícitamente marcados o una presentación inadecuada de aquélla en el mercado. Asimismo, la cuantía indemnizatoria podrá incluir, en su caso, los gastos de investigación en los que se haya incurrido para obtener pruebas razonables de la comisión de la infracción objeto del procedimiento judicial. 2. Para fijar la indemnización por daños y perjuicios se tendrá en cuenta, a elección del perjudicado: a) Las consecuencias económicas negativas, entre ellas los beneficios que el titular habría obtenido mediante el uso de la marca si no hubiera tenido lugar la violación y los beneficios que haya obtenido el infractor como consecuencia de la violación. En el caso de daño moral procederá su indemnización, aun no probada la existencia de perjuicio económico. b) La cantidad que como precio el infractor hubiera debido de pagar al titular por la concesión de una licencia que le hubiera permitido llevar a cabo su utilización conforme a derecho. 3. Para la fijación de la indemnización se tendrá en cuenta, entre otras circunstancias, la notoriedad, renombre y prestigio de la marca y el número y clase de licencias concedidas en el momento en que comenzó la violación. En el caso de daño en el prestigio de la marca se atenderá, además, a las circunstancias de la infracción, gravedad de la lesión y grado de difusión en el mercado. 4. A fin de fijar la cuantía de los daños y perjuicios sufridos, el titular de la marca podrá exigir la exhibición de los documentos del responsable que puedan servir para aquella finalidad. 5. El titular de la marca cuya violación hubiera sido declarada judicialmente tendrá, en todo caso y sin necesidad de prueba alguna, derecho a percibir en concepto de indemnización de daños y perjuicios el 1 por ciento de la cifra de negocios realizada por el infractor con los productos o servicios ilícitamente marcados. El titular de la marca podrá exigir, además, una indemnización mayor si prueba que la violación de su marca le ocasionó daños o perjuicios superiores, de acuerdo con lo dispuesto en los apartados anteriores". En este contexto, vid. la SAP de Barcelona (sección 15 ${ }^{\text {a }}$ ) de 14 de diciembre de 2016, ponente Ilmo. Sr. J.F. Garnica, f.j. $7^{\circ}$ (LA LEY 194624/2016).

${ }^{495}$ Previene el art. 55 LPDI que: "1. La indemnización de daños y perjuicios comprenderá no sólo las pérdidas sufridas, sino también las ganancias dejadas de obtener por el titular del diseño a causa de la violación de su derecho. El titular del diseño registrado también podrá exigir la indemnización del perjuicio causado al prestigio del diseño por el infractor, especialmente por una realización defectuosa de los productos ilícitamente comercializados, la realización defectuosa de las imitaciones o las condiciones en que haya tenido lugar su comercialización. Asimismo, la cuantía indemnizatoria podrá incluir, en su caso, los gastos de investigación en los que se haya incurrido para obtener pruebas razonables de la comisión de la infracción objeto del procedimiento judicial. 2. Para fijar la indemnización por daños y perjuicios se tendrá en cuenta, a elección del perjudicado: a) Las consecuencias económicas negativas, entre ellas los beneficios que el titular habría obtenido de la explotación del diseño si no hubiera tenido lugar la violación de su derecho y los beneficios obtenidos por el infractor como consecuencia de la violación del derecho del titular del diseño registrado. En el caso de daño moral procederá su indemnización, aun no probada la existencia de perjuicio económico. b) La cantidad que como precio el infractor hubiera debido de pagar al titular del diseño por la concesión de una licencia que le hubiera permitido llevar a cabo la explotación del diseño conforme a derecho. 3. Para la fijación de la 
Por otro lado, cabe precisar que nos encontramos ante una diligencia preliminar, en cierta medida, autónoma pero también complementaria de la contemplada en el ordinal $7^{\circ}$ del art. 256.1 LEC dado que, a nuestro juicio, no será necesaria la previa articulación de esta última si ya se conoce por el solicitante la identidad de infractor ${ }^{496}$, pero no podrá interesarse la exhibición de los documentos bancarios, financieros, comerciales o aduaneros si no se conoce tal identidad, pues exige el ordinal $8^{\circ}$ que la diligencia sea interesada respecto de la persona en poder de la que tales documentos se presuma se encuentren que, a su vez, debe coincidir con quien sería demandado como responsable. También, y al igual que con la diligencia preliminar del art. 256.1.7 LEC, ante una diligencia preliminar en la que se investiga la infracción desde el punto de vista de la organización de la misma ${ }^{497}$ pero, en este caso, cerrando el círculo de los datos necesarios que el solicitante debe conocer para plantear correctamente su demanda determinando la cuantía del perjuicio sufrido, cuestión de vital trascendencia en un sistema procesal como el español en el que no están permitidas las sentencias con reserva de liquidación (art. 219 LEC). De hecho, según la doctrina científica, esta última circunstancia justifica que el legislador haya contemplado la petición de documentos a que se refiere el art. 328.3 LEC como una diligencia preliminar dado que, una vez iniciado el proceso, la modificación de las cantidades reclamadas inicialmente, aún como consecuencia de la exhibición documental, no sería admisible por el efecto de la

indemnización se tendrá en cuenta especialmente la importancia económica del diseño y su incidencia en la demanda del producto que lo incorpora, su notoriedad e implantación en el mercado y el número y clases de licencias concedidas en el momento en que comenzó la actividad infractora. En caso de daño al prestigio del diseño se atenderá, además, a las circunstancias de la infracción, gravedad de la lesión y grado de difusión en el mercado de los productos infractores. 4. Para fijar la cuantía de los daños y perjuicios sufridos, el titular del diseño podrá exigir, de conformidad con lo previsto en el artículo

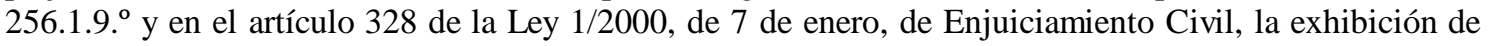
los documentos del presunto responsable de la vulneración del derecho, que puedan servir para aquella finalidad. 5. El titular del diseño registrado cuya violación hubiera sido declarada judicialmente tendrá, en todo caso y sin necesidad de prueba adicional alguna, derecho a percibir en concepto de indemnización de daños y perjuicios el uno por ciento de la cifra de negocios realizada por el infractor con los productos que incorporen el diseño protegido. El titular del diseño podrá exigir, además, una indemnización mayor si prueba que la infracción de su derecho le ocasionó daños o perjuicios superiores, de acuerdo con lo dispuesto en los artículos anteriores. 6. Cuando se condene a la cesación de los actos de violación de un diseño registrado, el tribunal fijará una indemnización coercitiva de cuantía determinada no inferior a 600 euros por día transcurrido hasta que se produzca la cesación efectiva de la infracción. El importe de esta indemnización y el día a partir del cual surgirá la obligación de indemnizar se fijará en ejecución de sentencia". Al respecto, vid. laSAP de Alicante (sección $8^{\text {a }}$ ) de 14 de febrero de 2017, ponente Ilmo. Sr. F.J. Soriano, f.j.4 (LA LEY 36312/2017).

${ }^{496}$ A sensu contrario podría admitirse la posibilidad de su rechazo.

${ }^{497}$ Villar Fuentes, I.M., Las diligencias preliminares..., ob. cit., p. 45. 
preclusión $^{498}$, lo que ha sido confirmado por la doctrina judicial ${ }^{499}$, salvedad hecha de resoluciones aisladas que entienden que tal determinación previa no es necesaria ${ }^{500}$.

Por último, debe precisarse que serán de aplicación todas las consideraciones efectuadas en el estudio de la diligencia preliminar del ordinal $7^{\circ}$ del art. 256.1 LEC en relación a la confidencialidad de la información requerida (art. 259.4 LEC) y la ausencia de incompatibilidad de la exhibición de los documentos con el secreto de la información contable del empresario ${ }^{501}$.

\footnotetext{
${ }^{498}$ Según Armengot Vilaplana, A., Las nuevas diligencias..., ob. cit., p. 30.

${ }^{499}$ En este sentido, la SAP de Segovia (sección única) de 28 de diciembre de 2007, ponente Ilmo. Sr. I. Pando, f.j. $2^{\circ}$ (LA LEY 324811/2007) señala que, con anterioridad a la reforma operada en la LEC por la Ley 19/2006, era frecuente la admisión por los tribunales de la determinación de la indemnización de acuerdo con el resultado de la prueba dado que hasta dicho momento no se habían establecido en la LEC, de forma expresa, los medios de acceso previos para evitar la indeterminación de la demanda. Sin embargo, esta situación cambia cuando, con aquella reforma, se introducen en la LEC las diligencias del art. 256.1.7 y 8 LEC, que ya permiten la determinación previa al proceso. De hecho, la SAP de Pontevedra (sección $1^{\mathrm{a}}$ ) de 18 de junio de 2010, ponente Ilmo. Sr. F.J. Valdés, f.j. $4^{\circ}$ (LA LEY 156604/2010) destaca que: “[...] a la alegación de indefensión de la actora-recurrente por la indisponibilidad de los datos necesarios para la concreta determinación del importe indemnizatorio y falta de colaboración de la demandada en su facilitación durante el curso del proceso, cabe responder que, a la vista de la reforma operada en la LEC por la ley 19/2006, de 5 de junio, por la que se amplían los medios de tutela de los derechos de propiedad intelectual e industrial, la demandante pudo muy bien recurrir a la vía de las diligencias preliminares para obtener la información que precisaba en orden a la exacta cuantificación de la reclamación dineraria a plantear (art. 256-1-7 y $8^{\circ}$ en relación con el 261-5 de la LEC), lo que no hizo, no pudiendo ahora invocar un desamparo cognoscitivo provocado por su indiligente actuación".

${ }^{500}$ Vid. el AAP de Sevilla (sección $5^{\text {a }}$ ) de 29 de noviembre de 2010, ponente Ilmo. Sr. C. Gallardo, f.j. $3^{\circ}$ (LA LEY 296879/2010) conforme al cual: “[...] La cuantificación de la cantidad que legalmente corresponde solicitar mediante la aplicación de la correspondiente tarifa no puede considerarse, desde el punto de vista procesal, imprescindible para la formulación de una demanda por infracción de derechos de la propiedad intelectual. Lo esencial en este tipo de demanda es conocer el tipo de infracción y la identidad del que la ha cometido. En cuanto a la cantidad a reclamar, es cierto que el artículo 219 de la Ley de Enjuiciamiento Civil prohíbe las sentencias con reserva de liquidación para la ejecución, pero no es menos cierto que permite solicitar una cantidad que resulte de una pura operación aritmética, lo que sería el caso de autos, ya que bastaría aplicar las tarifas oficialmente aprobadas a los datos objetivos que resulten de la prueba practicada en el litigio. Por otra parte ese mismo precepto en su apartado $3^{\circ}$ permite solicitar una sentencia que declare la infracción del derecho y condene al pago de una indemnización por ello, dejando para un pleito posterior los problemas de liquidación concretas de las cantidades, por lo que la fijación de la indemnización procedente ni es imprescindible para la correcta configuración del proceso, ni para asegurar la eficacia de la sentencia que se dicte en su día".

${ }^{501}$ Así lo pone de manifiesto, entre otros, el AAP de Madrid (sección 28 ${ }^{a}$ ) de 25 de septiembre de 2008, ponente Ilmo. Sr. E. Garcia, f.j.3º (LA LEY 191903/2008).
} 


\subsection{Origen de la diligencia}

El origen de esta diligencia preliminar, tal y como ha sido puesto de manifiesto en la doctrina, trae causa del art. 6.2 de la Directiva 48/2004/CE que contempla la posibilidad de que los Estados miembros adopten las medidas necesarias para permitir a las autoridades judiciales competentes la ordenación de la transmisión de documentos bancarios, financieros o comerciales que se encuentren bajo el control de una parte contraria $^{502}$. Pero si se procede a la lectura detenida de los Considerandos de la Directiva $^{503}$ se observará como, pese a haber sido introducida en la LEC como una diligencia preliminar, aquellos se refieren a la misma como un medio de prueba ${ }^{504}$ y no como una actuación puramente preparatoria del proceso posterior. Al menos, con el sentido que en el ordenamiento procesal civil español se confiere a dicha actividad preparatoria y a la que doctrina, científica y judicial, le ha negado eficacia probatoria alguna. No obstante, el origen de la diligencia no puede llevarnos a obviar que el legislador español la ha introducido en el ordenamiento procesal civil no como una actividad probatoria sino como una actividad preparatoria, lo que exige respetar los límites de dicha actividad configurados en la LEC negando cualquier finalidad probatoria que respecto del pleito posterior se pudiera pretender, aún cuando en el supuesto en cuestión los límites de la actividad estrictamente preparatoria que constituye la característica tradicional de la diligencia preliminar y la utilidad probatoria de los materiales que a través de la misma puedan obtenerse aparezcan tan difuminados $^{505}$. Tanto que, en las disposiciones que la LEC dedica a la prueba de

\footnotetext{
502 Armengot Vilaplana, A., Las nuevas diligencias..., ob. cit., p. 29. Así se recoge también en el AAP de Madrid (sección 28 $8^{\mathrm{a}}$ ) de 19 de octubre de 2015, ponente Ilmo. Sr. G. Plaza, f.j.4º (LA LEY 246907/2015). ${ }^{503}$ Concretamente, el Considerando 20 señala: “[...] Dado que la prueba es un elemento fundamental para el establecimiento de la infracción de los derechos de la propiedad intelectual, conviene garantizar que se pongan de manera efectiva a disposición de las partes medios de presentación, obtención y protección de pruebas. Los procedimientos deben tener en cuenta los derechos de la defensa y prever las garantías necesarias, incluida la protección de la información confidencial. Para las infracciones cometidas a escala comercial es asimismo importante que los tribunales puedan autorizar, cuando sea conveniente, el acceso a los documentos bancarios, financieros o comerciales que se encuentren bajo control del presunto infractor".

${ }^{504}$ Hasta el punto de afirmarse en la doctrina científica que el ordinal $8^{\circ}$ del art. 256.1 LEC supuso la encarnación del derecho de prueba (Vid. Obra 2: Castán Pérez-Gómez, A., El nuevo régimen..., ob. cit., p. 127).

${ }^{505}$ Así lo afirma el AAP de Madrid (sección 28 ${ }^{\mathrm{a}}$ ) de 5 de diciembre de 2008, ponente Ilmo. Sr. P.M ${ }^{\mathrm{a}}$. Gómez, f.j.2º (LA LEY 263211/2008).
} 
documentos, se incluye el art. 328.3 cuyo contenido es prácticamente idéntico al de la diligencia que nos ocupa. Sin embargo, el hecho de que, junto a la finalidad de preparar la demanda, el material obtenido mediante la diligencia preliminar pueda llegar a reportar al solicitante una utilidad estrictamente probatoria en el futuro proceso es una circunstancia que quedará sujeta a las reglas de la prueba del proceso que se pretenda preparar.

\subsection{Objeto de la diligencia}

En cuanto al objeto de la diligencia, como se desprende del propio tenor literal del art. 256.1.8 LEC, no será otro que los documentos bancarios, financieros, comerciales o aduaneros entre los que debemos entender incluidos los libros y contabilidad de los empresarios ${ }^{506} \mathrm{y}$, en este último caso, siempre y cuando se trate de información que no pueda ser obtenida del Registro Mercantil ${ }^{507}$. Documentos que, como ha sido puesto de manifiesto en la doctrina, tanto desde el punto de vista subjetivo como del objetivo, son diferentes de los que pueden ser exhibidos a través de la diligencia del art. 256.1.7 LEC $^{508}$. Desde el punto de vista subjetivo, porque los documentos que debieran o pudieran ser exhibidos al amparo del ordinal $7^{\circ}$ del mismo precepto legal serían aquellos que se encuentren en poder o a disposición de cuantos

\footnotetext{
${ }^{506}$ Coincidimos en este extremo con Soler Pascual, L.A., Las diligencias preliminares..., ob. cit., p. 6, sin desconocer el contenido de resoluciones aisladas que niegan tal posibilidad, como fue el AAP de Sevilla (sección $28^{\text {a }}$ ) de 29 de noviembre de 2010, ponente Ilmo. Sr. C. Gallardo, f.j.3º (LA LEY 296879/2010) señalando al efecto que: "[...] la solicitud que ha sido denegada por la resolución apelada en sede de diligencias preliminares constituye una petición de comunicación o reconocimiento general de los libros, correspondencia y demás documentos de un empresario durante un período de como mínimo cinco años que es contraria al carácter secreto que a los mismos otorga el apartado 1 del artículo 32 del Código de Comercio y a la prohibición del apartado 2 de dicho artículo, salvo en las excepciones expresamente previstas en el mismo; tal solicitud no puede incluirse en el artículo 256.1.8 $8^{\circ}$ de la Ley de Enjuiciamiento Civil, que habla sólo de exhibición de documentos bancarios,financieros, comerciales o aduaneros, es decir, documentos concretos y no revisión general de libros de contabilidad o de otros libros de un comerciante; por otra parte lo que se pide es absolutamente desproporcionado para conseguir la finalidad de calcular el importe resultante de aplicar la tarifa correspondiente; finalmente, como ya se ha indicado, no es imprescindible o esencial para iniciar correctamente el proceso. Por todas estas razones ha de considerarse ajustada a derecho la denegación que lleva a cabo la resolución apelada". También afirman la inclusión de los documentos contables en el objeto de la diligencia, Gil Nogueras, L.A., Las diligencias preliminares en materia de propiedad intelectual e industrial, en "Práctica de Tribunales", 2017, núm. 125 (LA LEY 2914/2017), p. 6.

${ }^{507}$ En dicho sentido, el AAP de Granada (sección $3^{\text {a }}$ ) de 27 de abril de 2007, ponente Ilmo. Sr J.M ${ }^{\text {a. }}$ Jiménez, f.j.2 (LA LEY 60757/2007).

${ }^{508}$ Armengot Vilaplana, A., Las nuevas diligencias..., ob. cit., p. 31.
} 
sujetos pudieran ser requeridos conforme a la misma y que podrán o no, en el futuro proceso, reunir la condición de demandados, mientras que los documentos que deben ser exhibidos con ocasión de la práctica de la diligencia preliminar del ordinal $8^{\circ} \mathrm{del}$ art. 256.1 LEC son aquellos que se presuma se encuentren en poder de quien sería demandado. Desde el punto de vista objetivo, porque los documentos a que se contrae la diligencia del ordinal $8^{\circ}$ son los concretamente determinados en ella, antes citados, mientras que aquellos a los que puede extenderse la diligencia del ordinal $7^{\circ}$ son los relacionados con los datos sobre los que verse la concreta diligencia de obtención de datos tales como los relativos a las obras, mercancías producidas, medios e instrumentos utilizados así como sujetos participantes en la infracción. Ello sin perjuicio del punto de conexión que se observa entre los documentos contemplados en el ordinal $8^{\circ}$ y aquellos cuya exhibición podría solicitarse para la obtención de los datos contemplados en el aptdo. c) del ordinal $7^{\circ}$ relativos a las cantidades producidas, fabricadas, entregadas, recibidas o encargadas y las cantidades satisfechas como precio por las mercancías o servicios de que se trate, los modelos y características técnicas de las mercancías, datos que obviamente, en la mayor parte de las ocasiones, se recogerán en documentos bancarios, financieros, comerciales y/o aduaneros.

Y debe recordarse en este punto que la información que se desprenda de los documentos que se obtengan a través de la práctica de la diligencia preliminar en modo alguno tiene el valor de prueba anticipada sino que servirá para constatar un hecho necesario para la prosperabilidad de la pretensión que se pretende ejercitar de forma tal que para que la misma alcance el valor de prueba dentro del futuro proceso deberá llevarse a dicho procedimiento con pleno respeto a los principios procesales establecidos al efecto ${ }^{509}$. Por ejemplo, procediéndose a su presentación con la demanda, tal y como así exige el art 265.1 LEC.

\footnotetext{
${ }^{509}$ SAP de Vizcaya (sección $4^{\text {a }}$ ) de 15 de enero de 2010, ponente Ilma. Sra. M $^{\text {a }}$ L. Arranz, f.j.3 ${ }^{\circ}$ (LA LEY $33826 / 2010)$.
} 


\subsection{Presupuestos particulares para la práctica de la diligencia}

Dichos documentos, cuya exhibición se requiera, habrán de ser debidamente reseñados e identificados en la solicitud de diligencias preliminares junto a la determinación del periodo de tiempo en el que estime el solicitante que los mismos han sido producidos ${ }^{510}$ no pudiendo acordarse la exhibición de más documentos que aquellos que guarden estrecha relación con la infracción que pudiera haberse cometido ${ }^{511}$.

Pero la diligencia del art. 256.1.8 LEC, a diferencia de la contemplada en el art. 256.1.7 LEC, viene condicionada, además, a la aportación, junto con la solicitud en la que se manifieste el propósito de preparar el futuro juicio por infracción de los derechos en cuestión ${ }^{512}$, de un principio de prueba de la realidad de la infracción que, como señala el propio precepto legal a mero título ejemplificativo ${ }^{513}$, podrá consistir en la presentación de una muestra de los ejemplares, mercancías o productos en los que se materialice la infracción ${ }^{514}$.

\footnotetext{
${ }^{510}$ Armengot Vilaplana, A., Las nuevas diligencias..., ob. cit., p. 32; Larena Beldarrain, J., Las diligencias preliminares..., ob. cit., p. 702 .

${ }_{511}^{511}$ López Sánchez, J., Las nuevas diligencias..., ob. cit., p. 10.

${ }^{512}$ En la que, como apuntamos con ocasión de la diligencia del ordinal $7^{\circ}$ del art. 256.1 LEC, deberá concretarse el detalle de la acción que se pretende ejercitar con indicación de los hechos en que la misma se sustenta y justificación de la posición jurídica que ampara al solicitante para la articulación de dicho juicio, además de cumplirse los presupuestos generales exigidos para las diligencias preliminares en general.

513 Así lo apunta Soler Pascual, L.A., Las diligencias preliminares..., ob. cit., p. 6, destacando que "cualquier otra actuación documental o incluso de naturaleza personal puede ser considerada suficiente por el juez competente al efecto de aperturar la práctica de la diligencia preliminar". Muestra de lo anterior lo constituye el el AAP de Madrid (sección 28 $8^{\mathrm{a}}$ ) de 5 de diciembre de 2008, ponente Ilmo. Sr. P.M ${ }^{a}$. Gómez, f.j. $2^{\circ}$ (LA LEY 263211/2008) en el que como principio de prueba fue admitido un dictamen en el que se ponía de relieve que determinadas prendas comercializadas y/o fabricadas por las virtuales demandadas habían sido decoloradas, con razonable grado de probabilidad, por el procedimiento patentado por la solicitante, al estimarse que "[...] no se ve de qué otro modo -distinto de ese- podría justificar mejor la solicitante la concurrencia de un interés legítimo y de una justa causa, y ello además de tener forzosamente que considerarse cumplimentado, merced a ese mismo documento, el requisito relativo a la aportación de un principio de prueba" y el AAP de Madrid (sección $28^{\mathrm{a}}$ ) de 10 de febrero de 2012, ponente Ilmo. Sr. A. Galgo, f.j. $4^{\circ}$ (ROJ AAP M 2773/2012) en el que se consideró que la realización de un previo requerimiento extrajudicial al que las requeridas no habían respondido satisfacía los estándares de verosimilitud a los que debe entenderse anudada la exigencia de un principio de prueba.

${ }^{514}$ Lo que, como señala Armengot Vilaplana, A., Las nuevas diligencias..., ob. cit., p. 33-34, no tiene su origen en el art. 8 de la Directiva 48/2004, a partir del cual se ha configurado la diligencia en cuestión, sino en el art. 6.2 de dicha Directiva que regula el derecho de información y que prevé la posibilidad de que los Estados miembros regulen la exhibición de documentos bancarios que obren en poder de la parte contraria exigiendo para su admisión la aportación de pruebas razonables de las que disponga el
} 
Y también condicionada a la circunstancia de ser cometida la infracción mediante "actos desarrollados a escala comercial". En cuanto a lo que debemos entender con tal expresión, el propio art. 256.1.8 LEC, in fine, recogiendo la propuesta contenida en el Considerando 14 de la Directiva 2004/48, dispone que se entiende por actos desarrollados a escala comercial aquellos que son realizados para obtener beneficios económicos o comerciales directos o indirectos ${ }^{515}$ y de los que quedarían excluidos los actos realizados por los consumidores finales de buena fe.

No obstante la anterior definición, la doctrina analiza el problema de la delimitación de la expresión planteándose si, por ejemplo, el lanzar por la red copias privadas para que sean utilizadas por terceros de manera gratuita es un hecho económico o comercial o, si por el contrario, la interpretación debe ser más estricta dado que el precepto no dice que la infracción deba ser comercial sino a escala comercial o económica, concluyendo que no teniendo lo individual el alcance propio de un acto de comercio y siendo lo comercial lo masivo, masividad y beneficio económico, que en determinados supuestos puede ser presumido $^{516}$, son los presupuestos que deben caracterizar la infracción del derecho para autorizar la práctica de la diligencia $\operatorname{preliminar}^{517}$.

\subsection{Legitimación}

En cuanto a la legitimación activa, al igual que en el supuesto del art. 256.1.7 LEC, corresponderá al sujeto que pretenda iniciar un proceso civil en solicitud de la

solicitante lo que, a su juicio, llama la atención habida cuenta que este principio de prueba no es exigido en la diligencia del art. 256.1.7 LEC que hunde sus raíces en aquel.

${ }^{515}$ Lo que ha sido confirmado por la doctrina. A tal efecto, vid. Garberí Llobregat, J., Las diligencias preliminares..., ob. cit., p. 58.

${ }^{516}$ Vid. AAP de Madrid (sección 28 a ) de 19 de octubre de 2015, ponente Ilmo. Sr. G. Plaza, f.j.4 (LA LEY 246907/2015).

${ }^{517}$ En dicho sentido, Gil Nogueras, L.A., Las diligencias preliminares..., ob. cit., p. 5 que en relación a la expresión "actos comerciales desarrollados a escala comercial" apunta que "La expresión no está exenta de matices, si bien el carácter necesariamente comercial de la actividad y su búsqueda de beneficios comerciales, permite entender la necesidad de actuaciones masivas (no individuales) como propias de toda actividad comercial, y lucrativas". También, Soler Pascual, L.A., Las diligencias preliminares..., ob. cit., pp. 6-7. 
tutela judicial de los derechos de propiedad intelectual e industrial ${ }^{518}$, siempre y cuando la acción que se pretenda ejercitar lo sea por infracción de un derecho de propiedad industrial o intelectual cometida mediante actos desarrollados a escala comercial ${ }^{519}$.

Sin embargo, la legitimación pasiva se atribuye únicamente a la persona que sería demandada como responsable adoptándose aquí una postura más restrictiva que la que rige la legitimación pasiva del ordinal $7^{\circ}$ del art. $256.1 \operatorname{LEC}^{520}$ y que de no observarse daría lugar a la inadmisión de la diligencia preliminar ${ }^{521}$.

\section{Diligencias y averiguaciones para la protección de determinados} derechos previstos en las leyes especiales (art. 256.1.9 LEC)

"Por petición de las diligencias y averiguaciones que, para la protección de determinados derechos, prevean las correspondientes leyes especiales”.

Probablemente no haya en el catálogo del art. 256.1 LEC otra diligencia preliminar que genere más desconcierto que la prevista en su ordinal $9^{\circ}$, lo que sin duda alguna se debe a la ambigüedad de su dicción literal que la doctrina ${ }^{522}$ se ha encargado de aclarar señalando que, al amparo del art. 256.1.9 LEC, tendrán cobertura diligencias tales como las diligencias de comprobación de hechos, las reguladas en los arts. 123 a $126 \mathrm{LP}^{523}$ o las mencionadas en la disposición adicional primera de la $\mathrm{LM}^{524} \mathrm{o} \mathrm{LPDI}^{525}$, y en el art. $36 \mathrm{LCD}^{526}$.

\footnotetext{
${ }^{518}$ Armengot Vilaplana, A., Las nuevas diligencias..., ob. cit., p. 32.

${ }^{519}$ Garberí Llobregat, J., Las diligencias preliminares..., ob. cit., p. 58.

${ }^{520}$ En dicho sentido, Armengot Vilaplana, A., Las nuevas diligencias..., ob. cit., p. 31 y Larena Beldarrain, J., Las diligencias preliminares..., ob. cit., p. 702.

${ }_{521}$ Garberí Llobregat, J., Las diligencias preliminares..., ob. cit., p. 58.

${ }^{522}$ Cfr. Álvarez Alarcón, A., Las diligencias preliminares..., ob. cit., p. 46; Garberí Llobregat, J., Las diligencias preliminares..., ob. cit., pp. 59-60. En idéntico sentido, vid. Soler Pascual, L.A., Las diligencias preliminares..., ob. cit., p. 8.

${ }_{523}$ Publicada en el BOE núm. 177, de 25 de julio de 2015, antes la Ley 11/1986, de 20 de marzo, de Patentes (arts. 129 a 132), publicada en el BOE, núm. 73, de 26 de Marzo de 1986.

${ }^{524}$ Publicada en el BOE núm. 294, de 08 de Diciembre de 2001 y cuya disposición adicional primera señala que: "Las normas vigentes contenidas en el Título XII de la Ley 24/2015, de 24 de julio, de Patentes serán de aplicación a las distintas modalidades de signos distintivos de la presente Ley en todo aquello que no sea incompatible con su propia naturaleza, sin perjuicio de lo dispuesto en el siguiente apartado".
} 
Estas diligencias de comprobación fueron introducidas en el ordenamiento jurídico español con el Protocolo núm. 8 del Tratado de Adhesión de España a la CE de 1985 y su patrón de estudio viene marcado por la LP $^{527}$ a través de un precepto remisorio, el art. 256.1.9 LEC, que carece de contenido alguno, que debe ser integrado por las disposiciones específicas de las leyes a las que se remite, es decir, por las disposiciones de la legislación especial sobre protección de determinados derechos y más concretamente, por lo que dispongan esas leyes en materia de peticiones de diligencias de averiguación ${ }^{528}$. Por ello, es presupuesto necesario para que pueda decretarse la práctica de las diligencias preliminares solicitadas que cualquiera de esas leyes especiales expresamente las prevea ${ }^{529}$.

Asimismo, deben distinguirse las diligencias de comprobación de hechos de las diligencias preliminares, aún cuando no son incompatibles y ambas están dirigidas a preparar el proceso posterior De hecho, esta diferencia la marca la propia LP al establecer que la persona legitimada para ejercitar las acciones derivadas de la patente podrá pedir al juez que, con carácter urgente, acuerde la práctica de las diligencias para la comprobación de hechos que pueden constituir violación del derecho exclusivo otorgado por la patente, sin perjuicio de las que puedan solicitarse al amparo del art. 256.1 LEC. Ello, sin que pueda perderse de vista que, conforme a lo prevenido en el art. 263 LEC, cuando se trate de las diligencias a que se refiere el art. 256.1.9 LEC, los

\footnotetext{
${ }_{525}^{525}$ Publicada en el BOE núm. 162, de 8 de Julio de 2003.

${ }^{526}$ Dispone el art. 36 LCD que: "1. Quien pretenda ejercitar una acción de competencia desleal podrá solicitar del juez la práctica de diligencias para la comprobación de aquellos hechos cuyo conocimiento resulte objetivamente indispensable para preparar el juicio. 2. Tales diligencias se sustanciarán de acuerdo con lo previsto en los artículos 129 a 132 de la Ley 11/1986, de 20 de marzo, de Patentes, y podrán extenderse a todo el ámbito interno de la empresa".

${ }^{527}$ Debe tenerse en cuenta que si bien las diligencias de comprobación fueron introducidas en la ALP, la entrada en vigor de las mismas lo fue a partir del 7 de octubre de 1992, en aplicación de lo dispuesto en la disposición transitoria $3^{\mathrm{a}}$ de aquella Ley, siendo aplicables tanto a la LM y LPJDI, por mor de su respectiva disposición adicional $1^{\text {a }}$, a la LCD (art. 24), así como a las marcas y diseños comunitarios, de conformidad con lo dispuesto en el art. 97.3 del Reglamento (CE) núm. 40/94 del Consejo, de 20 de diciembre de 1993 sobre marca comunitaria (codificado en el Reglamento 207/2009, de 26 de febrero de 2009) y en el art. 88 del Reglamento (CE) núm. 6/2002 del Consejo, de 21 de diciembre de 2001, sobre dibujos y modelos comunitarios.

${ }_{528}$ AAP de Santa Cruz de Tenerife (sección $4^{\text {a }}$ ) de 4 de julio de 2007, ponente Ilmo. Sr. E.F. Suárez, f.j. $2^{\circ}$ (LA LEY 183911/2007).

${ }_{529}$ AAP de Castellón (sección $3^{\mathrm{a}}$ ) de 20 de enero de 2005, ponente Ilma. Sra. M ${ }^{\mathrm{a}}$.A. Gil, f.j.2 ${ }^{\circ}$ (LA LEY 15654/2005).
} 
preceptos de la LEC dedicados a las diligencias preliminares se aplicarán en lo que no se oponga a lo dispuesto en la legislación especial sobre la materia de que se trate.

\section{1 Ámbito de aplicación y características}

Las diligencias de comprobación de hechos permiten, previa solicitud y admisión de la misma, la comprobación, a través del órgano judicial y a instancia del legitimado para ejercitar las acciones inherentes al derecho de patente, de los medios que se estén empleando para infringir el ámbito de la exclusiva que aquél otorga ${ }^{530}$ y su función y finalidad es la de garantizar el resultado de un proceso futuro sobre responsabilidad de la violación de un derecho de la propiedad industrial y por ello tienden a evitar la desaparición, alteración o difuminación de aquellos hechos que resulten necesarios para preparar el juicio ${ }^{531}$. En la doctrina judicial han sido definidas como el procedimiento por el que toda persona con derecho a actuar ante los tribunales en caso de usurpación de una patente puede solicitar una decisión judicial para que se proceda, en las instalaciones del posible demandado, mediante agente judicial asistido por peritos, a la descripción detallada de los procedimientos objeto de litigio, en particular mediante toma de fotocopias de documentos técnicos, con o sin retención real de prueba $^{532}$.

De ahí que en la doctrina científica se hayan caracterizado de forma singular y diferenciada a las diligencias preliminares del catálogo del art. 256.1 LEC ${ }^{533}$, como unas diligencias:

\footnotetext{
${ }^{530}$ García García, E., Las diligencias preliminares..., ob. cit., p. 7 y Armengot Vilaplana, A., Las nuevas diligencias..., ob. cit., p. 8, señalando esta última que a través de la misma el solicitante podrá obtener información sobre la adecuación de ciertos bienes para efectuar una posible violación del derecho de patente.

${ }_{331}$ Vid. Sobremonte Andrés, B. y Rubido de la Torre, J.L., El tratamiento de la marca en el tráfico mercantil. La protección civil de la marca ante la jurisdicción española. Algunos aspectos procesales, en "Diario La Ley", 1994, T.III (LA LEY 22015/2001), p. 4.

${ }^{532}$ AAP de Barcelona (sección $15^{\text {a }}$ ) de 26 de julio de 2002, ponente Ilmo. Sr. L. Garrido, f.j.4 $4^{\circ}$ (LA LEY 140501/2002).

${ }^{533}$ Villar Fuentes, I.M ${ }^{\mathrm{a}}$, Las diligencias preliminares..., ob. cit., pp. 40-47.
} 
a) Dispositivas, en tanto que no pueden ser decretadas sino a instancia de la parte que lo solicite.

b) Preparatorias, en cuanto sólo permiten la obtención de aquellos datos que resulten imprescindibles para la preparación del futuro proceso y para la comprobación de los hechos que puedan constituir la violación de los derechos de propiedad intelectual o industrial o un acto de competencia desleal.

c) Intervención del sujeto pasivo, que no intervendrá en la diligencia sino hasta el mismo momento de practicarse la misma, pues no se le efectuará notificación previa alguna, pero con la posibilidad de participar en su desarrollo efectuando las manifestaciones que tenga por conveniente (art. 124.1 LP).

d) Proporcionales, de forma especial en la materia que nos ocupa donde habrá que ponderarse el daño que se pretende evitar a través del futuro proceso por violación del derecho de exclusiva o ilícitos concurrenciales y el eventual daño que puede sufrir el requerido por la diligencia, teniendo en cuenta los derechos que pueden verse comprometidos mediante la práctica de las diligencias de comprobación de hechos tales como el secreto industrial.

Y sujetas a los principios de:

a) Sorpresa ${ }^{534}$, que se desprende del art. 124.1 LP, que niega la práctica de cualquier notificación previa al requerido y que determinará que, una vez admitida la diligencia, la comisión judicial se traslade al lugar donde la misma haya de ser practicada, personándose en el mismo sin previo aviso. Con ello, se pretende evitar la manipulación de las circunstancias de la infracción.

\footnotetext{
${ }^{534}$ Villar Fuentes, I.M ${ }^{\mathrm{a}}$, Las diligencias preliminares..., ob. cit., pp. 48-50.
} 
b) Urgencia ${ }^{535}$, pues conforme al art. 123.1 LP la persona legitimada podrá pedir al juez que con carácter urgente acuerde la práctica de las diligencias, con el fin de evitar que se diluyan futuros medios probatorios teniendo en cuenta que los ilícitos en materia de propiedad industrial e intelectual se producen de forma continua y con posibilidad de causar daños irreparables.

c) Numerus apertus, de forma tal que cualquier diligencia que resulte necesaria para esclarecer un elemento de la controversia resultaría admisible ${ }^{536}$.

\subsection{Presupuestos de admisibilidad}

Son presupuestos para su admisibilidad ${ }^{537}$ :

1) Que el solicitante esté legitimado para ejercitar las acciones inherentes al derecho de patente invocado (art. 123.1 LP).

2) Que se pretenda ejercitar una acción por violación del derecho exclusivo otorgado por la patente (art. 123.1 LP); en consecuencia no podrá solicitarse la práctica de estas diligencias cuando se pretenda ejercitar una acción distinta.

3) Que por las circunstancias puestas de manifiesto en la solicitud pueda presumirse la violación de la patente (art. $123.3 \mathrm{LP})^{538}$, lo que en la doctrina se ha identificado con la justa causa $^{539}$. Es decir, que el solicitante deberá acreditar la existencia de inicios objetivos de que se está produciendo la infracción del derecho de

\footnotetext{
${ }^{535}$ Villar Fuentes, I.M ${ }^{\mathrm{a}}$, Las diligencias preliminares..., ob. cit., pp. 51-55. Debe reseñarse que, sin embargo, el principio de urgencia no se contiene en las diligencias de comprobación de hechos que contempla el art. 36 LCD.

536 Obra 1: Castán Pérez-Goméz, A., El nuevo régimen..., ob. cit., p. 25.

${ }^{537}$ Vid. AAP de Barcelona (sección 15 $5^{\text {a }}$ de 19 de julio de 2007 y 10 de diciembre de 2007, ponente Ilmo. Sr. L. Garrido, f.j. $3^{\circ}$ (LA LEY 235816/2007 y 314557/2007) que señalan como tales, además de los por nosotros indicados, la legitimación del solicitante para ejercitar las acciones por violación de la parte, que por las circunstancias del caso sea presumible la violación de la patente y que no sea posible comprobar la realidad del comportamiento ilícito sin recurrir a las diligencias interesadas.

${ }_{538}$ Villar Fuentes, I.M ${ }^{\mathrm{a}}$, Las diligencias preliminares...., ob. cit., p. 127.

${ }^{539}$ Cfr. Obra 2: Castán Pérez-Gómez, El nuevo régimen..., ob. cit., p. 29, se ha identificado con la justa causa.
} 


\begin{abstract}
exclusiva inherente a la patente ${ }^{540}$ a cuyo efecto el solicitante deberá efectuar una exposición circunstanciada de las razones por las que entiende se está cometiendo una infracción de su derecho, dado que la norma excluye el automatismo de la medida ${ }^{541}$. No obstante, debe precisarse, la diligencia de comprobación de hechos no puede tener por
\end{abstract}

${ }^{540} \mathrm{Al}$ efecto, cabe traer a colación el AAP de Madrid (sección 28 $8^{\mathrm{a}}$ ) de 18 de enero de 2008, ponente Ilmo. Sr. P.Ma . Gómez, f.j.3º (LA LEY 115182/2008) que denegó las diligencias de comprobación interesadas señalando que: “[...] En efecto, el precepto no impone explícitamente carga procesal alguna, pero de lo que no cabe la menor duda es de que sí requiere que el tribunal ante el que se presenta la petición se encuentre en condiciones de "presumir", siquiera a nivel indiciario, la violación de la patente (en nuestro caso, la práctica desleal) a partir de las circunstancias del caso. Y, si tenemos en cuenta que el método presuntivo es una forma de razonamiento deductivo por el que, a partir de determinados hechos contrastados (los "hechos-base") se colige la existencia de otros hechos no contrastados (los "hechos presuntos") mediante la utilización de las reglas del criterio humano, no se ve -y nada sugiere al respecto la apelante- de qué manera podría el órgano judicial elaborar la operación deductiva o presuntiva (aún cuando fuera a un nivel de exigencia simplemente indiciario,insistimos en este matiz) si, no siendo notorios los "hechos base", tampoco la parte le proporciona indicio alguno de su existencia. Pues bien, al respecto hay que indicar: 1.- Que, pudiendo considerarse notorio -y por ello dispensado de prueba- el hecho de que PHILIPS es una empresa puntera en el sector de la electrónica, la Sala, al igual que le sucedía al juez de lo mercantil, no solo desconoce por completo si ostenta en dicho ámbito una posición de dominio sino que desconocía también el propio hecho de que entre sus actividades mercantiles se encontrase la consistente en licenciar tecnología. Y no hay que olvidar que, de concurrir la posición de dominio invocada, de la misma debería existir constancia pública suficiente como para que la labor de indiciar tal circunstancia no pudiera reputarse inaccesible para una empresa del sector en cuestión como lo es la solicitante. 2.- Que en modo alguno puede considerarse notorio el coste teórico de fabricación de DVD,s, coste que la solicitante ni menciona ni trata de analizar pese a tener que contar forzosamente, por razón de su dedicación mercantil (fabricación de dichos productos informáticos), con abundante información al respecto, y ni que decir tiene que la ausencia de dicho dato impide acometer análisis comparativo alguno con el precio de los DVD,s concurrentes actualmente en el mercado, precio éste que, por lo demás, tampoco menciona en momento alguno la solicitante pese a haberse podido colmar ese vacío con la simple aportación de folletos publicitarios del sector. Por lo tanto, es patente que la ausencia del menor indicio en relación con los expresados "hechos base" veda al tribunal toda posibilidad de deducir o presumir la concurrencia de cualquiera de las conductas de tolerancia discriminatoria que DUPLICO 2000, S.L. atribuye a su virtual demandada en calidad de hechos "presumibles" del Art. 129-3 L.P. y teóricamente deducibles de aquéllos". También los AAP de Barcelona (sección 15 a) de 19 de julio y 10 de diciembre de 2007, ponente Ilmo. Sr. L. Garrido, f.j.3 (LA LEY 235816/2007 y 314557/2007): "[...] que el juicio circunstancial exigido a fin de apreciar que la violación de la patente se presenta como presumible, necesariamente asentado en indicios, no ha de detenerse en la constatación de la mera posibilidad, en cuanto simple aptitud o potencialidad de la infracción, sino que es preciso un nivel mayor de elocuencia de los indicios aportados, el suficiente para deducir la probabilidad o verosimilitud de la violación, si bien, por la propia naturaleza de esta tutela instrumental, que se dirige precisamente a la comprobación de la infracción, no ha de ser requerida tal cualidad del acreditamiento, la probabilidad, en grado alto o intenso, lógica consecuencia de que no ha de ser posible comprobar la realidad de la infracción si no es recurriendo a estas diligencias. Se trata de aceptar la justa causa del recurso a las diligencias de comprobación sobre la base de una probabilidad media y razonable en atención a las circunstancias concurrentes, lo que de por sí conlleva una medida de incertidumbre”. Por último, en el AAP de Cantabria (sección $2^{\mathrm{a}}$ ) de 19 de julio de 2009, ponente Ilma. Sra. M. Martínez, f.j.3º (LA LEY 156894/2008) se consideró que la constatación de semejanzas técnicas sustanciales entre el proceso empleado por la demandada y el proceso patentado, que es lo que determina la infracción del derecho de patente, evidenciaba la necesidad de práctica de las diligencias de comprobación interesadas que, en el caso, se presentaban como recurso jurídico necesario para articular la adecuada y ulterior protección.

${ }^{541}$ Corbal Hernández, J.E., Diligencias Preliminares (arts...), ob. cit., p. 3513. 
objeto la comprobación o constatación de la violación del derecho de exclusiva o la comisión de un acto de competencia desleal ${ }^{542}$.

4) Que no sea posible comprobar la realidad de la violación de la patente sin recurrir a las diligencias solicitadas (arts. $123.3 \mathrm{LP})^{543}$; ello requiere una previa valoración por el juez de la necesariedad de las alegaciones en que se funde la petición y que el legitimado, previamente, haya agotado, y así lo exponga y justifique en su solicitud, los medios a su disposición para la comprobación de la actuación infractora ${ }^{544}$. Por ejemplo, recabando la oportuna información de los registro públicos, sondeos a clientes, cruzando correspondencia con posibles implicados, etc., sin haber podido acceder mediante ellos a todos los datos de hecho necesarios para poder elaborar su demanda ${ }^{545}$.

En este punto, debe tenerse en cuenta que el juez, ante de resolver sobre la petición formulada, podrá requerir los informes y ordenar las investigaciones que estime oportunas (art. 123.2LP), lo que en la doctrina se entiende podrá tener lugar cuando el juez albergue alguna duda que resulte razonable despejar con tales actuaciones y que podrán ser requeridos a la parte o de la institución u organismo que corresponda, a cargo del solicitante ${ }^{546}$.

\footnotetext{
${ }^{542}$ Villar Fuentes, I.M ${ }^{\mathrm{a}}$, Las diligencias preliminares..., ob. cit., p. 127. Al respecto, vid. la SAP de Granada (sección $3^{\mathrm{a}}$ ) de 12 de noviembre de 2002, ponente Ilmo. Sr. A. Gallo, f.j. ${ }^{\circ}$ (LA LEY 188828/2002), que al efecto consideró suficiente la acreditación de la titularidad y un indicio de la infracción.

543 Obra 2: Castán Pérez-Gómez, A., El nuevo régimen..., ob. cit., p. 29; Villar Fuentes, I.Ma , Las diligencias preliminares...., ob. cit., p. 127; y Álvarez Alarcón, Las diligencias preliminares..., ob. cit., p. 46. En cuanto a dicho requisito resulta procedente traer a colación la STS de 4 de marzo de $2005\left(\right.$ sala $\left.1^{\mathrm{a}}\right)$, ponente Ilmo. Sr. A. Gullón, f.j. $1^{\circ}$ (LA LEY 2774/2005) que estimó lícitas las pruebas de violación de la patente obtenidas por un detective privado, contratado por la titular de la patente, que, como representante de una sociedad interesada en adquirir el producto que la demandada fabricaba, sin autorización, con el procedimiento patentado, se presentó en las instalaciones de la demandada.

${ }_{544}$ Corbal Hernández, J.E., Diligencias Preliminares (arts...), ob. cit., pp. 3513-3514.

${ }_{545}$ Garcia García, E., Las diligencias preliminares..., ob. cit., p. 12.

${ }^{546}$ García Garcia, E., Las diligencias preliminares..., ob. cit., p. 13.
} 
5) Que la diligencia sea útil para la comprobación de los hechos ${ }^{547}$, pues las diligencias de comprobación se refieren a la concreción de los hechos en que consiste la infracción y a los medios empleados para la misma ${ }^{548}$;

6) Y la prestación por el solicitante de la caución que fije el juez para responder de daños y perjuicios que eventualmente puedan ocasionarse (art. 123.4 LP) ${ }^{549}$.

Nos encontramos ante unas diligencias que constituyen una apuesta decidida del legislador por un carácter flexible de las mismas que elimine cualquier cortapisa que en la preparación de los procesos a que sirven pueda existir y cuya finalidad, en suma, es la de permitir la comprobación `por parte del juez de los medios técnicos que se están empleando para infringir un derecho de exclusiva ${ }^{550}$. Por esta razón, se explica en la doctrina, el legislador ha sido cauteloso y no ha relacionado ni acotado las posibles diligencias a practicar, habida cuenta que la complejidad de las materias en cuestión hace muy difícil imaginar y delimitar las diligencias que a la postre resultarán apropiadas para preparar el futuro proceso ${ }^{551}$.

De hecho, con anterioridad a la vigencia de la nueva LP la doctrina judicial estimó pertinente la práctica de diligencias de comprobación de hechos consistentes en la exhibición de cuentas anuales, libros de contabilidad y documentación que sirviera de soporte a la misma ${ }^{552}$. Por ello entendemos que, bajo el imperio de la antigua LP la doctrina científica apuntó el carácter meramente ejemplificativo de las mismas ${ }^{553}$. De esta manera, la LP, sin determinar en qué consistirán tales diligencias de comprobación de hechos, permite la adopción de un amplio abanico que en la práctica habitual han venido consistiendo en: a) la inspección de maquinaria que pueda estarse empleando

\footnotetext{
${ }^{547}$ Villar Fuentes, I.M ${ }^{\mathrm{a}}$, La práctica de las diligencias de comprobación de hechos en la propiedad industrial y competencia desleal. (Una posible consecuencia probatoria), en "Revista General de Derecho Procesal", 2013, núm. 30, p. 3; también, Sobremonte Andrés, B. y Rubido de la Torre, J.L., El tratamiento de..., ob. cit., p. 7.

${ }_{548}$ Armengot Vilaplana, A., Las nuevas diligencias..., ob. cit., p. 9.

${ }_{550}^{54}$ Obra 2: Castán Pérez-Gómez, A., El nuevo régimen..., ob. cit., p. 29.

${ }_{550}$ Corbal Hernández, J.E., Diligencias Preliminares (arts...), ob. cit., p. 3509.

${ }_{551}^{552}$ Villar Fuentes, I...M ${ }^{\mathrm{a}}$., Las diligencias preliminares..., ob. cit., p. 169.

${ }^{552}$ AAP de Barcelona (sección 15ª ) de 21 de marzo de 2005, ponente Ilmo. Sr. I. Sancho, f.j. $3^{\circ}$ (LA LEY 65421/2005).

${ }^{553}$ García García, E., Las diligencias preliminares..., ob. cit., p.8.
} 
para fabricar un determinado producto; b) el registro de las instalaciones tales como naves industriales, fábricas, tiendas, oficinas, laboratorios y otras dependencias en que pueda estar elaborándose o almacenándose un determinado producto; c) el examen de la documentación relativa al proceso industrial de elaboración de un producto o al procedimiento de obtención de una determinada sustancia; d) la toma de muestras de un determinado producto o de los materiales, sustancias, componentes u otras sustancias o materias relacionadas con la patente; e) la realización de análisis y exámenes periciales sobre materias, sustancias, procesos de fabricación u obtención de determinados productos; y, f) en el caso concreto de los medicamentos, la realización de las averiguaciones oportunas para comprobar el proceso seguido para la fabricación del principio activo, la composición del fármaco, las cantidades producidas de las sustancias de que se trate y el destino de las mismas ${ }^{554}$.

\subsection{Legitimación}

La legitimación activa se corresponde con la ordinaria que la LP y la LCD reconocen en general ${ }^{555}$, al no existir regulación expresa en la LM como consecuencia de la remisión que la LP en lo relativo a las normas de carácter procesal.

Así, el art. 117 LP reconoce a los titulares de los derechos inscritos en el Registro de Patentes, a quienes acrediten haber solicitado debidamente la inscripción en dicho Registro del acto o negocio del que traiga causa el derecho que se pretenda hacer valer, si la inscripción llegare a ser concedida; al licenciatario exclusivo y al no exclusivo cuando acredite que previamente ha requerido al titular de la patente para promover las diligencias de comprobación de hechos y dicho titular se negara o no las promoviera en su propio nombre dentro del plazo de tres meses, a partir del cual el

\footnotetext{
${ }^{554}$ Cfr. García García, E., Las diligencias preliminares..., ob. cit., p. 8-9.

555 Villar Fuentes, I.M ${ }^{\mathrm{a}}$, Las diligencias preliminares..., ob. cit., pp. 91-100, con inclusión entre los legitimados de quien disfrute del derecho jurídico violado por cualquiera de las formas previstas de titularidad del derecho privado, del mero solicitante de la patente.
} 
licenciatario podría proceder a la solicitud de las diligencias de comprobación de hechos, en su propio nombre, acompañando el requerimiento efectuado al titular ${ }^{556}$.

Por su parte, el art. 36 LCD reconoce la legitimación activa para instar las diligencias preliminares a quien pretenda ejercitar una acción de competencia desleal, lo que nos obliga a precisar, conforme al art. 32 LCD, que la legitimación activa corresponderá a quienes a su vez la tengan para el ejercicio de la acción declarativa de deslealtad, de la acción de cesación de la conducta desleal o de prohibición de su reiteración futura, de la acción de remoción de los efectos producidos por la conducta desleal, de la acción de rectificación de las informaciones engañosas, incorrectas o falsas, de la acción de resarcimiento de los daños y perjuicios ocasionados por la conducta desleal, de la acción de enriquecimiento injusto que lesione una posición jurídica amparada por un derecho de exclusiva u otra de análogo contenido económico. Es decir, a todos aquellos a que se refiere el art. $33 \mathrm{LCD}^{557}$ y para la preparación de las acciones cuya legitimación tienen reconocida en la LCD.

\footnotetext{
${ }^{556}$ Vid. Corbal Hernández, J.E., Diligencias Preliminares (arts...), ob. cit., p. 3512; García García, E., Las diligencias preliminares..., ob. cit., p. 10; y Sobremonte Andrés, B. y Rubido de la Torre, J.L., El tratamiento de..., ob. cit., p. 6.

${ }_{557}$ Artículo 33. Legitimación activa:

"1. Cualquier persona física o jurídica que participe en el mercado, cuyos intereses económicos resulten directamente perjudicados o amenazados por la conducta desleal, está legitimada para el ejercicio de las acciones previstas en el artículo $32.1,1 .^{\mathrm{a}}$ a $5 .{ }^{\mathrm{a}}$

Frente a la publicidad ilícita está legitimada para el ejercicio de las acciones previstas en el artículo 32.1, $1 .^{\mathrm{a}}$ a $5 .^{\mathrm{a}}$, cualquier persona física o jurídica que resulte afectada y, en general, quienes tengan un derecho subjetivo o un interés legítimo.

La acción de resarcimiento de los daños y perjuicios ocasionados por la conducta desleal podrá ejercitarse, igualmente, por los legitimados conforme a lo previsto en el artículo 11.2 de la Ley 1/2000, de 7 de enero, de Enjuiciamiento Civil.

La acción de enriquecimiento injusto sólo podrá ser ejercitada por el titular de la posición jurídica violada.

2. Las acciones contempladas en el artículo 32.1,1. a a 4. ${ }^{a}$, podrán ejercitarse además por las asociaciones, corporaciones profesionales o representativas de intereses económicos, cuando resulten afectados los intereses de sus miembros.

3. Ostentan legitimación activa para el ejercicio de las acciones previstas en el artículo 32.1, 1. a a 4. a en defensa de los intereses generales, colectivos o difusos, de los consumidores y usuarios:

a) El Instituto Nacional del Consumo y los órganos o entidades correspondientes de las comunidades autónomas y de las corporaciones locales competentes en materia de defensa de los consumidores y usuarios.

b) Las asociaciones de consumidores y usuarios que reúnan los requisitos establecidos en el texto refundido de la Ley General para la Defensa de los Consumidores y Usuarios o, en su caso, en la legislación autonómica en materia de defensa de los consumidores y usuarios.
} 
Por lo que se refiere a la legitimación activa en la LM, la misma corresponderá, conforme a los arts. 35 y 36 LM, al titular de la marca registrada, al concesionario de una licencia de explotación exclusiva, conforme a los arts. 124 LP y 40 y 41.1 LM, a los titulares de marcas colectivas (arts. 58 y ss. LM), al titular de una marca de garantías (arts. 62 y ss. LM), al titular de una marca registrada en España que solicite el registro internacional (arts. 73 y ss. LM), al titular de un nombre comercial registrado (arts. $73 \mathrm{y}$ ss. LM) y al titular de un rótulo de establecimiento registrado (arts. 82 y ss. LM).

El sujeto pasivo de la diligencia será quien se presuma esté realizando actuaciones infractoras de la patente o sea poseedor de los medios utilizados con ese $\mathrm{fin}^{558}$, pues son actuaciones judiciales que recaen única y exclusivamente en el ámbito interno de la empresa supuestamente infractora del derecho de propiedad industrial con el fin de conocer la realidad de la infracción ${ }^{559}$.

Así, en la LCD la legitimación pasiva viene determinada en el art. 34 en relación a cualquier persona que haya realizado u ordenado la conducta desleal ${ }^{560}$ o haya cooperado a su realización, salvo en la acción de enriquecimiento injusto, que sólo podrá dirigirse contra el beneficiario del enriquecimiento.

\subsection{Asistencia letrada y práctica de la diligencia}

Sentado lo anterior, importante resulta abordar la cuestión relativa a la intervención en las diligencias preliminares de la asistencia letrada de las partes, en

c) Las entidades de otros Estados miembros de la Comunidad Europea constituidas para la protección de los intereses colectivos y de los intereses difusos de los consumidores y usuarios que estén habilitadas mediante su inclusión en la lista publicada a tal fin en el «Diario Oficial de las Comunidades Europeas».

4. El Ministerio Fiscal podrá ejercitar la acción de cesación en defensa de los intereses generales, colectivos o difusos, de los consumidores y usuarios".

${ }^{558}$ Corbal Hernández, J.E., Diligencias Preliminares (arts...), ob. cit., p. 3512 y García García, E., Las diligencias preliminares..., ob. cit., pp. 10-11.

559 STMC de 21 de diciembre de 2004, ponente Ilmo. Sr. E. García-Chamón, f.j.2 ${ }^{\circ}$ (LA LEY 268428/2004), en que las diligencias de comprobación de hechos interesadas por las mercantiles solicitantes consistían en el libramiento de oficios a organismos públicos y a dos empresas, terceros respecto de la mercantil que estaba desarrollando acciones de importación que presumiblemente violaban la marca comunitaria de la titular registral.

${ }^{560}$ Enumerados en los arts. 4 y ss. LCD. 
relación a la cual la doctrina científica se muestra dividida, encontrando autores que defienden su improcedencia en la necesidad de garantizar la confidencialidad de las actuaciones $^{561}$ y otros que afirman su indiscutible participación, al menos desde el momento en que el juez procede a la práctica de la diligencia ${ }^{562}$ dado que, como ya hemos puesto de manifiesto, la práctica de la diligencia excluye la previa notificación al afectado y, en consecuencia, la posibilidad de que con ocasión de la misma sea asistido legalmente. Ahora bien, una lectura detenida del art. 124 LP permite afirmar que, si bien nada impide que la solicitud de diligencias de comprobación de hechos sea efectuada con asistencia legal y representación procesal, la intervención del solicitante, o su defensa, en la diligencia de inspección y examen, resulta improcedente. En caso contrario ningún sentido tendría la previsión que hace el aptdo. $2^{\circ}$ del art. 124 LP cuando dispone la ordenación de pieza separada, con secreto de las actuaciones y notificación al solicitante de no darle a conocer el resultado de las diligencias efectuadas. Igualmente, aún cuando por razones distintas, la intervención de la defensa legal del afectado por la diligencia, dado que si algo caracteriza a estas diligencias de comprobación, como así ha sido recogido por la doctrina, es su urgencia y sorpresa, circunstancias estas que no deberían propiciar la intervención de defensa legal alguna en el desarrollo de las actuaciones de comprobación. No obstante, también la propia dicción literal del art. 124 LP, a pesar de que nada dice expresamente, permite afirmar la procedencia de la intervención del afectado en la práctica de las diligencias de comprobación, resultando admitido que dicha intervención se produzca, incluso, con asistencia letrada, siempre que con ello no interfiera en la urgente realización de la misma $^{563}$.

Por lo que respecta a su práctica, la dicción literal del art. 124 LP nos permite afirmar que las diligencias de comprobación de hechos parecen traducirse en actos de inspección y examen del juez, se entiende que de lugares o cosas, en el más amplio sentido de su significado e incluyendo los documentos que en el lugar se encuentren, el

\footnotetext{
${ }^{561}$ García García, E., Las diligencias preliminares..., ob. cit., p. 14.

562 Obra 2: Castán Pérez-Gómez, A., El nuevo régimen..., ob. cit., p. 33.

${ }^{563}$ García García, E., Las diligencias preliminares..., ob. cit., p. 14.
} 
cual, además, podrá hacerse asistir en dicho acto del correspondiente perito ${ }^{564}$, cuya intervención podrá ser acordada de oficio por el tribunal, incluso para la realización de las investigaciones previas que le permitan verificar la procedencia de la solicitud efectuada $^{565}$. La diligencia de inspección podrá terminar con la determinación positiva del tribunal de estarse llevando a cabo la infracción alegada en la patente o negativa de la misma acordando, en este segundo supuesto, dar por terminada la diligencia, y en el primero, efectuando una detallada descripción de las máquinas, dispositivos, productos, procedimientos, instalaciones o actuaciones mediante la utilización de los cuales se lleve presumiblemente a cabo la infracción alegada.

Y para ir terminando el estudio de las diligencias de comprobación de hechos, cabe resaltar que una de las muchas particularidades que presentan en relación a las diligencias preliminares del art. 256.1 LEC es la imposibilidad de utilizar la información obtenida si en el plazo de los treinta días hábiles a partir de la fecha de la entrega al solicitante de la certificación de las diligencias no se hubiere presentado la correspondiente demanda ejercitando la acción judicial que se pretende preparar (125.2 LP) y en el que únicamente podrá hacerse uso de la información obtenida con las diligencias preliminares (art. 125.1 LP). Lo anterior, se vincula con el férreo celo que el legislador ha dispensado al tratamiento de la información que de las mismas pueda obtenerse, incluso en el supuesto de que tras la inspección y examen el juzgador determine que no es presumible que se esté llevando a cabo la infracción de la patente, en cuyo caso ordenará la formación de una pieza separada en la que se incluirán las actuaciones realizadas, que se mantendrán secretas, disponiendo que el LAJ notifique al solicitante que no procede darle a conocer el resultado de las diligencias realizadas (art. 124.2 LP) ${ }^{566}$. No debe olvidarse que, conforme al art. 124.4 LP, en todo caso cuidará el juez de que la diligencia de comprobación no sirva como medio para violar secretos industriales o realizar actos que constituyan competencia desleal.

\footnotetext{
${ }_{564}^{564}$ Armengot Vilaplana, A., Las nuevas diligencias..., ob. cit., p. 7.

${ }_{565}$ Corbal Hernández, J.E., Diligencias Preliminares (arts...), ob. cit., p. 3114.

${ }^{566}$ Así se desprende del AAP de Barcelona (sección 15 ${ }^{\mathrm{a}}$ ) de 26 de julio de 2002, ponente Ilmo. Sr. L. Garrido, f.j.4 (LA LEY 140501/2002) cuando señala que: “[...] Y es que al legislador no escapa que este instrumento puede ser utilizado de forma abusiva y propiciar la desvelación de secretos industriales o actos concurrenciales desleales, de ahí el control judicial en su concesión y práctica”.
} 
Por último, cabe señalar que, conforme al aptdo. $5^{\circ}$ del art. $124 \mathrm{LP}$, contra la decisión del juez sobre el resultado de la diligencia practicada, no se dará recurso alguno.

\section{Identificación del PSSI (art. 256.1.10 LEC)}

"Por petición, de quien pretenda ejercitar una acción por infracción de un derecho de propiedad industrial o de un derecho de propiedad intelectual, para que se identifique al prestador de un servicio de la sociedad de la información sobre el que concurran indicios razonables de que está poniendo a disposición o difundiendo de forma directa o indirecta, contenidos, obras o prestaciones objeto de tal derecho sin que se cumplan los requisitos establecidos por la legislación de propiedad industrial o de propiedad intelectual, considerando la existencia de un nivel apreciable de audiencia en España de dicho prestador o un volumen, asimismo apreciable, de obras y prestaciones protegidas no autorizadas puestas a disposición o difundidas.

La solicitud estará referida a la obtención de los datos necesarios para llevar a cabo la identificación y podrá dirigirse a los prestadores de servicios de la sociedad de la información, de pagos electrónicos y de publicidad que mantengan o hayan mantenido en los últimos doce meses relaciones de prestación de un servicio con el prestador de servicios de la sociedad de la información que se desee identificar. Los citados prestadores proporcionarán la información solicitada, siempre que ésta pueda extraerse de los datos de que dispongan o conserven como resultado de la relación de servicio que mantengan o hayan mantenido con el prestador de servicios objeto de identificación, salvo los datos que exclusivamente estuvieran siendo objeto de tratamiento por un proveedor de servicios de Internet en cumplimiento de lo dispuesto en la Ley 25/2007, de 18 de octubre, de conservación de datos relativos a las comunicaciones electrónicas y a las redes públicas de comunicaciones”.

Como ya pusimos de manifiesto en el apartado relativo a la evolución legislativa de las diligencias preliminares, uno de los avances más importantes de la LEC en materia de diligencias preliminares ha venido de la mano de la Ley 21/2014 al posibilitar o facilitar la preparación de los procesos sobre infracciones de derechos de 
propiedad intelectual e industrial cometidas en línea y en las que no se había pensado hasta dicha fecha. El nivel tecnológico alcanzado por la sociedad, el impacto que el desarrollo de las nuevas tecnologías digitales de la información y las redes informáticas ha tenido en un espacio digital como Internet, basado en la libertad de los usuarios para aportar contenidos, lo hacían necesario.

Así, la Exposición de Motivos de la Ley 21/2014, tras poner de manifiesto la existencia de problemas cuya solución no puede esperar a la aprobación de una nueva ley integral de propiedad intelectual, anuncia el fortalecimiento de los instrumentos de reacción frente a las vulneraciones de aquellos derechos incidiendo en la necesidad de adaptar la vía jurisdiccional civil para que pueda mantener su papel de cauce ordinario para la solución de conflictos de intereses introduciendo mejoras en la redacción de determinadas medidas de información previa necesarias para la protección de los derechos de propiedad intelectual en el entorno digital en línea.

Y no obvia el legislador la relevancia que en dicho entorno adquieren los prestadores de servicios de la sociedad de la información, en adelante, PSSI, tanto en su condición de colaboradores como de responsables infractores de derecho de propiedad intelectual, en tanto que facilitadores de la descripción o localización de obras y prestaciones que indiciariamente se ofrezcan sin autorización y no meros intermediadores técnicos, al considerar el legislador que dicha actividad constituye una explotación conforme al concepto general de derecho exclusivo de explotación establecido en la normativa de propiedad intelectual e industrial.

\section{1 Ámbito de aplicación}

Partiendo de lo anterior, el legislador configura la diligencia preliminar contenida en el ordinal $10^{\circ}$ del art. 256.1 LEC dirigida a la identificación PSSI sobre el que concurran indicios razonables de que está poniendo a disposición o difundiendo de forma directa o indirecta, contenidos, obras o prestaciones objeto de los derechos de propiedad industrial o intelectual. Es decir, nos encontramos ante una diligencia preliminar específica para la averiguación de la identidad del PSSI lo que, como se 
señala en la doctrina, no impide que para la averiguación de otros datos relativos a infracciones cometidas en línea no pueda el titular del derecho infringido recurrir a otra u otras de las diligencias previstas en el catálogo del art. 256.1 LEC ${ }^{567}$.

Es decir, conforme al Anexo de la LSSI, nos encontramos ante una diligencia cuyo objeto es la identificación de la persona física o jurídica que proporciona un servicio de la sociedad de la información entendiéndose por tal servicio todo aquel prestado, normalmente, a título oneroso, a distancia, por vía electrónica y a petición individual del destinatario así como los servicios no remunerados por sus destinatarios en la medida en que constituyan una actividad económica para el prestador de servicios $^{568}$. Más concretamente, entre otros y siempre que representen una actividad económica, la contratación de bienes o servicios por vía electrónica, la organización y gestión de subastas por medios electrónicos o de mercados y centros comerciales virtuales, la gestión de compras en la red por grupos de personas, el envío de comunicaciones comerciales y el suministro de información por vía telemática. Por tanto, como se pone de manifiesto en la doctrina, el criterio que delimita la sujeción a la LSSI y la condición de ser PSSI es la onerosidad, aun cuando la prestación del servicio no conlleve un pago o remuneración por parte del usuario, en tanto en cuanto los patrocinios y publicidad digital reportan importantes ingresos para los $\operatorname{PSSI}^{569}$.

\subsection{Presupuestos de admisión}

Constituyen presupuestos necesarios para la admisión de la diligencia preliminar:

a) Que el solicitante acredite que existen indicios razonables de que el prestador de servicios de la sociedad de la información está poniendo a disposición o difundiendo de forma directa o indirecta contenidos, obras o prestaciones objeto de un derecho sin

\footnotetext{
${ }^{567}$ Vid. Obra 1: Castán Pérez-Gómez, A., El nuevo régimen..., ob. cit., pp. 141-142.

${ }^{568}$ Conforme a la Exposición de Motivos de la LSSI se consideran prestadores de servicios de la sociedad de la información los operadores de telecomunicaciones, los proveedores de acceso a Internet, los portales, los motores de búsqueda y cualquier sujeto que disponga de un sitio en Internet.

${ }^{569}$ Cfr. Gil Nogueras, L.A., Las diligencias preliminares..., ob. cit., p. 13.
} 
que se cumplan los requisitos establecidos en la legislación de propiedad industrial o intelectual.

$\mathrm{Al}$ respecto, no puede dejarse de exponer que pese a hacer referencia el precepto legal a ambos derechos, de propiedad intelectual e industrial, la Exposición de Motivos de la Ley 21/2014 que inspira el tenor de la reforma ninguna referencia hace a los derechos de propiedad industrial. No obstante, nos parece acertada la inclusión en el ámbito de la diligencia preliminar de los derechos de propiedad industrial dado que son frecuentes las infracciones en línea de este derecho. Así las usurpaciones de nombres de dominio mediante las que un tercero pretende aprovecharse de la fama de un sitio web, utilizando su nombre de dominio para, por ejemplo, reenviara quienes entren en la misma hacia otro sitio que no tenga nada que ver con el primero ${ }^{570}$. También la divulgación de patentes se presenta con relativa frecuencia ${ }^{571}$.

Por otro lado, debe indagarse que debe entenderse por indicios razonables con la precisión de que, en el caso que nos ocupa, y a diferencia de lo que ocurre con la diligencia preliminar del ordinal $8^{\circ}$ del art. 256.1.8 LEC, no se obliga al solicitante a aportar un principio de prueba. Al respecto, se señala en la doctrina científica que el empleo por el legislador del término indicios razonables, no conlleva el plus añadido del principio de prueba resultando suficiente la aportación de datos o indicios de los que pueda inferirse la existencia de una infracción de los derechos, en los que debe concurrir la cualidad de ser razonables, bastantes en calidad o en cantidad y en concordancia con la propia redacción de la diligencia ${ }^{572}$ lo que, sin duda alguna, quedará dentro del margen de apreciación del juzgador en cuestión.

\footnotetext{
${ }^{570} \mathrm{La} \mathrm{LM}$, en su art. 34, por ejemplo, precisa que la protección se aplica también a los nombres de dominio.

${ }^{571}$ Así, cuando existen malas conductas por parte de terceros, Internet puede ser el peor enemigo de los secretos industriales, siendo un claro ejemplo lo sucedido con la empresa Apple respecto de un ejemplar "iPhone 4" que, varios meses antes de su comercialización, fue encontrado en un bar en los Estados Unidos por una persona que vendió el aparato a un famoso periódico de Internet. La divulgación de todas las características fue muy rápida y, dada la globalidad de la red, el mundo entero pudo tenerse conocimiento de las mismas.

${ }^{572}$ Díaz Pita, Mª.P., Diligencias preliminares y..., ob. cit., p. 210.
} 
b) La existencia de un nivel apreciable de audiencia en España del prestador infractor o un volumen también apreciable de obras, prestaciones protegidas no autorizadas puestas a disposición o difundidas ${ }^{573}$.

Igualmente, debe destacarse que el legislador, en un nuevo alarde de flexibilidad, ha evitado delimitar los concretos datos que, para la identificación del prestador del servicio de la información, pueden obtenerse a través de la diligencia en cuestión y que en el ámbito de las infracciones en línea apuntan, de forma especial, a la dirección IP, nombre de dominio, dirección de Internet, nombre o razón social o dato similar de identificación, sin excluir los generales relativos a su domicilio, teléfono, etc.

\subsection{Legitimación}

En cuanto a la legitimación activa, al igual que en las diligencias preliminares contenidas en los ordinales $7^{\circ}$ y $8^{\circ}$ del art. 256.1 LEC, corresponderá a quien pretenda ejercitar una acción civil por infracción de un derecho de propiedad industrial o intelectual, pudiendo así instarla tanto los titulares originarios de los derechos citados como los titulares derivativos, en materia de propiedad intelectual, o licenciatarios de los mismos, en materia de propiedad industrial.

La legitimación pasiva corresponde a los $\operatorname{PSSI}^{574}$, más concretamente, a los proveedores de servicios de intermediación sobre los que, de conformidad con lo

\footnotetext{
${ }^{573}$ Si se quiere, y como se ha señalado por Obra 1: Castán Pérez-Gómez, A., El nuevo régimen..., ob. cit., p. 142, de arbitrariedad.

${ }^{574}$ Conforme apunta Obra 1: Castán Pérez-Gómez, A., El nuevo régimen..., ob. cit., p. 144, acogiendo el concepto amplio de servicios de la sociedad de la información que recoge la Exposición de Motivos de la LSSI que englobaría además de la contratación de bienes y servicios por vía electrónica, el suministro de información por dicho medio, como el que efectúan los periódicos o revistas que pueden encontrarse en la red, las actividades de intermediación relativas a la provisión de acceso a la red, a la transmisión de datos por redes de telecomunicaciones, a la realización de copia temporal de las páginas de Internet solicitadas por los usuarios, al alojamiento en los propios servidores de información, servicios o aplicaciones facilitados por otros o a la provisión de instrumentos de búsqueda o de enlaces a otros sitios de Internet, así como cualquier otro servicio que se preste a petición individual de los usuarios tal como descarga de archivos de video o audio, siempre que represente una actividad económica para el prestador, y que son ofrecidos por los operadores de telecomunicaciones, los proveedores de acceso a Internet, los portales, los motores de búsqueda o cualquier otro sujeto que disponga de un sitio de Internet a través del que realice alguna de las actividades indicadas, incluido el comercio electrónico.
} 
dispuesto en el art. 12 bis de la LSSI, pesa la obligación de facilitación de datos que exclusivamente estuvieran siendo objeto de tratamiento en cumplimiento de lo dispuesto en la LCDCE. También a los prestadores de servicios de pagos electrónicos y de publicidad.

Se advierte, por tanto, que nos encontramos ante la singularidad de no coincidir la persona legitimada pasivamente en las diligencias preliminares, el PSSI requerido, con el legitimado en el futuro proceso, el otro PSSI a cuya identificación se dirige la diligencia preliminar, y que con aquel mantenga o haya mantenido relaciones de prestación de un servicio ${ }^{575}$.

Y, en todo caso, se exige que los legitimados pasivamente mantengan o hayan mantenido en los últimos doce meses relaciones de prestación de un servicio con el prestador de servicios de la sociedad de la información que se pretenda identificar. Ello, en lógica coherencia con el periodo de conservación de datos que previene el art. 5 $\mathrm{LCDCE}^{576}$.

\footnotetext{
${ }^{575}$ Indica Gil Nogueras, L.A., Las diligencias preliminares..., ob. cit., p. 13, que el destinatario de la medida, "en principio (y ahí radica una diferencia con otras Diligencias) no tiene por qué ser el infractor, sino que serán otros Prestadores de Servicios de Información de otro nivel, de pagos electrónicos y de publicidad, si bien en alguna medida pueden resultar demandados por la vía del art. 138.4 LP si se trata de aquellos prestadores que actúen como intermediarios a cuyos servicios recurra un tercero para infringir derechos de propiedad intelectual”. Por otro lado, apunta Díaz Pita, $\mathrm{M}^{\mathrm{a}} \mathrm{P} .$, Las diligencias preliminares..., ob. cit., p. 209, que "Desde nuestro punto de vista, y en aplicación de los conceptos a que se refiere el Anexo de la Ley 348/2002, de 11 de julio, de servicios de la sociedad de la información y de comercio electrónico, muy probablemente la Ley 21/2014 está haciendo referencia al denominado "Servicio de intermediación", esto es, el "servicio de la sociedad de la información o el acceso a la información. Son servicios de intermediación la provisión de servicios de acceso a Internet, la transmisión de datos por redes de telecomunicaciones, la realización de copia temporal de las páginas de Internet solicitadas por los usuarios, el alojamiento en los propios servidores de datos, aplicaciones o servicios suministrados por otros y la provisión de instrumentos de búsqueda, acceso y recopilación de datos o de enlaces a otros sitios de Internet".

${ }^{576}$ Dispone el art. 5 LCDCE, que: "1. La obligación de conservación de datos impuesta cesa a los doce meses computados desde la fecha en que se haya producido la comunicación. Reglamentariamente, previa consulta a los operadores, se podrá ampliar o reducir el plazo de conservación para determinados datos o una categoría de datos hasta un máximo de dos años o un mínimo de seis meses, tomando en consideración el coste del almacenamiento y conservación de los datos, así como el interés de los mismos para los fines de investigación, detección y enjuiciamiento de un delito grave, previa consulta a los operadores. 2. Lo dispuesto en el apartado anterior se entiende sin perjuicio de lo previsto en el artículo 16.3 de la Ley Orgánica 15/1999, de 13 de diciembre, de Protección de Datos de Carácter Personal, sobre la obligación de conservar datos bloqueados en los supuestos legales de cancelación".
} 
Y debe recalcarse, como así hace la norma, que los legitimados pasivamente para las diligencias preliminares estarán obligados a proporcionar, únicamente, aquellos datos que puedan extraerse de los que dispongan o conserven como resultado de la relación de servicios que mantengan o hayan mantenido con el prestador de servicios objeto de identificación. Salvedad hecha de aquellos datos que exclusivamente estuvieran siendo objeto de tratamiento por un proveedor de servicios de Internet en cumplimiento de lo dispuesto en la LCDCE, lo que ha sido interpretado en la doctrina en el sentido de dejar a salvo de la obligación de proporcionar los datos que ya hayan sido cedidos en el contexto de una investigación criminal o estén siendo tratados en el momento en que se reciba la solicitud ${ }^{577}$.

Nada nos dice la norma respecto de la forma en que los datos serán obtenidos pero, sin perjuicio de la amplitud de medios o formas que la falta de previsión permitiría adoptar, lo razonable es pensar que tras la solicitud y admisión de la diligencia por el juez este procederá a notificar el auto que acuerda la acuerde al legitimado pasivamente que cumplirá, en el caso de no oponerse, con la mera presentación ante el tribunal del correspondiente escrito en el que haga constar los datos que le hayan sido requeridos.

\section{Identificación del usuario de SSI (art. 256.1.11 LEC)}

"Mediante la solicitud, formulada por el titular de un derecho de propiedad intelectual que pretenda ejercitar una acción por infracción del mismo, de que un prestador de servicios de la sociedad de la información aporte los datos necesarios para llevar a cabo la identificación de un usuario de sus servicios, con el que mantengan o hayan mantenido en los últimos doce meses relaciones de prestación de un servicio, sobre el que concurran indicios razonables de que está poniendo a disposición o difundiendo de forma directa o indirecta, contenidos, obras o prestaciones objeto de tal derecho sin que se cumplan los requisitos establecidos por la legislación de propiedad intelectual, y mediante actos que no puedan considerarse realizados por meros consumidores finales de buena fe y sin ánimo de obtención de beneficios económicos o

\footnotetext{
${ }^{577}$ Vid. Obra 1: Castán Pérez-Gómez, A., El nuevo régimen..., ob. cit., pp. 145-146.
} 
comerciales, teniendo en cuenta el volumen apreciable de obras y prestaciones protegidas no autorizadas puestas a disposición o difundidas".

Otra de las reformas introducidas por la Ley 21/2014 en el régimen de diligencias preliminares con la finalidad de superar las dificultades que presenta la identificación del infractor en las defraudaciones en el entorno digital es la expresa previsión en el catálogo contenido en el art 256.1 LEC de la diligencia tendente a la identificación del usuario de un PSSI sobre el que concurran indicios razonables de estar poniendo a disposición o difundiendo, de forma directa o indirecta, contenidos, obras o prestaciones objeto del derecho de propiedad intelectual ${ }^{578}$.

Nos encontramos ante una diligencia preliminar que nace como consecuencia de las reivindicaciones de las asociaciones de autores y creadores culturales ante la imposibilidad de proceder a la identificación de los usuarios que vulneraran sus derechos $^{579} \mathrm{y}$, en buena lid, dirigida, exclusivamente, y a diferencia del resto de diligencias preliminares especiales, a la obtención de información para la preparación de los procesos por infracción del derecho de propiedad intelectual, que no industrial.

\subsection{Objeto de la diligencia}

Su objeto, como hemos adelantado, es la identificación del usuario, infractor del derecho de propiedad industrial, de los servicios prestados por un prestador de servicios de la sociedad de la información. A priori, dicho usuario puede ser identificado, conforme al Anexo de la LSSI, con el destinatario del servicio o persona física o jurídica que utiliza, sea o no por motivos profesionales, un servicio de la sociedad de la información. Y no podrá ser identificado con el usuario y destinatario del servicio que pueda ser identificado con el consumidor, definido en el Anexo de la LSSI por remisión al art. 1 de la LGDCU, hoy art. 3 del TRLGDCU ${ }^{580}$ como lo demuestra el hecho de que

\footnotetext{
${ }^{578}$ Cfr. Obra 1: Castán Pérez-Gómez, A., El nuevo régimen..., ob. cit., p. 146.

${ }^{579}$ Vid. Díaz Pita, Ma P., Las diligencias preliminares..., ob. cit., pp. 211-212.

580 Dispone el art. 3 TRLGDCU que: "A efectos de esta norma y sin perjuicio de lo dispuesto expresamente en sus libros tercero y cuarto, son consumidores o usuarios las personas físicas que actúen con un propósito ajeno a su actividad comercial, empresarial, oficio o profesión.
} 
el propio ordinal $8^{\circ}$ del art. 256.1 LEC exija que los actos a través de los cuales se disponga o difunda los contenidos, obras o prestaciones objeto del derecho de propiedad intelectual no puedan considerarse realizados por meros consumidores finales de buena fe y sin ánimo de obtención de beneficios económicos o comerciales.

\subsection{Legitimación}

En cuanto a la legitimación activa, corresponderá a quien pretenda ejercitar una acción por infracción de un derecho de propiedad intelectual, pudiendo así instarla tanto los titulares originarios de los derechos citados como los titulares derivativos, en materia de propiedad intelectual.

La legitimación pasiva corresponde a los prestadores de servicios de la sociedad de la información. Al igual que en la diligencia del ordinal $10^{\circ}$ del art. 256.1 LEC, a los proveedores de servicios de intermediación sobre los que, de conformidad con lo dispuesto en el art. 12 bis de la LSSI, pesa la obligación de facilitación de datos que exclusivamente estuvieran siendo objeto de tratamiento en cumplimiento de lo dispuesto en la LCDCE. Pero no, como sucedía en aquella diligencia, a los prestadores de servicios de pagos electrónicos y de publicidad. Nuevamente aquí, el legitimado pasivamente en el procedimiento de diligencias preliminares no coincide con el legitimado pasivo del futuro proceso que se pretende preparar dado que el primero de ellos ha de ser un prestador de servicios de la sociedad de la información y el segundo será el usuario de los servicios de ese prestador.

$\mathrm{Y}$ al igual que respecto a la diligencia anterior, pero únicamente, se exige que los legitimados pasivamente, los prestadores de servicios de la sociedad de la información, mantengan o hayan mantenido en los últimos doce meses relaciones de prestación de un servicio con el prestador de servicios de la sociedad de la información que se pretenda identificar.

Son también consumidores a efectos de esta norma las personas jurídicas y las entidades sin personalidad jurídica que actúen sin ánimo de lucro en un ámbito ajeno a una actividad comercial o empresarial”. 


\subsection{Presupuestos para su admisión}

Constituyen presupuestos necesarios para la admisión de la diligencia preliminar:

a) Que el solicitante de la diligencia posea indicios razonables de que el usuario está poniendo a disposición o difundiendo de forma directa o indirecta, contenidos, obras o prestaciones objeto del derecho de propiedad intelectual sin que se cumplan los requisitos establecidos por la legislación de propiedad intelectual, resultando de aplicación todo cuanto al respecto se ha expuesto con ocasión de la diligencia preliminar del ordinal $10^{\circ}$ del art. 256.1 LEC.

b) Que la puesta a disposición o difusión se lleva a cabo por el usuario mediante actos que no puedan considerarse realizados por meros consumidores finales de buena fe y sin ánimo de obtención de beneficios económicos o comerciales, teniendo en cuenta el volumen apreciable de obras y prestaciones protegidas no autorizadas puestas a disposición o difundidas y resultando de aplicación todo cuanto al respecto se expuso con ocasión de la diligencia preliminar del ordinal $7^{\circ}$ del art. 256.1 LEC.

\subsection{Práctica de la diligencia}

La norma guarda silencio respecto de la forma en que los datos serán obtenidos pero, sin perjuicio de la amplitud de medios o formas que la falta de previsión al respecto permitiría adoptar, lo razonable es pensar que tras la solicitud de diligencias y admisión de la misma por el juez este procederá a notificar el auto que acuerda las mismas al legitimado pasivamente que cumplirá, en el caso de no oponerse, con la mera presentación ante el tribunal del correspondiente escrito en el que haga constar los datos que le hayan sido requeridos. 


\section{CAPÍTULO III. PROCEDIMIENTO}

Las diligencias preliminares reciben en la LEC una regulación procedimental aparentemente simple pero que, como veremos, ofrece una variedad de detalles procesales y materiales que habrán de ser tenidos en cuenta y serán examinados a lo largo del presente capítulo.

\section{Competencia}

Uno de los requisitos formales, quizá el principal, que condiciona la formulación y admisión de cualquier pretensión que se dirija a un tribunal y sin cuya concurrencia no puede el juez entrar a examinarla, es el relativo a la competencia ${ }^{581}$ que, en el caso de las diligencias preliminares, se encuentra determinada, objetiva y territorialmente, en el art. 257.1 $\mathrm{LEC}^{582}$.

Es el primer inciso del aptdo. $1^{\circ}$ de dicho precepto legal el que establece la regla general de competencia para resolver sobre la petición y solicitud de diligencia preliminar, al determinar que será competente el JPI o JMER, cuando proceda, del domicilio de la persona que, en su caso, hubiera de declarar, exhibir o intervenir de otro modo en las actuaciones que se acordaran para preparar el juicio ${ }^{583}$. Y como regla específica, el segundo inciso del art. 257.1 LEC, determina la competencia para los casos de los supuestos previstos en los números 6, 7, 8 y 9 del art. 256.1 LEC, señalando que corresponde al tribunal ante el que haya de presentarse la demanda determinada, sin perjuicio, en estos casos, de solicitarse nuevas diligencias que podrán instarse ante el mismo tribunal o ante el que resulte competente para conocer de la

\footnotetext{
${ }^{581}$ Conforme a lo dispuesto en el art. 9.2 LOPJ, los tribunales del orden jurisdiccional civil conocerán: “1) de las materias que les son propias, es decir, de la actuación del Derecho Privado; y 2) de todas aquellas materias que no estén atribuidas a otro orden jurisdiccional".

${ }_{582}$ Damián Moreno, J., Comentarios a la..., ob. cit., p. 1688, lo ha definido como un "fuero que goza de autonomía propia".

${ }^{583}$ En dicho sentido, señala Damián Moreno, J., Comentarios a la ..., ob. cit., p. 1688, que la LEC "se ha inclinado por adoptar un criterio de proximidad con el objeto de la medida que se pretenda". En el mismo sentido Garciandía González, P.M., La regulación de..., ob. cit., p. 786 cuando señala que "aproxima el conocimiento del tribunal al objeto de la diligencia solicitada y facilita la oposición del sujeto pasivo a su práctica".
} 
pretensión planteada o de otras que eventualmente puedan acumularse, como resultado de las diligencias previamente practicadas.

En dichos términos delimita el art. 257.1 LEC la competencia objetiva ${ }^{584}$, es decir, por razón de la materia, entre los JPI y los JMER. Y también la territorial ${ }^{585}$, como fuero imperativo, y con independencia de cuál sea el órgano competente para conocer del ulterior procedimiento que mediante la diligencia preliminar se pretende $\operatorname{preparar}^{586}$. Por tanto, no cabe predicar respecto de las diligencias preliminares la posibilidad de la sumisión tácita de las partes al tribunal (art. 54 LEC) habida cuenta el fuero imperativo del art. 257.1 LEC y la posibilidad, para el caso de formularse oposición, de la tramitación de la misma por los cauces del juicio verbal (art. 260 LEC), en cuyo caso la sumisión tácita es descartada por el aptdo. $1^{\circ}$, in fine, del art. 54 LEC.

Además, tal y como se desprende de art. 257.2 LEC, en las diligencias preliminares no se admitirá el planteamiento de declinatoria ${ }^{587}$, lo que en la doctrina ha sido interpretado como el intento de que, con carácter previo al comienzo del proceso, no se planteen cuestiones de competencia cuyo resultado no ha de servir para la fijación definitiva del órgano jurisdiccional que deba conocer del proceso ${ }^{588}$, y no es obstáculo al deber del juez de revisar de oficio su competencia absteniéndose de conocer para el caso de entender que ello, por razones objetivas, territoriales o funcionales, no le corresponde. En tal caso, así lo acordará indicando al solicitante el JPI, y añadimos nosotros el JMER, al que debe acudir, los que podrán inhibirse en su competencia

\footnotetext{
${ }^{584}$ Siguiendo a Gimeno Sendra, V., Derecho Procesal Civil..., ob. cit., p. 71, se entiende por competencia objetiva, "el conjunto de normas procesales que distribuyen jerárquicamente, entre los diversos órganos judiciales de un mismo orden jurisdiccional, el conocimiento de la fase declarativa de los objetos procesales".

585 Como indica Gimeno Sendra, V., Derecho Procesal Civil..., ob. cit., p. 83, se entiende por competencia territorial "las normas procesales que, en atención a la demarcación judicial, asignan el conocimiento en primera instancia de los objetos litigiosos entre los distintos Juzgados de un mismo grado de todo el territorio nacional".

${ }^{886}$ Así lo afirma Álvarez Alarcón, A., Las diligencias preliminares..., ob. cit., p. 47. Determinando que nos encontramos ante un fuero imperativo, vid. el ATS (sala $1^{\text {a }}$ ) de 11 de noviembre de 2002, ponente Ilmo. Sr. J.M. Martínez-Pereda, f.j.3º (LA LEY 2229360/2002).

587 Que, conforme a lo señalado en el art. 63 LEC, no es sino la forma de denuncia de la falta de jurisdicción o competencia de todo tipo del tribunal ante el que las diligencias preliminares se hayan interpuesto, bien por el solicitante bien por quienes puedan ser parte legítima en la mismas.

${ }^{588}$ En la doctrina científica, vid. Garciandía González, P.M., La regulación de..., ob. cit., p. 787 y Álvarez Alarcón, A., Las diligencias preliminares..., ob. cit., p. 48.
} 
decidiendo el conflicto negativo el tribunal inmediato superior común, según lo previsto en el art. 60 LEC.

$\mathrm{Al}$ respecto cabe resaltar lo llamativo de la regulación para el caso de abstención en el supuesto de diligencias preliminares, al remitirse la decisión del conflicto al art. 60 LEC, relativo al conflicto de competencia territorial, y no objetiva, que podría darse entre los JPI y JMER, observándose en las previsiones del art 257.2 LEC una cierta confusión. En primer lugar, porque de dicho precepto legal parece desprenderse que el término "abstención" es utilizado en referencia a la falta de competencia en cualquiera de sus modalidades cuando, en rigor jurídico, el mismo está ligado a la falta de competencia objetiva, como el de "inhibición", al que no se refiere, a la falta de competencia territorial. En segundo lugar, remite la decisión del posible conflicto, a la regulación propia del conflicto negativo de competencia territorial.

Ello pese a que el art. 257.1 LEC, en coherencia con la tipología de diligencias preliminares que recoge el art. 256.1 LEC y la distribución de competencia objetiva que se contiene en los arts. 85 y 86 ter LOPJ, distingue claramente la competencia de tal naturaleza entre los JPI y los JMER de la misma manera que establece un criterio de competencia territorial con la referencia al del domicilio de la persona que, en su caso, hubiera de declarar, exhibir o intervenir de otro modo en las actuaciones que se acordaran para preparar el juicio.

Es decir, que pese a los criterios diferenciados de competencia objetiva y territorial que se determinan en el núm. 1 del art. 257 LEC, el núm. 2 del mismo precepto legal parece establecer un régimen unitario de revisión de oficio de la competencia en el que, con escaso rigor, se mezclan los conceptos y trámites propios de cada una de los dos tipos de competencia enunciados.

Por ello, en este punto, resulta preciso recordar que la competencia objetiva es aquella que permite distinguir de entre los diversos órganos judiciales de un mismo orden jurisdiccional a quien le corresponde el conocimiento de un concreto asunto, por razón de la materia, de orden público y, por tanto, sujeto al control de oficio (art. 240.2 
LOPJ) hasta el punto de viciar de nulidad todas aquellas actuaciones que sean conocidas por el órgano no competente objetivamente ${ }^{589}$. Y respecto de la misma, el art. 48 LEC dispone que tan pronto como se advierta deberá ser apreciada de oficio por el tribunal que, previa audiencia de las partes y el Ministerio Fiscal, resolverá por medio de auto declarando la falta de competencia objetiva e indicando la clase de tribunal al que corresponde el conocimiento del asunto. En lógica coherencia, se entiende que para que la parte pueda promover el procedimiento ante el órgano competente objetivamente, dicho órgano podrá igualmente considerarse no competente objetivamente pero el conflicto no podrá resolverse sino a través de los correspondientes recursos de apelación frente a las resoluciones de cada uno de los órganos judiciales que no se consideren competentes objetivamente que, además, no serán concurrentes. Así, en términos generales, si el órgano judicial ante el que primeramente presentemos el asunto considera que no es competente objetivamente dictará auto absteniéndose de conocer y, por tanto, poniendo fin al mismo, decisión esta que, conforme a lo dispuesto en el art. 455.1 LEC, será susceptible de ser recurrida en apelación. Pero también podrá la parte optar por no interponer dicho recurso de apelación sino plantear el asunto ante el tribunal que aquel estimó competente objetivamente. Ello, con la posibilidad de que este segundo tribunal también considere que carece de competencia objetiva y que, por tanto, debe abstenerse de conocer del asunto. Y la parte no tendrá otra posibilidad que interponer el correspondiente recurso de apelación para la determinación de la competencia objetiva pues la LEC no dispone de norma alguna que de otra forma permita el tratamiento del conflicto negativo de competencia objetiva.

La competencia territorial es aquella que permite atribuir el conocimiento de un determinado asunto y en primera instancia, entre los órganos judiciales de un mismo grado de todo el territorio nacional ${ }^{590}$. Y al respecto de la misma, viniendo fijada por una regla imperativa (art. 257.1 LEC), advertida su falta y previa audiencia de las partes personadas y el Ministerio Fiscal, si el LAJ entiende que el tribunal carece de ella, dará cuenta al juez para que resuelva lo que proceda mediante auto remitiendo en su caso las actuaciones al tribunal que considere territorialmente competente (art. 58 LEC) que

\footnotetext{
${ }^{589}$ Gimeno Sendra, V., Derecho Procesal Civil..., ob. cit., p. 71.

${ }^{590}$ Gimeno Sendra, V., Derecho Procesal Civil..., ob. cit., p. 83.
} 
igualmente podrá determinar su falta de competencia territorial pero, en este caso, sin obligar a la parte a interponer recurso de apelación alguno, y con una fórmula que de forma directa permite resolver el conflicto por el tribunal inmediato superior común (art. 60.3 LEC) que decidirá por medio de auto, sin ulterior recurso, el tribunal al que corresponde conocer del asunto.

Como se observa, el tratamiento de la falta de competencia territorial está dotado en la LEC de una mejor y más rápida regulación que entendemos es la razón por la que, en el seno de las diligencias preliminares, el legislador, no sin cierta confusión, ha ordenado un trámite propio para el tratamiento de la falta de competencia objetiva y territorial cuyo conflicto, finalmente, decide sea resuelto aplicando el trámite previsto en la LEC para el conflicto negativo de competencia territorial. Y se dice que no sin cierta confusión porque, en primer término, no cabiendo duda alguna de que en sede de diligencias preliminares puede el juez revisar tanto su falta de competencia objetiva como territorial, el legislador utiliza el término abstención, propio de la falta de competencia objetiva, para ordenar la apreciación por el juez tanto de la falta de esta como de la territorial. En segundo lugar, porque al tiempo que ordena la LEC que, en caso de abstención, debe el juez indicar al solicitante el JPI al que debe acudir -trámite propio de la decisión por falta de competencia objetiva, y no territorial- determina que si el indicado inhibiere su competencia -decisión propia de la falta de competencia territorial- decidirá el conflicto negativo el tribunal inmediato superior común según lo previsto en el art. 60 LEC y, por tanto, conforme al trámite del conflicto negativo de competencia territorial, pero sin la previa remisión de los autos por el órgano que en primer lugar entendiera que no es competente, objetiva o territorialmente, sino imponiéndole al solicitante la carga de acudir directamente a aquel órgano judicial que el primero señale que es competente. Dicha situación, que impedirá que el señalado como competente tenga el expediente promovido a su disposición, pues no ordena el art. 257.2 LEC que se le sean remitidos los autos por aquel que se abstenga, obligará a la parte solicitante a poner en conocimiento del señalado como competente, cuantos antecedentes fueran necesarios para acreditar la previa decisión de abstención por falta de competencia objetiva o territorial. En cualquier otro caso, si dichas circunstancias no se pusieran de manifiesto y acreditaran debidamente, podrían dar lugar a una nueva 
decisión de falta de competencia, objetiva o territorial, sin orden de remisión de las actuaciones al superior común que, conforme a los arts. 257.2 y 60.3 LEC debiera resolver el conflicto.

Por otro lado, debe ponerse de manifiesto que ninguna referencia hace la LEC al tratamiento de la falta de competencia funcional, entendida en la doctrina como el criterio de atribución del conocimiento del objeto procesal en atención a las distintas fases procesales que las partes han de transcurrir a fin de obtener la tutela efectiva de sus pretensiones, a saber, la declarativa, la de impugnación o recurso y la de ejecución ${ }^{591}$. Y si bien es cierto que en el procedimiento de diligencias preliminares no se advierten las tres fases a las que acabamos de hacer referencia y que, por tanto, en sentido estricto, no podría hablarse de competencia funcional, la instrumentalidad de las diligencias preliminares que viene determinada por su finalidad preparatoria del ulterior proceso así como las previsiones del aptdo. $2^{\circ}$ del art. 257.1 LEC, en los supuestos de las diligencias contempladas en los ordinales $6^{\circ}, 7^{\circ}, 8^{\circ}$ y $9^{\circ}$ del art. 256.1 LEC, nos coloca ante dicha realidad competencial. En tales supuestos, el conocimiento de la solicitud de nuevas diligencias derivadas de las ya promovidas al amparo de los anteriores ordinales, se atribuye al tribunal que hubiera conocido de las primeras o bien al que, a raíz de los hechos averiguados en ellas, resulte competente para conocer de la misma pretensión principal o de nuevas pretensiones que a la principal pudieran eventualmente acumularse. Dichas previsiones introducen un criterio de competencia funcional cuya falta, igualmente, es apreciable de oficio ${ }^{592}$. En tal supuesto, entendemos que la decisión sobre la misma habrá de estar a lo dispuesto en el art. 61 LEC, relativo a la competencia funcional por conexión que, dicho sea de paso, ninguna norma de trámite al respecto ordena. En dicha tesitura, entendemos que la decisión sobre la referida falta de competencia funcional habrá de seguir el mismo trámite ordenado por el art. 257.2 LEC para la falta de competencia objetiva y territorial.

Por último, entendemos oportuno apuntar que, a nuestro juicio, la imposibilidad legal del planteamiento de la falta de competencia por las partes, mediante declinatoria,

\footnotetext{
${ }_{592}^{591}$ Entiende Gimeno Sendra, V., Derecho Procesal Civil..., ob. cit., p. 75.

${ }^{592}$ Gimeno Sendra, V., Derecho Procesal Civil..., ob. cit., p. 77.
} 
en modo alguno conlleva que la parte no pueda denunciar la falta de tal competencia ante el tribunal pues siendo la competencia, como ya hemos argumentado, una cuestión de orden público, siempre podrá la parte poner en conocimiento del tribunal las circunstancias que determinen tal falta de competencia de forma tal que, el tribunal, no habiéndolas observado de oficio, las tome en consideración provocando de esta forma la revisión de oficio de la misma ${ }^{593}$.

\subsection{Competencia objetiva}

Como se desprende del art. 257.1 LEC, la regla general de competencia objetiva para el conocimiento de las diligencias preliminares es que esta corresponde a los Juzgados de Primera Instancia.

Y, cuando proceda, a los JMER, cuya creación y determinación de competencias fue llevada a cabo por la Ley Orgánica 8/2003, de 9 de julio, para la reforma concursal, por la que se modifica la LOPJ, introduciendo en la planta judicial dichos nuevos órganos que no sólo conocerían del proceso de concurso de acreedores sino, como señala el art. 86 ter.2 LOPJ, de cuantas cuestiones sean de la competencia del orden jurisdiccional civil y respecto de las materias que en el mismo se enumeran ${ }^{594}$. Y aun cuando en dicha enumeración no se contemplan de forma expresa, puede afirmarse que los JMER serán competentes también para el conocimiento de cuantas diligencias preliminares vengan motivadas por ser el juicio que se quiera preparar uno de los supuestos cuyo conocimiento corresponda a tales órganos en virtud de lo dispuesto en el

\footnotetext{
${ }^{593}$ En la doctrina, así lo refuerza en relación a la competencia territorial Damián Moreno, J., Comentarios a la..., ob. cit., p. 1689.

${ }^{594}$ En concreto, "a) las demandas en las que se ejerciten acciones relativas a competencia desleal, propiedad industrial, propiedad intelectual y publicidad, así como todas aquellas cuestiones que dentro de este orden jurisdiccional se promuevan al amparo de la normativa reguladora de las sociedades mercantiles y cooperativas; b) las pretensiones que se promuevan al amparo de la normativa; en materia de transportes, nacional o internacional; c) aquellas pretensiones relativas a la aplicación del Derecho Marítimo; d) las acciones relativas a condiciones generales de la contratación en los casos previstos en la legislación sobre esta materia; e) los recursos contra las resoluciones de la Dirección General de los Registros y del Notariado en materia de recurso contra la calificación del Registrador Mercantil, con arreglo a lo dispuesto en la Ley Hipotecaria para este procedimiento; f) de los procedimientos de aplicación de los artículos 81 y 82 del Tratado constitutivo de la Comunidad Europea y su derecho derivado, así como los procedimientos de aplicación de los artículos que determine la Ley de Defensa de la Competencia".
} 
art. 86 ter 2. LOPJ, lo que tendrá lugar en los supuestos de los ordinales $7^{\circ}, 8^{\circ}, 9^{\circ}, 10^{\circ} \mathrm{y}$ $11^{\mathrm{o}}$ del art. 256.1 $\mathrm{LEC}^{595}$. Es decir, en los supuestos de las diligencias de obtención de datos por infracción de los derechos de propiedad intelectual e industrial y diligencias de comprobación de hechos.

La razón de esta atribución competencial ha sido contemplada por la doctrina judicial y, en buena lógica, asentada en la íntima unión a la posterior acción que pueda plantearse y en la necesidad de su conocimiento, el de las diligencias preliminares, por quien de forma más especializada esté llamado a conocer del proceso principal, lo que además permite la unificación de criterios en la rama específica del Derecho Privado que es el Derecho Mercantil ${ }^{596}$. También en una decisión más acorde con la idea legislativa acerca de esta jurisdicción mercantil como aquella que engloba todas las fases de los procedimientos que por ley le hayan sido atribuidos y entre los que se aprecian las diligencias preliminares ${ }^{597}$.

595 Así lo puso de manifiesto en la doctrina científica Garberí Llobregat, J., Las diligencias preliminares..., ob. cit., p. 61, en relación a las diligencias preliminares contenidas en los ordinales $7^{\circ}$ y $8^{\circ}$ del art. 256.1 LEC, lo que nosotros extendemos al resto de supuestos aludidos.

596 AAP de Lugo (sección $1^{\text {a }}$ ) de 16 de mayo de 2006, ponente Ilmo. Sr. J.V. Varela, f.j.2 ${ }^{\circ}$ (LA LEY 80128/2006).

${ }^{597}$ Con carácter previo a la reforma operada por la Ley 19/2006 y, por tanto, al la expresa referencia al Juez de lo Mercantil en el art. 257.1 LEC como órgano objetivamente competente,el AAP de Asturias

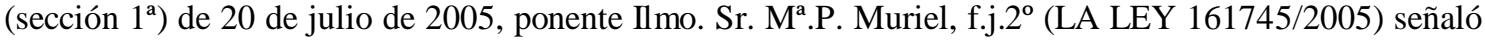
que: "[...] Concluir, pues, que una diligencia preliminar para la preparación de un procedimiento en el que se va a ejercitar acción enmarcada en la Ley de Propiedad Intelectual, corresponde a los Juzgados de lo Mercantil es lo que se considera más correcto desde el punto de vista de la congruencia y en la búsqueda de una interpretación unitaria de las materias que regula la reseñada legislación". En el mismo sentido, un día antes de la publicación en el BOE de la Ley 19/2006, el AAP de Sevilla (sección $5^{\text {a }}$ ) de 5 de junio de 2006, ponente Ilmo. Sr. F. Sanz, f.j.2º (LA LEY 191615/2006), determinó que: “[...] ha de declararse la competencia del Juzgado de lo Mercantil para conocer de una solicitud de Diligencias Preliminares con las que se pretende preparar una demanda de reclamación de cantidad que tiene su fundamento en las normas que regulan la propiedad intelectual, puesto que el artículo 86 ter 2.a) les atribuye el conocimiento de las acciones relativas a propiedad intelectual. En concreto el fundamento de la petición está en los preceptos de la Ley de Propiedad Intelectual de 12 de abril de 1996 que reconocen al autor el ejercicio exclusivo de los derechos de explotación de su obra en cualquier forma y, en especial, los derechos de reproducción, distribución, comunicación pública y transformación, que no podrán ser realizadas sin su autorización, salvo en los casos previstos en la propia LPI (art. 17 LPI). 


\subsection{Competencia territorial}

En relación a la competencia territorial, cabe señalar que el art. 257.1 LEC crea un fuero legal imperativo a favor del domicilio de la persona requerida ${ }^{598}$ a realizar la diligencia instada y que también tiene su excepción en el caso de las diligencias $6^{\mathrm{a}}$ a $9^{\mathrm{a}}$ del art. 256.1 LEC, en cuyo caso será competente el juzgado ante el que haya de presentarse la demanda determinada, tal y como establece el párrafo $2^{\circ}$ del art. 257.1 LEC $^{599}$.

Pero, como ya se apuntara en la doctrina científica, debe llamarse la atención sobre esta norma propia e insuficiente de competencia territorial que establece el art. 257 LEC que no prevé las eventualidades que si se regulan en los arts. 50 y 51 LEC, tales como el supuesto de la persona física que no tenga su domicilio en el territorio nacional, cuando se trate de empresarios y profesionales, o cuando se trate de personas jurídicas o entes sin personalidad, supuestos en los que se ha entendido que resultan de aplicación los fueros generales antes indicados ${ }^{600}$. Sin embargo lo anterior, esta solución ha sido expresamente contradicha por la doctrina judicial ${ }^{601}$ que en un supuesto de solicitud de diligencias preliminares para la exhibición de documentos frente a quien no tenía domicilio en España determinó la improcedencia de sostenerse la competencia de la jurisdicción española con fundamento en el art. 50.2 LEC, referido al fuero general territorial de las personas físicas, que contempla la posibilidad de demandar en España a quienes no teniendo domicilio ni residencia en ella se encontraren dentro del territorio nacional o hubieren tenido residencia en ella y, si tampoco así pudiera determinarse la competencia, en el lugar del domicilio del actor. En el supuesto contemplado, el órgano judicial consideró que la determinación de la competencia territorial de los juzgados españoles requería la concurrencia de su previa jurisdicción, de la que se carecía al no encontrarse las diligencias preliminares ante ninguna de las previsiones del art. 22

\footnotetext{
${ }^{598}$ Siguiendo el criterio sentado en los arts. 50 y 51 LEC, relativos al fuero general.

${ }^{599}$ Cfr. Gimeno Sendra, V., Derecho Procesal Civil..., ob. cit., p. 280. En este mismo sentido también el ATS de 2 de junio de 2009 (sala 1ª), ponente Ilmo. Sr. J.R. Ferrándiz, f.j. único (LA LEY 92211/2009).

${ }^{600}$ Álvarez Alarcón, A., Las diligencias preliminares..., ob. cit., pp. 47-48.

${ }^{601}$ Vid. el AAP de Valencia (sección $7^{\mathrm{a}}$ ) de 8 de julio de 2015, ponente Ilma. Sra. M. Ibañez, f.j.3 $3^{\circ}$ (AC 2015\1674).
} 
$\mathrm{LOPJ}^{602}$. Más aún, se trata de una materia que no ha sido recogida en los convenios internacionales suscritos por España tales como el Reglamento (UE) núm. 1215/2012 del Parlamento Europeo y del Consejo de 12 de diciembre de 2012, relativo a la competencia judicial, el reconocimiento y la ejecución de resoluciones judiciales en materia civil y mercantil, que en virtud del principio de primacía del Derecho de la Unión resulta de aplicación preferente.

Pero además del anterior supuesto, existen otros que, sin un elemento extranjero, también presentan cierta oscuridad. Por ejemplo, cuando la diligencia es articulada frente a más de un sujeto pasivo con domicilios en distintos partidos judiciales, en cuyo caso parte de la doctrina ha entendido que el juez ante el que se haya presentado la correspondiente solicitud sólo podrá acordar aquella que afecte al sujeto que tenga su domicilio en su circunscripción, rechazando aquella otra u otras que deba o deban cumplimentarse por sujetos pasivos con domicilio en otras diferentes circunscripciones $^{603}$. Sin embargo, la conclusión alcanzada por el TS es distinta, al entender que en dicho supuesto entrarían en juego los arts. 257.1, 53.2 y 58 LEC, en virtud de los cuales el juzgado competente sería el correspondiente al domicilio del codemandado por el que el solicitante de las diligencias haya optado ${ }^{604}$.

\subsection{Supuestos especiales de competencia}

Como ha sido puesto de manifiesto, con carácter general, el art. 257.1 LEC atribuye la competencia para conocer de las diligencias preliminares, al JPI o JMER del domicilio de la persona que, en su caso, hubiera de declarar, exhibir o intervenir de otro modo en las actuaciones que hayan de acordarse para preparar el juicio.

\footnotetext{
${ }^{602}$ Debe tenerse en cuenta que el art. 22 LOPJ fue modificado por la LO 7/2015, de 21 de julio, por la que se modifica la LO 6/1985, de 1 de julio, del Poder Judicial, que además añadió los arts. 22 bis a nonies LOPJ.

${ }_{603}$ Garberí Llobregat, J., Las diligencias preliminares..., ob. cit., p. 62. En la doctrina judicial, vid. el AAP de Cáceres (sección 1 1) de 20 de marzo de 2009, ponente Ilmo. Sr. A.Mํ. González, f.j.2º (ROJ AAP CC 100/2009). De forma particular, Consejo General Poder Judicial, 50 Cuestiones Prácticas sobre el Juicio Ordinario, en "Conclusiones Seminario Cuestiones Procesales del Juicio Ordinario", 2014, núm. 1, pp. 4-5.

${ }^{604}$ ATS de 9 de octubre de 2012 (sala 1a), ponente Ilmo. Sr. I. Sancho, f.j. $2^{\circ}$ (LA LEY 153992/2012) y de 10 de abril de 2012 (sala 1ª), ponente Ilmo. Sr. F.J. Arroyo, f.j. único (LA LEY 51434/2012).
} 
Sin embargo, por disposición del aptdo. $2^{\circ}$ del art. 257.1 LEC, dicho criterio de atribución de la competencia territorial, el del domicilio de la persona que, en su caso, hubiera de declarar, exhibir o intervenir de otro modo en las actuaciones que hayan de acordarse para preparar el juicio, no rige en los supuestos de los ordinales $6^{\circ}$, de concreción de los integrantes de un grupo de afectados, $7^{\circ}$ y $8^{\circ}$, de obtención de datos para la preparación de los procesos por infracción de los derechos de propiedad intelectual e industrial, y $9^{\circ}$, diligencias de comprobación de datos. En tales casos, y como circunstancia que caracteriza a las diligencias preliminares contempladas en los indicados ordinales, en contraposición al fuero general, corresponde la competencia al juzgado ante el que haya de presentarse la demanda determinada (aptdo. $2^{\circ}$ del art. 257.1 LEC) $)^{605}$, al haber optado la LEC por un criterio de especialización y de unidad, haciendo coincidir la competencia territorial para el conocimiento de las diligencias preliminares con la correspondiente al conocimiento del asunto principal ${ }^{606} \mathrm{y}$, dicho sea de paso también, con la competencia objetiva de los JMER.

Por lo que se refiere a esta última, si bien el aptdo. $1^{\circ}$ del art. 257.1 LEC no distingue los supuestos en serán competentes los JPI o los JMER, ello no obsta para afirmar que la competencia objetiva para conocer de todas las diligencias antes apuntadas (ordinales $6^{\circ}$ a $9^{\circ}$ del art. 256.1 LEC) corresponde a los JMER. En el caso del ordinal $6^{\circ}$ del art. 256.1.6 LEC, habida cuenta que, conforme al art. 86 ter 2 d) LOPJ ${ }^{607}$, los JMER conocerán de las acciones colectivas previstas en la legislación relativa a

\footnotetext{
${ }^{605}$ Fue la reforma operada por la Ley 19/2006 la que alteró el criterio general de competencia territorial además de la objetiva con la expresa referencia al Juez de lo Mercantil, como órgano con competencia objetiva por tratarse de diligencias relativas a la infracción de derechos de propiedad intelectual y/o industrial -art. 86 ter LOPJ. Según Álvarez Alarcón, A., Las diligencias preliminares..., ob. cit., p. 48, la razón fundamental de esta reforma, en especial del ordinal $6^{\circ}$, reside en que de este modo se proporciona al tribunal que conocerá del asunto principal, todos los datos necesarias para poder realizar las comprobaciones que la LEC le impone en cuanto al cumplimiento del trámite de comunicación previa (art. 15.2 LEC) o la verificación de la constitución del grupo de afectados por mayoría de estos (art. 6.7 LEC), lo que perfectamente puede hacerse extensivo a las diligencias de los ordinales $7^{\circ}, 8^{\circ}$ y $9^{\circ}$ del art. 256.1 LEC.

${ }^{606}$ Villar Fuentes, I.M ${ }^{\mathrm{a}}$, Competencia objetiva para conocer de las diligencias preliminares en procesos para la defensa de consumidores y usuarios, en "Los retos del Poder Judicial ante la sociedad globalizada: Actas del IV Congreso Gallego de Derecho Procesal (I Internacional)", 2012, p. 715.

${ }^{607}$ Modificado por la Ley 7/2015, de 21 de julio, de modificación de la LOPJ y que previamente a la misma prevenía que los Juzgados de lo Mercantil conocerían de las acciones relativas a condiciones generales de la contratación en los casos previstos en la legislación sobre esta materia, lo que parecía ceñir la competencia de tales órganos a las acciones ejercitadas al amparo de la LCC.
} 
condiciones generales de la contratación y a la protección de consumidores y usuarios, precisamente aquellas que, a través de las diligencias preliminares, pueden ser preparadas. También en el caso de las contempladas en los ordinales $7^{\circ}, 8^{\circ}$ y $9^{\circ}$, así como $10^{\circ}$ y $11^{\circ}$ del art. 256.1 LEC, conforme a lo dispuesto en el art. 86 ter 2 a) LOPJ, discrepando del planteamiento doctrinal que afirma que la competencia para el conocimiento de las diligencias preliminares para la preparación de acciones de competencia desleal, propiedad industrial, propiedad intelectual y publicidad le correspondería al JPI, por estar subordinada la del JMER a materias sometidas a la normativa de las sociedades mercantiles ${ }^{608}$. A nuestro juicio, la redacción legal del art. 86 ter 2 a) LOPJ $^{609}$ no contiene supeditación alguna sino que atribuye al conocimiento del JMER, además de las demandas en las que se ejerciten acciones relativas a competencia desleal, propiedad industrial, propiedad intelectual y publicidad, todas aquellas cuestiones que se promuevan al amparo de la normativa reguladora de las sociedades mercantil y cooperativas. Lo anterior se confirma, por ejemplo, por las previsiones contenidas en el art. 118.2 LP que dispone que para el conocimiento de los litigios que puedan surgir al amparo de la misma, entre los que se encuentran las diligencias preliminares, será objetivamente competente el Juez de lo Mercantil.

Determinada la competencia objetiva a favor de los JMER para el conocimiento de las diligencias preliminares contempladas en los ordinales $6^{\circ}$ a $11^{\circ}$ del art. 256.1 LEC, deben hacerse algunas precisiones que atañen a la competencia territorial para el conocimiento de las diligencias contenidas en los ordinales $6^{\circ}$ a $9^{\circ}$ del art. 256.1 LEC.

En primer lugar, a qué concreto JMER le corresponde el conocimiento de las diligencias a que se refiere el ordinal $9^{\circ}$ del art. 256.1 LEC. Es decir, las diligencias de comprobación de hechos reguladas en los arts. 123 a 126 LP o las mencionadas en la disposición adicional primera LM, cuanto de la LPDI, y en el art. 36 LCD, de las que

\footnotetext{
${ }^{608}$ Villar Fuentes, I.M ${ }^{\mathrm{a}}$, Competencia objetiva para conocer de las diligencias preliminares en procesos para la defensa de consumidores y usuarios, en "Los retos del Poder Judicial ante la sociedad globalizada: Actas del IV Congreso Gallego de Derecho Procesal (I Internacional)", 2012, p. 716.

${ }^{609}$ Conforme al art. 86 ter 2 a) LOPJ, los JMER conocerán, entre otras, de: "Las demandas en las que se ejerciten acciones relativas a competencia desleal, propiedad industrial, propiedad intelectual y publicidad, así como todas aquellas cuestiones que dentro de este orden jurisdiccional se promuevan al amparo de la normativa reguladora de las sociedades mercantiles y cooperativas".
} 
conocerá, conforme al aptdo. $2^{\circ}$ del art. 257.1 LEC el tribunal ante el que haya de presentarse la demanda determinada. Ello nos obliga, nuevamente, a acudir a la norma patrón de las referidas diligencias, la LP, cuyo art. $118.2^{610}$ determina que, será competente el JMER de la ciudad sede del TDJ de aquellas CCAA en las que el CGPJ haya acordado atribuir en exclusiva el conocimiento de los asuntos de patentes.

En dicho sentido, el Acuerdo de la Comisión Permanente del CGPJ de 2 de febrero de $2017^{611}$ que, en exclusiva, ha atribuido el conocimiento de los asuntos civiles que puedan surgir al amparo de las LP, LM y de la LPDI, a determinados órganos de los TSJ de Cataluña, Madrid y Comunidad Valenciana, nada dice respecto al resto de territorios al igual que tampoco respecto de las cuestiones relativas a la competencia desleal, cuya LCD ninguna previsión competencial contiene, por lo que tales supuestos entendemos quedarán sujetos a la competencia objetivamente genérica de los JMER. Y en cuanto al territorio, al domicilio del demandado o, en su defecto, del lugar de residencia del representante autorizado en España para actuar en nombre del titular de la patente, si en la CCAA de su domicilio existieran JMER especializados en asuntos de patentes conforme al aptdo. $3^{\circ} \mathrm{y}$, de no existir, a elección del actor, cualquier JMER a quien corresponda el conocimiento de asuntos de patentes de conformidad con el aptdo. $2^{\circ}$ (art. 118.3 LP).

\footnotetext{
${ }^{610}$ De aplicación al supuesto de marcas, en virtud del aptdo. $1^{\text {o }}$ de la disposición adicional $1^{\text {a }}$ LM que dispone: "Las normas vigentes contenidas en el Título XII de la Ley 24/2015, de 24 de julio, de Patentes serán de aplicación a las distintas modalidades de signos distintivos de la presente Ley en todo aquello que no sea incompatible con su propia naturaleza, sin perjuicio de lo dispuesto en el siguiente apartado". Y también a los supuestos de protección de la propiedad industrial del diseño, en virtud del aptdo. $1^{\circ}$ de la disposición adicional $1^{\text {a }}$ de la LPDI que señala: "Sin perjuicio de lo dispuesto en el apartado 2, las normas vigentes contenidas en el Título XII de la Ley 24/2015, de 24 de julio, de Patentes serán de aplicación en lo relativo al ejercicio de acciones derivadas de la presente Ley y a la adopción de medidas provisionales y cautelares, en todo aquello que no sea incompatible con lo previsto en la misma".

${ }^{611}$ Acuerdo de 2 de febrero de 2017, de la Comisión Permanente del CGPJ, por el que se actualiza el Acuerdo de 21 de diciembre de 2016, por el que se atribuye en exclusiva el conocimiento de los asuntos civiles que puedan surgir al amparo de la Ley 24/2015, de 24 de julio, de Patentes, de la Ley 17/2001, de 7 de diciembre, de Marcas, y de la Ley 20/2003, de 7 de julio, de Protección Jurídica del Diseño Industrial, a diversos Juzgados de lo Mercantil de Cataluña, Madrid y Comunitat Valenciana (BOE núm. 44, de 21 de febrero de 2017).
} 
En segundo lugar, por lo que respecta al supuesto especial de los $\mathrm{TMU}^{612}$ que, de conformidad con el art. 96 RMU, tendrán competencia exclusiva para conocer, de todos aquellos litigios que se promuevan al amparo de lo previsto en los Reglamentos núm.207/2009 del Consejo, de 26 de febrero de 2009, sobre la marca comunitaria ${ }^{613}$, y núm. 6/2002, del Consejo, de 12 de diciembre de 2001, sobre los dibujos y modelos comunitarios $^{614}$. Entre otros, para conocer: a) de cualquier acción por violación y -si la legislación nacional la admite- por intento de violación de una marca comunitaria; b) de las acciones de comprobación de inexistencia de violación si la legislación nacional las admite; c) de cualquier acción entablada a raíz de hechos contemplados en la segunda

\footnotetext{
${ }^{612}$ En España, creados con ocasión de la LO 8/2003, de 9 de julio, para la reforma concursal, por la que se introdujeron los artículos 82.4 y 86 bis LOPJ y cuyas funciones vienen siendo desempeñadas por la Sección $8^{\mathrm{a}}$ de la Audiencia Provincial de Alicante y el Juzgado de lo Mercantil núm. 1 de Alicante, creados por el Real Decreto 1649/2004, de 9 de julio, por el que se dispone la creación de una plaza de magistrado, de la sección $8^{\text {a }}$ de la AP de Alicante, y la creación y constitución de determinados juzgados, todos ello con competencia mercantil, correspondiente a la programación del año 2004 (BOE núm. 168 de 13 de julio de 2004). Debe tenerse en cuenta que con ocasión de la reforma operada por el Reglamento (UE) 2015/2424 del Parlamento Europeo y del Consejo, de 16 de diciembre de 2015, los Juzgados y Tribunales de la Marca Comunitaria han pasado a denominarse "tribunales de marca de la Unión Europea" o "tribunales de marca de la Unión".

${ }^{613}$ Debe tenerse en cuenta que el Reglamento núm. 207/2009 del Consejo, de 26 de febrero de 2009, sobre la marca comunitaria, que codifica el Reglamento (CE) 40/94 del Consejo, ha sido modificado por el Reglamento (UE) 2015/2424 del Parlamento Europeo y del Consejo, de 16 de diciembre de 2015, que ha venido a sustituir los términos "marca comunitaria" por "marca de la Unión Europea" o "marca de la Unión" al igual que sustituye la denominación de la Oficina de Armonización del Mercado Interior (Marcas, Dibujos y Modelos) por la de "Oficina de Propiedad Intelectual de la Unión Europea". También los términos "tribunal de marcas comunitarias" por el de "tribunal de marcas de la Unión Europea" o "tribunal de marcas de la Unión".

${ }^{614}$ De conformidad con el aptdo. $2^{\circ}$ de la disposición adicional $1^{\text {a }}$ de la LPDI: "Los Juzgados de lo Mercantil que, conforme a la Ley Orgánica del Poder Judicial, tienen atribuidas las funciones de Juzgados de Marca Comunitaria en aplicación del Reglamento (CE) n. ${ }^{\circ}$ 6/2002, del Consejo, de 12 de diciembre de 2001 sobre los dibujos y modelos comunitarios, serán competentes para conocer de los litigios civiles que deriven de la presente Ley cuando se ejerciten de manera acumulada acciones fundadas en títulos comunitarios y nacionales o internacionales sobre el mismo o similar diseño, o si existiere cualquier otra conexión entre las pretensiones y al menos una de ellas esté basada en un registro o solicitud de título comunitario. En estos casos la competencia corresponderá en exclusiva a los Juzgados de Marca Comunitaria". En la doctrina judicial, la competencia de dicho tribunal se plasma en la STMC de 21 de

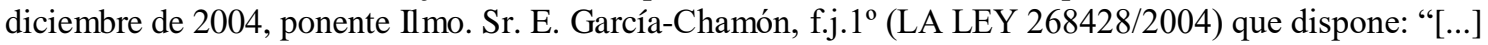
El Juzgado de Marca Comunitaria es un nuevo tipo de órgano jurisdiccional dentro de la estructura jurisdiccional nacional que, de conformidad con lo establecido en el artículo 86.bis.4 de la Ley Orgánica del Poder Judicial y en el artículo 3.6 de la Ley 39/1988, de 28 de diciembre, de Demarcación y Planta Judicial, tiene una denominación propia, con competencia objetiva (litigios que se promuevan al amparo del RMC) y competencia territorial (se extiende a todo el territorio nacional) específicas. Como tal Juzgado de Marca Comunitaria sólo puede conocer de las pretensiones relacionadas en el artículo 92 RMC, siendo las normas procesales aplicables, salvo que el RMC disponga otra cosa, las que corresponden al mismo tipo de acciones en materia de marca nacional en el Estado miembro en cuyo territorio radique el Juzgado de Marca Comunitaria, esto es, las normas del Título XIII de la Ley 11/1986, de 20 de marzo, de Patentes, en virtud de la remisión contenida en la Disposición adicional primera de la Ley 17/2001, de 7 de diciembre, de Marcas".
} 
frase del aptdo. $2^{\circ}$ del art. 9 ter RMU; y, de las demandas de reconvención por caducidad o por nulidad de la marca comunitaria contempladas en el art.100 ${ }^{615}$. Por tanto también, y de conformidad con lo prevenido en el art. 257.1.2 $2^{\circ}$ LEC, conocerán de las diligencias de comprobación de hechos que para la preparación de dichos procesos se planteen.

En tercer lugar, por lo que se refiere a la competencia territorial para conocer de las diligencias contenidas en los ordinales $6^{\circ}, 7^{\circ}$ y $8^{\circ}$ del art. 256.1 LEC que, conforme al art. 257.1.2 LEC, corresponderá al tribunal competente ante el que haya de presentarse la demanda determinada. Dicho criterio de atribución de la competencia territorial nos obliga a acudir a los criterios especiales de competencia territorial fijados en el art. 52 LEC. Conforme a ellos, en los procesos en que se ejerciten demandas sobre infracciones de la propiedad intelectual, será competente el tribunal del lugar en que la infracción se haya cometido o existan indicios de su comisión o en que se encuentren ejemplares ilícitos, a elección del demandante (art. 52.1.11 ${ }^{\circ}$ LEC). En los juicios en materia de competencia desleal, el tribunal del lugar en que el demandado tenga su establecimiento y, a falta de éste, su domicilio o lugar de residencia, y cuando no lo tuviere en territorio español, el tribunal del lugar donde se haya realizado el acto de competencia desleal o donde se produzcan sus efectos, a elección del demandante (art. 52.1.12 ${ }^{\circ}$ LEC). En el ámbito de la propiedad industrial, en materia de patentes y marcas, el tribunal que señale la legislación especial sobre dicha materia (art. 52.1.13 ${ }^{\circ} \mathrm{LEC}$ ). Y en los procesos en que se ejercite la acción de cesación en defensa de los intereses tanto colectivos como difusos de los consumidores y usuarios, será competente el tribunal del lugar donde el demandado tenga un establecimiento, a falta de éste, el de su domicilio y, si careciere del mismo en territorio español, el del lugar del domicilio del actor (art. 52.1.16 $\left.{ }^{\circ} \mathrm{LEC}\right)$.

\footnotetext{
${ }^{615}$ Quedarían fuera de su ámbito de competencia, en principio, acciones tales como las relativas a actos de competencia desleal, a la cesión de marca, a las licencias, a expropiaciones, así como las que se ejerciten simultánea sucesivamente sobre la base de una marca comunitaria y una marca nacional. La competencia para conocer de todas estas cuestiones distintas a la violación o validez de la marca la ostentan los tribunales nacionales que tengan a su vez competencia territorial y objetiva para conocer de las marcas nacionales.
} 
En cuarto y último lugar, debe tenerse presente la situación competencial que se produce en caso de solicitud de nuevas diligencias de los ordinales $6^{\circ}, 7^{\circ}, 8^{\circ}$ y $9^{\circ}$ del art. 256.1 LEC como consecuencia del resultado de las hasta entonces practicadas, determinando la LEC, con un criterio funcional de la competencia, que las nuevas podrán instarse del mismo tribunal o bien del que, a raíz de los hechos averiguados en la anterior diligencia, resultaría competente para conocer de la misma pretensión o de nuevas pretensiones que pudieran eventualmente acumularse (art. 257.2 LEC).

Es decir, que no solo obliga la LEC a solicitar las nuevas diligencias del mismo órgano judicial que concedió las primeras, sino que admite que las mismas sean instadas de un tribunal distinto en el caso de que, a consecuencia de la práctica de las iniciales, fuere otro el órgano competente para conocer de la misma pretensión o de otras nuevas que posteriormente pretendan formularse ${ }^{616}$.

\section{Solicitud}

\subsection{Forma}

La adopción de cualquier diligencia preliminar está sujeta al principio dispositivo $^{617} \mathrm{y}$, por tanto, requiere que el interesado formule una previa petición a la que la LEC atribuye el carácter de solicitud, sin especificar si la forma que ésta ha de revestir es oral o escrita. A pesar de ello, la LEC carece de acto de postulación procesal alguno que siendo iniciador del procedimiento pueda plantearse oralmente no existiendo razón que pueda dar lugar al planteamiento de una posible solicitud de diligencias preliminares de forma oral, lo que además ha sido descartado en la doctrina científica

\footnotetext{
${ }^{616}$ Así lo pone de manifiesto Larena Beldarraín, J., Las diligencias preliminares..., ob. cit., p. 694. Sobre las implicaciones de la petición de nuevas diligencias consecuencia de las anteriores, vid. Armengot Vilaplana, A., Las nuevas diligencias..., ob. cit., pp. 14-16.

${ }^{617}$ Lo que pone de manifiesto Bellido Penadés, R., Las diligencias preliminares..., ob. cit., p. 5-5, señalando que "la realización de actuaciones judiciales mediante diligencias preliminares con el fin de facilitar la preparación del proceso también requiere la previa petición del futuro demandante". También, Damián Moreno, Comentarios a la ..., ob. cit., p. 1682 cuando señala que: "Las diligencias preliminares están sometidas al principio de justicia rogada".
} 
que afirma que la misma ha de revestir la forma escrita ${ }^{618}$ y contener una estructura similar al escrito de demanda ${ }^{619}$.

Por otro lado, aún cuando pudiera surgir la duda sobre la forma de petición de las diligencias preliminares, oral o escrita, no debe olvidarse que la escrita constituye la regla general para iniciar un procedimiento civil y que, en el caso de las diligencias preliminares, se puede colegir del propio art. 258.1 LEC que dispone que la resolución sobre la presentación de diligencia preliminar deberá ser dictada por el juez en el plazo de cinco días desde su presentación, en tanto que esta, la presentación, es una actuación impropia de las alegaciones orales que se formulan o realizan pero no se presentan ${ }^{620}$.

Y cabe señalar que en esa solicitud escrita, habida cuenta la opinión mayoritaria de constituir el art. 256.1 LEC una lista cerrada, deberá señalarse la concreta diligencia preliminar que se pretende ${ }^{621}$ con referencia expresa al ordinal concreto de la lista en cuestión, si bien entendemos que la mera ausencia de dicha referencia no puede impedir la admisión de la petición si la diligencia preliminar solicitada se identifica correctamente en la solicitud deducida ${ }^{622}$. Sin duda alguna, y al margen de la procedente oportunidad de subsanación, una decisión en dicho sentido constituye una interpretación restrictiva de la norma que no encuentra justificación.

\footnotetext{
618 Vid. Garciandía González, P.M., La regulación de..., ob. cit., p. 790 y Bellido Penadés, R., Las diligencias preliminares..., ob. cit., p. 5-23.

${ }^{619}$ Cfr. Gimeno Sendra, V., Derecho Procesal Civil..., ob. cit., p. 281.

${ }^{620}$ En dicho sentido, Díaz Martínez, M., Las diligencias preliminares ..., ob. cit., p. 21.

${ }^{621}$ Como apunta Bellido Penadés, R., Las diligencias preliminares..., ob. cit., p. 5-24, resulta acorde con el principio dispositivo que el solicitante delimite el objeto de su petición que justifique la procedencia de la misma porque sin dicha concreción el órgano judicial no podrá resolver sobre la adecuación de la diligencia a la finalidad perseguida por el solicitante, salvedad hecha del ordinal $6^{\circ}$ del art. 256.1 LEC en cuyo caso entiende que la determinación de la diligencia preliminar no es una carga atribuida al solicitante. Al respecto se pronuncia también Damián Moreno, J., De las diligencias..., ob. cit., p. 1686 que además entiende que la solicitud debe justificar documentalmente los motivos por los cuales considera imprescindible su adopción.

${ }^{622}$ En el contexto de la ALEC, así lo consideró el AAP de Sevilla (sección $5^{\text {a }}$ ) de 4 de mayo de 1998, ponente Ilmo. Sr. P. Márquez, f.j.2º (AC 199815426).
} 
Igualmente, deberá identificarse con claridad la persona frente a la que se pretende la diligencia ${ }^{623} \mathrm{y}$, en su caso, la necesidad de identificar la cosa mueble objeto de la diligencia ${ }^{624}$ o las cuentas societarias a exhibir ${ }^{625}$.

Y también, con el debido detalle, la determinación de las circunstancias y acción que se pretende preparar, como única forma de poder realizar el tribunal la adecuación de la diligencia preliminar con el futuro juicio, lo que no significa que el solicitante de la diligencia quede estrictamente vinculado a plantear aquel en los términos expuestos en la solicitud de la diligencia preliminar ${ }^{626}$.

\subsection{Defensa y representación}

Tampoco refiere nada la LEC sobre la necesidad de abogado y procurador para la presentación de la solicitud inicial de las diligencias preliminares, cuestión esta que ha dado lugar a diversas posturas en el seno de la doctrina científica y judicial ${ }^{627}$ en la que encontramos opiniones que, estableciendo cierta relación entre las diligencias preliminares y las medidas urgentes, consideran innecesaria la intervención de defensa legal y representación procesal ${ }^{628}$, al entender que cuando los arts. 23.2.3 y 31.2.2 LEC aluden a las medidas urgentes como supuestos en que los interesados pueden actuar por sí solos tal alusión no incluiría las diligencias preliminares sino únicamente las medidas

\footnotetext{
${ }^{623}$ Como destaca Garciandía González, P.M., La regulación de..., ob. cit., pp. 794-795, con indicación de los domicilios del solicitante y destinatario de la diligencia preliminar, sin perjuicio de que, de conformidad con lo dispuesto en el art. 156 LEC el solicitante manifieste que le es imposible designar el domicilio del demandado para que por el órgano judicial se efectúen las averiguaciones oportunas; también vid. Bellido Penadés, R., Las diligencias preliminares..., ob. cit., p. 5-23; Damián Moreno, J., De las diligencias..., ob. cit., p. 1687.

${ }^{624}$ SAP de Pontevedra (sección $3^{\text {a }}$ ) de 5 de noviembre de 1996, ponente Ilmo. Sr. J.L. Núñez, f.j.3º (AC 199612071).

${ }_{625}$ AAP de Granada (sección $4^{\text {a }}$ ) de 18 de octubre de 2001, ponente Ilmo. Sr. J. Maldonado, f.j. $2^{\circ}$ (LA LEY 184669/2001).

${ }^{626}$ Garnica Martín, J.F., De las diligencias..., ob. cit., p. 1158.

${ }^{627}$ Así lo pone de manifiesto el AAP de Almería (sección $3^{a}$ ) de 23 de marzo de 2006, ponente Ilmo. Sr. J. Martínez, f.j.2 $2^{\circ}$ (LA LEY 67260/2006).

${ }^{628}$ En la doctrina científica, Armengot Vilaplana, A., Las nuevas diligencias..., ob. cit., p. 19 señala que la petición de diligencias preliminares para la preparación de las acciones por infracción de derechos de propiedad intelectual e industrial "se sujetara a las reglas generales de postulación procesal (necesidad de abogado y procurador) salvo que en el momento de presentarla concurran razones de urgencia (arts. 23.2.3 y 31.2.2 LEC), supuesto en el que no será necesaria la postulación para la petición inicial de la diligencia preliminar, pero si para las actuaciones posteriores".
} 
cautelares, y las que sostienen que dichas diligencias estarían incluidas en el concepto de medidas urgentes ${ }^{629}$.

Los arts. 23 y 31 LEC establecen como regla o principio general la necesidad de comparecer en todo juicio con asistencia legal y representación procesal, señalando tales preceptos los supuestos tasados de excepción a la misma y entre los que no se contiene referencia alguna a las diligencias preliminares. Esto, a priori y sin lugar a dudas, nos permitiría afirmar la necesaria comparecencia en diligencias preliminares con la preceptiva asistencia legal y representación procesal, si no fuera porque cuando el art. 23 LEC determina la necesidad de comparecencia mediante procurador lo hace por referencia al juicio, de cuya naturaleza no participan las diligencias preliminares, y que cuando el art. 31 LEC impone la dirección legal del abogado lo hace con excepción, entre otros, de la solicitud de medidas urgentes anteriores al juicio, cuyo carácter, en determinados supuestos, ha predicado la doctrina respecto de las diligencias preliminares ${ }^{630}$. No faltan autores que han aludido a la necesidad de la intervención de los profesionales cuando las diligencias sean necesarias pero no urgentes ${ }^{631} \mathrm{o}$, con un argumento un poco más desarrollado, entendiendo que ante la omisión de la LEC, debieran combinarse los criterios de urgencia de la solicitud y obligatoriedad de la postulación técnica en el asunto principal, considerando este último como criterio de mayor seguridad por venir la diligencia vinculada a dicho procedimiento principal $^{632}$.

\footnotetext{
${ }^{629}$ En dicho sentido Álvarez Alarcón, A., Las diligencias preliminares..., ob. cit., pp. 49-50, considera que las diligencias preliminares son urgentes en todo caso por la dificultad de tener que esperar a la decisión del juez sobre la urgencia de la preliminar que se solicite.

${ }^{630}$ En este contexto, Montero Aroca, J., Derecho Jurisdiccional II...., ob. cit., p. 186 señala que: "para la postulación los arts. 23 (procurador) y 31 (abogado) excluyen la necesidad de la misma cuando se trata de medidas urgentes con anterioridad al juicio, por lo que todo depende de que la diligencia concreta pueda considerarse urgente". También Asencio Mellado, J.M., Derecho Procesal Civil..., ob. cit., p. 37, apunta que que los arts. 23.2.3 y 31.2.2 excluyen la necesaria intervención de procurador y abogado en los casos en que se soliciten medidas urgentes con anterioridad al juicio y teniendo en cuenta que los gastos siempre revierten en la persona del solicitante es lógico que haya que concluir que no será obligatoria la presencia de procurador y abogado cuando las medidas sean solicitadas con carácter de urgencia.

${ }^{631}$ Cfr. Gimeno Sendra, V., Derecho Procesal Civil..., ob. cit., pp. 281-282.

${ }^{632}$ Cfr. Moreno Catena, V., Derecho Procesal Civil..., ob. cit., p. 121. Este último criterio ha sido sostenido en el AAP de Las Islas Baleares (sección $3^{\text {a }}$ ) de 23 de abril de 2004, ponente Ilma. Sra. C.M. Moragues, f.j. $2^{\circ}$ (LA LEY 96083/2004) cuando señala que: “[...] únicamente podría admitirse la exoneración de la intervención de abogado y procurador si las diligencias preliminares tuvieran la finalidad de preparar un juicio verbal de cuantía inferior a 900 euros, supuesto en el que no sería razonable exigir la intervención de tales profesionales cuando no es exigible en el juicio posterior". Vid.
} 
A pesar de todo lo expuesto, nosotros no podemos sino coincidir con aquel de los criterios doctrinales que entiende preceptiva la asistencia de abogado y procurador en el supuesto de las diligencias preliminares, tanto para su solicitud como para la oposición, habida cuenta que ninguno de los preceptos señalados contiene exoneración alguna relativa a estas ni la urgencia es una nota que pueda predicarse de aquella ${ }^{633}$. De hecho, este carácter urgente que de forma evidente se pone de manifiesto en la solicitud de diligencias de comprobación de hechos de la LP (art. 123.1) no justifica en la doctrina la exceptuación de la intervención de defensa legal y representación procesal en las mismas ${ }^{634}$. Por otro lado, no podemos olvidar que, pese a la aparente sencillez del mecanismo procesal de las diligencias preliminares, la solicitud debe observar el cumplimiento de determinados presupuestos y la oposición combatir la concurrencia de estos. Ambas actuaciones generan la necesidad de un soporte profesional jurídico que

también Bellido Penadés, R., Las diligencias preliminares..., ob. cit., p. 5-25 y Garnica Martín, J.F., De las diligencias..., ob. cit., p. 1159.

${ }^{633}$ Cfr. Garberí Llobregat, J., Las diligencias preliminares..., ob. cit., p. 63 y Moreno Catena, V. y Arnáiz Serrano, A., La intervención y designación del abogado y de los procesos de jura de cuentas (Arts. 31 a 35 LEC), en "InDret", 2006, núm. 1, p. 7, cuando distinguiendo las medidas previas al juicio de las medidas urgentes previenen que: "Por consiguiente, la aplicación del art. 31.2.2 $2^{\circ}$ no sólo exige que se trate de medidas previas al juicio, sean diligencias preliminares (art. 256), diligencias de anticipación de prueba (art. 293) o de aseguramiento de la prueba (art. 297), medidas cautelares (art. 730.2), o medidas provisionales previas a la demanda de nulidad, separación o divorcio (art. 771), sino que se requiere que, en su adopción, concurra el carácter de urgencia que justificaría la excepción a la postulación técnica". También Garnica Martín, J.F., De las diligencias..., ob. cit., p. 1159. Con un criterio intermedio, Damián Moreno, J., Comentarios a la..., ob. cit., p. 1687, sostiene la necesidad de abogado y procurador aún cuando estableciendo la salvedad, según él discutible, del caso de ser catalogadas como medidas urgentes.En el ámbito de los tribunales, el AAP de Murcia (sección $5^{\text {a }}$ ) de 14 de julio de 2003, ponente Ilmo. Sr. J.J. Hervás, f.j.1 (LA LEY 123474/2003) señala que: “[...] la intervención de Letrado sí es necesaria en las diligencias preliminares, como se desprende de lo dispuesto en el artículo 31 de la Ley de Enjuiciamiento Civil, pues cuando el precepto habla de "medidas urgentes" no incluye las Diligencias Preliminares, sino solamente las medidas cautelares, y, por tanto, debe regir la regla general de que sí es preceptiva la intervención de abogado; y debe añadirse que el artículo 256.3. de la Ley de Enjuiciamiento Civil también señala que los gastos que se ocasionen a las personas que hubieren de intervenir en las diligencias serán a cargo del solicitante de las diligencias preliminares" y el AAP de Barcelona (sección $13^{\mathrm{a}}$ ) de 13 de diciembre de 2005, ponente Ilmo. Sr. J.B. Cremades, f.j.2 ${ }^{\circ}$ (LA (LEY 239881/2005) que entre los presupuestos procesales de las diligencias preliminares señala las reglas generales sobre postulación y defensa, ex arts. 23 y 31.

${ }^{634}$ En dicho sentido, Villar Fuentes, I.Ma , Las diligencias preliminares..., ob. cit., pp.113-115 si bien finalmente concluye que no es preceptiva la intervención de procurador y letrado. También, García García, E., Las diligencias preliminares..., ob., cit. p. 10 entiende que la previsión legal de la excepción "está pensada para actuaciones que tiendan a la anticipación o al aseguramiento de los efectos del proceso ante situaciones perentorias que justifiquen que no pueda esperarse a localizar a un abogado, lo que aconsejaría pedirle directamente al juez que las adoptase, más no para aquéllas otras que simplemente van dirigidas a la preparación de una inminente demanda". Sobre esta cuestión no faltan resoluciones que, por ejemplo, en el ámbito de las diligencias de comprobación de hechos han entendido justamente lo contrario. Así, vid. el AAP de Barcelona (sección 15ª) de 21 de marzo de 2005, ponente Ilmo. Sr. Sancho, f.j. $2^{\circ}$ (LA LEY 65421/2005). 
de una u otra forma hará necesaria la intervención de abogado y procurador razón por la cual, junto con las anteriores, no podemos apostar por la posibilidad de hacer innecesaria la intervención de aquellos.

\subsection{Ofrecimiento de caución}

$\mathrm{El}$ art. 256.3 LEC dispone que el solicitante, al pedir las diligencias preliminares, ofrecerá caución que deberá prestarse (art. 258.1 LEC) en el plazo de tres días contados desde que se dicte el auto en que se conceda/n la/s diligencia/s (art. 258.3 LEC), archivándose definitivamente las actuaciones si no se prestase en dicho plazo.

El contenido de los anteriores preceptos legales nos obliga a distinguir entre el ofrecimiento de caución, su fijación y su efectiva prestación ${ }^{635}$, como actos procesales diferenciados con efectos y consecuencias diversas, siendo el acto del ofrecimiento de caución el único exigible en la solicitud inicial, como necesario, y por ser preceptivo para la admisión de la diligencia preliminar que reúna el resto de presupuestos ya estudiados. Es decir, una vez verificado por el órgano judicial que la diligencia preliminar solicitada es adecuada a la finalidad perseguida, que obedece a una justa causa y que en la persona del solicitante concurre el necesario interés legítimo. En tal supuesto, debe verificar el órgano judicial que el solicitante, en consideración a los daños y perjuicios susceptibles de producir la práctica de las diligencias preliminares, ha ofrecido caución. Así se desprende del propio art. 256.3 LEC cuando señala que el solicitante de las diligencias preliminares ofrecerá caución para responder tanto de los gastos que se ocasionen a las personas que hubieren de intervenir en las diligencias como de los daños y perjuicios que se les pudieren irrogar ${ }^{636}$.

Determinado, por tanto, que el ofrecimiento de la prestación de caución es un requisito necesario de la solicitud de diligencias preliminares, la siguiente cuestión que

\footnotetext{
${ }^{635}$ En dicho sentido, el AAP de Barcelona (sección 13aa) de 2 de diciembre de 2004, ponente Ilma. Sra. I. Carriedo, f.j. $2^{\circ}$ (ROJ AAP B 5858/2004).

${ }^{636}$ Así lo confirma el AAP de Alicante (sección $8^{\mathrm{a}}$ ) de 4 de junio de 2015, ponente Ilmo. Sr. L.A. Soler, f.j.3 (JUR 2015 206411).
} 
debemos plantearnos es si la omisión de dicho ofrecimiento puede dar lugar al rechazo, a limine, de la diligencia preliminar solicitada. En relación a dicha cuestión la doctrina judicial se muestra dividida ${ }^{637}$. Así, encontramos resoluciones que consideran que el ofrecimiento de la caución prevista en el art. 256.3 LEC es un requisito intrínseco en la formulación de la solicitud y, como tal, insubsanable $\mathrm{e}^{638}$; y también otras que entienden que el art. 231 LEC permite subsanar la falta del ofrecimiento de la prestación de caución hasta el punto de imponer al tribunal la obligación de su fijación aún cuando el ofrecimiento no se hubiera producido ${ }^{639}$

A la vista de de estas dos posiciones tan contrapuestas, una, que considera que el ofrecimiento de caución es un requisito intrínseco no subsanable y, otra, que considera que dicho ofrecimiento, al conectarse con el art. 231 LEC, es un acto procesal subsanable, cualquier postura que al respecto queramos adoptar pasa por considerar si, efectivamente, el ofrecimiento de prestar caución constituye un acto procesal por cuya subsanación debe velar el órgano judicial ${ }^{640}$.

En la búsqueda de un posicionamiento al respecto, deben traerse a colación aquellas resoluciones que sostienen su carácter subsanable con la invocación tanto del

\footnotetext{
${ }^{637}$ En este sentido lo ha puesto de manifiesto AAP de Murcia (Sección $5^{\text {a }}$ ) de 30 de diciembre de 2009, ponente Ilmo. Sr. J.M. Nicolás, f.j.2 (LA LEY 291667/2009).

${ }^{638}$ AAP de La Rioja (sección única) de 24 de julio de 2003, ponente Ilmo. Sr. R. Lacueva, f.j.2 ${ }^{\circ}$ (ROJ AAP LO 238/2003).

${ }^{639}$ AAP de Madrid (sección 14 $4^{\mathrm{a}}$ ) de 20 de noviembre de 2003, ponente Ilma. Sra. M ${ }^{\mathrm{a}}$.J. Alfaro, f.j. $2^{\circ}$ (JUR 2004l89142). En el mismo sentido. el AAP de León (sección $3^{\mathrm{a}}$ ) de 2 abril de 2004, ponente Ilmo. Sr. L.A. Mallo, (ROJ AAP LE 202/2004). En el mismo sentido, el AAP de Murcia (sección $5^{\text {a }}$ ) de 30 de diciembre de 2009, ponente Ilmo. Sr. J.M. Nicolás, f.j.2 $2^{\circ}$ (LA LEY 291667/2009) que resalta la inexistencia de disposición legal que señale que dicha omisión no sea subsanable.

${ }^{640} \mathrm{Al}$ respecto, debe tenerse en cuenta que el art. 231 LEC fue modificado por el art. decimoquinto, aptdo. ciento treinta de la Ley 13/2009, de reforma de la legislación procesal para la implantación de la nueva Oficina Judicial. En la redacción anterior a dicha modificación, se disponía: "El tribunal cuidará de que puedan ser subsanados los defectos en que incurran los actos procesales de las partes, siempre que en dichos actos se hubiese manifestado la voluntad de cumplir con los requisitos exigidos por la ley". Con el cambio de redacción, el legislador desplaza la carga de la subsanación de los defectos procesales en que incurran los actos procesales de las partes al tribunal y LAJ. De ahí que, pese al carácter subsanable que se reconoce por la doctrina judicial a la omisión del ofrecimiento de prestar caución en la solicitud inicial de diligencias preliminares, resoluciones tales como el AAP de Murcia (sección $5^{\mathrm{a}}$ ) de 30 de diciembre de 2009, ponente Ilmo. Sr. J.M. Nicolás, f.j.2 (LA LEY 291667/2009), desestimen el recurso de apelación interpuesto frente al auto dictado por el Juzgado de Primera Instancia que inadmite a trámite una petición de diligencia preliminar en la que se había omitido la prestación de caución al no haber manifestado la parte en dicho escrito inicial su voluntad de cumplir con los requisitos exigidos por la ley sin que previamente se hubiera efectuado requerimiento alguno de subsanación del defecto.
} 
art. 231 LEC como del marcado carácter restrictivo de la inadmisión de los escritos iniciales en demanda de tutela judicial efectiva, que sólo se encuentra justificada en casos excepcionales ${ }^{641}$. También, con invocación de la propia regulación que de las diligencias preliminares hace el art. 258 LEC que sólo contempla la posibilidad de rechazar la petición de diligencia si el tribunal considera que la petición no se encuentra justificada y que no impediría que, una vez admitida la diligencia preliminar, la caución no fuera efectivamente prestada en el plazo que señala el art. 258.3 LEC y, como consecuencia de ello, fuera inadmitida la diligencia preliminar solicitada. Por tanto, entendemos procedente concluir que la ausencia del ofrecimiento de la prestación de caución en el escrito de solicitud de la diligencia preliminar no puede dar lugar a una resolución de inadmisión de la misma salvo en el caso de que, previamente, el órgano judicial hubiera procedido a efectuar el correspondiente requerimiento de subsanación, con el correspondiente apercibimiento de inadmisión, y el mismo no hubiera sido cumplimentado satisfactoriamente por la parte solicitante de la diligencia.

Determinado lo anterior, cabe preguntarse cuál debe ser el importe de la caución que se ofrezca, circunstancia ésta sobre la que la LEC, ni en las previsiones relativas a las diligencias preliminares ni en el resto de sus preceptos legales, da medida alguna de la misma. Al respecto, ciertos autores entienden que el solicitante tiene la carga de determinar el importe de la caución en función de los gastos así como de los daños y perjuicios que va a ocasionar la práctica de la diligencia a la persona requerida afirmando que deberá ser el juez quien, finalmente, determine el importe exacto de la caución ${ }^{642}$. Así las cosas, ante la ausencia de previsión legal y de una doctrina consolidada, entendemos que el solicitante deberá ofrecer la caución que, a su entender, entienda suficiente, para responder de los gastos, daños y perjuicios a los que se refiere el aptdo. $3^{\circ}$ del art. 256 LEC. Resulta razonable pensar y así se afirma en la doctrina científica $^{643}$, que la medida de dicha caución dependerá de la diligencia preliminar solicitada y, más concretamente, de las circunstancias concurrentes en el caso concreto.

\footnotetext{
${ }^{641}$ Vid. el AAP de Las Islas Baleares (sección $3^{\mathrm{a}}$ ) de 10 de abril de 2008, ponente Ilma. Sra. C.M ${ }^{\mathrm{a}}$. Moragues, f.j. $2^{\circ}$ (JUR 2008\226206).

${ }_{642}^{64}$ Gimeno Sendra, V., Derecho Procesal Civil..., ob. cit., pp. 361-362.

${ }^{643}$ Ruiz de Gordejuela López, L., Las diligencias preliminares..., ob. cit., p. 191.
} 
Ahora bien, a nuestro juicio, la fórmula verbal imperativa "ofrecerá" empleada por dicho precepto legal no implica la obligación de ofrecer caución, en todo caso, si en el supuesto concreto el solicitante de las medidas justifica, debidamente, que ello será innecesario ante la más que presumible ausencia de gastos o indemnización alguna que satisfacer al requerido en la práctica de la diligencia preliminar. De hecho, encontramos resoluciones en la doctrina judicial en que el órgano judicial ha considerado dicha situación y, por tanto, no ha procedido afijar caución ${ }^{644}$, pese a que en la doctrina más autorizada al respecto, la fijación de caución es una obligación que la ley impone al órgano judicial, aún por una mínima cuantía ante la necesidad de garantizar el pago de los gastos, daños y perjuicios que, en cualquier caso, pudieran generarse ${ }^{645}$.

Cuestión distinta es que el parecer o entender del solicitante difiera del que, a la postre, exprese el órgano judicial y que, motivada la ausencia de necesidad de ofrecimiento y prestación de caución, se requiera por aquel el ofrecimiento. En tal caso, entendemos que debe el solicitante proceder al ofrecimiento de la prestación de caución con independencia de que el órgano judicial, a la postre, estime procedente su prestación en una cuantía o forma superior o distinta a la ofrecida.

\section{Decisión sobre la solicitud}

Hasta aquí, hemos analizado todas las circunstancias necesarias que de ordinario podrán derivar, en su caso, en la formulación de la petición de las diligencias preliminares ante el juez.

Llegado a este punto, es preciso examinar las opciones del que debe resolver sobre la admisión de la diligencia preliminar. Así se desprende del art. 258.1 LEC que dispone que:

\footnotetext{
${ }^{644}$ En dicho sentido, los AAP de Álava (sección $1^{\text {a }}$ ) de 12 de noviembre de 2007, ponente Ilma. Sra. $M^{a}$.M. Guerrero, f.j. $1^{\circ}$ (LA LEY 250988/2007) y M ${ }^{a}$.C. Escrig, f.j.5 ${ }^{\circ}$ (ROJ AAP V 344/2015).

${ }^{645}$ Así lo afirma Banacloche Palao, J., Las diligencias preliminares..., ob. cit., p. 161.
} 
"Si el tribunal apreciare que la diligencia es adecuada a la finalidad que el solicitante persigue y que en la solicitud concurren justa causa e interés legítimo, accederá a la pretensión, fijando la caución que deba prestarse. El tribunal rechazará la petición de diligencias realizada si no considerase que éstas resultan justificadas. La solicitud deberá resolverse en los cinco días siguiente a su pretensión”.

\subsection{Inadmisión de la diligencia preliminar}

El juez que reciba una petición de diligencias preliminares, podrá rechazarla si no cumple con los requisitos legalmente exigidos que, siguiendo la clasificación utilizada por en la doctrina científica ${ }^{646}$, pueden ordenarse en causas de inadmisión de orden procesal y de orden material.

En el orden procesal, el juez podrá acordar la inadmisión por la incompetencia del órgano judicial, por la falta de acreditación de la representación procesal, por no aportarse junto con la solicitud el necesario principio de prueba que exija la diligencia preliminar en cuestión, así como por no realizar el ofrecimiento de prestar caución.

En cuanto a la incompetencia del órgano judicial, como pusimos de manifiesto en el epígrafe dedicado a la competencia ${ }^{647}$, la primera de las cuestiones que ha de ser valorada por el órgano judicial, tanto en el procedimiento de diligencias preliminares como en cualquier otro que se le presente, es la relativa a su competencia, objetiva y territorial. En el caso de las diligencias preliminares, de conformidad con lo dispuesto con carácter general en el art. 257.1 LEC, por razón de la materia, podrán conocer los JMER o los JPI, y por razón del territorio, el que siendo competente por razón de la materia lo sea por razón del domicilio de la persona que, en su caso, hubiera de declarar, exhibir o intervenir de otro modo en las actuaciones que se acordaran para preparar el juicio. $\mathrm{Y}$ en los casos de los ordinales $6^{\circ}, 7^{\circ}, 8^{\circ}$ y $9^{\circ}$ del aptdo. $1^{\circ}$ del art. 256 , aquel ante el que haya de presentarse la demanda determinada y, sin perjuicio, del que resulte competente para conocer en función de las diligencias previamente practicadas.

\footnotetext{
${ }^{646}$ Garberí Llobregat, J., Las diligencias preliminares..., ob. cit., pp. 70-72.

${ }^{647}$ Vid. cap. III, epígrafe 3, dedicado al estudio de la "Competencia".
} 
Llegado el caso de incompetencia, tal y como indica el art. 257.2 LEC, ésta sólo podrá ser revisada de oficio por el juez, quedando vetada al solicitante su denuncia mediante declinatoria ${ }^{648}$. Así, si el juez entendiera que no le corresponde conocer de la solicitud se abstendrá indicando al solicitante el JPI al que debe acudir, lo que a nuestro juicio será igualmente procedente cuando el juez entendiera que le corresponde conocer al JMER. Aun cuando expresamente ello no se contemple en el precepto legal indicado, a nuestro juicio, la única referencia de la LEC, en el aptdo. $2^{\circ}$ del art. 257 LEC, al JPI como aquel que indicará el juez y al que debe acudir el solicitante, sin alusión alguna al JMER que por razón de la materia deba, en su caso, conocer de las diligencias preliminares, no debe llevarnos a entender que cabe la posibilidad de interponer declinatoria para denunciar la falta de competencia objetiva. En cualquiera de los casos, debe recordarse que la declinatoria también es el instrumento de denuncia de la falta de competencia objetiva $\mathrm{y}$, por tanto, no estándole permitido a la parte formular declinatoria también dicha competencia objetiva habrá de ser revisada de oficio por el juez y, en su caso rechazada, para el caso de corresponder a los JMER.

Por otro lado, debe tenerse en cuenta que nada impide -de hecho, a nuestro juicio resulta muy conveniente y podrá ser exigido cuando el tribunal lo entienda procedente $\mathrm{f}^{649}$ - que el solicitante de las diligencias preliminares presente su solicitud con asistencia letrada y representación procesal. En este caso, de conformidad con 1o dispuesto en el art. 24 LEC, a la petición deberá acompañarse el poder en que la parte otorgue su representación al procurador, que habrá de estar autorizado por notario o ser conferido apud acta por comparecencia personal ante el LAJ de cualquier Oficina

\footnotetext{
${ }^{648}$ Como indica Gimeno Sendra, V., Los presupuestos procesales..., ob. cit., p. 92, la declinatoria es una excepción a través de la cual puede denunciarse la competencia territorial o falta de Jurisdicción de los Tribunales españoles, la falta de Jurisdicción de los tribunales civiles, por pertenecer el conocimiento del objeto procesal a otro orden jurisdiccional, la excepción de arbitraje o de pendiente compromiso por tener que conocer o estar conociendo ya un tribunal arbitral como consecuencia de la previa suscripción por las partes de un convenio arbitral como consecuencia de la previa suscripción por las partes de un convenio arbitral, la falta de competencia objetiva y la falta de competencia territorial.

${ }_{649}$ Debe tenerse presente que, como ha sido analizado, la necesidad de presentación de la solicitud de diligencias preliminares con asistencia letrada y representación procesal es una cuestión controvertida que no goza de una respuesta práctica pacífica en los tribunales de forma tal que podremos encontrarnos con supuestos en que la solicitud, por voluntad de la parte, se presente con asistencia letrada y representación procesal y con otros en que las anteriores sean exigidas por el tribunal. En este segundo supuesto, será el solicitante quien valore las posibilidades de cumplimiento del requerimiento que al efecto pueda realizar el tribunal y los recursos que frente a la decisión de inadmisión puedan darse, si esta llega a producirse.
} 
Judicial o por comparecencia electrónica en la correspondiente sede judicial. Respecto de lo anterior, debemos discernir distintas situaciones que se pueden producir y que, en cualquier caso, pasan por el más que confirmado carácter subsanable de los defectos de representación en cuanto defecto de acto procesal en que puede incurrir la parte y de conformidad con lo dispuesto en el art. 231 LEC $^{650}$.

Así, para el caso de entenderse por el órgano judicial que no resulta necesaria la presentación de la solicitud de diligencias preliminares con asistencia letrada y representación procesal pero el solicitante decidiera hacerlo, debemos plantearnos si la ausencia de acompañamiento a la solicitud inicial del poder de representación procesal del procurador conllevaría la inadmisión de la solicitud. Al respecto, entendemos que el art. 231 LEC obliga al órgano judicial a procurar la subsanación del defecto pero si el solicitante no lo hiciera, ello no podría dar lugar a la inadmisión de la solicitud dado que, en cualquier caso, se estaría reconociendo la posibilidad de presentar la solicitud sin necesidad de asistencia letrada y representación procesal. En consecuencia, de no subsanarse el defecto de representación procesal por el solicitante entendemos que el órgano judicial debería tener la misma por formulada en su propio nombre y derecho y con la asistencia letrada que hubiera sido designada. Cuestión distinta es que el criterio del órgano judicial fuera el de la necesaria presentación de la solicitud de diligencias preliminares con asistencia letrada y representación procesal, en cuyo caso la falta de subsanación del defecto de representación procesal advertido conllevaría la inadmisión de la solicitud, ello al margen del éxito que el posible recurso frente a esta inadmisión pudiera tener dado que ya hemos visto no existe un criterio uniforme.

En tercer lugar, cabría la inadmisión de la solicitud de diligencias preliminares del art. 256.1.8 LEC cuando, conjuntamente con la misma, no se aportase el principio de prueba exigido. Como en su momento ya se puso de manifiesto ${ }^{651}$, constituye un requisito de la solicitud, si se quiere de procedibilidad, que la misma sea acompañada de

\footnotetext{
${ }^{650} \mathrm{Al}$ respecto, destacamos las SSTS de 13 de febrero de 2001 (sala $1^{\text {a }}$ ), ponente Ilmo. Sr. R. Varela, f.j. $2^{\circ}$ (LA LEY 1985/2001) y de 11 de junio de 2008 (sala 1 ${ }^{\text {a }}$ ), ponente Ilmo. Sr. J. Almagro, f.j.1º (LA LEY 86321/2008).

${ }^{651}$ Vid. cap. II, epígrafe 9, dedicado a la diligencia de "Exhibición documental en materia de propiedad industrial o intelectual" (art. 256.1.8 LEC).
} 
un principio de prueba de la realidad de la infracción del derecho de propiedad industrial o intelectual, que se identifica, aún a título ejemplificativo, en la presentación de una muestra de los ejemplares, mercancías o productos en los que se materialice la infracción ${ }^{652}$.

Por último, procedería la inadmisión de la solicitud, por no ofrecerse la prestación de caución cuando, como hemos expuesto anteriormente, no habiéndose contenido tal ofrecimiento en la solicitud, el órgano judicial hubiera efectuado requerimiento de subsanación y este no haya sido atendido. En los mismos términos, cuando se trate de las diligencias de comprobación de hechos de los arts. 123 y ss. LP, pues si bien esta no prevé el supuesto concreto de archivo de las actuaciones por falta de prestación de la caución fijada por el tribunal, por virtud del art. 263 LEC resultan de aplicación las previsiones del art. 258.3 LEC.

En el orden material, y de forma correlativa a lo expuesto en el capítulo dedicado a los presupuestos materiales de la solicitud de diligencias preliminares, el juez podrá rechazar la misma siempre que en ella no se aprecie su necesaria adecuación a la finalidad perseguida y la justa causa e interés legítimo del solicitante, remitiéndonos en este punto al estudio realizado en el capítulo correspondiente ${ }^{653}$.

Pero, además, se contemplan en la doctrina científica otros supuestos de rechazo de las diligencias preliminares tales como el de la atipicidad de la diligencia solicitada ${ }^{654}$ que, pese al tan admitido criterio de interpretación flexible ${ }^{655}$, ha conformado el grueso de la importante postura doctrinal que considera el catálogo del art. 256.1 LEC como una lista cerrada. También, el de la falta de cita por el solicitante del concreto precepto legal que recoge la diligencia solicitada y que, nuestro juicio, no podría determinar la inadmisión de la solicitud si la misma es típica y se encuadra en alguno de los supuestos

\footnotetext{
${ }^{652}$ Garberí Llobregat, J., Las diligencias preliminares..., ob. cit., p. 70.

653 Vid. cap. I, epígrafe 9, relativo a los presupuestos materiales de la solicitud de diligencias preliminares.

${ }^{654}$ Así lo afirma Álvarez Alarcón, A., Las diligencias preliminares ..., ob. cit., p. 51.

${ }^{655}$ De este modo lo han advertido, el AAP de Las Islas Baleares (sección $3^{\text {a }}$ ) de 14 de octubre de 2005 , ponente Ilma. Sra. Ma . R. Rigo, f.j.2º (LA LEY 199921/2005) y el AAP de Barcelona (sección $13^{\mathrm{a}}$ ) de 12 de marzo de 2007, ponente Ilma. Sra. M $^{\mathrm{a}}$. A. Gomis, f.j.2º (LA LEY 14888/2007).
} 
legalmente previstos, pues tal cita no es más que un mero formulismo cubierto por el principio iura novit curia o del sometimiento de los jueces y magistrados al imperio de la ley, que proclama el art. $117.1 \mathrm{CE})^{656}$.

Llegados a este punto podemos concluir que si la solicitud de diligencias preliminares no cuenta con la debida fundamentación, el juez podrá inadmitirla cuando entendiere que la justificación de la solicitud no es adecuada a la finalidad que se persigue, o que no concurre en ella causa o interés legítimo. En cambio, si se dan todas las circunstancias anteriores, accederá a ella ${ }^{657}$. Por tanto, la falta de fundamentación de las diligencias preliminares es una causa determinante de la inadmisibilidad ${ }^{658}$ que, al mismo tiempo, impone al juez el preceptivo deber del examen de oficio de la procedencia de la diligencia preliminar, en lógica consecuencia al carácter excepcional que respecto de las mismas se desprende en su consideración como numerus clausus.

Por último, en cuanto a la impugnación de la inadmisión de la diligencia preliminar, cabe señalar que, conforme a lo previsto en el art. 258.2 LEC, contra el auto que deniegue las diligencias preliminares, cabrá interponer recurso de apelación en los términos del art. 455 y ss. LEC.

\subsection{Admisión de la diligencia preliminar}

Presentada la solicitud de diligencias preliminares y si esta cumple los presupuestos antes apuntados, el juez, mediante auto, debe resolver sobre su admisión total o parcial- en el plazo de los cinco días siguientes al de su presentación. En caso de admisión, y de conformidad con lo dispuesto en los arts. 258 y 259 LEC, el órgano

\footnotetext{
${ }^{656}$ Garberí Llobregat, J., Las diligencias preliminares..., ob. cit., p. 72.

${ }^{657}$ Debe repararse que la actual regulación de las diligencias preliminares en la LEC no contempla de forma expresa la posibilidad de inadmisión o rechazo de las mismas. En este punto entendemos que la regulación actual ha dado un paso atrás frente a la contenida en la ALEC que, en su art. 497.1, preveía expresamente la posibilidad del rechazo de oficio de la diligencia preliminar si estimare que la petición no se comprendía en los supuestos previstos en el mismo o no presentare justa causa.

${ }^{658}$ Cfr. Garberí Llobregat, J., Las diligencias preliminares ...., ob. cit., p. 65.
} 
judicial deberá concretar ${ }^{659}$ la diligencia/s a realizar por la parte requerida, el lugar en que la misma debe realizarse, el plazo para ello y el importe de la caución.

En cuanto a la determinación de la diligencia/s que debe/n realizarse, entendemos que en virtud del principio dispositivo que rige en el orden jurisdiccional civil, a priori, aquella/s no podrá/n ser otra/s que las interesadas por la parte solicitante sin perjuicio de la posibilidad de rechazo parcial lo que tendrá lugar cuando siendo varias las solicitadas el tribunal no acceda a la práctica de todas ellas. Sin embargo, no debemos olvidar que en el catálogo de diligencias preliminares que se contiene en el art. 256.1 LEC existen supuestos en los que el principio dispositivo a que hemos aludido queda difuminado, cual es el caso del ordinal $6^{\circ}$, por lo que podrá el órgano judicial determinar las medidas más oportunas para la averiguación de los integrantes del grupo, coincidan o no con las interesadas en la solicitud inicial. También en los supuestos del ordinal $7^{\circ}$ de diligencias de obtención de datos sobre el posible infractor, origen y redes de distribución de las obras, mercancías o servicios que infrinjan los derechos de propiedad intelectual o industrial así como ordinal $9^{\circ}$ de diligencias y averiguaciones que, para la protección de determinados derechos, prevean las correspondientes leyes especiales. En tales supuestos, la norma no identifica las concretas diligencias a practicar, razón por la cual entendemos que no sólo el solicitante podrá interesar cuantas crea conducentes para la obtención de la información a que hacen referencia sino que, por su parte, el tribunal podrá acordar aquellas que entienda más oportunas al efecto sin quedar sujeto a las expresamente interesadas.

Además, el órgano judicial deberá determinar el lugar en el que deba de practicarse la diligencia acordada, que puede coincidir o no con el de la sede de la Oficina Judicial, al desprenderse así del propio art. 259.1 LEC que señala que en el auto en el que se acceda a la solicitud se citará y requerirá a los interesados para que, en la sede de la Oficina Judicial o en el lugar y del modo que se consideren oportunos, lleven a cabo la diligencia, que haya sido solicitada y acordada.

\footnotetext{
${ }^{659}$ Siguiendo el criterio expuesto por Gimeno Sendra, V., Derecho Procesal Civil...., ob. cit., p. 284.
} 
Podrá coincidir con la sede de la Oficina Judicial en aquellos supuestos en los que nos encontremos ante las diligencias de declaración o exhibición documental, e incluso de la exhibición de la cosa cuando la misma sea susceptible de traslado. Ello teniendo en cuenta que en el supuesto de imposibilidad de traslado de la cosa objeto de exhibición a la Oficina Judicial, incluso por lo gravoso de la medida, lo oportuno será que dicha circunstancia sea puesta en conocimiento del órgano judicial con la antelación suficiente para que pueda disponer de otra forma la exhibición.

También, en los supuestos de exhibición de documentos y títulos, los cuales podrán ser presentados al órgano judicial por medios telemáticos o electrónicos realizándose la exhibición en la sede de la Oficina Judicial el día señalado al efecto.

Otro tratamiento requiere la diligencia contemplada en el ordinal $4^{\circ}$, en atención al cual, y como ha sido expuesto ${ }^{660}$, podrá ser acordada la exhibición de los documentos y cuentas en la sede de la sociedad. Y también la práctica de las diligencias a que se refiere el ordinal $9^{\circ}$, en general, las diligencias de comprobación de hechos que según la dicción literal del art. 124 LP parecen traducirse en actos de inspección y examen del juez, se entiende que de lugares o cosas, tales como máquinas, dispositivos, productos, procedimientos, instalaciones o actuaciones mediante la utilización de los cuales se lleve presumiblemente a cabo la infracción alegada, lo que parece exigir el examen directo de todos ellos en el lugar en que pudieran encontrarse.

Por último, las diligencias contempladas en los ordinales $6^{\circ}, 7^{\circ}, 8^{\circ}, 10^{\circ}$ y $11^{\circ} \mathrm{del}$ art. 256 LEC, cuya naturaleza apunta a una mera labor de facilitación de datos, que no de exhibición, que entendemos deberán aportarse en la sede de la Oficina Judicial sin necesidad de una expresa cita de comparecencia al efecto pero si de un requerimiento temporal en que los mismos deban ser aportados, mediante soporte papel o presentación telemática y en los términos generales prevenidos por la LEC para la presentación de escritos.

\footnotetext{
${ }^{660} \mathrm{Al}$ respecto, vid. cap. II, epígrafe 4.4, dedicado a práctica de la diligencia de exhibición de los documentos o cuentas de sociedades o comunidades (art. 256.1.4 LEC).
} 
En cuanto a la determinación del plazo para la realización de la diligencia admitida, señala el art. 259.1 LEC que ésta deberá tener lugar dentro de los diez días siguientes a la citación de los interesados para su práctica. No obstante lo anterior, será francamente difícil, sino imposible, que la diligencia preliminar que se resulte admitida pueda ser practicada en el plazo señalado. Más aún que la citación y requerimiento del sujeto pasivo para la realización de la diligencia preliminar llegue a su conocimiento en el plazo de los diez días siguientes al de la fecha del auto que acuerde aquella siendo un hecho obvio que, salvedad de las diligencias de comprobación de hechos, la diligencia preliminar no podrá practicarse en tanto en cuanto la citación y el auto que acuerde su práctica llegue al conocimiento del sujeto pasivo, momento temporal este de imposible determinación al tiempo del dictado del auto que resuelva sobre la oportunidad de su práctica. Estas circunstancias nos llevan a entender que la fijación por la LEC de un plazo concreto para la realización de la diligencia preliminar resulta, además de inútil, contrario a lo dispuesto en el art. 133 LEC. Inútil porque, en la práctica, el auto que la acuerde debe ser notificado al requerido que, además, tendrá la posibilidad de oponerse, tal y como así previene el art. 260.1 LEC, en el plazo de los cinco días siguientes a aquel en que reciba la citación, momento este absolutamente incierto que no sólo dependerá de la diligencia del órgano judicial en la realización del acto de comunicación sino también de otras circunstancias tales como la localización del requerido que, de formular oposición, impedirá la práctica de la diligencia preliminar en el plazo de los diez días siguientes a la fecha del auto que acuerde su práctica. Y, contrario a lo dispuesto en el art. 133 LEC porque con claridad se señala en el mismo que los plazos comenzarán a correr desde el día siguiente a aquél en que se hubiere efectuado el acto de comunicación, luego, en el supuesto que nos ocupa, el plazo para la práctica de las diligencias preliminares quedará supeditado, en todo caso, al tiempo de la notificación del auto que acuerde su práctica. Por tanto, entendemos que lo correcto será que el órgano judicial, para la práctica de la diligencia, sin atender al plazo de diez días que señala el art. 259.1 LEC, fije una fecha que permita la realización del acto de comunicación en un tiempo prudencial, sin perjuicio de que la misma quede sin efecto para el caso de formular oposición el requerido. Ello, sin perjuicio de hacerse constar en el auto que la diligencia preliminar deberá practicarse en el plazo de los diez días siguientes a su notificación al requerido y salvedad hecha de formularse por este 
oposición, en cuyo caso dependerá del resultado de la oposición, lo que si bien garantiza la defensa del requerido y su comparecencia a la práctica de la diligencia no elimina todas las posibles dificultades a las que esta, con fijación de un tiempo concreto, se enfrenta ${ }^{661}$. En cuanto a la forma de la citación, la misma tendrá lugar conforme a las reglas generales de los arts. 149 y ss. LEC $^{662}$.

Por último, en el auto en el que se acceda a la práctica de la diligencia preliminar, el órgano judicial deberá fijar el importe de la caución que ha de prestar el solicitante (art. 258.1 LEC y $123.4 \mathrm{LP}^{663}$ ), asumiendo, reduciendo o aumentando la inicialmente propuesta por el solicitante, según las circunstancias del caso, pues le corresponde al juzgador la cuantificación definitiva de la misma ${ }^{664}$. Además, contra el auto que acuerde las diligencias preliminares no se dará recurso alguno (art. 258.2 LEC), razón por la cual no tendrá el solicitante oportunidad de impugnar la decisión del juez en cuanto a la cuantía de la caución que definitivamente fije, si es que esta no le pareciera correcta o ajustada a la diligencia preliminar solicitada y/o acordada.

Respecto a la determinación de la cuantía de la caución, otra de las cuestiones que llama la atención es la omisión de cualquier regla o parámetro en la LEC que sirva al juzgador para determinar la cuantía de dicha caución, introduciendo dicho escenario un alto grado de discrecionalidad en su determinación. No obstante, el jurista sabe que dicha situación no se produce única y exclusivamente en relación a las diligencias preliminares pues la lectura de los distintos preceptos de la LEC en los que se hace referencia a las actuaciones procesales en las que debe prestarse caución esta realidad se

\footnotetext{
${ }^{661}$ En dicho sentido, podemos imaginar la imposibilidad de proceder a la práctica de la diligencia preliminar en la sede del tribunal,por ejemplo, cuando se acuerde el reconocimiento de un bien inmueble en presencia judicial, lo que dependerá de la disponibilidad del órgano judicial.

${ }^{662}$ Garciandía González, P.M., La regulación de..., ob. cit., p. 794.

${ }^{663}$ Dispone el art. 123.4 LP que: "Al acordar, en su caso, la práctica de las diligencias solicitadas, el Juez, de acuerdo con lo previsto en la Ley de Enjuiciamiento Civil, fijará la caución que deberá prestar el peticionario para responder de los daños y perjuicios que eventualmente puedan ocasionarse".

${ }^{664}$ Cfr. Garciandía González, P.M., La regulación de..., ob. cit., p. 794 y Gimeno Sendra, V., Derecho Procesal Civil..., ob. cit., p. 283. Y debe tenerse en cuenta que, en el caso de ser la audiencia provincial la que, en fase de apelación, acceda a las diligencias preliminares, será esta quien deba proceder a la fijación de caución. En dicho sentido lo afirma el AAP de Barcelona (sección 13ª) de 2 de diciembre de 2004, ponente Ilma. Sra. I. Carriedo, f.j. $2^{\circ}$ (JUR 2005135189).
} 
repite $^{665}$. Sin embargo, parece razonable, en la fijación de la cuantía de la caución, atender a parámetros tales como el grado de probabilidad del daño que pueda producirse al requerido con la práctica de la diligencia preliminar y los hipotéticos gastos que al mismo se le puedan causar, sin que en tal determinación, como ya ha sido analizado, el criterio de la mayor o menor solvencia del solicitante, incluso de la comparecencia con el beneficio de la justicia gratuita, deba tener influencia alguna.

\subsection{Prestación de caución}

Como ya anunciamos al tiempo del estudio del ofrecimiento de la caución, constituye una actuación diferenciada de este el acto el de la efectiva prestación, la que debe tener lugar una vez que el órgano judicial fije definitivamente el importe de la caución en el auto en el que se proceda a acceder a la práctica de las diligencias preliminares $^{666}$.

Así, conforme a lo prevenido en el art. 258 LEC, el solicitante de las diligencias preliminares a las que se acceda deberá proceder a la efectiva prestación de caución en el plazo de los tres días siguientes contados desde que se dicte el auto en que conceda las diligencias. Matizamos, nuevamente, que este plazo, pese al tenor literal del precepto legal más arriba citado, no podrá entenderse comenzado y, por tanto, transcurrido, sino a partir de la fecha en que el mismo sea notificado al solicitante de las diligencias preliminares (art. 133 LEC) ${ }^{667}$.

\footnotetext{
${ }^{665}$ Así en los supuestos de declinatoria (art. 64.2 LEC) al que se remite el art. 256.3 LEC; aseguramiento de la prueba (arts. 298.2 y 3 LEC); continuación de la obra suspendida (art. 441.2 LEC); derechos reales inscritos (arts. 439.2, 440 y 444.2 LEC); ejecución provisional (arts. 528-530 LEC); oposición a la ejecución (art. 561.3); suspensión de la actividad ejecutiva impugnada (art. 563.2 LEC); suspensión de la ejecución (arts. 566, 567 y 569); tercerías (art. 598 LEC); realización del proceso por persona o entidad especializada (art. 641 LEC); administración sobre vehículo de motor hipotecado (art. 690 LEC); medidas cautelares (arts. 728, 732, 737 y 738 LEC); administración del caudal hereditario (arts. 795, 797 y 800 LEC); alzamiento del embargo en juicio cambiario (art. 823 LEC).

${ }^{666}$ En el supuesto en que la diligencia preliminar sea admitida con ocasión del recurso de apelación, será el órgano de apelación quien deba fijar el importe de la caución. En dicho sentido, el AAP de Barcelona (sección 13 $3^{\mathrm{a}}$ ) de 2 de diciembre de 2004, ponente Ilma. Sra. I. Carriedo, f.j. $2^{\circ}$ (JUR 2005135189).

${ }^{667}$ Así lo entiende también, el AAP de Barcelona (sección $13^{\mathrm{a}}$ ) de 19 de marzo de 2004, ponente Ilmo. Sr. J.L. Valdivieso, f.j.3º (LA LEY 69342/2004) cuando señala: “[...] "En cuanto a su prestación, la verdad es que la forma de computar el plazo para constituirla que señala la ley presenta ciertos problemas, por lo
} 
Pero debe precisarse en que, aún la admisión de la diligencia preliminar, si el solicitante de la misma no prestase la caución fijada en el plazo prevenido, el LAJ, mediante decreto, procederá al archivo definitivo de las actuaciones. Por tanto, puede afirmarse que la prestación de caución es una condición sine qua non para la práctica de las diligencias que hayan sido acordadas ${ }^{668}$, de forma tal que si dicha caución no se presta en la cuantía fijada por el tribunal y en la forma prevista por la LEC, las diligencias preliminares acordadas no se realizarán.

Ahora bien, esta circunstancia nos lleva a reparar en dos cuestiones. La primera, que será recomendable que la citación del requerido a la práctica de las diligencias preliminares no sea expedida hasta que la prestación de caución por parte del solicitante se haya producido y verificado por el órgano judicial. Ningún sentido tiene proceder a la citación del requerido en un momento en que no se conoce si el solicitante procederá a la prestación de caución y, por tanto, si las diligencias preliminares se practicarán o no. La segunda, que el archivo por el LAJ, ante la ausencia de prestación de caución, podrá ser recurrido en revisión (art. 455.1 LEC), en cuanto resolución que pone fin al procedimiento, sin que dicho recurso pueda ser utilizado como medio para manifestar la disconformidad de la parte con la cuantía fijada por el tribunal, frente a la que, ya hemos visto, no cabe impugnación alguna. Ello, porque dado el tenor literal del art. 258.3 LEC entendemos que la revisión del decreto de archivo del LAJ por el juez debe quedar ceñida a la verificación de la efectiva prestación de caución y no a la proporcionalidad de la cuantía fijada, actuación esta en la que ninguna intervención tiene el LAJ. Lo contrario, entendemos, llevaría a admitir, implícitamente, la posibilidad de un recurso que frente al auto de admisión de las diligencias preliminares niega el art. 258.2 LEC, por mucho que se sostenga, y así lo compartimos, que la fijación por el tribunal de una cuantía excesiva o desproporcionada puede determinar una privación del derecho de defensa de quien deba prestarla, vulnerando su derecho a la tutela judicial efectiva del

que lo más ortodoxo es que el plazo se cuente desde la notificación de este auto a la parte actora, debiendo constituirse, no obstante, ante el Juzgado".

${ }^{668}$ En dicho sentido, Gimeno Sendra, V., Derecho Procesal Civil..., ob. cit., pp. 355 y 361 . También Garberí Llobregat, J., Las diligencias preliminares..., ob. cit., p. 73. 
art. 24.1 $\mathrm{CE}^{669}$. No debemos olvidar que pese, a no prever la LEC posibilidad alguna de recurso de apelación frente a la resolución que acceda a la práctica de las diligencias preliminares y en el que el órgano judicial habrá de determinar y fijar la caución, la imposibilidad de prestar una caución excesiva determinará el fin del procedimiento y la imposibilidad de acceder al mismo. Por tanto, no puede descartarse la posibilidad de interponer recurso de apelación frente al auto de admisión de las diligencias preliminares que determina y fija la caución, fundado el mismo en la vulneración que de aquel derecho produce la resolución que fija, con exceso, la caución ${ }^{670}$. Y aún cuando tampoco puede descartarse que el órgano judicial inadmita el recurso de apelación que por dicho motivo se interponga, al no prever la LEC la posibilidad de recurso frente al auto que acuerda la práctica de las diligencias preliminares, frente a dicha inadmisión cabría interponer recurso de queja (art. 494 LEC) ${ }^{671}$.

Por otro lado, debe aclararse que no están exentos de prestar caución los beneficiarios de asistencia jurídica gratuita. A tal efecto, cabe recordar que el art. 6 LAJG, relativo al contenido material del derecho a la asistencia jurídica gratuita, no contempla exención alguna de los beneficiarios relativa al pago de aquellas cautelas que exigen determinados trámites procesales de la LEC, cual es el caso del pago de la caución como requisito inexcusable de realización de las diligencias preliminares. De hecho, si afinamos en el tenor literal de la LAJG podría entenderse que el contenido material del derecho no podría extenderse a las diligencias preliminares dado que el mismo lo es, entre otras circunstancias, para la defensa y representación gratuitas por abogado y procurador en el procedimiento judicial, cuando la intervención de estos

\footnotetext{
${ }^{669}$ Así lo afirma la STC 45/2002, de 25 de febrero de 2002, ponente Ilma. Sra. E. Pérez, f.j. $5^{\circ}$ (JUR 2010445).

${ }^{670}$ Ejemplo de ello es el AAP de Sevilla (sección $2^{\mathrm{a}}$ ) de 10 de noviembre de 2005, ponente Ilmo. Sr. A. Palacios, f.j. $1^{\circ}$ (LA LEY 219084/2005).

${ }^{671}$ Conforme se desprende de los arts. 494 y ss. LEC dicho recurso de queja debería interponerse ante la AP si bien, dadas las singularidades de su tramitación, con noticia del mismo al órgano judicial que conozca de las diligencias preliminares. Debe tenerse en cuenta que el recurso de queja debe interponerse ante el órgano al que corresponda resolver el recurso no tramitado, y no, como en el recurso de apelación (art. 458.1 LEC), ante el tribunal que haya dictado la resolución que se impugne, en este caso, el auto acordando la práctica de las diligencias preliminares y en el que se proceda a la determinación y fijación de la caución. Por ello, si el recurrente no da noticia al órgano judicial que conoce de las diligencias preliminares y que ha dictado la resolución del recurso interpuesto frente a esta, el LAJ del órgano judicial que conoce de las diligencias preliminares, ante la ausencia de prestación de caución, procederá a su archivo (art. 258.3 LEC).
} 
profesionales sea legalmente preceptiva o, cuando no siéndolo, sea expresamente requerida por el juzgado o tribunal mediante auto motivado para garantizar la igualdad de las partes en el proceso. Y ya hemos visto que la intervención preceptiva de estos profesionales es una cuestión controvertida ${ }^{672}$.

No obstante esto último, y dando por válida la extensión material del derecho a las diligencias preliminares, al efecto de determinar si los solicitantes de ellas y beneficiarios del derecho deben o no proceder a la efectiva prestación de caución, debe recordarse cuál es la finalidad de tal prestación de caución en las diligencias preliminares. A saber, responder de los gastos, daños y perjuicios que pudieran causarse al requerido como consecuencia directa de la práctica de las diligencias preliminares, razón por la cual su práctica se condiciona a la efectiva prestación de caución por quien las solicite. Ello, sin que proceda aplicar por analogía la exención que contempla el aptdo. $5^{\circ}$ del art. 6 LAJG en relación a la exención del pago de las tasas judiciales y el pago de depósitos necesarios para la interposición de recursos, al no encontrarnos ante supuestos forzosamente iguales entre los que se aprecie la identidad de razón que obligue a aplicar la norma prevista para el caso regulado al supuesto no contemplado ${ }^{673}$.

Como afirma el TC, la situación referida a los depósitos para recurrir y la exigencia de caución para salvaguardar el posible perjuicio causado por una medida cautelar, en nuestro caso, por la práctica de una diligencia preliminar, que exige al juez una ponderación de los intereses contrapuestos, son supuestos dispares. En el primero de los casos, la exigencia de depósito previo para recurrir es un obstáculo, un presupuesto legal de acceso al recurso, del que se exime al litigante impecune para completar con su exención el beneficio de justicia gratuita ${ }^{674}$. En el segundo, la caución,

\footnotetext{
${ }^{672}$ Vid. cap. III, epígrafe 2.2, dedicado a la defensa y representación en la solicitud de diligencias preliminares.

${ }^{673}$ Así lo afirma la STC 45/2002, de 25 de febrero de 2002, ponente Ilma. Sra. E. Pérez, f.j.4 (JUR 201045). En el mismo sentido, AAP de Barcelona (sección 15 a) de 1 de julio de 2004, ponente Ilmo. Sr. L. Garrido, f.j.2 $2^{\circ}$ (JUR 2004l219656).

${ }^{674}$ Como señala la SAP de Málaga (sección $4^{\text {a }}$ ) de 13 de abril de 2015, ponente Ilmo. Sr. J.I. Delgado, f.j. $2^{\circ}$ (LA LEY 126982/2015), “[...] el depósito es o implica una cláusula sancionadora ante la desestimación del recurso o su ejercicio con afán de dilación procesal”.
} 
es una garantía accesoria, en beneficio de la parte requerida a la práctica de la diligencia preliminar, de quien se ve compelido a la misma ${ }^{675}$.

Partiendo de tales presupuestos, la caución en el procedimiento de diligencias preliminares se configura como una garantía de la que el goce del derecho a la asistencia jurídica gratuita no exime a quien debe prestarla. Tal derecho no produce el efecto de exonerar a su titular de la obligación de prestar las fianzas que le sean exigibles en el ámbito del proceso civil dado que la práctica de una diligencia preliminar es susceptible de originar unos daños y perjuicios en el requerido, en atención a los cuales la ley admite que pueda condicionarse, exigiendo la oportuna caución de quien la solicite.

\section{Oposición a la diligencia preliminar}

\subsection{Introducción}

Una vez presentada y admitida a trámite la solicitud de diligencias preliminares, la persona requerida para su práctica puede formular oposición. Ello se contempla en el art. 260.1 LEC que dispone que:

"Dentro de los cinco días siguientes a aquel en que reciba la citación, la persona requerida para la práctica de diligencias preliminares podrá oponerse a ellas y en tal caso, se citará a las partes para una vista, que se celebrará en la forma establecida para los juicios verbales".

\footnotetext{
${ }^{675}$ STC 202/197, de 17 de diciembre de 1987, ponente Ilmo. Sr. C. de la Vega, f.j.3º (LA LEY 920TC/1988). En la justicia ordinaria, el AAP de Valladolid (sección $1^{\text {a }}$ ) de 26 de septiembre de 2003, ponente J.R. Alonso-Mañero, f.j.3 (LA LEY 149194/2003) que señala: “[...] en todo caso sería también muy discutible que la exención del número $5^{\circ}$ del artículo sexto de la Ley de Asistencia Jurídica Gratuita a los beneficiarios del derecho, y que se refiere al pago de depósitos necesarios para interponer recursos, pudiera extenderse a un supuesto específico y muy determinado como es el de abono de una caución para prevenir gastos, daños y perjuicios que pudieran ocasionarse a quienes se vieran avocados a intervenir en dichas diligencias preliminares".
} 
De modo similar al supuesto en el que se acuerda una medida cautelar inaudita parte, la LEC prevé la posibilidad de oposición a la práctica de la diligencia preliminar acordada para el requerido y citado a tal efecto, evitándose así la indefensión en la que podría colocarse a dicha parte al no poder recurrir el auto que acuerda la práctica de aquellas y que se dicta sin previa audiencia ${ }^{676}$.

Ahora bien, debe advertirse que en el caso de las diligencias de comprobación de hechos del ordinal $9^{\circ}$ del art. 256.1, la regulación que de las mismas se contiene en los arts. 123 y ss. LP obvia toda posibilidad de oposición del sujeto pasivo, omisión que tampoco puede verse colmada por la previsión supletoria del art. 263 LEC que permite, cuando se trate de las diligencias a que se refiere el ordinal indicado, la aplicación de los preceptos de la LEC relativos a las diligencias preliminares, en lo que no se oponga a lo dispuesto en la legislación especial sobre la materia de que se trate ${ }^{677}$. Como ya ha sido puesto de manifiesto, los arts. 123 y 124 LP imponen la práctica de las diligencias de comprobación de hechos, con carácter urgente y sin noticia previa a quien deba soportarlas, que sólo podrá realizar manifestaciones en el acto de la práctica. Por esta razón se explica que no pueda formularse oposición previa a la práctica de las mismas y en los términos contenidos en el art. 260 LEC. Dicha situación no se justifica ni por el carácter urgente de las diligencias de comprobación de hechos ni por los términos en los que las mismas deben practicarse, sin previa noticia de las mismas a quien deba soportarlas. Ello porque el necesario carácter sorpresivo de las diligencias de comprobación de hechos no justifica la vulneración del derecho fundamental a la defensa que contiene el art. $24 \mathrm{CE}$, que podría quedar cubierto si, con posterioridad a la práctica de las diligencias de comprobación de hechos, se permitiera al sujeto pasivo formular la correspondiente oposición, no a su práctica, sino a los efectos que el resultado de aquellas pudieran tener en el proceso posterior incluso sin desvelar tal resultado hasta el tiempo en que la oposición que pudiera formularse hubiera sido resuelta en sentido satisfactorio para el sujeto pasivo.

\footnotetext{
${ }^{676}$ Cfr. Gimeno Sendra, V., Actos previos al..., ob. cit., pp. 284-285.

${ }^{677}$ Situación contemplada por Corbal Hernández, J.E., Diligencias Preliminares (arts...), ob. cit., p. 3516.
} 
Por tanto, en el supuesto de las diligencias de comprobación de hechos, únicamente podrá el afectado reclamar las indemnizaciones que le correspondieran como consecuencia de los daños sufridos durante la práctica de las mismas (art. 126 LP).

\subsection{Forma}

Nada dice la LEC respecto a la forma en que debe hacerse la oposición a la diligencia preliminar que haya sido acordada. A pesar de ello entendemos que, en todo caso, y con fundamento en los mismos argumentos ofrecidos para la solicitud ${ }^{678}$ y en el sentido confirmado por la doctrina deberá efectuarse por escrito ${ }^{679}$. Más fundamento tiene esta afirmación tras la reforma operada en la LEC por la Ley 42/2015,que despejó las dudas que, con anterioridad a dicha reforma, planteaba la entonces redacción del art. 260.1 LEC, conforme al cual dentro de los cinco días siguientes a la recepción de la citación por el requerido para la práctica de las diligencias preliminares podría oponerse a ellas citándose a las partes, en tal caso, a una vista que se celebraría en la forma establecida para los juicios verbales. La redacción del precepto legal hacía plantearnos si la exposición y fundamentación de los concretos motivos de oposición debía tener lugar en ese plazo de cinco días y por escrito o si, por el contrario, bastaba con que en dicho escrito de oposición el requerido manifestara, sin más, que se oponía a la práctica de la diligencia preliminar acordada, postergando la exposición y fundamentación de los concretos motivos de oposición al acto de la vista referido en el art. 260.1 LEC. Tales circunstancias permitían entender que sería en el trámite de la vista, que se debía celebrar en la forma entonces establecida para los juicios verbales, cuando el requerido debía exponer los hechos y fundamentos de derecho en que fundaba su oposición.

\footnotetext{
${ }^{678}$ Vid. cap. III, epígrafe 2.1, relativo a la forma de la solicitud de diligencias preliminares.

${ }^{679}$ En este sentido, Gimeno Sendra, V., Actos previos al..., ob. cit., p. 285 indica: "Sin embargo, debiera exigirse que la oposición se formulara en todo caso por escrito" (al igual que sucede con la solicitud de las diligencias) y Garberí Llobregat, J., Las diligencias preliminares..., ob. cit., p. 75 cuando señala que: "Como nada al respecto dice la norma de manera expresa, el hecho que la vista oral donde se debatirá la oposición planteada por el sujeto pasivo de las diligencias preliminares deba celebrarse conforme a lo que dispone el art. 443 LEC para las vistas de los juicios verbales hace pensar que dicha oposición podrá formularse mediante un escrito...". También Montero Aroca, J., Derecho Jurisdiccional II..., ob. cit., p. 190, al referirse al trámite de oposición indica que lo será "formulando el escrito correspondiente".
} 
No obstante, con ocasión de la reforma apuntada, fue modificada la redacción del precepto legal de forma tal que, en la actualidad, de la oposición que se formule se dará traslado al requirente, quien podrá impugnarla por escrito en el plazo de cinco días, sin perjuicio de la posibilidad de solicitud de vista que las partes puedan realizar y que habrá de desarrollarse conforme a los trámites previstos para los juicios verbales. Así las cosas, a nuestro juicio, esta modificación impide que la fundamentación de la oposición pueda postergarse para un trámite posterior como el de la vista, dado que no sólo el art. 438.1 LEC exige que la contestación a la demanda del juicio verbal se haga en forma escrita sino que la impugnación que a la oposición tiene derecho a formular el solicitante exige el previo conocimiento de los argumentos de aquella.

\subsection{Defensa y representación}

En cuanto a la necesidad de postulación y representación en la oposición a las diligencias preliminares procede aquí dar por reproducidas todas las consideraciones hechas al respecto y en relación a la solicitud inicial ${ }^{680}$.

\subsection{Motivos de oposición}

Como se desprende de lo expuesto al hilo de la motivación de la solicitud de diligencias preliminares y a sensu contrario de lo dicho en cuanto a las condiciones de aquella para su admisión, la oposición podrá fundamentarse en "la carencia de cualesquiera presupuestos, tanto procesales como materiales, que determinan la admisibilidad de aquellas diligencias" ${ }^{681}$, debiendo darse aquí por reproducidas todas las consideraciones efectuadas al respecto ${ }^{682}$.

\footnotetext{
${ }^{680}$ Vid. cap. III, epígrafe 2.2 dedicado al estudio de la defensa y representación de la solicitud de diligencias preliminares.

${ }^{681}$ Garberí Llobregat, J., Las diligencias preliminares..., ob. cit., p. 76. Algún autor como Damián Moreno, J., Comentarios a la..., ob. cit., p. 1692, ha señalado que al no establecer la LEC motivos tasados de oposición "el requerido puede alegar cualquier hecho tendente a desvirtuar la procedencia de la medida solicitada" si bien, con carácter general, tal y como señala el AAP de Zaragoza (sección $5^{\text {a }}$ ) de 20 de marzo de 2006, ponente Ilmo. Sr. P.A. Pérez, f.j.1º (LA LEY 31213/2006): "[...] El Tribunal resolverá mediante Auto si considera que la oposición es justificada, o si, por el contrario, carece de justificación", exigencias estas relativas a la causa justa e interés legítimo que, a tenor de los preceptos citados, vienen siendo exigidas con una cierta rigurosidad habida cuenta de la amplitud de las diligencias cuya práctica
} 


\subsection{Decisión sobre la oposición}

Así, formuladas las correspondientes alegaciones, en los escritos de oposición e impugnación y, en su caso, celebrada la vista que sea solicitada, el tribunal deberá resolver, mediante auto, si considera que la oposición es justificada o si, por el contrario, carece de justificación (art. 260.2 LEC), no debiendo apuntarse aquí más que dicha razón no concurrirá si, efectivamente, carece la solicitud de los presupuestos procesales y materiales que determinan su admisión. De no concurrir, la oposición será estimada, y en caso contrario, será desestimada, cobrando plena virtualidad lo acordado respecto de la práctica de la diligencia preliminar, del mismo modo que cuando no se formulase oposición.

Cierto es que parece un contrasentido la posibilidad de éxito de la oposición a la práctica de las diligencias preliminares, habida cuenta que al tiempo de su solicitud el órgano judicial habrá debido de verificar y constatar la concurrencia de los presupuestos procesales y materiales determinantes de su admisión y, sólo cuando el juicio resulte positivo, habrá debido de proceder a la admisión. Pero no es menos cierto que, a nuestro juicio, la LEC, mediante la oposición a la práctica de las mismas, además del derecho a la tutela judicial efectiva del requerido garantiza también la posibilidad de revisión de la decisión inicialmente acordada.

La decisión que se adopte como consecuencia de la oposición, sólo podrá ser recurrida en apelación cuando aquella se considere justificada (art. 260.3 y 4 LEC). Llama por tanto la atención que el requerido a la práctica de las diligencias preliminares no goce del derecho a la segunda instancia. No se advierten las razones por las cuales el legislador ha decidido que sólo el rechazo a la práctica de las diligencias preliminares es susceptible de revisión y que aquel en cuya esfera personal, incluso más íntima, se pueda ver afectado carezca del reconocimiento legal del derecho a la segunda instancia. No debemos olvidar pues, como más adelante veremos, que el rechazo de la oposición a

\footnotetext{
puede pedirse y la debida protección de los derechos que pudieran quedar afectado (...)".

${ }^{62}$ Vid. cap. III, epígrafes 3.1 y 3.2, dedicados a inadmisión y admisión de la diligencia preliminar, respectivamente.
} 
la práctica de las diligencias preliminares y la persistencia del requerido en la negativa a dicha práctica, conllevará que el tribunal acuerde las medidas contempladas en el art. 261 LEC y que frente a la decisión de adopción de las mismas no quepa interponer recurso alguno.

Así, sin desconocer que en la LEC se contemplan otros supuestos en que no es posible interponer recurso de apelación ${ }^{683}$, entendemos que en el caso de oposición a la práctica de las diligencias preliminares se hace preciso la reforma del art. 260.3 LEC, permitiendo su recurso en vía de apelación cuando aquella sea considerada injustificada.

\subsection{El pago de las costas}

Una importante cuestión que debe ser analizada al hilo de la resolución de la oposición, es la ausencia de previsión alguna en la LEC de condena en costas para el caso de estimación de la oposición (260.4 LEC), a diferencia de lo que sucede para el supuesto de desestimación de la misma, por considerarse injustificada, en cuyo caso, el art. 260.3 LEC prevé su expresa imposición al requerido a la práctica de las diligencias preliminares.

Los distintos autores que han tenido ocasión de estudiar la institución objeto de análisis no se han pronunciado a este respecto, lo que parece lógico si tenemos que, al disponer la LEC su imposición únicamente cuando la oposición sea rechazada, y no cuando sea estimada, el principio de legalidad veta imponerlas en este segundo supuesto. Ahora bien, la doctrina judicial no se ajusta a la previsión legal y, como en tantas otras ocasiones, mantiene un criterio dispar.

Así, nos encontramos con resoluciones que claramente determinan que sólo en caso de estimarse injustificada la oposición podrá procederse a la imposición de costas, al requerido, debiendo en consecuencia, cuando la misma se estime justificada, pechar

\footnotetext{
${ }^{683}$ En dicho sentido, el art. 455 LEC que impide interponer recurso de apelación frente a las sentencias dictadas en juicios verbales por razón de lacuantía cuanto ésta no supere los 3.000 euros.
} 
cada parte con las propias ${ }^{684}$. Se considera de este modo que el hecho de hacer responsable la LEC al promotor de las diligencias de los gastos, daños y perjuicios que se pudieren irrogar al requerido deben ser cubiertos, no con la condena en costas, sino con el importe de la caución prestada ${ }^{685}$, aún cuando lo anterior no es conforme con la propia naturaleza y finalidad de la caución que ya hemos examinado.

Por otro lado, se afirma que el hecho de que el art. 260.4 LEC guarde silencio sobre la condena en costas no debe interpretarse en el sentido de que la omisión legal excluye la condena en costas en caso de estimación de la oposición, debiendo producirse estas en perjuicio de quien ha visto desestimadas sus pretensiones, esto es, el solicitante de las medidas ${ }^{686}$. En la misma línea, y con expresa cita de la aplicación del criterio general del vencimiento contenido en el art. 394 LEC, se afirma igualmente la

\footnotetext{
${ }^{684}$ Sobre este particular, el AAP de Barcelona (sección 13aa de 8 de mayo de 2007, ponente Ilma. Sra. I. Carriedo, f.j. $1^{\circ}$ (LA LEY 113407/2007) que señala que: “[...] sólo en el caso de considerarse injustificada la oposición ( $\mathrm{n}^{\circ} 3$ del art. 260), prevé la ley la imposición de costas del incidente al requerido, sin hacerse ninguna otra mención al respecto de los demás supuestos". En el mismo sentido, el AAP de Guipúzcoa (sección $3^{\text {a }}$ ) de 31 de octubre de 2006, ponente Ilma. Sra. B. Argal, f.j.3º (LA LEY 229882/2006) justifica la no condena en costas en caso de estimación de la oposición " [...] porque a la oposición se llega en virtud de una resolución judicial, dictada al amparo de lo establecido en el art. 258 de la Ley, por la que el Juez o Tribunal considera que la diligencia es adecuada a la finalidad que el solicitante persigue y que en la solicitud concurren justa causa e interés legítimo, fijando la caución que deba prestarse" siendo al "juez a quien le corresponde acordar la práctica de la diligencia preliminar con lo que, al mismo tiempo, permite la oposición del requerido y la iniciación de un trámite incidental, y en esta situación difícilmente se pueden imponer las costas a la parte que solicitó unas diligencias preliminares que en principio fueron consideradas adecuadas por el Juez" de forma tal que "la oposición se dirige contra una resolución judicial que ha acordado la práctica de la diligencia preliminar interesando su revocación, y por lo tanto, estimada la oposición por estar justificada, el único pronunciamiento que cabe en materia de costas es el no efectuar pronunciamiento expreso sobre las mismas". En el mismo sentido, Consejo General Poder Judicial, 50 Cuestiones Prácticas..., ob. cit., pp. 11-12, de las que se extrae que al no preverlo la ley no hay posibilidad de imposición.

${ }^{685}$ AAP de Barcelona (sección $1^{\text {a }}$ ) de 29 de julio de 2008, ponente Ilmo. Sr. J.L. Barrera, f.j. $2^{\circ}$ (LA LEY 129377/2008).

${ }^{686} \mathrm{Al}$ respecto, el AAP de Barcelona (sección 15ª) de 29 de septiembre de 2006, ponente Ilmo. Sr. I. Sancho, f.j. $2^{\circ}$ (LA LEY 237147/2006) dispone: “[...] pues la resolución se dicta después de un breve incidente contradictorio en el que ha resultado vencido, siendo razonable que quien ha tenido que oponerse a las diligencias inicialmente solicitadas pueda resarcirse de los gastos procesales que le ha ocasionado la oposición", indicando que "Es lógico que la primera fase, de examen y adopción de las diligencias preliminares solicitadas, puesto que se hace inaudita parte y, por ello, sin posibilidad de ser aceptadas por los interesados, no conlleve pronunciamiento en costas. De modo que la ausencia de oposición, supone su aceptación y un tratamiento análogo al del allanamiento anterior a la contestación, de no imposición de costas" y "Solo si hay oposición, al resolver el breve incidente contradictorio que se ventila en una vista, cuando el Juez juzgue sobre la justificación de la oposición, tendría sentido un pronunciamiento de imposición de costas a aquella "parte" que vea desestimadas sus pretensiones, y así se prevé expresamente en el caso de desestimación de la oposición (art. 260.3 LEC) e implícitamente cuando se estime la oposición, por aplicación del régimen general del art. 394 LEC...".
} 
imposición de costas al solicitante en caso de estimación parcial, que no total, de la oposición del requerido ${ }^{687}$. Incluso, encontramos resoluciones que, en caso de estimación de la oposición, justifican la ausencia de previsión de condena en costas al solicitante, en la circunstancia de haber superado la solicitud el filtro de admisión del art. $258.1 \mathrm{LEC}^{688}$.

A la vista de lo expuesto, y ante la ausencia de pronunciamiento expreso de la LEC, parece que son dos los criterios fundamentales mantenidos en cuanto a la condena en costas en caso de estimación de la oposición a la práctica de la diligencia preliminar. Por un lado, el que se sustenta en la literalidad del art. 260.4 LEC y su omisión intencionada que lleva a considerar que, en dicho supuesto, no cabe imposición de las costas al solicitante, habida cuenta que el art. 256.3 LEC ya prevé, a cargo del mismo, el resarcimiento de los gastos que se ocasionen a las personas que hubieren de intervenir

\footnotetext{
${ }^{687}$ Vid. el AAP de León (sección $1^{\text {a }}$ ) de 25 de febrero de 2009, ponente Ilma. Sra. A. del Ser, f.j. $2^{\circ}$ (LA LEY 26737/2009), disponiendo que: “[...] al no contemplar el artículo 260 LEC expresamente la condena en costas en el supuesto de estimar la oposición, resulta evidente que será de aplicación el criterio general sin que se aprecie en la litis la concurrencia de circunstancias excepcionales que permitieran no hacer imposición de costas ya que las cuestiones que plantea la parte recurrente sobre la realización de actos ilegales en la liquidación de la sociedad exceden del ámbito del procedimiento. Tampoco resulta de aplicación el criterio de estimación parcial pues la oposición prospera, con independencia de que se estime únicamente uno de los motivos, pues en definitiva ello implica la desestimación de las pretensiones ejercitadas en el escrito de solicitud inicial de diligencias". En el mismo sentido, el AAP de Ciudad Real (sección $2^{\mathrm{a}}$ ) de 25 de noviembre de 2008, ponente Ilma. Sra. C.P. Catalán, f.j $2^{\circ}$ (LA LEY 294700/2008).

${ }^{688}$ En dicho sentido, el AAP de Zamora (sección $1^{\text {a }}$ ) de 30 de diciembre de 2005, ponente Ilmo. Sr. A.M. Encinas, f.j. $3^{\circ}$ (LA LEY 250771/2005) dispone: “[...] El hecho de que, en el caso de que se estime injustificada la oposición, se prevea de forma expresa la imposición de las costas del incidente a la parte requerida y que, en cambio, se omita todo tipo de pronunciamiento sobre la condena en costas para el caso de que la oposición se declare justificada, conduce a afirmar -a juicio de esta Sala- que, en este segundo caso, no procede imponer las costas del incidente a ninguna de las partes, lo que -según nuestro criterio- encuentra su fundamento, precisamente, en el hecho de que, en el primer estadio del Procedimiento (antes de la oposición), se hubiera acordado por el Órgano Jurisdiccional las diligencias solicitadas (vid art 258) al considerar que la diligencia es adecuada a la finalidad que el solicitante persigue y que en la solicitud concurren justa causa e interés legítimo, fijando la caución que deba prestarse. Por lo tanto es el Juez quien, en principio, abre la puerta a la práctica de la diligencia preliminar con lo que, al mismo tiempo, permite la oposición del requerido y la iniciación de un trámite incidental, y en esta situación difícilmente se pueden imponer las costas a la parte que solicitó unas diligencias preliminares que en principio fueron consideradas adecuadas por el Juez. y después, con motivo de la oposición, se haya declarado justificada esta última. Es decir, la oposición se dirige contra una resolución judicial pretendiendo su revocación, de forma similar a lo que ocurre con los recursos y, por lo tanto estimada la oposición por ser esta justificada, el único pronunciamiento que cabe en materia de costas es el no efectuar pronunciamiento expreso sobre las mismas". En el mismo sentido, la SAP de Lleida (sección $2^{\mathrm{a}}$ ) de 18 de septiembre de 2003, ponente Ilmo. Sr. A. Guilanya i Foix, f.j.3 ${ }^{\circ}$ (LA LEY 142941/2003) y el AAP de Cáceres (sección única) de 27 de enero de 2004, ponente Ilmo. Sr. A.M ${ }^{a}$. González Floriano, f.j.4º (LA LEY 23342/2004).
} 
en las diligencias. Por otro, el criterio que sostiene que la omisión del art. 260.4 LEC conlleva la aplicación del criterio general del vencimiento que recoge el art. 394.1 LEC.

En nuestra opinión, en sede de diligencias preliminares la LEC introduce una previsión especial en materia de condena en costas siendo intencionada la voluntad del legislador de no proceder a su imposición cuando la oposición se considere justificada en tanto en cuanto compartimos aquella postura conforme a la cual pudo entender el legislador que previendo el art. 256.3 LEC el resarcimiento de los gastos que se ocasionen a las personas que hubieren de intervenir en las diligencias, estimándose su oposición la condena en costas resultaba innecesaria.

Pero, a nuestro juicio, este entendimiento parte de una confusión de conceptos jurídicos, pues una cosa son los gastos, daños y perjuicios que deben satisfacerse con cargo a la caución y otra muy distinta las costas procesales. Como así se desprende del art. 241 LEC, una cosa son los gastos del proceso, es decir, los desembolsos que tengan su origen directo e inmediato en la existencia de dicho proceso y que, en sede de diligencias preliminares, serían resarcibles con cargo a la caución, y otra muy distinta las costas procesales de la parte, con cargo a las cuales se satisfacen, de forma principal, los honorarios de la defensa y de la representación técnica, cuando sean preceptivas. Y ya hemos visto como en sede de diligencias preliminares, la preceptiva intervención de defensa y representación técnica es una cuestión controvertida. Aun más, en la práctica forense son numerosos los supuestos de diligencias preliminares en que la intervención con defensa y representación no se produce y, de producirse, se entiende que es meramente facultativa, por lo que la posibilidad de satisfacerse con cargo al concepto de costas los gastos de defensa y representación procesal quedará al albur del mero criterio del juzgador.

Por lo expuesto, considerando que es intencionada la voluntad del legislador de no proceder a la imposición de las costas, cuando la oposición se considere justificada y considerando que dicha voluntad parte de una confusión de conceptos jurídicos, proponemos, a través de la oportuna reforma legal, el sometimiento del régimen específico de imposición de costas que se contiene en el art. 206 LEC al general del art. 
394 LEC pues ni las costas procesales participan del carácter de gastos del proceso, o del de gastos y perjuicios indemnizables como consecuencia de la práctica de las diligencias preliminares, ni se entiende que cuando la oposición se estime justificada el requerido deba cargar con el pago de los honorarios de los profesionales que le asistan. Más aún, si la intervención de los profesionales se impone como preceptiva y cuando la oposición ha venido precedida de una previa resolución judicial que el posterior declarado carácter justificado de la oposición, pone en tela de juicio.

\section{Práctica de la diligencia preliminar}

Tanto en el caso de desestimación de la oposición como en el de no formulación de la misma, procede, en los términos acordados en el auto de admisión de las diligencias o resolutorio de la oposición, la práctica de las diligencias preliminares, de conformidad con el art. 259.1 LEC. En virtud de dicho precepto legal, las diligencias preliminares se practicarán en el lugar (generalmente y como indica el art. 259.1 LEC en la Oficina Judicial) y modo consignados en el auto que acuerde su práctica y en el plazo que el mismo determine. Y, según lo previsto en el aptdo. $2^{\circ}$ del art. 259.2 LEC, podrá el solicitante, a su costa, acudir a la práctica de las diligencias preliminares asesorado por un experto en la materia ${ }^{689}$.

No obstante, deben considerarse las siguientes y especiales circunstancias en orden a la práctica de cada una de las diligencias preliminares enumeradas en el art. 256.1 LEC, toda vez que nada se dice en el texto legal sobre cómo se desarrollarán estas actuaciones.

\footnotetext{
${ }^{689}$ Lo que considera Álvarez Alarcón, A., Las diligencias preliminares..., ob. cit., p. 62, especialmente interesante cuanto se trata de valorar o comprobar el bien cuya exhibición se insta o cuando se trata de un documento toda vez que a la vista de los mismos el peticionario puede mostrar su interés respecto de lo exhibido y emitirse un informe para ser aportado posteriormente al ulterior proceso principal. Incluso en los supuestos en los que las diligencias admitidas consistieran en la declaración o interrogatorio del requerido, nada impediría, a nuestro juicio, que el requerido a su práctica estuviera asistido por abogado.
} 
Comenzando por las diligencias que consistan en la declaración o interrogatorio del requerido, consideramos que nada puede impedir que el requerido a su práctica intervenga asistido por abogado.

En el caso de la práctica de la diligencia preliminar de exhibición del acto de última voluntad por quien lo tenga en su poder, podrá producirse con citación de todos los presuntos coherederos para que estén presentes en la práctica de la diligencia ${ }^{690}$ aún cuando a nuestro juicio, únicamente cuando no sea posible dilucidar quién de tales presuntos coherederos pueda tener en su poder el acto de última voluntad.

En el supuesto del art. 256.1.7 LEC, y para garantizar la confidencialidad de la información requerida, podrá el tribunal ordenar que la práctica del interrogatorio se lleve a cabo a puerta cerrada, adoptando dicha decisión en la forma establecida en el art. $138.3^{691}$ y a solicitud de cualquiera que acredite interés legítimo (art. 259.3 LEC).

Cuando la práctica de la diligencia preliminar consista en la exhibición de documentos y títulos, conforme previene el art. 259.2 LEC, podrán ser presentados ante el juzgado para su exhibición por medios telemáticos o electrónicos, en cuyo caso su examen se realizará en la sede de la Oficina Judicial, pudiendo obtener la parte solicitante de las diligencias, con los medios que aporte, copia electrónica de los mismos.

La anterior previsión legal debe ponerse en relación con el art. 273 LEC conforme al cual:

\footnotetext{
${ }^{690}$ Así lo admite Álvarez Alarcón, A., Las diligencias preliminares..., ob. cit., p. 62.

${ }^{691}$ Dispone el art. 138.3 LEC que: "Antes de acordar la celebración a puerta cerrada de cualquier actuación, el tribunal oirá a las partes que estuvieran presentes en el acto. La resolución adoptará la forma de auto y contra ella no se admitirá recurso alguno, sin perjuicio de formular protesta y suscitar la cuestión, si fuere admisible, en el recurso procedente contra la sentencia definitiva.

Los Secretarios Judiciales podrán adoptar mediante decreto la misma medida en aquellas actuaciones procesales que deban practicarse en materias de su exclusiva competencia. Frente a este decreto sólo cabrá recurso de reposición".
} 
a) Todos los profesionales de la justicia están obligados al empleo de los sistemas telemáticos o electrónicos existentes en la Administración de Justicia para la presentación de escritos, iniciadores o no, y demás documentos (art. 273.1 LEC).

b) Las personas que no estén representadas por procurador podrán elegir en todo momento si actúan ante la Administración de Justicia a través de medios electrónicos o no, salvo que estén obligadas a relacionarse a través de medios electrónicos con la misma. El medio elegido podrá ser modificado en cualquier momento (art. 273.2 LEC).

c) Y que, en todo caso, están obligados a intervenir a través de medios electrónicos con la Administración de Justicia, las personas jurídicas, las entidades sin personalidad jurídica, quienes ejerzan una actividad profesional para la que se requiera colegiación obligatoria para los trámites y actuaciones que realicen con la Administración de Justicia en ejercicio de dicha actividad profesional, los notarios y registradores quienes representen a un interesado que esté obligado a relacionarse electrónicamente con la Administración de Justicia y los funcionarios de las Administraciones Públicas para los trámites y actuaciones que realicen por razón de su cargo (art. 273.3 LEC).

Conforme a lo anterior, y teniendo presentes las previsiones del art. 259.2 LEC, puede afirmarse que cuando la práctica de la diligencia preliminar consista en la exhibición de documentos y títulos:

1) Si quien tiene que proceder a la exhibición de documentos y títulos es una persona física que no actúa representada por procurador y, por consecuencia, tampoco asistida por letrado, podrá, a su elección, proceder o no a la presentación por medios telemáticos (art. 273.2 LEC). En el caso de no optar por la presentación telemática, deberá procederse en tal sentido en el servicio común correspondiente.

2) Si quien tiene que proceder a la exhibición de documentos y títulos es una persona física que actúa representada por procurador y, por consecuencia, asistida por 
letrada, deberá proceder a la presentación de los documentos y títulos, por medios telemáticos (art. 273.1 LEC).

3) Si quien tiene que proceder a la exhibición de documentos y títulos es alguno de los sujetos contemplados en el art. 273.3 LEC deberá proceder a la presentación de los documentos y títulos, por medios telemáticos, siempre y cuando, aún cuando las comunicaciones electrónicas estén disponibles en el concreto órgano judicial que conoce del procedimiento de diligencias preliminares, podrá exigirse que la presentación de los documentos se haga por estas de forma electrónica.

No obstante, en cualquier caso, el órgano judicial, en la resolución por la que se acceda a la práctica de la diligencia preliminar, deberá indicar al requerido el modo de exhibición y presentación de los documentos (art. 259.1 LEC) pudiendo este, formulando oposición, manifestar su disconformidad, por contravención de la norma, a los términos en los que aquélla resolución haya ordenado la presentación de los documentos y títulos.

Además de lo anterior, debe tenerse en cuenta que el art. 259.2 LEC parece distinguir entre la presentación de los documentos y títulos que, conforme a lo indicado, puede llevarse a cabo forma telemática, y su examen, actuación ésta que entendemos será practicada, a priori, después del tiempo de su presentación y, más concretamente, el día en que las partes hayan sido citadas a la práctica de la diligencia preliminar. Entendemos que será en ese momento cuando se podrá solicitar que se extienda testimonio de los documentos exhibidos para su incorporación a la diligencia practicada $^{692}$ y la recuperación por el requerido de la documentación exhibida. Ello, porque la diligencia no consiste en la entrega de los documentos al solicitante sino en su exhibición ante el tribunal que entendemos no tendrá interés alguno en disponer de los originales si, previamente, una copia autentificada por el LAJ, testimoniada, obra en autos. De ahí que el art. 259.2 LEC disponga expresamente que el examen de los documentos y títulos, se realizará en la sede de la Oficina Judicial pudiendo, con los

\footnotetext{
692 Vid. Corbal Hernández, J.E., Diligencias Preliminares (arts...), ob. cit., p. 3523 y Armengot Vilaplana, A., Las nuevas diligencias..., ob. cit., p. 37.
} 
medios que aporte, obtener una copia electrónica de los mismos. Y al igual que ocurre con la presentación, siempre y cuando pese sobre el requerido el deber de presentar telemáticamente los documentos requeridos o el órgano judicial disponga de los medios materiales oportunos para realizar dicha copia electrónica, pues en caso contrario, tal y como tradicionalmente viene sucediendo, no podrá obtener copia alguna sino en papel.

Resta por último señalar, la posibilidad de que a la citación para la práctica de la diligencia preliminar no comparezcan ambas o alguna de las partes, lo que puede dar lugar a tres situaciones distintas, en función de si quien deja de comparecer es la parte solicitante de la diligencia, la requerida a su práctica o ambos sujetos.

Para el supuesto de no comparecer la parte solicitante, considerando que la LEC no establece previsión alguna al respecto y que dicha situación responde a una falta de interés del solicitante en la práctica de una diligencia preliminar que, como ya se puso de manifiesto, está sujeta al principio dispositivo, y no sólo en cuanto a su petición inicial sino también en el desarrollo del propio mecanismo procesal, entendemos que nada impide que el órgano judicial dé por concluido el trámite, aún sin llevarse a término la práctica de aquella, teniendo por desistida a la parte solicitante de las diligencias preliminares (art. 20 LEC). A nuestro juicio, con pérdida por el solicitante de la caución prestada siempre y cuando por el requerido se justifiquen los gastos y daños y perjuicios producidos. Cierto es que el art. 262.1 LEC sólo parece permitir dicha decisión en los supuestos de práctica de las diligencias o denegación de las mismas, pero nada obsta a que al amparo de lo dispuesto en el art. 256.3 LEC ello se entienda procedente en supuestos en los que las diligencias no se practican por culpa o desinterés del solicitante. Lo anterior, salvo excepciones tales como aquellos supuestos de diligencias preliminares consistentes en la mera presentación telemática de los documentos requeridos ${ }^{693}$.

\footnotetext{
${ }^{693}$ En dicho sentido se pronuncia Garberí Llobregat, J., Las diligencias preliminares ..., ob. cit., p. 78, con cita del AAP de Madrid (sección 14ª de 12 de diciembre de 2005, ponente Ilma. Sra. A. Camazón, f.j. $2^{\circ}$ (238362/2005), al entender que diligencias preliminares como la prevista en el ordinal $5^{\circ}$, relativa a la petición de la historia clínica, únicamente requieren la comparecencia, el día señalado al efecto, del sujeto pasivo y para la entrega de una copia de la misma. Más dudoso es a nuestro juicio que, como sostiene el autor, la comparecencia del solicitante de las diligencias preliminares no resulte precisa en los supuestos
} 
A la misma conclusión habrá de llegarse en los supuestos de incomparecencia de ambas partes, con la salvedad referida a la aplicación de caución cuya finalidad desaparece por la incomparecencia del requerido.

Por último, en los supuestos de incomparecencia del requerido, que no responden sino a la falta de atención al requerimiento practicado, resulta de aplicación lo dispuesto en el art. 261 LEC, relativo a la negativa a llevar a cabo las diligencias, lo que constituye objeto de estudio del siguiente epígrafe.

\section{Negativa a la práctica de las diligencias preliminares}

\subsection{Planteamiento general}

Acordada la diligencia preliminar por el órgano judicial competente, y citado y requerido el sujeto pasivo obligado a su práctica, puede ocurrir que éste, habiendo o no formulado oposición y, en todo caso, desestimada la misma, tácita o expresamente, se niegue a cooperar en su práctica. En dicho supuesto, el art. 261 LEC autoriza al tribunal a acordar, mediante auto, y cuando resulte proporcionado, medidas coercitivas y restrictivas de derechos a fin de que pueda obtenerse el mismo resultado o un resultado alternativo, pero igualmente provechoso, al que hubiera podido cosecharse si la diligencia preliminar se hubiese practicado regularmente, con el concurso voluntario del sujeto requerido al efecto ${ }^{694}$.

A nuestro juicio, es esta respuesta del legislador la que en sede de diligencias preliminares ha de considerarse el mayor exponente de su voluntad de dar virtualidad a la institución al tiempo que de dar cumplimiento al derecho a la tutela judicial efectiva

del art. 256.1.1 LEC pues aún cuando, en cualquier caso, la declaración del requerido se produzca a presencia del tribunal, dejando constancia de la misma y en las actuaciones el LAJ, ello pasaría por admitir que la práctica de la diligencia se debe limitar a la respuesta de las preguntas que se consignen en la solicitud inicial por el solicitante o estime oportunas realizar el tribunal, resultando que la LEC ni exige la consignación de las preguntas objeto de declaración en la solicitud inicial ni debe descartarse la posibilidad, con ocasión de la práctica de la diligencia preliminar, de otras en el sentido de la práctica de la diligencia que haya sido acorado al tiempo de la admisión resulte necesario.

${ }^{694}$ Garberí Llobregat, J., Las diligencias preliminares..., ob. cit., p. 79. 
previsto en el art. $24 \mathrm{CE}$, en cuanto que procura evitar que la mera negativa del requerido a prestar su colaboración deje vacío de contenido el recurso al auxilio recabado por el solicitante de la diligencia preliminar.

Dicha previsión legislativa constituye una novedad en la regulación que de la institución hizo la $\mathrm{ALEC}^{695}$, que más allá de la responsabilidad de los daños y perjuicios que pudieran causarse como consecuencia de la negativa a la práctica de la diligencia preliminar, no preveía consecuencia alguna que evitara convertir las diligencias preliminares en un trámite absurdo por la falta de efectividad de la resolución del juez, lo que al auspicio de la ALEC constituyó una de las principales razones de la decadencia de la institución ${ }^{696}$. La inexistencia de sanción a la negativa del sujeto pasivo a la práctica de la diligencia preliminar hacía inútil la decisión positiva de su adopción cuando en la práctica no cooperaba el requerido ${ }^{697}$. Por tanto, nos encontramos ante una disposición de suma importancia dado que sin unas medidas adecuadas que conminen al sujeto pasivo a la colaboración en la práctica de la diligencia preliminar acordada por el tribunal, las mismas no tendrán utilidad alguna ${ }^{698}$.

Así, nos encontramos ante un precepto legal, el art. 261 LEC, que contiene un único apartado en el que, tras el enunciado inicial, se establecen las diferentes medidas

\footnotetext{
${ }^{695}$ Así lo pone de manifiesto el AAP de Vizcaya (sección $3^{\text {a }}$ ) de 16 de julio de 2007, ponente Ilma. Sr. A. I. Gutiérrez, f.j.2 ${ }^{\circ}$ (LA LEY 201929/2007) cuando apunta: “[...] En todo caso, y ello es una de las novedades de su regulación actual respecto de la anterior,la no atención por la parte frente a quien se ha instado y admitido la diligenciapreliminar, tiene sus consecuencias, en atención a las características de cada una de ellas, tal y como previene el art. 261 LECn".

${ }^{696}$ En dicho sentido Pérez Benítez, J.J., Efectos de las..., ob. cit., pp. 8-9, cuando señala que: "Las diligencias preliminares del proceso establecidas en la Ley de Enjuiciamiento Civil de 1881 no distaban mucho del completo desuso, al no considerarse de utilidad, dadas las escasas consecuencias de la negativa a llevar a cabo los comportamientos preparatorios previstos, pese a que el tribunal considerara justificada la solicitud del interesado". A dicha situación se refiere también, Callejo Carrión S., Las diligencias preliminares..., ob. cit., p. 5, al establecer que "la regulación que trae consigo la LEC 1/2000 en esta materia (...) trata de paliar la inoperancia que mostró la regulación anterior, dado que se consideraban en gran medida inútiles debido, por un lado, a las escasas consecuencias establecidas ante la negativa a llevar a cabo los comportamientos preparatorios previstos y, por otro, por la ausencia de medios coercitivos para que los requeridos llevaran a cabo las diligencias planteadas".

${ }^{697}$ Como indica Garberí Llobregat, J., Las diligencias preliminares..., ob. cit., p. 79, “Tras la nueva LEC, y por la introducción de las medidas previstas en dicho art. 261 LEC, puede decirse que el panorama ha cambiado radicalmente, y que ahora más que nunca el solicitante de una diligencia preliminar fundada tiene verdaderas posibilidades de conseguir los resultados que persigue con su puesta en práctica".

${ }^{698}$ Así lo afirman, entre otros, Garberí Llobregat, J., Las diligencias preliminares..., ob. cit., p. 79 y Álvarez Alarcón, A., Las diligencias preliminares..., ob. cit., p. 64.
} 
que podrá adoptar el juzgador para hacer efectiva la diligencia preliminar acordada y que no se haya podido llevar a efecto, bien por la oposición del requerido, bien porque éste haya desoído el requerimiento. Ello sucederá, por ejemplo, por incomparecencia a la citación debidamente efectuada o cuando, comparecido, se niegue a la práctica de las diligencias acordadas, cuando las respuestas dadas en la declaración resulten evasivas o inconcluyentes, se oponga resistencia a exhibir documentos o bienes o afirme que ignora si los tiene o que desconoce su contenido y no consiente en que sea conocido por el peticionario ${ }^{699}$.

Ahora bien, estas medidas, tal y como expresamente apunta el precepto legal, sólo serán acordadas cuando resulte proporcionado. Tal previsión encuentra su razón de ser en lo que se ha identificado como su denominador común. A saber, su naturaleza coercitiva o restrictiva de derechos que impide su adopción de forma mecánica o automática e implica la formulación por el juez de un juicio de proporcionalidad entre los perjuicios capaces de ser ocasionados con la puesta en práctica de la medida coercitiva de que se trate y los que pueden originarse al solicitante de la diligencia ante la negativa del requerido a su práctica. Conforme a tal parámetro, se sostiene que si los perjuicios que provocan la falta de práctica de la diligencia por la negativa del requerido son de tal entidad como para justificar la adopción de las medidas, así las acordará el juez, mediante auto; y, si no lo son, también por auto, decretará la conclusión y archivo de las actuaciones ${ }^{700}$.

Tal afirmación nos lleva a reflexionar sobre el tipo de perjuicio que podrá ocasionarse si, aún admitida la diligencia preliminar, en caso de negativa del requerido a colaborar en su práctica, el tribunal decide no aplicar las medidas contempladas en el art 261 LEC. La respuesta es evidente. El solicitante se verá privado del legítimo derecho, que legalmente se le reconoce y que ha obtenido el beneplácito judicial con la admisión de la solicitud, de preparar el ulterior proceso. De ahí que, a nuestro juicio, sea criticable el parámetro de proporcionalidad que el legislador ha introducido en la decisión de la

\footnotetext{
${ }^{699}$ Álvarez Alarcón, A., Las diligencias preliminares ..., ob. cit., p. 65.

${ }^{700}$ Garberí Llobregat, J., Las diligencias preliminares..., ob. cit., p. 80.
} 
aplicación de las medidas del art. 261 LEC $^{701}$ pues así se viene a reconocer la posibilidad de un segundo juicio de admisión de la procedencia de las diligencias, ya no a la vista del cumplimiento de los presupuestos materiales para su adopción, sino del efecto que las medidas previstas para el caso de negativa del requerido a colaborar puedan causar sobre la persona del requerido. Es decir, si se reconoce el derecho del solicitante a la preparación del juicio ulterior y si su solicitud resulta admitida, por concurrir en ella todos los presupuestos exigibles, no resulta admisible que tanto aquel derecho como esta admisión se dejen vacíos de contenido porque, a la postre, en el caso de negativa del requerido a su práctica, las consecuencias de esta negativa puedan considerarse no proporcionadas. Ello, porque las medidas que prevé el art. 261 LEC están ordenadas de forma correlativa a cada uno de los supuestos del catálogo de diligencias que contiene el art. 256.1 LEC teniendo su origen en cada uno de ellos y, por tanto, entendemos también, de forma proporcionada a la negativa del requerido a su práctica en el caso concreto. En consecuencia, entendemos procedente concluir que la proporcionalidad de la medida viene ya dada por la negativa a la práctica de la diligencia preliminar sin que, a nuestro juicio, resulte procedente examen alguno de proporcionalidad de la medida prevista y ante la rebeldía del requerido.

Cuestión distinta sería que el legislador hubiera optado por una fórmula abierta dejando al arbitrio del juzgador las medidas a adoptar en caso de negativa, lo cual no sucede, en cuya tesitura podría exigirse que la medida que se adoptase, de entre todas

\footnotetext{
${ }^{701} \mathrm{Y}$ al que hacen referencia en la doctrina judicial resoluciones tales como el AAP de Cádiz (sección $5^{\mathrm{a}}$ ) de 14 de junio de 2011, Ilmo. Sr. A.L. Sanabria, f.j.2 $2^{\circ}$ (ROJ AAP CA 490/2011) cuando señala: "[...] no estaría de más recordar que frente a la insatisfactoria regulación de la Ley de Enjuiciamiento Civil de 1.881, la vigente Ley de Enjuiciamiento Civil, sobre todo a partir de la reforma operada por la Ley 19/2.006, de 5 de Junio, por la que se amplían los medios de tutela de los derechos de propiedad intelectual e industria y se establecen normas procesales para facilitar la aplicación de diversa normativa comunitaria, prevé, en función de cual sea la diligencia pedida y acordada, para que la pasividad de la persona frente a la que se deduce la petición no se resuelva, en último término, en una denegación de tutela del solicitante de las diligencias, actuaciones sustitutorias o complementarias dirigidas a persuadir o vencer esa actitud negativa o pasiva y, en su caso, vencer la resistencia de la misma. Ahora bien, no puede ponerse en duda que la expresa, y antes implícita, referencia a la "proporcionalidad" de las actuaciones coactivas, de suyo revestidas de extraordinaria gravedad, no solo impone una exquisita prudencia a la hora de acordarlas y una cuidadosa ponderación de los intereses en juego y de los datos disponibles en el momento en que se acuerde una medida que, en definitiva, puede ser restrictiva de derechos fundamentales, así como de los interese en conflicto, sobre la necesidad de conveniencia e idoneidad de la medida, pues no debemos olvidar que en la mayor parte de los casos ni siquiera se trata de proteger un interés social o público sino meramente particular o privado".
} 
las posibles, fuera proporcionalmente adecuada al cumplimiento del derecho del solicitante, objetivo este al que no se puede renunciar para el caso de cumplirse todos los presupuestos legalmente exigidos en la admisión de la diligencia preliminar en cuestión.

Aquella conclusión, a nuestro juicio, sólo podría verse excepcionada en un único supuesto. A saber, cuando la medida acordada afectara a alguno de los derechos fundamentales reconocidos en el Título I de la $\mathrm{CE}$, dado que en tales supuestos la doctrina constitucional exige el dictado de una resolución judicial especialmente motivada y proporcionada en relación con un fin constitucionalmente legítimo ${ }^{702}$. De hecho, a nuestro juicio, es esta excepción la que motivó que, con ocasión de la reforma operada por la Ley 19/2006, se refinara la fórmula de la decisión sobre la procedencia de las medidas coercitivas contenidas en el art. 261 LEC, sustituyendo la forma de la resolución que aquella debía de revestir, providencia por auto, e introduciendo la expresa necesidad del juicio de proporcionalidad. Ello, sin prever que, como nosotros entendemos, ese juicio de proporcionalidad de las medidas consecuencia de la negativa a colaborar en la práctica de la diligencia preliminar se encuentra implícito en las mismas y que sólo cuando tales medidas afecten a un derecho fundamental debe realizarse un juicio de proporcionalidad al tiempo de ser acordadas.

Determinado lo anterior, y adentrándonos en el estudio de las concretas consecuencias de la negativa a la práctica de la diligencia preliminar, la lectura del art.261 LEC nos permite clasificar los efectos que la misma prevé para dicho supuesto y que han sido sistematizados en la doctrina en tres tipos de consecuencias ${ }^{703}$.

En primer lugar, la posibilidad de tener por respondidas afirmativamente las preguntas que el solicitante pretendiera formular al sujeto pasivo o requerido a la

\footnotetext{
702 Al respecto, vid. SSTC 207/1996, de 16 de diciembre de 1996, ponente Ilmo. Sr. V. Gimeno, f.j.4 ${ }^{\circ}$ (LA LEY 1527/1997) y 25/2005, de 14 de febrero de 2005, ponente Ilmo. Sr. R. García-Calvo, f.j.6º (LA LEY 462/2005). En relación con la concreta facultad de disposición y control de datos personales, cfr. la STC 292/2000, de 30 de noviembre de 2000, ponente Ilmo. Sr. J.D. González, f.j.13º (LA LEY $11336 / 2000)$.

${ }^{703}$ Álvarez Alarcón, A., Las diligencias preliminares..., ob. cit., pp. 65-67.
} 
práctica de las diligencias preliminares, y los hechos admitido o por ciertos, a efectos del juicio posterior. Conforme prevé el art. 261.1 ${ }^{\text {a }}$ LEC, si se hubiere pedido declaración sobre hechos relativos a la capacidad, representación o legitimación del citado (art. 256.1.1 LEC), se podrán tener por respondidas afirmativamente las preguntas que el solicitante pretendiera formularle, y los hechos correspondientes se considerarán admitidos a efectos del juicio posterior; así como, si se hubiera pedido la exhibición de documentos contables (art. 256.1.4 LEC), se podrán tener por ciertos, a los mismos efectos, las cuentas y datos que presente el solicitante (art. 261.4ª LEC).

En segundo lugar, la posibilidad de obtener por la fuerza el documento, cosa o datos objeto de la diligencia preliminar. Ello, conforme prevé el art. 261.2 ${ }^{\mathrm{a}}$ LEC, al disponerse que si se hubiese solicitado la exhibición de títulos y documentos (art. 256.1.1, 3, 5 LEC, y el tribunal apreciare que existen indicios suficientes de que pueden hallarse en un lugar determinado, ordenará la entrada y registro de dicho lugar, procediéndose, si se encontraren, a ocupar los documentos y a ponerlos a disposición del solicitante, en la sede del tribunal. También, al prever el art. 261.3 ${ }^{\mathrm{a}}$ LEC que, si se tratase de la exhibición de una cosa (art. 256.1.2 LEC) y se conociese o presumiese fundadamente el lugar en que se encuentra se procederá de modo semejante a lo dispuesto en el número anterior y se presentará la cosa al solicitante, que podrá pedir el depósito o medida de garantía más adecuada a la conservación de aquélla. Incluso, como especifica el art. 261.5 $5^{\text {a }}$ LEC, ante la negativa del requerido o de cualquier otra persona que pudiera colaborar, en la determinación de los integrantes del grupo (art. 256.1.6 LEC), para encontrar los documentos o datos precisos, y, en la exhibición de aquellos, para la obtención de la historia clínica (art. 256.1.5 bis LEC) así como, en los supuestos de infracciones en materia de propiedad industrial e intelectual, para la obtención de los datos sobre el posible infractor, el origen y redes de distribución de las mercancías o servicios (art. 256.1.7 LEC) y la exhibición de documentos bancarios, financieros, comerciales o aduaneros (art. 256.1.8 LEC).

En tercer lugar, y en el supuesto de la diligencia contemplada en el ordinal $6^{\circ}$ del art. 256.1 LEC, prevé el art. 261.5 ${ }^{\mathrm{a}}$ LEC que, ante la negativa del requerido o de cualquier otra persona que pudiera colaborar en la determinación de los integrantes del 
grupo, el tribunal ordenará que se acuerden las medidas de intervención necesarias, incluida la de entrada y registro, para encontrar los documentos o datos precisos, sin perjuicio de la responsabilidad penal en que se pudiera incurrir por desobediencia a la autoridad judicial. Las mismas medidas podrá ordenar el tribunal en los casos de los ordinales $5^{\circ}$ bis, $7^{\circ}$ y $8^{\circ}$ del art. 256.1 LEC, ante la negativa del requerido a la exhibición de documentos.

Nada en especial prevé el art. 261 LEC en relación a la negativa a la práctica de las diligencias preliminares contempladas en los ordinales $9^{\circ}, 10^{\circ}$ y $11^{\circ}$ del art. 256.1 LEC y que se diferencian del resto, las del ordinal $9^{\circ}$, de comprobación de hechos, por encontrarse reguladas en normas ajenas a la LEC, y las de los ordinales $10^{\circ}$ y $11^{\circ}$, por haber sido introducidas en el catálogo del art. 256.1 LEC con ocasión de la reforma operada en ella por la Ley 21/2014 pero sin previsión de medida alguna para el caso de negativa a su práctica.

Siendo esto así, resulta necesario plantearnos las posibles medidas a adoptar en caso de negativa del requerido a la práctica de la diligencias de comprobación de hechos, a que se refiere el ordinal $9^{\circ}$, y de obtención de datos del ordinal $10^{\circ}$ del art. 256.1 LEC.

Por lo que se refiere a las diligencias de comprobación de hechos, los arts. 123 y ss. LP omiten cualquier referencia a la imposibilidad de práctica de las diligencias lo que no será infrecuente que ocurra, incluso sin la expresa negativa de quien deba soportarla. Debe tenerse en cuenta que el art. 123 y ss. LP ordena la práctica de las diligencias de comprobación de hechos sin que medie noticia previa a quien deba soportarlas o de la persona con quien las mismas deban entenderse. Por ello, no será extraño que personada la comisión judicial en el lugar en que deba procederse al examen y comprobación de las máquinas, dispositivos, productos, procedimientos, instalaciones o actuaciones a través de los cuales se produzca, presumiblemente, la infracción alegada por el solicitante, se encuentre aquel cerrado o no se encuentre persona alguna con la que entender la práctica de la diligencia. Tampoco puede descartarse que la persona que deba soportar las diligencias o aquella con la que las 
mismas deban entenderse se nieguen a ello. Por ejemplo, negando a la comisión judicial el acceso al lugar cerrado donde tales bienes se encuentren o las concretas actuaciones se estén llevando a cabo.

En tales supuestos entendemos que no será posible la práctica de las diligencias de comprobación de hechos sin una previa resolución judicial que, debidamente motivada, acuerde, sin otra opción, la medida de entrada y registro en el lugar en que los bienes se encuentren. Y decimos que sin otra opción porque la realización de la práctica de las diligencias de comprobación de hechos, en términos generales, impone el reconocimiento de los bienes y o actuaciones indicados en el lugar que se encuentren o se desarrollen, al pretender la constatación del estado o utilización de bienes así como de actuaciones que, por el contexto industrial con el que se relacionan, están destinados a encontrarse o desarrollarse en lugares cerrados.

A falta de previsión legal alguna al respecto, entendemos que nada obstará a que en la propia resolución en que se acuerde la práctica de las diligencias de comprobación de hechos se disponga la posibilidad de entrada y registro en lugar cerrado para el caso de negativa del que deba soportarlas o de aquel con el que se deban entender las mismas. Máxime si tenemos en cuenta que el intento fallido de su práctica puede llegar a conocimiento de los sujetos pasivos interesados, de forma tal que una resolución posterior a dicho intento fallido por la que se acuerde la entrada y registro para el reconocimiento y examen propio de las diligencias preliminares frustrará el carácter urgente y sorpresivo típico de las diligencias de comprobación de hechos.

Por lo que se refiere a las diligencias de los ordinales $10^{\circ}$ y $11^{\circ}$ LEC, de identificación y aportación de datos, debe tenerse en cuenta que las mismas participan de la naturaleza de las contenidas en el ordinal $7^{\circ}$ del art. 256.1 LEC, respecto de la cual prevé el art. 261.5 $5^{\mathrm{a}}$ LEC la adopción de las medidas de intervención necesarias, incluida la entrada y registro, para encontrar los documentos o datos precisos que sean objeto de la diligencia preliminar. 
Por tanto, sin perjuicio de considerar que resultaría procedente una reforma legislativa que colme la laguna legal del art. 261 LEC, en cuanto a la falta de previsión de las medidas a adoptar para el caso de negativa a colaborar a la práctica de las diligencias preliminares de los ordinales $10^{\circ}$ y $11^{\circ}$ del art. 256.1 LEC, al igual que en el supuesto de las diligencias de comprobación de hechos, entendemos procedente la aplicación analógica de las previstas para el supuesto del ordinal $7^{\circ}$, dado que el objeto de aquellas se traduce en la obtención y aportación de los datos necesarios a efecto.

Y resta por último apuntar que pese a la dicción legal del art. 261.5 ${ }^{\mathrm{a}} \mathrm{LEC}$, que parece limitar la responsabilidad penal en que pudiera incurrirse en el caso de negativa a colaborar en la práctica de las diligencias preliminares al supuesto del ordinal $6^{\circ}$ del art. 256.1 LEC, tal responsabilidad será exigible igualmente, en el resto de supuestos, dado que la desobediencia es, precisamente, la razón que subyace en la activación de todas las medidas que se contemplan en el supuesto del art. 261 LEC $^{704}$.

Ello, pese a que en la práctica forense no resulta habitual que se activen los mecanismos necesarios para que, en los supuestos de negativa a colaborar del requerido a la práctica de las diligencias preliminares, se depure la responsabilidad penal que de tal conducta pudiera desprenderse.

\subsection{Efectos de la negativa en el ulterior proceso}

Una de las concretas medidas que, para el caso de negativa a colaborar en la práctica de la diligencia preliminar, prevé el art. 261 LEC guarda relación con las diligencias en las que el destinatario o requerido se niegue a declarar sobre hechos relativos a su capacidad, representación o legitimación (256.1.1 LEC, aptdo. $1^{\circ}$ ) o se niegue a exhibir documentos y cuentas de la sociedad o de la comunidad (art. 256.1.4 LEC).

\footnotetext{
${ }^{704}$ En dicho sentido, Bancloche Palao, J., Las diligencias preliminares..., ob. cit., pp. 208-209.
} 
Respecto al primero de los supuestos, prevé el art. 261.1 LEC que si se hubiere pedido declaración sobre hechos relativos a la capacidad, representación o legitimación del citado, se podrán tener por respondidas afirmativamente las preguntas que el solicitante pretendiera formularle y los hechos correspondientes se considerarán admitidos a efectos del juicio posterior.

Lo primero que llama la atención del efecto asociado a la medida prevista en el art. 256.1.1 LEC es la previsión, que distintos autores han considerado contradictoria ${ }^{705}$, de la posibilidad de tener por respondidas afirmativamente las preguntas que el solicitante pretendiere formular cuando, por otro lado, en cuanto a los hechos, se impone la consideración de tenerlos como admitidos a efectos del juicio posterior. Además, sin determinar quién podrá tener por respondidas afirmativamente aquellas o, en todo caso, por admitidos estos.

$\mathrm{Al}$ respecto, en la doctrina científica existen posturas que intentan despejar esta contradicción que se mantiene en la actualidad pese a la importancia que parece trascender a la misma. Por un lado, se sostiene que la referencia que el art. 261.1 LEC hace al juicio posterior permite afirmar que quien ha de tener por respondidas las preguntas que se hubieran formulado es el tribunal que está conociendo de las diligencias preliminares, haciéndolo constar en la resolución que se dicte poniendo fin al proceso. Igualmente, obligando ello al tribunal que conozca del ulterior proceso principal a tener por admitidos los hechos referidos a aquellas, con independencia de la actitud concreta que, en relación con ellos adopte el demandado y sin posibilidad de

\footnotetext{
${ }^{705}$ En dicho sentido, Pérez Benítez, J.J., Efectos de las..., ob. cit., p. 10 que, con cita de Garciandía González explica que tal circunstancia trae causa de la modificación del precepto a través de una enmienda introducida por el Grupo Parlamentario Catalán en el Congreso de los Diputados (enmienda 118) al texto del anteproyecto de LEC que disponía que "si se hubiere pedido declaración sobre hechos relativos a la capacidad, representación o legitimación del citado, se tendrán por respondidas afirmativamente las preguntas que el solicitante pretendiera formularle y los hechos correspondientes se considerarán admitidos a efectos del juicio posterior" con el objeto de excluir la imperatividad en la consideración de tener por respondidas afirmativamente las preguntas por resultar demasiado excesivo al eliminar toda la capacidad de actuación del órgano jurisdiccional. Y en dicho sentido también, Lorca Navarrete, A.M., La regulación de..., ob. cit., p. 17; y Damián Moreno, J., Comentarios a la ..., ob. cit., p. 1696 cuando se pregunta: “¿Cómo es posible que sin que exista ficta confessio se puedan considerar admitidos los hechos correspondientes (a la capacidad, representación o legitimación) a los efectos del juicio (proceso declarativo) posterior?".
} 
práctica de prueba sobre ellos al tratarse de hechos admitidos (art. 281.3 LEC) ${ }^{706}$. Por otro lado, que será el juez del ulterior proceso declarativo el que, con la valoración que en conjunto haga de la prueba, aplique o no la sanción prevista en el art. 261.1 LEC $^{707}$.

${ }^{706}$ Esta postura es la sostenida por Banacloche Palao, J., Las diligencias preliminares..., ob. cit. pp. 198199. Sin embargo, también en la doctrina científica es contradicha por Pérez Benítez, J.J., Efectos de las..., ob. cit., p. 10, cuando al respecto advierte que "el art. 281 de la Ley de Enjuiciamiento Civil, cuando se refiere a los hechos exentos de necesidad de prueba, toma como objeto de su consideración los hechos sobre los que se proyecta el consentimiento de los litigantes (a salvo de aquellos que queden fuera de su poder de disposición), lo que es una consecuencia de la vigencia del principio dispositivo en el proceso civil, sin que se contenga reserva alguna a una suerte de hechos fijados como ciertos por una resolución judicial". También en la doctrina judicial esta posibilidad es rechazada. A modo de ejemplo, procede traer a colación el AAP de Cádiz (sección 5a) de 14 de junio de 2011, Ilmo. Sr. A.L. Sanabria, f.j. $2^{\circ}$ (ROJ AAP CA 490/2011) conforme al cual: "[...] Ahora bien, el carácter imperativo con que resuelve la Juez "a quo" en el auto recurrido supondría la innecesariedad del juicio posterior ya que será el Juez ante el que se celebre en su caso el juicio el que valorará todas las pruebas que se practiquen en dicho procedimiento, y entre ellas, lo actuado en lasdiligencias preliminares, conforme con lo previsto en el artículo 261.4 de la Ley de Enjuiciamiento Civil: "se podrán tener por ciertos" a los efectos del juicio posterior. A diferencia del supuesto de la ficta confessio que se contempla en el aludido precepto legal, la dicción del precepto es inequívoca y su interpretación literal abona que no es el Juez del procedimiento preliminar sino aquel que conozca del procedimiento principal, en el que lo actuado debe desplegar alguna virtualidad, quien podrá valorar el resultado de lo acontecido en aquel. Con independencia de lo que quisiera decir la norma, la locución "a los efectos del juicio posterior" vale tanto como en el seno del procedimiento posterior, y, en consecuencia, quien conozca del mismo será el llamado a ponderar, atendiendo las circunstancias del caso y a la actividad probatoria que ante él se practique, la eficacia que daba atribuirse a la conducta, omisiva o no de quien fue sujeto pasivo en el procedimiento preliminar, aunque solo sea porque el peticionario no tiene que aportar documentos contables o cuentas de clase alguna sobre cuya certeza haya de pronunciarse el Juez. La doctrina jurisprudencial de las Audiencias Provinciales es prácticamente unánime al considerar que el procedimiento preliminar ni se oriente ni puede serle reconocida una función que trascienda la meramente declarativa del proceso posterior y eventual, ajena por ello al aseguramiento o preconstitución y anticipación probatorias respecto a las cuestiones de fondo a dilucidar en el contingente proceso principal. A lo sumo, del resultado negativo de la diligencia preliminar puede seguirse una presunción iuris tantum favorable a las afirmaciones y datos suministrados por el peticionario de aquella y puede integrarse, si se presentara en el proceso principal posterior, como un elemento más de juicio junto con el resto del acervo probatorio que se practique, el cual acaso desvirtúe, en mayor o menor medida o revele completamente inexactos los datos, argumentos y documentos presentados por quien fue solicitante en las diligencias preliminares, existiendo dos preceptos específicos (los artículos 328 y 329 de la Ley de Enjuiciamiento Civil) que regulan dicha solicitud dentro ya del proceso principal". En el mismo sentido, el AAP de Barcelona (sección 4a) de 27 de noviembre de 2003, ponente Ilma. Sra. Montserrat Nebrera, f.j.2 $2^{\circ}$ (LA LEY 196590/2003) cuando señala: "[...] La doctrina se ha expresado ya sobre el hecho de que la negativa a declarar sobre hechos relativos a la capacidad, representación o legitimación no provoca la ficta confessio, y ello ha de entenderse necesariamente correcto, a pesar de la dicción del art. 261,1de la LEC, en el que primero se dice que:"se podrán tener por respondidas afirmativamente las preguntas que el solicitante pretendiera formularle" y a renglón seguido (unido por conjunción copulativa) se dice que:"los hechos correspondientes se considerarán admitidos a efectos del juicio posterior."Además de recordar todos los autores la necesidad de que la actuación judicial se someta al principio de proporcionalidad ya enunciado en numerosas ocasiones por el Tribunal Constitucional (STC 126/1995, 59/1995, etc.), respecto de actuaciones del juez civil que puedan incidir directamente en las libertades ciudadanas, traen algunos a colación lo que a juicio de esta Sala es el meollo de la cuestión, cuanto menos en orden a la aparente contradicción que incorpora el mencionado apartado primero del art. 261.En efecto, interpretado de modo lógico-sistemático, el efecto del precepto legal no puede referirse al momento en que pretenden practicarse las diligencias preliminares, sino al juicio posterior en el que éstas se utilicen.En dicho juicio, la valoración de la prueba debe hacerse de acuerdo con las reglas de la sana crítica y en el conjunto de las 
A la vista de todo lo expuesto, entendemos que concurren razones más que suficientes para afirmar que los términos de la medida contemplada en el art. 261.1 LEC responden a una contradicción propia de un descuido que, además, y a nuestro juicio, da lugar a una deficiente técnica legislativa ${ }^{708}$.

Y es que no se entiende que el art. 261.1 LEC conserve, como no podría ser de otra manera, la capacidad de decisión del juzgador respecto de las preguntas que formule el solicitante en relación a la capacidad, representación o legitimación, al prever que podrán, o no, tenerse por respondidas afirmativamente y, sin embargo, imponga la admisión de hechos al determinar que estos se considerarán admitidos, cuando se entiende que aquellas guardarán relación con estos y que, por tanto, responden a una misma dimensión. Es decir, que no se entiende que el legislador imponga la admisión de unos hechos determinados que pueden resultar contradictorios con el sentido de las respuestas que se tengan o no por respondidas afirmativamente.

Por otro lado, no se entiende que el art. 261.1 LEC imponga que los hechos correspondientes se consideren admitidos a efectos del juicio posterior cuando las afirmaciones y certezas que se deriven del efecto contemplado en el art. 261.1 LEC, en dicho juicio posterior, no podrán tener más consideración que la de prueba material, es

practicadas, de modo que pueda (o no) llegar a tenerse por confeso a quien se negó a la práctica de las diligencias.De tal modo, la presunción iuris tantum que operaba en su contra desde las diligencias, puede quedar destruida por prueba en contrario, pero incluso también podría determinarse la absolución del sujeto en cuestión en la sentencia". También el AAP de Castellón (sección $1^{\text {a }}$ ) de 30 de diciembre de 2002, ponente Ilmo. Sr. J.F. Morales, f.j.3 (LA LEY 218074/2002) cuando señala: “[...] Pasando al fondo del asunto, y enlazado con lo anterior debe de significarse, sin entrar a dilucidar que suponen las diligencias preliminares, perfectamente definidas en el fundamento segundo de la sentencia recurrida, respecto a la acreditación del crédito que se esgrime por la apelante, hemos de apuntar que el Auto de tan repetida referencia, relativo a las diligencias preliminares, en su parte dispositiva, estimó la oposición formulada por el demandado, hoy apelado, resolución que resultó firme, precisando en su segundo apartado «que se tienen por cierto a los efectos del juicio posterior la factura y los documentos de disolución, liquidación y reparto entre los socios de Dirección 000, CB", es decir, el efecto pretendido no puede alcanzar al demandado, y aunque si bien debió de existir algún error de transcripción, al decir «se tienen por cierto», cuando hubo de usar la expresión «se podrán tener», eliminando toda presunción de carácter inatacable, no es menos cierto, que en el fundamento de derecho segundo de la sentencia se expresa correctamente «la posibilidad de tener por cierto», siendo conforme con lo previsto en el art. 261.4 de la LEC «se podrán tener por ciertos» a los efectos del juicio posterior»"

${ }^{707}$ Garnica Martín, J.F., De las diligencias..., ob. cit., p. 1185.

${ }^{708}$ Así parece considerarlo Damián Moreno, J., Comentarios a la ..., ob. cit., p. 1697 cuando apunta que: "la LEC merece el suspenso más rotundo en cuanto a la técnica procesal que adopta". 
decir, que el de la prueba que se práctica y surte sus efectos fuera del proceso ${ }^{709}$. La posibilidad de que tales afirmaciones y certezas sean llevadas al proceso que se pretende preparar no les confiere el carácter procesal que reviste la prueba como acto del proceso que ha de darse en éste y bajo la dirección de la autoridad judicial que conozca del mismo. Lo anterior, sin perder de vista que, conforme al art. 216 LEC, los tribunales civiles decidirán los asuntos en virtud de las aportaciones de hechos, pruebas y pretensiones de las partes, excepto cuando la ley disponga otra cosa en casos especiales. $\mathrm{Y}$ respecto de las afirmaciones y hechos que, conforme al tenor literal del art. 261.1 LEC, puedan tenerse por efectuadas y deban tenerse por admitidos en el ámbito de las diligencias preliminares, ninguna excepción prevé la LEC. Es decir, que en modo alguno la LEC permite a los tribunales decidir los asuntos que se sometan a su consideración conforme al sentido de las afirmaciones que se hayan tenido por efectuadas y los hechos que se hayan debido admitir en sede de diligencias preliminares.

Por último, las previsiones del art. 261.1 LEC no son acordes al espíritu de otras similares contenidas en la LEC, como es el caso del art. 304 LEC cuando dispone que si la parte citada para el interrogatorio no compareciere al juicio, el tribunal podrá considerar reconocidos los hechos en que dicha parte hubiese intervenido personalmente y cuya fijación como ciertos le sea enteramente perjudicial, además de imponerle la multa a que se refiere el aptdo. $4^{\circ}$ del art. 292 LEC, señalando expresamente el apercibimiento al interesado de producirse el efecto indicado para el caso de incomparecencia injustificada, lo que no ocurre en el caso del art. 256.1.1LEC aún cuando debe entenderse igualmente necesario. Ni que decir tiene que el efecto analizado no es acorde a la posibilidad de que quien finalmente resulte demandado en el ulterior juicio no sea quien haya comparecido en las diligencias preliminares como sujeto legitimado pasivamente ${ }^{710}$ y que las cuestiones relativas a la legitimación, capacidad o

\footnotetext{
${ }^{709}$ Cfr. Gimeno Sendra, V., Derecho Procesal Civil..., ob. cit., p. 402.

${ }^{710}$ Así lo pone de manifiesto Pérez Benítez, J.J., Efectos de las..., ob. cit., p. 10 afirmando que "desde el punto de vista subjetivo: la consecuencia de la posible o forzada ficta confessio tan sólo puede afectar al requerido de quien se ha solicitado la declaración, sin que quepa su posible extensión a otras personas, a diferencia de lo previsto en el ap. 5. ${ }^{\circ}$, donde expresamente se prevé la referencia a cualquier otra persona que pudiere colaborar en la determinación de los integrantes del grupo... o a los intervinientes en la infracción de los derechos especiales; de evidencia, la persona objeto de la diligencia ha de ser parte demandada principal en el proceso ulterior, para que pueda cerrarse el círculo de la previsión legal".
} 
representación son cuestiones de orden público apreciables de oficio por el tribunal ${ }^{711}$ que, aún la incomparecencia del demandado en el posterior proceso, han de ser objeto de especial consideración por parte del juzgador. En consecuencia, aún el efecto previsto en el art. 261 LEC, si en el ulterior proceso el tribunal efectúa una valoración de la legitimación, capacidad y representación distinta, o contraria, a la que se hubiera alcanzado por aplicación de las medidas previstas en el art. 261.1 LEC, no podrá otorgarse a esta mayor y superior relevancia que la que dimane de la propia valoración del juzgador en el proceso principal ${ }^{712}$.

Lo señalado anteriormente, con mayor importancia, resulta de aplicación al segundo de los supuestos antes apuntados, contemplado en el art. 261.4 LEC, relativo a la exhibición de documentos contables, a cuyo respecto dispone el precepto legal que se podrán tener por ciertos las cuentas y datos que presente el solicitante. Ello habida cuenta que la presentación en juicio posterior de los referidos documentos contables y, más concretamente, del contenido real que se desprenda de los mismos, en virtud de la

También, Álvarez Alarcón, A., Las diligencias preliminares..., ob. cit., p. 66. En la doctrina judicial vid. la SAP de Castellón (sección $1^{\text {a }}$ ) de 30 de diciembre de 2002, ponente Ilmo. Sr. J.F. Morales, f.j.3º (LA LEY 218074/2002), cuando señala: “[...] En todo caso, independientemente del razonamiento expuesto, es meridiano que sólo en los supuestos en que el destinatario de la diligencia coincida con el demandado pueden producir los efectos de la ficta confessio, y en el caso, justificada la oposición del demandado, los efectos pretendidos sólo pueden darse respecto a los participes en la comunidad de bienes objeto de las diligencias, careciendo de eficacia lo dispuesto en el Auto con el carácter de general que se aduce, y sin consecuencia alguna con respecto al demandado, por tanto, el argumento ha de ser desestimado".

${ }^{711}$ Es doctrina del TS la que establece que "la existencia o no de legitimación "ad causam" es cuestión que afecta al orden público procesal, examinable de oficio y aún cuando las partes no la hayan planteado. En dicho sentido, SSTS de 3 de julio de 2000 (sala 1 ${ }^{\text {a }}$, ponente Ilmo. Sr. D. P. González, f.j.2º (LA LEY 10014/2000), de 12 de diciembre de 2006 (sala $1^{\text {a }}$ ), ponente Ilmo. Sr. P. González, f.j.4 ${ }^{\circ}$ (LA LEY 150010/2006) y de 13 de diciembre de 2006 (sala $1^{\text {a }}$ ), ponente Ilmo. Sr. P. González, f.j.5º (LA LEY 150016/2006), entre otras. En cuanto a la posibilidad de apreciar de oficio la capacidad o conducción procesal, Gimeno Sendra, V., Derecho Procesal Civil..., ob. cit., p. 132.

${ }^{71}$ Al respecto, García Vila, M., Diligencias preliminares y..., ob. cit., pp. 8-9, cuando afirma que en ningún caso lo acordado por el órgano que conoce de las diligencias preliminares, en cuanto al resultado de la diligencia en caso de negativa del sujeto pasivo a la práctica de la misma, vinculará al tribunal del ulterior proceso dado que es posible que las respuestas en aquellas dadas o tenidas por ciertas se desvirtúen a lo largo de este siendo al tiempo del dictado de la sentencia cuando, junto con la valoración del resto de las pruebas, el tribunal decida sobre la certeza de las mismas. En similares términos, indica Álvarez Alarcón, A., Las diligencias preliminares..., ob. cit., p. 63 que: “considerando las razones de orden público que subyacen en las cuestiones objeto de esta clase declaraciones preliminares, no parece que pueda quedar vinculado el tribunal postrero por ellas" y en el caso de acreditarse el carácter falso de las respuestas "además de podérsele imponer al declarante una multa por contrariar la buena fe procesal (artículo 247), el actor debe tener la facultad de exigir indemnización por los daños y perjuicio, que comprenderá, cuando menos, las costas del proceso posterior fallido por casa del dañino comportamiento del declarante falsario". 
actividad probatoria cuya correcta valoración debe llevar a término el tribunal, no podrá decaer frente a esa certeza que pudiera derivarse de la negativa a la práctica de la diligencia.

\subsection{Medidas de intervención}

De forma particular, el aptdo. $5^{\circ}$ del art. 261 LEC dispone que tratándose de las diligencias previstas en ordinal $6^{\circ}$ del art. 256.1 LEC, ante la negativa del requerido o de cualquier otra persona que pudiera colaborar en la determinación de los integrantes del grupo, el tribunal ordenará que se acuerden las medidas de intervención necesarias, incluida la de entrada y registro, para encontrar los documentos o datos precisos, sin perjuicio de la responsabilidad penal en que se pudiera incurrir por desobediencia a la autoridad judicial.

En relación a dicha disposición, y al margen de la medida de entrada y registro cuyo análisis será abordado más adelante, debe llamarse la atención sobre las que el precepto legal, sin mayor detalle, denomina medidas de intervención necesarias y respecto de las que la doctrina apenas se ha pronunciado. De hecho, no encontramos en la judicial supuesto alguno que haya sido publicado, lo cual tampoco es extraño si tenemos en cuenta que entre las resoluciones judiciales que habitualmente acceden a las bases de datos jurídicas no están las de los Juzgados de Primera Instancia y que las que estos dicten acordando las medidas que resulten oportunas en el caso de negativa a colaborar en la práctica de las diligencias preliminares no son susceptibles de recurso alguno.

Por ello, nuestro estudio al respecto únicamente podrá recoger las escasas opiniones doctrinales habidas en relación a la cuestión y que apuntan a la voluntad del legislador de dejar a criterio del tribunal la adopción, en el caso concreto, de cuantas medidas resulten necesarias en unos supuestos tan complejos como los de la defensa de los intereses colectivos de los consumidores ${ }^{713}$ afirmando que en ellas pueden

\footnotetext{
${ }^{713}$ En dicho sentido, Álvarez Alarcón, A., Las diligencias preliminares de..., ob. cit., p. 68.
} 
entenderse incluidas las declaraciones, exhibiciones de libros o documentos, entre otras $^{714}$. Ello, en consecuencia lógica a los tan amplios términos en los que el ordinal $6^{\circ}$ del art. 256.1 LEC prevé la posibilidad de adoptar, para la concreción de los integrantes del grupo de afectados, las medidas oportunas para su averiguación ${ }^{715}$.

Conforme a todo lo hasta ahora expuesto, es nuestro parecer el de entender que, efectivamente, cuando en el art. 261.5 LEC el legislador hace referencia a la orden de las medidas de intervención necesarias, utilizando un tiempo verbal imperativo, y determinando que en ellas debe entenderse incluida la entrada y registro, está dejando la puerta abierta al juzgador para que, en atención al caso concreto, pueda adoptar cuantas medidas imaginables sean conducentes a la obtención de la información que permita la individualización e identificación de los integrantes del grupo de consumidores y usuarios afectados. Tal decisión se justificaría, a nuestro juicio, en la notoria voluntad del legislador de reforzar la protección jurisdiccional del colectivo aludido eliminando cortapisas que en una interpretación rigorista de la norma puedan mermar las posibilidades de preparación del ulterior proceso. Más aún cuando en la práctica de la diligencia preliminar trasciende una verdadera actividad investigadora que en muchos casos habrá de entenderse con aquellos frente a los que se dirigirá el ulterior proceso.

Con dicho objetivo, entendemos que al amparo de la previsión del art. 261.5 LEC el órgano judicial podrá acordar cuantas medidas o actuaciones resulten idóneas para la identificación del grupo de consumidores y usuarios afectados.

\footnotetext{
${ }^{714}$ Corbal Hernández, J.E., Diligencias Preliminares (arts...), ob. cit., p. 3357. En el mismo sentido parece apuntar Banacloche Palao, J., Las diligencias preliminares..., ob. cit., p. 209 cuando explica que las singularidades del art. 261.5 $5^{\mathrm{a}}$ LEC al origen exclusivamente parlamentario de la norma en el que para completar y reforzar la regulación del art. 256.1.6 LEC se decidió aprovechar la enmienda referida a la supresión de la medida de garantía que puede acompañar a la diligencia de exhibición de la cosa (núm. 298 del Grupo Socialista) para la modificación del art. 261 LEC añadiendo su aptdo. $5^{\circ}$, lo que le lleva al autor a entender que las citadas medidas de intervención podrían referirse a las reguladas en casos anteriores como la de entrada y registro o a otras cuya mención específica no sería necesaria, tales como la exigencia de responsabilidad penal.

${ }^{715}$ Garnica Martín, J.F., De las diligencias..., ob. cit., p. 1190.
} 


\subsection{La entrada y registro como consecuencia de la negativa a la práctica de las diligencias preliminares}

\subsubsection{Planteamiento general de la cuestión}

La Exposición de Motivos de la LEC, en su apartado X, ya señaló que las diligencias preliminares del proceso establecidas en la ALEC no distaban mucho del completo desuso. Las escasas consecuencias prácticas ante la negativa a llevar a cabo los comportamientos preparatorios previstos, pese a que el tribunal considerara justificada la solicitud del interesado, explicaban su casi nula utilidad.

Por ello, con el convencimiento de que caben medidas eficaces para la preparación del proceso, la LEC innova el régimen anterior introduciendo una serie de consecuencias a dicha negativa, con la finalidad de dotar a las diligencias preliminares de una mayor efectividad. De este modo, se sustituye el sistema sancionador e indemnizatorio contenido en el art. 501 ALEC por una serie de medidas de carácter coercitivo $^{716}$.

Sin embargo, esta voluntad renovadora de la LEC que tan necesaria se hacía para evitar la extinción de las diligencias preliminares, vino acompañada de una fuerte crítica que, si bien se ha visto mitigada con las distintas reformas que desde la aprobación de aquella se han venido sucediendo, se mantiene hoy en día en relación a alguna de las consecuencias previstas para el caso de que el sujeto pasivo obligado a prestar la colaboración fijada por el tribunal no atienda al requerimiento que se le efectúe.

De entre todas las consecuencias que la LEC prevé para el caso de negativa injustificada a la práctica de las diligencias preliminares, la entrada y registro en lugar determinado constituye tanto la más novedosa como la más cuestionada ${ }^{717}$. La

\footnotetext{
${ }^{716}$ Así se recoge en Corbal Hernández, J.E., Diligencias Preliminares (arts...), ob. cit., p. 3533.

${ }^{717}$ La línea crítica fue encabezada por autores como Lorca Navarrete, A.M., Las diligencias preliminares, en "Comentarios a la nueva Ley de Enjuiciamiento Civil”, T.II, edit. Lex Nova, Valladolid, 2000, pp.
} 
incidencia que la misma pudiera tener sobre el derecho fundamental a la inviolabilidad del domicilio reconocido en el art. $18 \mathrm{CE}$ es la piedra angular de una polémica que se mantiene en la actualidad.

No obstante, partiendo del reconocimiento de la posibilidad de acordar la entrada y registro como consecuencia de la negativa del requerido a la práctica de determinadas diligencias preliminares, la LEC contempla una serie de supuestos tasados en que dicha medida puede ser adoptada.

Ahora bien, los términos en que la LEC configura los supuestos en que puede ser acordada no siempre tienen fácil encaje en la realidad de la práctica forense, aunque veremos cómo pueden ser adaptados para dar cumplimiento a ese fin que el legislador persiguió con la nueva regulación de las diligencias preliminares.

Por otro lado, no en todos los supuestos en que la LEC prevé la adopción de la medida de entrada y registro, como consecuencia de la negativa a la práctica de la diligencia preliminar, procederá su adopción, pues se requiere el cumplimiento de una serie de requisitos que, en todo caso, deberán concurrir para que el tribunal adopte la medida de entrada y registro. Así, la concurrencia de indicios suficientes, la falta de atención del requerimiento o de oposición y la proporcionalidad de la medida se presentan como circunstancias que, ineludiblemente, tienen que estar presentes para la aceptación de la medida de entrada y registro.

1680-1702. Más tarde, por Callejo Carrión, S., Las diligencias preliminares..., ob. cit., pp. 17-23. Incluso, antes de introducirse la medida en el ordenamiento jurídico español, el informe del Consejo General del Poder Judicial al Anteproyecto de la LEC, puso de manifiesto la posibilidad de que la realización de la medida "generase situaciones de conflicto con el derecho a la inviolabilidad del domicilio, con las consecuencias problemáticas que la casuística pudiera plantear, incluyendo la necesidad de un expreso razonamiento y de un juicio de proporcionalidad sobre la necesidad de la medida, aunque con una eficacia relativa a efectos pretendidos". Señalaba igualmente dicho informe, que "el hecho de que el Juez civil pudiera en estos casos ser considerado al propio tiempo juez de las libertades, que esté facultado para llevar a cabo la ponderación preventiva de los intereses en juego como garantía del derecho fundamental (STC 160/1991) no excluía la necesidad de cumplimiento de los demás requisitos establecidos por la doctrina constitucional (SSTC 126/1995, 59/1995, 22/1984, 137\1985)”. Concluía el CGPJ que "Sería más razonable quizá anudar consecuencias a dicha negativa semejantes a la no presentación de documentos contables (art. 263.4) teniendo por ciertas las manifestaciones efectuadas sobre su contenido por el solicitante satisfaciendo así las exigencias de la propia jurisprudencia constitucional en torno a la proximidad a las fuentes de prueba (SSTC 227/1991 y 116/1995)". 


\subsubsection{Precedentes de la medida en otros órdenes jurisdiccionales}

Como ya se ha apuntado en el planteamiento general de la cuestión, la diligencia de entrada y registro en lugar determinado, como consecuencia de la negativa injustificada a la práctica de determinadas diligencias preliminares, constituye una novedad introducida en el orden jurisdiccional civil español por la actual LEC como reacción al desuso en que las diligencias preliminares cayeron bajo el imperio de la $\mathrm{ALEC}^{718}$.

No obstante, la entrada y registro es una medida de investigación tan habitual como tradicional en el proceso penal que, como medio de investigación del delito, la recoge en los arts. 545 y ss. LECRIM.

También, el art. 8.6 LJCA prevé la autorización por los Juzgados de lo Contencioso-administrativo de la entrada en domicilios y restantes lugares para la ejecución forzosa de actos de la administración pública ${ }^{719}$.

\footnotetext{
${ }^{718}$ Según Ramos Méndez, F., Enjuiciamiento Civil. Cómo..., ob. cit., p. 1154, "la parte más novedosa y más interesante de la nueva regulación es la relativa a las consecuencias de la conducta oclusiva de la parte gravada por las diligencias, si no atiende el requerimiento judicial o si no formula oposición".

${ }^{719}$ Debe recordarse en este punto que, inicialmente, la autorización de la entrada en determinados lugares, en ejecución forzosa de los actos de la Administración, correspondía a los Juzgados de Instrucción. Como señala Ariza Colmenarejo, M.J., Consideraciones en torno a la entrada y registro del proceso civil. Aspectos constitucionales, en "Diario La Ley", 2004, núm. 6015, p. 2, operaba el principio de exclusividad jurisdiccional con el fin de que una medida limitativa de un derecho fundamental fuera adoptada por un órgano jurisdiccional y sin que la Administración pudiera autorizarlo, de forma tal que "sólo el orden jurisdiccional penal podía acordar medidas limitativas de derechos fundamentales, como es el caso del derecho a la inviolabilidad del domicilio, pero únicamente con el fin de asegurar los requisitos de la entrada, sin entrar a analizar la legalidad del acto administrativo que se pretendía ejecutar (STC 144/1987, de 23 de septiembre de 1987)". En la redacción inicial del art. 87.2 LOPJ se disponía que a los Juzgados de Instrucción correspondía "la autorización en resolución motivada para la entrada en los domicilios y restantes edificios o lugares de acceso dependiente del consentimiento de su titular, cuando ello proceda para la ejecución forzosa de los actos de la Administración”. Sin embargo, hoy, el art. 91.2 LOPJ atribuye expresamente a los órganos de la jurisdicción Contencioso-Administrativa la autorización, mediante auto, de la entrada en los domicilios y restantes edificios o lugares cuyo acceso requiera el consentimiento de su titular, cuando ello proceda para la ejecución forzosa de los actos de la Administración, salvo que se trate de la ejecución de medidas de protección de menores acordadas por la entidad pública competente en la materia.
} 
Y, en el específico ámbito mercantil de la jurisdicción civil, el art. 1.1.3 ${ }^{\mathrm{a}}$ LORC, prevé la competencia del Juez de lo Mercantil para la adopción de la medida de entrada en el domicilio del deudor y su registro.

Ello, al margen de otra serie de medidas ejecutivas como el típico lanzamiento del procedimiento de desahucio (art. 703 LEC) que, aún constituyendo una auténtica injerencia en el domicilio de los ciudadanos, apenas merecen crítica alguna por parte de la doctrina científica y judicial.

Sin embargo lo anterior, en el orden jurisdiccional procesal civil más puro, el de la LEC, la diligencia de entrada y registro en lugar cerrado, como consecuencia de la negativa a la práctica de la diligencia preliminar ya acordada, constituye el objeto de un debate constitucional que, a la fecha, sigue sin ser resuelto. Esta duda de constitucionalidad junto al tradicional halo penal que la misma reviste ${ }^{720} \mathrm{es,} \mathrm{a} \mathrm{nuestro}$ juicio, la causa de lo inusual de su adopción por los órganos de la jurisdicción civil y con fundamento en el art. 261 LEC.

\footnotetext{
${ }^{720}$ Ello, pese a que el TC señaló que el juez penal no ostenta el monopolio de las autorizaciones para la entrada y registro en los domicilios. La STC 22/1984, de 17 de febrero de 1984, ponente Ilmo. Sr. L. Díez-Picazo f.j. $3^{\circ}$ (LA LEY 8565-JF/0000), tras declarar que no comparte la tesis según la cual «sólo el Juez que conoce de una causa criminal puede expedir un mandamiento de entrada y registro y que el art. 117.3 y 4 de la Constitución impide al Poder Judicial ejercitar otras funciones que no sean las de juzgar y hacer ejecutar lo juzgado», afirma que «la Autoridad judicial está investida de la suficiente potestad para otorgar las autorizaciones de entrada y registro, de la misma manera que ocurre en el apartado 3 del art. 18, donde se inviste a los Jueces de potestad para permitir el levantamiento parcial del secreto de las comunicaciones», sino, aún más claramente, que «ante todo, hay que dejar claro que el Juez a quien se confiere la protección del derecho fundamental a la inviolabilidad del domicilio no es necesariamente el Juez penal encargado de una instrucción sumarial, el cual sólo tiene que intervenir cuando la entrada en un domicilio guarde relación directa con la investigación sumarial que lleve a cabo». Y concluye: «Nada permite inferir que ningún orden jurisdiccional -fuera del Juez penal- puede intervenir cuando se le solicite la autorización para la entrada en el domicilio de una persona» (fundamento jurídico 3). Es decir, el Tribunal Constitucional deja muy claro en la sentencia citada que el juez penal no ostenta el monopolio de las autorizaciones para la entrada y registro en los domicilios, con lo que está dando a entender que también pueden ser competentes, por ejemplo, los jueces civiles, concretamente, en aquellos supuestos en los que no exista relación directa entre la necesidad de obtener dicha autorización y la persecución de un delito.
} 


\subsubsection{Cuestionamiento constitucional de la adopción de la medida en el orden jurisdiccional civil}

La polémica de la dudosa constitucionalidad de la entrada y registro como consecuencia de la negativa a la práctica de determinadas diligencias preliminares, considerando que la entrada y registro en sede de diligencias preliminares se encuentra regulada en una norma con rango de ley ordinaria, se ha planteado desde dos perspectivas distintas ${ }^{721}$.

De un lado, por la supuesta necesidad de regular esta competencia mediante ley orgánica. En atención a lo dispuesto en el art. 122 CE, se entendía necesario el rango de ley orgánica para toda normativa atributiva de competencia jurisdiccional a los tribunales ordinarios, como así se materializó en el caso de art. 1.1.3 ${ }^{\mathrm{a}}$ LORC y el art. 91.2 LOPJ, respecto de la competencia de los JCA para la autorización de la entrada en los domicilios y restantes edificios o lugares cuyo acceso requiera el consentimiento de su titular en ejecución forzosa de los actos de la Administración.

Y de otro, por la necesidad impuesta constitucionalmente de que las medidas limitativas de derechos fundamentales se regulen mediante ley orgánica (art. 81.1 CE).

En suma, se planteaba si el art. 261 LEC contravenía el derecho fundamental a la inviolabilidad del domicilio consagrado en el art. 18.2 CE en tanto que configura una medida de entrada y registro invasiva del ámbito personal que constituye el domicilio, sin encontrarse específicamente prevista la atribución de la competencia a los órganos de la jurisdicción civil en una ley orgánica, más concretamente en la LOPJ, y sin respetarse la reserva de ley orgánica que el art. 81.1 CE exige para el desarrollo de un derecho fundamental como el contenido en el art. 18.2 CE, que consagra la inviolabilidad del domicilio.

\footnotetext{
${ }^{721}$ Explica con detalle la cuestión Ariza Colmenarejo, M.J, Consideraciones en torno a la entrada y registro del proceso civil. Aspectos Constitucionales, en "Diario La Ley", 2004, núm. 6015 (LA LEY 845/2004), p. 2.
} 
Tal planteamiento, que efectuó el JPI núm. 31 de Barcelona, dio origen a la cuestión de inconstitucionalidad 5090/2002 ${ }^{722}$ de la que conoció el Pleno del TC dictando sentencia de fecha 27 de noviembre de $2012^{723}$ que, finalmente, deja sin resolver la cuestión al ser inadmitida por la concurrencia de defectos procesales en el trámite del art. 35.2 LOTC. Similar planteamiento se reprodujo en el recurso de amparo 5406/2006 en que el TC dicta la sentencia de fecha 3 de noviembre de $2014^{724}$ dejando, igualmente, sin resolver la cuestión al considerar que el demandante de amparo no denunció en la instancia, a través del oportuno recurso, la vulneración del art. 18.2 CE.

\subsubsection{Ausencia de atribución expresa en la LOPJ de la competencia para} adoptar la medida de entrada y registro a los órganos del orden jurisdiccional civil

En atención a lo dispuesto por el art. $122 \mathrm{CE}$, que señala que la LOPJ determinará la constitución, funcionamiento y gobierno de los juzgados y tribunales, se sostenía ${ }^{725}$ la necesidad de regular la competencia en la adopción de la medida de entrada y registro en sede de diligencias preliminares y por los juzgados del orden jurisdiccional civil, mediante la atribución expresa de dicha competencia en la LOPJ. Ello, en iguales términos a lo sucedido con la reforma operada en la LOPJ por la LO 6/1998, que expresamente reconoció la competencia de los Juzgados de lo Contenciosoadministrativo para la autorización de la entrada en los domicilios y en los restantes

\footnotetext{
${ }^{722}$ La cuestión de inconstitucionalidad núm. 5090/2002 fue registrada en el órgano indicado el día 10 de septiembre de 2002 y publicada en el BOE núm. 83, de 7 de abril de 2003, STC 222/2012, de 27 de noviembre de 2012, ponente Ilmo. Sr. L.I. Ortega (LA LEY 198392/2012).

${ }^{723}$ Debe tenerse en cuenta que la sentencia se dicta con posterioridad a la reforma operada por la Ley 19/2006, de 5 de junio, no obstante lo cual ello no produce la carencia sobrevenida de su objeto. A diferencia de lo que sucede en los recursos de inconstitucionalidad, en los que, como regla general y salvo que se trate de una controversia competencial, la derogación de la norma legal impugnada supone la pérdida de objeto del proceso (STC 196/1997, de 13 de noviembre de 1997, ponente Ilmo. Sr. F. GarcíaMon, f.j.2 (LA LEY 66/1998), en las cuestiones de inconstitucionalidad los efectos extintivos sobre el objeto del proceso como consecuencia de la derogación o modificación de la norma cuestionada vienen determinados por el hecho de que, tras esa derogación o modificación, resulte o no aplicable en el proceso a quo y de su validez dependa la decisión a adoptar en el mismo (STC 200/2001, de 4 de octubre de 2001, ponente Ilmo. Sr. V. Conde, f.j. $3^{\circ}$, LA LEY 8066/2001) cual es el caso que nos ocupa en que la disposición transitoria única de la Ley 19/2006, de 5 de junio, preserva para la tendencia existente en el momento de su entrada en vigor la aplicación de las normas anteriores a la misma.

${ }_{725}^{724}$ STC 175/2014, de 3 de noviembre de 2014, ponente Ilma. Sra. E. Roca, f.j.4 (LA LEY 160976/2014).

${ }^{725}$ Ariza Colmenarejo, M.J., Consideraciones en torno..., ob. cit., p. 2.
} 
edificios o lugares cuyo acceso requiriese el consentimiento de su titular y cuando ello procediera para la ejecución forzosa de los actos de la Administración ${ }^{726}$.

No obstante, incluso antes de la publicación de la referida LO 6/1998, las SSTC 93/1988 y 91/1998, de 24 de mayo de 1988 y 23 de abril de $1998^{727}$ respectivamente, ya habían zanjado la cuestión afirmando que no puede concluirse que se requiera rango de Ley orgánica para toda norma atributiva de competencia jurisdiccional a los diversos tribunales ordinarios en tanto que la existencia de tales normas constituye un presupuesto para la efectividad del derecho al juez ordinario predeterminado por la Ley, pero no representan un desarrollo del mismo en los términos del art 81.1 CE.

De hecho, una mera lectura del art. 87 LOPJ, que regula las competencias de los Juzgados de Instrucción, basta para advertir que la competencia para la autorización de la diligencia de entrada y registro que puede adoptarse en el proceso penal, con fundamento en los arts. 545 y ss. LECRIM, no se encuentra atribuida de forma expresa a los Juzgados de Instrucción que habitualmente hacen uso de ella ${ }^{728}$.

No obstante todo lo anterior, tras la promulgación del texto constitucional queda claro que es la propia norma constitucional, y más concretamente su art. $18.2 \mathrm{CE}^{729}$, la que habilita al órgano judicial, sin distingo de jurisdicción alguna, para acordar la medida en cuestión.

\footnotetext{
${ }^{726}$ Debe tenerse en cuenta que el art. 91.2 LOPJ ha sido recientemente reformado por el aptdo. $2^{\circ}$ de la Disposición Final Primera de la Ley Orgánica 8/2015, de 22 de julio, en el sentido de excluir de tal competencia la ejecución de las medidas de protección de menores acordadas por la entidad pública competente en la materia.

${ }^{727}$ SSTC 91/1998, de 23 de abril de 1998, ponente Ilmo. Sr. M. Jiménez de Parga, f.j.2º (LA LEY 6663/1998) y 93/1988, de 24 de mayo de 1988, ponente Ilmo. Sr. L. López, f.j.2 (LA LEY 1008TC/1988).

${ }^{728}$ Algún autor como Banacloche Palao J., Las diligencias preliminares..., ob. cit., p. 203, considera que el art. 87 LOPJ no atribuye específicamente a los Juzgados de Instrucción la competencia para ordenar entradas y registros en los procesos penales porque se considera que la misma es una actuación que forma parte de las competencias naturales de aquéllos en materia de instrucción. Aun cuando, a nuestro juicio, no puede olvidarse que la LECRIM es una norma anterior a la CE y que, por dicho motivo, no hubo de observar lo dispuesto en el art. 81.1 de la misma.

${ }^{729}$ Como señala Ramos Méndez, F., Enjuiciamiento Civil. Cómo..., ob. cit., p. 1154, la autorización de una entrada y registro por parte de un tribunal civil y en el ámbito de sus competencias colman las exigencias del art. 18.2 CE y no puede cuestionarse dicha resolución por el hecho de ser adoptada en función de un juicio futuro que puede llegar a no existir, toda vez que es una actuación necesaria para el éxito de la diligencia preliminar y una actuación reglada como cualquier otra.
} 
Por lo expuesto, y a nuestro juicio, el legislador de la LEC pudo entender que resultaba innecesario que la atribución de la competencia para la adopción de la medida de entrada y registro por los órganos del orden jurisdiccional civil, en sede de diligencias preliminares, debiera contemplarse de forma expresa en la LOPJ. Máxime, cuando el propio art. 257 LEC dispone que corresponde a los JPI o JMER, la competencia para resolver las peticiones y solicitudes de diligencias preliminares y, por ende, entendemos, para acodar, conforme al art. 261 LEC, las medidas contempladas por la propia LEC para el caso de negativa injustificada del requerido a la práctica de las diligencias preliminares.

\subsubsection{Ausencia de reserva de ley orgánica que el art. 81.1 CE exige para el desarrollo de un derecho fundamental como el contenido en el art. 18.2 CE}

Disponiendo el art. 81.1 CE que son leyes orgánicas las relativas, entre otras, al desarrollo de los derechos fundamentales y de las libertades públicas, el segundo plano del debate de constitucionalidad que el art. 261 LEC plantea es la circunstancia de posibilitar dicha norma procesal, que no tiene el carácter de orgánica, sino de ordinaria, una medida de entrada y registro que pueda afectar, de forma directa, al derecho a la inviolabilidad del domicilio contemplado en el art. 18.2 CE.

La LEC se separa de la técnica legislativa seguida tras las promulgación de la CE en la habilitación a otros órganos jurisdiccionales, como los de lo Contenciosoadministrativo, cuya regulación de competencia para la autorización de entrada y registro se ha hecho en ley orgánica, manteniéndose en la actualidad como el único supuesto legal de entrada y registro que, previsto en norma posterior a la entrada en vigor a la $\mathrm{CE}$, no se contiene en norma con rango de orgánica, pese a su posible directa incidencia sobre el derecho a la inviolabilidad del domicilio contenido en el art. 18.2 CE. 
Sentado lo anterior, debe recordarse, en relación a la necesidad de ley orgánica para el supuesto de afección de derechos fundamentales, que como reiteradamente ha declarado el TC sólo se requiere para la definición del derecho fundamental ${ }^{730}$. Bien cuando dicha definición se efectúe con una regulación directa, general y global del mismo, bien cuando lo sea de forma parcial o sectorial pero, en todo caso, cuando aborde aspectos esenciales del derecho, aún parciales, pero que contribuyan a la delimitación y definición legal del derecho.

Pero, igualmente, debe recordarse que la STC 22/1986, de 14 de febrero, señaló que las normas reguladoras de las vías procesales previstas en el ordenamiento, como la LEC, no son normas de desarrollo del art. 24.1 CE, en el sentido del art. 81.1 CE, por lo que no precisan ley orgánica ${ }^{731}$.

Así las cosas, requiriéndose una ley orgánica sólo para la definición del derecho fundamental o para el caso de regulación de aspectos esenciales del derecho, como pudiera ser la regulación que la LEC hace de la medida de entrada y registro en lugar determinado, y siendo la LEC, que no tiene el rango de orgánica, por definición, una norma reguladora de las vías procesales en el orden jurisdiccional civil, resulta que, a nuestro juicio, en su art. 261, configura una auténtica habilitación al Juez de Primera Instancia para la adopción de tal medida, que bien puede considerarse una norma de desarrollo en el sentido del art. 81.1 CE.

Ello, en términos similares a las previsiones del art. 763.1 LEC que regulan tanto la habilitación al juez para acordar la medida de internamiento forzoso de las personas

\footnotetext{
${ }^{730}$ En dicho sentido, SSTC 6/1982, de 22 de febrero de 1982, ponente Ilmo. Sr. P. Fernández, f.j. $6^{\circ}$, (LA LEY 41-TC/1982), 67/1985, de 24 de mayo de 1985, ponente Ilmo. Sr. R. Gómez-Ferrer, f.j.3으, (LA LEY 10027-JF/0000), 140/1986, de 11 de noviembre de 1986, ponente Ilmo. Sr. L. López, f.j.5º (LA LEY 686TC/1987), 149/1986, de 26 de noviembre de 1986, ponente Ilmo. Sr. E. Díaz, f.j. $2^{\circ}$ (LA LEY 673TC/1987), 160/1987, de 27 de octubre de 1987, ponente Ilmo. Sr. C. De la Vega, f.j. $2^{\circ}$, (LA LEY 888TC/1988),12711994, de 5 de mayo de 1994, ponente Ilmo. Sr. V. Gimeno, f.j.3 (LA LEY 17142/1994) y 132/1989, de 18 de julio de 1989, ponente Ilmo. Sr. L. López, f.j.6º, (LA LEY 2382/1989), añadiendo esta última como campo reservado a la Ley orgánica el establecimiento de límites o restricciones a los derechos fundamentales.

${ }^{731}$ STC 22/1986, de 14 de febrero de 1986, ponente Ilmo. Sr. M. Díez de Velasco, f.j.3º (LA LEY 597/1986). A mayor abundamiento, vid. Picó i Junoy, J., Las garantías constitucionales del proceso, edit. J.M. Bosch, $2^{\mathrm{a}}$ edic., Barcelona, 2012, pp. 40-42.
} 
que padezcan trastornos psíquicos como las reglas procedimentales para la conformación de la decisión judicial de internamiento y que llevó al Pleno del TC, en su sentencia 132/2010, de 2 de diciembre, a declarar la inconstitucionalidad de algunos de sus incisos ${ }^{732}$.

Siguiendo el razonamiento expuesto en esta última resolución, a priori, cabe afirmar que no cabe duda de que la garantía de la inviolabilidad del domicilio establecida en el art. 18.2 CE alcanza a quienes se nieguen injustificadamente a la práctica de una diligencia preliminar cuya consecuencia sea la posible adopción de la medida de entrada y registro que se acuerde por el JPI en el seno de unas diligencias preliminares.

Ahora bien, si se repara en que la LEC, cuando se refiere al lugar objeto de la medida de entrada y registro, no lo hace al domicilio ${ }^{733}$ sino al "lugar determinado" en que se encuentren los títulos y documentos, la cosa o los datos en cuestión, se entenderá que tampoco, de forma indiscriminada, pueda afirmarse que la garantía de inviolabilidad del domicilio establecida en el art. 18.2 CE alcanza, en todo caso, a quienes se nieguen injustificadamente a la práctica de una diligencia preliminar cuya consecuencia sea la posible adopción de la medida de entrada y registro. De ahí que, a nuestro juicio, el legislador no utilizara el término "domicilio" y si la expresión "lugar determinado", pues si se atiende al contenido y naturaleza de las diligencias preliminares que enumera el art. 256.1 LEC, resulta fácil colegir que el legislador, al identificar el lugar sobre el que podía recaer la medida con el "lugar determinado", lo hizo en consonancia con la propia naturaleza de las mismas y, por tanto, considerando la posibilidad de que la entrada y registro pudiera ser acordada en relación a cuantos lugares pudieran contener la oportuna información, documentación o datos que a través

732 La STC 132/2010, de 2 de diciembre de 2010, ponente Ilmo. Sr. E. Gay, f.j.2 ${ }^{\circ}$ (LA LEY 213836/2010), parte del planteamiento del JPI núm. 8 de A Coruña, a saber, que el art. 763.1 LEC, párrafos $1^{\circ}$ y $2^{\circ}$, de la Ley 1/2000, de Enjuiciamiento Civil, en cuanto establece uno de los supuestos en que cabe privar a una persona de su libertad, debiera haber sido aprobado con el carácter de ley orgánica.

733 Señala Garnica Martín, J.F., De las diligencias..., ob. cit., p. 1187, que: "La LEC no es todo lo precisa que nos gustaría y no determina lo que debe entenderse por lugar determinado". 
de las mismas diligencias se pretendiera obtener, y que pueden responder o no, en su caso, al concepto de domicilio constitucionalmente protegido.

Por ello, y no haciendo el art. 261 LEC alusión directa al domicilio sino al "lugar determinado", entendemos que la garantía de constitucionalidad que despliega el art. 18.2 CE solo se extendería a aquellos lugares determinados que se identifiquen con el concepto de domicilio constitucionalmente protegido ${ }^{734}$. Cuestión distinta es que, siendo posible que dicho "lugar determinado" coincida con el de domicilio constitucionalmente protegido, se entienda que su regulación, ante tal posibilidad, deba efectuarse por ley orgánica, en todo caso.

En consonancia con lo anterior, entendemos que resulta coherente concluir que, en tanto que constitutiva la medida de entrada y registro de un supuesto de privación o limitación del derecho a la inviolabilidad del domicilio, el precepto que la hace posible sólo puede contenerse en una ley orgánica dada la condición de norma que fija uno de los supuestos en que una persona puede ver limitado tal derecho fundamental y como desarrollo del mismo pues, a nuestro juicio, el art. 261 LEC no constituye una mera regla procedimental para la conformación de la decisión judicial de entrada y registro ${ }^{735}$ sino toda una habilitación legal del juez para la adopción de la medida en los supuestos previstos.

Por todo lo expuesto, y a diferencia de lo considerado en una de las pocas resoluciones de los tribunales ordinarios españoles que tratan la cuestión ${ }^{736}$, no podemos

\footnotetext{
734 Sobre el domicilio constitucionalmente protegido, vid. SSTC 22/1984, de 17 de febrero de 1984, ponente Ilmo. Sr. L. Díez-Picazo, f.j.5º (LA LEY 8565-JF/0000), 94\1999, de 31 de mayo de 1999, ponente Ilmo. Sr. T. Vives, f.j.5 (LA LEY 8094/1999) y 10/2002, de 17 de enero de 2002, ponente Ilma.

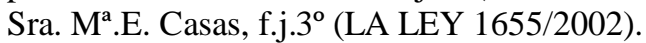

${ }^{735}$ Lo que, conforme a la doctrina establecida en la STC 129/1999, de 1 de julio de 1999, ponente Ilmo. Sr. F. Garrido, f.j.2º (LA LEY 10526/1999), excluiría la inconstitucionalidad.

${ }^{736}$ AAP de Toledo (sección $1^{a}$ ) de 30 de marzo de 2005, ponente Ilmo. Sr. M. Gutiérrez, f.j. $2^{\circ}$ (LA LEY 70219/2005), que: "Debe salirse al paso de una posible denuncia de inconstitucionalidad de la norma por suponer una importante restricción de los derechos fundamentales, en la medida en que pudiera serlo en el proceso penal, y con ello que el legislador haya incurrido en inconstitucionalidad; y ello porque aquí no se trata de un medio de investigación; y no se puede poner en duda que el Juez tiene facultades para allanar la resistencia de un ciudadano condenado a abandonar una vivienda en la que tiene s domicilio y que se niega a abandonarla, tampoco se le puede negar esa misma facultad cuando lo que se pretende es
} 
sino afirmar, con toda la prudencia, que la cuestión merece el vicio de inconstitucionalidad de que adolece el art. 261 LEC.

\subsubsection{Supuestos en que puede acordarse la medida de entrada y registro en} lugar determinado del art. 261 LEC.

Teniendo siempre presente que no puede confundirse la medida de entrada y registro en lugar cerrado que prevé el art. 261 LEC con la diligencia de entrada y registro que puede acordarse en el proceso penal, examinaremos ahora los supuestos en que cabe la adopción de la medida y que, en definitiva, buscan dar efectividad a una diligencia judicial que ya ha sido acordada.

Conforme a lo que dispone el art. 261 LEC $^{737}$, podemos identificar dos supuestos en que puede acordarse la medida de entrada y registro como consecuencia de la negativa del sujeto pasivo a la práctica de la diligencia preliminar previamente adoptada.

\footnotetext{
vencer su resistencia a exhibir un documento u objeto, pues en ambos casos nos encontramos ante la facultad de hacer ejecutar lo juzgado, que forma parte esencial de la potestad jurisdiccional".

737 "Si la persona citada y requerida no atendiese el requerimiento ni formulare oposición, el tribunal acordará, cuando resulte proporcionado, las siguientes medidas, por medio de un auto, en el que expresará las razones que las exigen:

$1^{a} \mathrm{Si}$ se hubiese pedido declaración sobre hechos relativos a la capacidad, representación o legitimación del citado, se podrán tener por respondidas afirmativamente las preguntas que el solicitante pretendiera formularle y los hechos correspondientes se considerarán admitidos a efectos del juicio posterior.

$2^{\mathrm{a}} \mathrm{Si}$ se hubiese solicitado la exhibición de títulos y documentos y el tribunal apreciare que existen indicios suficientes de que pueden hallarse en un lugar determinado, ordenará la entrada y registro de dicho lugar, procediéndose, si se encontraren, a ocupar los documentos y ponerlos a disposición del solicitante, en la sede del tribunal.

$3^{\mathrm{a}} \mathrm{Si}$ se tratase de la exhibición de una cosa y se conociese o presumiese fundadamente el lugar en que se encuentra, se procederá de modo semejante al dispuesto en el número anterior y se presentará la cosa al solicitante, que podrá pedir el depósito o medida de garantía más adecuada a la conservación de aquélla. $5^{a}$ Tratándose de las diligencias previstas en el artículo $256.1 .6^{\circ}$, ante la negativa del requerido o de cualquier otra persona que pudiera colaborar en la determinación de los integrantes del grupo, el tribunal ordenará que se acuerden las medidas de intervención necesarias, incluida la de entrada y registro, para encontrar los documentos o datos precisos, sin perjuicio de la responsabilidad penal en que se pudiera incurrir por desobediencia a la autoridad judicial. Iguales medidas ordenará el tribunal en los casos de los números 5 bis, $7^{\circ}$ y $8^{\circ}$ del apartado 1 del artículo 256 , ante la negativa del requerido a la exhibición de documentos".
} 
Uno, cuando con la medida de entrada y registro se pretenda dar satisfacción al derecho del peticionario de exhibición de títulos y documentos así como para la obtención de estos y otros datos; supuestos contenidos en los números 1 y 3 a 5 , así como 5 bis a 8 del art. 256.1 LEC $^{738}$.

Otro, cuando con la medida de entrada y registro se pretenda dar satisfacción al derecho del peticionario de exhibición de la cosa que el requerido tenga en su poder y a la que se haya de referir el juicio (art. 256.1.2 LEC).

\subsubsection{Entrada y registro para la exhibición de títulos y documentos y obtención de estos y otros datos}

El art. 261.2 LEC contempla la posibilidad de adopción de la medida de entrada y registro en lugar determinado para todos aquellos casos en que, conforme al art. 256.1 LEC, se haya solicitado la exhibición de títulos y documentos o cuando resulte preciso la obtención de estos y otros datos, salvo el supuesto previsto en el art. 256.1.4 LEC, cuya consecuencia, se encuentra en el art. 261.4 LEC $^{739}$.

\footnotetext{
${ }^{738}$ En dicho sentido, Garciandía González, P.M., La regulación de..., ob. cit., p. 799.

${ }^{739}$ En relación a las consecuencias de la negativa a la práctica de la diligencia preliminar prevista en el art. 256.1.4 LEC, el art. 261.4 LEC prevé la posibilidad de tener por ciertos, a los efectos de un juicio posterior, la cuentas y datos que presente el solicitante. Ahora bien, la lectura completa del art. 261 LEC permite advertir que el mismo no prevé consecuencia alguna para el supuesto de negativa a la exhibición de otros documentos de la comunidad que no revistan el carácter de contables. Así, al margen de precisiones legales que nos permiten afirmar la escasa virtualidad de la diligencia preliminar prevista en el art. 256.1.4 LEC en cuanto que el objeto de la misma sean los documentos, contables o no, de una sociedad y, que, por imperativo legal, deben ser custodiados en la sede de la sociedad (art. 33 CCo), y nunca por el consocio, cabe plantearse si, ante aquella omisión legal, cabría la posibilidad de adoptar la medida de entrada y registro como consecuencia de la negativa a la práctica de la diligencia preliminar. A nuestro juicio, dadas las características de la medida, el principio de legalidad lo impediría de forma tal que sólo en aquellos supuestos en los que el art. 261 LEC prevé la entrada y registro, entre los que no se encuentran los supuestos de negativa a la exhibición de documentos de una comunidad, podría ser acordada la misma. Matiza la cuestión Álvarez Alarcón, A. Las diligencias preliminares..., ob. cit., p. 66 cuando hace una observación en relación a la duda que pudiera plantear el art. 261.4 LEC. Al respecto, señala el autor que dicho precepto legal se refiere a la exhibición de documentos contables, pero no a la exhibición de documentos de la sociedad, siendo la razón de ello que cuando de documentos de la sociedad se trata, estos pueden ser sometidos al régimen de entrada y registro de la diligencia preliminar, pudiendo ser ocupados y puestos a disposición del actor preliminar. Sin embargo, los documentos contables de una empresa o sociedad no pueden ser llevados de la sede de esta, conforme al art. 327 LEC.
} 
Es decir, cuando se haya solicitado la exhibición de documentos relativos a la capacidad, representación o legitimación (art. 256.1.1 LEC), la última voluntad del causante de la herencia o legado (art. 256.1.3 LEC), el contrato de seguro (art. 256.1.5 LEC), cuando se haya solicitado la historia clínica (art. 256.1.5 bis LEC), o cuando, para la consecución de las diligencias previstas en los supuestos $6^{\circ}$ a $8^{\circ}$ del art. 256.1 LEC, se haga preciso la obtención de documentos y datos.

Respecto de dichos supuestos, cabe advertir que la técnica empleada por la LEC en la regulación de la ordenación de la entrada y registro, y en cada uno de los supuestos agrupados en esta clasificación, es distinta. Por un lado, conforme al art. 261.2 LEC, deben ocuparse los títulos y documentos para así ponerlos a disposición del solicitante, en la sede del tribunal; y, por otro, conforme al art. 261.5 LEC, se debe proceder a encontrar los documentos y datos, sin hacer más precisión al respecto.

a) Ocupación de los documentos y su puesta a disposición del solicitante.

Partiendo de lo anterior, la primera cuestión que nos planteamos, por las dificultades legales y prácticas que a continuación se expondrán, es qué debe entenderse por ocupación y puesta a disposición de solicitante (art. 261.2 LEC), en la sede del tribunal, de los títulos y documentos a que se refieren los supuestos contenidos en los arts. 256.1.1 LEC (exhibición de los documentos en los que conste la capacidad, representación o legitimación), 256.1.3 LEC (exhibición, por quien lo tenga en su poder, del acto de última voluntad del causante de la herencia o legado) y 256.1.5 LEC (exhibición del contrato de seguro por quien lo tenga en su poder). Concretando más aún, si la ocupación y puesta a disposición del solicitante de tales títulos y documentos, en la sede del tribunal, comprende la mera exhibición de los mismos o también su entrega al propio solicitante, al existir alguna opinión doctrinal favorable a su entrega ${ }^{740}$.

\footnotetext{
740 Álvarez Alarcón, A., Las diligencias preliminares..., ob. cit., p. 67, sostiene que esta puesta a disposición no significa que se le exhiban sino que se le hará entrega de ellos para que pueda aportarlos allí donde sea procedente.
} 
Para resolver tal cuestión, entendemos que debemos acudir a la propia regulación de las diligencias preliminares en cuestión advirtiendo que en ninguno de los supuestos contemplados se pretendió por el legislador que tales títulos o documentos en los que debía constar la capacidad, representación o legitimación, contenerse el acto de última voluntad del causante de la herencia o legado, o el contrato de seguro fueran entregados al solicitante. Así, el art. 261.2 LEC refiere la ocupación y puesta a disposición del solicitante de los títulos y documentos en la sede del tribunal y no en otro lugar. Por otro lado, entendemos que la medida de entrada y registro, como consecuencia de la negativa a la práctica de la diligencia preliminar, no puede amparar una realización forzosa de la diligencia en términos distintos a los acordados inicialmente. Es decir, que si la diligencia preliminar que ha dado lugar a la medida de entrada y registro sólo prevé la exhibición del documento o título, no puede concluirse que a través de la medida de entrada y registro pueda obtenerse un resultado que exceda del objeto considerado en la regulación de la diligencia en el art. 256.1 LEC. Así, si la diligencia que pueda dar lugar a la medida de entrada y registro sólo le exige al sujeto pasivo la actividad de exhibición de documentos y títulos, en modo alguno, entendemos, la realización forzosa de dicha actuación puede amparar un efecto distinto tal como la entrega de aquellos.

Además de lo anterior, la entrega al peticionario de los documentos, incluso la mera exhibición en la sede del tribunal que prevé la LEC, puede dar lugar a actuaciones contrarias a otras disposiciones normativas distintas de la LEC pero con el mismo rango. Piénsese en el supuesto de la diligencia preliminar contemplada en el art. 256.1.3 LEC que permite el requerimiento de exhibición de títulos y documentos diversos, entre los que se encuentran aquellos que contengan los actos de última voluntad del causante de la herencia o legado. Y considérese que el documento objeto de la diligencia preliminar se encuentre en un protocolo notarial. Pues bien, conforme a lo dispuesto en el art. $32 \mathrm{LN}$, las escrituras matrices y protocolos no pueden ser extraídos del edificio en que se custodien, ni aún por decreto judicial u orden superior ${ }^{741} \mathrm{y}$ sin perjuicio de la

\footnotetext{
741 Salvedad hecha del desglose del protocolo la escritura matriz contra la cual aparezcan indicios o méritos bastantes para considerarla cuerpo de un delito y previa providencia del Juzgado que conozca del
} 
posibilidad, prevista por dicho precepto legal, del examen de tales documentos por interesados con derecho adquirido, herederos y causahabientes o del protocolo en los casos determinados por las leyes y en virtud de mandamiento judicial, a fin de extender en su virtud las diligencias que se hallen acordadas.

A la vista de lo anterior, es claro el conflicto de normas que se plantea y la imposibilidad legal de que algunos de los títulos y documentos que se contemplan en el art. 256.1.3 LEC sean exhibidos en la sede del tribunal o entregados al solicitante de la diligencia preliminar salvo que la ocupación que se pretenda, y que ampara el art. 261.2 LEC, lo sea en relación a la copia autorizada o simple que obre en poder de otro sujeto o, en relación al documento original que, por la razón que sea, no obre en este. Y debe tenerse en cuenta, además, que aún cuando ello es una cuestión que entendemos debiera analizarse en sede de admisión de la diligencia, el interés legítimo que el peticionario ostente para que el tribunal acceda a la práctica de la diligencia preliminar del art. 256.1.3 LEC sea suficiente para, de la misma forma, denegar la práctica de la diligencia prevista en dicho precepto legal cuando el documento en cuestión se encuentre en un protocolo notarial pues, como ya se ha puesto de manifiesto, con fundamento en el art. $32 \mathrm{LN}$, el notario que custodie el protocolo en cuestión deberá permitir el examen de las escrituras matrices y protocolos a las partes interesadas con derecho adquirido, sus herederos o causahabientes. Así, si el peticionario de la diligencia no acredita haber intentado, previamente, la exhibición del documento comprendido en el art. 256.1.3 LEC por el notario que custodie el protocolo donde aquel se encuentre, con la consecuente acreditación de la negativa de este, deberá inadmitirse la diligencia preliminar toda vez que, no debemos olvidar, la naturaleza de auxilio subsidiario de la institución de las diligencias preliminares.

Aún más, la entrega de documentos y títulos al peticionario sólo se justificaría por la necesidad de aportación al procedimiento posterior, lo que la LEC salva con la designación del archivo, protocolo o lugar en que se encuentren (265.2 LEC) y el deber de exhibición documental entre las partes (art. 328, 329 y 330 LEC). Por otro lado, 
conforme a lo dispuesto en el art. 331 LEC, si la persona de la que se requiera la exhibición no estuviere dispuesta a desprenderse del documento para su incorporación a los autos, la LEC determina que se extenderá testimonio de éste por el LAJ en la sede del tribunal, si así lo solicitare el exhibiente.

Por lo expuesto, entendemos que en el caso de la consecuencia prevista en el art. 261.2 LEC la ocupación de títulos y documentos y su puesta a disposición del solicitante en la sede del tribunal no puede amparar sino la exhibición de los documentos en cuestión. Y no siempre, pese a disponerlo así el precepto legal, en la sede del tribunal, lo que nos llevaría incluso a cuestionarnos, en el caso, la procedencia de la medida de entrada y registro en determinados supuestos como los anteriormente puestos de manifiesto. En otros casos, nada impedirá que los documentos sean puestos a disposición del peticionario en la sede del tribunal para que le sean exhibidos y reconocidos por él, incluso, asesorado por un experto en la materia ${ }^{742}$.

b) Búsqueda de documentos y datos.

Caso distinto es el de la medida de entrada y registro para el supuesto de no prestarse por el centro sanitario o profesional la colaboración requerida conforme a lo dispuesto en el art. 256.1.5 bis LEC, pues hace referencia a la petición, y ya no a la exhibición, de la historia clínica. Conforme prevé el art. 256.1.5 bis LEC dicha petición debe atenderse en las condiciones y con el contenido que la Ley establece.

$\mathrm{Al}$ respecto, lo primero que cabe destacar es que, a diferencia de los supuestos de exhibición de títulos y documentos antes analizados, en el caso de esta diligencia preliminar, el art. 261.5 LEC no prevé que la diligencia de entrada y registro deba llevarse a cabo para la exhibición y puesta a disposición del solicitante de la historia clínica del paciente. Simplemente, el art. 261.5 LEC prevé que en el supuesto del art. 256.1.5 bis LEC, el tribunal pueda ordenar las medidas de intervención necesarias,

\footnotetext{
${ }^{742}$ Vid. Garciandía González, P.M., La regulación de ..., ob. cit., p. 800.
} 
incluida la entrada y registro. Ahora bien, nuevamente, entendemos que la solución se encuentra en la propia previsión que de la diligencia hace el art. 256.1.5 bis LEC.

Esta norma dispone que dicha petición debe atenderse en las condiciones y con el contenido que la Ley establece. Así, en cuanto a la normativa reguladora de la materia en cuestión, el art. 3 LABP, establece que la historia clínica es el conjunto de documentos que contienen los datos, valoraciones e informaciones de cualquier índole sobre la situación y evolución clínica de un paciente a lo largo del proceso asistencial. Y respecto de la misma señala el art. 15.2 LODP, a la que remite el art. 16 LABP, que la información podrá obtenerse mediante la mera consulta de los datos por medio de su visualización, o la indicación de los datos que son objeto de tratamiento mediante escrito, copia, telecopia o fotocopia, certificada o no, en forma legible e inteligible, sin utilizar claves o códigos que requieran el uso de dispositivos mecánicos específicos. De ahí que, previendo el art. 261.5 LEC la entrada y registro para encontrar el documento y el art. 256.1.5 bis LEC que la petición que puede deducirse ante el tribunal es la de la historia clínica, entendemos que la medida de entrada y registro lo será en orden a encontrar la misma y ser entregada al peticionario.

En este punto resta por examinar la finalidad que para el supuesto del art. 261.5 LEC previene la medida de entrada y registro. Como se desprende del citado precepto legal, tratándose de las diligencias previstas en el art. 256.1.3 LEC (por petición de quien pretenda concretar a los integrantes del grupo de afectados), 256.1.7 LEC (mediante solicitud de diligencias de obtención de datos sobre el posible infractor de un derecho de propiedad industrial o intelectual que no sea un mero consumidor final de buena fe y sin ánimo de obtención de beneficios económicos o comerciales, el origen y redes de distribución de obras, mercancías o servicios que infringen los anteriores derechos) y 256.1.8 LEC (por petición de exhibición de los documentos bancarios, financieros, comerciales o aduaneros, producidos en un determinado tiempo), el tribunal podrá acordar la diligencia de entrada y registro para encontrar los documentos o datos precisos. 
Es decir, que el art. 261.5 LEC, más allá de la mera previsión de la posible adopción de la medida y a diferencia de lo prevenido en los supuestos $2^{\circ}$ y $3^{\circ}$ del art. 261 LEC, no dispone lo que habrá de hacerse con aquellos documentos y datos para cuya búsqueda se haya dispuesto la medida de entrada y registro. Ante dicha omisión y no observándose dato o circunstancia alguna que suponga contradicción, una vez que se encuentren los documentos y datos que en el auto que acuerde la medida de entrada y registro se hayan señalado, deberá procederse conforme a lo prevenido en el aptdo. $2^{\circ}$ del propio art. 261.2 LEC y para los supuestos de ocupación de títulos y documentos pues atendiendo a la naturaleza de las diligencias preliminares que pueden dar lugar a la medida de entrada y registro en estos casos, lo que se pretende no es más que obtener aquella información que no ha sido facilitada por el sujeto pasivo de la diligencia.

\subsubsection{Entrada y registro cuando se haya solicitado la exhibición de una} cosa

La diligencia de entrada y registro como consecuencia de la negativa a la exhibición de la cosa sobre la que haya de versar la diligencia preliminar para su presentación al peticionario que, además, podrá pedir el depósito o medida de garantía más adecuada a su conservación, nos obliga a conectar el estudio de la medida coactiva consecuencia de la negativa con el propio de la diligencia preliminar y en el que ya determinamos que era posible, conforme al ordinal $2^{\circ}$ del art. 256.1 LEC, solicitar y obtener la exhibición de la cosa inmueble ${ }^{743}$. Ello habida cuenta que, conforme a lo prevenido en el art. 261.2 y por remisión del art. 261.3 LEC, en el caso de negativa a la exhibición de la cosa, deberá procederse a la entrada y registro, ocupándose la cosa objeto de exhibición para su presentación al solicitante y que tal medida coactiva parece incompatible con la naturaleza inmueble de la cosa objeto de la diligencia, que no podrá ser ocupada para ser presentada al solicitante que, por otro lado, tampoco podrá solicitar respecto de la misma su depósito o medida de garantía alguna. Incluso también incompatible cuando el objeto de exhibición sea una cosa mueble que, por sus condiciones, no permita su ocupación.

\footnotetext{
${ }^{743}$ Vid. cap. II, epígrafe 2, dedicado al estudio de la diligencia de exhibición de cosas (art. 256.1.2 LEC).
} 
En dichos supuestos, la medida de entrada y registro sólo será hábil para alcanzar la finalidad perseguida por la diligencia preliminar previamente acordada, cuando la cosa, por sus condiciones físicas y jurídicas, pueda ser ocupada y presentada al peticionario pues, al igual que en los supuestos anteriores, la diligencia preliminar del art. 256.1.3 LEC sólo busca la exhibición con la posibilidad, en su caso, de que el solicitante interese la constitución del depósito ${ }^{744}$, incluso en poder de quien previamente ya la tenía pero con los efectos legales inherentes a dicha situación, o la medida de garantía ${ }^{745}$ más adecuada a la conservación de aquella.

En otros casos, al igual que para la admisión de la referida diligencia en relación a inmuebles, entendemos que la diligencia de entrada y registro sólo podrá amparar la exhibición o reconocimiento de la cosa, mueble o inmueble.

6.3.5 Presupuestos para la adopción de la medida de entrada y registro en lugar determinado

\subsubsection{Concurrencia de indicios suficientes, conocimiento o presunción fundada de que los títulos y documentos o la cosa se encuentra en lugar determinado}

Partiendo del tenor literal del art. 261.2 LEC, es claro que, sólo cuando se niegue la exhibición de títulos y documentos o de la cosa, la entrega de la historia clínica, o cuando se rechace ofrecer determinada información, y el tribunal apreciare indicios suficientes de que los mismos pueden hallarse en un lugar determinado o se presumiere o conociere el lugar donde la cosa se encuentra así como en los supuestos de negativa del requerido o cualquier otra persona, se podrá acordar la medida de entrada y registro.

\footnotetext{
${ }_{744}^{74} \mathrm{Al}$ depósito judicial se refieren los arts. 626 a 628 LEC.

${ }^{745}$ Entendemos que dicha posibilidad lo sería al amparo de la regulación que la LEC hace de las medidas cautelares, conforme a lo dispuesto en los arts. 727 y ss. LEC.
} 
El propio art. $261 \mathrm{LEC}$, en sus aptdos. $2^{\circ}$ y $3^{\circ}$, pone de manifiesto la necesidad de que el tribunal, para la adopción de la medida de entrada y registro como consecuencia de la negativa a la práctica de la diligencia preliminar, aprecie la existencia de indicios suficientes de que los títulos y documentos se encuentran en un lugar determinado o que conozca o presuma fundadamente donde se encuentra la cosa objeto de la diligencia ${ }^{746}$.

Por ello, puede afirmarse que la autorización de la entrada y registro en lugar determinado debe venir precedida del correspondiente juicio de suficiencia, sobre la concurrencia de indicios, de que la documentación, datos o cosa objeto de la/s diligencia/s se encuentran en ese lugar determinado sobre el que recaerá la entrada y registro. Y habrá de tenerse en cuenta que la posibilidad de adopción de la medida se planteará, en no pocos casos, cuando el requerido haya comparecido formulando oposición, pero sin ofrecer razón alguna del paradero del objeto de la diligencia, o directamente cuando no haya comparecido. Es decir, que la decisión de adopción de la medida de entrada y registro se planteará incluso cuando el juez cuente con la única información que pueda ofrecerle el propio solicitante de la diligencia.

Conforme a lo anterior entendemos que el auto que acuerde la medida de entrada y registro en lugar determinado deberá contener un mínimo razonamiento de las circunstancias que se hubieran alegado por el solicitante, o consten de otra forma en los autos, y que permitan concluir sobre la concurrencia de indicios suficientes de que los

\footnotetext{
${ }^{746}$ Así lo ponen de manifiesto resoluciones judiciales como el AAP de Madrid (sección $21^{\text {a }}$ ) de 28 de julio de 2010, ponente Ilma. Sr. A.M ${ }^{\mathrm{a}}$. Olalla, f.j.2 $2^{\circ}$ (LA LEY 155141/2010). O, el AAP de Lugo (sección $1^{\mathrm{a}}$ ) de 26 de septiembre de 2012, ponente Ilmo. Sr. J.Ma. Moreno, f.j. . $^{\circ}$ (JUR 20121369729). En este último caso, el tribunal señala que: "para que se viera proporcionada y sensata la diligencia interesada, tan gravosa para el carácter privado del domicilio de la persona física, haría falta, cuando menos, la constancia o la alta probabilidad de que los documentos cuya exhibición dice pretenderse existan, y de que se hallen en la vivienda que constituye el hogar del requerido a la exhibición".
} 
títulos, documentos, cosa o datos se hallan en el lugar concreto ${ }^{747}$ o domicilio sobre el que recae la medida de entrada y registro ${ }^{748}$.

Y dicho juicio de suficiencia, a diferencia de lo sostenido por algún autor al inicio de la vigencia de la $\mathrm{LEC}^{749}$, entendemos que debe realizarse en el auto motivado a que alude el art. 261 LEC, y una vez quede patente en el procedimiento la falta de colaboración del requerido a la práctica de las diligencias preliminares, bien por su incomparecencia en el procedimiento bien por la formulación de injustificada oposición.

\subsubsection{Que la persona requerida no atienda el requerimiento ni formule}

\section{oposición}

Comienza señalando el art. 261 LEC que:

"Si la persona citada y requerida no atendiese el requerimiento ni formulare oposición, el tribunal acordará, cuando resulte proporcionado, las siguientes medidas, por medio de un auto, en el que expresará las razones que las exigen: (...)”.

Una primera lectura del art. 261 LEC nos puede llevar a pensar que, en todo caso, si la persona citada y requerida no atendiese el requerimiento ni formulare oposición, el tribunal debe acordar la medida de entrada y registro, pues el tiempo verbal, acordará, empleado en la redacción a ello pudiera dar lugar. Sin embargo, entendemos que el término imperativo de la norma, que en otros ámbitos como el de la

\footnotetext{
${ }^{747}$ Como apunta Banacloche Palao, J., Las diligencias preliminares..., ob. cit., p. 205, "Si se careciera de indicios acerca de dónde se halla la cosa o el documento requeridos no sería posible ordenar entrada y registro alguno. Entonces, no queda otra opción que dar por finalizado el procedimiento sin realizar la diligencia preliminar acordada".

${ }^{748}$ En dicho sentido se pronuncia el AAP de Madrid (sección 21 a) de 28 de julio de 2010, ponente Ilma. Sr. A.M ${ }^{\mathrm{a}}$. Olalla, f.j. $2^{\circ}$ (LA LEY 155141/2010).

${ }_{749}$ Garnica Martín, J.F., De las diligencias preliminares..., ob. cit., p. 1187, entendió que siquiera era preciso fundar la medida adoptada al tratarse de dar efectividad a una diligencia judicial acordada en forma fundada y exigiendo una caución al solicitante, de forma que es el auto de admisión a trámite de la diligencia, e incluso el incidente de oposición, el que resuelve el eventual conflicto que pudiera surgir entre el derecho del solicitante a la tutela judicial efectiva, que incluye acudir a las diligencias preliminares, y los derechos fundamentales del solicitado, entre ellos, el derecho a la inviolabilidad de su domicilio y el derecho a su intimidad.
} 
jurisdicción penal no dejaría margen a la duda, no tiene el efecto que pudiera imaginarse. Máxime, si se tiene en cuenta que el propio art. 261 LEC subordina la adopción de la medida a otras circunstancias como la proporcionalidad, la existencia de indicios o el conocimiento fundado de que los títulos y/o documentos o la cosa se encuentran en un lugar determinado.

Por otro lado, el tenor literal del precepto legal tampoco debe llevarnos a pensar que si se ha formulado oposición no podrá el tribunal acordar la medida, pues si la misma es desestimada, por injustificada, siempre podrá el tribunal adoptar la medida para dar satisfacción al derecho del requirente, que el ordenamiento jurídico también protege.

A nuestro juicio, discrepando de los autores que han sostenido que el art. 261 LEC contempla la posibilidad de decretar una entrada y registro con un automatismo legal que margina los presupuestos que deben concurrir para adoptar una medida de tanta trascendencia ${ }^{750}$, entendemos que en todo caso concurre la obligación del tribunal de valorar si existe o no una negativa a la práctica de la diligencia $\operatorname{preliminar}^{751}$, que debe ser injustificada, o una verdadera imposibilidad ${ }^{752}$.

\footnotetext{
${ }^{750}$ Callejo Carrión, S., Las diligencias preliminares..., ob. cit., p. 20.

${ }^{751}$ Álvarez Alarcón, A., Las diligencias preliminares..., ob. cit., p. 65, indica que la negativa se entiende que se produce cuando el sujeto pasivo no comparece a la citación debidamente efectuada (art. 259), o cuando, habiendo comparecido, se niega a practicar las actuaciones que se piden y aún cuando se formule oposición y ésta no se apoye en argumento alguno pues ello no se traduce más que en una actitud obstruccionista del sujeto pasivo que se resiste a exhibir documentos o bienes, o dice que ignora si los tiene o que desconoce su contenido y no consiente que sea conocido por el actor.

${ }^{752}$ Tal sería el supuesto contemplado en el AAP de Madrid (sección 13a) de 6 de febrero de 2004, ponente Ilmo. Sr. V.J. Navarro, f.j.3 (LA LEY 32297/2004), en cuyo caso se entendió no procedente adoptar la medida al haber comparecido el requerido manifestando que no disponía de la documentación requerida, por haber desaparecido, por lo que el órgano judicial consideró que no tenía sentido tratar de violentar el domicilio personal del mismo, a mayor abundamiento cuando la sociedad cuya documentación contable era objeto de la diligencia preliminar, había causado baja. En similares términos, el AAP de Madrid (sección 20ª) de 20 de julio de 2006, ponente Ilmo. Sr. R.F. Rodríguez, f.j.1º (LA LEY 173636/2006).
} 


\subsubsection{Proporcionalidad de la medida. Entre el fin perseguido y el medio} empleado

La ausencia de una expresa exigencia de proporcionalidad en la redacción inicial del art. 261 LEC, unido a la previsión legal de poder ser acordada la medida mediante providencia, permitía la tacha de la medida de desproporcionada. Al respecto, se venía sosteniendo que, en pro de la efectividad de unas diligencias que no dejan de ser preliminares, se incurría en la vulneración de un derecho fundamental, lo que se entendía desproporcionado teniendo en cuenta las cautelas del proceso penal para la adopción de una medida como la entrada y registro que, aún limitadora de un derecho fundamental, se encontraba plenamente justificada en función de la gravedad y la finalidad perseguida, que no era otra que la investigación de hechos presumiblemente delictivos y la averiguación de sus responsables. A ello se venía a añadir la posibilidad de adoptar otras medidas menos restrictivas de derechos fundamentales ${ }^{753}$.

No obstante lo anterior, tras la reforma operada en el art. 261 LEC por la Ley 19/2006, la exigencia de proporcionalidad se hace expresa en el texto legal, lo que tampoco calmó las voces de aquellos que en su día tacharon la medida de desproporcionada $^{754}$ por el mero hecho de ser consecuencia de una diligencia que revestía el carácter de preliminar. Y ello, aún cuando esa tan invocada desproporción se hacía sin considerar que la recurrida medida de constitucionalidad no podía aplicarse por igual a los supuestos en que no resultara afectado el domicilio constitucionalmente protegido. Igualmente, sin considerar que la medida de entrada y registro no es más que la consecuencia del incumplimiento de una obligación, y consiguiente satisfacción de un derecho, con semejante respaldo constitucional. A saber, la obligación y el derecho que consagra el art. $118 \mathrm{CE}$ de cumplir con las resoluciones de los jueces y tribunales y de prestar la colaboración requerida por éstos en el curso del proceso. También el derecho

\footnotetext{
${ }^{753}$ Como señala Lorca Navarrete, A.M., Las diligencias preliminares..., ob. cit., p. 1969: "Lo razonable es que se tengan por ciertos, a los efectos del proceso declarativo posterior, los datos que presente en relación con esos títulos y documentos, el solicitante de la diligencia preliminar, como así se prevé, por lo demás para cuando se trata de exhibir documentos contables (art. 261.4 ${ }^{\mathrm{a}}$ LEC)".

${ }^{754}$ Lorca Navarrete, A.M., Las diligencias preliminares..., ob. cit., p. 1968, cuando señala que: "Es excesivo, como poco, que para la práctica de una diligencia preliminar (y repárese en lo de preliminar) se ordene la entrada y registro".
} 
consagrado en el art. $24 \mathrm{CE}^{755}$, de todas las personas, a obtener la tutela efectiva de jueces y tribunales en el ejercicio de sus derechos e intereses legítimos. En suma, que la adopción de la medida de entrada y registro se traduce en el medio articulado en el art. 256.1 LEC para la consecución satisfactoria de una de las múltiples manifestaciones del derecho a la tutela judicial efectiva del peticionario y en el cumplimiento de la obligación de cumplir con las resoluciones judiciales.

Y si bien algún reparo puede suscitar la entrada en una vivienda, dado el peculiar régimen de protección que la misma recibe desde la perspectiva constitucional (art. 18.2 $\mathrm{CE}$ ), siempre que la diligencia se limite y constriña a la observación de lo que sea interés para el futuro litigio, debe poderse realizar sin problema alguno. Desde luego ésta viene precedida por una decisión judicial motivada, rellenándose así el requisito constitucional, y nuestro ordenamiento conoce además otros supuestos de invasión en la intimidad domiciliaria ajenos a las causas penales que están completamente normalizados y admitidos por la jurisprudencia constitucional ${ }^{756}$.

Ahora bien, y al margen de lo anterior, la proporcionalidad que ahora nos ocupa, tal y como así se desprende del propio art. 261 LEC, es la que debe existir entre el medio empleado y el fin perseguido. Es decir, lo que se debe considerar para la adopción de la medida de entrada y registro en el ámbito de las diligencias preliminares, a nuestro juicio, incluso cuando la misma no recaiga sobre el lugar determinado que pueda identificarse con el concepto de domicilio constitucionalmente protegido, es si

\footnotetext{
${ }^{755}$ Ello, pese a la existencia de resoluciones como la de el AAP de Madrid (sección $20^{\text {a }}$ ) de 20 de julio de 2006, ponente Ilmo. Sr. R.F. Rodríguez, f.j. $1^{\circ}$ (LA LEY 173636/2006), que ponen de manifiesto que: "[...] se trata de una diligencia que puede afectar de lleno a derechos constitucionales de la persona, y al solicitarse en un procedimiento civil, sólo podrá ser adoptada con la máxima de las cautelas y con criterios de proporcionalidad en circunstancias de cierta gravedad, de peligro inminente para los derechos legítimos del solicitante". En el mismo sentido, el AAP de Madrid (sección 12a) de 17 de noviembre de 2010, ponente Ilma. S. M. Orejas, f.j.4 (LA LEY 241227/2010).

${ }^{756}$ En este sentido, el AAP de Las Islas Baleares (sección $3^{a}$ ) de 30 de junio de 2009, ponente Ilma. Sra. $M^{a}$.R. Rigó, f.j. $2^{\circ}$ (LA LEY 133792/2009), señala que siempre que la diligencia se limite y constriña a la observación de lo que sea interés para el futuro litigio, no parece que haya problema alguno de constitucionalidad, al venir precedida de una decisión judicial motivada rellenándose así el requisito constitucional teniendo en cuenta que nuestro ordenamiento conoce otros supuestos de invasión en la intimidad domiciliaria ajenos a las causas penales que están completamente normalizados y admitidos por la jurisprudencia constitucional. En idénticos términos se pronuncia el AAP de Madrid (sección $21^{\mathrm{a}}$ ) de 28 de julio de 2010, ponente Ilmo. Sr. R. Belo, f.j.2º (LA LEY 138625/2010).
} 
aquella guarda proporcionalidad con el fin perseguido, debiendo adoptarse sólo en el caso de que no existan otros medios alternativos (necesidad) y descartándola cuando sea previsible su escaso éxito (utilidad e idoneidad), es decir, cuando no existan indicios suficientes.

Conforme a dicha proporcionalidad entendemos que, el juez en cuestión, deberá valorar la idoneidad de la medida en relación con el fin perseguido, y la necesidad de la misma, como mecanismo menos oneroso al fin buscado. Y además, deberá llevar a cabo el correspondiente juicio de proporcionalidad de la medida adoptada ponderando, en el caso de que esta pueda responder al concepto de domicilio constitucionalmente protegido, la existencia de los límites del derecho a la inviolabilidad del domicilio, en coexistencia con otros derechos en juego y en los bienes constitucionalmente protegidos. Es decir, el tribunal deberá realizar "un juicio de ponderación de las circunstancias y de proporcionalidad que contempla el debido equilibrio entre el sacrificio sufrido por el derecho limitado y la ventaja que se obtendrá del mismo, del que resulte, como indica un sector doctrinal, la necesidad de la adopción de una medida restrictiva concreta en un caso también individualizado" 757 .

$\mathrm{Al}$ respecto, se indica en la doctrina que para que se viera proporcionada $\mathrm{y}$ sensata la diligencia interesada, tan gravosa para el carácter privado del domicilio de la persona física, haría falta, cuando menos, la constancia o la alta probabilidad de que los documentos cuya exhibición dice pretenderse existen, y de que se hallan en la vivienda que constituye el hogar del requerido a la exhibición ${ }^{758}$ pues, según el TC, la autorización judicial a la entrada en el domicilio no puede consistir jamás en un apoderamiento en blanco sino que el juez debe ponderar las circunstancias e intereses del caso en concreto

\footnotetext{
${ }^{757}$ Corbal Hernández, J.E., Diligencias preliminares (arts...), ob. cit., p. 3536.

${ }^{758}$ En este sentido, el AAP de Madrid (sección 12a) de 17 de noviembre de 2010, ponente Ilma. S. M. Orejas, f.j. $4^{\circ}$ (LA LEY 241227/2010) señala: “[...] Por otra parte y siguiendo el criterio sustentado por esta Audiencia en la resolución dictada por la sección 20 de 20 de julio de 2006, el recurso no puede prosperar, puesto que, como acertadamente señala la resolución recurrida, se trata de una diligencia que puede afectar de lleno a derechos constitucionales de la persona, y al solicitarse en un procedimiento civil, solo podrán ser adoptada con la máxima de las cautelas y con criterios de proporcionalidad en circunstancias de cierta gravedad, de peligro inminente para los derechos legítimos del solicitante, que en el presente caso no concurren". Y de forma idéntica, vid. también el AAP de Madrid (sección 21 $1^{\text {a }}$ ) de 28 de julio de 2010, ponente Ilmo. Sr. R. Belo, f.j.2 (LA LEY 138625/2010).
} 
en orden a respetar los principios de oportunidad y de ejecución por un medio menos gravoso y motivar, específicamente, las circunstancias fácticas y jurídicas que conducen a dar o rechazar la autorización de registro o de escucha ${ }^{759}$.

Por último, resta analizar cuándo debe efectuarse el juicio de proporcionalidad. $\mathrm{Al}$ respecto, nos encontramos con resoluciones que sitúan dicho momento en el auto de admisión a trámite de la diligencia o en el auto resolviendo el incidente de oposición ${ }^{760}$. No obstante lo anterior, entendemos que no resulta prudente colocar el tiempo del juicio de proporcionalidad de la medida de entrada y registro en el de admisión a trámite de la diligencia preliminar, pues aún cuando el objeto de la medida sea el de dar efectividad a una resolución judicial previamente dictada, el devenir posterior de las cosas, por ejemplo, con una oposición justificada, podría hacer innecesaria su adopción. Máxime, cuando la solicitud de diligencias preliminares no tiene por qué partir, necesariamente, de la suposición de la negativa de colaboración del requerido y cuando lo razonable será que el sujeto pasivo colabore, incluso formulando oposición.

Por lo expuesto, entendemos que sólo cuando transcurra el término del requerimiento, sin oposición, o cuando esta se formule y la misma sea desestimada, el tribunal, y siempre a instancia del peticionario, deberá efectuar el correspondiente juicio de proporcionalidad decidiendo, finalmente, si accede o no a la medida de entrada y registro como consecuencia de la negativa del sujeto pasivo a la práctica de la diligencia preliminar.

\subsubsection{Reflexión final}

La medida de entrada y registro como consecuencia de la negativa a la práctica de determinadas diligencias preliminares por parte del sujeto pasivo, constituye la

\footnotetext{
${ }^{759}$ Cfr. AAP de Lugo (sección $1^{\text {a }}$ ) de 26 de septiembre de 2012, ponente Ilmo. Sr. J.M ${ }^{\text {a }}$. Moreno, f.j. $1^{\text {o }}$ (JUR 2012 1369729).

${ }^{760}$ AAP de Toledo (sección $1^{\text {a) }}$ ) de 30 de marzo de 2005, ponente Ilmo. Sr. M. Gutiérrez, f.j. $2^{\circ}$ (LA LEY 70219/2005).
} 
medida más novedosa que la LEC dispone para evitar que la mera falta de colaboración de aquel frustre el legítimo derecho del peticionario a la tutela judicial efectiva.

Sin embargo, es la más cuestionada por la doctrina científica y judicial española por la incidencia que puede tener sobre el derecho fundamental a la inviolabilidad del domicilio reconocido en el art. $18 \mathrm{CE}$ que, unida a su falta de regulación mediante ley orgánica, pone en duda su constitucionalidad.

No obstante, la regulación en la norma procesal civil de la medida previendo su adopción en relación al lugar determinado en que pudieran hallarse los títulos, documentos y otros datos así como la cosa que sean objeto de las diligencias, y no en relación al domicilio de los sujetos requeridos, permite afirmar la existencia de esa duda de constitucionalidad sólo cuando dicha medida recaiga sobre un lugar determinado que, además, se corresponda con el concepto de domicilio constitucionalmente protegido. Por ello, y a nuestro juicio, en estos casos sería aconsejable que esta medida se regulase mediante ley orgánica al entender que la que hace la LEC de la misma en el art. 261 LEC no constituye una mera regla procedimental para la conformación de la decisión sino una habilitación legal del juez para su adopción. A la fecha, hasta en dos ocasiones el TC ha tenido la cuestión sobre la mesa, dejándola sin resolver por circunstancias ajenas al fondo.

Al margen de la duda de constitucionalidad que ofrece la medida, la LEC prevé su posible adopción ante la negativa del sujeto pasivo a la colaboración en la práctica de determinadas diligencias preliminares. Fundamentalmente, cuando dicha negativa afecte al deber de exhibición de títulos y documentos, datos y cosas que dimane de los supuestos previstos en los números 1 y 3 a 5, así como 5 bis a 8 del art. 256.1 LEC.

Por otro lado, en cuanto al modo de practicarse la medida, la LEC se limita a ordenar, genéricamente, la ocupación y puesta a disposición del solicitante, en la sede del tribunal de los títulos y documentos; la presentación de la cosa ante el mismo, y la búsqueda de distintos documentos y datos. No obstante, dicha regulación deja de atender otras limitaciones prácticas o legales que impiden la realización de la medida en 
los términos previstos. Por tanto, y sin perjuicio de la debida acomodación que los tribunales ordinarios puedan hacer a la realidad práctica, en este punto se pone de manifiesto la necesidad de una revisión de esta ordenación legal.

Por último, y a modo de conclusión final, cabe determinar que la propia introducción del art. 261 LEC, así como los matices contenidos en los apartados que lo conforman, ponen de manifiesto que la adopción de la medida nunca podrá responder a una arbitraria decisión del tribunal. La negativa injustificada del requerido a prestar la colaboración interesada es el punto de partida del proceso de conformación de una decisión judicial que deberá plasmarse en un auto motivado, cuando la medida resulte proporcionada y cuando, bien concurran indicios suficientes de que los documentos y títulos, así como los datos, se encuentren en un lugar determinado, o bien, y en el caso de exhibición de una cosa, cuando se presuma que se encuentra en dicho lugar determinado.

\section{Aplicación de la caución}

De acuerdo con el art. 258 LEC, el auto que acuerda las diligencias preliminares solicitadas, deberá fijar la caución que debe prestar el peticionario de las diligencias para responder de los daños y perjuicios que eventualmente puedan ocasionarse. De tal modo que, conforme al art. 262 LEC, el juez por medio de un auto, una vez practicadas las diligencias acordadas o cuando las deniegue por considerar justificada la oposición, debe resolver sobre la aplicación de la caución prestada a la vista de la petición de indemnización y de la justificación de gastos que se le presente, entendemos que por el requerido, oído el solicitante.

Este precepto, que no se remite a ningún trámite específico para resolver sobre la procedencia de la aplicación de la caución a la indemnización de daños y perjuicios solicitados regula, a juicio de algún sector doctrinal, un incidente específico, novedoso y breve, que tiene como principal problema interpretativo el de la determinación del momento en que puedan las personas, ya físicas o jurídicas, respecto de las cuales se 
hubiese solicitado las diligencias preliminares, interesar el abono de los gastos y la indemnización de daños y perjuicios ${ }^{761}$.

No obstante, lo cierto es que el art. 262 LEC dispone que el juez resolverá sobre la aplicación de la caución prestada a la vista de la petición de indemnización y de la justificación de gastos que se le presente, oído el solicitante, lo que parece indicar, como se afirma en la doctrina, que la aplicación de la caución a los gastos, daños y perjuicios ocasionados durante el procedimiento preliminar debe producirse previa solicitud de parte, sin que pueda incoarse su inicio de oficio por el órgano jurisdiccional ${ }^{762}$.

Ello, sin precisar el precepto legal el plazo del que dispone el sujeto pasivo para formular tal solicitud. El art. 262.1 LEC se limita a disponer que el tribunal, practicadas las diligencias o denegadas por estimarse la oposición, resolverá en el plazo de cinco días, dejando sin raspiest cuestiones tan importantes como el tiempo en que el requerido deberá proceder a la solicitud de indemnización de los gastos, daños y perjuicios, el tiempo del que dispondrá el solicitante de las diligencias para ser oído y, por tanto, formular alegaciones a la solicitud deducida de contrario, o la forma en que, contradictoriamente, podrá discutirse tanto la procedencia de la aplicación de la caución a los gastos, daños y perjuicios invocados de contrario como el importe al que asciendan los $\operatorname{mismos}^{763}$.

Dicha situación ha provocado un debate doctrinal en el coexisten soluciones para todos los gustos. Así, en un extremo encontramos soluciones para las que todo el

\footnotetext{
761 Así lo califica el AAP de Madrid (sección 19a) de 23 de diciembre de 2005, ponente Ilmo. Sr. E. Legido, f.j.3ํ (LA LEY 247641/2005). En similares términos Garnica Martín, J.F., De las diligencias..., ob. cit., p. 1192.

${ }^{762}$ Garberí Llobregat, J., Las diligencias preliminares..., ob. cit., p. 82 y Lorca Navarrete, A.M., La regulación de..., ob. cit., p. 29. En la doctrina judicial, el AAP de Madrid (sección 19a) de 23 de diciembre de 2005, ponente Ilmo. Sr. E. Legido, f.j.3 (LA LEY 247641/2005) y el AAP de Valladolid (sección $1^{\text {a }}$ ) de 29 de marzo de 2007, ponente Ilmo. Sr. J.R. Alonso-Mañero, f.j.2 ${ }^{\circ}$ (LA LEY 110405/2007) conforme al cual, sin una previa petición el tribunal no podrá dictar pronunciamiento alguno sobre el destino de la caución en orden al sufragio de los gastos, daños y perjuicios no reclamados. ${ }^{763}$ Como pone de manifiesto Garnica Martín, J.F., De las diligencias..., ob. cit., p. 1193, "la posibilidad de practicar prueba no puede descartarse, pues en otro caso no se entiende cómo puede el reclamante acreditar sus daños o cómo podría el solicitante que prestó la caución defenderse adecuadamente frente a una reclamación abusiva que se formule".
} 
procedimiento, inclusive la presentación del escrito inicial del sujeto pasivo y la audiencia al solicitante de las diligencias, debe realizarse en el plazo máximo de cinco días, que es el plazo que otorga la ley al juez para resolver ${ }^{764}$, lo que choca con la propia dicción del precepto en que el legislador no limita el tiempo hábil para la solicitud. Para otros, el tiempo de cinco días se refiere a aquel del que dispone el sujeto pasivo para solicitar el inicio del incidente del que tratamos, solución esta última que también se encuentra con el anterior obstáculo de la dicción literal del precepto y que, además, conlleva una interpretación restrictiva y, a nuestro juicio, injustificada del resarcimiento, más aún si tenemos en cuenta que en dicha línea se sostiene la preclusión de la posibilidad de solicitar la indemnización en el propio procedimiento de diligencias preliminares y la remisión al ejercicio de la acción autónoma que se pueda deducir en un proceso distinto ${ }^{765}$. Incluso, otros, señalan que el sujeto pasivo debe presentar la solicitud de gastos y de indemnización antes de que transcurra el plazo de un mes desde la terminación de las diligencias, ya que una vez presentada la demanda o justificada su no presentación, se le devolverá al solicitante la caución o el remanente de ésta que quede $^{766}$.

No obstante todo lo expuesto, y a la vista de la ausencia de regulación de trámite alguno que en sede de diligencias preliminares permita resolver sobre el destino de la caución, entendemos que cualquier sistema que arbitre el juzgador y que respete los términos esenciales del art. 262 LEC será válido al efecto de resolver sobre la aplicación de la caución. Es decir, siempre y cuando, una vez practicadas las diligencias preliminares, o denegadas estas por considerar justificada la oposición, y habiéndose deducido la oportuna petición de resarcimiento de los daños y perjuicios causados, el tribunal resuelva previa audiencia de la parte solicitante de las mismas. Audiencia que entendemos, en todo caso, deberá permitir al solicitante controvertir la petición deducida de contrario, incluso mediante la proposición y práctica de la oportuna prueba,

\footnotetext{
${ }^{764}$ Damián Moreno, J., Comentarios a la Ley..., ob. cit., p. 1701.

${ }^{765}$ En dicho sentido, Garnica Martín, J.F., De las diligencias..., ob. cit., p. 1192.

${ }^{766}$ En la doctrina judicial, así lo refleja los AAP de Madrid (sección 19 ${ }^{\mathrm{a}}$ ) de 1 y 23 de diciembre de 2005, ponentes Ilmos. Srs. R. Ruíz y E. Legido, f.j. $2^{\circ}$ y $3^{\circ}$ (LA LEY 234511/2005 y 247641/2005). Parece que también en este sentido se pronuncia el AAP de Alicante (sección $8^{\mathrm{a}}$ ) de 4 de junio de 2015, ponente Ilmo. Sr. L.A. Soler, f.j.3º (LA LEY 248240/2015).
} 
a cuyo efecto resulta perfecto el procedimiento de liquidación de daños y perjuicios regulado en los arts. 712 y ss. LEC. Más aún si, como es el caso, entendemos que nada impone que el resarcimiento de los gastos, daños y perjuicios que se hayan ocasionado a quien, como sujeto pasivo, haya intervenido en la práctica de las diligencias preliminares, se extienda más allá de la cuantía que en concepto de caución se haya prestado por el solicitante. Cierto es que un trámite como el apuntado puede llegar a convertir la cuestión de la aplicación de la caución en una cuestión mucho más compleja que la propia tramitación de las diligencias preliminares pero, a nuestro juicio, ello no justifica que la decisión sobre la misma se efectúe sin respetar las mínimas garantías legales. Porque, como hemos dicho, los gastos, daños y perjuicios deben ser justificados en todo caso y la efectiva prestación de caución que como requisito indispensable para la práctica de las diligencias preliminares impone la LEC en modo alguno conlleva que, en cualquier caso, la caución prestada deba perderse en perjuicio del solicitante.

Por último, entendemos que la falta de previsión expresa de la LEC de un trámite y tiempo específico para ventilar la pretensión de indemnización del perjudicado no obsta a que, transcurrido el mes a que se refiere el art. 256.3 LEC, el órgano judicial le requiera para la formulación de la correspondiente petición. Y que, si esta no se produce, verificado por el tribunal que la demanda ulterior del proceso ha sido interpuesta o no, en este segundo caso justificadamente, proceda a la devolución de la caución al solicitante de las diligencias preliminares.

Ello, porque introducir restricciones al trámite de la aplicación de la caución cuando el mismo goza de una regulación tan deficitaria como la expuesta, no redunda más que en la merma de garantías de los que hayan de intervenir, activa o pasivamente, en las diligencias preliminares. 


\section{CAPÍTULO IV. EFICACIA DE LAS DILIGENCIAS PRELIMINARES: ESPECIAL REFERENCIA AL EFECTO INTERRUPTIVO DE LA PRESCRIPCIÓN}

En la jurisprudencia y la doctrina judicial es reconocida la eficacia de las diligencias preliminares como instrumento útil para expresar la voluntad conservativa de un derecho al objeto de interrumpir la prescripción. Pero este reconocimiento no se entiende con carácter general sino sujeto a una serie de requisitos jurisprudencialmente fijados y relacionados con la identidad de acción, los sujetos y el conocimiento del acto conservativo que, en el presente capítulo consideraremos a través de las decisiones de los tribunales habidas al respecto y que han ido configurando una serie de supuestos concretos en los que las diligencias preliminares no poseen esa eficacia interruptiva.

\section{El efecto interruptivo de la prescripción de las diligencias preliminares}

La LEC, consciente de las dificultades que supone el ejercicio de la acción judicial ante el desconocimiento de determinadas circunstancias esenciales para la correcta articulación de un procedimiento, introdujo una novedosa regulación de las llamadas diligencias preliminares con la finalidad de preparar el proceso. Así lo recogió en su Exposición de Motivos apuntado que "la presente Ley se asienta sobre el convencimiento de que caben medidas eficaces para la preparación del proceso"767.

Esta finalidad preparatoria del proceso posterior fundamenta la instrumentalidad que, en relación al mismo, se ha predicado de las diligencias preliminares ${ }^{768}$ hasta el punto, como veremos, de servir de medio útil de interrupción de la prescripción

\footnotetext{
${ }^{767}$ Aptdo. X de la Exposición de Motivos de la LEC.

${ }^{768}$ Para Álvarez Alarcón, A., Las diligencias preliminares..., ob. cit., pp. 35-36, el carácter instrumental que estas diligencias tienen es notorio toda vez que no pueden acordarse sino en función de un proceso ulterior cuyos presupuestos deben darse y en el que los efectos de aquella deben verificarse y agotarse. Concluye al respecto el autor que no puede admitirse preliminar alguna que no se encuentre en relación con un proceso principal al que debe servir, lo que constituye un requisito fundamental para su admisión.
} 
extintiva $^{769}$ del derecho a ejercitar a través del correspondiente proceso judicial al que se encuentran unidas por esa relación de instrumentalidad y, más concretamente, de la acción que en el futuro juicio se pretende ejercitar. La acción, “como facultad o poder exigir a otro un comportamiento, activo o positivo, para la satisfacción de nuestro interés" ${ }^{\prime 770}$ y su ejercicio ante los tribunales, se encuentra sujeta a la institución de la prescripción extintiva del derecho y a la regla general ${ }^{771}$ contenida en el art. $1.930 \mathrm{CC}$ que proclama la prescriptibilidad de todos los derechos y acciones, de cualquier clase que sean.

Pero esta regla general de la prescriptibilidad de todos los derechos se encuentra sujeta a la interrupción de la prescripción ${ }^{772}$, esto es, al conjunto de circunstancias o causas que, individualmente puestas de manifiesto, impiden que la prescripción opere y que, también con carácter general, se encuentran recogidas en el art. $1.973 \mathrm{CC}^{773}$.

No obstante, entre ellas no se encuentran expresamente reconocidas las diligencias preliminares ${ }^{774}$. Tampoco el CCo contempla las diligencias preliminares entre aquellas causas interruptivas de la prescripción que recoge su art. $944^{775}$.

\footnotetext{
${ }^{769}$ Según O’Callaghan Muñoz, X., Código Civil. Comentado..., ob. cit., p. 2086, la prescripción se entiende como "aquella institución que, uniendo el tiempo y otros requisitos, produce como efecto la extinción o adquisición de un derecho" suponiendo la extintiva, a diferencia de laadquisitiva, "la extinción de un derecho subjetivo por permanecer inactivo e irreconocido durante el tiempo que la ley señala".

${ }_{770}$ Cfr. Díez-Picazo, L. y Gullón, A. Sistema de Derecho..., ob. cit., p. 443.

${ }^{771}$ Porque no todas las acciones prescriben, existiendo excepciones como las contempladas en el art. 1.965 Código Civil, en cuanto a la acción para pedir la partición de la herencia, la división de la cosa común o el deslinde de las propiedades contiguas, o derivadas de la propia acción o derecho, como es el caso de la acción declarativa de nulidad, de derechos, las acciones relativas al estado civil o de la personalidad.

${ }_{772}$ Que, según O’Callaghan Muñoz, X., Código Civil. Comentado.... ob. cit., p. 2141, "es el acto que evita la consumación de la misma. Su efecto es que el derecho vuelve a tener plena eficacia y, por ello, el tiempo debe volver a comenzar a contarse de nuevo para dar lugar a una nueva prescripción. Cuyo cómputo empieza al día siguiente al que termina el acto interruptivo".

${ }^{773}$ Como causas de interrupción de la prescripción el art. $1.973 \mathrm{CC}$ recoge el ejercicio de la acción ante los tribunales, la reclamación extrajudicial del acreedor y cualquier acto de reconocimiento de la deuda por el deudor.

${ }^{774}$ De hecho, el efecto interruptivo de la prescripción de las diligencias preliminares ha sido negado por algún autor como Banacloche Palao, J., Las diligencias Preliminares..., ob. cit., p. 155, cuando señala que "la solicitud de diligencias preliminares no interrumpe la prescripción adquisitiva, ni la extintiva, ni, por supuesto, la caducidad", debiendo aclararse que el autor, cuando habla de solicitud de diligencias preliminares, lo hace en relación a aquellas que hayan resultado admitidas al señalar que lasolicitud de
} 
Sin embargo lo anterior, el principio establecido en el art. 1.6 CC nos insta a poner de manifiesto el contenido de la STS, de 12 de noviembre de $2007^{776}$, desde cuyo dictado ninguna duda cabe de la utilidad de las diligencias preliminares en orden a interrumpir la prescripción del derecho a ejercitar a través de la oportuna acción judicial. Como señala la referida resolución “[...] no sólo la presentación de la demanda interrumpe la prescripción, sino también otros actos procesales tendentes a preparar la acción o para obtener la satisfacción del derecho pretendido y que revelan una voluntad claramente conservativa del mismo [...] resultan igualmente útiles para expresar la voluntad conservativa de un derecho al objeto de interrumpir el plazo prescriptivo", concluyendo que "[...] Las diligencias preliminares, dirigidas contra quien luego será demandado constituyen un instrumento idóneo y eficaz para llevar a cabo el requerimiento judicial conservativo que según el art. 1973 CC permite interrumpir el plazo de prescripción [...]". Por otro lado, son numerosas las resoluciones de los tribunales españoles que consagran el efecto interruptivo de la prescripción de las diligencias preliminares configurándose estas como un acto de reclamación al deudor que, como tal, tiene efectos interruptivos ${ }^{777}$.

\section{Requisitos que han de concurrir en el procedimiento de diligencias} preliminares para que opere la prescripción en el proceso posterior

Determinado que, pese a no relacionarse de forma expresa en el art. $1.973 \mathrm{CC}$, las diligencias preliminares sí tienen el efecto de interrumpir la prescripción extintiva de la acción que en el futuro proceso se quiere ejercitar y a través de ellas se pretende preparar, debe advertirse que la STS, de 12 de noviembre de 2007 antes citada no se

\footnotetext{
diligencias preliminares no implica la existencia de una verdadera reclamación individualizada ni su analogía con un acto de conciliación.

${ }^{775}$ Esta norma presenta una especialidad frente al art. $1.973 \mathrm{CC}$ en cuanto a las causas de interrupción de la prescripción que este último contempla (acción ante los tribunales, reclamación extrajudicial y reconocimiento). El art. 944 CCo sólo contempla la interpelación judicial, el reconocimiento y la renovación del documento contractual, excluyendo, parece que deliberadamente, la reclamación extrajudicial como causa de interrupción de la prescripción.

776 STS de 12 de noviembre de 2007 (sala $1^{\text {a }}$ ), ponente Ilmo. Sr. J. Almagro, f.j.2 ${ }^{o}$ (LA LEY 185155/2007).

${ }^{777}$ En dicho sentido, vid. la SAP de Cádiz (sección $5^{\text {a }}$ ) de 5 de mayo de 2010, ponente Ilmo. Sr. C. Ercilla, f.j.1 ${ }^{\circ}$ (LA LEY 166436/2010) y la SAP de Málaga (sección $4^{\text {a }}$ ) de 4 de marzo de 2011, ponente Ilmo. Sr. F.J. Arroyo, f.j.3º (LA LEY 116585/2011).
} 
limita a efectuar una declaración general sobre la indicada eficacia de las diligencias preliminares en orden a la interrupción de la prescripción. Además, dicha resolución identifica dos requisitos que deben concurrir para que opere tal eficacia interruptiva. Primero, que en el acto de exteriorización se identifique con claridad tanto el derecho que se pretende conservar al que se refiere el acto interruptivo, como la persona frente a la que se trata de hacer valer, con el fin de que derecho y persona coincidan, respectivamente, con la acción o derecho ejercitado en la demanda y con la persona frente a la que se dirige en calidad de demandado ${ }^{778}$. Segundo, que la voluntad conservativa del concreto derecho, la que se manifiesta a través de las diligencias preliminares, llegue a conocimiento del deudor entendiendo incluido en esta condición el interesado en la práctica de la diligencia preliminar o requerido a la misma ${ }^{779}$. Y, como señala la referida resolución, sin la concurrencia de las anteriores circunstancias las diligencias preliminares, en modo alguno, tendrán la utilidad predicada.

\subsection{Identificación del derecho que se quiere conservar y de la persona frente} a la que se trata de hacer valer

El art. 256.2 LEC señala que: "En la solicitud de diligencias preliminares se expresarán sus fundamentos, con referencia circunstanciada al asunto objeto del juicio que se quiera preparar" para, posteriormente, el art. 258.1 LEC, indicar que: "Si el tribunal apreciare que la diligencia es adecuada a la finalidad que el solicitante persigue y que en la solicitud concurren causa e interés legítimo, accederá a la pretensión, fijando la caución que deba prestarse".

De lo anterior se desprende que el tribunal, en orden a la admisión de la diligencia preliminar, deberá efectuar un primer y único examen de la petición, el acto de exteriorización, para determinar si la diligencia es adecuada a la finalidad que se

\footnotetext{
${ }^{778}$ En cuanto a la identificación entre requerido en diligencias preliminares y demandado en el proceso ulterior, se pronuncia la SAP de Girona (sección $1^{\mathrm{a}}$ ) de 3 de mayo de 2013, ponente Ilma. Sra. M M $^{\mathrm{a}}$.I. Soler f.j. $2^{\circ}$ (LA LEY 89454/2013).

${ }_{779}$ Debiendo tenerse en cuenta que en el presente estudio hacemos una adaptación de la teoría general de la prescripción a la institución de las diligencias preliminares como instrumento hábil para la interrupción de la prescripción toda vez que en aquel marco el conocimiento de la voluntad conservativa del derecho viene referido al deudor como persona obligada a una conducta.
} 
persigue, la preparación del juicio ulterior. Es decir, si la diligencia solicitada, efectivamente, está encaminada a la preparación del juicio que se anuncia.

Pues bien, en relación al examen de la interrupción de la prescripción, el tribunal al que se someta tal consideración, deberá repetir ese primer y único examen de la petición, como ya hizo el que conoció de la diligencia preliminar pero, en este caso, en orden a determinar si en aquella se identificó con claridad el derecho que se pretende conservar, al que se refiere el acto interruptivo, determinando si coincide con el derecho o acción ejercitado en el juicio en que la interrupción de la prescripción se plantea ${ }^{780}$. Y, además, que en la petición de diligencia preliminar se identificó debidamente la persona frente a la que se pretende hacer valer el acto interruptivo y que, en su caso, alegue la prescripción de la acción en el posterior procedimiento que se pretende preparar y en el que se analice la prescripción ${ }^{781}$, al tener que coincidir en ambos casos. Entendemos que ello debe ser así porque como recuerda la STS, Sala Primera, de lo Civil, de 21 de julio de $2004^{782}$, con cita de la de 14 de marzo de $1989^{783}$, no cualquier tipo de reclamación judicial genera los efectos de interrupción de la prescripción requiriendo esta que la demanda "[...] haya determinado un proceso con contenido sustancialmente idéntico al presente, esto es con la misma pretensión de mantener los derechos y acciones presentes, ya que, en tal caso, no sería justo suponer abandono de derechos por quien manifestó su voluntad contraria pidiéndolos oportunamente en otro juicio que, en este orden de cosas, tiene el sentido de dar fe del "animus conservandi" del derecho

\footnotetext{
${ }^{780} \mathrm{Y}$ a tal efecto deberá acreditarse, en el procedimiento en que se invoque la interrupción de la prescripción, el contenido de la solicitud de diligencias preliminares dado que su mera invocación no permitirá tomar en consideración la interrupción, tal y como así se desprende de la SAP Madrid (sección $8^{\text {a }}$ ) de 29 de marzo de 2012, ponente Ilma. Sra. Ma.V. Salcedo, f.j.2 $2^{\text {o }}$ (LA LEY 53724/2012).

${ }^{781}$ Téngase en cuenta que al tiempo de promoverse las diligencias preliminares la acción que se pretende preparar y que, como tal, se indique en la solicitud, tiene que haber nacido. Así lo puso de manifiesto la SAP de Murcia (sección 5a) de 24 de marzo de 2011, ponente Ilmo. Sr. M.A. Larrosa, f.j.6 $6^{\text {a }}$ (AC 2011 1895$)$, en la que se analiza la prescripción de la acción de reclamación de indemnización por clientela a la que se opuso, por quien ejercitaba la acción, la previa tramitación de diligencias preliminares. A juicio de la sala, las diligencias preliminares planteadas no tenían el efecto interruptivo pretendido ni habían incluido en su día la pretensión o anuncio del ejercicio de las acciones de indemnización por clientela ejercitadas posteriormente en la demanda ni podían incluirlas, en tanto en cuanto al momento de su planteamiento la demandada no había resuelto el contrato que justificaría la reclamación de la indemnización. Concluye la resolución en este punto que "[...] ello supone que mal pueden servir las diligencias preliminares para el interrumpir el plazo de ejercicio de una acción que todavía no ha nacido en dicho momento".

${ }_{782}^{782}$ STS de 21 de julio de 2004 (sala 1 ${ }^{\text {a }}$ ), ponente Ilmo. Sr. P. González, f.j.2º (LA LEY 172176/2004).

${ }^{783}$ STS de 14 de marzo de 1989 (sala 1ª), ponente Ilmo.Sr. R. Casares (LA LEY 736-JF/0000).
} 
controvertido" y porque la identidad de acciones, a juicio de la misma Sala, “[...] constituye una exigencia tanto legal como jurisprudencial [...] al haber manifestado la jurisprudencia que es absolutamente necesario para estimar la interrupción de una acción determinada que ésta se haya ejercitado y no otra que con ella tenga mayor o menor analogía",784.

Por tanto, se puede determinar que si existe divergencia entre la acción a que se dirigió al acto interruptivo y la que después resulta ejercitada, o si tal divergencia afecta al sujeto pasivo, la prescripción no queda interrumpida, pues no vale a tales efectos cualquier acción y, con mayor razón, si no se da coincidencia de sujetos, de objeto, ni de causa de pedir.

Así las cosas, en relación a este primer requisito, debemos plantear una reflexión. Si bien el criterio de la correlación o coincidencia entre la acción que se diga en la solicitud de diligencias preliminares que se quiere preparar y la que posteriormente se interponga no plantea problema alguno pues, como ha determinado el TS, para que opere la interrupción de la prescripción se exige la absoluta identidad entre una y otra, la necesaria identidad entre la persona a quien se dirige la diligencia preliminar y la que posteriormente resulte demandada en el pleito que se pretende preparar, quiebra la eficacia interruptiva de aquellas diligencias preliminares a través de las cuales se busca, precisamente, la identificación del futuro demandado y que no tiene por qué coincidir con aquel que resulte requerido en la diligencia preliminar.

Tal es el caso de la diligencia preliminar contemplada en el art. 256.1.5 LEC, que admite la preparación del juicio por petición del que se considere perjudicado por un hecho que pudiera estar cubierto por seguro de responsabilidad civil, de que se exhiba el contrato de seguro por quien lo tenga en su poder. Nos encontramos ante una

\footnotetext{
${ }^{784}$ STS de 9 de marzo de 2006 (sala $1^{\text {a }}$ ), ponente Ilmo. Sr. R. García, f.j. $2^{\circ}$ (LA LEY 21549/2006). Y en el ámbito de los tribunales inferiores encontramos resoluciones como, por ejemplo, la SAP de Girona (sección $1^{\text {a }}$ ) de 3 de mayo de 2013, ponente Ilma. Sra. M $^{a}$. I. Soler, f.j.2 ${ }^{\circ}$ (LA LEY 89454/2013), que rechaza el efecto interruptivo de la prescripción de la acción de unas diligencias preliminares en que la acción que se dijo preparar en aquellas y la que, en juicio posterior se planteó, son distintas, pues la finalidad de aquellas era reclamar la legítima de una madre, solicitándose la aportación de la escritura de manifestación y aceptación de herencia de su padre.
} 
diligencia preliminar que parte del supuesto del tercero perjudicado por un evento dañoso cubierto por un seguro de responsabilidad civil cuya existencia desconoce, así como también la identidad de la persona que asegura y frente a la que le cabe ejercitar la acción directa prevista en el art. 76 LCS $^{785}$. El art. 256.1 LEC permite al perjudicado dirigirse a quien tenga en su poder el seguro de responsabilidad civil, normalmente el tomador del seguro, beneficiario, propietario o conductor del vehículo, reclamando la exhibición de la póliza concertada con la aseguradora a la que pretende demandar, conjuntamente o no con el asegurado y/o propietario del vehículo, en reclamación del daño causado. En este supuesto, la identidad de acción y sujetos que exige el TS para que pueda operar la interrupción de la prescripción impide que la concreta diligencia preliminar la produzca frente a la entidad que asegure el evento dañoso y frente a la que no se pudo dirigir la misma porque, precisamente, su finalidad es la averiguación de la identidad del asegurador del daño y los términos en que el seguro ha sido concertado. Así, la propia naturaleza indagatoria de la diligencia preliminar impide que frente a quien se determine como responsable civil se pueda oponer la interrupción de la prescripción. Ello, aún cuando el causante del evento dañoso y la entidad aseguradora se encuentren unidos frente al perjudicado y promovente de la diligencia preliminar, por una relación de solidaridad pues, como ha declarado la jurisprudencia, se trata de un supuesto de solidaridad impropia ${ }^{786}$, ajeno a lo dispuesto en el art. $1.974 \mathrm{CC}$, en el que no puede "aprovecharse" la interrupción de la prescripción de la acción que opera frente

\footnotetext{
${ }^{785}$ Según el art. 76 LCS:"El perjudicado o sus herederos tendrán acción directa contra el asegurador para exigirle el cumplimiento de la obligación de indemnizar, sin perjuicio del derecho del asegurador a repetir contra el asegurado, en el caso de que sea debido a conducta dolosa de éste, el daño o perjuicio causado a tercero. La acción directa es inmune a las excepciones que puedan corresponder al asegurador contra el asegurado. El asegurador puede, no obstante, oponer la culpa exclusiva del perjudicado y las excepciones personales que tenga contra éste. A los efectos del ejercicio de la acción directa, el asegurado estará obligado a manifestar al tercero perjudicado o a sus herederos la existencia del contrato de seguro y su contenido".

${ }^{786}$ Conforme se recoge, entre otras, en la STS de 7 de marzo de 2013 (sala $1^{\text {a }}$ ), ponente Ilmo. Sr. J.A. Xiol, f.j.4 (LA LEY 30424/2013), la solidaridad impropia es la que “[...] dimana de la naturaleza del ilícito y de la pluralidad de sujetos que hayan concurrido a su producción y que surge, cuando no resulta posible individualizar las respectivas responsabilidades, esto es, el grado de participación de cada uno de ellos, lo que debe entenderse sin perjuicio de las reclamaciones que puedan formularse los condenados entre sí, las cuales pertenecen al ámbito de su no construida relación interna que es ajeno al proceso en que la condena solidaria se impone (SSTS, entre otras, de 22 de enero de 2004 y 19 de octubre de 2007). Este tipo de solidaridad, denominada impropia, operará cuando varias personas quedan vinculadas a realizar una misma prestación derivada de la concurrencia de la misma causa, que es idéntica para todos los implicados".
} 
a aquel a quien se dirige la diligencia $\operatorname{preliminar}^{787}$. En el caso, el sujeto pasivo de la diligencia preliminar nunca será la entidad aseguradora sino el asegurado o causante del daño al ser objeto de dicha diligencia, precisamente, la identificación del asegurador. Y, en consecuencia nunca será la entidad aseguradora nunca se dará la necesaria identidad de sujetos en la diligencia preliminar y proceso ulterior que se pretende preparar, para el caso de que se ejercite la acción directa del art. 76 LCS, que tiene por sujeto pasivo únicamente el asegurador. Luego, nunca frente al asegurador podrá invocarse el efecto interruptivo de la prescripción de aquellas diligencias preliminares que, al amparo del art. 256.1.5 LEC, se hayan instado para averiguar la identidad, precisamente, del asegurador.

A nuestro juicio, esta postura jurisprudencial constituye una quiebra del derecho fundamental a la tutela judicial efectiva que subyace en el fundamento de las diligencias preliminares. No cabe ninguna duda de que la investigación de la identidad del asegurador constituye una verdadera manifestación de la voluntad conservativa del derecho del perjudicado frente al propio causante del daño, tomador del seguro, asegurado o beneficiario que, salvo el primero de los enunciados, se hallan obligados a comunicar el siniestro a su entidad aseguradora, conforme establece el art. 16 LCS, pudiendo esta, incluso, reclamar los daños y perjuicios por la falta de declaración.

Por ello, y sin perjuicio de las relaciones internas derivadas del contrato de seguro (solidaridad impropia), existiendo la obligación de comunicar el siniestro al asegurador, no se entiende que la diligencia preliminar instada para la identificación del asegurador, aún tácitamente, carezca del efecto interruptivo que, en abstracto, se predica de las diligencias preliminares. Cierto es que en el caso no concurre el supuesto de identidad de sujetos que requiere la eficacia interruptiva de la prescripción. Pero no es menos cierto que la propia diligencia preliminar busca facilitar el ejercicio de una acción de resarcimiento del daño causado por un hecho cubierto por un seguro de responsabilidad civil frente a quien es responsable en el mismo grado que el causante,

\footnotetext{
${ }^{787}$ En dicho sentido, la STS de 14 de marzo de 2003 (sala $1^{\text {a }}$ ), ponente Ilmo. Sr. J. Almagro, f.j. $4^{\circ}$ (LA LEY 1951/2003).
} 
esto es, el asegurador. Más aún, si tenemos en cuenta que la identidad de este último, en principio, no puede ser conocida sino no concurre la voluntad del interesado causante, asegurado, tomador o beneficiario del seguro mediante su participación en la práctica de la diligencia preliminar cuando, además, tiene la obligación de comunicar el siniestro al asegurador. Así, si el ordenamiento jurídico permite el ejercicio de la acción directa (art. 76 LCS) frente al asegurador, sin necesidad de reclamación alguna frente al asegurado, con la única finalidad de proteger al perjudicado, no se entiende por qué la necesidad de acudir a una diligencia preliminar para identificar al asegurador carece del efecto interruptivo de la prescripción que sí se produce frente al causante del daño, asegurado, tomador o beneficiario del contrato de seguro cuando el asegurador ha debido de conocer el siniestro, por declaración de aquellos, y, además, puede reclamar por el perjuicio que la falta de declaración le produzca.

Ante esta realidad, sería oportuna una reflexión jurisprudencial o legal sobre la cuestión expuesta que siquiera, a nuestro juicio, requiere una modificación de la doctrina habida sobre la solidaridad impropia. Quizá, mediante la expresa regulación de la interrupción de la prescripción en sede de diligencias preliminares y, en el caso concreto, por ejemplo, supeditando la interrupción de la prescripción a la noticia que del siniestro pudiera dar el perjudicado a la entidad aseguradora que resulte identificada en la práctica de la diligencia preliminar. Al margen quedarían los supuestos de negativa del requerido a la práctica de la diligencia preliminar a los que, en todo caso, pudiera darse solución mediante la creación de un registro obligatorio de titulares activos y pasivos de seguros de responsabilidad civil de modo similar al Registro de contratos de seguros de cobertura de fallecimiento. Es decir, mediante la creación de un registro público cuya finalidad fuera la de suministrar la información necesaria para el conocimiento de los posibles interesados de la existencia del contrato de seguro de responsabilidad civil así como de la identidad de la entidad aseguradora con la que lo hubiese suscrito, a fin de permitir que los posibles perjudicados pudieran dirigirse a ésta para constatar si el hecho se encuentra cubierto por un seguro de responsabilidad civil. Podría decirse que una medida como la propuesta eliminaría la necesidad de la previsión de la diligencia preliminar contemplada en el art. 256.1.5 LEC pero entendemos que la diligencia en cuestión tiene un objeto más amplio que la mera 
identificación del asegurador. A saber, la exhibición del contrato y, por tanto, de su contenido, para la determinación de si el concreto evento generador del daño se encuentra o no cubierto por el seguro en cuestión.

Por último, en el contexto de la ausencia de identidad subjetiva exigida, podemos encuadrar el supuesto de que quien insta las diligencias preliminares no sea el titular del derecho controvertido en el futuro procedimiento judicial por cuanto para interrumpir el curso del plazo de prescripción, el ejercicio de la acción o la reclamación extrajudicial deben proceder del titular del derecho ${ }^{788}$. Es decir, que no opera la interrupción de la prescripción a favor de aquel que no es titular de la relación jurídica controvertida y, por tanto, tampoco acreedor de los efectos de su derecho, pese a que a su instancia se siguieran las diligencias preliminares a las que pretende se otorgue tal efecto, por mucho que el objeto y finalidad de aquellas fuera la de preparar el ulterior proceso en el que se analiza la interrupción de la prescripción. Ello, sin perjuicio de admitir tal efecto interruptivo en los supuestos en que las diligencias preliminares si bien no son instadas por el titular del derecho controvertido o de la relación jurídica planteada en ulterior proceso lo son por su mandatario, siempre y cuando actúe por cuenta del mandante y no por la suya propia ${ }^{789}$.

\subsection{Que la voluntad conservativa del concreto derecho llegue a conocimiento} del futuro demandado

El segundo de los requisitos exigidos por el TS es que la voluntad conservativa del concreto derecho llegue a conocimiento del deudor, en el caso de las diligencias preliminares, requerido o futuro demandado. Ello, al ser doctrina reiterada que la eficacia del acto interruptivo exige no sólo la actuación del acreedor, sino que llegue a conocimiento del deudor su realización ${ }^{790}$.

\footnotetext{
788 STS de 4 de diciembre de 2013 (sala $1^{\text {a }}$ ), ponente Ilmo. Sr. J.R. Ferrándiz, f.j. $7^{\text {o }}$ (LA LEY 226489/2013).

${ }^{789}$ STS de 23 de marzo de 2011 (sala 1ª), ponente Ilmo. Sr. J.R. Ferrándiz, f.j.3º (LA LEY 14235/2011).

${ }^{790}$ Y así lo dispone, entre otras, la STS de 13 de octubre de 1994 (sala $1^{\text {a }}$ ), ponente Ilmo. Sr. A. Gullón, f.j. $2^{\circ}$ (LA LEY 61/1995).
} 
Siendo esto así, los tribunales han contemplado distintos supuestos en los que la voluntad conservativa del derecho expresada a través de la correspondiente diligencia preliminar no llega a conocimiento del deudor, y que a continuación pasamos a examinar.

En primer lugar, el supuesto en que la diligencia preliminar se promueva ante un juzgado objetivamente incompetente. Como se desprende del art. 257.1 LEC, la regla general de competencia para el conocimiento de las diligencias preliminares ${ }^{791}$, en cuanto a la objetiva, corresponde a los JPI o JMER, en función de la materia o acción a que aquellas se refieran, así como, en cuanto a la territorial, del domicilio de la persona que, en su caso, hubiera de declarar, exhibir o intervenir de otro modo en las actuaciones que se acordaran para preparar el juicio ${ }^{792}$.

Pues bien, de conformidad con lo dispuesto en el art. 225.1 LEC son nulos de pleno derecho los actos procesales que se produzcan con falta de competencia objetiva o funcional. Y debiendo ser apreciados de oficio tan pronto como sean advertidos por el tribunal que conozca del asunto (arts. 48 y 227.2 LEC), con eficacia ex nunc, puede concluirse que la promoción de diligencias preliminares ante un juzgado incompetente es nula de pleno derecho y carece de virtualidad para interrumpir la prescripción ${ }^{793}$.

En segundo lugar, el supuesto de las diligencias preliminares inadmitidas. Dispone el art. 259.1 LEC que: "En el auto en el que se acceda a la solicitud, se citará y requerirá a los interesados para que, en la sede de la Oficina Judicial o en el lugar y del modo que se consideren oportunos, y dentro de los diez días siguientes, lleven a cabo la diligencia, que haya sido solicitada y acordada". Y de ello se desprende que sólo cuando

\footnotetext{
${ }^{791}$ Pues en los casos de los números 6, 7, 8 y 9 del aptdo. $1^{\circ}$ del artículo 256.1 LEC, será competente el tribunal ante el que haya de presentarse la demanda determinada. $\mathrm{Si}$, en estos casos, se solicitasen nuevas diligencias, a raíz del resultado de las hasta entonces practicadas, podrán instarse del mismo tribunal o bien del que, a raíz de los hechos averiguados en la anterior diligencia, resultaría competente para conocer de la misma pretensión o de nuevas pretensiones que pudieran eventualmente acumularse.

${ }^{792}$ Vid. cap. III, epígrafes 1.1 y 1.2, dedicados a la "competencia objetiva" y la "competencia territorial", respectivamente.

${ }^{793}$ En dicho sentido se ha pronunciado la SAP de Zaragoza (sección $5^{\text {a }}$ ) de 16 de julio de 2013, ponente Ilmo. Sr. J. Seoane, f.j. $4^{\circ}$ (LA LEY 129831/2013).
} 
dicha citación se produzca, el interesado y requerido a la práctica de la concreta diligencia preliminar tendrá conocimiento de la misma y su contenido.

A sensu contrario, si el tribunal no accediese a la solicitud de diligencia preliminar, en este caso, porque la inadmitiera, concluirá así el procedimiento, no procediéndose a la citación de quien como interesado se señalare en la solicitud y, por tanto, sin conocimiento de este de la diligencia preliminar y su contenido. Por ello, si el tribunal inadmitiese la petición, impidiendo así el conocimiento de la misma por parte de quien se señaló como interesado o persona a requerir para su práctica, la diligencia preliminar no tendría la eficacia de interrumpir la prescripción ${ }^{794}$. Así lo considera la doctrina judicial citada, incluso, en interpretación del párrafo segundo del art. 944 CCo que, junto al desistimiento ${ }^{795}$, de la interpelación judicial, la caducidad de la instancia o la desestimación de la demanda no contempla la inadmisión de las diligencias preliminares como supuesto de prescripción ${ }^{796}$. Por ello, podemos concluir que de inadmitirse la solicitud de diligencias preliminares ad limine no podría admitirse su eficacia interruptiva. Y debe tenerse en cuenta que esa negativa del efecto interruptivo de la prescripción opera, incluso, cuando admitida la diligencia preliminar se produzca su archivo por falta de prestación de caución ${ }^{797}$.

En tercer lugar, el supuesto de las diligencias preliminares que resulten admitidas por el tribunal y en las que no se halle al destinatario de las mismas. Son frecuentes en la práctica forense los supuestos en que el requerido, o demandado en

\footnotetext{
${ }^{794}$ Vid. la SAP Barcelona (sección 19 $9^{\text {a }}$ de 29 de mayo de 2013, ponente Ilma. Sra. A. Claret, f.j. $3^{\circ}$ (LA LEY 164756/2013); la SAP de Burgos (sección $3^{\mathrm{a}}$ ) de 12 de septiembre de 2012, ponente Ilmo. Sr. I.J. Barcala f.j. $3^{\circ}$ (LA LEY 144105/2012). Por otro lado, destacamos la SAP de Navarra (sección 2a) de 6 de marzo de 2013, ponente Ilmo. Sr. E.J. Vitalle, f.j.3º (LA LEY 52503/2013), en la que que la solicitud de diligencias preliminares no llegó a ser admitida por falta de actividad de la promovente.

${ }^{795}$ Ello teniendo en cuenta que en el ejercicio de acciones civiles, conforme a la STS de 25 de mayo de $2010\left(\right.$ sala $1^{\text {a }}$ ), ponente Ilmo. Sr. A. Xiol, f.j. $4^{\circ}$ (LA LEY 76113/2010), el desistimiento de una demanda ya comunicada a la parte demandada que ya conoce la reclamación sí que produce el efecto de interrupción de la prescripción, habida cuenta la procedencia de interpretar la prescripción con criterios restrictivos y el hecho de no contener el CC, en materia de prescripción, una norma semejante al art. 944 CCo.

${ }^{796}$ Pese a ello, la SAP de Barcelona (sección 19a) de 29 de mayo de 2013, ponente Ilma. Sra. A. Claret, f.j. $3^{\circ}$, (LA LEY 164756/2013), en aplicación del referido precepto legal, consideró que la inadmisión de las diligencias preliminares promovidas en el caso en cuestión no producían el efecto de interrumpir la prescripción.

${ }^{797}$ Como así lo recoge la sentencia anterior.
} 
cualquier proceso judicial, no es hallado, incluso, tras las correspondientes medidas de averiguación que la LEC contempla y, en otros casos, impone al tribunal. Para estos supuestos, en general, el art. 164 LEC permite la conocida citación edictal, constitucionalmente amparada por el $\mathrm{TC}^{798}$. Pero en el caso de las diligencias preliminares nada dice la LEC respecto a la posibilidad de citación edictal del interesado en la práctica de la diligencia preliminar. Tal falta de previsión pudiera obedecer a la propia naturaleza de la diligencia en la que parece subyacer la absoluta necesidad de la participación del requerido en su práctica, lo que resulta ser una ilusión o mera formalidad sin efecto cognoscitivo alguno en un supuesto de citación edictal.

Tomando en consideración lo anterior, en defecto de pronunciamiento doctrinal o jurisprudencial alguno, nos atrevemos a afirmar que, en el supuesto de diligencias preliminares, y con todas las garantías legales y efectos inherentes a las mismas, cabe realizar la citación edictal para su práctica. Y, en consecuencia, entender producida la interpelación del interesado y el conocimiento de la voluntad conservativa de la acción del promovente. De hecho, la notificación edictal se admite sin problemas en los procesos civiles, en general, y en los que incluso puede darse una condena de quien voluntariamente se mantiene en ignorado paradero o siendo cierto éste no quiere comparecer en el proceso.

En dicho sentido puede señalarse que, aún cuando la propia naturaleza de la institución y de cada una de las diligencias preliminares ponen de manifiesto la importancia de la participación del requerido en las mismas -lo que se torna muy evidente a la vista de los efectos que el art. 261 LEC dispone para el caso de negativa del requerido a comparecer a su práctica- debemos destacar que tanto la doctrina científica como judicial encuentran en las preliminares el fundamento a ejercitar el

\footnotetext{
${ }^{798}$ Entre otras, vid. las SSTC 162/2004, de 4 de octubre de 2004, ponente Ilmo. Sr. G. Jiménez, f.j. $4^{\circ}$ (LA LEY 10005/2005), 216/2002, de 25 de noviembre de 2002, ponente Ilma. Sra. E. Pérez, f.j. $2^{\circ}$ (LA LEY 10524/2003), 106/2006, de 3 de abril de 2006, ponente Ilmo. Sr. R. García-Calvo, f.j.2 $2^{\circ}$ (LA LEY 36231/2006), 131/2014, de 21 de julio de 2014, ponente Ilmo. Sr. A. Ollero, f.j.2 (LA LEY 100512/2014).
} 
derecho a la tutela judicial efectiva ${ }^{799}$. Ello se evidencia en ese espíritu de impulso renovador que la LEC dio a las diligencias preliminares introduciendo, respecto a la negativa injustificada de los requeridos a participar de las mismas, consecuencias prácticas de efectividad muy superior a las previstas bajo el imperio de ALEC y que las llevaron a casi su olvido ${ }^{800}$.

Por ello, en aquellos supuestos frecuentes en los que la ausencia de comparecencia ante el tribunal pueda considerarse provocada o maliciosa e, incluso, evidentemente negligente debe afirmarse la posibilidad de citación a la práctica de las diligencias preliminares mediante edictos y, consecuentemente, su eficacia interruptiva de la prescripción. Hoy en día resulta prácticamente imposible que ninguna de las instituciones u organismos del estado carezcan de datos ciertos sobre el paradero de cualquier español y, en el caso de que así fuera, no puede entenderse sino que lo será por voluntad propia. Por ello, en aquellos supuestos en los que el interesado no sea

\footnotetext{
${ }^{799}$ Respecto a la doctrina científica, vid. Carnero Sobrado, J.I., La flexibilización del..., ob. cit., p. 1, cuando señala que: "La vigente Ley de Enjuiciamiento Civil, en sus arts. 256 a 263, viene a regular las denominadas diligencias preliminares, instrumento legal que, al socaire del art. $24 \mathrm{CE}$, protege al justiciable de modo que pueda preparar con garantías su ulterior demanda"; Lorca Navarrete, A.Ma,$L a$ regulación de..., ob. cit., p. 2, cuando señala que la diligencia preliminar: "se integra en la tutela judicial efectiva declarativa preparándola anticipadamente"; Banacloche Palao, J., Las diligencias preliminares..., ob. cit., p. 28, cuando apunta que: "si bien no se mencionada nada sobre el posible fundamento constitucional de las diligencias preliminares ni sobre su vinculación con el acceso efectivo a la tutela jurisdiccional (....) se deduce de sus palabras que la razón de ser de su existencia no está simplemente en el deseo del legislador de evitar procesos inútiles, sino en el interés público existente en que las partes puedan preparar bien un proceso (....)" ampliándose las diligencias que cabe solicitar y con importantes consecuencias prácticas en orden a su negativa que "sólo se explican si se considera este instituto como estrechamente vinculado al derecho a la tutela judicial efectiva garantizado por el art. 24 CE". Y con referencia a la doctrina judicial, vid. el AAP de La Rioja (sección única), ponente Ilma. Sra. $\mathrm{M}^{\mathrm{a}}$. Carmen Araujo, f.j. $1^{\circ}$ (LA LEY 247768/2005); el AAP de Barcelona (sección 19a) de 27 de abril de 2006, ponente Ilmo. Sr. M.J. Collado, f.j. $2^{\circ}$ (LA LEY 123501/2006), el AAP de Vizcaya (sección $3^{\mathrm{a}}$ ) de 17 de octubre de 2007, ponente Ilma. Sra. M $^{\mathrm{a}}$.C. Marco, f.j. $2^{\circ}$ (LA LEY 255653/2007) y el AAP de Cáceres (sección 1ª) de 24 de marzo de 2009, ponente Ilmo. Sr. A.Mª . González, f.j.2 (LA LEY 35709/2009), éste último en relación a los derechos de propiedad intelectual.

${ }^{800}$ Al respecto, el apartado X de la Exposición de Motivos de la LEC señala: "Las diligencias preliminares del proceso establecidas en la Ley de Enjuiciamiento Civil de 1881 no distaban mucho del completo desuso, al considerarse de utilidad, dadas las escasas consecuencias de la negativa a llevar a cabo los comportamientos preparatorios previstos, pese a que el tribunal considerara justificada la solicitud del interesado. Por estos motivos, algunas iniciativas de reforma procesal civil se inclinaron a prescindir de este instituto.

Sin embargo, la presente Ley se asienta sobre el convencimiento de que caben medidas eficaces para la preparación del proceso. Por un lado, se amplían las diligencias que cabe solicitar, aunque sin llegar al extremo de que sean indeterminadas. Por otra parte, sin incurrir en excesos coercitivos, se prevén, no obstante, respecto de la negativa injustificada, consecuencias prácticas de efectividad muy superior a la responsabilidad por daños y perjuicios".
} 
hallado tras agotarse todos los medios de averiguación a disposición del tribunal, en un tiempo como el presente en que a este, de forma telemática y al instante, le es posible saber la práctica totalidad de los datos domiciliarios de cualquier interesado con el mero conocimiento de su documento nacional de identidad, debe afirmarse la validez y eficacia de la citación mediante edictos y su eficacia interruptiva de la prescripción.

Lo anterior nos lleva a concluir, pese a la falta de pronunciamiento expreso, que si tras la admisión de la diligencia preliminar la citación personal del requerido no puede llevarse a término una vez agotados todos los medios de averiguación a disposición del tribunal cabe practicar aquella edictalmente teniendo al mismo por citado y, por tanto, por conocedor de la voluntad del promovente de conservar su derecho al ejercicio de la acción, pues no cabe el amparo de quien voluntariamente se mantiene ajeno al proceso.

\section{Ineficacia de las diligencias preliminares atípicas como instrumento de interrupción de la prescripción}

Pero también en este punto cabe reflexionar sobre la eficacia interruptiva de las diligencias preliminares atípicas, es decir, aquellas diligencias preliminares en las que, existiendo identidad de objeto y sujetos en relación al proceso ulterior, no se hallen expresamente contempladas en el art. 256.1 LEC. Debe recordarse que tanto en el ámbito doctrinal como en la práctica de los tribunales, existe una postura mayoritaria que considera que el art. 256.1 LEC constituye una lista cerrada que hace que puedan ser objeto de solicitud, única y exclusivamente, aquellas diligencias que el texto enumera de forma exhaustiva ${ }^{801}$. Conforme a lo anterior, si sólo procede la admisión y práctica de aquellas diligencias preliminares que, en su diversidad de supuestos, encajen en una de las señaladas en el art. 256.1 LEC, debe concluirse que en aquellos supuestos en los que la diligencia preliminar admitida y practicada no sea una de las referidas en el listado anterior carecerá del efecto interruptivo que, con carácter general, se predica de

\footnotetext{
${ }^{801}$ Vid. cap. I, epígrafe 6, "Numerus clausus o numerus apertus".
} 
las mismas ${ }^{802}$, lo que podrá determinar el tribunal que examine la prescripción aún cuando el que conoció de la diligencia preliminar, siendo planteada en cuestión atípica, la hubiera admitido. Ello, por cuanto no puede admitirse la eficacia interruptiva de una diligencia preliminar que, según la doctrina considerada, no tiene el carácter de tal, y por ello no debió de ser admitida.

No obstante procede hacer notar aquellas resoluciones que han admitido los efectos interruptivos de la prescripción extintiva de una diligencia preliminar como la promovida por el arrendatario de una vivienda en régimen de propiedad horizontal dirigida frente a su arrendador propietario para la identificación de la persona de la presidencia de la CCPP y aportación de los datos de la compañía aseguradora de los daños imputables a aquella, para preparar demanda de responsabilidad por daños por las lesiones sufridas tras caerse por las escaleras de la comunidad por la falta de alumbrado ${ }^{803}$.

Sin embargo, en este supuesto se torna evidente que el arrendador requerido en diligencias preliminares no era la persona frente a la que se dirigiría la demanda, lo sería la comunidad, luego no se da la identidad subjetiva, como tampoco en el caso de la aseguradora visto anteriormente. También, que a los efectos de interponer la demanda, no era necesaria la identificación de la presidencia y que la obtención de los datos relativos a la compañía aseguradora de la comunidad, que no hay razón para pensar que debieran estar en poder del arrendador, se podrían haber obtenido instando la diligencia del art. 256.1.5 LEC directamente frente a la comunidad de propietarios y sin necesidad de intimar al arrendador. También se ha admitido el efecto interruptivo, pese a no ser un supuesto de numerus clausus, en el caso de promoción de diligencias preliminares por el perjudicado por los daños causados en el cierre perimetral de su finca por el ganado vacuno que circulaba por la colindante. Tales diligencias fueron promovidas frente a la

\footnotetext{
${ }^{802}$ La SAP de Valencia (sección $7^{\text {a }}$ ) de 22 de julio de 2010, ponente Ilmo. Sr. J.A. Lahoz, f.j. $1^{\circ}$ (LA LEY 164626/2010) niega eficacia interruptiva de la prescripción a una diligencia preliminar solicitada y admitida, consistente en dirigir oficio a la Policía Local con el objeto de que remitiera un atestado de un siniestro de tráfico con el fin de conocer la identidad de las personas involucradas, lo que fue acordado por el JPI.

${ }^{803}$ SAP de Alicante (sección $8^{\mathrm{a}}$ ) de 21 de febrero de 2013, ponente Ilmo. Sr. E. García-Chamón, f.j.2º (LA LEY 35753/2013).
} 
aseguradora del propietario de la finca colindante en petición de la presentación del informe pericial de los daños evaluados en su finca, al tener el propósito de instar acción tanto frente al propietario de la finca donde se encontraba el ganado como en ejercicio de la acción directa del art. 76 LCS frente a la aseguradora ${ }^{804}$.

Con todo, aún lo expuesto y la postura mayoritaria de la doctrina científica y judicial que aboga por la ineficacia interruptiva de la prescripción de aquellas diligencias preliminares que no encajen en la lista cerrada del art. 256.1 LEC, nosotros entendemos que dicha postura es contraria a la finalidad de la institución de las diligencias preliminares y, de alguna manera también, al derecho a la tutela judicial efectiva, que no admite distinción de clases, y a la seguridad jurídica. Si como señala la Exposición de Motivos de la LEC la misma "se asienta sobre el convencimiento de que caben medidas eficaces para la preparación del proceso" pero, por otro lado, no se justifica que un especie o clase concreta de proceso requiera una preparación que otro no, es decir, si no existe una causa objetiva que determine que un proceso concreto requiera de una preparación que otro no requiera, carece de toda razón que se limite la práctica de diligencias preliminares a una lista cerrada que además no tiene un denominador común. Si además tenemos en cuenta que existen resoluciones judiciales que admiten la práctica de diligencias preliminares atípicas, conforme a un criterio de numerus apertus, la consecuencia de una interpretación ceñida a la admisión de diligencias preliminares conforme a un criterio de numerus clausus, cuando se pretenda que aquellas una vez practicadas surtan el efecto de la interrupción de la prescripción, será la, por todos, indeseada inseguridad jurídica. Ello, porque la confianza generada por una decisión judicial en el interesado y en cuanto al efecto interruptivo de la prescripción que se predica de la diligencia que como preliminar y en su favor haya sido practicada puede ser defraudada por la posterior que siguiendo un criterio de numerus clausus deba valorar aquel efecto concluyendo que por ser atípica la diligencia carece de él.

\footnotetext{
${ }^{804}$ SAP de Asturias (sección $4^{\text {a }}$ ) de 13 de octubre de 2010, ponente Ilmo. Sr. J.A. Soto-Jove, f.j. $1^{\circ}$ (LA LEY 211103/2010).
} 


\section{Consideraciones finales}

Como se puso de manifiesto al inicio del presente capítulo, la LEC introdujo una novedosa regulación de las diligencias preliminares con la finalidad de preparar el proceso y a las que jurisprudencialmente se les ha venido a reconocer la virtualidad de servir de instrumento útil de interrupción de la prescripción extintiva. Exponente máximo de esta conclusión lo constituye la STS de 12 de noviembre de 2007, que exige que en la solicitud de diligencias preliminares se identifique con claridad y exactitud el derecho que se pretende conservar y la persona frente a la que se quiere hacer valer debiendo, en todo caso, coincidir con aquellos que se identifiquen como objeto y sujeto pasivo del ulterior proceso que se pretende preparar; y que la voluntad conservativa del concreto derecho que se manifieste a través de las diligencias preliminares llegue a conocimiento del deudor.

No obstante, el estudio realizado nos permite concluir que las exigencias jurisprudenciales establecidas en términos generales, en relación al conjunto de causas de interrupción de la prescripción, en algunos casos, impiden afirmar el efecto interruptivo de las diligencias preliminares contempladas en el art. 256.1 LEC y de aquellas que aún no estándolo puedan ser acordadas siguiendo un criterio de numerus apertus.

Por lo expuesto, consideramos necesaria una modificación de la regulación de las diligencias preliminares introduciendo las previsiones necesarias que permitan dar satisfacción al derecho a la tutela judicial efectiva que tanto la doctrina científica como la judicial reconocen subyace en las mismas como medio de preparación del futuro proceso civil y como instrumento útil para la interrupción de la prescripción extintiva.

En este sentido, nada debiera impedir que, reconocido en abstracto por la jurisprudencia el efecto interruptivo de las diligencias preliminares, este fuese expresamente contemplado en la actual regulación que les dedica la LEC. Al respecto, además de su expreso reconocimiento, también deberían considerarse las particularidades que presentan algunas diligencias preliminares, como la del art. 256.1.6 
LEC, e introducir las previsiones necesarias en aras a contemplar un plazo razonable de suspensión de la prescripción en el caso de diligencias que hayan sido inadmitidas por falta de competencia objetiva o por no ajustarse al criterio de numerus clausus. Y en este último caso, cuando resulten admitidas, aún cuando no típicas, determinar su expresa eficacia interruptiva a fin de que la facultad interpretadora de los jueces y tribunales no cause perjuicio a quien confió en la Administración de Justicia. 


\section{CONCLUSIONES}

Una de las labores más complejas para la defensa del justiciable en el proceso civil es el de su correcta preparación. La demanda rectora del procedimiento constituye el principal acto de alegación en el que, con efecto preclusivo, deben contenerse los hechos constitutivos o fundamentales de la pretensión de la parte actora. Por ello, la solución de un conflicto entre particulares con visos de ser judicializado mediante la interposición de la correspondiente demanda, pasa por un proceso de estudio, análisis, valoración y acopio de materiales e información que permita la adecuada preparación del proceso en que aquel pueda derivar o, en su caso, su evitación.

Así, la preparación del proceso civil constituye una fase previa al mismo, pero de esencial trascendencia, a la que el legislador español nunca ha permanecido ajeno, pues ya en el Derecho Romano se identifican los vestigios de la institución que la actual LEC contempla para la preparación del proceso civil: las diligencias preliminares. Nos encontramos, por tanto, ante una institución de honda raigambre en el derecho español que, pese a ello, y la utilidad que puede reportar, no ha tenido el uso y eficacia esperados.

La regulación de las diligencias preliminares sigue presentando lagunas y, en ocasiones también, una deficiente técnica legislativa que ha dado lugar a vacíos interpretados de forma muy dispar. Vacíos que en este trabajo hemos pretendido plasmar e intentado colmar mediante la recopilación de las posiciones de la doctrina científica y judicial y la elaboración de una serie de propuestas que esperamos sean acogidas. En dicho sentido, podemos concluir que:

PRIMERO: Las diligencias preliminares constituyen un mecanismo idóneo y previo al proceso para la adquisición del conocimiento de determinados presupuestos que la LEC, y los tribunales en interpretación de la misma, han considerado imprescindible conocer para un correcto planteamiento del proceso. En suma, para la correcta preparación del proceso civil. 
SEGUNDO: Nos encontramos ante una institución procesal en la que confluyen elementos que también se observan en otras actuaciones procesales respecto de las que las diligencias preliminares deben ser diferenciadas. Así, aún la circunstancia de ser una actuación previa al proceso que ayuda a conocer, antes de su inicio, determinados datos del mismo, previa prestación de caución, puede concluirse que nos encontramos ante una institución netamente diferenciada de otras de las que ha sido considerada afín. Las diligencias preliminares no tienen una finalidad probatoria, siquiera aseguratoria de la prueba o del resultado del proceso. También las diligencias preliminares deben ser distinguidas de otras figuras como el discovery que, en los países del common law, no sólo sirven a la preparación del proceso civil sino también, en un contexto extrajudicial y no facultativo, al conocimiento por las partes de las pruebas disponibles y su recopilación.

TERCERO: Aún su carácter facultativo y voluntario, nos encontramos ante un mecanismo procesal propio de la jurisdicción contenciosa en el que el efecto coercitivo que la LEC dispone que recaiga sobre quien sea requerido a su práctica y niegue su colaboración, lleva a una de las máximas expresiones que del derecho a la tutela judicial efectiva reconocido en el art. 24 CE cabía esperar sobre la base de la también exigencia constitucional del deber de colaborar con los jueces y tribunales que dispone el art. 118 del mismo texto constitucional.

CUARTO: Lo anterior, mediante el desarrollo de una amplia tipología de diligencias preliminares que responden a las necesidades de las relaciones jurídicas actuales y que, nosotros entendemos, resultaría conveniente flexibilizar en su aplicación al caso concreto que la práctica judicial ponga de manifiesto. Si bien puede afirmarse que sigue vigente la consideración de constituir el art. 256.1 LEC un catálogo numerus clausus de las diligencias preliminares que pueden ser acordadas, tal afirmación entra en cierta contradicción con el criterio de interpretación flexible que de las mismas se predica. A nuestro juicio, porque al mismo parece trascender una lucha que pretende compensar el veto de la indeterminación que impone la Exposición de Motivos de la LEC, y sobre el que se asienta el carácter de numerus clausus, con las exigencias del derecho a la tutela judicial efectiva (art. 24 CE) acordes con tal criterio de interpretación flexible, en virtud 
del cual la preparación del proceso civil no debería limitarse a los supuestos que contempla el art. 256.1 LEC.

Sin embargo, entendemos que dicha flexibilización, en aras a una mejor y más correcta administración de justicia, no puede desmerecer frente a su invocado carácter excepcional que en la práctica se ha traducido a su uso, también excepcional, lo que, en una vuelta al pasado, puede dar lugar a un nuevo olvido. De hecho, una revisión de las fechas de la doctrina judicial citada en el presente trabajo, pone de manifiesto como, si bien tras la publicación de la LEC proliferaron las interpretaciones judiciales de la regulación de las diligencias preliminares contenidas en la LEC, lo que se acentuó con la reforma operada por la Ley 19/2006, el transcurso de los años ha ido mermando los pronunciamientos de la práctica forense en la materia. Ello, pese a que la Ley 21/2014 introdujo en el catálogo del art. 256.1 LEC dos novedosas diligencias preliminares dirigidas a facilitar la preparación de las acciones por infracción de los derechos de propiedad industrial e intelectual en la sociedad de la información. Después de más de dos años de vigencia de la reforma no encontramos resoluciones judiciales que hayan procedido a la interpretación de las nuevas diligencias preliminares.

QUINTO: Por ello, y como criterio de admisión, debe preconizarse la finalidad fundamental de las diligencias preliminares que atiende a la preparación del proceso civil y, en su caso, evitación, mediante el conocimiento a través de ellas de aquellos aspectos o elementos que se consideren necesarios para la correcta articulación del ulterior proceso. Aspectos que, conforme a la regulación actual de las diligencias preliminares, no se ciñen a los meramente procesales, tales como la capacidad o representación y, en su caso, legitimación (arts. 256.1.1, 256.1.2, 256.1.5 y 256.1.6 LEC), sino que se extienden a verdaderas circunstancias que atañen al fondo del asunto. Así, al conocimiento, mediante la exhibición, del contenido de los actos de última voluntad (art. 256.3 LEC), de los documentos o cuentas de sociedades o comunidades (art. 256.1.4 LEC), de la historia clínica (art. 256.1.5 bis LEC) o, en materia de propiedad industrial e intelectual, de documentos bancarios, financieros, comerciales o aduaneros (art. 256.1.8 LEC). Pero también, en esta última materia, al suministro de los datos de identificación del posible infractor o sobre el origen y redes de distribución de 
obras, mercancías y servicios que infrinjan tales derechos (art. 256.1.7 LEC), para la identificación del PSSI o usuario de SSI sobre los que concurran indicios razonables de disponer o difundir contenidos, obras o prestaciones objeto de aquellos derechos sin cumplir los requisitos propios de su legislación (art. 256.1.10 y 11 LEC). También, a la constatación o comprobación de los hechos desarrollados o los medios empleados para infringir el ámbito de la exclusiva que el derecho de patente concede a su titular.

SEXTO: Y, a tal efecto, exige la LEC que el interesado deduzca la oportuna y fundada solicitud, pues las diligencias preliminares no cabe sean acordadas de oficio, en la que concurran los requisitos de adecuación a la finalidad perseguida, justa causa e interés legítimo. En suma, que de la solicitud presentada se desprenda que la diligencia preliminar solicitada resulta adecuada para la preparación del ulterior proceso (adecuación), la necesidad del solicitante de conseguir a través de ella datos imprescindibles para la preparación del ulterior proceso y que el mismo no ha podido obtener por sus propios medios (justa causa) y que aquel, en cuanto titular del concreto objeto del debate, se encuentra incurso en un conflicto que justifique el nacimiento de dicho ulterior proceso (interés legítimo).

Pero también, que se proceda al ofrecimiento y prestación de caución como garantía del resarcimiento de los daños y perjuicios que se puedan causar al requerido a intervenir en la práctica de las diligencias preliminares y, en su caso, de la sanción civil que se entienda deba recaer sobre el solicitante que, injustificadamente, deje de promover el ulterior proceso.

Así, la adecuación de las diligencias preliminares, la justa causa, el interés legítimo y la prestación de caución se constituyen en los elementos esenciales que, en términos generales, han de concurrir en toda solicitud de diligencias preliminares para que la misma resulte admitida y, en su caso, practicada y sobre los cuales nosotros formulamos nuestra propuesta de flexibilización del catálogo de diligencias preliminares contenido en el art. 256.1 LEC. Abogamos por una limitación de aquellas resoluciones que rechazan las diligencias preliminares solicitadas por considerarse atípicas o no poder incluirse en el catálogo que con el carácter de numerus clausus se 
sostiene se incluyen en el art. 256.1 LEC. El estudio realizado nos permite concluir que no concurren razones para que la preparación del proceso civil, con un criterio restrictivo, se limite a los supuestos contemplados en dicho catálogo. A nuestro juicio, partiendo de la decidida voluntad del legislador de facilitar la preparación del proceso civil, el derecho a la tutela judicial efectiva que reconoce el art. $24 \mathrm{CE}$ ampara la admisión de toda aquella solicitud de diligencias preliminares en la que, concurriendo los elementos esenciales antes apuntados, deba conducir, necesariamente, a una adecuada y necesaria preparación del proceso. En dicho sentido, la intervención judicial es suficiente para garantizar el rechazo de peticiones indiscriminadas, injustificadas o que persigan una finalidad distinta a la preparación del proceso civil y, en su caso, su evitación, tales como las dirigidas a la obtención de fuentes de prueba.

SÉPTIMO: En lo que atañe al catálogo concreto de diligencias preliminares, debemos destacar la importancia de la diligencia de declaración o exhibición documental sobre hechos relativos a la capacidad, representación o legitimación de la persona frente a quien se dirigirá la demanda (art. 256.1.1 LEC), en tanto que dichas circunstancias atañen de forma directa a los presupuestos procesales, y en el caso de la legitimación en ocasiones también materiales, que deben verificarse de forma inexcusable en todo procedimiento para que el juez pueda entrar en la totalidad del examen jurídico material de la pretensión. Ahora bien, negamos que la misma ampare la práctica de pruebas de interrogatorio anticipadas.

Por lo que se refiere a la diligencia de exhibición de cosas (art.256.1.2 LEC), en sintonía con la doctrina judicial, concluimos sobre la posibilidad de extender el objeto de la diligencia no sólo a los bienes inmuebles sino también a los documentos. En el caso de los inmuebles no debe perderse de vista que, a diferencia de tiempos pasados, la regulación actual de la diligencia en cuestión ha eliminado la mención expresa a la cosa mueble y, por otro lado, la utilidad que la misma puede reportar en el correcto planteamiento del ulterior proceso no puede verse limitada por interpretaciones restrictivas que no encuentran justificación ni en la norma ni en la elaboración parlamentaria de esta. Por otro lado, desde la entrada en vigor de la LEC, los supuestos de exhibición de bienes inmuebles son más numerosos en la doctrina judicial. En el caso 
de los documentos, en relación al cual la doctrina se encuentra dividida, entendemos que el hecho de que el legislador, en el catálogo del art. 256.1 LEC, se haya ocupado de identificar determinados documentos que, en todo caso, pueden ser objeto de las diligencias preliminares, no puede llevarnos a afirmar que sólo tales documentos, y no otros, pueden ser exhibidos. En el caso, la concurrencia de los elementos esenciales contemplados en el art. 258 LEC entendemos que debe ser la medida de la admisión de su exhibición al amparo del art. 256.1.2 LEC. Por otro lado, en términos de legitimación, consideramos procedente una reforma legal que no vincule la pasiva a la propia del proceso ulterior, habida cuenta que la mayor utilidad de la medida reside en la exhibición de la cosa.

Por su parte, el art. 256.1.3 LEC contempla la diligencia preliminar de exhibición de actos de última voluntad, cuya mayor utilidad reside en aquellos que no hayan sido otorgados ante Notario. Singularmente, el testamento ológrafo. Ahora bien, dada la realidad social actual y el criterio de interpretación flexible que propugnamos, entendemos factible la posibilidad de extender el objeto de la diligencia a las conocidas como instrucciones previas a que se refiere el art. 11 LBAP, a través de las cuales se manifiesta anticipadamente la voluntad sobre los cuidados y el tratamiento de la salud o, llegado el fallecimiento, el destino del cuerpo u órganos de la persona.

La exhibición de los documentos o cuentas de sociedades o comunidades, como dimensión diferenciada del derecho de información que el ordenamiento jurídico le reconoce a sus miembros, podrá ser obtenida a través de la diligencia contemplada en el art. 256.1.4 LEC. De la misma debe destacarse que su utilidad práctica permite ir más allá del texto legal extendiendo la legitimación activa, dada la diversidad de situaciones en que puede adquirirse o perderse la condición de socio o comunero, al solicitante que no reúna tal condición, y la legitimación pasiva, en una interpretación amplia, a cuantos entes puedan responder a la estructura de una masa en común de intereses. Y, en general, por lo que se refiere a su objeto, en relación a cuanta documentación societaria o comunitaria deba conocer el socio o comunero para la preparación de cuantos ulteriores pleitos estime oportuno interponer contra la sociedad o comunidad o cualquiera de sus representantes o socios. 
Por lo que respecta a la diligencia de exhibición del contrato de seguro (art. 256.1.5 LEC), debemos destacar que, pese a ser la misma una de las más firmes expresiones de tipicidad de las diligencias preliminares, al ceñirse el texto legal a la exhibición de del contrato de seguro de responsabilidad civil, apostamos por una extensión del objeto de la diligencia a otros contratos de seguro.

El art. 256.1.5 bis LEC recoge la diligencia de exhibición y entrega de la historia clínica que fue introducida en nuestro ordenamiento jurídico por una ley con cuya regulación ninguna relación guardaba, la Ley 19/2006, pero como consecuencia de un derecho reconocido en la legislación sanitaria cuyo ejercicio se encuentra estrechamente vinculado con el derecho a la tutela judicial efectiva. Respecto de la misma debe llamarse la atención sobre la limitación que a su objeto puede oponerse por los profesionales sanitarios a través de las anotaciones subjetivas, cosa que rechazamos por entender que, en todo caso, la misma queda supeditada a la decisión del juzgador.

Con la diligencia para la concreción de los integrantes del grupo de consumidores y usuarios (art. 256.1.6 LEC) la publicación de la LEC, consecuente con la protección que dispensa a estos grupos, puso a disposición de sus integrantes un verdadero medio de preparación del proceso civil que permite su identificación y determinación. De la misma cabe resaltar la indeterminación de las medidas a través de las cuales el tribunal podrá obtener los datos necesarios para la identificación de los miembros del grupo de afectados, que serán las necesarias en atención al caso concreto y el objeto de la diligencia, y el posible conflicto que la realización de la diligencia puede conllevar respecto de los derechos fundamentales a la intimidad y a la protección de datos de carácter personal.

Y, por último, mención especial, pero conjunta, merecen las diligencias para la preparación de los procesos por infracción de los derechos de propiedad intelectual e industrial (arts. 256.1.7 a 11 LEC) que, desde la Ley 19/2006 y hasta prácticamente la actualidad, con la Ley 21/2014, han venido configurándose gracias al impulso del legislador comunitario. También, por la aplastante irrupción de las nuevas tecnologías en la realidad social y la puesta de manifiesto de la necesidad de facilitar la preparación 
del proceso civil cuando objeto de aquellos ulteriores procesos lo sean las infracciones cometidas "en línea".

Si algo llama la atención de estas diligencias es, precisamente, la delgada línea que separa las mismas de una actividad de obtención de pruebas justificada, en tanto que diligencias preliminares, por la imposibilidad del legitimado activamente de averiguar, por otros medios, una serie de datos que resultan imprescindibles para emprender con garantías el proceso judicial ulterior, por infracción de aquellos derechos, y frente a quien no ostente la condición de mero consumidor final. No sólo por la necesidad de identificar al infractor y los medios a través de los cuales desarrolla su conducta sino por la necesidad de proceder, previamente al proceso civil, en el que se tendrán en cuenta las cifras de negocio alcanzadas como consecuencia de la conducta infractora, a la determinación del perjuicio sufrido.

Así, la decidida apuesta del legislador comunitario y nacional por la protección de los titulares de los derechos especiales se traduce, ante la complejidad de las materias objeto de la preparación del proceso civil y de la actividad de las actuaciones infractoras de tales derechos, en la mínima limitación de las posibles fórmulas de obtención de la información que sirva para la preparación del proceso civil. Sin embargo, manteniendo el contrapeso que suponen las garantías de confidencialidad que recoge la norma acordes con la naturaleza de la actividad concurrencial que se desarrolla por los sujetos que pueden verse implicados en la práctica de las diligencias preliminares. Igualmente, en la eliminación, en el supuesto del art. 256.1.7 LEC, de la preparación del proceso civil a las conductas infractoras ejecutadas mediante "actos desarrollados a escala comercial" ampliándose tales conductas a los actos que "no puedan considerarse realizados por meros consumidores finales de buena fe y sin ánimo de obtención de beneficios económicos o comerciales". Es decir, facilitando la preparación del proceso por infracción de los derechos de propiedad industrial e intelectual cometidos no sólo mediante "actos desarrollados a escala comercial" sino mediante cualquier acto que no pueda entenderse desarrollado por cualquier consumidor final. También, adecuándose a la nueva realidad social y como respuesta a la agresiva y negativa afección que los derechos de propiedad industrial e intelectual vienen sufriendo a través de las nuevas 
tecnologías de la información, en la expresa contemplación de la posibilidad de la preparación de los procesos por infracciones de tales derechos cometidas "en línea" y la implicación, en dicha tarea de preparación del proceso civil, de agentes esenciales en el ámbito de la sociedad de la información tales como los PSSI.

Por otro lado, en esta materia, cobran una relevancia singular las diligencias de comprobación de hechos a que se refiere el ordinal $9^{\circ}$ del art. 256.1 LEC con la mención a las diligencias y averiguaciones que, para la protección de determinados derechos, prevean las correspondientes leyes especiales, cuyo patrón lo marca la LP. Su finalidad no es otra que la comprobación, a través del órgano judicial y a instancia de legitimado, de los medios empleados para infringir el ámbito de la exclusiva que el derecho de patente le otorga tendiendo a evitar la desaparición, alteración o difuminación de los hechos necesarios para preparar el proceso civil. Son verdaderos actos de inspección y examen por parte del órgano judicial. Su peculiaridad deriva, además, de las diferencias que presentan respecto de los rasgos esenciales de las diligencias preliminares que contempla el art. 256.1 LEC. Las diligencias de comprobación de hechos están sujetas a los principios de sorpresa, el sujeto pasivo no tendrá conocimiento de la práctica de la diligencia hasta el mismo momento en que esta tenga lugar, urgencia, con el fin de evitar que se diluyan futuros medios probatorios, y numerus apertus, pudiendo practicarse cualquier diligencia que resulte necesaria para esclarecer los elementos de controversia.

OCTAVO: En cuanto al procedimiento, la competencia del tribunal para el conocimiento de las diligencias preliminares se muestra como otro de los elementos, en este caso puramente procesal, que necesariamente debe concurrir para la admisión de las diligencias preliminares, sin posibilidad de plantear declinatoria y con una clara diferenciación para el conocimiento de aquellas, gracias a la reforma operada en la LEC por Ley 19/2006, entre los JPI y los JMER. Así, el art. 257 LEC, en función de la naturaleza del procedimiento que se pretenda preparar, sienta un criterio de competencia objetiva a favor de los anteriores acompañado de un criterio imperativo de competencia territorial, con carácter general y con independencia de cuál sea el órgano competente para conocer del ulterior procedimiento que se pretende preparar, a favor del órgano 
judicial del domicilio de la persona que, en su caso, hubiera de declarar, exhibir o intervenir de otro modo en las diligencias. Y, con carácter específico, a favor del tribunal ante el que haya de presentarse la demanda determinada, en los supuestos de los ordinales $6^{\circ}$ a $9^{\circ}$ del art. 256.1 LEC.

Partiendo de los anteriores criterios, la LEC ordena un trámite propio pero confuso para el tratamiento de la falta de competencia objetiva y territorial. En primer lugar, al utilizar el término abstención, propio de la falta de competencia objetiva, para ordenar la apreciación por el juez tanto de la falta de esta como de la territorial. En segundo lugar, remitiendo la decisión sobre la falta de competencia, tanto objetiva como territorial, al trámite propio del conflicto negativo de competencia territorial. También, omitiendo cualquier referencia al tratamiento de la falta de competencia funcional a que, en los supuestos de los ordinales $6^{\circ}$ a $9^{\circ}$ del art. 256.1 LEC, pudieran dar lugar las previsiones del aptdo. $2^{\circ}$ del art. 257.1 LEC en el caso de solicitud de nuevas diligencias, a raíz del resultado de las ya practicadas, y cuyo conocimiento se atribuye al mismo tribunal que conoció inicialmente o al que, conforme a los hechos averiguados en las iniciales, resultaría competente para conocer de la misma pretensión o de nuevas pretensiones que pudieran eventualmente acumularse. Por último, y pese a la transnacionalidad que pudiera concurrir en las diligencias preliminares, no se establece criterio alguno de competencia, ni pueden remediarse subsidiariamente los supuestos de diligencias preliminares en los que concurran elementos extranjeros.

No existe un criterio general que pueda servir para determinar la legitimación activa y pasiva del procedimiento de diligencias preliminares sino que estas se van determinando en función de la diligencia en cuestión, tanto por vía legal como por vía de interpretación doctrinal.

Es cuestión controvertida la necesidad de asistencia letrada y representación procesal, tanto para la solicitud como para la oposición, también escrita, a la práctica de las diligencias preliminares, no obstante lo cual nosotros entendemos preceptiva la misma al considerar que la LEC no exime de dicha asistencia letrada y representación en las diligencias preliminares que, salvo en el caso de las diligencias de comprobación 
de hechos, carecen del carácter de urgentes, además de presentar una complejidad técnica que aconseja la intervención de dichos profesionales.

La resolución que acceda a la práctica de las diligencias preliminares quedará supeditada, en todo caso, a la efectiva prestación de caución que el órgano judicial deberá determinar y cuantificar en aquella, sin vinculación a la ofrecida por el solicitante y sin sujeción legal a parámetro alguno pero con observación de criterios tales como el grado de probabilidad y entidad de los daños y gastos que puedan producirse al requerido, los que el juzgador habrá de valorar. La prestación de caución se convierte en una condición sine qua non para la práctica de las diligencias preliminares de la que siquiera cabe eximir al beneficiario de la justicia gratuita. Pese a ello, la LEC no arbitra la posibilidad de que el solicitante muestre su disconformidad con la caución fijada por el órgano judicial, la que entendemos podría darse a través del recurso de apelación, no previsto expresamente, frente a la resolución que admita la práctica de las diligencias preliminares fijando una cuantía excesiva de la misma. Ello, porque la imposibilidad de prestar una caución excesiva conllevaría el archivo del procedimiento y, en consecuencia, la imposibilidad de acceso al mismo.

Una cuestión controvertida también en este punto es la relativa al pago de las costas, al no contener la LEC previsión alguna de su imposición para el caso de estimación de la oposición (art. 260.4 LEC), a diferencia de lo que sucede para el supuesto de desestimación de la misma (art. 260.3 LEC) con una expresa previsión de imposición de costas al requerido que formule injustificada oposición. Dada la intencionada pero, a nuestro juicio, equivocada voluntad del legislador de no imponer el pago de las costas procesales al solicitante frente al que se estime la oposición, entendemos procedente una reforma legal que determine la aplicación del régimen general de imposición de costas contenido en el art. 394 LEC.

Frente a la resolución que acuerde la práctica de las diligencias preliminares no podrá interponerse recurso alguno pero sí formular el requerido oposición (art. 260 LEC) en el plazo de los cinco días siguientes al de la citación. La oposición podrá ser impugnada por el solicitante, por escrito y en el plazo de cinco días pudiendo tanto este 
como el requerido instar la celebración de vista conforme a los trámites del juicio verbal. Dicho trámite concluirá con el dictado del auto que resuelve la oposición, con estimación o desestimación de la misma y sin posibilidad de recurso de apelación en este segundo caso. Por ello, y en el caso de ser desestimada la oposición, sugerimos la reforma del art. 260.3 LEC que permita al requerido a la práctica de las diligencias preliminares una debida valoración de sus derechos. Más aún, ante la inminente aplicación de las medidas contempladas en el art. 261 LEC que conllevará su renuencia a la práctica de las diligencias preliminares y la imposibilidad de revisión de aquellas en vía de recurso.

Para el caso de no formularse oposición, el requerido dispone de un plazo de diez días para llevar a cabo las diligencias en el tiempo, lugar y forma prevenida en el auto que las acuerde. Llama la atención la falta de previsión especial de la LEC en cuanto al lugar de la práctica de las diligencias de exhibición de los documentos societarios cuyo reconocimiento, de conformidad con el art. $33 \mathrm{Cco}$, debe hacerse en el establecimiento del empresario. También, la determinación de un plazo de diez días para la práctica de las diligencias preliminares (art. 259.1 LEC) concurrente con el de cinco para formular oposición, en ambos casos siguientes a la recepción de la citación.

También cuando la oposición se desestime deberá el requerido llevar a cabo las diligencias acordadas. Ello, ante la inminente aplicación, en caso contrario, de las medidas contempladas en el art. 261 LEC y que constituyen una auténtica novedad respecto del régimen contenido en la ALEC además de una novedosa y decidida apuesta por eliminar el desuso en el que las preliminares habían caído bajo el imperio de aquella, precisamente, por la ausencia de consecuencias prácticas ante la negativa del requerido a la práctica de las diligencias preliminares.

Así, el art. 261 LEC establece las diferentes medidas que podrá adoptar el juzgador para hacer efectiva la diligencia preliminar acordada en el caso de que la misma no se haya podido llevar a efecto, bien por la oposición del requerido, bien porque éste haya desoído el requerimiento efectuado. En relación a dichas medidas se ha sostenido la procedencia de ser acordadas, únicamente y habida cuenta su naturaleza 
coercitiva, cuando ello resulte proporcionado, admitiéndose la posibilidad de archivo de las diligencias preliminares acordadas, en caso contrario. Sin embargo lo anterior, nosotros entendemos que el juicio de proporcionalidad de las medidas coercitivas al tiempo de acordarse las mismas y una vez se ha accedido a la práctica de las diligencias preliminares, es extemporáneo. Las medidas del art. 261 LEC están ordenadas de forma correlativa a los supuestos del catálogo de diligencias preliminares que se contiene en el art. 256.1 LEC y tienen su origen en cada uno de los supuestos en él contemplados. En consecuencia, y sin desconocer la expresa previsión legal, entendemos que viniendo dada la proporcionalidad de la medida por la negativa a la práctica de la diligencia preliminar, no debería preverse ni admitirse examen alguno de la proporcionalidad al tiempo de acordarse la medida y una vez constatada la rebeldía del requerido.

En cuanto a la clase de medidas que pueden acordarse, la LEC prevé tres tipos de consecuencias. Primera, a efectos del ulterior juicio, la posibilidad de tener por respondidas afirmativamente las preguntas que el solicitante pretendiera formular, y los hechos admitidos o por ciertos, cuando se hubiere pedido la declaración sobre hechos relativos a la capacidad, representación o legitimación del citado o se hubiera pedido la exhibición de documentos contables (art. 261.1 $1^{\mathrm{a}}$ en relación con los ordinales $1^{\circ}$ y $4^{\mathrm{o}} \mathrm{del}$ art. 256.1 LEC); segunda, la posibilidad de obtener por la fuerza el documento, cosa o datos objeto de la diligencia preliminar, mediante la entrada y registro en lugar determinado, cuando se hubiese solicitado la exhibición de títulos y documentos, la exhibición de la cosa, la exhibición de la historia clínica o la colaboración para la determinación de los integrantes del grupo y, en materia de propiedad industrial e intelectual, la obtención de datos sobre el posible infractor, el origen y redes de distribución de las obras, mercancías o servicios y la exhibición de documentos bancarios, financieros, comerciales o aduaneros (art. 261.2 ${ }^{\mathrm{a}}$ y $5^{\mathrm{a}}$ en relación con los ordinales $1^{\circ}$ a $3^{\circ}$ y $5^{\circ}$ a $8^{\circ}$ del art. 256.1 LEC); y, en tercer lugar, acordándose las medidas de intervención necesarias (art. $261.5^{\mathrm{a}}$ en relación con los ordinales $5^{\circ}$ bis a $8^{\circ}$ del art. 256.1 LEC). Sin duda alguna, la entrada y registro, introducida con la LEC, es la medida que ha merecido mayores críticas y reticencias en la doctrina científica y judicial por la incidencia que la misma pudiera tener sobre el derecho fundamental a la inviolabilidad del domicilio reconocido en el art. $18 \mathrm{CE}$ que, unida a su falta de 
regulación mediante ley orgánica, pone en duda su constitucionalidad. Al respecto, la regulación en la norma procesal civil de la medida previendo su adopción en relación al lugar determinado en que pudieran hallarse los títulos, documentos y otros datos así como la cosa que sea objeto de las diligencias, y no en relación al domicilio de los sujetos requeridos, permite afirmar la existencia de esa duda de constitucionalidad sólo cuando dicha medida recaiga sobre un lugar determinado que, además, se corresponda con el concepto de domicilio constitucionalmente protegido. Por ello, y a nuestro juicio, en estos casos sería aconsejable que la medida de entrada y registro se regulase mediante ley orgánica dado que el art. 261 LEC no constituye una mera regla procedimental para la conformación de la decisión sino una habilitación legal del juez para su adopción.

Olvida la LEC cualquier referencia a las consecuencias a la negativa a la práctica de las diligencias preliminares contempladas en los ordinales $9^{\circ}$, relativo a las diligencias de comprobación de hechos, $10^{\circ}$ y $11^{\circ}$ del art. 256.1 LEC, estas últimas introducidas con ocasión de la reforma operada por la Ley 21/2014. No obstante, sin perjuicio de considerar necesaria una adaptación del régimen de medidas del art. 261 LEC a los supuestos de diligencias de comprobación de hechos y a los contemplados en los ordinales $10^{\circ}$ y $11^{\circ}$ del art. 256.1 LEC, dada la naturaleza de tales diligencias, concluimos oportuno la aplicación de la medida de entrada y registro.

Por otro lado, en cuanto al modo de practicarse la medida, la LEC se limita a ordenar, genéricamente, la ocupación y puesta a disposición del solicitante, en la sede del tribunal de los títulos y documentos; la presentación de la cosa ante el mismo, y la búsqueda de distintos documentos y datos. No obstante, dicha regulación deja de atender otras limitaciones prácticas o legales que impiden la realización de la medida en los términos previstos. Por tanto, y sin perjuicio de la debida acomodación que los tribunales ordinarios puedan hacer a la realidad práctica, en este punto se pone de manifiesto la necesidad de una revisión de esta ordenación legal.

Por último, y a modo de conclusión final, cabe determinar que la propia introducción del art. 261 LEC, así como los matices contenidos en los apartados que lo 
conforman, ponen de manifiesto que la adopción de la medida nunca podrá responder a una arbitraria decisión del tribunal. La negativa injustificada del requerido a prestar la colaboración interesada es el punto de partida del proceso de conformación de una decisión judicial que deberá plasmarse en un auto motivado, cuando la medida resulte proporcionada y cuando, bien concurran indicios suficientes de que los documentos y títulos, así como los datos, se encuentren en un lugar determinado, o bien, y en el caso de exhibición de una cosa, cuando se presuma que se encuentra en dicho lugar determinado.

Concluye el estudio del procedimiento de las diligencias preliminares con el análisis relativo a la aplicación de la caución (art. 262 LEC) cuyo destino parece ligar el art. 256.3 LEC al pago de los gastos, daños y perjuicios que, con ocasión de la práctica de las diligencias preliminares, se causen al requerido. Nos encontramos ante otra dimensión de las diligencias preliminares que la LEC regula con una deficiente técnica legislativa. Así, no aclara la LEC la necesidad de una previa solicitud de las partes sobre la aplicación de la caución o el tiempo en que esta deberá deducirse, determinando un plazo de cinco días, desde la práctica de las diligencias preliminares o la resolución de la oposición, para resolver sobre el destino de las mismas y previa audiencia del solicitante por un tiempo que no se expresa y que tampoco contempla la contradicción del instante de las diligencias preliminares. Por ello, concluimos que cualquier sistema que arbitre el juzgador y que respete los términos esenciales del art. 262 LEC, así como el principio de contradicción, será válido al efecto de resolver sobre la aplicación de la caución.

NOVENO: No debemos dar por finalizadas las presentes conclusiones sin hacer referencia a la virtualidad de las diligencias preliminares como instrumento útil de interrupción de la prescripción extintiva, así reconocida por el TS, que exige que en la solicitud de diligencias preliminares se identifique con claridad y exactitud el derecho que se pretende conservar y la persona frente a la que se quiere hacer valer debiendo, en todo caso, coincidir con aquellos que se identifiquen como objeto y sujeto pasivo del ulterior proceso que se pretende preparar; y que la voluntad conservativa del concreto 
derecho que se manifieste a través de las diligencias preliminares llegue a conocimiento del deudor.

No obstante, el estudio realizado nos permite concluir que las exigencias jurisprudenciales establecidas en términos generales, en relación al conjunto de causas de interrupción de la prescripción, en algunos casos, impiden afirmar el efecto interruptivo de las diligencias preliminares contempladas en el art. 256.1 LEC y de aquellas que aún no estándolo puedan ser acordadas siguiendo un criterio de numerus apertus.

Por todo, consideramos necesaria una modificación de la regulación de las diligencias preliminares introduciendo las previsiones necesarias que permitan dar satisfacción al derecho a la tutela judicial efectiva que tanto la doctrina científica como la judicial reconocen subyacen las mismas como medio de preparación del futuro proceso civil y como instrumento útil para la interrupción de la prescripción extintiva.

A la vista de cuanto ha sido expuesto, es claro, que tanto en la dimensión particular como en el contexto del tráfico jurídico mercantil, las diligencias preliminares reportan un mecanismo idóneo para la concreta determinación de los términos en que debe y puede ser preparado el proceso. Y no podemos sino concluir sobre la evidente utilidad que presenta la institución, que esperamos siga contando con el respaldo suficiente del legislador en su desarrollo e implantación. Más aún en un contexto como el actual de la administración de justicia en el que la activación de un proceso judicial se presenta como una industria costosa y, a veces, imposible de asumir.

A ello contribuiría la subsanación de las deficiencias que su regulación actual presenta y han sido apuntadas, a cuyo efecto hemos realizado las oportunas propuestas. También, la eliminación o flexibilización de la tipicidad de las diligencias que cabe practicar, permitiendo que sea el juez el que, en el caso concreto y de conformidad con los parámetros indispensables de adecuación de la diligencia al futuro proceso, interés legítimo, justa causa, decida sobre su procedencia. 


\section{ÍNDICE CRONOLÓGICO DE DOCTRINA JUDICIAL}

- STJUE de 19 de abril de 2012 (Asunto C-461/10), ponente Ilmo. Sr. J. Malenovský (LA LEY 39746/2012)

- STJUE de 29 de enero de 2008 (Asunto C-275/06), ponente Ilmo. Sr. J. Malenovský (LA LEY 20/2008)

- STC 175/2014, de 3 de noviembre de 2014, ponente Ilma. Sra. E. Roca (LA LEY $160976 / 2014)$

- STC 131/2014, de 21 de julio de 2014, ponente Ilmo. Sr. A. Ollero (LA LEY $100512 / 2014)$

- STC 222/2012, de 27 de noviembre de 2012, ponente Ilmo. Sr. L.I. Ortega (LA LEY $198392 / 2012)$

- STC 96/2012, de 7 de mayo de 2012, ponente Ilmo. Sr. M. Aragón (LA LEY $66248 / 2012)$

- STC 12/2012, de 30 de enero de 2012, ponente Ilma. Sra. A. Asua (LA LEY 2303/2012)

- STC 173/2011, de 7 de noviembre de 2011, ponente Ilmo. Sr. E. Gay (LA LEY 211654/2011)

- STC 132/2010, de 2 de diciembre de 2010, ponente Ilmo. Sr. E. Gay (LA LEY 213836/2010)

- STC 159/2009, de 29 de junio de 2009, ponente Ilmo. Sr. V. Conde (LA LEY $119316 / 2009)$ 
- STC 70/2009, de 23 de marzo de 2009, ponente Ilma. Sra. M ${ }^{\text {a }}$.E. Casas (LA LEY $14334 / 2009)$

- STC 206/2007, de 24 de septiembre de 2007, ponente Ilmo. Sr. M. Aragón (LA LEY $139143 / 2007)$

- STC 106/2006, de 3 de abril de 2006, ponente Ilmo. Sr. R. García-Calvo (LA LEY $36231 / 2006)$

- STC 86/2006, de 27 de marzo de 2006, ponente Ilmo. Sr. P. Pérez (LA LEY 36241/2006)

- STC 25/2005, de 14 de febrero de 2005, ponente Ilmo. Sr. R. García-Calvo (LA LEY 462/2005)

- STC 196/2004, de 15 de noviembre de 2004, ponente Ilmo. Sr. F.J. Delgado (LA LEY 2437/2004)

- STC 162/2004, de 4 de octubre de 2004, ponente Ilmo. Sr. G. Jiménez (LA LEY $10005 / 2005)$

- STC 216/2002, de 25 de noviembre de 2002, ponente Ilma. Sra. E. Pérez (LA LEY $10524 / 2003)$

- STC 45/2002, de 25 de febrero de 2002, ponente Ilma. Sra. E. Pérez (JUR 2010 445)

- STC 10/2002, de 17 de enero de 2002, ponente Ilma. Sra. Mª.E. Casas (LA LEY $1655 / 2002)$

- STC 200/2001, de 4 de octubre de 2001, ponente Ilmo. Sr. V. Conde (LA LEY $8066 / 2001)$ 
- STC 292/2000, de 30 de noviembre de 2000, ponente Ilmo. Sr. J.D. González (LA LEY 11336/2000)

- STC 254/2000, de 30 de octubre de 2000, ponente Ilmo. Sr. R. de Mendizabal (LA LEY 11996/2000)

- STC 129/1999, de 1 de julio de 1999, ponente Ilmo. Sr. F. Garrido (LA LEY 10526/1999)

- STC 94\1999, de 31 de mayo de 1999, ponente Ilmo. Sr. T. Vives (LA LEY 8094/1999)

- STC 49/1999, de 5 de abril de 1999, ponente Ilmo. Sr. T. Vives (LA LEY 4215/1999)

- STC 91/1998, de 23 de abril de 1998, ponente Ilmo. Sr. M. Jiménez de Parga (LA LEY 6663/1998)

- STC 196/1997, de 13 de noviembre de 1997, ponente Ilmo. Sr. F. García-Mon (LA LEY 66/1998)

- STC 114/1997, de 16 de junio de 1997, ponente Ilmo. Sr. M. Jiménez de Parga (LA LEY 7686/1997)

- STC 207/1996, de 16 de diciembre de 1996, ponente Ilmo. Sr. V. Gimeno (LA LEY $1527 / 1997)$

- STC 127\1994, de 5 de mayo de 1994, ponente Ilmo. Sr. V. Gimeno (LA LEY 17142/1994)

- STC 254/1993, de 20 de julio de 1993, ponente Ilmo. Sr. F. García-Mon (LA LEY 2282-TC/1993) 
- STC 197/1991, de 17 de octubre de 1991, ponente Ilmo. Sr. J. Leguina (LA LEY 7518/1991)

- STC 132/1989, de 18 de julio de 1989, ponente Ilmo. Sr. L. López (LA LEY 2382/1989)

- STC 231/1988, de 2 de diciembre de 1988, ponente Ilmo. Sr. L. López (LA LEY 1166-TC/1989)

- STC 93/1988, de 24 de mayo de 1988, ponente Ilmo. Sr. L. López (LA LEY 1008TC/1988)

- STC 202/1987, de 17 de diciembre de 1987, ponente Ilmo. Sr. C. De la Vega (LA LEY 920-TC/1988)

- STC 160/1987, de 27 de octubre de 1987, ponente Ilmo. Sr. C. De la Vega (LA LEY 888-TC/1988)

- STC 89/1987, de 3 de junio de 1987, ponente Ilmo. Sr. F. Rubio (LA LEY 810TC/1987)

- STC 149/1986, de 26 de noviembre de 1986, ponente Ilmo. Sr. E. Díaz (LA LEY 673TC/1987)

- STC 140/1986, de 11 de noviembre de 1986, ponente Ilmo. Sr. L. López (LA LEY 686-TC/1987)

- STC 22/1986, de 14 de febrero de 1986, ponente Ilmo. Sr. M. Díez de Velasco (LA LEY 597/1986)

- STC 67/1985, de 24 de mayo de 1985, ponente Ilmo. Sr. R. Gómez-Ferrer (LA LEY 10027-JF/0000) 
- STC 110/1984, de 26 de noviembre de 1984, ponente Ilmo. Sr. A. Latorre (LA LEY 353-TC/1985)

- STC 22/1984, de 17 de febrero de 1984, ponente Ilmo. Sr. L. Díez-Picazo (LA LEY 8565-JF/0000)

- STC 73/1982, de 2 de diciembre de 1982, ponente Ilmo. Sr. L. Díez-Picazo (LA LEY 7397-JF/0000)

- STC 6/1982, de 22 de febrero de 1982, ponente Ilmo. Sr. P. Fernández (LA LEY 41 $\mathrm{TC} / 1982)$

- STC 13/1981, de 22 de abril de 1981, ponente Ilmo. Sr. M. Velasco (LA LEY 6406JF/0000)

- STC 9/1981, de 31 de marzo de 1981, ponente Ilmo. Sr. R. Gómez-Ferrer (LA LEY 6278-JF10000)

- STS de 3 de mayo de 2017 (sala 1ª), ponente Ilmo. Sr. I. Sancho (LA LEY 35031/2017)

- STS de 4 de diciembre de 2013 (sala $1^{\text {a }}$ ), ponente Ilmo. Sr. J.R. Ferrándiz (LA LEY 226489/2013)

- STS de 7 de marzo de 2013 (sala 1ª), ponente Ilmo. Sr. J.A. Xiol (LA LEY 3042412013)

- ATS de 9 de octubre de 2012 (sala 1ª), ponente Ilmo. Sr. I. Sancho (LA LEY 153992/2012)

- ATS de 10 de abril de 2012 (sala 1ª), ponente Ilmo. Sr. F.J. Arroyo (LA LEY 51434/2012) 
- STS de 23 de marzo de 2011 (sala 1ª), ponente Ilmo. Sr. J.R. Ferrándiz (LA LEY $14235 / 2011)$

- STS de 25 de mayo de 2010 (sala $1^{\text {a }}$ ), ponente Ilmo. Sr. A. Xiol (LA LEY $76113 / 2010)$

- ATS de 2 de junio de 2009 (sala 1ª), ponente Ilmo. Sr. J.R. Ferrándiz (LA LEY 92211/2009)

- STS de 11 de junio de 2008 (sala $1^{\text {a }}$ ), ponente Ilmo. Sr. J. Almagro (LA LEY $86321 / 2008)$

- STS de 12 de noviembre de 2007 (sala 1ª), ponente Ilmo. Sr. J. Almagro (LA LEY $185155 / 2007)$

- STS de 13 de diciembre de $2006($ sala 1ª), ponente Ilmo. Sr. P. González (LA LEY 150016/2006)

- STS de 12 de diciembre de 2006 (sala 1ª), ponente Ilmo. Sr. P. González (LA LEY $150010 / 2006)$

- STS de 18 de septiembre de 2006 (sala $1^{\text {a }}$ ), ponente Ilmo. Sr. A. Salas (LA LEY 177099/2009)

- STS de 9 de marzo de 2006 (sala 1ª), ponente Ilmo. Sr. R. García (LA LEY 21549/2006)

- STS de 4 de marzo de 2005 (sala 1 ${ }^{\mathrm{a}}$ ), ponente Ilmo. Sr. A. Gullón (LA LEY 2774/2005)

- STS de 21 de julio de 2004 (sala 1ª), ponente Ilmo. Sr. P. González (LA LEY $172176 / 2004)$ 
- STS de 14 de marzo de 2003 (sala 1 ${ }^{\mathrm{a}}$ ), ponente Ilmo. Sr. J. Almagro (LA LEY $1951 / 2003)$

- ATS de 11 de noviembre de 2002 (sala 1ª), ponente Ilmo. Sr. J.M. Martínez-Pereda (LA LEY 222960/2002)

- STS de 13 de febrero de $2001\left(\right.$ sala $1^{\mathrm{a}}$ ), ponente Ilmo. Sr. R. Varela (LA LEY $1985 / 2001)$

- STS de 3 de julio de 2000 (sala 1ª), ponente Ilmo. Sr. D. P. González (LA LEY 10014/2000)

- STS de 17 de mayo de 1999 (sala $1^{\text {a }}$ ) ponente Ilmo. Sr. F. Morales (LA LEY 80046/1999)

- STS de 13 de octubre de 1994 (sala 1ª), ponente Ilmo. Sr. A. Gullón (LA LEY $61 / 1995)$

- STS de 9 de octubre de 1993 (sala 1 ${ }^{\text {a }}$ ), ponente Ilmo. Sr. F. Morales (LA LEY $13445 / 1993)$

- STS de 16 de abril de 1993 (sala 1ª), ponente Ilmo. Sr. L. Martínez-Calcerrada (LA LEY 13128/1993)

- STS de 14 de marzo de 1989 (sala 1ª), ponente Ilmo.Sr. R. Casares (LA LEY 736$\mathrm{JF} / 0000)$

- STS de 20 de junio de 1986 (sala 1ª), ponente Ilmo. Sr. J.L. Albácar (LA LEY 11145$\mathrm{JF} / 0000)$

- STCJ de 5 de marzo de 2007, ponente Ilmo. Sr. E. Calvo (LA LEY 11590/2007) 
- SAP de Alicante (sección 8 $8^{\text {a }}$ de 14 de febrero de 2017, ponente Ilmo. Sr. F.J. Soriano (LA LEY 36312/2017)

- SAP de Barcelona (sección 15ª) de 14 de diciembre de 2016, ponente Ilmo. Sr. J.F. Garnica (LA LEY 194624/2016)

- SAP de Barcelona (sección 13 ${ }^{\text {a }}$ ) de 2 de noviembre de 2016, ponente Ilma. Sra. I. Carriedo (LA LEY 216704/2016)

- SAP de Valencia (sección $7^{\mathrm{a}}$ ) de 30 de junio de 2016, ponente Ilmo. Sr. Ma.P.E. Cerdán (LA LEY 231584/2016)

- SAP de Vizcaya (sección 5a) de 10 de marzo de 2016, ponente Ilma. Sra. L.A. Cuenca (LA LEY 52499/2016)

- SAP de Madrid (sección 25a) de 22 de enero de 2016, ponente Ilmo. Sr. C. LópezMuñiz (LA LEY 5843/2016)

- AAP de Cantabria (sección $2^{a}$ ) de 6 de noviembre de 2015, ponente Ilmo. Sr. B. Arias (ROJ S 60112015)

- AAP de Madrid (sección 28 ) de 19 de octubre de 2015, ponente Ilmo. Sr. G. Plaza (LA LEY 246907/2015)

- AAP de Alicante (sección 5 $5^{\mathrm{a}}$ ) de 9 de septiembre de 2015, ponente Ilmo. Sr. Ma.V. Pérez (ROJ AAP A 81 12015)

- AAP de Valencia (sección 7 $7^{\text {a }}$ de 8 de julio de 2015, ponente Ilma. Sra. M. Ibañez (AC2015\1674)

- AAP de Madrid (sección 12ª) de 18 de junio de 2015, ponente Ilmo. Sr. J.Mª Torres (ROJ AAP M 45612015) 
- AAP de Alicante (sección $8^{\mathrm{a}}$ ) de 4 de junio de 2015, ponente Ilmo. Sr. L.A. Soler (JUR 2015 206411)

- AAP de Cantabria (sección 2 $2^{a}$ ) de 3 de junio de 2015, ponente Ilmo. Sr. D. M.C. Fernández (ROJ AAP S 107\2015)

- SAP de Málaga (sección 4a) de 13 de abril de 2015, ponente Ilmo. Sr. J.I. Delgado (LA LEY 126982/2015)

- SAP de Burgos (sección 2a) de 19 de febrero de 2015, ponente Ilmo. Sr. J.M. Carreras (LA LEY 26271/2015)

- AAP de Madrid (sección 28 a) de 31 de marzo de 2014, ponente Ilmo. Sr. E. García (LA LEY 36709/2014)

- SAP de Zaragoza (sección 5a) de 16 de julio de 2013, ponente Ilmo. Sr. J. Seoane (LA LEY 129831/2013)

- SAP de Barcelona (sección 19a) de 29 de mayo de 2013, ponente Ilma. Sra. A. Claret (LA LEY 164756/2013)

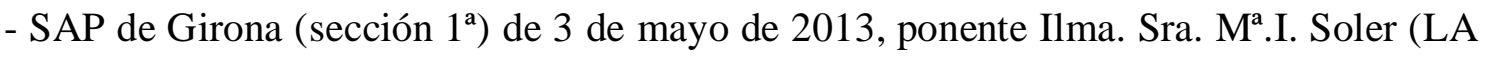
LEY 89454/2013)

- SAP de Navarra (sección 2a) de 6 de marzo de 2013, ponente Ilmo. Sr. E.J. Vitalle (LA LEY 52503/2013)

- SAP de Alicante (sección 8 ( $^{\text {) de }} 21$ de febrero de 2013, ponente Ilmo. Sr. E. GarcíaChamón (LA LEY 35753/2013)

- AAP de Granada (sección 3 $3^{\text {a }}$ de 11 de octubre de 2012, ponente Ilmo. Sr. E.P. Pinazo (ROJ AAP GR 553 2012) 
- SAP de Cáceres (sección 1ª) de 4 de diciembre de 2012, ponente Ilmo. Sr. L.A. Sanz (AC 2012\2280)

- AAP de Lugo (sección 1 $1^{\text {a }}$ ) de 26 de septiembre de 2012, ponente Ilmo. Sr. J.Ma Moreno (JUR 2012 1369729)

- SAP de Madrid (sección 14ª) de 19 de septiembre de 2012, ponente Ilma. Sra. A. Camazón (LA LEY 151352/2012)

- SAP de Burgos (sección $3^{\text {a }}$ ) de 12 de septiembre de 2012, ponente Ilmo. Sr. I.J. Barcala (LA LEY 144105/2012)

- SAP Madrid (sección 8a) de 29 de marzo de 2012, ponente Ilma. Sra. Mª.V. Salcedo (LA LEY 53724/2012)

- AAP de Salamanca (sección 1 ${ }^{\text {a }}$ ) de 29 de febrero de 2012, ponente J.R. González (LA LEY 280744/2012)

- AAP de Madrid (sección 28 $8^{a}$ de 10 de febrero de 2012, ponente Ilmo. Sr. A. Galgo (ROJ AAP M 2773/2012)

- AAP de Madrid (sección 18 ${ }^{a}$ ) de 21 de diciembre de 2011, ponente Ilmo. Sr. L. Pérez (LA LEY 266342/2011)

- AAP de Valencia (sección 11 ${ }^{\mathrm{a}}$ ) de 24 de octubre de 2011, ponente Ilmo. Sr. M.J. López (LA LEY 254572/2011)

- AAP de Murcia (sección $4^{\mathrm{a}}$ ) de 6 de octubre de 2011, ponente Ilmo. Sr. C. Moreno (LA LEY 215728/2011)

- AAP de Barcelona (sección 16 ${ }^{\text {a }}$ ) de 31 de mayo de 2011, ponente Ilma. Sra. I. Zapata (AC 2011\1347) 
- AAP de Las Palmas (sección 5 ${ }^{\text {a }}$ de 28 de abril de 2011, ponente Ilma. Sra. M. García (LA LEY 103652/2011)

- AAP de A Coruña (sección 4a $4^{\text {a de }} 28$ de abril de 2011, ponente Ilmo. Sr. C. Fuentes (AC 2011\11317)

- SAP de Málaga (sección 4a) de 4 de marzo de 2011, ponente Ilmo. Sr. F.J. Arroyo (LA LEY 116585/2011)

- AAP de Madrid (sección 28 ${ }^{\mathrm{a}}$ ) de 4 de febrero de 2011, ponente Ilmo. Sr. A. Arribas (AC 20111378)

- AAP de Girona (sección $1^{\text {a }}$ ) de 31 de enero de 2011, ponente Ilmo. Sr. F. Ferrero (LA LEY 24220/2011)

- SAP de Jaén (sección 3a) de 21 de enero de 2011, ponente Ilmo. Sr. S. Regidor (LA LEY 62353/2011)

- AAP de Alicante (sección $5^{\text {a }}$ ) de 12 de enero de 2011, ponente Ilmo. Sr. J.L. Úbeda (AC2011279)

- AAP de Sevilla (sección 5 $5^{\text {a }}$ de 29 de noviembre de 2010, ponente Ilmo. Sr. C. Gallardo (LA LEY 296879/2010)

- AAP de Madrid (sección 12a) de 17 de noviembre de 2010, ponente Ilma. S. M. Orejas (LA LEY 241227/2010)

- AAP de Madrid (sección 28 $) 12$ de noviembre de 2010, ponente Ilmo. Sr. E. García (AC 2010\2305)

- AAP de Teruel (sección 1 ${ }^{\mathrm{a}}$ ), de 2 de noviembre de 2010, ponente Ilma. Sra. Ma.D. Cerda (LA LEY 24915512010) 
- SAP de Asturias (sección 4 ${ }^{a}$ ) de 13 de octubre de 2010, ponente Ilmo. Sr. J.A. SotoJove (LA LEY 21110312010)

- AAP de Madrid (sección 21ª) de 28 de julio de 2010, ponente Ilma. Sr. A.Ma . Olalla (LA LEY 155141/2010)

- SAP de Valencia (sección $7^{a}$ ) de 22 de julio de 2010, ponente Ilmo. Sr. J.A. Lahoz (LA LEY 164626/2010)

- AAP de Madrid (sección 20ª) de 8 de julio de 2010, ponente Ilmo. Sr. R.F. Rodríguez (LA LEY 138539/2010)

- SAP de Pontevedra (sección 1 ${ }^{\mathrm{a}}$ ) de 18 de junio de 2010, ponente Ilmo. Sr. F.J. Valdés (LA LEY 156604/2010)

- AAP de Las Palmas (sección 4a $4^{\text {}}$ de 10 de junio de 2010, ponente Ilma. Sra. Ma E. Corral (LA LEY 221255/2010)

- AAP de Madrid (sección 11 a) de 1 de junio de 2010, ponente Ilmo. Sr. C.F. Duro (LA LEY 107207/2010)

- AAP de Madrid (sección 28 $8^{a}$ de 21 de mayo de 2010, ponente Ilmo. Sr. P.Ma. Gómez (LA LEY 101083/2010)

- SAP de Cádiz (sección 5a) de 5 de mayo de 2010, ponente Ilmo. Sr. C. Ercilla (LA LEY 166436/2010)

- AAP de Sevilla (sección 5 $5^{\text {a }}$ de 30 de abril de 2010, ponente Ilmo. Sr. F. Sanz (LA LEY 180840/2010)

- AAP de Cádiz (sección 2a) de 20 de abril de 2010, ponente Ilmo. Sr. J.C. Ruiz (LA LEY 77645/2010). 
- AAP de Madrid (sección 28 $8^{a}$ de 12 de abril de 2010, ponente Ilmo. Sr. J. Zarzuelo (AC 2010\1001)

- AAP de Madrid (sección 28 a) de 19 de febrero de 2010, ponente Ilmo. Sr. A. Arribas (LA LEY 25238/2010)

- SAP de Girona (sección $1^{\text {a }}$ ) de 17 de febrero de 2010, ponente Ilmo. Sr. F. Ferrero (LA LEY 37550/2010)

- SAP de Vizcaya (sección 4 ${ }^{\mathrm{a}}$ ) de 15 de enero de 2010, ponente Ilma. Sra. Ma.L. Arranz (LA LEY 33826/2010)

- AAP de Murcia (sección $5^{\text {a }}$ ) de 30 de diciembre de 2009, ponente Ilmo. Sr. J.M. Nicolás (LA LEY 291667/2009)

- AAP de Castellón (sección 1ª) de 15 de diciembre de 2009, ponente Ilmo. P.L. Garrido (LA LEY 309054/2009)

- AAP de Barcelona (sección 5a) de 15 de diciembre de 2009, ponente Ilmo. Sr. I. Sancho (LA LEY 308468/2009)

- AAP de Barcelona (sección 5a) de 10 de diciembre de 2009, ponente Ilmo. Sr. I. Sancho (LA LEY 308466/2009)

- AAP de Cantabria (sección 2a) de 19 de julio de 2009, ponente Ilma. Sra. M. Martínez (LA LEY 156894/2008)

- AAP de Valencia (sección $6^{a}$ ) de 2 de julio de 2009, ponente Ilma. Sra. M. Mestre (LA LEY 191888/2009)

- AAP de Madrid (sección 8a) de 30 de junio de 2009, ponente Ilma. Sra. Ma.V. Salcedo (ROJ AAP M 8367/2009) 
- AAP de Las Islas Baleares (sección $3^{\text {a }}$ ) de 30 de junio de 2009, ponente Ilma. Sra. $M^{a}$.R. Rigo (LA LEY 133792/2009)

- AAP de Burgos (sección 3 $3^{\text {a }}$ de 19 de junio de 2009, ponente Ilmo. Sr. I.J. Barcala (LA LEY 105789/2009)

- AAP de Barcelona (sección 16 ${ }^{\text {a }}$ de 4 de junio de 2009, ponente Ilmo. Sr. I.C. Zapata (LA LEY 174400/2009)

- AAP de Cáceres (sección $1^{\text {a }}$ ) de 14 de mayo de 2009, ponente Ilmo. Sr. A.M. González (LA LEY 77071/2009)

- AAP de Barcelona (sección 15ª) de 29 de abril de 2009, ponente Ilmo. Sr. L. Garrido (JUR 20091410747)

- AAP de Madrid (sección 20a) de 31 de marzo de 2009, ponente Ilma. Sra. S. Arroyo (LA LEY 61310/2009)

- AAP de Cáceres (sección $1^{\mathrm{a}}$ ) de 24 de marzo de 2009, ponente Ilmo. Sr. A.Mª González (LA LEY 35709/2009)

- AAP de Cáceres (sección $1^{\mathrm{a}}$ ) de 20 de marzo de 2009, ponente Ilmo. Sr. A.Ma González (ROJ AAP CC 100/2009)

- AAP de León (sección $1^{\text {a }}$ ) de 25 de febrero de 2009, ponente Ilma. Sra. A. del Ser (LA LEY 26737/2009)

- AAP de Madrid (sección 8 s $^{\text {) de }} 23$ de febrero de 2009, ponente Ilmo. Sr. A. García (LA LEY 44613/2009)

- AAP de Barcelona (sección 19a) de 11 de febrero de 2009, ponente Ilmo. Sr. M.J. Collado (LA LEY 33734/2005) 
- AAP de Cádiz (sección 2aa) de 19 de enero de 2009, ponente Ilma. Sra. M. ÁlvarezOssorio (LA LEY 9593/2009)

- AAP de Madrid (sección 13ª) de 14 de enero de 2009, ponente Ilmo. Sr. J. González (LA LEY 36758/2009)

- AAP de La Rioja (sección única) de 9 de diciembre de 2008, ponente Ilmo. Sr. L.M. Rodríguez (LA LEY 312622/2008)

- AAP de Madrid (sección 28 $8^{\mathrm{a}}$ ) de 5 de diciembre de 2008, ponente Ilmo. Sr. P.M ${ }^{\mathrm{a}}$ Gómez (LA LEY 263211/2008)

- AAP de Ciudad Real (sección 2a) de 25 de noviembre de 2008, ponente Ilma. Sra. C.P. Catalán (LA LEY 294700/2008)

- AAP de Cádiz (sección 2a) de 18 de noviembre de 2008, ponente Ilmo. Sr. A. Marín (LA LEY 237789/2008).

- AAP de Madrid (sección 19ª) de 24 de octubre de 2008, ponente Ilmo. Sr. E. Legido (LA LEY 231309/2008)

- AAP de Barcelona (sección 16ª) de 17 de octubre de 2008, ponente Ilmo. Sr. J.L. Valdivieso (JUR 2009\51421)

- AAP de Madrid (sección 28 ) de 25 de septiembre de 2008, ponente Ilmo. Sr. E. García (LA LEY 191903/2008)

- AAP de Tarragona (sección $3^{\text {a }}$ ) de 24 de septiembre de 2008, ponente Ilmo. Sr. J. Perarnau (LA LEY 225630/2008)

- AAP de Barcelona (sección 1ª) de 29 de julio de 2008, ponente Ilmo. Sr. J.L. Barrera (LA LEY 129377/2008) 
- AAP de Cádiz (sección 5a) de 2 de julio de 2008, ponente Ilma. Sra. R.Mª Fernández (LA LEY 196482/2008)

- AAP de Madrid (sección 28 ) de 19 de junio de 2008, ponente Ilmo. Sr. P. Gómez (LA LEY 110440/2008)

- AAP de Barcelona (sección $4^{\mathrm{a}}$ ) de 10 de junio de 2008, ponente Ilma. Sra. M.M. Hernández (LA LEY 129981/2008)

- AAP de Madrid (sección 10ª) de 28 de mayo de 2008, ponente Ilmo. Sr. A.V. Illescas (LA LEY 84016/2008)

- AAP de Barcelona (sección 14a) de 28 de mayo de 2008, ponente Ilma. Sra. M. Font (LA LEY 105101/2008)

- AAP de Córdoba (sección 1ª) de 15 de mayo de 2008, ponente Ilmo. Sr. E. Baena (LA LEY 199232\2008)

- AAP de Madrid (sección 28a) de 15 de abril de 2008, ponente Ilmo. Sr. R. Sarazá (LA LEY 37506/2008)

- AAP de Las Islas Baleares (sección 3 $3^{\text {a }}$ de 10 de abril de 2008, ponente Ilma. Sra. C.M ${ }^{\mathrm{a}}$. Moragues (JUR 2008\226206)

- AAP de A Coruña (sección 4a) de 21 de febrero de 2008, ponente Ilmo. Sr. J.M. Busto (LA LEY 28300/2008)

- AAP de Santa Cruz de Tenerife (sección $3^{a}$ ) de 6 de febrero de 2008, ponente Ilma. Sra. C.M. González (LA LEY 45516/2008)

- AAP de Barcelona (sección 19a) de 23 de enero de 2008, ponente Ilmo. Sr. M.J. Collado (LA LEY 7780/2008) 
- AAP de Madrid (sección 28 $8^{a}$ de 18 de enero de 2008, ponente Ilmo. Sr. P.Ma . Gómez (LA LEY 115182/2008)

- SAP de Segovia (sección única) de 28 de diciembre de 2007, ponente Ilmo. Sr. I. Pando (LA LEY 324811/2007)

- AAP de Madrid (sección 28 $8^{\text {a }}$ de 13 de diciembre de 2007, ponente Ilmo. Sr. E. García (LA LEY 300153/2007)

- AAP de Barcelona (sección 15ª de 10 de diciembre de 2007, ponente Ilmo. Sr. L. Garrido (LA LEY 314557/2007)

- AAP de Castellón (sección $3^{\text {a }}$ ) de 7 de diciembre de 2007, ponente Ilma. Sra. A. Bardón (LA LEY 311060/2007)

- AAP de Vizcaya (sección 5a) de 4 de diciembre de 2007, ponente Ilma. Sra. LA. Cuenca (LA LEY 320478/2007)

- AAP de Jaén (sección 2a) de 27 de noviembre de 2007, ponente Ilma. Sra. M.E. AriasSalgado (LA LEY 269250/2007)

- AAP de Vizcaya (sección $3^{\text {a }}$ ) de 15 de noviembre de 2007, ponente Ilma. Sra. A.I. Gutiérrez (LA LEY 239652/2007)

- AAP de Madrid (sección 10a) de 12 de noviembre de 2007, ponente Ilma. Sra. A.M. Olalla (LA LEY 252724/2007)

- AAP de Álava (sección $1^{\text {a }}$ ) de 12 de noviembre de 2007, ponente Ilma. Sra. Mª.M. Guerrero (LA LEY 250988/2007)

- AAP de Valencia (sección 11 ${ }^{a}$ ) de 22 de octubre de 2007, ponente Ilmo. Sr. A.F. Giménez (LA LEY 288126/2007) 
- AAP de Vizcaya (sección $3^{\mathrm{a}}$ ) de 17 de octubre de 2007, ponente Ilma. Sra. Ma.C. Marco (LA LEY 255653/2007)

- AAP de Guipúzcoa (sección 3ª) de 3 de octubre de 2007, ponente Ilma. Sra. J.Ma Unanue (ROJ AAP SS 790/2007)

- AAP de Madrid (sección 9a) de 6 de septiembre de 2007, ponente Ilmo. Sr. J.L. Gordillo (LA LEY 163525/2007)

- AAP de Barcelona (sección 15ª) de 19 de julio de 2007, ponente Ilmo. Sr. L. Garrido (LA LEY 235816/2007)

- AAP de Vizcaya (sección $3^{\text {a }}$ ) de 16 de julio de 2007, ponente Ilma. Sra. A. I. Gutiérrez (LA LEY 201929/2007)

- AAP de Santa Cruz de Tenerife (sección 4ª) de 4 de julio de 2007, ponente Ilmo. Sr. E.F. Suárez (LA LEY 183911/2007)

- AAP de Guipúzcoa (sección 2a) de 14 de junio de 2007, ponente Ilma. Sra. Y. Domeño (LA LEY 172255/2007)

- AAP de Barcelona (sección 13ª) de 8 de mayo de 2007, ponente Ilma. Sra. I. Carriedo (LA LEY 113407/2007)

- AAP de Granada (sección $3^{\text {a }}$ ) de 27 de abril de 2007, ponente Ilmo. Sr. J.Ma . Jiménez (LA LEY 60757/2007)

- AAP de Santa Cruz de Tenerife (sección 4a) de 18 de abril de 2007, ponente Ilma. Sr. P. Aragón (LA LEY 50149\2007)

- AAP de Madrid (sección 9a) de 13 de abril de 2007, ponente Ilmo. Sr. J.L. Gordillo (JUR 2007/232324) 
- AAP de Cádiz (sección 2a) de 15 de marzo de 2007, ponente Ilmo. Sr. A. Marín (ROJ AAP CA 419/2007)

- AAP de Barcelona (sección 13ª) de 12 de marzo de 2007, ponente Ilma. Sra. MaA. Gomis (LA LEY 14888/2007)

- AAP de Madrid (sección 11ª) de 8 de enero de 2007, ponente Ilmo. Sr. J. Zarzuelo (LA LEY 35128/2007)

- AAP de Madrid (sección 28 ) de 16 de noviembre de 2006, ponente Ilmo. Sr. G. Plaza (JUR 2007/75909)

- AAP de Tarragona (sección $1^{\text {a }}$ ) de 6 de noviembre de 2006, ponente Ilmo. Sr. J.L. Portugal (ROJ AAP T 862/2006)

- AAP de Guipúzcoa (sección 3 $3^{\text {a }}$ de 31 de octubre de 2006, ponente Ilma. Sra. B. Argal (LA LEY 229882/2006)

- AAP de Badajoz (sección $3^{\text {a }}$ ) de 27 de octubre de 2006, ponente Ilmo. Sr. J. Souto (LA LEY 169173/2006)

- AAP de Sevilla (sección 5 $5^{\text {a }}$ de 11 de octubre de 2006, ponente Ilmo. Sr. F. Sanz (LA LEY 269449/2006)

- AAP de Barcelona (sección 15ª de 29 de septiembre de 2006, ponente Ilmo. Sr. I. Sancho (LA LEY 237147/2006)

- AAP de Madrid (sección 20a) de 20 de julio de 2006, ponente Ilmo. Sr. R.F. Rodríguez (LA LEY 173636/2006)

- AAP de León (sección $2^{\text {a }}$ ) de 6 de julio de 2006, ponente Ilmo. Sr. A.F. Álvarez (LA LEY 969173/2006) 
- AAP de Huelva (sección $2^{a}$ ) de 4 de julio de 2006, ponente Ilmo. Sr. F. G. Ruíz (LA LEY 204861/2006)

- AAP de Barcelona (sección 15ª) de 27 de junio de 2006, ponente Ilmo. Sr. J.L. Forgas (LA LEY 232044/2006)

- AAP de Sevilla (sección $5^{\text {a }}$ ) de 5 de junio de 2006, ponente Ilmo. Sr. F. Sanz (LA LEY 191615/2006)

- AAP de Pontevedra (sección $1^{\text {a }}$ ) de 25 de mayo de 2006, ponente Ilma. Sra. MB. Rodríguez (LA LEY 326148/2006)

- AAP de Lugo (sección $1^{\text {a }}$ ) de 16 de mayo de 2006, ponente Ilmo. Sr. J.V. Varela (LA LEY 80128/2006)

- AAP de Barcelona (sección 19a) de 27 de abril de 2006, ponente Ilmo. Sr. M.J. Collado (LA LEY 123501/2006)

- AAP de Barcelona (sección 11 ${ }^{\text {a }}$ ) de 18 de abril de 2006, ponente Ilmo. Sr. F. Herrando (LA LEY 116299/2006)

- SAP de Barcelona (sección 16 ${ }^{a}$ ) de 12 de abril de 2006, ponente Ilmo. Sr. A. Ferrer (LA LEY 104338/2006)

- AAP de Barcelona (sección 11ª) de 29 de marzo de 2006, ponente Ilmo. Sr. J.A. Ballester (LA LEY 94232/2006)

- AAP de Almería (sección 3 $3^{\text {a }}$ de 23 de marzo de 2006, ponente Ilmo. Sr. J. Martínez (LA LEY 67260/2006)

- AAP de Las Palmas (sección $3^{\text {a }}$ ) de 27 de enero de 2006, ponente Ilmo. Sr. R. Moyano (LA LEY 11866/2006) 
- AAP de Zamora (sección $1^{\text {a }}$ ) de 30 de diciembre de 2005, ponente Ilmo. Sr. A.M. Encinas (LA LEY 250771/2005)

- AAP de Madrid (sección 19ª) de 23 de diciembre de 2005, ponente Ilmo. Sr. E. Legido (LA LEY 24761/2005)

- AAP de La Rioja (sección única) de 23 de diciembre de 2005, ponente Ilma. Sra. Ma Carmen Araujo (LA LEY 247768/2005)

- AAP de Barcelona (sección 13ª) de 13 de diciembre de 2005, ponente Ilmo. Sr. J.B. Cremades (LA LEY 239881/2005)

- AAP de Madrid (sección 19ª) de 1 de diciembre de 2005, ponente Ilmo. Sr. R. Ruíz (LA LEY 234511/2005)

- AAP de Sevilla (sección $2^{a}$ ) de 10 de noviembre de 2005, ponente Ilmo. Sr. A. Palacios (LA LEY 219084/2005).

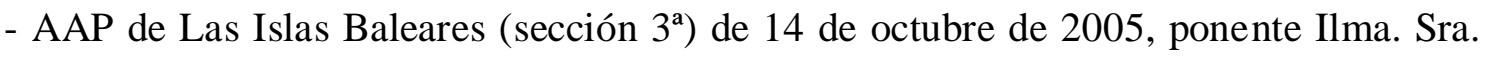
$M^{a}$.R. Rigo (LA LEY 199921/2005)

- AAP de Las Palmas (sección 4ª) de 23 de septiembre de 2005, ponente Ilma. Sra. E. Galcerán (LA LEY 183769/2005)

- AAP de Madrid (sección 19ª de 13 de septiembre de 2005, ponente Ilmo. Sr. N. Díaz (LA LEY 175959/2005)

- AAP de Asturias (sección 1 ${ }^{\text {a }}$ ) de 20 de julio de 2005, ponente Ilmo. Sr. Mª. Muriel (LA LEY 161745/2005)

- AAP de Vizcaya (sección $3^{\text {a }}$ ) de 28 de junio de 2005, ponente Ilma. Sr. A.I. Gutiérrez (LA LEY 145270/2005). 
- AAP de Madrid (sección 19a) de 20 de mayo de 2005, ponente Ilmo. Sr. E. Legido (LA LEY 114140/2005)

- AAP de Granada (sección $3^{\mathrm{a}}$ ) de 5 de mayo de 2005, ponente Ilmo. Sr. A. Mascaró (ROJ AAP GR 399/2005)

- AAP de Valencia (sección 11 ${ }^{\mathrm{a}}$ ) de 26 de abril de 2005, ponente Ilmo. Sr. J.A. Arolas (LA LEY 93056/2005)

- AAP de Toledo (sección 1 ${ }^{\text {a }}$ ) de 30 de marzo de 2005, ponente Ilmo. Sr. M. Gutiérrez (LA LEY 70219/2005)

- AAP de Barcelona (sección 15ª) de 21 de marzo de 2005, ponente Ilmo. Sr. I. Sancho (LA LEY 65420/2005)

- AAP de Barcelona (sección 15ª) de 21 de marzo de 2005, ponente Ilmo. Sr. Sancho (LA LEY 65421/2005)

- AAP de Las Islas Baleares (sección $3^{\mathrm{a}}$ ) de 15 de marzo de 2005, ponente Ilma. Sra. R. Rigo (LA LEY 60287/2005)

- AAP de Madrid (sección 14ª) de 3 de marzo de 2005, ponente Ilmo. Sr. P. Quevedo (LA LEY 5094212005)

- AAP de Sevilla (sección 5 ${ }^{\text {a }}$ ) de 1 de marzo de 2005, ponente Ilmo. Sr. J. Herrera (LA LEY 48585/2005)

- AAP de Castellón (sección 3 $3^{\mathrm{a}}$ ) de 20 de enero de 2005, ponente Ilma. Sra. Ma.A. Gil (LA LEY 15654/2005)

- AAP de Vizcaya (sección $3^{\mathrm{a}}$ ) de 18 de enero de 2005, ponente Ilma. Sra. Mª .C. Marco (LA LEY 9171/2005) 
- AAP de Guipúzcoa (sección 2a) de 22 de diciembre de 2004, ponente Ilma. Sra. Ma.T. Fontcuberta (LA LEY 270202/2004)

- AAP de Barcelona (sección 13 ${ }^{a}$ ) de 2 de diciembre de 2004, ponente Ilma. Sra. I. Carriedo (ROJ AAP B 5858/2004)

- AAP de Valladolid (sección $1^{\text {a }}$ ) de 18 de noviembre de 2004, ponente Ilmo. Sr. J.A. San Millán (LA LEY 10985/2005)

- AAP de Madrid (sección 14 ${ }^{a}$ ) de 14 de septiembre de 2004, ponente Ilmo. Sr. J.M. Salcedo (LA LEY 188968/2004)

- AAP de Soria (sección 1ª) de 7 de septiembre de 2004, ponente Ilmo. Sr. J.M. García (JUR 20041315253)

- AAP de Madrid (sección 11ª) de 19 de julio de 2004, ponente Ilmo. Sr. F. Almazán (LA LEY 170886/2004)

- AAP de Barcelona (sección 15ª) de 1 de julio de 2004, ponente Ilmo. Sr. L. Garrido (JUR 20041219656)

- AAP de Valladolid (sección $3^{\text {a }}$ ) de 24 de mayo de 2004, ponente Ilmo. Sr. F. Salinero (LA LEY 121728/2004)

- AAP de Sevilla (sección 5a) de 13 de mayo de 2004, ponente Ilmo. Sr. F. Sanz (LA LEY 113404/2004)

- AAP de Cádiz (sección 5a) de 12 de mayo de 2004, ponente Ilma. Sra. Ma .V. Pérez (LA LEY 112104/2004)

- AAP Les Illes Balears (sección 3 $3^{\text {a }}$ de 23 de abril de 2004, ponente Ilma. Sra. C.M. Moragues (LA LEY 96083/2004) 
- AAP de Madrid (sección 19a) de 23 de abril de 2004, ponente Ilmo. Sr. R. Ruíz (LA LEY 95517/2004)

- AAP de Las Palmas (sección 5 ${ }^{\text {a }}$ ) de 19 de abril de 2004, ponente Ilmo. Sr. J. Manrique de Lara (LA LEY 90223/2004)

- AAP de León (sección $3^{\text {a }}$ ) de 2 abril de 2004, ponente Ilmo. Sr. L.A. Mallo (ROJ AAP LE 202/2004)

- AAP de Barcelona (sección 14ª) de 17 de marzo de 2004, ponente Ilma. Sra. Ma .E. Alegret (LA LEY 67562/2004)

- AAP de Madrid (sección 13ª) de 6 de febrero de 2004, ponente Ilmo. Sr. V.J. Navarro (LA LEY 32297/2004)

- AAP de Asturias (sección $7^{\text {a }}$ ) de 30 de enero de 2004, ponente Ilmo. Sr. J. Pavieso (LA LEY 26999/2004)

- AAP de Las Islas Baleares (sección 5ª de 16 de enero de 2004, ponente Ilmo. Sr. M.J. Cabrer (LA LEY 9974/2004)

- AAP de Asturias (sección 4a) de 23 de diciembre de 2003, ponente Ilmo. Sr. R. Avelló (LA LEY 217713/2003)

- AAP de Toledo (sección 2a) de 17 de diciembre de 2003, ponente Ilmo. Sr. J.M. de la Cruz (JUR 2004\100380)

- AAP de Almería (sección 1ª) de 10 de diciembre de 2003 (LA LEY 206392/2003)

- AAP de Jaén (sección $3^{\text {a }}$ ) de 4 de diciembre de 2003, ponente Ilmo. Sr. J.Mª Passolas (JUR 2004l20056) 
- AAP de Madrid (sección 11ª) de 29 de noviembre de 2003, ponente Ilma. Sra. L. Ruíz de Gordejuela (LA LEY 198054/2003)

- AAP de Madrid (sección 14ª) de 20 de noviembre de 2003, ponente Ilma. Sra. M ${ }^{\mathrm{a}}$.J. Alfaro (JUR 2004189142)

- AAP de Las Islas Baleares (sección 3ª) de 18 de noviembre de 2003, ponente Ilma. Sra. C. Moragues (ROJ AAP IB 317/2003).

- AAP de Asturias (sección 7a) de 23 de septiembre de 2003, ponente Ilmo. Sr. J.L. Casero (JUR 2004\47732)

- AAP de Sevilla (sección 5 ${ }^{\text {a }}$ ) de 16 de septiembre de 2003, ponente Ilmo. Sr. J. Herrera (LA LEY 141979/2003)

- AAP de Castellón (sección $3^{a}$ ) de 10 de septiembre de 2003, ponente Ilma. Sra. A. Bardón (LA LEY 138302/2003)

- AAP de Almería (sección 2a) de 9 de septiembre de 2003, ponente Ilmo. Sr. J. RuízRico (LA LEY 137189/2003)

- AAP de La Rioja (sección única) de 24 de julio de 2003, ponente Ilmo. Sr. R. Lacueva (ROJ AAP LO 238/2003)

- AAP de Murcia (sección 5a) de 14 de julio de 2003, ponente Ilmo. Sr. J.J. Hervás (LA LEY 123474/2003)

- AAP de Las Islas Baleares (sección $3^{\text {a }}$ ) de 5 de junio de 2003, ponente Ilma. Sra. G. Rosello (LA LEY 100036/2003)

- AAP de Girona (sección 2a) de 5 de Junio de 2003, ponente Ilmo. Sr. J.M. Fernández (LA LEY 100175/2003) 
- AAP de Lleida (sección $2^{a}$ ) de 30 de mayo de 2003, ponente Ilma. Sra. A.V. Sainz (LA LEY 97510/2003)

- AAP de Cáceres (sección 1ª) de 27 de mayo de 2003, ponente Ilmo. Sr. J.F. Bote (LA LEY 94997/2003)

- AAP de Asturias (sección 4ª) de 14 de mayo de 2003, ponente Ilmo. Sr. F. Tuero (JUR 2003 232663)

- AAP de Cádiz (sección 7ª) de 30 de abril de 2003, ponente Ilmo. Sr. M. Gutiérrez (LA LEY 79289 2003)

- AAP de Granada (sección 4a) de 24 de enero de 2003, ponente Ilmo. Sr. J. Maldonado (LA LEY 18105/2003)

- AAP de Zamora, (sección $1^{\text {a }}$ ) de 8 de enero de 2003, ponente Ilmo. Sr. A. Encinas (LA LEY 4170/2003)

- SAP de Castellón (sección 1 ${ }^{\text {a }}$ ) de 30 de diciembre de 2002, ponente Ilmo. Sr. J.F. Morales (LA LEY 218074/2002)

- AAP de Palma de Mallorca (sección $3^{\text {a }}$ ) de 25 de noviembre de 2002, ponente Ilma. Sra. C. Moragues (LA LEY 197295/2002)

- AAP de Asturias (sección 7ª) de 19 de noviembre de 2002, ponente Ilma. Sra. B. Álvarez (LA LEY 193224/2002)

- SAP de Granada (sección 3 $3^{\text {a }}$ ) de 12 de noviembre de 2002, ponente Ilmo. Sr. A. Gallo (LA LEY 188828/2002)

- AAP de Burgos ( $\operatorname{sección} 7^{\mathrm{a}}$ ) de 1 de octubre de 2002 ponente Ilma. Sra. Ma .E. Villimar (ROJ AAP BU 386/2002) 
- AAP de Asturias (sección $7^{\text {a }}$ ) de 28 de junio de 2002, ponente Ilma. Sr. B. Álvarez (LA LEY 122404/2002)

- AAP de Barcelona (sección 17ª) de 27 de mayo de 2002, ponente Ilma. Sra. M. Sambola (JUR 2002 208711)

- AAP de Cádiz (sección 8a) de 10 de mayo de 2002, ponente Ilmo. Sr. L.A. De Diego (LA LEY 90365/2002)

- AAP de Granada (sección 4a) de 18 de octubre de 2001, ponente Ilmo. Sr. J. Maldonado (LA LEY 184669/2001)

- AAP de Cáceres (sección $1^{\text {a }}$ ) de 13 de junio de 2001, ponente Ilmo. Sr. A.Ma González (JUR 2001 228492)

- SAP de Zaragoza (sección 2a) de 27 de febrero de 2001, ponente Ilma. Sra. M.E. Mata (LA LEY 46729/2001)

- SAP de Burgos (sección 2a) de 21 de febrero de 2001, ponente Ilmo. Sr. A. Picón (LA LEY 41445/2001)

- AAP de Las Islas Baleares (sección $3^{\text {a }}$ ) de 5 de Octubre de 2000, ponente Ilma. Sra. C.M. Moragues (LA LEY 178637/2000)

- AAP de Asturias (sección 6 $6^{\text {a }}$ de 22 de noviembre de 1999, ponente Ilmo. Sr. J.M. Barral (AC 199918143)

- SAP de Jaén (sección 1 ${ }^{\text {a }}$ ) de 15 de octubre de 1999, ponente Ilma. Sra. M.J. Jurado (LA LEY 140024/1999)

- AAP de Navarra (sección 1ª) de 20 de mayo de 1999, ponente Ilmo. Sr. R. Ruíz de la Cuesta (AC 19991840) 
- AAP de Córdoba (sección 3 $3^{\text {a }}$ ) de 6 de noviembre de 1998, ponente Ilmo. Sr. E. Baena (AC 199812155)

- AAP de Navarra (sección 1ª) de 23 de octubre de 1998, ponente Ilmo. Sr. R. Ruíz (AC 199812003)

- AAP de Cuenca (sección 1 ${ }^{a}$ ) de 21 de octubre de 1998, ponente Ilmo. Sr. L. Puente (AC 199817927)

- AAP de Sevilla (sección 5ª) de 4 de mayo de 1998, ponente Ilmo. Sr. P. Márquez (AC 1998\5426)

- SAP de Pontevedra (sección $3^{\text {a }}$ ) de 5 de noviembre de 1996, ponente Ilmo. Sr. J.L. Núñez (AC 199612071)

- SAP de Madrid (sección 8 $8^{\text {a) }}$, de 4 de julio de 1996, ponente Ilmo. Sr. M. Camino (AC 1996\1400)

- SAP de Barcelona (sección 16ª) de 29 de julio de 1994, ponente Ilmo. Sr. E. Mendaña (AC 1994\1401)

- STMC de 21 de diciembre de 2004, ponente Ilmo. Sr. E. García-Chamón (LA LEY 268428/2004) 


\section{BIBLIOGRAFIA}

- Aguilera Morales, M., Las diligencias preliminares, en "Tribunales de Justicia: Revista española de derecho procesal”, 2001, núm. 4, pp. 25-29.

- Alonso Furelos, J.M., La exhibición de cosa mueble en el Derecho Español, en “Revista Jurídica de Catalunya”, 1991, núm. 2, pp. 399-440.

- Álvarez Alarcón, A. Las diligencias preliminares de la LEC: conceptos generales, en "Cuadernos de Derecho Judicial”, edit. Consejo General del Poder Judicial, Madrid, 1995, núm. 27, pp. 1-54.

- Álvarez Alarcón, A., Las diligencias preliminares, en "Instituciones del nuevo proceso civil. Comentarios sistemáticos a la Ley 1/2000”, Vol. II, coord. Jaume AlonsoCuevillas Sayrol, edit. Difusión Jurídica, Barcelona, 2000, p. 29-70.

- Alvariño Viega, C., La tutela judicial efectiva de las asociaciones de consumidores y usuarios tras la Ley de Enjuiciamiento Civil, en "Boletín del Ministerio de Justicia", 2003, núm. 1953, p. 3659-3694.

- Ariza Colmenarejo, M.J., Consideraciones en torno a la entrada y registro del proceso civil. Aspectos constitucionales, en "Diario La Ley", 2004, núm. 6015 (LA LEY 845/2004).

- Armengot Vilaplana, A., Las nuevas diligencias preliminares y las especialidades en materia probatoria introducidas por la Ley 19/2006 en la LEC, en "Revista General de Derecho Procesal", 2007, núm. 13.

- Asencio Mellado, J.M., Derecho Procesal Civil, 2a edic., edit. Tirant Lo Blanch, Valencia, 2012.

- Banacloche Palau, J., Las diligencias Preliminares, edit. Civitas, Madrid, 2003. 
- Bachmaier Winter, L., La tutela de los derechos e intereses colectivos de consumidores y usuarios en el proceso civil español, en "Las acciones para la tutela de los intereses colectivos y de grupo", UNAM, México, https://archivos.juridicas.unam.mx/www/bjv/libros/7/3046/3.pdf, (consultado el 10 de agosto de 2017).

- Bellido Penadés, R., Comentario al artículo 256 LEC, en "Proceso Civil Práctico", T.III, edit. Lex Nova, Valladolid, 2002.

- Beltrán, J.M., et. al., Intimidad, confidencialidad y secreto, en "Guías de ética en la práctica médica”, Fundación de Ciencias de la Salud, 2005, Madrid, pp. 33-59.

- Calaza López, S., Homenaje al profesor Antonio Fernández de Buján en el veinticinco aniversario de su cátedra. Hacia una Teoría General de la Jurisdicción Voluntaria, en “Revista de Derecho UNED”, 2008, núm. 3, pp.345-374.

- Callejo Carrión, S., Las diligencias preliminares de la LEC 1/2000 y consecuencias derivadas de la negativa a realizarlas, en “Actualidad Civil”, 2006, núm. 1 (LA LEY $5375 / 2005)$.

- Capilla Casco, A., Diligencias preliminares y medidas de anticipación y aseguramiento de prueba, en “Actualidad Jurídica Uría Menéndez”, 2005, núm. 12, pp. 91-95.

- Carballo Piñeiro, L., La actividad preparatoria de un litigio internacional: de las diligencias preliminares a la pre-trial discovery (Los interrogantes que suscita la STCE St. Paul Dairy Insdustries NV c. Unibel Exser BVBA), en “Diario La Ley”, 2005, núm. 6370 (LA LEY 5211/2005).

- Carnero Sobrado, J.I., La flexibilización del carácter numerus clausus de las diligencias preliminares en la reciente jurisprudencia, en "Diario La Ley”, 2012, núm. 7960 (LA LEY 17805/2012). 
- Castán Pérez-Gómez, A., El nuevo régimen de diligencias preliminares en propiedad intelectual frente a las defraudaciones en el entorno digital, en "Estudios sobre la ley de propiedad intelectual: últimas reformas y materias pendientes", coord. Juan Pablo Aparicio Vaquero, edit. Dykinson, 2016, pp.121-154.

- Castán Pérez-Gómez, A., El nuevo régimen de las diligencias preliminares en propiedad industrial, en “Estudios de Derecho Judicial”, 2007, núm. 145, pp. 17-42.

- Cerrato Guri, E., Límites a la actividad probatoria en el derecho inglés, en "La prueba civil: aspectos problemáticos", Aranzadi, Barcelona, 2017, pp. 335-337 y 346-347.

- Consejo General Poder Judicial, 50 Cuestiones Prácticas sobre el Juicio Ordinario, en “Conclusiones Seminario Cuestiones Procesales del Juicio Ordinario", 2014.

- Corbal Hernández J.E., Diligencias preliminares (arts. 256 a 263), en "Práctica procesal civil, Brocá-Majada-Corbal”, Tomo IV, 23 a edic., edit. Bosch, Barcelona, 2014, pp. 3483-3599.

- Damián Moreno, J., De las diligencias preliminares, en "Comentarios a la nueva Ley de Enjuiciamiento Civil, $2^{\text {a }}$ edic., edit. Lex Nova, Valladolid, 2000, p. 1680-1693.

- Díaz Martínez, M., Las diligencias preliminares: supuestos y requisitos de la solicitud, en "Práctica de Tribunales”, 2007, núm. 40 (LA LEY 2228/2007).

- Díaz Núñez, J.J., Medidas cautelares y diligencias preliminares, en "Cuadernos Digitales de Formación”, 2014, núm. 28.

- Díaz Pita, P., Diligencias preliminares y propiedad intelectual tras la reforma operada por la Ley 21/2014, de 4 de noviembre en la Ley de Enjuiciamiento Civil 1/2000, de 7 de enero, en "Cuestiones de actualidad en el ámbito de la propiedad intelectual”, edit. Dykinson, Madrid, 2015, p. 175-213. 
- Díez-Picazo Giménez, I., Las diligencias preliminares, en "Curso de Derecho Procesal Civil II. Parte Especial”, edit. Ramón Areces, Madrid, 2014, pp. 36-42.

- Díez-Picazo, L. y Gullón, A., Sistema de Derecho Civil, Tecnos, 9a edic., Vol. I, Madrid, 1998.

- Esteban de la Rosa, G., Prueba judicial y práctica del discovery en la Unión Europea, en "Revista Internacional de Doctrina y Jurisprudencia", 2014, núm. 5, p. 1-32.

- Flores Prada, I., Algunas consideraciones sobre el régimen jurídico-procesal de los informes clínicos, en "Revista Electrónica de Ciencia Penal y Criminología", 15-17, 2013.

- Gallego Riestra, S., Historia Clínica Electrónica y derecho a la autonomía del paciente: un conflicto de intereses, en "Papeles Médicos", Vol. 23, núm. 1, 2014, p. 7 19.

- Garberí Llobregat, J., Las diligencias preliminares en la Ley de Enjuiciamiento Civil, edit. Bosch, Barcelona, 2009.

- García García, E., Las diligencias preliminares en los litigios sobre infracción de patentes en España, en "XXIV Jornadas de estudio sobre propiedad industrial e intelectual”, 2009, núm. 42.

- García Sanz, F.J. y Vendrell Cervantes, C., Doctrina judicial en torno a las diligencias preliminares en materia de propiedad intelectual, en "Diario La Ley", 2013, núm. 8128 (LA LEY 4398/2013).

- García Vila, M., Diligencias preliminares y la negativa a su práctica (art. 261 LEC 1/2000), en “Revista peruana de derecho procesal”, 2003, núm. 6, pp. 149-172. 
- Garciandía González, P.M., La regulación de las diligencias preliminares en la ley de Enjuiciamiento Civil de 2000, en "Homenaje a Don Eduardo Font Serra", edit. Centro de Estudios Jurídicos, T. I, Madrid, 2004, p. 773-803.

- Garnica Martín, J.F., De las diligencias preliminares, en "Comentarios a la Nueva Ley de Enjuiciamiento Civil. Art. 1 al 280”, coords. Miguel Ángel Fernández Ballesteros, José María Rifá-Soler, José Francisco Valls Gombau, Iurgium Editores, Barcelona, 2000, pp. 1144-1195.

- Gascón Inchausti, F., La protección de los consumidores en el proceso civil español, en

http://eprints.ucm.es/23856/1/2005_La_protecci\%C3\%B3n_de_los_consumidores_en_e 1_proceso_civil_espa\%C3\%B1ol.pdf(consultado el 10 de agosto de 2017).

- Gil Nogueras, L.A., Las diligencias preliminares en materia de propiedad intelectual e industrial, en "Práctica de Tribunales”, 2017, núm. 125 (LA LEY 2914/2017).

- Gimeno Sendra, V., Derecho Procesal Civil. I. El proceso de declaración. Parte General, $4^{\text {a }}$ edic., edit. Colex, Madrid, 2012.

- Gimeno Sendra, V., Derecho Procesal Civil. I. El proceso de declaración. Parte General,", $1^{\text {a }}$ edic. edit. Ediciones Jurídicas Castillo de Luna, Madrid, 2015.

- Gómez Orbaneja, E. y Herce Quemada, V., Derecho Procesal Civil. Juicios y procedimientos especiales. Ejecución procesal. Jurisdicción voluntaria, Vol. II, 1976, Madrid.

- Gual Grau, C., Breves apuntes sobre el discovery, en “Actualidad Jurídica (Uria \& Menéndez), 2011, núm. 29, pp. 114-119.

- Guasp, J., Derecho Procesal Civil, T.II. Parte Especial, $3^{\text {a }}$ edic., Instituto de Estudios Políticos, Madrid, 1968. 
- Hernando, P., Seoane, J.A., y De Asís, J.F., La reserva de las anotaciones subjetivas: ¿derecho o privilegio?, en "Revista Calidad Asistencial”, Vol. 21, núm. 1, 2006, pp. 31 38.

- Lamarca Iturbe, I., Los problemas que la ciudadanía ha planteado al Ararteko con relación a la historia clínica, en "Papeles Médicos”, Vol. 23, n¹, 2014, pp. 20-24.

- Larena Beldarrain, J., Las diligencias preliminares en materia de propiedad industrial e intelectual, en "Revista Vasca de Administración Pública", 2010, núm. 87-88, pp. 689-705.

- Larrosa Amante, M.A., Mecanismos procesales para el acceso de los consumidores a la justicia, en "Revista Jueces para la Democracia. Información y Debate," 2003, núm. 47, pp. 12-21.

- Liébana Ortíz, J.R., La nueva jurisdicción voluntaria, en “Actualidad Civil”, 2016, núm. 1 (LA LEY 263/20116).

- López Sánchez, J., Las nuevas diligencias preliminares en materia de propiedad intelectual y propiedad industrial: el denominado "derecho de información" y la “exhibición de documentos comerciales (1), en “Diario La Ley”, 2006, núm. 6429 (LA LEY 320/2006).

- Lorca Navarrete, A.M., La regulación de las diligencias preliminares en la nueva Ley de Enjuiciamiento Civil. Una regulación inconstitucional, en "Diario La Ley", 2000, núm. 6 (LA LEY 21122/2001).

- Lorca Navarrete, A.M., Las diligencias preliminares, en "Comentarios a la nueva Ley de Enjuiciamiento Civil”, T.II, edit. Lex Nova, Valladolid, 2000, pp. 1694-1700. 
- Marcos Francisco, D., Nuevas medidas de defensa de los consumidores en materia de acciones colectivas, asistencia jurídica gratuita, costas y tasas judiciales, en "InDret", 2015, núm. 4.

- Montero Aroca, J., Derecho Jurisdiccional II. Proceso Civil, 20ª edic., edit. Tirant Lo Blanch, Valencia, 2012.

- Moreno Catena, V. y Arnáiz Serrano, A., La intervención y designación del abogado y de los procesos de jura de cuentas (Arts. 31 a 35 LEC), en “InDret”, 2006, núm. 1.

- Moreno Catena, V., Derecho Procesal Civil. Parte General, 6 edic., edit. Tirant Lo Blanch, Valencia, 2012.

- O’Callaghan Muñoz, X., Código Civil. Comentado y con Jurisprudencia, $6^{\mathrm{a}}$ edic., edit. La Ley, Madrid, 2008.

- Pérez Benítez, J.J., Efectos de las diligencias preliminares sobre el proceso ulterior: la negativa del requerido a llevar a cabo la diligencia acordada, en "Diario La Ley", 2006, núm. 6598 (LA LEY 3969/2006).

- Picó i Junoy, J., Las garantías constitucionales del proceso, edit. J.M. Bosch, $2^{\text {a }}$ edic., Barcelona, 2012.

- Picó i Junoy, J., La prueba anticipada en la nueva Ley de Enjuiciamiento Civil, en “Diario La Ley”, 2001, T.VII (LA LEY 1330/2002).

- Picó I Junoy, J., Los principios del nuevo proceso civil, en "Instituciones del nuevo proceso civil. Comentarios sistemáticos a la Ley 1/2000", Vol. I, coord. J. AlonsoCuevillas Sayrol, edit. Difusión Jurídica, Barcelona, 2000, pp. 25-66.

- Picó i Junoy, J., La prueba en el Proyecto de Ley de Enjuiciamiento Civil, en "Diario La Ley”, 1999, núm. 3 (LA LEY 11116/2001). 
- Ramos Méndez, F., Enjuiciamiento Civil. Cómo gestionar los litigios civiles, T.II, edit. Atelier, Barcelona, 2008, pp. 1145-1155.

- Rives Seva, J.M., Consideraciones generales acerca de la responsabilidad civil médica y sanitaria. Cuestiones de Derecho sustantivo y procesal en la materia, en “Diario La Ley”, 2004, núm. 6011 (LA LEY 846/2004).

- Rizo Gómez, B., La anticipación de la prueba en el proceso civil, edit. Tirant lo Blanch, Valencia, 2010.

- Ruíz de Gordejuela López, L., Las diligencias preliminares, en "Cuadernos de Derecho Judicial”, Vol. 6, edit. Consejo General Poder Judicial, Madrid, 2000.

- Sáiz Ramos, M. y Larios Risco, D., El derecho de acceso a la historia clínica por el paciente: Propuesta para la reserva de anotaciones subjetivas, en "DS: Derecho y Salud, Vol. 18, núm. 1, 2009, p. 21-42.

- Sánchez Caro, J. y Abellán-García, F., Derechos y deberes de los pacientes (Ley 41/2002, de 14 de noviembre: consentimiento informado, historia clínica, intimidad e instrucciones previas), edit. Comares, 2003.

- Sánchez Gómez, R., La naturaleza jurídica de la jurisdicción voluntaria según la delimitación prevista en la Ley 15/2015, de 2 de julio, de la Jurisdicción Voluntaria, en “Diario La Ley”, 2015, núm. 8623 (LA LEY 5654/2015)

- Sobremonte Andrés, B. y Rubido de la Torre, J.L., El tratamiento de la marca en el tráfico mercantil. La protección civil de la marca ante la jurisdicción española. Algunos aspectos procesales, en “Diario La Ley”, 1994, T.III (LA LEY 22015/2001).

- Soler Pascual, L.A., Las diligencias preliminares. Notas sobre la reforma acaecida por la Ley 19/2006, de 5 de junio, con relación a los derechos de autor e inventor, en “Práctica de los Tribunales", 2007, núm. 40 (LA LEY 2227/2007). 
- Strong, S.I., Fach Gómez, K., y Carballo Piñeiro, L., Derecho comparado para abogados algo- e hispanoparlantes, edit. Edward Elgar, Northampton, 2016.

- Troncoso Reigada, A., La protección de datos personales en búsqueda del equilibrio, edit. Tirant Lo Blanch, Valencia, 2010.

- Vallespín Pérez. D., Diligencias Preliminares ¿Numerus Clausus? (Art. 256 LEC), en “Justicia: Revista de derecho procesal”, 2007, núm. 3-4, pp. 128-129.

- Vargas Portillo, J.P., Notas relativas a la relevancia del acuerdo sobre los aspectos de los derechos de propiedad intelectual relacionados con el comercio en Honduras, en "Revista Internacional del Mundo Económico y del Derecho", Vol. V, 2013, pp. 14-46.

- Villar Fuentes, I.M, Competencia objetiva para conocer de las diligencias preliminares en procesos para la defensa de consumidores y usuarios, en "Los retos del Poder Judicial ante la sociedad globalizada: Actas del IV Congreso Gallego de Derecho Procesal (I Internacional)", 2012, pp. 713-719.

- Villar Fuentes, I.Mª La práctica de las diligencias de comprobación de hechos en la propiedad industrial y competencia desleal. (Una posible consecuencia probatoria), en "Revista General de Derecho Procesal”, 2013, núm. 30.

- Villar Fuentes, I.M ${ }^{\mathrm{a}}$, Las diligencias preliminares de los procesos de propiedad industrial y competencia desleal, edit. Tirant Lo Blanch, Valencia, 2014.

- Xalabarder Plantada, R., Jornada Usos y abusos del peer-to-peer, en "Revista de Internet, Derecho y Política”, 2010, núm. 10. 
